\title{
Vitrification Publication Bibliography
}

Prepared by:

Eric Schmieman

Pacific Northwest National Laboratory

William E. Johns

Washington State University

February 1996

RECEIVED

AUG 191997

OSTI

Prepared for

the U.S. Department of Energy

under Contract DE-AC06-76RLO 18030

Pacific Northwest National Laboratory

Richland, WA 99352

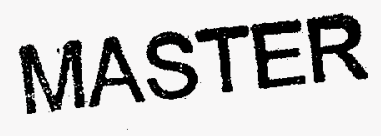

BETRIBUTION OF THIS DOCUMENT IS UNLIMTI 


\title{
DISCLAIMER
}

This report was prepared as an account of work sponsored by an agency of the United States Government. Neither the United States Government nor any agency thereof, nor Battelle Memorial Institute, nor any of their employees, makes any warranty, express or implied, or assumes any legal liability or responsibility for the accuracy, completeness, or usefulness of any information, apparatus, product, or process disclosed, or represents that its use would not infringe privately owned rights. Reference herein to any specific commercial product, process, or service by trade name, trademark, manufacturer, or otherwise does not necessarily constitute or imply its endorsement, recommendation, or favoring by the United States Government or any agency thereof, or Battelle Memorial Institute. The views and opinions of authors expressed herein do not necessarily state or reflect those of the United States Government or any agency thereof.

\section{PACIFIC NORTHWEST NATIONAL LABORATORY}

\author{
operated by
}

\section{BATTELLE}

for the

\section{UNITED STATES DEPARTMENT OF ENERGY}

under Contract DE-AC06-76RLO 1830

Printed in the United States of America

Available to DOE and DOE contractors from the

Office of Scientific and Technical Information

P.O. Box 62, Oak Ridge, TN 37831;

prices available from (615) 576-8401.

Available to the public from the National Technical Information Service, U.S. Department of Commerce, 5285 Port Royal Rd., Springfield, VA 22161

This document was printed on recycled paper. 


\section{DISCLAMIER}

Portions of this docament moy be Iliegible in electronic image products. Images are produced from the best available original doccoment 


\section{Background}

This literature search was performed during the Summer of 1994 by a group of about 12 graduate students in the Department of Mechanical Engineering and Material Science at Washington State University. The work was funded by the U.S. Department of Energy through the TWRS Technology Development Program Office.

The literature search was designed to be an exhaustive search for research and development work involving the vitrification of mixed wastes, published by both domestic and foreign researchers, primarily during 1989-1994. "Exhaustive" means that all publications related to the topic, even tangentially, would be found. Each citation appears only once in the data base, even though it may have been located many times. The search techniques were dominated by electronic methods.

The original purpose for conducting this literature search was not to obtain technical information, although many researchers have since found it useful for that purpose. The Department's purpose was to locate all active researchers that might have an interest in technology development Request for Proposals.

There are numerous documents available to the public that have been released subsequent to this search; the Offeror is encouraged to perform searches for alternate sources of information.

The citations are sorted alphabetically by author. The bibliography is also available in electronic format, Windows Reference Manager.

For additional information, please contact

Eric Schmieman

e-mail: EricSch@wsu.edu

fax: 509-335-7632

101 Sloan Hall

Department of Civil \& Environmental Engineering

Washington State University

Pullman, WA 99164-2910

The cited documents, and other relevant information, are available through several sources:

1) Benton Franklin County Law Library (Federal and Washington State codes)

Columbia Basin College

Attention: Stephanie Badalamente

Telephone No: (509) 547-0511 Ext. 290 
2) Center for Environmental Management (DOE-EM)

Telephone No: (800) 736-3282

3) Hanford Technical Library

Telephone No: (509) 376-1606

Facsimile No: (509) 376-1422

Note: A limited number of documents will be provided by the Hanford Technical Library at no cost, generally in microfiche format; however, rush service is not available for off-site requests.

4) Internet Resources (there may be a fee for some services) -

- ANSI Homepage - http://www.ansi.org/

- ASME Homepage - http://www.asme.org/

- $\quad$ ASTM Hompage - http://www.astm.org/

- Code of Federal Regulations - http://www.pls.com:8001/his/cfr.html/ also, http://www.counterpoint.com/

- DEARs - http://apollo.osti.gov/procure/dear.html/

- DOE Orders - http://www.hr.doe.gov/

- DNFSB Recommendations - http://www.dnfsb.gov/

- DOE Homepage - http://www.doe.gov/

- FARs - http://www.gsa.gov:80/far/

- Hanford Homepage - http://www.hanford.gov/

- NUREG Homepage - http://www.nrc.gov/

- PNL External Homepage - http://www.pnl.gov:2080/

- $\quad \mathrm{RCW}-$ The Revised Code of Washington is at gopher://marvel.doc.gov:70/http703Aleginfo.leg.wa.gov@/pub/rcw/

- TWRS Characterization On-line Document Library http://www.hanford.gov/twrs/char.pub/doc_toc.htm/

- U.S. Code - http://www.law.cornell.edu/uscode/ 
- WAC - The Washington Administrative Code may be found at gopher://cfr.counterpoint.com:3147/11/

5) National Technical Information Service, telephone (800) 553-6847

6) Office of Civilian Radioactive Waste Management (DOE-RW) Telephone No: (800) 225-6972

7) Public Request (primarily WHC documents and DOE documents) Attention: Ms. Ann Sada Telephone No: (509) 372-2420

Facsimile No: (509) 376-4989

8) Richland Public Library (Federal and Washington State codes) Telephone No: (509) 943-7457

Note:

1 There is a duplicating charge of $\$ .10$ per page, payable in advance. 
1. Anonymous Doe management of high-level waste at the hanford site. (Unknown Journal!) : (22 p), 1914 .

2. Anonymous Hanford environmental information system (heis). (Unknown Journal!) :(72 p), 1914.

3. Anonymous The mixed alkali effect in glass. Journal. of.Non-Crystalline.Solids. 1:235-261, 1969.

4. Anonymous Characterization of Glass Corrosion and Durability. Journal. of.Non-Crystalline.Solids. 19:27-39, 1975.

5. Anonymous Ceramic \& glass radioactive waste forms /, Washington : Energy Research and Development Administration, Division of Physical Research, 1977.

6. Anonymous Conceptual design of a nuclear waste vitrification facility, Richland, Wash. : Springfield, Va. :Pacific Northwest Laboratory; available from NTIS, 1978.

7. Anonymous Physical Chemistry of Glass surfaces. Journal.of.Non-Crystalline.Solids. 28:83-105, 1978.

8. Anonymous Rupture of plutonium oxide storage container, March 13, 1979. (Unknown Journal!) , 1979.

9. Anonymous Vitrification of Hanford waste in a joule-heated ceramic melter and evaluation of resultant canisterized product, Richland, Wash. : springfield, Va. :Pacific Northwest Laboratory ; available from NIIS, 1979.

10. Anonymous Technical summary, Nuclear waste vitrification project, Richland, Wash. : Springfield, Va. :Pacific Northwest Laboratory ; available from NTIS, 1979.

11. Anonymous development of multibarrier nuclear waste formsx. Report, Pal-Sa-7292, 14 pp, 1980.

12. Anonymous KBS (Swedish Nuclear Fuel Supply Company, Stockholm. Division KBS) Annual Report 1979. Including Summaries of Technical Reports Issued During 1979. (Unknown Journal!), 1980.

13. Anonymous process arrangement options for defense waste immobilizationx. Report, Dpst-80-203, 209 pp, 1981.

14. Anonymous description of dwpf reference waste form and canisterX. Report, Dp-1606, 54 Pp, 1981.

15. Anonymous independent review panel to evaluate and review alternative wastex forms to immobilize the idaho chemical processing plant (icpp)X calcined wastex. Report, Enico-1088, 42 pp, 1981. 
16. Anonymous current techniques and management strategy for plutonium- $X$ contaminated wastes at pncX. Report, PnC-N-141-81-06, 25 pp, 1982.

17. Anonymous Glass containing phosphate, 1982.

18. Anonymous Reaction and devitrification of a prototype nuclear waste storage glass with hot magnesium-rich brine technical report /, Columbus, ohio :' Springfield, VA :Office of Nuclear Waste Isolation, Battelle Project Management Division; Available from National Technical Information Service, 1982.

19. Anonymous Final report of experimental laboratory-scale brittle fracture studies of glasses and ceramics /, Argonne, IIl. :- Springfield, Va. :Argonne National Laboratory; available at NTIS, 1982.

20. Anonymous environmental assessment: waste-form selection for srp high-levelX wasteX. Report, Doe/Ea-0179; Order No.De82019365, 92 pp, 1982.

21. Anonymous General Requirements Applicable to the Production, Inspection, Processing, Packaging and Storage of High Activity Wastes Packed in Glass Form and Resulting from the Reprocessing of Fuels Irradiated in Pressurized Light Water Reactors. (Unknown Journal!) , 1982.

22. Anonymous Radioactive waste vitrification in France, [France] :Cogema, 1983.

23. Anonymous Conceptual waste package interim product specifications and data requirements for disposal of glass commercial high-level waste forms in salt geologic repositories : technical report, Columbus, $O H$ : springfield, VA :Battelle Project Management Division, Office of Nuclear Waste Isolation ; Available from National Technical Information . Service, 1983.

24. Anonymous Assessment of power reactor waste immobilization by vitrification final report /, Palo Alto, Calif. :The Institute, 1983.

25. Anonymous Sandia develops technique to simulate changes in glass and ceramic nuclear waste forms. American.Ceramic.society.Bulletin. v. 62 (Sept. '83) : 957,1983 .

26. Anonymous conceptual waste-package designs for disposal of nuclear waste inX tuffX. Report, Onwi-439; Order No.De83013112, 462 pp, 1983.

27. Anonymous Safety Analysis of off-Air and off-Gas Systems in Reprocessing. Summarizing Interim Report. Pt. 2. (Unknown Journal!) , 1983.

28. Anonymous Trial storage of High-Level Waste Cylinders in the Asse II Salt Mine. (Unknown Journal!), 1984.

29. Anonymous Testing and evaluation of solidified high-level waste forms: joint annual progress report, 1982 : final report / Luxembourg :Commission of the European Communities, Directorate-General Information, Market, and Innovation : Office of Publications of the European Communities, 1984. 
30. Anonymous Summary of radioactive operations for zeolite vitrification demonstration program /, Springfield, Va. :1984.

31. Anonymous (A Cer S) Nuclear Division. (Annual Meeting, Pittsburgh, PA, Apr. 30-May 2; program and abstracts of papers). American.Ceramic.Society,Bulletin. v. 63 (Mar. '84):507-514, 1984 .

32. Anonymous Feasibility study of the Offshore Disposal of Radioactive Waste by Drilled Emplacement. 3. Cost and Logistical Study. (Unknown JounnaI!), 1984 .

33. Anonymous collection of Lectures Given on the Occasion of the 5TH Status Report of the Project of Reprocessing and Waste Treatment. (Uniknown Journal!) , 1984.

34. Anonymous Evaluation of Alternatives for Defense Waste Management at the Savannah River Plant: Final Report for FY-84, February 1984 to September 1984. (Unknown Journal!), 1984.

35. Anonymous Systems Study' 'Alternative Entsorgung'. Final Report. Technical Annex 23. Concept of Fuel Element Processing and Final storage in Barrels Analogous to. (Unknown Journal!) , 1984.

36. Anonymous Concept and Plans for a Station for the Encapsulation of Vitrified Highly Radioactive Waste into Containers for Final Disposal. (Unknown Journal!) , 1984 .

37. Anonymous Geological Disposal of Heat Generating Radioactive Waste. Container Design Study. (Unknown Journal!), 1985.

38. Anonymous FY 1986 current fiscal year work plan. (Unknown Journal!), 1985.

39. Anonymous BIF develops calciners for vitrification. Nuclear. Engineering. International. v. 30 (Sept. '85):56, 1985 .

40. Anonymous HMI Department of Nuclear Chemistry and Reactor. Scientific Report 1984. (Unknown Journal!) , 1985.

41. Anonymous Gas bubbles in glass: round robin analysis, gas chromatography and mass spectrometry, growth and dissolution of gas bubbles, sulfur solubility in glass melts, International Commission on Glass, 1985.

42. Anonymous Wackersdorf Fuel Reprocessing Plant. (Unknown Journal!), 1985.

43. Anonymous Interim Hanford Waste Management Technology Plan, September 1985. (Unknown Journal!), 1.985.

44. Anonymous Project Guarantee 1985. Final Repository for High-Level Radioactive Wastes: The System of Safety Barriers. (Unknown Journal!), 1985.

45. Anonymous Project Guarantee 1985. Final Repository for High-Level Radioactive Wastes: Safety Report. (Unknown Journal!) , 1985. 
46. Anonymous Savannah River Laboratory Monthly Report, March 1985. (Unknown Journal!) , 1985.

47. Anonymous Defense Waste and Byproducts Management. Monthly Report, June 85. (Unknown Journal!), 1985.

48. Anonymous Defense Waste and Byproducts Management. Monthly Report. (Unknown Journal!) , 1985.

49. Anonymous Corrosion Behaviour of Container Materials for Geological Disposal of High-Level Waste. Joint Annual Progress Report 1983. (Unknown Journal!) , 1985.

50. Anonymous Defense Waste and Byproducts Management Monthly Report. (Unknown Journal!) , 1985.

51. Anonymous Institut fuer Nukleare Entsorgungstechnik: Status Report on Research and Development 1984. (Unknown Journal!) , 1985.

52. Anonymous Defense Waste and Byproducts Management Monthly Report, October 1985. (Unknown Journal!) , 1985.

53. Anonymous Defense Waste and Byproducts Management Monthly Report, November 1985. (Unknown Journal!) , 1985 .

54. Anonymous Defense Waste and Byproducts Management Monthly Report, May 1985. (Unknown Journal!) , 1985.

55. Anonymous Ocean Disposal of Heat Generating Waste. Penetrator Engineering Study. (Unknown Journal!), 1985.

56. Anonymous Fiscal year 1986 program plan for the Defense Transuranic Waste Program (DTWP). (Unknown Journal!) , 1985.

57. Anonymous Design Study on Containers for Geological Disposal of High-Level Radioactive Waste. Phase 2. (Unknown Journal!), 1986.

58. Anonymous Response to Environmental policy Institute report on Savannah River Plant high-level waste management. (Unknown Journal!) , 1986.

59. Anonymous Geological Disposal of Heat Generating Radioactive Waste. Container Design Study - Phase 2. (Unknown Journal!) , 1986.

60: Anonymous Defense Waste and Byproducts Management. Monthly Report, February 1986. (Unknown Journal!), 1986.

61. Anonymous Section A5 Drywell/Berm Concept for the storage of HLRW Canisters: Survey and Assessment of Radioactive Waste Management Facilities in the United States: Addendum. (Unknown Journal!), 1986.

62. Anonymous Centralized processing of contact-handled TRU waste feasibility analysis. (Unknown Journal!) , 1986. 
63. Anonymous Defense Waste and Byproducts Management Monthly Report, January 1986. (Unknown Journal!), 1986.

64. Anonymous Proceedings of the US DOE/UK AEA Workshop on Facility Design. (Unknown Journal!) , 1986.

65. Anonymous CEGB/SSEB (Central Electricity Generating Board/South of Scotland Electricity Board) Response to Recommendations 17 and 18 in the Environment Committee's Report on Radioactive Waste. An Overview. (Unknown Journal!), 1986 .

66. Anonymous Support of International Waste Management Agreements in the field of TRU Waste Management. Technical work plan, FY 1986. (Unknown Journal!), 1986 .

67. Anonymous G03.02 revises one weathering standard, publishes another. ASTM.Standardization.News v. 14 (Dec. '86):16+, 1986.

68. Anonymous Jahrestagung Kerntechnik 186. Fachsitzung Versuchsanlagen und Teststaende fuer die Demonstration der nuklearen Entsorgungstechnik. (Annual) meeting on nuclear technology '86. Technical session on experimental facilities and test rigs for the demonstration of nuclear waste management processes). (Unknown Journal!) , 1986.

69. Anonymous Hazardous Waste Treatment Technology. (Unknown Journal!), 1986.

70. Anonymous Static Corrosion of Radioactive Glass at $40 \mathrm{C}$ and Corrosion of Radioactive Glass under Dynamic Conditions. Final Report JSS Project Phase. III. (Unknown Journal!) , 1986.

71. Anonymous Long-term leaching behavior of simulated Savannah River plant waste glass : part I: MCC-I leachability results, four-year leaching data /, Aiken, SC :E. I. du Pont de Nemours, Savannah River Laboratory, 1986.

72. Anonymous Reference vitrification process and equipment description with results from checkout testing /, West Valley, N.Y. : Springfield, Va. :West Valley Nuclear Services Co.; Available from National Technical Information Service, 1986.

73. Anonymous FY 1987 current fiscal year work plan. (Unknown Journal!), 1986.

74. Anonymous Waste Package Reference Conceptual Designs for a Repository in Salt. (Unknown Journal!), 1986.

75. Anonymous Long-Term Management of the Existing Radioactive Wastes and Residues at. the Niagara Falls storage site. Final Environmental Impact Statement. (Unknown Journal!) , 1986.

76. Anonymous Performance of borosilicate glass high-level waste forms in disposal systems. Nuclear. Technology. v. 73 (May '86):139-209, 1986. 
77. Anonymous CEGB/SSEB (Central Electricity Generating Board/South of Scotland Electricity Board) Response to Recommendation 17 in the Environment Committee's Report on Radioactive Waste. V.1. Executive Summary and Main Report. (Unknown Journal!) , 1986.

78. Anonymous Disposal of Hanford Defense High-Level, Transuranic and Tank Wastes, Hanford Site, Richland, Washington. Draft Environmental Impact Statement. Volume 1. (Unknown Journal!), 1986.

79. Anonymous Disposal of Hanford Defense High-Level, Transuranic and Tank Wastes, Hanford Site, Richland, Washington. Draft Environmental Impact Statement. Volume 2. Appendices A-I. (Unknown Jounnal!), 1986.

80. Anonymous Disposal of Hanford Defense High-Level, Transuranic and Tank Wastes, Hanford Site, Richland, Washington. Draft Environmental Impact Statement. Volume 3. Appendices M-V. (Unknown Journal!) , 1986.

81. Anonymous Survey and Assessment of Radioactive Waste Management Facilities in the United States. Section 2.5. Air-Cooled Vault storage Facilities. (Unknown Journal!) , 1986.

82. Anonymous Savannah River Laboratory Monthly Report, February 1986. (Unknown Journal!) , 1986.

83. Anonymous Development of a Evaluation Code for Radioactive Source Residing in the Vitrification Apparatus. (Unknown Journal!) , 1986.

84. Anonymous Hanford Waste Vitrification Plant Reference Conceptual Design Report. (Unknown Journal!), 1987.

85. Anonymous Waste Management Program (Savannah River Plant): Technical Progress Report, January-June 1985. (Unknown Journal!) , 1987.

86. Anonymous Sol Gel Processes. January 1970-September 1987 (Citations from the NTIS Database). Rept. for Jan 70-Sep 87. (Unknown Journal!), 1987.

87. Anonymous Disposal of Hanford Defense High-Level, Transuranic and Tank Wastes, Hanford Site, Richland Washington: Final Environmental Impact Statement, Volume 5. Public Comments. (Unknown Journal!) , 1987.

88. Anonymous Preliminary results of durability testing with borosilicate glass compositions /, West Valley, N.Y. : Springfield, Va. :West Valley Nuclear Services Co. ; Available from National Technical Information service, 1987.

89. Anonymous Disposal of Hanford Defense High-Level, Transuranic and Tank Wastes, Hanford Site, Richland, Washington: Final Environmental Impact Statement, Volume 3. Appendices M-V. (Unknown Journal!), 1987.

90. Anonymous Disposal of Hanford Defense High-Level, Transuranic and Tank Wastes, Hanford Site, Richland, Washington: Final Environmental Impact Statement, Volume 2. Appendices A-I. (Unknown Journal!) , 1987. 
91. Anonymous Disposal of Hanford Defense High-Level, Transuranic and Tank Wastes, Hanford Site, Richland, Washington: Final Environmental Impact Statement, Volume 1. (Unknown Journal!) , 1987.

92. Anonymous Method for manufacturing a calcium phosphate crystalline glass, 1987.

93. Anonymous Long-term performance of high-level glass waste forms, Washington, D.C. :U.S. Nuclear Regulatory Commission, 1987.

94. Anonymous preliminary results of durability testing with borosilicate glass compositions /, West Valley, N.Y. : Springfield, Va. :West Valley Nuclear Services Co. ; Available from National Technical Information Service, 1987.

95. Anonymous JSS Project Phase 4: Experimental and Modeling studies of HLW Glass Dissolution in Repository Énvironments. Final Report. (Unknown Journal!) , 1987.

96. Anonymous Oak Ridge Model Conference (1987): Proceedings of a Conference on Waste Problems Held at Oak Ridge, Tennessee on October 13, 1987. (Unknown Journal!) , 1987.

97. Anonymous Disposal of Hanford Defense High-Level, Transuranic and Tank Wastes, Hanford Site, Richland, Washington: Final Environmental Impact Statement, Volume 4. Public Comments and Responses. (Unknown Journal!), 1987.

98. Anonymous Waste Management Program: Technical Progress Report, July-December 1985. (Unknown Journal!) , 1987.

99. Anonymous West Valley Demonstration Project: Annual Report. (Unknown Journal!) , 1988.

100. Anonymous Defense Waste and Transportation Management (DWTM): Primer. (Unknown Journal!) , 1988.

101. Anonymous survey of degradation modes of candidate materials for high-level radioactive-waste disposal containers. Volume 5. Localized corrosion of copper-based alloys. (Unknown Journal!). 1988.

102. Anonymous Health Assessment for Cooper Road National Priorities List (NPL) Site, Voorhees Township, Camden County, New Jersey, Region 2 . CERCLIS No. (Unknown Journal!) , 1988.

103. Anonymous Criticality Safety Analysis for Remote Handled TRU (Transuranic) Waste at the Waste Isolation Pilot Plant. (Unknown Journal!) , 1988.

104. Anonymous Survey of degradation modes of candidate materials for high-level radioactive-waste disposal containers. Volume 6 . Effects of hydrogen in austenitic and copper-based alloys. (Unknown Journal!), 1988.

105. Anonymous Hanford Waste Vitrification Plant Quarterly Review, second Quarter FY 1988. (Unknown Journal!) , 1988. 
106. Anonymous survey of degradation modes of candidate materials for high-level radioactive-waste disposal containers. Overview. (Unknown Journal!) , 1988.

107. Anonymous Survey of degradation modes of candidate materials for high-level radioactive-waste disposal containers. Volume 8 . Weldability of copper-based alloys. (Unknown Journal!), 1988.

108. Anonymous Hanford Waste Vitrification Plant Briefing Booklet. (Unknown Journal!) : 1988.

109. Anonymous Survey of degradation modes of candidate materials for high-level radioactive-waste disposal containers. Volume 1 . Phase stability. (Unknown Journal!) , 1988.

110. Anonymous Technological Approaches to the Cleanup of Radiologically Contaminated Superfund Sites. (Unknown Journal!) , 1988.

111. Anonymous Summary of Campaigns SGM-9 and SGM-10 of the DWPF Scale Glass Melter (U). (Unknown Journal!), 1988.

112. Anonymous Grout Treatment Facility Dangerous Waste Permit Application (Volume 3). (Unknown Journal!) , 1988.

113. Anonymous survey of degradation modes of candidate materials for high-level radioactive-waste disposal containers. Volume 2 . Oxidation and corrosion. (Unknown Journal!) , 1988.

114. Anonymous Waste Management Program: Technical Progress Report, July-December 1986. (Unknown Journal!). 1988.

115. Anonymous survey of degradation modes of candidate materials for high-level radioactive-waste disposal containers. Volume 3. Localized corrosion and stress corrosion cracking of austenitic alloys. (Unknown Journal!), 1988.

116. Anonymous Survey of degradation modes of candidate materials for high-level radioactive-waste disposal containers. Volume 4 . Stress corrosion cracking of copper-based alloys. (Unknown Journal!) , 1988.

117. Anonymous Grout Treatment Facility Dangerous Waste Permit Application. (Unknown Journal!), 1988.

118. Anonymous Grout Treatment Facility Dangerous Waste Permit Application (Volume 2). (Unknown Journal!) , 1988.

119. Anonymous Energetics of silicate melts from thermal diffusion studies. Progress report, January 1989-December 1989. (Unknown Journal!) , 1989.

120. Anonymous Defense Waste Processing Facility (DWPF): The Vitrification of High-Level Nuclear Waste. January 1980-September 1989 (Citations from the NTIS Database). Rept. for Jan 80-Sep 89. (Unknown Journal!) , 1989. 
121. Anonymous High Level Radioactive Waste: Doing Something About It. (Unknown Journal!) , 1989.

122. Anonymous Double-shell tank waste disposal integration plan. Revision 1. (Unknown Journal!) , 1989.

123. Anonymous overview of radwaste management technology development: Current status and trends in the United States. (Unknown Journal!) , 1989.

124. Anonymous Impact of a delay in the completion of the Defense Waste Processing Facility. (Unknown Journal!), 1989.

125. Anonymous DOE Land Disposal Restrictions strategy report for radioactive mixed waste. (Unknown Journal!), 1989.

126. Anonymous Radioactive Waste Storage Sites: Reclamation and Remedial Action. January 1970-July 1989 (Citations from the NTIS Database). Rept. for Jan 70-Jul 89. (Unknown Journal!) , 1989.

127. Anonymous Sol Gel Processes. January 1970-September 1989 (Citations from the NIIS Database). Rept. for Jan 70-Sep 89. (Unknown Journal!) , 1989.

128. Anonymous Sol Gel Processes. January 1976-September 1989 (Citations from the Energy Data Base). Rept. for Jan 76-Sep 89. (Unknown Journal!) , 1989.

129. Anonymous Hanford Waste Vitrification Plant technology progress. (Unknown Journal!) , 1989.

130. Anonymous Grout Fixation of Variable Phosphate/Sulfate Waste. NTIS Tech Note. (Unknown Journal!), 1989.

131. Anonymous West Valley Demonstration Project, West Valley, New York: Annual Report. (Unknown Journal!) , 1989.

132. Anonymous Application of Stochastic Dynamic Simulation to Waste Form Qualification for the HWVP Vitrification Process. (Unknown Journal!) , 1989.

133. Anonymous Grout Treatment Facility. Dangerous Waste Permit Application. Drawings: Addendum 1. (Unknown Journal!) , 1989.

134. Anonymous Grout Treatment Facility Dangerous Waste Permit Application: Engineering Reports: Supplement 1. (Unknown Journal!) , 1989.

135. Anonymous Technical Safety Appraisal of the West Valley Demonstration Project. (Unknown Journal!) , 1989.

136. Anonymous Use of Additives for Reducing Hydrogen Yield in Mortar Containing Slag and Chloride Salts. (Unknown Journal!) , 1989.

137. Anonymous Making headway at West Valley's new vitrification plant. Nuclear. Engineering.International. v. 35 (Mar. '90):39-40, 1990.

138. Anonymous Hanford Waste Vitrification Plant preliminary safety analysis report. Appendix. (Unknown Journal!) , 1990. 
139. Anonymous Radioactive waste processing: borosilicate glasses and synthetic rocks. june 1977-february 1990 (a bibliography from the ntis data base). report for june 1977-february 1990. (Unknown Journal!) : (105 p), 1990.

140. Anonymous Reactor operation safety information document. (Unknown Journal!) , 1990.

141. Anonymous Radioactive waste processing: fixation in cements and bitumens. november 1973-february 1990 (a bibliography from the ntis data base). report for november 1973-february 1990. (Unknown Journal!): (116 p), 1990.

142. Anonymous Hanford waste vitrification plant foreign alternatives feasibility study. (Unknown Journal!) :(55 p), 1990.

143. Anonymous Hanford Waste Vitrification Plant preliminary safety analysis report. Draft, Revision B: Volume 4. (Unknown Journal!), 1990.

144. Anonymous West Valley Demonstration Project annual report to Congress. Progress rept. (Unknown Journal!) , 1990.

145. Anonymous Waste management program. Technical progress report, January-June 1988. (Unknown Journal!) , 1990.

146. Anonymous Hanford Waste Vitrification Plant Dangerous Waste Permit Application. Revision 1: Volume 1. (Unknown Journal!) , 1990.

147. Anonymous Hanford waste vitrification plant preliminary safety analysis report. (Unknown Journal!). : (523 p), 1990.

148. Anonymous Hanford Waste Vitrification Plant preliminary safety analysis report. Draft, Revision B, Volume 3. (Unknown Journal!) , 1990.

149. Anonymous Hanford waste vitrification plant preliminary safety analysis report. (Unknown Journal!) : (626 p), 1990.

150. Anonymous Hanford Waste Vitrification Plant preliminary safety analysis report. Draft, Revision B, Volume 2. (Unknown Journal!) , 1990.

151. Anonymous Defense waste treatment and disposal activities at the Hanford Site. (Unknown Journal!) , 1990.

152. Anonymous New insights into the structure of alkali borate glasses. Journal.of.Non-Crystalline.Solids. 123:283-285, 1990.

153. Anonymous Anonymous 1990, p. 1095-1102.

154. Anonymous Hanford waste vitrification plant preliminary safety analysis report. (Unknown Journal!) : (474 p), 1990.

155. Anonymous Thermochemistry of minerals stable near the earth's surface. (Unknown Journal!) , 1990. 
156. Anonymous Hanford Waste Vitrification Plant Dangerous Waste Permit Application. Revision 1: Volume 2. (Unknown Journal!), 1990.

157. Anonymous Hanford Waste Vitrification Plant foreign alternatives feasibility study. Revision 1. (Unknown Jounnal!) , 1990.

158. Anonymous Anonymous 1990,p. 1086-1094.

159. Anonymous Progress in hazardous waste management. Engineering.Digest. $v$. 36 (Feb. '90):37-38, 1990.

160. Anonymous Grout disposal system for Hanford site mixed waste. '(Unknown Journal!), 1990.

161. Anonymous Overview of the vitrification of defense high-level waste at the Hanford Site. (Unknown Journal!) , 1990.

162. Anonymous Hanford Waste Vitrification Plant foreign alternatives feasibility study. (Unknown Journal!) , 1990.

163. Anonymous Assessment of double-shell tank waste pretreatment options. Revision 1: (Unknown Journal!) , 1990.

164. Anonymous Measurement of soluble nuclide dissolution rates from spent fuel. (Unknown Journal!) , 1990.

165. Anonymous Hanford Waste Vitrification Plant Preliminary Safety Analysis Report. Draft, Revision B: Volume 1. (Unknown Journal!), 1990.

166. Anonymous Hanford federal facility agreement and consent order. Quarterly progress report for the period ending June 30, 1990. (Unknown Journal!), 1990.

167. Anonymous Hanford waste vitrification plant dangerous waste permit application. (Unknown Journal!) :(463 p), 1990.

168. Anonymous Anonymous 1990,p. 1103-1109.

169. Anonymous on the formation of silicon oxynitride by ion implantation in fused silica. Journal.of.Non-Crystalline.Solids. 125:293-301, 1990.

170. Anonymous Hanford waste vitrification plant preliminary safety analysis report. (Unknown Journal!) : (395 p), 1990.

171. Anonymous Infrared reflectance spectra of lithium borate glasses. Journal. of.Non-Crystalline.Solids. $126: 52$, 1990.

172. Anonymous Hanford waste vitrification plant preliminary safety analysis report. (Unknown Journal!) : (433 p), 1990.

173. Anonymous Hanford waste vitrification plant clean air act permit application. (Unknown Journal!) : (170 p), 1990. 
174. Anonymous Assessing Sellafield's vitrification technology. Nuclear. Engineering. International. v. 35 (Mar. '90):43-46, 1990.

175. Anonymous Radioactive waste processing: vitrification. november 1973-october 1989 (a bibliography from the ntis data base). report for november 1973 -october 1989. (Unknown Journal!) : (122 p), 1990.

176. Anonymous Nuclear waste management IV /, Westerville, Ohio :American Ceramic Society, 1991.

177. Anonymous Environmental restoration and waste management site-specific plan for richland operations office <augmentation> contains glossary. (Unknown Journal!) : (380 p), 1991.

178. Anonymous Thermal processes evaluation for RWMC wastes. (Unknown Journal!) , 1991.

179. Anonymous Hanford waste vitrification systems risk assessment: final report supporting information. (Unknown Journal!) : (485 p), 1991.

180. Anonymous Hanford waste vitrification plant dangerous waste permit application. (Unknown Journal!) :(642 p), 1991.

181. Anonymous Soil remediation. january 1985-january 1992 (citations from the ntis data base). rept. for jan 85-jan 92. (Unknown Journal!) : (27 p), 1991.

182. Anonymous Hanford waste vitrification systems risk assessment: final report supporting information. (Unknown Journal!) : (482 p), 1991.

183. Anonymous Independent engineering review of the hanford waste vitrification system. (Unknown Journal!) : (214 p), 1991.

184. Anonymous Hanford federal facility agreement and consent order quarterly progress report for the period ending june 30, 1991. (Unknown Journal!) : (84 p), 1991.

185. Anonymous West Valley Demonstration Project. Annual report to Congress. Progress rept. (Unknown Journal!), 1991.

186. Anonymous Ergebnisbericht ueber Forschungs- und Entwicklungsarbeiten 1990, Institut fuer Nukleare Entsorgungstechnik. (Report on research and development results in 1990 by the Institute for Nuclear Waste Management). Progress rept. (Unknown Journal!), 1991.

187. Anonymous Hanford Waste Vitrification Plant Dangerous Waste Permit Application. Revision 2: Volume 1. (Unknown Journal!), 1991.

188. Anonymous Environmental restoration and waste management site-specific plan for Richland operations office. Hanford site five-year plan, fiscal years 1993--1997. (Unknown Journal!) , 1991.

189. Anonymous Performance of high level waste forms and engineered barriers under repository conditions. Final report of a Co-ordinated Research Programme 1984-1989. (Unknown Journal!) , 1991. 
190. Anonymous Glassification and leachability of hazardous wastes and hazardous waste residues (Environmental Research). (Unknown Journal!) , 1991.

191. Anonymous 242-A evaporator dangerous waste permit application. Volume 1. (Unknown Journal!), 1991.

192. Anonymous Leaching behavior of microtektite glass compositions in sea water and the effect of precipitation on glass leaching. Technical report, Jauary 1, 1986-March 31, 1987. Progress rept. (Unknown Journal!) , 1991.

193. Anonymous Environmental. assessment for. Retech, Inc.'s Plasma Centrifugal Furnace Evaluation. (Unknown Journal!) , 1991.

194. Anonymous Waste acceptance preliminary specifications for vitrified high-level waste forms, [Washington, D.C.] :Office of Civilian Radioactive Waste Management, U.S. Dept. of Energy, 1991.

195. Anonymous NNWSI waste form testing at Argonne National Laboratory semi-annual report, January-June 1988 /, Livermore, Calif. :Lawrence Livermore National Laboratory, 1991.

196. Anonymous Long-lived legacy: managing high-level and transuranic waste at the doe nuclear weapons complex. background paper. (Unknown Journal!) :(109 p), 1991.

197. Anonymous Design and operation of high level waste vitrification and storage facilities, Vienna : International Atomic Energy Agency, 1992.

198. Anonymous Analysis of the Hanford Waste Vitrification Plant Canister storage Building under varying heat loads and a subjective analysis of costs. (Unknown Journal!) , 1992.

199. Anonymous Institut fuer Nukleare Entsorgungstechnik. Ergebnisbericht ueber Forschungs - und Entwicklungsarbeiten 1991. (Institute of Nuclear Waste Management Engineering. Progress report on research and development in 1991). (Unknown Journal!), 1992.

200. Anonymous Analysis of the hanford waste vitrification plant canister storage building under varying heat loads and a subjective analysis of costs. (Unknown Journal!) :(52 p), 1992.

201. Anonymous Babcock \& Wilcox cyclone furnace vitrification technology, Cincinnati, Ohio :Risk Reduction Engineering Laboratory, Office of Research and Development, U.S. Environmental Protection Agency, 1992.

202. Anonymous Hanford Federal Facility Agreement and Consent order quarterly progress report for the period ending December 31, 1991. (Unknown Journal!), 1992.

203. Anonymous Radioactive-site-remediation technologies seminar. speaker slide copies. (Unknown Journal!) : $(69$ p), 1992. 
204. Anonymous Quality assurance program description: Hanford Waste Vitrification Plant, Part 1. Revision 3. (Unknown Journal!), 1992.

205. Anonymous Radioactive waste processing: borosilicate glasses and synthetic rocks. (latest citations from the ntis data base). published search. (Unknown Journal!) : (vp.), 1992 .

206. Anonymous Integrated sampling and analysis plan for samples measuring $>10$ mrem/hour. (Unknown Journal!) : (72 p), 1992.

207. Anonymous Mixed and Low-Level Waste Treatment Facility project. Executive summary: Volume 1, Program summary information; Volume 2 , Waste stream technical sümary: Draft. (Unknown Journal!), 1992.

208. Anonymous Independent technical review of the Hanford Tank Farm Operations. (Unknown Journal!) , 1992.

209. Anonymous Treatment methods and waste forms for long-term storage and ultimate disposal of radioactive biological materials. National Low-Level Waste Management Program. (Unknown Journal!) , 1992.

210. Anonymous Hanford Waste Vitrification Plant technical background document for toxics best available control technology demonstration. (Unknown Journal!) , 1992 .

211. Anonymous Vitrification technologies for treatment of hazardous and radioactive waste, Washington, DC :United States Environmental Protection Agency, Office of Research and Development, 1992.

212. Anonymous Nuclear technology programs semiannual progress report, october 1990--march 1991. (Unknown Journal!) : (163 p), 1992.

213. Anonymous Defense Waste Processing Facility (DWPF): The Vitrification of High-Level Nuclear Waste. (Latest citations from the NTIS Database). Published Search. (Unknown Journal!), 1992.

214. Anonymous Hanford waste vitrification plant technical background document for toxics best available control technology demonstration. (Unknown Journal!) : $(181 \mathrm{p}), 1992$.

215. Anonymous Institute of nuclear waste management engineering. progress report on research and development in 1991 Institut fuer nukleare entsorgungstechnik. ergebnisbericht ueber forschungs- und entwicklungsarbeiten 1991. (Unknowri Journal!) : (28 p), 1992.

216. Anonymous Radioactive air emissions notice of construction and application for approval to construct the hanford waste vitrification plant. (Unknown Journal!) : $(253 \mathrm{p}), 1992$.

217. Anonymous Radioactive waste storage and disposal. (latest citations from pollution abstracts). published search. (Unknown Journal!) :([10] p), 1992.

218. Anonymous Chemical Technology Division, Annual technical report, 1991. Progress rept. (Unknown Journal!) , 1992. 
219. Anonymous Defense was-te processing facility (dwpf): the vitrification of high-level nuclear waste. (latest citations from the ntis data base). published search. (Unknown Journal!) : (vp.), 1992.

220. Anonymous Nuclear waste. (Unknown Journal!) : (62 p), 1992.

221. Anonymous Sol Gel Processes. (Latest citations from the Energy Data Base). Published Search. (Unknown Journal!) , 1992.

222. Anonymous Mixed and low-level waste treatment facility project. (Unknown Journal!) : (244 p), 1992 :

223. Anonymous Characteristics of potential repository wastes. (Unknown Journal!) : (218 p), 1992.

224. Anonymous Independent technical review of savannah river site defense waste processing facility technical issues. (Unknown Journal!) : (90 p), 1992.

225. Anonymous Radioactive Waste Storage and Disposal. (Latest citations from Pollution Abstracts). Published Search. (Unknown Journal!), 1992.

226. Anonymous Environmental audit: West Valley Demonstration Project. (Unknown Journal!), 1992 .

227. Anonymous Integrated sampling and analysis plan for samples measuring $>10$ mrem/hour. (Unknown Journal!), 1992.

228. Anonymous Nuclear Technology Programs semiannual progress report, October 1990--March 1991. (Unknown Journal!) , 1992.

229. Anonymous Em international. (Unknown Journal!) : (44 p), 1993.

230. Anonymous Influence of temperature on strength of cemented surrogate nitrate salt waste. (Unknown Journal!), 1993.

231. Anonymous Hanford Waste Vitrification Plant Qiality Assurance Program description for high-level waste form development and qualification. Revision 3, Part 2. (Unknown Journal!), 1993.

232. Anonymous IHI Engineering Review, Vol. 33, No. 1, January 1993. (Unknown Journal!), 1993.

233. Anonymous Sol Gel Processes. (Latest citations from the NTIS Bibliographic Database). Published Search. (Unknown Journal!), 1993.

234. Anonymous Radioactive waste processing: vitrification. (latest citations from the ntis bibliographic database). published search. (Unknown Journal!) :([10] p), 1993 .

235. Anonymous Radioactive Waste Processing: Borosilicate Glasses and Synthetic Rocks. (Latest citations from the NTIS Bibliographic Database). Published Search. (Unknown Journal!), 1993. 
236. Anonymous Hanford waste vitrification plant quality assurance program description: overview and applications. (Unknown Journal!) :(6 p), 1993.

237. Anonymous Defense waste processing facility (dwpf): the vitrification of high-level nuclear waste. (latest citations from the bibliographic database). published search. (Unknown JournaI!) : ([10] p), 1993.

238. Anonymous Synroc Process: Immobilization of Nuclear Wastes. (Latest citations from the Energy Science and Technology Ddatabase). Published Search. (Unknown Journal!), 1993.

239. Anonymous Radioactive Waste Storage Sites: Reclamation and Remedial Action. (Latest citations from the NTIS Bibliographic Database). Published Search. (Unknown Journal!), 1993.

240. Anonymous EPA/Navy CERCLA Remedial ACtion Technology Guide. (Unknown Journal!) , 1993.

241. Anonymous Sol Gel Processes. (Latest citations from the Energy Science and Technology Database). Published Search. (Unknown Journal!), 1993.

242. Anonymous solidification of radioactive wastesx. Jpn.Kokai Tokkyo Koho, 6 pp, 1994.

243. Anonymous Glass Melting Technology. (Latest citations from the Energy Science and Technology Database). Published Search. (Unknown Journal!), 1994.

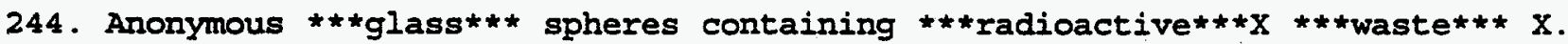
Jpn.Kokai Tokkyo Koho, 3 pp, 1994.

245. Anọnymous (Unknown Journal!) , 1994.

246. Anonymous apparatus for continuous production of **tglass*** materialsX

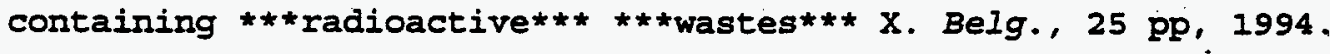

247. Anonymous oxide glassification material for low-level radioactive wastex. Jpn.Kokai Tokkyo Koho, 5 pp, 1994.

248. Anonymous $* *$ glass $* *$ material for $* * *$ glass*** -solidification of low-level $\star * \star$ radioactive $* \star \star \star \star \star$ waste $* \star x$. Jpn.Kokai Tokkyo Koho, 5 pp, 1994.

249. Anonymous stirring of radioactive waste melts in smelting furnacesX. Jpn.Kokai Tokkyo Koho, 3 pp, 1994.

250. Anonymous backfill for vitrified high-level wastex. Jpn.Kokai Tokkyo Koho, 2 pp, 1994.

251. Anonymous Radioactive waste storage sites: reclamation and remedial action. (latest citations from the ntis bibliographic database). published search. (Unknown Journal!) :([10] p), 1994.

252. Anonymous final storage of radioactive fission productsx. Ger.offen., 9 pp, 1994. 
253. Anonymous Radioactive Waste Storage Sites: Reclamation and Remedial Action. (Latest citations from the NTIS Bibliographic Database). Published Search. (Unknown Journal!), 1994.

254. Anonymous solidification of high level $\star * \star$ radioactive $* \star \star \star * *$ waste $* \star * X$ in

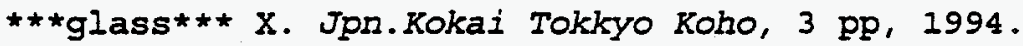

255. Anonymous borosilicate zeolite for nuclear waste disposalx. Eur.Pat.Appl., 9 pp, 1994.

256. Anonymous solidification of $* \star *$ radioactive*t* ***waste*** X. Jpn.Kokai Tokkyo Koho, 5 pp, 1994.

257. Anonymous glass-forming slurries for solidification of nuclear wastesX. Jpn.Kokai Tokkyo Koho, 8 pp, 1994.

258. Anonymous Reacti. (Unknown Journal!), 1994.

259. Anonymous ***vitrification** of ***radioactive*** ***wastes** $X$. Jpn.Kokai Tokkyo Koho, 3 pp, 1994.

260. Anonymous preliminary assessment of blending hanford tank wastes $X \mathrm{X}$ errors of dwpf frit analysis: final report: revision $1 \mathrm{x} x$ treatment technology for transuranic waste streams: cementation, $x$ vitrification, and incineration testing for the treatment of spentx ion exchange mediax statistical analysis of dwpf reference canister dimensionsx $x$ evaluating long-term performance of in situ vitrified waste forms: $X$ methodology and results $X$ X effects of container material on pct leach test results forX high-level nuclear waste glassesX perspectives on performance assessment and high-level waste glass inX a geologic repositoryx $X$ high-level waste glass compendium; what it tells us concerning theX durability of borosilicate waste glassX $X$ inorganic analyses of volatilized and condensed species withinx prototypic defense waste processing facility (dwpf) canistered wastex $x$ development of spent solvent treatment process by a submergedx combustion techniquex remaining uncertainties in predicting long-term performance ofX nuclear waste glass from experimentsX $X$ the role of natural glasses as analogs in projecting the long-termx alteration of high-level nuclear waste glasses: part $1 \mathrm{X} X$ waste glass weatheringX characterization of projected dwpf glasses heat treated to simulatex canister centerline coolingX $X$ characterization of the defense waste processing facility (dwpf) $X$ environmental assessment (ea) glass standard reference materialx $X$ vitrification of simulated intermediate-level waste from nuclearx power plants.ii.chemical stability of vitrified products in acidicx solutionsx $x$ determination of the amount and retention efficiency of aerosols $x$ arising during the vitrification of medium-level activity wastesx from nuclear power plantsx the behavior of ruthenium, cesium and antimony during simulated hllwX vitrification $X$ off-gas treatment and characterization for a radioactive in situx vitrification test $x$ effects of .alpha.-radiolysis on leaching of $a$ nuclear waste glassX $X$ chemical forms of vapors over sodium oxide-boron oxide-siliconX dioxide-tellurium dioxide glassx. (Unknown Journal!) , 1994.

261. Anonymous Defense waste Processing Facility (DWPF): The Vitrification of High-Level Nuclear Waste. (Latest citations from the NTis Bibliographic Database). Published Search. (Unknown Journal!), 1994. 
262. Anonymous treatment of uranium-containing $\star * \star$ radioactive $* \star \star \star \star * *$ waste $* \star \star X$

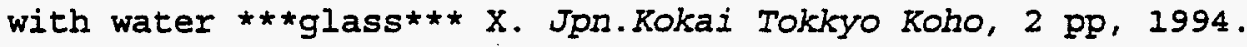

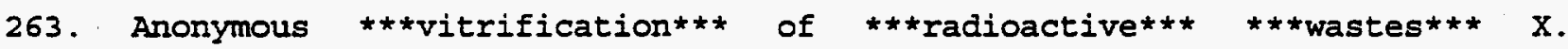
Jpn.Kokai Tokkyo Koho, 3 pp, 1994.

264. Anonymous solidification of radioactive wastex. Jpn.Kokai Tokkyo Koho, 5 pp, 1994.

265. Anonymous Mixed waste integrated program (mwip): technology summary. (Unknown Journal!) : (101 p), 1994.

266. Anonymous high level liquid waste solidification in ***glass*** $x$. Jpn.Kokai Tokkyo Koho, 9 pp, 1994.

267. Anonymous method and apparatus for waste vitrificationx. PCt Int.AppI., 27 pp, 1994.

268. Anonymous $\star \star \star$ radioactive $* * * * \star *$ waste $* \star *$ solidificationX. Jpn.Kokai Tokkyo Koho, 4 pp, 1994.

269. Anonymous Radioactive Waste Processing: Borosilicate Glasses and Synthetic Rocks. (Latest. citations from the NTIS Bibliographic Database). Published Search. (Unknown Journal!) , 1994.

270. Anonymous glass-forming component-rich siliceous waste for the manufacture ofX glassX. Ger.Offen., 3 pp, 1994.

271. Anonymous Minimum additive waste stabilization (maws). (Unknown Journal!) : (69 p), 1994 .

272. Anonymous disposal of radioactive metal-containing wastewatersx. Jpn.Kokai Tokkyo Koho, 2 pp, 1994.

273. Anonymous Defense waste processing facility (dwpf): the vitrification of high-level nuclear waste. (latest citations from the ntis bibliographic database). published search. (Unknown Journal!) : (10] p), 1994.

274. Anonymous vitrification of radioactive sodium nitrate from nuclear fuelx treatmentX. Jpn.Kokai Tokkyo Koho, 4 pp, 1994.

275. Anonymous microwave melting furnace for the vitrification and/or thex thickening of materialsX. Eur.Pat.Appl., $10 \mathrm{pp}, 1994$.

276. Anonymous removal of dust particles attached to offgas pipes in $\star \star \star$ glass $\star \star \star X$-melting furnaces for treating $\star \star \star$ radioactive $* \star \star \star * \star$ wastes $\star \star \star X$. Jpn.Kokai Tokkyo Koho, 4 pp, 1994.

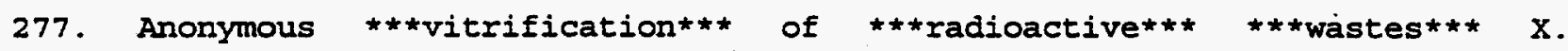
Jpn.Kokai Tokkyo Koho, 3 pp, 1994.

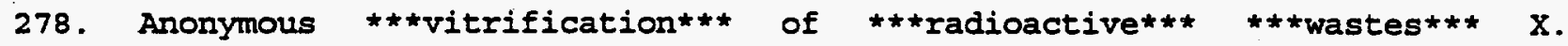
Jpn.Kokai Tokkyo Koho, 4 pp, 1994. 
279. Anonymous treatment of radioactive wastesx. Eur.Pat.Appl., 9 pp, 1994.

280. Anonymous liquidation of spent combined sorbent containing aluminosilicates, $x$ glass, and trapped radionuclides by vitrificationx. Czech., 3 pp, 1994 .

281. Anonymous apparatus for ruthenium removal in solidification ofX

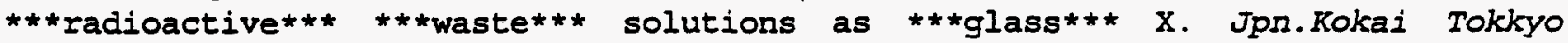
Koho, 5 pp, 1994.

282. A.Carneral, P.Mazzoldi1, A.Boscolo-Boscoletto1, F.Caccavale2, R.Bertoncello3, G.Granozzi3, I.Spagnol3, and G.Battaglin4 on the formation of silicon oxynitride by ion implantation in fused silica. Journal. of.Non-Crystalline.Solids. $125: 293-301,1990$.

283. A.Manara1, F.Lanzal, G.Cecconel, G.Della Mea2, and G.Salvagno2 BT Leaching Mechanisms CT - Application of XPS and Nuclear Technique to the Study of the Gel Layers Formed Under Different Redox Conditions on Leached Glasses ED - Carol M.Jantzen ED - John A.Stone ED - Rodney C.Ewing Anonymous 1985,p. $63-71$.

284. Abdelkader, A., Higazy, A.A., Elkholy, M.M., and Farag, H.I. Thermoluminescence Dosimetry in the Mu-Gy Range of Neodymium-Doped Tellurite Phosphate-Glass. J.MATER.SCI. 28:5133-5137, 1993.

285. Abe, Y. Phosphate glasses and glass ceramics, 1985.

286. Abernathy, C. Formation and characterization of nickel sulfide stones in thermaliy tempered glass, 1980.

287. Abrajano, Bates, and Bradley Analytical electron microscopy of leached nuclear waste glasses. Ceram.Trans. , 1990.

288. Abrajano, Bates, and Byers Aqueous corrosion of natural and nuclear waste glasses: $i$, comparativerates of hydration in liquid and vapor environments at elevatedtemperatures. J.Non-Cryst.Solids, 1986.

289. Abrajano, Bates, and Ebert Effect of gamma radiation on groundwater chemistry and glass leaching asrelated to the nnwsi (nevada nuclear waste storage investigation] repository site. Adv.Ceram. , 1986.

290. Abrajano, Bates, and Mazer Aqueous corrosion of natural and nuclear waste glasses: $i i$, mechanisms ofvapor hydration of nuclear waste glasses. J.Non-Cryst.Solids , 1989.

291. Abrajano, Bates, and Woodland Secondary phase formation during nuclear waste glass dissolution. Clays Clay Miner. , 1990.

292. Abrajano, T., A., , ; Bates, J., K., ; Bradley, J., P., and X analytical electron microscopy of leached nuclear waste glassesX. Ceram.Trans., 9 , $211-28 \mathrm{X}-28 \mathrm{X}, 1994$. 
293. Abrajano, T., A., ; Bates, J., K., ; woodland, A., B., ; Bradley, J., P., iX Bourcier, W., L., and $X$ secondary phase formation during nuclear waste-glass dissolutionX. Clays Clay Miner., 38, 537-48X-48X, 1994.

294. Abrajano, T., Bates, J., Ebert, W., and Gerding, T. Effect of gamma Radiation on Groundwater Chemistry and Glass Leaching as Related to the NNWSI Repository Site. (Unknown Journal!) , 1986.

295. Abrajano, T.A., Bates, J.K., and Bradley, J.P. Analytical Electron Microscopy of Leached Nuclear Waste Glasses. (Unknown Journal!), 1989.

296. Abrajano, T.A., Bates, J.K., Gerding, T.J., and Ebert, W.L. Reaction of Glass during gamma Irradiation in a Saturated Tuff Environment. Part 3: Long-Term Experiments at 1 x 10 Sup $4 \mathrm{Rad} /$ Hour. (Unknown Journal!) , 1988.

297. Adams, P., B., and X chemistry of nuclear waste ***glass*** reactions: problems andx potential of predictionx. Sci.Basis Nucl.Waste Manage., , MeetingX Date 1978, 123-9:lenum: NewX York, 1994.

298. Adams, R. The effect of iron in glass on glass-platinum and glass-iron contact angles and adherence, 1960.

299. Adel Hadadi, M., Adiga, R., Barkatt, A., and Feng, X. Preliminary Results of Durability Testing with Borosilicate Glass Compositions. (Unknown Journal!) , 1987.

300. Adiga, R. Leaching behavior of nuclear waste glasses under laboratory simulated repository conditions /, 1984.

301. Adiga, R., Barkatt, A., and Clark, D. Leach behavior of a defense waste [borosilicate] glass under static and dynamic conditions. Adv.Ceram. $20: 487-494$, 1986 .

302. Adiga, R., ; Barkatt, A., ; Clark, D., E., and $x$ leach behavior of a defense waste glass under static and dynamicx conditionsx. Adv.Ceram., 20 , $487-94 X-94 X, 1994$.

303. Adiga, R., B., ; Akomer, E., P.. ; Clark, D.; E., and X effects of flow parameters on the leaching of nuclear waste glassX. Mater.Res.Soc.Symp.Proc., $44, X \quad 45-54 X-54 X, 1994$.

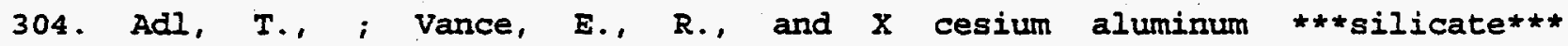
(csalsi5012): a possible hostX for cesium-137 immobilizationX. J.Mater.Sci., $17,849-55 X-55 x, 1994$.

305. Advocat, Crovisier, and Vernaz, E. Hydrolysis of 777 nuclear waste glass in dilute mediaùmechanisms and rateas a function of $\mathrm{ph}$. Mater.Res.SOC.Symp.Proc. , 1991.

306. Advocat, $T$. aqueous corrosion of french $r 7 t 7$ nuclear waste glass: selectivex then congruent dissolution by ph increasex. C.R.Acad.Sci., Ser.Ii, 313, 407-12X-12X, 1994 . 
307. Advocat, $T$. Les mecanismes de corrosion en phase aqueuse du verre nucleaire R7T7. Approche experimentale. Essai de modelisation thermodynamique et cinetique. (Aqueous corrosion mechanisms of the nuclear glass R7T7. Experimental approach. Kinetics and thermodynamic simulation). (Unknown Journal!) , 1991.

308. Advocat, T., ; Crovisier, J., L., ; Vernaz, E., ; Ehret, G., ; Charpentier, $X .$, and $X$ hydrolysis of $r 7 t 7$ nuclear waste glass in dilute media: mechanismsx and rate as a function of phx. Mater.Res.Soc.Symp.Proc., 212, $57-64 X-64 X, 1994$.

309. Advocat, T., Vernaz, E., Crovisier, J.L., and Fritz, B. Thermokinetic model of borosilicate glass dissolution: contextual affinity. (Unknown Journal!) , 1989.

310. Affatigato, M. The glass transition temperature of lithium and lithium-sodium $x$ borate glasses over wide ranges of composition, 1989.

311. Ahlf, D. and Frischat, G. Extension of glass-forming region in a ZrF//4-based system by rapid quenching. Journal.of. the.American.Ceramic.Society. J Am Ceram Soc v 72, 1989.

312. Ahn and Hrma, P. Effect of heat pretreatment on foaming of simulated nuclear waste in aborosilicate glassmelt. Adv.Ceram. , 1986.

313. Ahn, J., S., ; Hrma, P., and $x$ effect of heat pretreatment on foaming of simulated nuclear waste inX a borosilicate glass meltx. Adv.Ceram., 20, $181-90 x-90 x, 1994$.

314. Aines, R. Estimates of radionuclide release from glass waste forms in a tuff repository and the effects on regulatory compliance. Adv. Ceram. 20:91-98, 1986.

315. Aines, R.D. Estimates of Radionuclide Release from Glass Waste Forms in a Tuff Repository and the Effects on Regulatory Compliance. (Unknown Journal!) , 1986 .

316. Aines, R.D. Plan for Glass Waste Form Testing for NNWSI (Nevada Nuclear Waste Storage Investigations). (Unknown Journal!) , 1987.

317. Aines, R.D., ; Weed, H.C., ; Bates, J.K., and $X$ hydrogen speciation in hydrated layers on nuclear waste glassx. Mater.Res.Soc.Symp.Proc., 84, $\mathrm{X}$ $547-58 x-58 x, 1994$.

318. Aiyar, G.S. and Hsiu, F.J. Design of Saltstone Vaults. (Unknown Journal!) , 1987.

319. Akgunduz The regulatory compliance plan for the minimum additive waste stabilization (maws) program. (Unknown Journal!) : (10 p), 1927.

320. Akgunduz, N.K., Gimpel, R.F., and Finger, S.M. Regulatory compliance plan for the Minimum Additive Waste Stabilization (MAWS) Program. (Unknown Journal!) , 1993. 
321. Akimov, V.V. Thermal Expansion of Potassium Borosilicate Glasses. The.Soviet.journal.of.glass.physics.and.chemistry. 17, Number 4:357-361, 1992.

322. Alamo, J. Formation of nzp ceramics for the immobilization of radionuclides. Glasses and Glass-Ceram.for Nuclear Waste Managem, 1987.

323. Alcorn, S.R., Coons, W.E., Christian Frear, T.L., and Wallace, M.G. Theoretical investigations of grout seal longevity. (Unknown Journal!), 1991.

324. Alder, J., C., and $x$ the jss [japan, sweden, switzerland] project.a study on thex corrosion of high-level radioactive glassesX. Nagra Inf., 8, 20-22X-22X, 1994.

325. Alexa, J., Stejskal, J., and Vrba, K. calcination and ***vitrification*** of IiquidX $\star \star \star$ radioactive $* \star * * *$ wastes $* * X$. Czech., 3 pp, 1994.

326. Alexa, $J$, and $X$ the advantages and problems of the $* * * v i t r i f i c a t i o n * * *$ ofx standard $\star * \star$ radioactive*****wastes*** from nuclear powerX plantsX. Nukleon, (2), 10-13X-13X, 1994 .

327. Alexa, J. decontamination of vitreous depositsx. Czech., 2 pp, 1994.

328. Alexa, J. treatment of dehydrated radioactive liquid wastes fixed in glass forX their storagex. Czech., 3 pp, 1994.

329. Alexandre, D. New Directions in Liquid Wastes Treatment. (Unknown Journal!), 1984.

330. Alexandre, D., Maillet, J., and sombret, C. Vitrification of high-level waste in france.over 30 years ofx continuous development from the laboratory to industrial facilities. In: High Level Radioactive Waste and Spent Fuel Management Proc 1989 JointX Int Waste Manage Conf $v 2$ (of 2).Publ by American Soc of MechanicalX Engineers (ASME), New York, NY, USA.p 141-145, Anonymous New York, NY, USA:American Soc of MechanicalX Engineers (ASME), 1989,p. 141-145.

331. Aliaga, Fonteneau, and Lucas Synthesis and spectroscopical study of zirconium-, uranium- andX barium-based mixed fluoride glassesx. Ann.Chim. (Paris) $-8 \mathrm{X}, 1994$.

332. Aliprandi, G. 1979.

333. Allard, J. The electrical properties of a titanium phosphate glass, Alfred, N.Y.New York State College of Ceramics at Alfred University, 1978.

334. Allen, C.C., Lane, D.I., Johnston, R.G., Marcy, A.D., and Adee, R.R. Hydrothermal studies of Simulated Defense Waste Glass Plus Basalt. (Unknown Journal!) , 1984 .

335. Allen, J.C. Decontamination of the Warm Aisles at the West Valley Demonstration Project. Final Topical Report, January 1985-February 1986. (Unknown Journal!), 1986. 
336. Allen, T., Routt, K., and Porter, M. Start up of joule-heated glassmelter with a graphite slurry. Adv.Ceram. , 1985.

337. Allen, T.L., Iverson, D.C., and Plodinec, M.J. History of the Small Cylindrical Melter. (Unknown Journal!) , 1985.

338. Alles, M., Lung, M., and Jouan, A. High-level waste vitrification: the french industrial program. In: PubI by ASME, New York, NY, USA $p$ 17-22, Anonymous New York, NY, USA:ASME, 1987,P. 17-22.

339. Almeida, R. Preparation and properties of chlorophosphate glasses, 1978.

340. Aloi, A., S., ; Vishnevskii, A., ; Kuznetsov, B., ; Trofimenko, A., X V., ; Faddeev, I., and $X$ investigation on incorporation of cesium concentrates and finelyx dispersed pulps into glassy and ceramic materialsx. At. Energ., 70, $85-8 X-8 X, 1994$.

341. Aloi, A., S., ; Kolycheva, T., I., ; Trofimenko, A., V., ; Shashukov, E., $A .$, and $X$ investigation of structural transformations in the surface layer of phosphate glasses incorporating radioactive wastesX. Radiokhimiya, 27 , $822-6 \mathrm{X}-6 \mathrm{X}, 1994$.

342. Alpas, A.T., Edwards, L., and Reid, C.N. Fracture and fatigue crack propagation in a nickel-base metallic . Metallurgical.Transactions.A. (Physical.Metaliurgy.and.Materials.Science) .

Metall Trans A $v 20 A, 1989$.

343. Altenhein, F., Lutze, W., and Ewing, R. Long-term radioactivity release from solidified high-level waste: III, The effect of canister lifetime. Adv. Ceram. 8:636-644, 1985.

344. Andersen, D. Coated diatomite for treatment of radioactive wastesX. 142.pp.Avail.68-2798X. From:XDiss.Abstr.B.1968. , 1968.

345. Anderson summary of radioactive solid waste burials in the 200 areas duringx 1972X. Report. , 1974.

346. Anderson Waste glass melting stages. (Unknown Journal!) : (9 p), 1993.

347. Anderson, L.D., Dennis, T., Elliott, M.L., and Hrma, P. Noble metal behavior during melting of simulated high-level nuclear waste glass feeds. (Unknown Journal!), 1993.

348. Anderson, L.D., Dennis, T., Elliott, M.L., and Hrma, P. Waste glass melting stages. (Unknown Journal!), 1993.

349. Anderson, T.D. Hanford Waste Vitrification Plant Project Advanced Conceptual Design Summary Report. (Unknown Journal!), 1988.

350. Andersson and Ericsson Waste streams from reprocessing operationsx. Report. , 1978.

351. Andrews Radioactive demonstration of dwpf product control strategy. (Unknown Journal!) : (7 p), 1922. 
352. Andrews Durability of glasses vitrified from high copper feed in the 774 research melter. (Unknown Journal!) : $(9 \mathrm{p}), 1928$.

353. Andrews, Bibler, N., and Jantzen, C. Initial demonstration of the dwpf [defense waste processing facility]vitrification process and product control strategy using actualradioactive waste. Ceram.Trans. , 1991.

354. Andrews and Clark Initial demonstration of dwpf process and product control strategy using actual radioactive waste Low-level liquid waste disposal at the savannah river site: a large scale demonstration of saltstone. (Unknown Journal!) : (13 p), 1990.

355. Andrews, M., K., ; Bibler, N., E., ; Jantzen, C., M., ; Beam, D., C., and $X$ initial demonstration of the dwpf ***vitrification*** processX and product

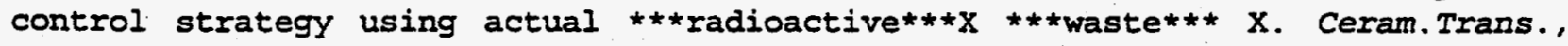
23, 569-76x-76x, 1994 .

356. Andrews, M., K., ; Bibler, N., E., and $X$ radioactive demonstration of dwpf product control strategyX. Report, Wsrc-Tr-92-217; Order No.De93002168, 7 pp, 1993.

357. Andrews, M., K., ; Cicero, C., A., ; Marra, S., I., ; Beam, D., C., ; Jantzen, X., M., and $X$ phase stability determinations of dwpf waste glassesX. Ceram.Trans., 30, 371-4X-4X, 1994.

358. Andrews, M.K., Bibler, N.E., Jantzen, C.M., and Beam, D.C. Initial demonstration of DWPF process and product control strategy using actual radioactive waste. (Unknown Journal!) , 1991.

359.. Andrews, M.K., Cicero, C.A., Marra, S.I., and Beam, D.C. Durability of simulated DWPF annealed glasses. (Unknown Journal!) , 1993.

360. Andrews, M.K., Cicero, C.A., Marra, S.I., Beam, D.C., and Jantzen, C.M. Phase stability determinations of DWPF waste glasses. (Unknown Journal!), 1992 .

361. Angel, P., Ray, C., and Day, D. Glass formation and properties in the system calcia-gallia-silica. Journal.of.the.American.Ceramic.society. J Am Ceram Soc v 73, 1990.

362. Angerman and ankin Durability of containers for storing solidified radioactive wastes. So-Mater.Perform, 1978.

363. Angerman and Rankin Durability of containers for storing solidified radioactive wastesx. Report. , 1977.

364. Anon.l Research and development on radioactive waste management and storage N. (Unknown Journal!) , 1981.

365. Anon.| Panel discussion on control emissions and hazardous waste [in the glassindustry]. Ceram.Eng.Sci.Proc. , 1990.

366. Anon| "radwastes" safe nuclear storage. Ind.Res./Dev.;21 (2): 64,1994 . 
367. Antonini, M., ; Camagni, P., ; Lanza, F., ; Manara, A., and X atomic displacements and radiation damage in glasses incorporatingX hlwX. Sci.Basis Nucl. Waste Manage., 2, 127-33X-33X, 1994.

368. Antonini, M., ; Caprile, C., ; Merlini, A., ; Petiau, J., ; Thornley, F., $R$., and $X$ exafs and xanes investigation of the coordination of technetium inx borosilicate $\star \star \star g l a s s * \star * X$. Springer Ser.Chem.Phys., 27, 261-4X-4X, 1994.

369. Antonini, M., ; Lanza, F., ; Manara, A., and X simulations of radiation damage in glassesx. Ceram.Nucl.Waste Manage., Proc.Int.Symp., Issue Conf-790420, X 289-93-93, 1994.

370. Antonini, M., ; Manara, A., ; Buckley, S., N., ; Manthorpe, S., A., and $X$ microstructural changes induced in borosilicate glasses by 1 -mevX electronsx. J.Phys.Chem.Solids, 46, 287-96X-96X, 1994.

371. Antonini, M., ; Manara, A., ; Buckley, S., and X microstructural changes in irradiated silica based glassesX. Radiat.Eff., 65, 55-61X-61X, 1994.

372. Antonini, M., ; Merlini, A., ; Thornley, F., R., and $X$ exafs and near edge absorption in glasses for nuclear waste storagex. Springer Proc.Phys., 2, $349-51 X-51 X, 1994$.

373. Antonini, M.B.,Samuel N., ; Camagni, P.G.,X Peter N., and ; Manara, A. point defects and microstructural stability of glasses underX irradiationx. Mater.Res.Soc.Symp.Proc., 6,X 709-16X-16X, 1994.

374. Antroponova, T.V. and Mazurin, O.V. Some Features of the Physicochemical Processes in the XTreatment of Two-Phase Sodium Borosilicate Glasses Xin Acid Solutions. The.Soviet.journal.of.glass.physics.and.chemistry. 16, Number $3: 1-239,1991$.

375. Antropova, T.V. Mechanism of Interaction between Glasses Which Are Identical Xin Composition to the Chemically Unstable Phase of xLiquid-Phase Separated Sodium. Borosilicate Glass Xand Nitric Acid Solutions. The.Soviet.journal.of.glass.physics.and.chemistry. 16, Number 5, 1991.

376. Antropova, T.V., Kostyreva, T.G., and Polyakova, I.G. Effect of the Composition of single-Phase Alkali Borosilicate XGlasses on Their Chemical Durability in Nitric Acid . xsolutions. The.Soviet.journal.of.glass.physics.and.chemistry. 19, Number $2: 174,1993$.

377. Antropova, T.V., Shakhamtkin, B.A., and Polyakova, I.G. The mechanism behind the extraction of $\mathrm{Na2O}$ and $\mathrm{B2O3}$ from the unstable phase of liquated sodium borosilicate glass to nitric acid solutions, 1988.

378. Applewhite Ramsey, A., ; Wolf; K., Z., ; Plodinec, M., J., and X epa tests of simulated dwpf waste glassX. Ceram.Trans., 29,X 515-22X-22X, 1994 .

379. Applewhite Ramsey, A. and Sproull, J.F. Waste acceptance product specifications for vitrified high-level waste forms. Revision 1 . (Unknown Journal!) , 1993. 
380. Applewhite Ramsey, A., Wolf, K.Z., and Plodinec, M.J. EPA tests of simulated DWPF waste glass. (Unknown Journal!), 1992.

381. Applewhite-Ramsey Epa tests of simulated dwpf waste glass. (Unknown Journal!) : (8 p), 1992 .

382. Apps, J. Alteration of natural glass in radioactive waste repository hostrocksùa conceptional review. Glasses and Glass-Ceram.for Nuclear Waste Managem , 1987.

383. Apps, J.A. Alteration of National Glass in Radioactive Waste Repository Host Rocks: A Conceptional Review. (Unknown Journal!), 1987.

384. Apted, M., J., ; Myers, J., and $x$ comparison of the hydrothermal stability of simulated spent fuel andx borosilicate $* \star * g l a s s * *$ in a basaltic environmentx. Report, Rho-Bw-St-38-P; Order No.De83010203, 88 pp, 1983.

385. Apted, M.J. and Engel, D.w. Mass-transfer analysis of waste packages containing defense waste processing facility glass as a waste form. (Unknown Journal!) , 1990.

386. Apted, M.J., MCVay, G.I., and Wald, J.W. Release of actinides from defense waste glass under simulatedx repository conditions. Nuclear Technology $73: 165-178$, 1986 .

387. Arai, K., Namikawa, H., and Kumata, K. Aluminum or phosphorus co-doping effects on the fluorescence XXand structural properties of neodymium-doped silica glass.Jo -Journal of Applied Physics. (Unknown Journal!) v. 59 (May 15 (86) : $3430-3436,1986$.

388. Arai, T., Yusa, Y., Kamei, and Gento Natural analogue study of long-term leaching behavior of vitrification glass. Weathering of volcanic glass in Fuji and Izu-Oshima. (Unknown Journal!), 1990.

389. Arai, T., Yusa, Y., Sasaki, N., Tsunoda, N., and Takano, H. Natural Analogue study of Volcanic Glass. A Case Study of Basaltic Glasses in Pyroclastic Fall Deposits of Fuji Volcano, Japan. (Unknown Journal!) , 1989.

390. Arai, T. Natural analogue study of long-term leaching behavior of vitrification glass. (Unknown Journal!) : (vp.), 1990.

391. Archer, F.A.C. and street, K.w.C. Spectrophotometric determination of silicon in bismuth Xborosilicate glass by flow injection.Jo - Analytica Xchimica acta. PY - 1992. (Unknown Journal!) 262, Number 2:243-252, 1994.

392. Axita, I., Wilkinson, D., and Purdy, G. Crystallization of yttria-alumina-silica glasses. Journal.of.the.American.Ceramic.society. v. 75 (Dec. ' 92):3315-3320, 1992 .

393. Armstrong, K., M., ; Klingler, L., and $X$ evaluation of a processing technique for immobilization of low levelx radioactive wastex. Report, M1m-3149; Order No.De84013116, 14 pp, 1984. 
394. Armstrong, K.M. and Klingler, L.M. Nitrate Waste Processing by Means of the Joule-Heated Glass Fumace. (Unknown Journal!), 1985.

395. Armstrong, K.M. and Klingler, L.M. Evaluation of a Unique System for the Thermal Processing of Radioactive and Mixed Wastes. (Unknown Journal!) , 1986.

396. Arnal, Cousinou, Desille, and Maigret Nuclear Rich alpha Cellulosic Waste Management Experiments by Acid Digestion. (Unknown Journal!) , 1985.

397. Arnal, T., Pajot, J., and Bertolotti, G. Volume Reduction and Plutonium Recovery in alpha Wastes by Cryogenic Crushing and Lixiviation. (Unknown. Journal!), 1986 .

398. Arneson, M.C., Boase, C.A., and Chambers, K.W. Design and use of a sealed radioactive leach test apparatus. Adv.Ceram. 20:551-556, 1986.

399. Arnold, G., พ., ; Doyle, B., L., and X trapping and release of implanted deuterium/hydrogen ions in fusedX silicax. Nucl.Instrum.Methods Phys.Res., 194, $491-5 X-5 X, 1994$.

400. Arnold, G., W., ; Northrup, C., J., M., ; Bibler, N., E., and $X$ near-surface leaching studies of lead-implanted savannah river wasteX ***glass*** X. Mater.Res.Soc.Symp.Proc., 11, X 357-68X-68X, 1994.

401. Annold, G., W., ; Petit, J., C., and $X$ ion-beam analysis of implanted simulated nuclear waste glassesx. Nucl.Instrum.Methods Phys.Res., 209-210, 1071-7X-210, 1071-7X, 1994.

402. Arnold, G., W., and $X$ ion implantation effects in glassesX. Radiat.Eff., $65,17-30 X-30 X, 1994$.

403. Arnold, G., พ., and $x$ ion implantation damage processes in nuclear waste glass and otherX silicate glassesX. Mater.Res.Soc.Symp.Proc., 44,X 617-22X-22X, 1994 .

404. Arnold, G., W., and X radiation damage effects in nuclear waste glassesX. Radiat.Eff., 74, 151-9X-9X, 1994.

405. Arnold, G., W., and $x$ ion implantation effects in alkali-borosilicate glassesX. Radiat.Eff., 98, 55-61X-61X, 1994.

406. Arnold, G.W. Ion implantation damage in silicate glasses. In: Materials Research Society Symposia Proceedings $v 15$. Publ by ElsevierX Science Publ Co, New York, NY, USA and Amsterdam, Neth $p$ 423-428, Anonymous New York, NY, USA:ElsevierX Science Publ Co, 1983,p. 423-428.

407. Arnold, G.W. Ion implantation damage processes in nuclear waste glass and otherX silicate glasses. In: <CI> Held as part of the Fall Meeting of the Materials ResearchX Society Materials Research Society Symposia Proceedings $v$ 44. Publ by MaterialsX Research Soc,Pittsburgh, PA, USA $p$ 617-622, Anonymous Pittsburgh, PA, USA:MaterialsX Research Soc, 1985,p. 617-622. 
408. Arnold, G.W., Ewing, R.C., Chakoumakos, B.C., Lumpkin, G.R., Murakami, T., Greegor, R.B., Lytle, F.W., and Marples, J.A.C. Ion-implantation-induced stress in glasses: variation of damage modex efficiency with changes in glass structure Metamict minerals: natural analogues for radiation damage effects inX ceramic nuclear waste forms Dose rate effects in radiation damage to vitrified radioactive waste. <CT> Radiation Effects in Insulators: Proceedings of the Fourthx International Conference on Radiation Effects in Insulators, includingx the Workshop on Radiation Damage in Nuclear Waste Materials 〈CL> Lyon, Fr 〈CD> 1987 Jul 6-10 Nuclear Instruments \& Met B32:480-486x, 1988 .

409. Arnold, G.W., Northrup, C.J.M., and Bibler, N.E. Near-surface leaching studies of pb-implanted savannah river wastex glass. In: Materials Research Society Symposia Proceedings VII.PubI byX North-Holland, New York, NY, USA and Amsterdam, Neth p 357-368, Anonymous New York, NY, USA: 1982,p. 357-368.

410. Arnold, G.W. and $X$ ion implantation damage in $* * \star s i l i c a t e * *$ glassesX. Mater.Res.Soc.Symp.Proc., 15,X 423-8X-8X, 1994.

411. Arthur, M.F., Hayes, T.D., Tolle, D.A., Pierce, G.E., and deJolsvay, T.A. Biodegradation of Uranium-Containing Waste oils and Degreaser Sludge in Soil. (Unknown Journal!), 1985.

412. Arthur, R.C. and Criscenti, L.S. Evaluating uncertainty in reactive-solute transport calculations. (Unknown Journal!), 1989.

413. Arup, O. Design Study on Containers for Geological Disposal of High-Level Radioactive Waste. (Unknown Journal!) , 1985.

414. Asahina, K.S.,Masataka; Seki handling 'system for $\star * \star v i t r i f i e d * \star *$ high-level radioactiveX liquid wasteX. R\&D, Res.Dev. (Kobe Steel Ltd.), 33, $25-8 \mathrm{X}-8 \mathrm{X}, 1994$.

415. Asano, M., Harada, T., Mizutani, Y., Ebert, W.I., Hoburg, R.F., and Bates, J.K. Vaporisation of borosilicate glasses containing all the alkali metals Sorption of water on obsidian and a nuclear waste glass. Physics and Chemistry of Glasses Physics and Chemistry of Glasses 32:133-137, 1991.

416. Asano, M., Kou, T., Harada, T., and Mizutani, Y. Vaporisation of rubidium and strontium from borosilicate glasses. Physics and Chemistry of Glasses $32: 258-262$, 1991 .

417. Asano, M., Kou, T., and Mizutani, Y. Vaporization of alkali borosilicate glasses. <CT> Proceedings of the Third International Symposium on Glass <CL> Shanghai, China $\langle C D\rangle 1988$ oct 31-Nov 4 Journal of Non-Crystalline Solids $112: 381-384,1989$.

418. Asano, M. and Yasue, $Y$. Chemical forms of vapors over $\mathrm{na} / / 20-\mathrm{b} / / 20 / / 3-\mathrm{sio} / / 2-\mathrm{teo} / / 2$ glass. Journal of Nuclear Materials 132:288-290, 1985 .

419. Asano, M. and Yasue, Y. Vapor species over $\mathrm{na} / / 20-\mathrm{b} / / 20 / / 3-\mathrm{sio} / / 2 \mathrm{cs} / / 20$ glass. Journal of Nuclear Science and Technology 22-1032, 1985. 
420. Asano, M. and Yasue, $Y$. Mass spectrometric study of the vaporization of sodium borosilicatex glasses. Journal of Nuclear Materials 138:65-72, 1986 .

421. Asano, M., Yasue, Y., and sombret, C.G. Thermochemical study of vaporization of sodium borosilicate glass meltX containing tellurium Melters and furnace equipment used for radioactive waste conditioning. Journal of Nuclear Materials <CT> Proceedings of the 1987 International Waste Management Conference. $X$ <CL> Hong Kong <CD> 1987 Nov 29-Dec 5 Publ by ASME, New York, NY, USA P 259-263 151:259-263, 1987.

422. Asano, M. thermochemistry of vaporization of simulated high-level radioactivex waste borosilicate glassesx. Kyoto Daigaku Genshi Enerugi Kenkyrusho Iho, 70, 1-16X-16X, 1994.

423. Ashida, T., Miyahara, K., Uchida, M., Yusa, Y., and Sasaki, N. Radionuclides sorption testing of granite using leachate from fullyX radioactive waste glass. In: High Level Radioactive Waste and Spent Fuel Management Proc 1989 Jointx Int Waste Manage Conf $v 2$ (of 2). Publ by American Soc of MechanicalX Engineers (ASME), New York, NY, USA.p 319-321, Anonymous New York, NY, USA:American Soc of MechanicalX Engineers (ASME), 1989,p. 319-321.

424. Assmann, D. Verfahren zur Konditionierung von Rueckstaenden einer Sondermuellverbrennungsanlage fuer die Endlagerung auf einer Uebertagedeponie. (Fixation of residues from special hazardous waste incinerators for shallow land disposal). (Unknown Journal!); 1990.

425. Assmann, D. Konditionierung von Borsaeure mit Natronwasserglas und AIPO sub 4 -Haerter. (Fixation of boric acid with sodium silicate and AlPO sub 4 ). (Unknown Journal!), 1992.

426. Assmann, D. Entsorgung eines Molke beladenen $\mathrm{Cu}$ sub 2 (Fe(CN) sub 6 )-Polystyrolionenaustauscherharzes. (Disposal of a whey-loaded Cu sub 2 (Fe(CN) sub 6) polystyrene ion exchanger resin). (Unknown Journal!), 1992.

427. Atkins, M., Glasser, F.P., Kindness, A., and Macphee, D.E. Solubility data for cement hydrate phases $(25$ (sup o) C). Experimental data generated at Aberdeen University during 1987 -1990. (Unknown Journal!) , 1991.

428. Atkinson, A., Claisse, P.A., Harris, A.W., and Nickerson, A.K. Transport of Gases Through Concrete. Annual Progress Report, 1988. (Unknown Journal!), 1989.

429. Atkinson, A., Everitt, N.M., and Guppy, R.M. Evolution of pH in a radwaste repository: internal reactions between concrete constituents. (Unknown Journal!) , 2988.

430. Atkinson, A. and Guppy, R.M. Evolution of pH in a radwaste repository. Leaching of modified cements and reactions with groundwater. (Unknown Journal!) . 1988 .

431. Atkinson, A., Hearne, J.A., and Knights, C.F. Thermodynamic modelling and aqueous chemistry in the CaO-Al2O3-SiO2-H2O system. (Unknown Journal!), 1990. 
432. Atkinson, A. and Marsh, G.B. Engineered barriers: current status 1989. (Unknown Journal!), 1989.

433. Atomic Energy of Canada Limited. AECL technical reports : waste management, Chalk River, Ontario ;Atomic Energy of Canada Limited, 1978.

434. Atomic Energy Research Establishment The phosphate glass dosimeter, H.M.S.O. 1958 .

435. Aubert, B. Process for the immobilization of nuclear waste in a borosilicate glass. (Unknown Joumal!), 1988.

436. Aubert, B. Process for the preparation of a borosilicate glass containing nuclearwaste. (Unknown Journal!) , 1989.

437. Aubert, B. ***vitrification*** of fission product $\star \star *$ radioactive $* * X$

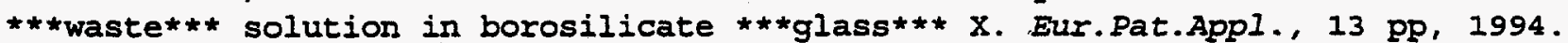

438. Aubert, B. process for preparing a borosilicate glass containing nuclear wastesX. Eur.Pat.Appl., 14 pp, 1994.

439. Auchapt, P., Bonniaud, R., Bourgeois, M., Courouble, J.M., and Tarnero, M. CEA $R$ And D Contribution to the La Hague Extension Plant. (Unknown Journal!), 1986 .

440. Aupperle, K.J. Independent Assessment of the Overall Defense Waste Processing Facility Project: Semi-Annual Report, May 1987. (Unknown Journal!) , 1987.

441. B.C.Bunker 1, G.w.Arnold 1, D.E.Day 2, and P.J.Bray 3 The Effect of Molecular Structure on Borosilicate Glass Leaching. Journal. of.Non-Crystalline.Solids. 87:226-253, 1986.

442. B.C.Sales, C.W.White, G.M.Begun 1, and I.A.Boatner Surface Layer Formation on Corroded Nuclear Waste Glasses. Jo -Journal of Non-Crystalline Solids. (Unknown Journal!) 67:245-264, 1984 .

443. B.Grambow BT - Leaching Mechanisms CT - A General Rate Equation for Nuclear Waste Glass Corrosion ED - CarOl M.Jantzen ED - JOhn A.Stone ED Rodney C.Ewing Anonymous 1985, p. 15-27.

444. Baba, T., Izumida, T., and Kikuchi, M. Process for disposing of radioactive Iiquid waste. Jpn.Kokai Tokkyo Koho J.P. , 1988.

445. Backus, P.M., Berry, J.B., Coyle, G.J., Lurk, P.พ., and wolf, S.M. Development of treatment technologies for the processing of US Department of Energy mixed waste. (Unknown Journal!), 1993.

446. Bae, B.S. and Weinberg, M.C. Oxidation-Reduction Equilibrium in Copper Phosphate-Glass Melted in Air. J.AMER. CERAM.SOC. 74:3039-3045, 1991.

447. Bae, B.S. and Weinberg, M.C. Crystallization of Copper Metaphosphate Glass. J. AMER. CERAM. SOC. 76:1395-1400, 1993. 
448. Baechmann, K., Schmitz, J., and Feldmann, F.K. Untersuchungen zur Reduzierung der alpha-aktiven Abgaenge durch Grubenwasser und anfallende Sedimente aus der Uranerzgrube Krunkelbach bei Menzenschwand. Abschlussbericht. (studies on the reduction of alpha-active tailings with mine water and sediments in Krunkelbach uranium mine near Menzenschwand. Final report). (Unknown Journal!) , 1989.

449. Baehr, W. Industrial vitrification processes for high-level liquid wastex solutions. International Atomic Energy Agency Bulletin 31:43-46, 1989.

450. Bagaasen Evaluating the technical aspects of mixed waste treatment technologies. (Unknown Journal!) : (16 p), 1992.

451. Baker, M.N., Mateer, W.E., Metzler, G.H., Reeves, S.R., and Rickettson, D.J. Design and Construction of the Low-Level Liquid Waste Treatment System. (Unknown Journal!), 1989.

452. Baker, R. and Berreth, J. Glass-ceramic composition to immobilize icpp hlw [high-level waste]. Ceram.Trans. , 1990.

453. Baker, R., ; Berreth, J., and X a glass-ceramic composition to immobilize icpp hIwX. Ceram.Trans., 9, 13-22X-22X, 1994.

454. Baker, R.S., ; Staples, B.A., ; Knecht, D.A., ; Berreth, X.J., and X experimental glass-ceramic products to immobilize icpp hlwX. Mater.Res.Soc.Symp.Proc., 112, 53-60X-60X, 1994.

455. Balasco, A.A., Stevens, J.I., Adams, J.W., Brouns, R., and Cerundolo, D.L. Bench-Scale Glassification Test on Rocky Mountain Arsenal Basin $F$ Material. Final rept. Jul 86-Dec 88. (Unknown Journal!), 1988.

456. Balasubramanian, S. and Rao, K.J. Preferential Paths in Alkali Ion Migration and the Mixed-Alkali Effect in silicate-Glasses. J.PHYS.CHEM. 97:8835-8838, 1993 .

457. Balaya, P. and Sunandana, C.S. Crystallization studies of 30Ii20-70Te02 Glass. J.NON-CRYST.SOLIDS. 162:253-262, 1993.

458. Baliga Nuclear waste managementx. Sci.Cult. $-9 x, 1994$.

459. Ballard, C. Ferrite crystallization in iron oxide-soda-silica glasses, Alfred, N.Y.New York State College of Ceramics at Alfred University, 1972.

460. Bamberger, J.A., Bates, J.M., Waters, E.D., and Heimberger, D.T. System design specification for the 1/4-scale tank and ancillary equipment. (Unknown Journal!) , 1993.

461. Bamberger, J.A., Eyler, I.I., and Dodge, R.E. Mathematical modeling of mixer pump performance for agitation of radioactive slurries in one-million-gallon underground storage tanks at Hanford. (Unknown Journal!), 1993. 
462. Banba, T. studies of high-level radioactive waste form performance at japanx atomic energy research institutex. Nippon Genshiryoku Kenkyusho, Jaeri-M, Jaeri-M 92-008, 19 pp-8, 19 pp, 1919.

463. Banba, $T$. chemical analysis of simulated high-level $\star \star \star$ radioactive $* \star \star X$ $\star \star \star$ waste $* \star \star \star * \star$ glass $* \star *$ by icp-aes and aasX. Bunseki Kagaku, 42, 317-23X-23X, 1994 .

464. Banba, T. Leaching model of nuclear waste glass. Journal of Nuclear Science and Technology 23-1082, 1986.

465. Banba, T., ; Murakami, T., ; Isobe, H., and $X$ growth rate of alteration layer and elemental mass losses during $X$ leaching of borosilicate nuclear waste glassX. Mater.Res.SOc.Symp.Proc., 176, 363-70X-70X, 1994.

466. Banba, T., Hagiya, H., Tamura, Y., and Yonezawa, C. Chemical-Analysis of Simulated High-Level Radioactive-Waste Glass by ICP-AES and AAS. BUNSEKI. KAGAKU. $42: 317-323,1993$.

467. Banba, T., Kamizono, H., and Mitamura, H. Studies of high-level radioactive waste form performance at Japan Atomic Energy Research Institute. (Unknown Journal!), 1992.

468. Banba, T., Matsumoto, S., Tashiro, S., and Nakamura, H. Leaching Test of the Radioactive Glass Waste Form. (Unknown Journal!) , 1984.

469. Banba, T., Mitamura, H., Kozai, N., and Inagaki, Y. Studies of waste form and buffer material performance at Japan Atomic Energy Research Institute. (Unknown Journal!) , 1993.

470. Banba, T., Murakami, T., and Kimura, H. Moving boundary model for leaching of nuclear waste glass. In: <CI> Held as part of the Fall Meeting of the Materials ResearchX Society Materials Research Society Symposia Proceedings $v$ 44. Publ by MaterialsX Research Soc, Pittsburgh, PA, USA $p$ 113-120, Anonymous Pittsburgh, PA, USA:MaterialsX Research Soc, 1985,p. 113-120.

471. Banba, T., Murakami, T., and Kimura, H. Leaching behavior of a glass waste form - part iii: the mathematicalx leaching model. Nuclear Technology 76:84-90, 1987.

472. Banba, T., Nukaga, K., and Sagawa, T. Temperature effect on plutonium leach rate of nuclear waste glass. Journal of Nuclear science and Technology $26: 705-711$, 1989 .

473. Banba, T., Tashiro, S., Nukaga, K., Sagawa, T., and Nomura Adsorption on various leach container materials of plutonium and curiumx leached from nuclear waste glasses. Nuclear and Chemical Waste Management 8:45-54, 1988.

474. Banba, T., ; Murakami, T., ; Kimura, H., and $X$ moving boundary model for leaching of nuclear waste glassX. Mater.Res.Soc.Symp.Proc., 44,X 113-20X-20X, 1994. 
475. Banba, T.T.,ShingoX safety evaluation of simulated high-level waste $\star \star \star g l a s s * * \star X$ products, (I).thermal stabilityX. Report, Jaeri-M-8706, 20 pp, 1980 .

476. Banba, T.T.,Shingo; Senoo ceramic solidification tests of high level wastes with naturalx zeolite, (1).effects of treatment procedures and additivesX. Report, Jaeri-M-9193, 22 pp, 1981.

477. Banba, T.M.,Seiichiro; Tashiro leaching test of the radioactive glass waste formX. Report, Jaeri-M-84-140, 15 pp, 1985.

478. Banba, T. leaching model of nuclear waste glassx. J.Nucl.Sci.Technol., 23, $1075-82 X-82 X, 1994$.

479. Banba, T.T.,Shingo; Araki safety evaluation of simulated high-level waste ***glass***X products.(ii). (preliminary tests on durability of $* * * g l a s s * \star \star X$ products in accelerated electron beam irradiation)X. Nippon Genshiryoku Kenkyusho, Jaeri-M, Jaeri-M-9189, 19 pp, 1994.

480. Banba, T.K.,Hiroshi; Nakayama studies of glass waste form performance at japan atomic energyx research institutex. Nippon Genshiryoku Kenkyusho, Jaeri-M, Jaeri-M-89-110, 21 pp, 1994.

481. Banba, T.M.,Takashi; Kimura the leaching behavior of a glass waste form part iil: theX mathematical leaching modelX. Nucl.Technol., 76, 84-90X-90X, 1994.

482. Banba, T.T.,Shingo; Nukaga adsorption on various leach container materials of plutonium andx curium leached from nuclear waste glassesX. Nucl.Chem. Waste Manage., 8, 45-54X-54X, 1994.

483. Basba, T.N.,Kiyoshi; Sagawa temperature effect on plutonium leach rate of nuclear waste glassX. J.Nucl.Sci.Technol., 26, 705-11X-11X, 1994.

484. Bancroft, G.M., Metson, J.B,, and McIntyre, N.S. Microstructural characterization of sphene ceramics. In: CCI> Held during the 85th Annual Meeting of the American Ceramicx Society Advances in Ceramics $v 8$. Publ by American Ceramic SOC Inc, Columbus, $X$ OH, USA p 282-290,Anonymous Columbus, $X$ OH, USA:American Ceramic Soc Inc, 1984,p. 282-290.

485. Bando, Y., ; Iijima, S., ; Kawamoto, Y., ; Tomozawa, M., and X application of stem to elemental analysis in ***glass*** $X$. J.Non-Cryst.Solids, 42, $151-6 \mathrm{X}-6 \mathrm{X}, 1994$.

486. Bandyopadhyay, G. Interim waste forms for high-level radioactive wastes: processing andx properties. In: Materials Research Society Symposia Proceedings $\checkmark$ 6.Publ byX North-Holland, New York, NY, USA and Amsterdam, Neth $p$ 623-631, Anonymous New York, NY, USA: 1982,p. 623-631.

487. Bannochie Factors affecting the rate of hydrolysis of phenylboronic acid in lab-scale precipitate reactor studies. (Unknown Journal!) :(26 p), 1992 .

488. Bannochie, C.J. Technical bases for precipitate hydrolysis process operating parameters. (Unknown Journal!), 1992. 
489. Bannochie, C.J., Marek, J.C., Eibling, R.E., and Baich, M.A. Factors affecting the rate of hydrolysis of phenylboronic acid in lab-scale precipitate reactor studies. (Unknown Journal!) , 1992.

490. Bansal, N. Sol-gel synthesis of magnesium oxide-silicon dioxide glass compositions. Joumal.of.the.American.Ceramic.Society. v. 71 (Aug. (88): 666-672, 1988 .

491. Baranowski, F.P., Goodlett, C.B., Beard, S.J., Duckworth, J.P., and Schneider, A. Final report of the systems engineering technical advisory board for the Tank Waste Remediation Program. Progress rept. (Unknown Journal!), 1993.

492. Barbieri, L., Leonelli, C., Manfredini, T., Paganelli, M., and Pellacani, G.C. Kinetic-study of surface Nucleated MgO-CaO-Al2O3-SiO2 Glasses. J. THERM. ANAL. 38:2639-2647, 1992 .

493. Barbu, A., Bibole, M., Le Hazif, R., Bouffard, S., and Ramillon, J.C. Radiation effects of very, heavy ions on the viscosity of a simplex glass. Journal of Nuclear Materials 165:217-221, 1989.

494. Baret, G., Madar, R., and Bernard, C. Silica-based oxide systems $I$. Experimental and calculated phase equilibria in silicon, boron, phosphorus, germanium, and arsenic oxide mixtures. Journal.of.the.Electrochemical.Society. $\mathrm{J}$ Electrochem Soc v, 1991.

495. Baricco, M., Allia, P., Vinai, F., and Riontino G. Structural relaxation in FeNiCrPB amorphous alloys by joint isothermal and tempering measurements of the electrical resistivity. Journal.of.Materials.Science J Mater Sci $v 23 \mathrm{n} \mathrm{l}$, 1988 .

496. Baricco, M., Battezzati, I., Braglia, M., Cocito, G., Kraus, J., and Modone, E. Crystallization Behavior of Fluorozirconate Glasses. J.NON-CRYST.SOLIDS. 161:60-65, 1993.

497. Barkatt, A. and Boroomand, M. Application of chemical etching techniques for modeling of leachedsurfaces. Adv.Ceram. , 1985.

498. Barkatt, A., Macedo, P., and Sutter, H.C.M. Method of separating and purifying cations by ion exchange with regenerable porous glass. (Unknown Journal!) , 1987.

499. Barkatt, A., Saad, E.E., and Adiga, R. Leaching of microtektite glass compositions in seawater. Adv. Ceram. 20:681-687, 1986.

500. Barkatt, A., Simmons, J., and Macedo, P. Evaluation of chemical stability of vitrification media for radioactivewaste products. Phys.Chem.Glasses , 1981.

501. Barkatt, A., ; Olszowka, S., A., ; Sousanpour, w., ; Choudhury, T., ; Guo, X., ; Barkatt, A., ; Adiga, R., and $x$ the use of partial-replenishment tests in modeling the leachx behavior of glassesx. Mater.Res.Soc.symp.Proc., 212, $133-9 \mathrm{X}-9 \mathrm{X}, 1994$. 
502. Barkatt, A., Adiga, R., Adel-Hadadi, M.A., Freeborn, W.P., Macedo, P.B., Montrose, C.J., Mohr, R.K., Mowad, R., and Sousanpour, W. Chemical durability studies on glass compositions pertaining to wastex immobilization at west valley. In: <CI> Volume 2: High-Level Waste $v 2$. Publ by Arizona Board of Regents, AZ, USA $p$ 507-511, Anonymous AZ, USA:Arizona Board of Regents, 1986,p. 507-511.

503. Barkatt, A., Boroomand, M.A., and sousanpour, w. Application of chemical etching techniques for modeling of leachedx surfaces. In: <CI> Held during the 85 th Annual Meeting of the American Ceramicx Society Advances in Ceramics $v 8$. Publ by American Ceramic SOC Inc, Columbus, $X$ OH, USA $P$ 482-490, Anonymous Columbus, $X$ OH, USA:American Ceramic SOC Inc, 1984,p. 482-490.

504. Barkatt, A., Gibson, B.C., and Brandys, M. Kinetic model of nuclear waste glass dissolution in flowing waterX environments. In: 〈CI > Held as part of the Fall Meeting of the Materials Researchx Society Materials Research Society Symposia Proceedings $v$ 44. Publ by MaterialsX Research Soc, Pittsburgh, PA, USA $p$ 229-236, Anonymous Pittsburgh, PA, USA:MaterialsX Research SOC, 1985,p. 229-236.

505. Barkatt, A., Gibson, B.C., Macedo, P.B., Montrose, C.J., Sousanpour, W., Boroomand, M., Rogers, and Penafiel, M. Mechanisms of defense waste glass dissolution. Nuclear Technology 73:140-164, 1986.

506. Barkatt, A., Gibson, B.C., Macedo, P.B., Montrose, C.J., Sousanpour, w., Boroomand, M., Rogers, V., and Penafiel, M. Mechanisms of defense waste glass dissolution. Nuclear Technology 73:140-164, 1986.

507. Barkatt, A., Macedo, P.B., Gibson, B.C., and Montrose, C.J. Modeling of waste form performance and system release. Nuclear Technology 73:179-187, 1986.

508. Barkatt, A., Macedo, P.B., Gibson, B.C., Mowad, R., Sousanpour, Boroomand, M.A., Adel-Hadadi, M., and Rogers, V.L. Behavior of defense waste reference glass in a long-term pulsed-flowX leach test. In: <CI> Volume 1. Waste Policies and Programs, Low-Level Waste $v 1$. Publ by Univ of Arizona, Tucson, AZ, USA $p$ 471-476, Anonymous Tucson, AZ, USA:Univ of Arizona, 1985,p. 471-476.

509. Barkatt, A., Olszowka, S.A., and Sousanpour, w. Use of partial-replenishment tests in modeling the leach behavior of glasses. .Mater.Res.SOC.Symp.Proc. 212:133-139, 1991.

510. Barkatt, A., Olszowka, S.A., and Sousanpour, W. Leach rate excursions in borosilicate glasses--effects of glass and leachant composition. Mater.Res.Soc.Symp.Proc. 212:65-76, 1991.

511. Barkatt, A., Saad, E.E., Adiga, R., Sousanpour, W., Barkatt, Adel-Hadadi, M.A., O'Keefe, J.A., and Alterescu, S. Leaching of natural and nuclear waste glasses in sea water. Applied Geochemistry 4:593-603, 1989.

512. Barkatt, A., Sousanpour, W., and Boroomand, M.A. Effects of metals and metal oxides on the leaching of nuclear wastex glasses. In: <CI> Symposium held as part of the Annual Meeting of the MaterialsX Research society Materials Research Society Symposia Proceedings $v$ 26. Publ byX North-Holland, New York, 
NY, USA and Amsterdam, Neth $p$ 689-696,Anonymous New York, NY, USA: 1984,p. 689-696.

513. Barkatt, A., ; Adiga, R., ; Adel Hadadi, M., A., ; Barkatt, A., ; Feng, $X .$, ;X Finger, S., M., ; Sousanpour, W., and $X$ development of qC and predictive leach tests for west valley glassesX. Proc.symp.Waste Manage., (Waste Manage.' 88 , Vol. 2), 473-81X-81X, 1994.

514. Barkatt, A., ; Boulos, E., N., ; DePaula, R., P., ; El Bayoumi, O., H., ;X Lagakos, N., ; Macedo, P., B., ; Moynihan, C., T., ; Rekhson, S., M., ;X Simmons, $J .$, and $x$ stability of fixation solids for high-level

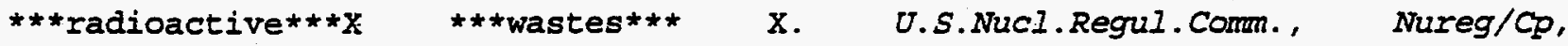
Nureg/Cp-0005, Proc.X Conf.High-Level Radioact.Solid Waste Forms, 1978; PB294865, 81-1:B294865，81-B294865154X， 1994 .

515. Barkatt, A., ; Macedo, P., B., ; Gibson, B., C., ; Mowad, R., ; Sousanpour, X.W., ; Barkatt, A., ; Boroomand, M., A., ; Adel Hadadi, M., ; Rogers, V., $I .$, and $X$ the behavior of defense waste reference glass in $a$ long-termX pulsed-flow leach testX. Proc.Symp. Waste Manage., (1), 471-6X-6X, 1994.

516. Barkatt, A., ; Macedo, P., B., ; Sousanpour, W., ; Boroomand, M., A., ;X Rogers, V., I., ; Nazari, A., ; Pimenov, G.; ; Shirron, J., J., and X leach mechanisms of borosilicate glass defense waste forms -effectsX of compositionX. Proc.Symp. Waste Manage., (1), 627-31X-31X, 1994.

517. Barkatt, A., ; Simmons, J., H., ; Macedo, P., B., and $x$ evaluation of chemical stability of $* * *$ vitrification*** mediax for $* * *$ radioactive*** ***waste*** productsX. Phys.Chem.Glasses, 22, 73-85X-85X, 1994.

518. Barkatt, A.B.,Alisa; Sousanpour effects of .gamma. radiation on the leaching kinetics of variousX nuclear waste-form materialsX. Nature (London), $300,339-41 X-41 X, 1994$.

519. Barkatt, A.B.,Alisa; Sousanpour gamma radiolysis of aqueous media and its effects on the leachingX processes of nuclear waste disposal materialsX. Nucl. Technol., 60, 218-27X-27X, 1994.

520. Barkatt, A.G.,Barbara C. and ; Brandys, M. a kinetic model of nuclear waste glass dissolution in flowing waterX environmentsx. Mater.Res.Soc.Symp.Proc., 44,X 229-36X-36X, 1994 .

521. Barkatt, A.M.,Pedro B., ; Gibson, B.C., ; Montrose, X.C., and X modeling of waste form performance and system releasex. Mater.Res.Soc.Symp.Proc., 44, $\mathrm{X}$ $3-13 X-13 X, 1994$.

522. Barkatt, A.M.,Pedro B., ; Gibson, B.C., ; Montrose, X.C., and X modeling of waste form performance and system releasex. Nucl.Technol., 73, 179-87X-87X, 1994 .

523. Barkatt, A.M.,Karen A., ; Hojaji, H.S.,Herbert G., and $X$ treatment of various nuclear generating station wastewaters withx durasil mediax. Aiche Symp. Ser., 83, 73-9x-9x, 1994. 
524. Barkatt, A.B.,Alisa; Pehrsson, ; Macedo, P.B., ; $X$ Simmons, J.H., and $x$ the importance of carbon dioxide buffering and of the total ionicx balance in measurements on the durability of glassesX. Nucl.Technol., 56, 271-7X-7X, 1994.

525. Barkatt, A.S.,William; Barkatt, ; Macedo, P.B., and X leach behavior of srl tds-131 defense waste $\star \star \star$ glass $* \star *$ in waterX at high/low flow ratesx. Mater.Res.Soc.Symp.Proc., 26,X 643-53X-53X, 1994.

526. Barkatt, A.S.,Joseph.H., ; Macedo, P.B., and $X$ corrosion mechanisms and chemical durability of $* * * g l a s s * * * X$ media proposed for the fixation of

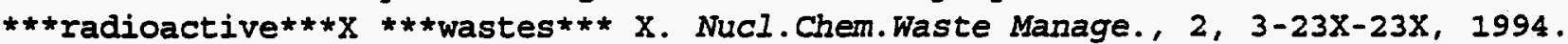

527. Barkatt, A.B.,Alisa; Boroomand, ; Sousanpour, W., and X application of chemical etching techniques for modeling of leachedx surfacesX. Adv.Ceram., 8 , 482-90x-90x, 1994.

528. Barkatt, A.B.,Alisa; Pehrsson, ; Szoke, P.M.,Pedro B., and $X$ static and dynamic tests for the chemical durability of nuclearX waste $* \star * g l a s s * * * X$. Nucl.Chem. Waste Manage., 2, 151-64X-64X, 1994.

529. Barkatt, A.M.,K., A., ; Sousanpour, W., ; Barkatt, A.P.,I., M., ; Macedo, B., P., ; Sutter, H., G., and $X$ the use of an inorganic glassy cation exchanger for the purificationx of nuclear waste streamsX. Proc.- Int.water Conf., Eng.Soc.West.Pa., 46th, 240-4X-4X, 1994.

530. Barkatt, A.S.,E., E., ; Adiga, R., ; Sousanpour, W., ; Barkatt, A., ;X Adel Hadadi, M., A., ; O'Reefe, J., ; Alterescu, S., and X leaching of natural and nuclear waste glasses in seawaterX. Appl.Geochem., 4, 593-603X-603X, 1994.

531. Barkatt, A.S.,William; Barkatt and $X$ effects of metals and metal oxides on the leaching of nuclear wasteX glassesX. Mater.Res.Soc.Symp.Proc., 26,X $689-96 \mathrm{X}-96 \mathrm{X}, 1994$.

532. Barker Annual report of tank waste treatability. (Unknown Journal!) : (124 p), 1992 .

533. Barner, J., O., ; Daniel, J., I., ; Marshall, R., R., and X zeolite ***vitrification*** demonstration program:X characterization of radioactive ***vitrified*** zeolitex materialsx. Report, Gend-Inf-043; Order No.De84007353, $80 \mathrm{pp}, 1984$.

534. Barnes, S., M., ; Brouns, R., A., ; Hanson, M., S., and X processing of high-temperature simulated waste $\star \star \star g l a s s * \star$ in ax continuous ceramic melterX. Sci.Basis Nucl.Waste Manage., 2, 859-66X-66X, 1994.

535. Barnes, S., M., ; Larson, D., E., and $x$ materials and design experience in

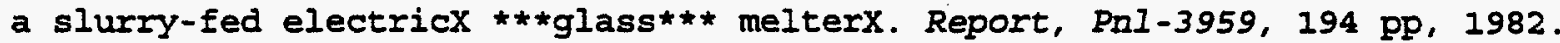

536. Barnes, S., M., ; Petkus, L., L., ; Murawski, T., F., ; Chapman, C., C., ; Pope, X.J., and $X$ reference vitrification process and equipment description 
withx results from checkout testingx. Report, Doe/Ne/44139-32; Order No.De87009317, 25 pp, 1987.

537. Barnes, S., M., ; Pope, J., ; Chapman, C., C., and X three years' progress of the west valley demonstration projectx vitrification systemX. Proc.Symp. Waste Manage., (Waste Manage. '88, Vol. 2), 195-202X-202X, 1994.

538. Barnes, S., M., ; Sevigny, G., J., ; Goles, R., W., and X corrosion experience with a slurry-fed ceramic melterX. Treat.Handl.Radioact. Wastes, , Meeting Date 1982, 203-7:ress: Columbus, Ohio, 1994.

539. Barnes, S., M., and $X$ high-temperature $* * *$ vitrification** of hanford residual-1iquidx waste in a continuous melterX. Report, Pnl-3343, 39 pp, 1980.

540. Barnes, S.M., Chapman, C.C., Petkus, L.I., Murawski, T.F., and Pope, J.M. Startup and initial experimental results for the west valleyx vitrification demonstration project. In: <CI> Volume 2: High-Level Waste $v 2$. Publ by Arizona Board of Regents, AZ, USA p 441-448, Anonymous AZ, USA:Arizona Board of Regents, 1986, p. $441-448$.

541. Barnes, S.M., Petkus, L.L., Murawski, T.F., Chapman, C.C., and Pope, J.M. Reference Vitrification Process and Equipment Description with Results from Checkout Testing. (Unknown Journal!), 1986.

542. Barnes, S.M., Westsik, J.H.J., and Wise, B.M. Instrumentation concepts for nuclear waste glass melters. In: <CI> Volume 1. Waste Policies and Programs, High-Level Waste $v 1$. Publ by Univ of Arizona, Tucson, AZ, USA $P$ 289-293, Anonymous Tucson, AZ, USA: Univ of Arizona, 1985,p. 289-293.

543. Barnes, S.M., Wise, B.M., and Westsik, J.H. Instrumentation Concepts for Nuclear Waste Glass Melters. (Unknown Journal!) , 1985.

544. Barnet, G., S., ; Wood, B., J., and $X$ identification of key radionuclides in a nuclear waste repository inx basaltx. Report, Rho-Bwi-st-9, 33 pp, 1980.

545. Barney Immobilization of aqueous radioactive cesium wastes by conversion tox aluminosilicate mineralsx. Report. , 1975.

546. Barrere, M. Vitrification of nuclear wastesx. Recherche. $-702 x, 1994$.

547. Barrett, N., T., ; Antonini, G., M., ; Thornley, F., R., ; Greaves, G., N., ; X Manara, $A .$, and $X$ structural changes around uranium at the surface of waste glassesX caused by leachingX. Mater.Res.Soc.Symp.Proc., 84, X 571-6X-6X, 1994.

548. Barrett, N.T. and $X$ glancing angle $x$-ray absorption spectroscopy to investigate changesx in. the local atomic structure around uranium in leached glassesX. (Unknown Journal!) 170 pp-83542X From: Diss, 1989.

549. Barry, J.C. A study of Nickel sulfide stones in Tempered Glass. ULTRAMICROSCOPY $52: 297-305$, 1993 . 
550. Barry, J.M., Miskelly, P.C., and Pollard, J.P. Thermal profiles for high-level radioactive waste burial. In: Publ by North-Holland, Ansterdam, Neth and New York, NY, USA $p$ 604-614,Anonymous Amsterdam, Neth and New York, NY, USA : North-Holland, 1984,p. 604-614.

551. Bart, G., Aerne, E.T., Grauer, R., Linder, H., Z'Berg, and Zwicky, H.U. surface film characterization of corroded hlw glass specimens. In: <CI> Held as part of the Fall Meeting of the Materials ResearchX Society Materials Research Society Symposia Proceedings $v$ 44. Publ by MaterialsX Research SOC,Pittsburgh, PA, USA p 213-220,Anonymous Pittsburgh, PA, USA:MaterialsX Research SOC, 1985,p. 213-220.

552. Bart, G., Aerne, E.T., and Zwicky, H. Experience in sims surface analysis of radioactive waste glasses. Nuclear Instruments \& Methods in Physics Research, Section B: Beam Interactions with Materials and Atoms B17:127-136, 1986.

553. Bart, G., Aerne, E.T., and Zwicky, H. Experience in sims surface analysis of radioactive waste glasses. Nuclear Instruments \& Methods in Physics Research, Section B: BeamX Interactions with Materials and Atoms B17:127-136, 1986 .

554. Bart, G., ; Zwicky, H., U., ; Aerne, E., T., ; Graber, T., ; Z'Berg, D., ;X Tokiwai, M., and X borosilicate glass corrosion in the presence of steel corrosionX productsX. Mater.Res.Soc.Symp.Proc., 84, X 459-70X-70X, 1994.

555. Bart, G.A.,Ernst Tino; Zwicky experience in sims surface analysis of radioactive waste glassesx. Nucl.Instrum.Methods Phys.Res., Sect.B, BI7(2), $127-36 \mathrm{X}-36 \mathrm{X}, 1994$.

556. Bart, G.A.,Ernst T., ; Grauer, R.L.,Hanspeter;X Z'Berg, and X surface film characterization of corroded hlw glass specimensX. Mater.Res.Soc.Symp.Proc., $44, \mathrm{X} 213-20 \mathrm{X}-20 \mathrm{X}, 1994$.

557. Barth, E.F. Technology Evaluation Report: Chemfix Technologies, Inc. Solidification/stabilization Process,. Clackamas, oregon. Volume 1. (Unknown Journal!) , 1990.

558. Barton, G. Solidification of high level wastes. vi. mixed phosphate, borate, $X$ silicate melts for fixation of purex-type wastesX. U.S.A.E.C. , 1967.

559. Barton, J.I. Innovation in glass melting. Glass.Technology. Glass Technology v 3, 1993.

560. Basore, C. A transparent aluminum glass from blast furnace slag, Auburn:Alabama Polytechnic Institute, Engineering Experiment Station, 1931.

561. Bastien Thiry, H., ; Laurent, J., P., ; Ricaud, J., I., and $\mathrm{X}$ french experience and projects for the treatment and packaging ofX radioactive wastes from reprocessing facilitiesx. Radioact.Waste Manage., Proc.Int.Conf., Meeting Date 1983, Volumex 2, 2-37, 1994. 
562. Batchelor, B. A Numerical Leaching Model for Solidified Stabilized Wastes. WATER.SCI.TECHNOL. 26:107-115, 1992.

563. Bates Application of the nnwsi (nevada nuclear waste storage investigations) unsaturated test method to actinide doped srl (savannah river Iaboratory) 165 type glass. (Unknown Journal!) : (83 p), 1990.

564. Bates strategy for experimental validation of waste package performance assessment. (Unknown Journal!) : (64 p), 1990.

565. Bates Initial comparison of leach behavior between fully radioactive and simulated nuclear waste glass through long-term testing: part 2, reacted layer analysis. (Unknown Journal!) : (15 p), 1992.

566. Bates, Jardine, and steindler Hydration aging of nuclear waste glass. Science (Washington, 1982.

567. Bates, Steindler, and MCDaniel Hydration of stressed nuclear waste glass. Mater.Lett. , 1984 .

568. Bates, J., Ebert, W., and Mazer Role of surface layers in glass leaching performance. Mater.Res.SoC.Symp.Proc. , 1991.

569. Bates, J., ; Buck, E., and X waste glass weatheringX. Mater.Res.Soc.Symp.Proc., 333, 41-53X-53X, 1994.

570. Bates, J., K., ; Bradley, J., P., ; Teetsov, A., ; Bradley, C., R., ; BuchholtzX ten Brink, $M .$, and $X$ colloid formation during waste form reaction: implications forx nuclear waste disposalx. Science (Washington, D.C., 1883-), $256,649-52 \mathrm{X}-1,256,649-52 \mathrm{X}, 1994$.

571. Bates, J., K., ; Ebert, W., I., ;.Feng, X., ; Bourcier, W., and X issues affecting the prediction of glass reactivity in anx unsaturated environmentx. J.Nucl.Mater., 190, 198-227X-227X, 1994.

572. Bates, J., K., ; Gerding, T., J., and $X$ application of the nnwsi [nevada nuclear waste storagex investigations] unsaturated test method to actinide doped srlX [savannah river laboratory] 165 type glassx. Report, An]-89/24; Order No.De91000583, 83 pp, 1990.

573. Bates, J., R., ; Fischer, D., F., ; Gerding, T., J., and $X$ reaction of glass during gamma irradiation in a saturated tuffX environment.part $1 . s \times 1165$ glassX. Report, Anl-85-62; Order No.De86008792, 88 pp, 1986.

574. Bates, J., K., ; Gerding, T., J., ; Fischer, D., F., ; Bbert, W., L., and $X$ the reaction of glass in a gamma-irradiated saturated tuffX environment: part 2,data package for atm-1c and atm-8 glasssesx. Report, Uerl-15991, San1-610-008-11/87; Order No.De88006239, 131X pp. 1988 .

575. Bates, J., K., ; Gerding, T., J., and $x$ one-year results of the nnwsi unsaturated test procedure: srl $165 X$ glass applicationX. Report, Anl-85-41; Order NO.De86015892, 83 pp, 1986. 
576. Bates, J., K., ; Jardine, L., J., ; Flynn, K., F., ; steindler, M., and X application of neutron activation analysis to the determination ofX leach rates of simulated nuclear waste formsX. Report, Anl-81-34; Order No.De82008709, 50 pp, 1982 .

577. Bates, J., K., ; Jardine, L., J., ; Flynn, K., F., ; Steindler, M., and X the application of neutron activation analysis to leach rate studiesx. Nucl.Chem. Waste Manage., 2, 213-18X-18X, 1994.

578. Bates, J., K., ; Jardine, L., J., ; Steindler, M., and X measurement of leaching from simulated nuclear waste $* \star \star g l a s s * \star \star X$ using radiotracersX. Report, AnI-82-10; Order No.De83003340, 72 pp, 1983.

579. Bates, J., K., ; Jardine, L., J., ; Steindler, M., and $\mathrm{X}$ hydration aging of nuclear waste $* *$ glass*** $X$. Science (Washington, D.C., 1883-), 218, $51-4 X-1,218,51-4 X ; 1994$.

580. Bates, J., K., ; Steindler, M., J., ; MCDaniel, P., L., and X hydration of stressed nuclear waste $\star * \star$ glass $* \star * X$. Mater.Lett., 2, 296-300X-300X, 1994.

581. Bates, J., R., ; Steindler, M., J., ; Tani, B., ; Purcell, F., and $x$ the hydration alteration of a commercial nuclear waste glassX. Chem.Geol., 51, 79-87X-87X, 1994 .

582. Bates, J.K. Disposal of vitrified waste in an unsaturated environment. (Unknown Journal!) , 1991.

583. Bates, J.K., Abrajano, T.A., Ebert, W.L., Mazer, J.J., and Gerding, T.J. Experimental Hydration Studies, of Natural and Synthetic Glasses. (Unknown Journal!) , 1988 .

584, Bates, J.K., Bradley, C.R., Buck, E.C., Cunnane, J.C., and Dietz, N.I. ANL Technical Support Program for DOE Environmental Restoration and Waste Management. Annual report, October 1990--September 1991. Progress rept.

(Unknown Journal!) , 1992.

585. Bates, J.K., Bradley, C.R., Buck, E.C., Cunnane, J.C., and Dietz, N.I. ANI technical support program for DOE Environmental Restoration and Waste Management. Annual report, October 1991--September 1992. Progress rept. (Unknown Journal!) , 1993.

586. Bates, J.K., Bradley, C.R., Dietz, N.I., Ebert, W.I., and Emery, J.W. Unsaturated glass testing for DOE Program in Environmental Restoration and Waste Management. Annual report, October 1989-September 1990. Progress rept. (Unknown Journal!), 1991.

587. Bates, J.K., Bradley, J.P., Teetsov, A., Bradley, C.R., and Tenbrink, M.B. Colloid Formation During Waste Form Reaction - Implications for Nuclear Waste-Disposal. SCIENCE 256:649-651, 1992.

588. Bates, J.K., Ebert, W.I., and Gerding, T.J. Vapor hydration and subsequent leaching of transuranic-containing SRL and. (Unknown Journal!) , 1989. 
589. Bates, J.K. and Gerding, T.J. Nnwsi waste form test method for unsaturated disposal conditions. In: <CI> Volume 1. Waste Policies and Programs, High-Level Waste $v 1$. Publ by Univ of Arizona, Tucson, AZ, USA p 459-465, Anonymous Tucson, Az, USA: Univ of Arizona, 1985,p. 459-465.

590. Bates, J.K. and Gerding, T.J. One-Year Results of the NNWSI Unsaturated Test Procedure: SRI 165 Glass Application. (Unknown Journal!) , 1986.

591. Bates, J.K. and Gerding, T.J. Application of the NWWSI unsaturated test method to actinide doped SRI 165 type glass. (Unknown Journal!) , 1990,

592. Bates, J.K., Gerding, T.J., Abrajano, T.A., and Ebert, W. NNWSI (Nevada Nuclear Waste Storage Investigations) Waste from Testing at Argonne National Laboratory. Semiannual Report, July-December 1985. (Unknown Journal!) , 1986.

593. Bates, J.K., Gerding, T.J., Abrajano, T.A., Ebert, W.I., and Mazer, J.J. NNWSI waste form testing at Argonne National Laboratory. Semiannual. (Unknown Journal!) , 1988.

594. Bates, J.K., Gerding, T.J., Ebert, W.I., Mazer, J.J., and Biwer, B.M. NWWSI (Nevada Nuclear Waste storage Investigation) Waste Form Testing at Argonne National Laboratory: Semiannual Réport, July-December 1987. (Unknown Journal!), 1988 .

595. Bates, J.K., Gerding, T.J., Fischer, D.F., and Ebert, w.I. Reaction of Glass in a gamma Irradiated Saturated Tuff Environment: Part 2, Data Package for ATM-1C and ATM-8 Glasses. (Unknown Journal!) , 1987.

596. Bates, J.K., Gerding, T.J., and Veleckis, E. Repository-Relevant Testing Applied to the Yucca Mountain Project. (Unknown Journal!) , 1989.

597. Bates, J.K., Gerding, T.J., and Woodland, A.B. Parametric Effects of Glass Reaction under Unsaturated Conditions. (Unknown Journal!) , 1989.

598. Bates, J.K., Lam, D.J., and Steindler, M.J. Extended leach studies of actinide-doped srl 131 glass. In: Materials Research Society Symposia Proceedings $v$ 15. Publ by ElsevierX Science Publ Co,New York, NY, USA and Amsterdam, Neth p 183-190, Anonymous New York, NY, USA:ElsevierX Science Publ Co, 1983, P. $183-190$.

599. Bates, J.K., Seitz, M.G., and Steindler, M.J. The relevance of vapor phase hydration aging to nuclear waste isolation. Nuclear.and. Chemical. Waste.Management. v. 5 nol ('84):63-73, 1984.

600. Bates, J.K. and Steindler, M.J. Alteration of nuclear waste glass by hydration, In: Materials Research Society Symposia Proceedings $v$ 15. Publ by ElsevierX Science Publ Co, New York, NY, USA and Amsterdam, Neth p 83-90, Anonymous New York, NY, USA:ElsevierX Science Publ Co, 1983,p. 83-90.

601. Bates, J.K., Steindler, M.J., and MCDaniel, P.I. Hydration of stressed nuclear waste glass. Materials Letters 2:296-300, 1984. 
602. Bates, J. Application of the NNWSI unsaturated test method to actinide doped SRL 165 type glass /, Argonne, Ill. : Springfield, Va.:Argonne National Laboratory ; available from N.T.I.S., 1990.

603. Bates, J. NNWSI waste form testing at Argonne National Laboratory semi-annual report, January-June 1988, Livermore, Calif.Lawrence Livermore National Laboratory, 1991.

604. Bates, J.K., ; Abrajano, T.A., , Ebert, w.L., ; Mazer, X.J., ; Gerding, T.J., and $X$ experimental hydration studies of natural and synthetic glassesX. Mater.Res.Soc.Symp.Proc., 123,X 237-44X-44X, 1994.

605. Bates, J.K., ; Ebert, W.L., ; Fischer, D.F., ; Gerding, X.T., and X the reaction of reference commercial nuclear waste glasses duringx gamma irradiation in a saturated tuff environmentX. J.Mater.Res., 3, 576-97X-97X, 1994.

606. Bates, J.K., ; Ebert, W.I., ; Fischer, D.F., ; Gerding, X.T., and X the reaction of reference commercial nuclear waste glasses duringx gamma irradiation in a saturated tuff environmentX. J.Mar.Res., 46, 576-97X-97X, 1994.

607. Bates, J.K., ; Gerding, T.J., ; woodland, A.B., and X parametric effects of glass reaction under unsaturated conditionsX. Mater.Res.Soc.Symp.Proc., 176, $347-54 X-54 X, 1994$.

608. Bates, J.K., ; Gerding, T.J., and $X$ nnwsi waste form test method for unsaturated disposal conditionsX. Proc.Symp.Waste Manage., (1), 459-65X-65X, 1994.

609. Bates, J.K., ; Gerding, T.J., and $X$ the performance of actinide-containing srl 165 type glass inX unsaturated conditionsX. Mater.Res.Soc.Symp.Proc., 112, $651-62 X-62 X, 1994$.

610. Bates, J.K., ; Lam, D.J., ; Steindler, M.J., and X extended leach studies of actinide-doped srI $131 * \star \star g l a s s * \star X$. Mater.Res.Soc.Symp.Proc., 15, X $183-90 x-90 x, 1994$.

611. Bates, J.K., ; Oversby, V.M., and $\mathrm{X}$ the behavior of actinide containing glasses during gamma irradiationx in a saturated tuff environmentx. Mater.Res.SOC.Symp.Proc., 44,X 257-64X-64X, 1994.

612. Bates, J.K., ; Steindler, M.J., and $X$ alteration of nuclear waste ***glass*** by hydrationX. Mater.Res.Soc.Symp.Proc., 15,X 83-90X-90X, 1994.

613. Bates, S., O.; ; Piepel, G., F., ; Johnston, J., W., and $x$ leach testing of simulated hanford waste vitrification plantX reference glass hw-39X. Report. Pnl-6884; Order No.De89012821, 180 pp, 1989.

614. Bates, S.O., Piepel, G.F., and Johnston, J.W. Leach Testing of Simulated Hanford Waste Vitrification Plant Reference Glass HW-39. (Unknown Journal!) , 1989. 
615. Bathellier, Guillaume, and Moulin Separation of transuranium elements from high-level wastes in theX reprocessing of nuclear fuelsx. Comm. Eur. Communities. $-43 \mathrm{X}, 1977$.

616. Battelle Memorial Institute.Pacific Northwest Laboratory, H. Vitrification of Hanford waste in a joule-heated ceramic melter and evaluation of resultant canisterized product /, Richland, Wash. : [Springfield, Va. :Dept. of Energy, Pacific Northwest Laboratory ; for sale by the National Technical Information Service], 1979.

617. Battles, J.E., Myles, K.M., Laidler, J.J., and Green, D.W. Chemical Technology Division annual technical report, 1992. Progress rept. (Unknown Journal!) , 1993.

618. Batyukhnova, O., G., ; Devyatkova, L., I., ; Ozhovan, M., ; Sobolev, I., X $A .$, and $X$ study of the state of $* * *$ vitrified $* * * * * *$ radioactive $* * * X * * *$ wastes $* * *$ following their long-term tests in the open areax. Dokl.Akad.Nauk SssY, 315, 373-7 X-7 X, 1994 .

619. Baucke, F.G.K. and Duffy, J.A. Oxidation-States, of Metal-Ions in Glass Melts. PHYS. CHEM. GLASSES. 35:17-21, 1994 .

620. Baudin, G. Ceramics and Glasses for Radioactive Waste storage. (Unknown Journal!) , 1984 .

621. Baudin, $G$. and $X$ ceramics and glasses for the storage of radioactive wasteX. Ann.Chim. (Paris), 10, 481-97X-97X, 1994.

622. Bauer, L.R. Gas Phase Migration of C-14 (Carbon 14) Through Barrier Materials Applicable for Use in a High-Level . Nuclear Waste Repository Located in Tuff. Thesis (Ph.D.). (Unknown Journal!), 1988.

623. Baumann, E., $W .$, and $X$ determination of iron(ii)/iron(iii) ratio in glassX. Report, Dpstm-87-700-6; Order No.De91004324, 13 pp, 1991.

624. Baumann, E.W. Colorimetric Determination of Iron(II) and Iron(III) in Glass. ANALYST 117:913-916, 1992.

625. Baumgartner, F., Krebs, K., and Merte, B. Investigations Concerning the Source Term for the Emission of Fission Products and Transuranic Elements from the Highly Radioactive Waste in the Temperature Region Between 200 and 1100 deg C. (Unknown Journal!) , 1984.

626. Baumgartner, F., Krebs, K., and Petzoldt, $O$. Overall and single-stage decontamination factors during the 1985-87X hlw-vitrification campaigns in the pamela. In: High Level Radioactive Waste and Spent Fuel Management Proc 1989 Jointx Int Waste Manage Conf $v 2$ (of 2).Publ by American Soc of MechanicalX Engineers (ASME), New York, NY, USA.P 25-30,Anonymous New York, NY, USA:American Soc of MechanicalX Engineers (ASME), 1989,p. 25-30.

627. Baxter, $R_{\text {, , }}$, , and $X$ defense waste processing facility wasteform and canisterX description: revision 2X. Report, Dp-1606-Rev.2; Order No.De89011276, 65 Pp, 1989. 
628. Baxter, R.G. Design and construction of the defense waste processing facilityx project at the savannah river plant. In: <CI> Volume 2: High-Level Waste $v 2$. Publ by Arizona Board of Regents, AZ, USA $P$ 449-454, Anonymous AZ, USA:Arizona Board of Regents, 1986,p. 449-454 .

629. Baxter, R.G. Design and Construction of the Defense Waste Processing Facility Project at the Savannah River Plant. (Unknown Journal!) , 1986.

630. Baxter, R.G. Defense Waste Processing Facility Wasteform and Canister Description: Revision 2. (Unknown Journal!) , 1988.

631. Baxter, R.G., Maher, R., Mellen, J.B., Shafranek, L.F., and stevens, W.R.I. Defense waste processing facility. In: <CI> Volume 1: Waste Policies and Programs, High-Level Waste Publ by Arizona Board of Regents, AZ, USA $p$ 275-278, Anonymous AZ, USA:Arizona Board of Regents, 1984,p. 275-278.

632. Baynes Tank waste remediation system mission analysis. (Unknown Journal!) : $(57 \mathrm{p}), 1993$.

633. Bazan, F. and Rego, J. Parametric testing of a dwpf borosilicate glass. In: <CI> Held as part of the Fall Meeting of the Materials ResearchX Society Materials Research Society Symposia Proceedings $v 44$. Publ by MaterialsX Research SOC,Pittsburgh, PA, USA P 303-310,Anonymous Pittsburgh, PA, USA:MaterialsX Research SOC, 1985,p. 303-310.

634. Bazan, F. and Rego, J. Parametric Testing of a DWPF Glass. (Unknown Journal!) , 1985.

635. Bazan, F., Rego, J., and Aines, R.D. Leaching of Actinide-Doped Nuclear Waste Glass in a Tuff-Dominated System. (Unknown Journal!) , 1987.

636. Bazan, F., ; Rego, J., ; Failor, R., ; Coles, D., and X waste form/rock interaction leaching study using pnl 76-68X $* * \star$ glass*** beads and umtanum basalt.part ix. Report, Ucid-19764; Order No.De83012449, 197 pp, 1983.

637. Bazan, F., ; Rego, J., ; Failor, R., ; Coles, D., and $x$ leaching studies using pnl 76-68 ***glass*** beads and uraniumx dioxide rods with umtanum basalt and nugget sandstoneX. Report, Ucid-20013; Order No.De84006994, 127 pp, 1984.

638. Bazan, F., ; Rego, J., H., and X tuff reaction vessel experimentX. Report, UCr1-53735; Order No.De86015288, 38 pp, 1986.

639. Bazan, F.R.,J., ; Aines, R., D., and $X$ leaching of actinide-doped nuclear waste glass in a tuff-dominatedx systemx. Mater.Res.Soc.Symp.Proc., $84, \dot{x}$ $447-58 \mathrm{X}-58 \mathrm{X}, 1994$.

640. Beale, H. Development of a strategy for the Management of High Level Radioactive Wastes. (Unknown Journal!), 1981.

641. Beale, H., ; George, M., W., ; Robertson, T., J., M., and $X$ surface storage of $\star * *$ vitrified $* \star *$ high-levelX $* * *$ radioactive*** $* * *$ waste*** in reinforced-concrete casksX. U.K.At.Energy Res.Establ., Rep., Aere-R 10222, 35 pp, 1994. 
642. Beale, $H$. and $X$ development of a strategy for the management of high

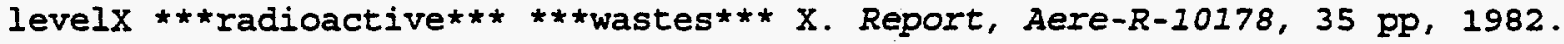

643. Beale, $H$. and $X$ storage of high-level $\star \star \star$ radioactive*t* $\star \star *$ waste*** $X$. Nucl.Energy (Br.Nucl.Energy Soc.), 21, 245-52x-52x, 1994.

644. Beall, G. and Rittler, H. Highly refractory glass-ceramics suitable for incorporating radioactivewastes. (Unknown Journal!) , 1982.

645. Beam and Colburn Performing a chemical durability test on radioactive high-level nuclear waste glass Hanford waste vitrification plant preliminary waste form and canister description: fiscal year 1990 update. (Unknown Journal!) : (43 p), 1990 .

646. Beamer, N.V., Bourns, W.T., Buckley, L.P., Pettipas, W.H., and Burrill, K.A. Studies of Reactor Waste Conditioning and Disposal at CRNL (Chalk River Nuclear Laboratories, Canada). (Unknown Journal!) , 1982.

647. Beary, Chick, Ely, and Gott Preliminary flowsheet for the conversion of hanford high-level wastex to glassx. Report. , 1978.

648. Beaven, G.W., Cross, J.E., and Hooper, E.W. Study of the Behavior of Inorganic Ion Exchangers in the Treatment of Medium Active Effluents. Pt. 5. The Encapsulation of Inorganic Ion Exchangers in Cement. (Unknown Journal!), 1988 .

649. Beazell, W. and Humenik, M. The influence of iron additions upon the ferrous - ferric equilibrium in glass, Alfred, N.Y.New York State College of Ceramics at Alfred University, 1949.

650. Beerkens, R.C. and de Waal, H. Mechanism of oxygen diffusion in glassmelts containing variable-valence ions. Joumal.of.the.American.Ceramic.Society. J Am Ceram Soc $v 73,1990$.

651. Beeston, J.M. and Larsen, M.M. Centrifugal Castings of Stainless steel Spiked with Radioactive Tracers. (Unknown Journal!) , 1985.

652. Bege, D., Faust, H.J., Puthawala, A., and Stuenkel, H. terminal storage of

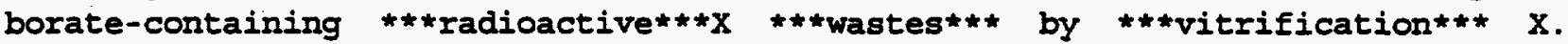
Ger.Offen., 6 pp, 1994.

653. Bege, D., Faust, H.J., Puthawala, A., and Stuenkel, H. final storage of

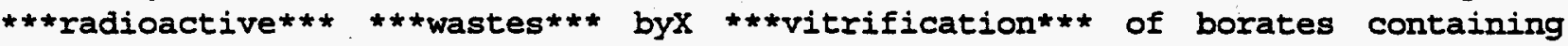
themX. Fr.Demande, 7 pp, 1994.

654. Belousov, V.V., Ananichev, V.A., Kovalgin, A.Y., and Baidakov, L.A. Vitrification and structure of Glasses of the Gesesub 2 --GeBrsub 4 system. The. Soviet.journal.of.glass.physics.and.chemistry. 17, Number 1:10-12, 1991.

655. Bengus, V.z., Diko, P., Csach, K., Miskuf, J., Ocelik, V., Korolkova, E.B., Tabachnikova, E.D., and Duhaj, P. Failure crack orientation at ductile shear fracture of $\mathrm{Fe} / / 8 / / 0 / /$ minus $/ / \mathrm{xNi} / / \mathrm{xB} / / 2 / / 0$ metallic glass ribbons. Journal.of.Materials.Science J Mater Sci v 25 I 3, 1990. 
656. Bennert, D.M., Overcamp, T.J., Compton, K.L., Sargent, T.N., and Resce, J.L. Pilot scale vitrification studies on hazardous and mixed wastes. (Unknown Journal!) , 1993.

657. Benny, H.I. and Olson, L.D. Application of remote nondestructive test methods for quality verification of grouted radioactive waste. (Unknown Journal!) , 1990.

658. Bernadzikowski, T., Allender, J., and Stone, J. High-level nuclear waste form performance evaluation. Am.Ceram.Soc.Bull. , 1983.

659. Bermer, U. Thermodynamic description of the evolution of pore water chemistry and uranium speciation during the degradation of cement. (Unknown Journal!) , 1990.

660. Berreth, J., R., ; Gombert, D., Ii; Cole, H., $S .$, and $X$ ***vitrification*** of icpp high-level zirconia calcinex. Report, Conf-790420-1, $15 \mathrm{pp}, 1979$.

661. Berretz, M. The electronic and magnetic properties of some of the first row $x$ transition metals in lithium phosphate glass, 1972.

662. Berry, J.B., Backus, P.M., Conley; T.B., Coyle, G.J., and Lurk, P.W. US Department of Energy, Office of Technology Development, mixed-waste treatment research, development, demonstration, testing, and evaluation. (Unknown Journal!) , 1993.

663. Bertozzi, Girardi, and Mousty Removal of long-lived alpha.-emitters from aqueous high level wastex. Transplutonium.1975. $-57,1975$.

664. Besson, J., Billieres, D., Rouxel, T., Goursat, P., Flynn, R., and Hampshire, S. Crystallization and properties of a Si-Y-Al-O-N glass-ceramic. Journal.of.the.American.Ceramic.Society. Journal of the Ameri, 1993.

665. Beug-Deeb, M.U.D. and Schweikert, E.A. Application of particle desorption mass spectrometry to glass surfaces.x. American Ceramic society Bulletin $66: 1635-1639,1987$.

666. Beveridge, G.D. Product quality and process control in the windscale vitrificationx plant. In: High Level Radioactive Waste Management. Publ by ASCE, New York, NY,X USA.p 420-426, Anonymous New York, NY,X USA:ASCE, 1991,p. $420-426$.

667. Bevilacqua, A.M., Russo, D.O., Messi de Bernasconi, N., and Audero, M.A. Immobilization of High-Level wastes into Sintered Glass: 2. Pressing Process at Ambient Temperature. (Unknown Journal!) , 1987.

668. Bhowmik, S. A study of extremely dense lead and bismuth based glass systems, 1993.

669. Bibler Development of a nuclear waste glass product consistency test. (Unknown Journal!) : (21 p), 1994. 
670. Bibler Analytical study plan: shielded cells batch I campaign^ revision. (Unknown Journal!) : (14 p), 1994.

671. Bibler and Kelley Effect of internal alpha radiation on borosilicate glass containingx savannah river plant wastex. Report. , 1978.

672. Bibler, J.P., Wallace, R.M., and Bray, L.A. Testing a new cesium-specific ion exchange resin for decontamination of alkaline high-activity waste. (Unknown Journal!), 1989.

673. Bibler, J.P., Wallace, R.M., and Ebra, M.A. Mercury Removal from SRP (Savannah River Plant) Radioactive Waste Streams Using Ion Exchange. (Unknown Journal!) , 1986 .

674. Bibler, N. Leaching fully radioactive srp nuclear waste glass in tuff groundwater instainless steel vessels. Adv.Ceram. , 1986.

675. Bibler, N., E., ; Jantzen, C., M., and $X$ the product consistency test and its role in the waste acceptancex process for dwpf glassx. Proc.Symp.Waste Manage... (Waste Manage. '89, Vol. 1), 743-9X-9X, 1994.

676. Biblex, N., E., ; Jurgensen, A., R., and $X$ leaching technetium-99 from srp glass in simulated tuff and saltX groundwatersX. Mater.Res.Soc.Symp.Proc., 112, 585-93X-93X, 1994.

677. Bibler, N., E., ; Wicks, G., G., ; Oversby, V., M., and X leaching savannah river plant nuclear waste glass in a saturatedx tuff environmentx. Mater.Res.Soc.Symp.Proc., 44,X 247-56X-56X, 1994.

678. Bibler, N.E. Leaching Fully Radioactive SRP Nuclear Waste Glass in Tuff Groundwater in Stainless steel Vessels. (Unknown Journall) , 1986.

679. Bibler, N.E. and Bates, J.K. Product consistency leach tests of Savannah River Site radioactive waste glasses. (Unknown Journal!) , 1989.

680. Bibler, N.E., Bibler, J.P., Andrews, M.K., and Jantzen, C.M. Initial demonstration of the vitrification of nuclear waste sludge containing an organic Cs-loaded ion exchange resin. (Unknown Journal!) , 1991.

681. Bibler, N.E. and Jantzen, C.M. Material Interactions Relating to Long-Term Geologic Disposal of Nuclear Waste Glass. (Unknown Journal!) , 1986.

682. Bibler, N.E. and Jantzen, C.M. Leach Tests at Savannah River Laboratory for Radioactive and Nonradioactive Nuclear Waste Glasses. (Unknown Journal!) , 1989.

683. Bibler, N.E., Jantzen, C.M., and Plodinec, M.J. Development of a nuclear waste glass product consistency test. (Unknown Journal!) , 1990.

684. Bibler, N.E. and Smith, K.P. Characterization of borosilicate glass containing savannah river plantx radioactive waste. In: Materials Science Research $v$ 15. Publ by Plenum Press, New York, $N Y, X$ USA and London, Engl $p$ 591-601,Anonymous New York, NY,X USA:Plenum Press, 1983,p. 591-601. 
685. Bibler, N.E., Tosten, M.H., and Beam, D.C. Recent results on the effect of gamma radiation on the durability and microstructure of DWPF glass. (Unknown Journal!) , 1989.

686. Bibler, N.E., Tosten, M.H., and Beam, D.C. Recent results on the effect of gamma radiation on the durability andx microstructure of dwpf glass. In: Proc Ist Annu Int Top Meet High Level Radioact Waste Manage Part $2 . x$ PubI by ASCE,Boston Society of Civil Engineers Sect,Boston, MA,USA.X. $p$ 1103-1109, Anonymous Boston Society of Civil Engineers Sect, Boston, MA, USA:ASCE, 1990,p. 1103-1109.

687. Bibler, N.E., Tosten, M.H., and Beam, D.C. Resent results on the effect of gamma radiation on the durability and microstructure of DWPF Glass. In: Vitrified Waste Forms, edited by Shipler, D.B. and Allen, C.R. 1990,p. 1103-1109.

688. Bibler, N.E., ; Bates, J.K., and $X$ product consistency leach tests of savanriah river site radioactiveX waste glassesX. Mater.Res.Soc.Symp.Proc., 176, $327-38 \mathrm{X}-38 \mathrm{X}, 1994$.

689. Bibler, N.E. and $x$ effects of alpha, gamma, and alpha-recoil radiation on borosilicatex ***glass*** containing savannah river plant defense high-levelx nuclear wasteX. Mater.Res.Soc.Symp.Proc., 6,X 681-7X-7X, 1994.

690. Bibler, N.E. and $X$ leaching fully radioactive srp nuclear waste glass in tuffX groundwater in stainless steel vesselsX. Adv.Ceram., 20, 619-26X-26X, 1994.

691. Bibler, N.E. and $X$ characterization of borosilicate $* *$ glass*** containing

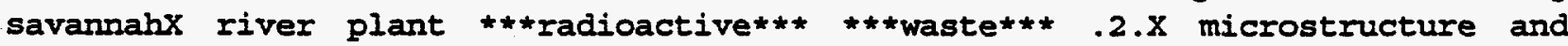
durabilityX. Glastech.Ber., 56, 736-4IX-41X, 1994.

692. Bickford Control of radioactive waste-glass melters. (Unknown Journal!) : (38 p), 1990.

693. Bickford Advanced radioactive waste-glass melters. (Unknown Journal!) :(29 p), 1990.

694. Bickford Control of high-level radioactive waste-glass melters. (Unknown Journal!) : (22 p), 1990.

695. Bickford Control of high level radioactive waste-glass melters. (Unknown Journal!) : (25 p), 1990.

696. Bickford Control of high level radioactive waste-glass melters. (Unknown Journal!) : (17 p), 1991.

697. Bickford, D. Waste glass structures, basicity, and sensors for glass quality monitoring. Ceram.Trans. . 1991.

698. Bickford, D. Advanced radioactive waste-glass melters. Ceram.Trans. , 1991. 
699. Bickford, D., Applewhite-Ramsey, A., and Jantzen, C. Control of radioactive waste glass melters: $i$, preliminary generallimits at savannah river. J.Am.Ceram.SoC. , 1990.

700. Bickford, D. and Choi Control of high-level radioactive waste-glass melters: $v$, modeling ofcomplex redox effects. Ceram.Trans. , 1991.

701. Bickford, D. and Coleman Control of high-level radioactive waste-glass melters: iv, preliminaryanalysis of dwpf [defense waste processing facility] process laboratorycapabilities. Ceram.Trans. , 1991.

702. Bickford, D., Corbett, R., and Morrison, w. Test methods for selection of materials of construction for high-levelradioactive waste vitrification. Adv. Ceram. , 1986.

703. Bickford, D., Diemer, and Iverson Redox controi of electric melters with complex feed compositions: $i$,preliminary limits for radioactive waste melters. J.Non-Cryst.Solids , 1986.

704. Bickford, D., Horsfall, and Woolley, F. Advances in the fusion of glass $Y$. (Unknown Journal!), 1988.

705. Bickford, D., Hrma, P., and Bowan, B. Control of radioactive waste glass melters: ii, residence time and meltrate limitations. J.Am.Ceram.Soc. , 1990.

706. Bickford, D. and Jantzen, C. Devitrification of defense nuclear waste glassesurrole of melt insolubles. J.Non-Cryst.Solids, 1986.

707. Bickford, D., Ondrejcin, R., and Salley, L. High-temperature materials for radioactive waste incineration andvitrification. Adv.Ceram. , 1986.

708. Bickford, D., Propst, and Plodinec Control of radioactive waste-glass meltersùglass electrical stability. Adv.Fusion Glass , 1988.

709. Bickford, D., ; Applewhite Ramsey, A., ;X Brown, K., and X control of ***radioactive*** ***waste*** ***glass***X melters: 1 .preliminary general limits at savannah riverX. J.Am.Ceram.Soc., 73, 2896-902X-902X, 1994.

710. Bickford, D., F., ; Choi, A., S., and $X$ control of high level

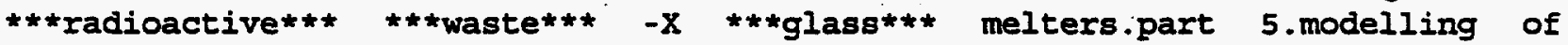
complex redox effectsX. Ceram.Trans., 23, 267-81X-81X, 1994.

711. Bickford, D., F., ; Coleman, C., J., and $x$ control of high-level ***radioactive*** ***waste*** $-\mathrm{X} * * *$ glass*** melters - part 4: preliminary analysis of dwpfx process laboratory capabilitiesx. Ceram.Trans., 23, 597-606X-606X, 1994.

712. Bickford, D., F., ; Smith, M., E., ; Allen, P., M., ; Faraci, J., P., ; Langton, X., A., ; Wolf, K., Z., and X application of high-level waste-glass technology to the volumex reduction and immobilization of tru,low-level, and mixed wastesX. Waste Manage. (Tucson, Ariz.), (Vol. 1), 537-45X-45X, 1994.

713. Bickford, D., F., and $X$ waste glass structures,basicity, and sensors for glass qualityX monitoringX. Ceram.Trans., 23, 607-20X-20X, 1994. 


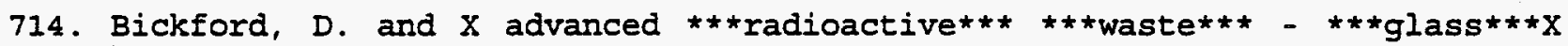
meltersX. Ceram. Trans., 23, 335-47X-47X, 1994.

715. Bickford, D., F., ; Jantzen, C., M., and X devitrification of defense nuclear waste glasses: role of meltx insolublesx. J.Non-Cryst.Solids, 84, 299-307X-307X, 1994.

716. Bickford, D., F., ; Propst, R., C., ; Plodinec, M., J., and $\mathrm{X}$ control of

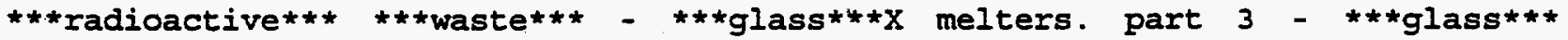
electrical stabilityx. Adv.Fusion Glass, Proc.Int.Conf., 1st, 19-19, 1994.

717. Bickford, D.F. Hot Corrosion of Inconel 690 in DWPF Melter: Recommendation for Design Change to Melter Lid Heaters: (Unknown Journal!), 1986.

718. Bickford, D.F. Advanced radioactive waste-glass melters. (Unknown Journal!) , 1990.

719. Bickford, D.F., Allen, P.M., and Peters, S.M. Noble Metal Accumulation and Recovery in DWPF Waste-Glass Melter. (Unknown Journal!) , 1989.

720. Bickford, D.F., Applewhite Ramsey, A., Jantzen, C.M., and Brown, K.G. Control of radioactive waste glass melters. Part 1, Preliminary general limits at Savannah River. (Unknown Journal!) , 1990.

721. Bickford, D.F., Applewhite-Ramsey, A., Jantzen, C.M., and Brown Control of radioactive waste glass melters. $i$, preliminary generalx limits at savannah river. Journal of the American Ceramic Society 73:2896-2902, 1990.

722. Bickford, D.F. and Choi, A.S. Control of high level radioactive waste-glass melters. Part 5, Modelling of complex redox effects. (Unknown Journal!) , 1991.

723. Bickford, D.F. and Coleman, C.J. Control of high-level radioactive waste-glass melters. Part 4, Preliminary analysis of DWPF process laboratory capabilities. (Unknown Journal!), 1990.

724. Bickford, D.F., Coleman, C.J., Hsu, C.L.W., and Eibling, R.E: Control of high level radioactive waste-glass melters. Part 6 , Noble metal catalyzed formic acid decomposition, and formic acid/denitration. (Unknown Journal!) , 1990.

725. Bickford, D.F., Corbett, R.A., and Morrison, w.S. Test Methods for Selection of Materials of Construction for High-Level Radioactive waste Vitrification. Revision. (Unknown Journal!), 1986.

726. Bickford, D.F. and Diemer, R.B. Redox Control of Electric Melters with Complex Feed Compositions. Part 1: Analytical Methods and Models. (Unknown Journal!) , 1985.

727. Bickford, D.F., Diemer, R.B., and Iverson, D.C. Redox Control of Electric Melters with Complex Feed Compositions. Part 2: Preliminary Limits for Radioactive Waste Melters. (Unknown Journal!) , 1985. 
728. Bickford, D.F., Hrma, P., and Bowan, B.w. Control of radioactive waste-glass melters. Part 2, Residence time and melt rate limitations. (Unknown Journal!) , 1990.

729. Bickford, D.F., Hrma, P., and Bowan, B.W.I. Control of radioactive waste glass melters. $i i$, residence time and meltx rate limitations. Journal of the American Ceramic Society 73:2903-2915, 1990.

730. Bickford, D.F. and Jantzen, C.M. Devitrification of defense nuclear waste glasses: role of meltx insolubles. Journal of Non-Crystalline Solids $84: 299-307,1986$.

731. Bickford, D.F., Ondrejcin, R.S., and Salley, L. High Temperature Materials for Radioactive waste Incineration and Vitrification. Revision 1. (Unknown Journal!) , 1986.

732. Bickford, D.F., Propst, R.C., and Plodinec, M.J. Control of Radioactive Waste-Glass Melters: Part 3, Glass Electrical stability. (Unknown Journal!), 1988 .

733. Bickford, D.F., Smith, M.E., Allen, P.M., Faraci, J.P., and Langton, C.A. Application of high level waste-glass technology to the volume reduction and immobilization of TRU, low level, and mixed wastes. (Unknown Journal!), 1991.

734. Bickford, D.F., Smith, P.K., Erma, P., and Bowan, B.W. Control of radioactive waste-glass melters. Parts 1 and 2. (Unknown Journal!), 1987.

735. Bickford, D.F., ; Jantzen, C.M., and $x$ devitrification behavior of srl defense waste $\star \star \star$ glass $* \star \star X$. Mater.Res.Soc.Symp.Proc., 26,X 557-66X-66X, 1994 .

736. Bickford, D.F., ; Pellarin, D.J., and X large scale leach testing of dwpf canister sectionsX. Mater.Res.Soc.Symp.Proc., 84,X 509-18X-18X, 1994.

737. Bidoglio, G., offermann, P., and Saltelli, A. Neptunium migration in oxidizing clayey sand. Applied Geochemistry 2:275-284, 1987.

738. Bidoglio, G., ; Offermann, P., ; De Plano, A., ; Lazzari, G., P., and X influence of groundwater composition on glass leaching and actinidex speciationx. Mater.Res.Soc.Symp.Proc., 112, 621-30X-30X, 1994.

739. Bihuniak, P. Structures,spectra and related properties of titanium-, $X$ zirconium-, and hafnium-doped vitreous silica, Alfred, N.Y.New York state College of Ceramics at Alfred University, 1979.

740. Bihuniak, P. Effect of trace impurities on devitrification of vitreous silica. Journal.of.the.American.Ceramic.Society. v. 66 (Oct. '83):C188-C189, 1983 .

741. Billon, A., Nomine, J.C., and Deyson, M. Scale Effect in Lixiviation. (Unknown Joumal!) , 1988. 
742. Bindon, F.J.L. Synroc. the australian solution to radioactive waste management. Nuclear Engineer: Journal of the Institution of Nuclear Engineers $30 \mathrm{x}: 174-178,1989$.

743. Birnbaum Chemical composition of hanford tank sy-102. (Unknown Journal!) : (99 p), 1993 .

744. Birmbaum, E., Agnew, S., Jarvinen, G., and Yarbro, S. Chemical composition of Hanford Tank SY-102. (Unknown Journal!) , 1993.

745. Bish, D.L. Smectite Dehydration and Stability: Applications to Radioactive Waste Isolation at Yucca Mountain, Nevada. (Unknown Journal!) , 1988.

746. Bish, D.I. and Chipera, S.J. Revised Mineralogic Sunmary of Yucca Mountain, Nevada. (Unknown Journal!) , 1989.

747. Biwer, B.M., ; Bates, J.K., ; Abrajano, T.A., , ; Bradley, X.J., and X comparison of the layer structure of vapor phase and leached srix glass by use of aemX. Mater.Res.Soc.Symp.Proc., 176, 255-63X-63X, 1994.

748. Bjoerner, I.K., Zwicky, H.U., Magrabi, C., Ewing, R.C., and Grambow, B. JSS Project phase 5: Testing and modelling of the corrosion of simulated nuclear waste glass powders in a waste package environment, Final report. Progress rept. (Unknown Journal!), 1988.

749. Bjoerner, I.K.,H., ; Hermansson, H., P., ; Tsukamoto, X.M., ; Werme, L., and $\mathrm{X}$ corrosion of radioactive, crushed waste glassX. Mater.Res.Soc.Symp.Proc., 127, 113-20X-20X, 1994.

750. Bjorklund Fluidized bed calcination experience with simulated commercialx high-level nuclear wastex. Report. , 1977.

751. Bjorklund, w., J., ; Hanson, M., S., and $X \star \star \star \star v i t r i f i c a t i o n * \star \star$ of actual high-level waste from light waterx reactor fuelx. Proc.Conf.Remote Syst. Technol., Volume Date 1979, 27, 396-401X-401X, 1994.

752. Bjorklund, W., J., ; Irish, E., R., ; McElroy, J., L., ; Siemens, D., H., iX Wheelwright, $E .$, and $X * * * v i t r i f i c a t i o n * * *$ of high-level liquid waste from light-waterX reactor fuelx. Waste Manage.'79: State Waste Disposal Technol.X Soc.Polit.Implic., Proc.Symp., 310-14:ost, RoY G, 1994.

753. Bjorklund, W., J., ; Mellinger, G., B., ; Pope, J., M., and $X$ ***vitrification*** of simulated west valley waste using aX liquid-fed ceramic melterX. Adv.Ceram., 8, 193-9X-9X, 1994.

754. Bjorklund, W., J., and $X$ defense waste $* *$ vitrification $* *$ studies during fy 1980X. Report, Pnl-3818, 91 pp, 1981.

755. Bjorklund, W.J. and Brouns, R.A. Operating characteristics of a direct liquid-fed vitrification process.x. In: 〈CI> Selected Papers presented at the American Nuclear Society TopicalX Meeting Publ by Battelle Press, Columbus, $O H$ and Richland,WA, USA andX Springer-Verlag, New York, NY, USA and Heidelberg, West Ger $p$ 197-202,Anonymous Columbus, $\mathrm{OH}$ and Richland, WA, USA:Battelle Press, 1983, p. 197-202. 
756. Bjorklund, w.J., Holton, L.K., and Knowlton, D.E. Vitrification of high level radioactive waste in a pilot-scalex liquid-fed ceramic melter. In: <CI> Volume 1. Waste Policies and Programs, High-Level Waste $v 1$. Publ by Univ of Arizona, Tucson, AZ, USA $p$ 331-339,Anonymous Tucson, AZ, USA:Univ of Arizona, 1985,p. $331-339$.

757. Bjorklund, W.J., Holton, L.K., and Knowlton, D.E. Vitrification of High-Level Radioactive waste in a Pilot-Scale Liquid-Fed Ceramic Melter. (Unknown Journal!) , 1985.

758. Bjorklund, w.J. and McElroy, J.L. Operating Radioactive Liquid-Fed Ceramic Melter System. (Unknown Journal!) , 1986.

759. Bjorklund, W.J., MCElroy, J.I., and Mendel, J.E. Calcination of radioactive wastesX. Ger.Offen. , 1994.

760. Bjorklund, w.J., Mellinger, G.B., and Pope, J.M. Vitrification of simulated west valley waste using a liquid-fed ceramicX melter. In: 〈CI> Held during the 85th Annual Meeting of the American Ceramicx Society Advances in Ceramics $\vee 8$. Publ by American Ceramic SOC Inc, Columbus, $x$ OH, USA $p$ 193-199, Anonymous Columbus, X OH, USA:American Ceramic SOC Inc, 1984,p. 193-199.

761. Blair Vitrification of nuclear waste calcines by in-can meltingx. Report. , 1977.

762: Blair, G. Analysis and control of ferrous and ferric iron in glasses, Alfred, N.Y.New York State College of Ceramics at Alfred University, 1948.

763. Blair, H., T., ; Mellinger, G., B., and $X$ process for $\star \star \star v i t r i f i c a t i o n * \star *$ of contaminated sodium oxideX. Adv.Ceram., 8, 603-10X-10X, 1994.

764. Blair, H. and Thomasx full-scale in-can melting for $* \star \star v i t r i f i c a t i o n * \star *$ of nuclearX wastesX. Nucl.Technol., 49, 267-73X-73X, 1994.

765. Blair, H.T. and McMakin, A.E. Modifying the rheological properties of melter feed for the hanfordx waste vitrification plant. In: <CI> Volume 2: High-Level Waste $v 2$. Publ by Arizona Board of Regents, AZ, USA $p$ 489-494, Anonymous AZ, USA:Arizona Board of Regents, 1986,p. 489-494.

766. Blair, H.T. and MoMakin, A.H. Modifying the Rheological Properties of Melter Feed for the Hanford Waste Vitrification Plant. (Unknown Journal!), 1986.

767. Blair, H.T. and Mellinger, G.B. Process for vitrification of contaminated sodium oxide. In: <CI> Held during the 85th Annual Meeting of the American CeramicX Society Advances in Ceramics $v 8$. Publ by American Ceramic Soc Inc, Columbus, $X$ OH, USA $p$ 603-610,Anonymous Columbus, $X$ OH, USA:American Ceramic SOC Inc, 1984,p. 603-610.

768. Blair, H.T. and Mellinger, G.B. Process for vitrification of contaminated sodium oxide. Adv. Ceram. 8:603-610, 1985. 
769. Blasewitz, McElroy, and Schneider Solidification of high-level liquid radioactive wastesX. Report. , 1973.

- 770. Blasewitz, Richardson, McElroy, Mendel, and X, S.K.. High-level waste solidification demonstration programx.

Symp.Manage.Radioactive.Wastes.Fuel.Reprocess. -54, 1972.

771. Blomeke, J.O. Review and Analysis of European Industrial Experience in Handling LWR (Light Water Reactor) Spent Fuel and Vitrified High-Level Waste. (Unknown Journal!), 1988.

772. Blomquist Leaching of french, english and canadian glass withx incorporated highly radioactive waste $\mathrm{X}$. Report. , 1978.

773. Blomqvist Calculated leaching of certain fission products from a cylinder ofx french glassX. Report. , 1978.

774. Blomqvist Introductory calculations of temperatures in a rock storage forx final disposal of radioactive waste.report no.2X. Report. , 1978.

775. Bloom, I., Bradley, J., and Roche, M.F. Chemical stability of Na2O-ZrO2-Al2O3-SiO2 glasses in sodium, sodium polysulfides, and sulfur. Journal. of. the. Electrochemical. Society.v.134. (Sept. '87).p.2102-6.bibl. 13-4651, 1987.

776. Blum, J. and Verot, J.I. Safe storage of fission products in a dry mannerX. Ger. Offen. , 1994.

777. Boatner, L. and Sales, B. Lead iron phosphate glass as a containment medium for disposal ofhigh-level nuclear waste. (Unknown Journal!) , 1989.

778. Boatner, L.A. and Sales, B.C. Lead-Iron Phosphate Glass as a Containment Medium for the Disposal of High-Level Nuclear Wastes. Patent Application. (Unknown Journal!) , 1984.

779. Boatner, I.A. and Sales, B.C. lead iron phosphate glasses for solidifying and containing highlyx radioactive. nuclear wastesx. Belg., 31 pp, 1994.

780. Boatner, I.A. and Sales, B.C. chemically and physically durable iron lead phosphate glassX. U.S., 3 pp-in-part of U, 1994.

781. Bobe, J.M., Senegas, J., Reau, J.M., and Poulain, M. Ionic-Conductivity and F-19 NMR Investigations of Some Series of ZrF4-Based Fluoride Glasses Containing LaF3 or Yf3. J.NON-CRYST.SOLIDS. 162:169-177, 1993.

782. Boccaccini, A. Anisotropic densification during sintering of glass powder compacts. Journal of Materials Science Letters 12:943-945, 1993.

783. Boccaccini, A., R., and $x$ anisotropic densification during sintering of glass powder compactsX. J.Mater.Sci.Lett., 12, 943-5X-5X, 1994.

784. Bocola Pot-vitrification of fully radioactive fuel reprocessing wastes: $x$ planning of hot-cell experimentsx. Manage.Radioact. Wastes.Nucl.Fuel.Cycle -13 , 1994. 
785. Bocola and Donato Treatment of radioactive liquid wastes obtained during thex reprocessing of irradiated fuels.[a solidification process]X. G.Fis.Sanit.Prot.Radiaz. -16X, 1994.

786. Bocola and Donato Ester program.solidification of waste liquid of increasedx activity. vitrification of simulated fission products solutions inx a bench-scale laboratory.formation of phosphate glassesX. Com.Naz. Energ.Nucl. , 1994 .

787. Bocola and Donato Ester program-high-level radioactive wastex solidification. bench-scale phosphate glassX vitrification tests with simulated fission product solutionsX. Energ.Nucl. (Milan). $-401 X, 1994$.

788. Bocola and Donato Ester program.solidification of high activity liquid wastes.X characteristics of phosphate glasses prepared from solutionsX simulating fission productsX. Com.Naz.Energ.Nucl. , 1994.

789. Bodalbhai, $L$. and Hrma, P. The dissolution of silica grains in isothermally heated batches of sodium carbonate and silica sand. Glass. Technology. v. 27 (Apr. 186):72-78, 1986.

790. Bodocsi, A. and Bowers, M.T. Permeability of acrylate, urethane, and silicate grouted sands withx chemicals. Journal of Geotechnical Engineering $117: 1227-1244$, 1991.

791. Boehmer, A.M. and Larsen, M.M. Hazardous and Mixed Waste Solidification Development Conducted at the Idaho National Engineering Laboratory. (Unknown Journal!) , 1986.

792. Boekenhauer, $R$. The density of lithium borosilicate glasses related to atomic $X$ arrangement, 1991.

793. Boen, R., Bousquet, F., Hery, Y., and Jouan, A. Some Applications of Melting in a Cold Crucible. (Unknown Journal!), 1987.

794. Boersma, M., D., and X process technology for vitrification of defense high-level waste atx the savannah river plantx. Fuel Reprocess. Waste Manage., Proc. - Am.Nucl.Soc.Int.Top.X Meet., Volume 1, 131-46:ark, Ill, 1994.

795. Boersma, M.D. Process technology for vitrification of defense high-level waste at theX savannah river plant. In: $v 1$. Publ by ANS, La Grange Park, IL, USA $p$ 131-146, Anonymous La Grange Park, IL, USA:ANS, 1984,p. 131-146.

796. Boersma, M.D. Applications of Chemical Engineering Principles to Glassmaking for Nuclear Waste Fixation. (Unknown Journal!) , 1988.

797. Boersma, M.D., MCDonell, W.R., Goodlett, C.B., and Thomas, S.D. Long-term strategy for management of savannah river site defensex high-level nuclear wastes (u). In: High Level Radioactive Waste and Spent Fuel Management Proc 1989 Jointx Int Waste Manage Conf $v 2$ (of 2).Publ by American Soc of MechanicalX Engineers (ASME), New York, NY, USA.p 531-536, Anonymous New York, NY, USA:American SOC of MechanicalX Engineers (ASME), 1989,p. 531-536. 
798. Boersma, M.D., McDonell, W.R., Goodlett, C.B., Thomas, S.D., and slate, S.C. Long-Term Strategy for Management of Savannah River Plant Defense High-Level Nuclear Wastes. (Unknown Journal!) , 1989.

799. Boettcher Analytical solutions for simple heat-transfer problems in thex disposal of solidified high-level radioactive wastesx. Kernenergie. -61X, 1994.

800. Bogomolova, I.D., Ivanov, I.A., Stefanovskii, S.V., Teplyakov, Y.G., and Trul', O.A. The structure of Aluminoborosilicate, Borosilicophosphate, and Aluminoborosilicophosphate Vitreous Materials Simulating Vitrified Radioactive wastes. The.Soviet.journal.of.glass.physics.and.chemistry. 19, Number $5: 413-420$, 1993 .

801. Boike, M., Hilpert, $K .$, and Muller, F. Thermodynamic activities in $\mathrm{B} / / 2 \mathrm{O} / / 3-\mathrm{SiO} / / 2$ melts at $1475 \mathrm{~K}$. Journal.of.the.American.Ceramic.Society. Journal of the Ameri, 1993.

802. Bokelund, H., ; Deelstra, K., and X statistical tests applied as quality control measures to leaching of $X$ nuclear waste glasses and in the evaluation of the leach vesselX. Radioact. Waste Manage.Nucl.Fuel Cycle, 11, 61-75X-75X, 1994.

803. Bokhari, W. and Nazar, F. Variation of band gap with temperature in cadmium phosphate glass. International.Journal.of.Electronics. $v 65$ n 4 oct $1988: 809-813$; 1988 .

804. Bolon, W.D., Herzog, J.D., and Olson, A.I. Glass-ceramic processing flowsheet for ICPP high-level waste: status report. Progress rept. (Unknown Journal!) , 1991.

805. Bolotin, V.P., Mikhailovskii, I.P., and Cherepov, E.I. Precipitation Speed of Phosphorosilicate Glass Layers from SiH4-02-(Ch30)3Po Gas-Phase in Nonisothermal Reactor Using the Cat-CVD Method. KHIM.FIZ. 12:268-273, 1993.

806. Boncoeur, M., Lieven, T., Palacio, M., and Mandet, F. Hot Isostatic Pressing of Ceramics. (Unknown Journal!) , 1985.

807. Bonetti Characterization of vitreous materials for nuclear wasteimmobilization. Riv.Stn.Sper.Vetro', 1986.

808. Bonetti, G. Vitreous titania enamels for nuclear waste disposal. Riv.Stn.Sper.vetro， 1987.

809. Bonetti, G. and $X$ vitreous titania enamels for nuclear wastesX. Riv.Sta.Sper.Vetro (Murano, Italy), 17, 73-85X-85X, 1994.

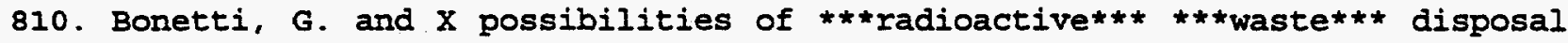
inX vitreous matrixesX. Riv.Stn.Sper.Vetro (Murano, Italy), 12, 15-28X-28X, 1994.

811. Bonetti, G. and $X$ characterization of vitreous materials used for immobilization ofX radioactive wastex. Riv.Stn.Sper.Vetro (Murano, Italy), 16, 109-18X-18X, 1994. 
812. Bonithonkopp, C., Levenson, J., Scarabin, P.Y., Guillanneuf, M.T., Kirzin, J.M., Malmejac, A., and Guize, L. Longitudinal Associations Between Plasma Viscosity and Cardiovascular Risk-Factors in a Middle-Aged French Population. ATHEROSCLEROSIS 104:173-182, 1993.

813. Bonnell, Plante, and Hastie Vaporization of simulated nuclear waste glass. J.Non-Cryst.Solids, 1986.

814. Bonnell, D., W., ; Plante, E., R., ; Hastie, J., and $x$ vaporization of simulated nuclear waste glassX. J.Non-Cryst.Solids, 84, 268-75X-75X, 1994 .

815. Bonnell, D.W., Plante, E.R., and Hastie, J.W. Vaporization of simulated Nuclear Waste Glass. Final rept. (Unknown Journal!), 1986.

816. Bonnell, D.W., Plante, E.R., and Hastie, J.W. Vaporization of simulated nuclear waste glass. Journal of Non-Crystalline Solids 84:268-275, 1986.

817. Bonnenberg Buried waste integrated demonstration fy-93 deployment plan. (Unknown Journal!) : (68 p), 1993.

818. Bonner, W.F., ; Bjorklund, w., J., ; Hanson, M., S., ; knowlton, D., E., and $X$ engineering-scale $\star \star \star v i t r i f i c a t i o n * \star *$ of commercial high-levelX wastex. Proc.Symp.Waste Manage., (2, Waste Manage.'80: State WasteX Disposal Technol., Mill Tailings, Risk Anal.Models), 339-63X-63X, 1994.

819. Bonniaud Fission product vitrification. fabrication of glasses and storageX. Report. , 1975.

820. Bonniaud Actinides in glassesX. Bull.Inf.Sci.Tech. -53X, 1994.

821. Bonniaud Vitrification of concentrated fission productsx. Bul1.Inform.Sci.Tech. (Paris) -30X, 1994.

822. Bonniaud Solidification of fission product solutionsx. Bull. Inform.Sci. Tech. -37x, 1994.

823. Bonniaud, Jouan, Laude, and Sombret Treatment of gaseous wastes in vitrification plants for fissionx productsX. Report. , 1978.

824. Bonniaud, Laude, and Sombret Experience in france in the treatment of concentrated fissionx product . solutions by vitrificationx. Symp.Manage.Radioactive. Wastes.Fuel.Reprocess. -91, 1972.

825. Bonniaud and Laude, F. Piver vitrification plantx. Colog.Hisp-Fr. Trat.Combust. Irradiados.Quim.Plutonio. -33, 1969.

826. Bonniaud, Pacaud, and Sombret Behavior of ultimate stored radionuclides in the form of glass orX glassy matrix productsX. Confinement.Radioact.Util. Energ.Nucl. $-62,1994$.

827. Bonniaud, Pacaud, and Sombret Behavior of radionuclides fixation in the form of glass or a glassX matrix productx. Verres.Refract. [Part].1. -33X, 1994. 
828. Bonniaud, Redon, and Sombret Application of borate glasses and various boron bearing glasses tox the management of french radioactive wastesX. Mater.Sci.Res. -616X, 1994.

829. Bonniaud and Sombret statement of research in the field of solidification of high levelx radioactive wastes in francex. Report. , 1976.

830. Bonniaud and Sombret glass as a coating material for radioactivex waste $\mathrm{X}$. Verres.Refract. -70X, 1994.

831. Bonniaud, R. Studies conducted in france on the solidification of concentratedX fission product solutionsx. Aec.Access.Nos. , 1966.

832. Bonniaud, R. Vitrification of solutions of fission products in francex. NUCL. TECHNOL. -60X, 1994 .

833. Bonniaud, R., Sombret, C., and Barbe, A. French industrial plant avm for continuous vitrificationx of high level radioactive wastes $\mathrm{X}$. Report. :Avail INISX From:XIN, 1977.

834. Bonniaud, R., Sombret, C., Rozand, Barbe, A., Auchapt, X, and Coste French industrial plant avm for continuous vitrificationx of high level radioactive wastes X. Aiche.Symp.Ser. :Ser, 72(154, Radioac-Ser, 72(154, Radi50X, 1994.

835. Bonniaud, R., Gougeard, J.M., Moulin, J., Reboux, J., and sombret, C. Apparatus for disposal of fission productsX. Brit. , 1994.

836. Bonniaud, R., Jouan, A., and Sombret, C. Sealing in radioactive wastes into a glasslike mass and furnace forX the processX. Ger.Offen. , 1994.

837. Bonniaud, R., Richter, R., Roznad, I., and Demay, R. Glass Melter Materials Technical Options for the French Vitrification Process and Operations Experience Authors. (Unknown Journal!) , 1986.

838. Bonniaud, R., ; Jouan, A., ; Sombret, C., and X large scale waste ***glass*** productionx. U.S.Nucl.Regul.Comm., Nureg/Cp, Nureg/Cp-0005, Proc.X Conf.High-Level Radioact.Solid Waste Forms, 1978: PB294865, 155-:B294865, 155-B294865, 97X, 1994.

839. Bonniaud, R., ; Jouan, A., ; Sombret, C., and X large scale production of

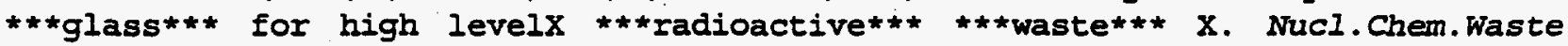
Manage., 1, 3-16X-16X, 1994.

840. Bonniaud, R., A., ; Francillon, N., R., Jacquet; Laude, F., I., ; Sombret, $X . C ., G .$, and $X$ glasses as materials used in france for management of high-levelx wastesx. Ceram.Nucl.Waste Manage., Proc.Int.Symp., Issue Conf-790420, X 57-61-61, 1994.

841. Bonniaud, R., A., ; Jacquet Francillon, N., R., ; Sombret, C., G., and $x$ the behavior of actinides in alpha.-doped glasses with regards tox the long-term disposal of high-level radioactive materialsx. Sci.Basis Nucl. Waste Manage., 2, 117-25X-25X, 1994. 
842. Bonniaud, R., A., ; Jouan, A., F., ; Sombret, C., G., and $X$ status of the french avm ***vitrification*** facilityx. Waste Manage.'79: State Waste Disposal Technol.X Soc.Polit.Implic., Proc.Symp., 263-95:ost, Roy G, 1994.

843. Bonzon, C.J. and Fogdaill, S.P. Buried waste program at the idaho national engineering laboratory. In: Low and Intermediate Level Radiactive Waste Management $v$ I (of 2). PublX by American Soc of Mechanical Engineers (ASME), New York, NY, USA.pX 549-553, Anonymous New York, NY, USA: 1989, -553.

844. Boolchand, P. and Phillips, J.C. Structure of Covalently Bonded Glass-Forming Melts - A Full Partial-Structure-Factor Analysis of Liquid GeSe2 - Comment. PHYS.REV.LETT. 68:252, 1992.

845. Boomer Tank waste technical options report. (Unknown Journal!) : (378 p), 1931.

846. Boomer systems engineering study for the closure of single-shell tanks. (Unknown Joumal!) : (502 p), 1991.

847. Boomer Hanford waste vitrification plant dangerous waste permit application systems engineering study for the closure of single-shell tanks. (Unknown Journal!) : (101 p), 1991.

848. Boomer, K.D., Baker, S.K., Boldt, A.L., Galbraith; J.D., and Garfield, J.S. Tank waste technical options report. (Unknown Journal!) , 1993.

849. Borg, J., ; Dran, J., C., ; Langevin, Y., ; Maurette, M., ; Petit, J., ;X Vassent, $B .$, and $X$ the planar track model and the prediction of alpha-recoil aging inX radwaste formsX. Radiat.Eff., 65, 173-81X-81X, 1994 .

850. Borisch Functional description of the west valley demonstration project vitrification facility. (Unknown Journal!) : (39 p), 1990.

851. Borisch, R., R., ; Leap, D., and $X$ the design and construction of the west valley demonstration projectX vitrification facilityx. Proc.Symp. Waste Manage., (Waste Manage. '89, Vol. 1), 273-7X-7X, 1994.

852. Borisch, R., R., ; Leap, D., and $X$ design and construction of the west valley supernatant treatmentX systemX. Nucl.Mater.Manage., 17, 54-9X-9X, 1994.

853. Borisch, R.R. Programmatic challenges and the value of testing on the west valleyx demonstration project's vitrification facility design. In: Proc Ist Annu Int Top Meet High Level Radioact Waste Manage Part 2.X Publ by ASCE,Boston Society of Civil Engineers Sect,Boston, MA, USA.X p 802-805, Anonymous Boston Society of Civil Engineers Sect, Boston, MA, USA:ASCE, 1990,p. 802-805.

854. Borisch, R.R. and Marchetti, S. Supernatant Treatment of the Final Decontamination Method for the Supernatant Treatment system: Progress Report for the Period March 1982-September 1987. (Unknown Journal!) , 1987.

855. Borisch, R.R. and MoMahon, C.L. Functional description of the Wegt Valley Demonstration Project Vitrification Facility. (Unknown Journal!), 1990. 
856. Borisch, R. Functional description of the West Valley demonstration project vitrification facility : topical report /, West Valley, N.Y. :West Valley Nuclear Services Co., Inc., 1990.

857. Borisov, G., B., ; Polyakov, A., S., ; Khasanov, Z., and X testing of some refractory and electrode materials for liquid activex waste vitrification furnacesX. Proc.Symp. Waste Manage., (Waste Manage.'90, Vol. 1), 39-4IX-4IX, 1994 .

858. Bort, H., Leistikow, S., and Wolf, I. Preselection of ni-cr(-mo) alloys as potential canister materials forX vitrified high active nuclear waste by electrochemical testing. Journal of Nuclear Materials 149:132-137, 1987.

859. Boswell, G. Glass bubble, Crewe, Cheshire:Stride, 1986.

860. Boulos, De Paula, El-Bayoumi, and et al Crystallization of nuclear waste disposal glass. J.Am.Ceram.Soc. , 1980.

861. Boulos, E., N., ; DePaula, R., P., ; El Bayoumi, O., H., ; Lagakos, N., ;X Macedo, P., B., ; Moynihan, C., T., ; Rekhson, S., M., and X crystallization of nuclear waste disposal ***glass*** X. J.Am.Ceram.Soc., 63, 496-501X-501X, 1994.

862. Boult, Dalton, Hall, Hough, and Marples The leaching of radioactive waste storage glassesX. U.K.At.Energy.Res.Establ. -R, 1994.

863. Boult, K., A., ; Dalton, J., T., ; Hall, A., R., ; Hough, A., ; Marples,

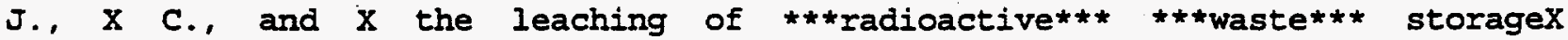
glassesX. Ceram.Nucl.Waste Manage., Proc.Int.Symp., Issue Conf-790420,X 248-55-55, 1994 .

864. Boult, K.A., Dalton, J.T., Eccles, E.W., Hough, A., and Marples, J.A.C. Glass Compositions Suitable for PFR (Prototype Fast Reactor) Wastes. Annual Progress Report 1985-1986. (Unknown Journal!) , 1987.

865. Boult, K.A. and Hall, A.R. Measurement of the Specific Resistance of Vitrified Highly-Active Waste. (Unknown Journal!) , 1985.

866. Bouniol, P. Means for the conditioning of radioactive or toxic waste in cement and itsproduction process. (Unknown Journal!) , 1990.

867. Bouniol, P. Study of Cesium Trapping Mechanism by Cement-Additive Mixtures for Nitrate Waste Embedment. (Unknown Journal!) , 1987 :

868. Bouniol, P. Capacity of Different Cements for Nitrated Effluent Conditioning. (Unknown Journal!) , 1988.

869. Bouniol, P.E. and Peyre, C.H. Preliminary Results of the Immobilization of . Highly-Salt-Ladened Concentrate in Cement-Based Grout: A Joint DOE/CEA (Department of Energy/Comissariat a l'Energie Atomique) Research Effort. (Unknown Journal!), 1988.

870. Bourcier, $w$. Overview of chemical modeling of nuclear waste glass dissolution. Mater.Res.Soc.Symp.Proc. , 1991. 
871. Bourcier, W., ; Ebert, W., L., ; Feng, X., and X modeling surface area to volume effects on borosilicate glassX dissolutionx. Mater.Res.Soc.Symp.Proc., $294,577-82 X-82 X, 1994$.

872. Bourcier, $W$. and $X$ overview of chemical modeling of nuclear waste glass dissolutionx. Mater.Res.Soc.Symp.Proc., 212, 3-18X-18X, 1994.

873. Bourcier, W.L. Geochemical modeling of radioactive waste glass dissolution using EQ3/6: Preliminary results and data needs. (Unknown Journal!), 1990.

874. Bourcier, W.L., Ebert, W.L., and Feng, X. Modeling surface area to volume effects on borosilicate glass dissolution. (Unknown Journal!) , 1992.

875. Bourcier, W.L., Knauss, K.G., and Merzbacher, C.I. Kinetic Model for Dissolution of Borosilicate Glass. (Unknown Journal!) , 1989.

876. Bourcier, W.L., ; Peiffer, D.W., ; Knauss, K.G., ;X McKeegan, K.D., ; Smith, D.K., and $X$ a kinetic model for borosilicate glass dissolution based on thex dissolution affinity of a surface alteration layerx. Mater.Res.Soc.Symp.Proc., 176, 209-16X-16X, 1994.

877. Bowan, B., Palmer, R., and Barnes, S. Operation of a slurry-fed ceramic melter for the vitrification of nuclearwaste: the west valley experience. Adv. Fusion Process.Glass , 1990.

878. Brackenbury Disposal of failed melters from defense waste vitrification facilities. (Unknown Journal!) : (7 p), 1992.

879. Brackenbury, P.J., King, J., and Norman, E.C. Disposal of failed melters from defense waste vitrification facilities. (Unknown Journal!) , 1992.

880. Bradley Leaching of fully radioactive high-level waste glassx. Report. , 1979.

881. Bradley spent fuels reprocessing and associated waste management operations at sellafield, united kingdom. (Unknown Journal!) : (24 p), 1992.

882. Bradley West valley transfer cart control system design description. (Unknown Journal!) : (154 p), 1993.

883. Bradley Travel to russia to convene a technology exchange workshop on chemical separations at the khlopin radium institute in st. petersburg, and to conduct the second meeting of the us doe-russian minatom joint coordinating committee on environmental restoration and waste management (jccem) in moscow. (Unknown JournaI!) : (78 p), 1994.

884. Bradley, D., J., ; Harvey, C., O., ; Turcotte, R., P., and $X$ leaching of

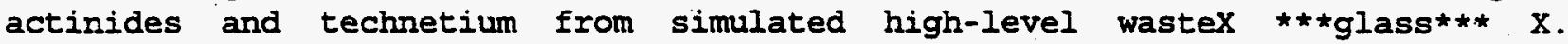
Report, Pal-3152, 104 pp, 1980.

885. Bradley, D.J., Frank, C.W., Fryberger, T.A., De La Torre, G., and Solecki, J.E. Travel to Russia to convene a technology exchange workshop on chemical separations at the Khlopin Radium Institute in St. Petersburg, and to conduct 
the second meeting of the US DOE-Russian MINATOM Joint Coordinating Committee on Environmental Restoration and Waste Management (JCCEM) in Moscow. Foreign trip report, October 30--November 7, 1992. (Unknown Journal!) , 1992.

886. Bradley, D.J. and Luksic, A.T. Spent fuels reprocessing and associated waste management operations at Sellafield, United Kingdom. Foreign trip report, July 10--20, 1992. (Unknown Journal!)! 1992.

887. Bradley, D.J. and Schneider, K.J. Radioactive Waste Management in the USSR: A review of unclassified sources, 1963-1990. (Unknown Journal!), 1990.

888. Bradley, D.J.D. Leaching of fully radioactive high-level waste glass /, Richland, Wash. : [Springfield, Va. :Dept. of Energy, Pacific Northwest Laboratory ; for sale by the National Technical Information Service], 1978 .

889. Bradley, J., P., ; Bates, J., K., and X leached nuclear waste glasses: ultramicrotomy and electronx microscopic characterizationx. Microbeam Anal., 25 th, 313-17X-17X, 1994.

890. Bradley, N., Brown, G.A., O'Tallamhain, C., and Ealing, C.J. Providing flexibility in spent fuel and vitrified waste management. Nuclear Engineering International 31:27-33, 1986 .

891. Bradley, R., F., and $\mathrm{X}$ savannah river $\star \star \star v i t r i f i c a t i o n * \star *$ programx. Waste Manage.'79 : State Waste Disposal Technol.X Soc.Polit.Implic., Proc.Symp., 296-309: ost, Roy G, 1994.

892. Branda, F., Costantini, A., and Buri, A. Nonisothermal Devitrification Behavior of Diopside Glass. THERMOCHIM.ACTA 217:207-212, 1993.

893. Brandys, M., ; Barkatt, A., and $X$ analysis of brine leachates from materials interface interactionsx tests.2.leaching of lithium and zirconium from nuclear wasteX glassX. Ceram.Trans., 9, 287-95X-95X, 1994.

894. Brandys, M., Gong, M., and Sassoon, R. Analysis of brine leachates from materials interface interaction tests[miit]: $i i$, leaching of lithium and zirconium from nuclear waste glass. Ceram.Trans. , 1990.

895. Brat, S. and Balu Syntheses of phyllitic minerals. their utilization in radioactivex waste treatment.iii.from mixed gels of silica and alumina inX presence of lithium sulfateX. India. , 1971.

896. Brat, S. and Balu Syntheses of phyllitic minerals. their utilization in: radioactivex waste treatment.i.from silica gel and mixed gels of silica andx alumina in presence of magnesium acetatex. India. , 1994.

897. Brat, $\mathrm{S}$. Synthetic mg-al-na silicates in radioactive waste treatment. Indian Journal of Technology 23:345-347, 1985.

898. Brat, S.R.,N., S., and SunderX investigation of the utility of some synthetic magnesiumx $\star * *$ silicates $* *$ in $\star * *$ radioactive*** $* * *$ waste $* \star *$ treatmentX. J.Indian Inst.Sci., 62, 1-7X-7X, 1994. 
899. Brat, S. synthetic magnesium-aluminum-sodium ***silicate*** inX $\star * \star$ radioactive $* \star * * *$ waste $* \star$ treatmentX. Indian J.Technol., 23, 345-7X-7X, 1994.

900. Braun, D.J., Lindberg, S.E., Reardon, M.F., and Wilson, G.P. Hanford Waste Vitrification Project Building limited scope risk assessment. (Unknown Journal!) , 1992.

901. Bray Decontamination testing of radioactive-contaminated stainless steel coupons using a ce(iv) solution. (Unknown Jounnal!) : (31 p), 1992.

902. Bray, L.A. and Seay, J.M. Development and Design Application of Cerium (IV) Decontamination Process. (Unknown Journal!), 1988.

903. Brenner Experience gained with source terms for high-level active reprocessing wastes applied to long-term safety analyses of radwaste repositories Erfahrungen mit quelltermen fuer haw-wiederaufarbeitungsabfall in langzeitsicherheitsanalysen von endlagern: (Unknown Journal!) :(42 p), 1993.

904. Brewer, K.N. and Murphy, J.A. Hydrofluoric acid dissolution of spent radioactive and hazardous HEPA filters. (Unknown Journal!) , 1992.

905. Brezhneva, Oziraner, Minaev, and Kuznetsov Properties of phosphate and silicate glasses used for thex solidification of radioactive waste $x$. Manage.Radioact. Wastes.Nucl.Fuel.Cycle -94, 1994.

906. Brezhneva, N., E., ; Minaev, A., A., ; Oziraner, S., N., and $X$ ***itrification*** of high sodium-aluminum wastes: compositionX ranges and propertiesX. Sci.Basis Nucl.Waste Manage., , MeetingX Date 1978, 43-50:lenum: NewX York, 1994.

907. Brezny, R. and Green, D. Uniaxial strength behavior of brittle cellular materials. Journal.of.the.American.Ceramic.Society. Journal of the Ameri, 1993.

908. Bricka, R.M. and Jones, L.W. Evaluation of Factors Affecting the Solidification/stabilization of Heavy Metal sludge. Final rept. (Unknown Journal!) , 1993.

909. Briggs, A., Jones, D.V.C., Cole, G.B., Valentine, T.M., and Preston, R.F. Immobilisation of sup $137 \mathrm{Cs}$ and sup $90 \mathrm{Sr}$ in Hot-Pressed Clinoptilolite. (Unknown Journal!) , 1984.

910. Briggs, A., ; Jones, D., V., C., ; Cole, G., B., ; Valentine, T., M., ; Preston, X.R., F., ; Hawes, R., W., ; Fones, M., D., and X inmobilization of cesium-137 and strontium-90 in hot-pressedx clinoptilolitex. Report, Aere-R-11268, $38 \mathrm{pp}, 1985$.

911. Brinker, Clark, D., and Ulrich, D. Materials research society symposia. proceedings, vol. 32: better ceramicsthrough chemistry. (Unknown Journal!), 1985 .

912. Brinker, C. Atomic sodium diffusion and crystallization in silicate and borosilicate glasses, 1979. 
913. Brockelhurst, J., Gilchrist, K., Adam, R., and et al.| Method for measuring the viscosity of radioactive waste glasses. High Temp.-High Pressures , 1980.

914. Brocklehurst, J.D., ; Gilchrist, K.E., ; Adam, R.W., ;X Preston, S.D.; and

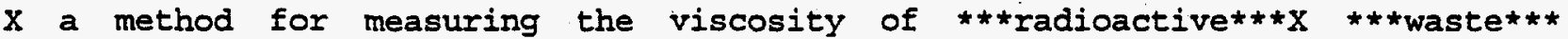
glassesX. High Temp.- High Pressures, 12, 317-25X-25X, 1994.

915. Brodersen, $K$. and Larsen, I Inactive pilot plant studies of a process for vitrificationX of highly radioactive waste at the researchX. Aec.Access.Nos. , 1966.

916. Brodersen, $\mathrm{K}$. and Nilsson, K. Mechanisms and interaction phenomena influencing releases in low-and medium-level waste disposal systems. Final report 1986-1990. (Unknown Journal!) , 1990.

917. Brodersen, $K$. and $X$ production and properties of solidified high-level wastex. Report, Riso-R-431, $85 \mathrm{pp}, 1981$.

918. Broer, M. Melting apparatus for the synthesis of bulk $\mathrm{ZrF} / / 4$-based fluoride glass. Journal.of.the.American.Ceramic.Society. J Am Ceram Soc v 72, 1989.

919. Broglia, M. 'ULISSE' Project for the Treatment of Radioactive Wastes of ENEA (European Nuclear Energy Agency) Department of Fuel. A Comparative Study for Defining the Glass Matrix to Immobilize High Activity Wastes. (Unknown Journal!) , 1988 .

920. Broikos, S. Relation of viscosity and nucleation temperature of titania glass ceramic systems, 1963.

921. Brosnan, D.A., Skrovankova, D., Bennerova, I., and Hlavac, J. Solution release of lead from incinerator slags - state of the art vitrification of simulated intermediate-level waste from nuclear powerx plants i.melting behaviour and properties of selected glasses. <CT> 94 th Annual Meeting and the 1992 Fall Meeting of the Materials andX Equipment and Whitewares Divisions <CL> Minneapolis, MN, USA Ceramic Engineering and Science Proceedings Ceramics Silikaty 37:49-55, 1993.

922. Brotzman, J., $R_{.}$, and $X * * *$ vitrification*** of high-level alumina nuclear wasteX. Report, Enico-1040, 23 pp, 1980.

923. Brotzman, J., R., and $X \star \star \star * v i t r i f i c a t i o n * \star *$ of high-level alumina nuclear wasteX. Sci.Basis Nucl. Waste Manage., 2, 215-22X-22X, 1994.

924. Brouns, R., A., ; Mellinger, G., B., ; Nelson, T., ; Oma, K., H., and X immobilization of high-level defense waste in a slurry-fed electricX ** glass*** melterX. Report, Pnl-3372, 109 pp, 1981.

925. Brouns, R.A., Allen, C.R., and Powell, J.A. LFCM (Liquid-Fed Ceramic Melter) Vitrification Technology: Quarterly Progress Report, October-December 1986. (Unknown Journal!), 1987. 
926. Brouns, R.A., Allen, C.R., and Powell, J.A. LFCM Vitrification Technology: Qualterly Progress Report April--June 1987. (Unknown Journal!) , 1988.

927. Brouns, R.A., Allen, C.R., and Powell, J.A. LFCM (Liquid-Fed Ceramic Melter) Vitrification Technology: Quarterly Progress Report, January--March 1987. (Unknown Journal!), 1988.

928. Brouns, R.A. and Hanson, M.S. Nuclear waste glass melter: an update of technical progress. In: $v 1$. Publ by ANS, La Grange Park, IL, USA $p$ 101-115, Anonymous La Grange Park, IL, USA:ANS, 1984,p. 101-115.

929. Brouns, R.A., Perez, J.M.; and Wise, B.M. Selection of a Feed Composition for the West Valley Demonstration Project Slurry-Fed Melter. (Unknown Journal!) , 1986 .

930. Brouns, R.A. and Powell, J.A. Nuclear waste Treatment Program: Annual Report for FY 1987. (Unknown Joumal!) , 1988.

931. Brouns, R.A. and Powel1, J.A. Nuclear Waste Treatment Program Annual Report for FY 1988. (Unknown Journal!), 1989.

932. Brow, R.K. Nature of Alumina in Phosphate-Glass .1. Properties of Sodium Aluminophosphate Glass. J.AMER. CERAM.SOC. 76:913-918, 1993.

933. Brow, R.K., Kirkpatrick, R.J., and Turner, G.L. Nature of Alumina in Phosphate-Glass .2. Structure of Sodium Aluminophosphate Glass. J. AMER. CERAM. SOC. $76: 919-928,1993$.

934. Brow, R., Kirkpatrick, R.J., and Turner, G. Nature of Alumina in Phosphate Glass: II, Structure of Sodium Aluminophosphate Glass. Journal.of.the.American.Ceramic.Society. 46, Number 4:915-919, 1930.

935. Brown Quarterly briefing book on environmental and waste management activities. (Unknown Journal!) : (175 p), 1991.

936. Brown soil density and mass attenuation coefficients for use in shielding calculations at the hanford waste vitrification plant. (Unknown Journal!) : (7 p), 1992 .

937. Brown Design basis personnel exposure estimates for the hanford waste vitrification plant. (Unknown Journal!) : (14 p), 1992.

938. Brown Dwpf waste glass product composition control system. (Unknown Journal!) : (8 p), 1992 .

939. Brown Hanford waste vitrification plant project plan. (Unknown Journal!) :(37 p), 1993 .

940. Brown, F.H., Randall, C.T., Cosper, M.B., and Moseley, J.P. Savannah river laboratory's operating experience with glass melters. In: <CI> Selected papers presented at the American Nuclear Society TopicalX Meeting Publ by Battelle Press, Columbus, OH and Richland,WA, USA andX Springer-Verlag, New York, NY, USA and Heidelberg, West Ger $p$ 191-196,Anonymous Columbus, $\mathrm{OH}$ and Richland, WA, USA:Battelle Press, 1983,p. 191-196. 
941. Brown, K., G., ; Postles, R., L., and $X$ dwpf waste glass product composition control system (u)X. Ceram.Trans., 29,X 495-502X-502X, 1994 .

942. Brown, K.G. Product Composition Control System at Savannah River: The statistical process control algorithm. Revision 1. (Unknown Journal!) , 1993.

943. Brown, K.G., Edwards, R.E., Postles, R.I., and Randall, C.T. Control of DWPF melter feed composition. (Unknown Journal!), 1989.

944. Brown, K.G. and Postles, R.L. DWPF waste glass Product Composition Control system. (Unknown Journal!), 1992.

945. Brown, M.C. Quarterly briefing book on environmental and waste management activities. (Unknown Journal!) , 1991.

946. Brown, P. and Boryta, D. Lithium carbonate/sodium sulfate eutectic--an additive for improving glass production. Journal.of. the.American.Ceramic.Society. v. 66 (Sept. '83):660-663, 1983.

947. Brown, $R$. and $X$ soil density and mass attenuation coefficients for use in shieldingx calculations at the hanford waste vitrification plantx. Proc.Top.Meet.New Horiz.Radiat.Prot.Shielding, 144-9:ark, Ill, 1994.

948. Brown, R.C. Soil density and mass attenuation coefficients for use in shielding calculations at the Hanford waste Vitrification Plant. (Unknown Journal!) , 1992.

949. Brown, R.C. and Iwatate, D.F. Design basis personnel exposure estimates for the Hanford Waste Vitrification Plant. (Unknown Journal!), 1992.

950. Brown, R.W. Hanford Waste Vitrification Plant Project Plan. Revision 1. (Unknown Journal!) , 1993.

951. Brown, S.H., ; Gordon, J.W., and X development of site specific radiological decommissioning criteriax for a high-level waste processing and vitrification projectx. Proc.Symp.Waste Manage., (Waste Manage.'88, Vol. 2), $603-9 X-9 X, 1994$.

952. Bruce, A.J., Moynihan, C.T., and Loehr, S.R. Intrinsic instabilities of heavy metal fluoride glasses. Optical.Engineering. v. 24 (May/June '85) :522-526, 1985 .

953. Bruckner, R. and Hessenkemper, H. Influence of Water-Content and Basicity on Redox Ratio -Consequences on Radiation Heat Absorption and Emission of Glass Melts During Fusion and Processing. GLASTECH.BER. 66:245-253, 1993.

954. Bruening, R.I., Camaioni, D.M., Colton, N.G., and Morrey, J.R. Potential uses of silica-bonded macrocyclic ligands for separation of metal ions from nuclear waste. (Unknown Journal!) , 1991.

955. Brumley William, J. Defense waste processing facility [dwpf]--the vitrification of high-levelnuclear waste. Adv.Ceram. , 1986. 
956. Brumley, w.J. Defense Waste Processing Facility: The Vitrification of High-Level Nuclear Waste. (Unknown Journal!) , 1986.

957. Brumley, W.J. and $X$ the defense waste processing facility: the vitrification ofX high-level nuclear wasteX. Adv.Ceram., 20, 37-43X-43X, 1994.

958. Bryan and Wittenbrock supplement to safety analysis report for the 325 radiochemistryx buildingx. Report. , 1978.

959. Bryan, G., H., ; Bjorklund, W., J., ; Kuhn, W., L., and X high-level waste ***vitrification*** product characterizationX. Sci.Basis Nucl.Waste Manage., 2, $147-54 X-54 X, 1994$.

960. Bryan, G., H., ; Goles, R., W., ; Knox, C., A., ; Siemens, D., and X summary of radioactive operations for zeolite $* * *$ vitrification*** $X$ demonstration programx. Report., Gend-038; Order No.De84006260, 36. pp, 1984.

961. Bryan, G., H., ; Knox, C., A., ; Goles, R., G., ; Ethridge, L., J., ; Siemens, X.D., and $X$ zeolite $* * * v i t r i f i c a t i o n * * *$ demonstration programX nonradioactive-process operations summaryx. Report, Gend-024, 44 pp, 1983.

962. Bryan, G.H., Goles, R.w., and knox, C.A. Vitrification of TMI decontamination

Nuclear.and. Chemical. Waste.Management.v.7.no2.('87).p.141-8.diags. 191-815X, 1987.

963. Buchanan, H. Mossbauer effect spectroscopy studies of some iron phosphate glasses, Nashville:1972.

964. Buckwalter and Pederson, I. Inhibition of nuclear waste glass leaching by chemisorption. J.Am.Ceram.SoC. , 1982.

965. Buckwalter, C., Q., ; Chick, L., A., and X coated particle waste form developmentX. Report, Pal-4108, 173 pp, 1983.

966. Buckwalter, C., Q., ; Pederson, L., R., and $X$ inhibition of nuclear waste **tglass*** leaching byX chemisorptionX. J.Am.Ceram.Soc., 65, 431-6X-6X, 1994 .

967. Buddemeier, R., w., ; Coles, D., G., ; Mensing, R., ; Rego, J., ; Weed, H., $X$ C., and X leaching study of pnl 76-68 ***glass** beads using the linlX continuous-flow method and the pnl-modified iaea methodx. Report, Ucid-19492; Order No.De82021539, 257 pp, 1982.

968. Budhwani, K. Physical properties of and structures in lithium, sodium, and $\mathrm{X}$ potassium borosilicate glass systems, 1993.

969. Buechele, A., C., ; Feng, X., ; Gu, H., ; Muller, I., S., ; Wagner, w., ; Pegg, X., L., and $x$ effects of composition variations on microstructure and chemicalx durability of west valley reference glassx. Mater.Res.Soc.Symp.Proc., $212,141-52 \mathrm{X}-52 \mathrm{X}, 1994$. 
970. Buechele, A., Feng, X., and Gu, H. Redox state effects on microstructure and leaching properties of West Valley SF-12 glass. Ceram.Trans. 23:85-94, 1991.

971. Buechele, A., C., ; Feng, X., ; Gu, H., ; Pegg, I., L., and X alteration of microstructure of west valley glass by heat treatmentx. Mater.Res.Soc.Symp.Proc., 176, 393-402X-402X, 1994.

972. Buechele, A.C., Feng, X., and Gu, H. Effects of composition variations on microstructure and chemical durability of West valley reference glass. Mater.Res.Soc.Symp.Proc. 212:141-152, 1991.

973. Buelt Containment and stabilization technologies for mixed hazardous and radioactive wastes. (Unknown Journal!) : (8 p), 1993.

974. Buelt and Chapman Liquid-fed ceramic melter: a general description reportx. Report. , 1979.

975. Buelt, J., L., ; Oma, K., H., and X incineration/ ***vitrification*** of simulated low-levelx institutional wastes in a joule-heated ***glass*** melterX. Nucl. Chem. Waste Manage., 2, 175-82X-82X, 1994.

976. Buelt, J.L. Mobile Encapsulation and Volume Reduction system for wet Low-Level Wastes. (Unknown Journal!) , 1985.

977. Bukrey, R. A Mossbauer-effect study of the structure and magnetic properties of iron in alkaliborate glass, 1972.

978. Bulbulian, S., Olguin, M.T., and Bosch, P. sup 9 sup 9 Mo-labeled zeolites. ZEOLITES. 10[6]:588-592, 1990 .

979. Bullock, M.G. and Rodriguez, R.R. Implementation Plans for Buried Transuranic Waste and Stored Special-Case waste at the Idaho National Engineering Laboratory. (Unknown Journal!) , 1987.

980. Bunde, A. and Maass, P. Anomalous Ion-Transport in Glasses. PHYSICA.A. $191: 415-425,1992$.

981. Bunde, A. and Maass, P. Transport Anomalies in Glasses. PHYSICA.A. $200: 80-94,1993$.

982. Bunker, B.C. Waste Glass Leaching: Chemistry and Kinetics. (Unknown Journal!) , 1986.

983. Bunker, B.C. and Arnold, G.W. Effect of solution ph and ion concentrations on leaching of silicatex glass. In: Materials Research Society Symposia Proceedings $v$ 15. Publ by ElsevierX Science Publ Co,New York, NY, USA and Amsterdam, Neth p 151-158, Anonymous New York, NY, USA:ElsevierX Science Publ Co, 1983, p. $151-158$.

984. Bunker, B., Arnold, G., and Rajaram, M. Corrosion of phosphorus oxynitride glasses in water and humid air. Journal.of.the.American.Ceramic.Society. v. 70 (June '87):425-430, 1987. 
985. Bunker, B.C., ; Arnold, G.W., and $X$ the effect of solution ph and ion concentrations on leaching of X $\star \star \star$ silicate*** $* *$ glass $* * *$. $X$. Mater.Res.Soc.Symp.Proc., 15,X 151-8X-8X, 1994.

986. Bunker, B.C. and $X$ waste glass leaching: chemistry and kineticsX. Mater.Res.Soc.Symp.Proc., 84,X 493-507X-507X, 1994.

987. Bunnell, Maupin, and Oma High-temperature glasses for nuclear waste isolation. Adv. Ceram., 1986.

988. Bunnell, L.R. Laboratory Work in Support of West Valley Glass Development. (Unknown Journal!) , 1988.

989. Bunnell, L. Effects of aluminum oxide additions on the viscosity of vitreous silica, University of Utah, 1965.

990. Bunuel, M.A., Alcala, R., and Cases, R. Time-Resolved Spectroscopy of Ni-Doped Fluorozirconate Glasses. J.NON-CRYST.SOLIDS. 161:137-140, 1993.

991. Burda, P. Dissolution of copper and leaching of borosilicate waste glass in solutions synthesizing groundwaters, 1989.

992. Burkat, T.M. and Dobychin, D.P. Marcokinetics of Porous Glass Alkali Leaching. The.Soviet.journal.of.glass.physics.and.chemistry. 18, Number $2: 165-170$, 1992:

993. Burkholder Radioactive waste vitrification technology. (Unknown JournaI!) : (5 p), 1992.

994. Burkholder Nuclear waste partitioning incentivesx. Proc. Conf.Manage. Rádioact. Waste: Waste. Partitioning.AlternativexxX. $\quad-81,1994$.

995. Burkholder, H.C., Brouns, R.A., and Powell, J.A. Nuclear waste Treatment Program: Annual Report for FY 1986. (Unknown Journal!) , 1987.

996. Burkholder, H.C. and Jarrett, J.H. Conmercial LFCM Vitrification Technology. Quarterly Progress Report, October-December 1984. (Unknown Journal!) , 1985.

997. Burkholder, H.C., Jarrett, J.H., and Minor, J.E. IFCM (Liquid-Fed Ceramic Melter) Vitrification Technology. Quarterly Progress Report, January-March 1985. (Unknown Journal!) , 1985.

998. Burkholder, H.C., Jarrett, J.H., and Minor, J.E. LFCM Vitrification Technology. Quarterly Progress Report, July-September 1985. (Unknown Journal!) , 1986.

999. Burkholder, H.C., Jarrett, J.H., and Minor, J.E. LFCM (Liquid-Fed Ceramic Melter) Vitrification Technology. Quarterly Progress Report, October-December 1985. (Unknown Journal!) , 1986. 
1000. Burkholder, H.C., Jarrett, J.H., and Minor, J.E. LFCM (Iiquid-Fed Ceramic Melter) Vitrification Technology. Quarterly Progress Report, April-June 1985. (Unknown Journal!) , 1986.

1001. Burkholder, H.C. and Minor, J.E. LFCM Vitrification Technology. Quarterly Progress Report, January-March 1986. (Unknown Journal!) , 1986.

1002. Burkholder, H.C. and Rusin, J.M. Nuclear Waste Treatment Program. Annual Report for FY 1984. (Unknown Journal!) , 1985.

1003. Burman, C., ; Wang, K.M.,W., A., and $X$ application of ion beam techniques to the study of $\star \star \star$ glass $* \star \star X$ durability: enhanced dissolution in saline and radiation effectsX. Mater.Res.Soc.Symp.Proc., 6,X 641-9X-9X, 1994.

1004. Burnell, J., Coles, D., and Thomas, L. Initial hydrothermal waste package release experiments using spent fuel with waste package components. Adv.Ceram. $20: 361-371,1986$.

1005. Burns; D., B., ; Upton, B., H., ; Wicks, G., G., and X glass/metal interactions, leaching, waste glass, canister materialx. Report, Dpst-85-217; Order NO.De85015825, 72 pp, 1985.

1006. Burns, D.B., Upton, B.H., and Wicks, G.G. Glass/Metal Interactions, Leaching, Waste Glass, Canister Material. (Unknown Journal!) , 1985.

1007. Burns, D.B., Opton, B.H., and Wicks, G.G. Interactions of SRP (Savannah River Plant) Waste Glass with Potential Canisters and overpack Metals. (Unknown Journal!) , 1985.

1008. Burns, D.B., Upton, B.H., Wicks, G.G., Abrajano, T.A.J., Bates, J.K., and Byers, C.D. Interactions of srp waste glass with potential canister and overpackx metals Aqueous corrosion of natural and nuclear waste glasses. $i$. comparativex rates of hydration in liquid and vapor environments at elevatedx temperatures. Journal of Non-Crystalline Solids Journal of Non-Crystalline Solids $84: 251-257,1986$.

1009. Burns, H.H. Waste treatment evaluation for aqueous secondary waste from mixed waste incineration. (Unknown Journal!), 1992.

1010. Burns, W., G., ; Hughes, A., E.; ; Marples, J., A., C., ; Nelson, R., S., ; $X$ Stoneham, A., M., and $X$ effects of radiation damage and radiolysis on the leaching ofX $\star \star \star v i t r i f i e d * \star *$ wasteX. Mater.Res.Soc.Symp.Proc., 11,X $339-48 X-48 X, 1994$.

1011. Burns, W., G., ; Hughes, A., E., ; Marples, J., A., C., ; Nelson, R., S., ;X Stoneham, A., M., and $X$ effects of radiation on the leach rates of

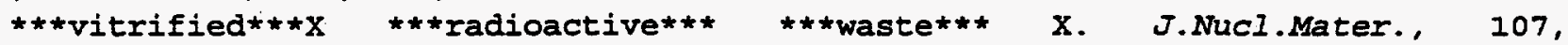
245-70X-70X, 1994 .

1012. Burrill, K., A., and $x$ development of a batch process for immobilizing

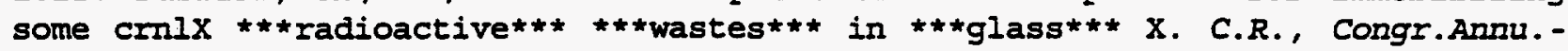
Soc.Nucl.Can., 2nd, 363-9x-9x, 1994. 
1013. Burrill, K., A., and X immobilizing isotope production waste in glassX. Proc.Symp. Waste Manage., (1), 93-8X-8X, 1994 .

1014: Burrill, K.A. Development of a batch process for immobilizing some crnl radioactivex wastes in glass. In: <CI > Compilation of Papers presented at the 2nd Annual Meeting of theX Canadian Nuclear Society Atomic Energy of Canada Limited, AECL (Report) 7551. Publ by ChalkX River Nuclear Lab, Chalk River, Ont, Can p 23-29, Anonymous Chalk River, Ont, Can p 23-29:ChalkX River Nuclear Lab, 1982,p. 23-299.

1015. Byeong-SoO, B. and Weinberg, M. Oxidation-Reduction Equilibrium in Copper Phosphate Glass Melted in Air. Journal.of.the.American.Ceramic.Society. 74, Number $12: 3039-3045,1991$.

1016. Byers, Ewing, R., and Jercinovic Experimental alteration of basalt glass applied to the alteration ofnuclear waste glass. Adv.Ceram. , 1986.

1017. Byers, C., D., ; Ewing, R., C., ; Jercinovic, M., J., and X experimental alteration of basalt glass applied to the alteration of $X$ nuclear waste glassX. Adv. Ceram., 20, 733-44X-44X, 1994.

1018. Byers, C., D., ; Jercinovic, M., J., ; Ewing, R., C., ; Keil, K., and X basalt glass: an analog for the evaluation of the long-termx stability of nuclear waste form borosilicate glassesX. Mater.Res.Soc.Symp.Proc., 44,X 583-90X-90X, 1994 .

1019. Byers, C.D. A study of natural glass analogues as applied to alteration of nuclear waste glass, Washington, D.C. :U.S. Nuclear Regulatory Commission, 1987 .

1020. Byers, C.D., Ewing, R.C., and Jercinovic, M.J. Experimental Alteration of Basalt Glass Applied to the Alteration of Nuclear waste Glass. (Unknown Journal!) , 1986 .

1021. Cable, M. and Martlew, D. Dissolution of silica in melts of the sodium carbonate-sodium metasilicate system. Glass.Technology. v. 25 (June 184) :139-144, 1984.

1022. Cable, M. and Martlew, D. The effective binary diffusivity of silica in sodium silicate melts: a review and recommendation. Glass.Technology. v. 25 (Dec. ' 84):270-276, 1984 .

1023. Cable, M. and Martlew, D. Formation of solid reaction products in the dissolution of silica in molten sodium carbonate. Glass.Technology. v. 25 (Feb. '84) : 24-30, 1984 .

1024. Cable, M. and Martlew, D. The dissolution of silica in melts containing sodium carbonate, sodium sulphate, and silica. Glass. Technology.v.28. (Oct. '87) .p.203-7.bibl. 17-1050, 1987.

1025. Cadoff, L. and Smith-Magowan, D. Glass-former composition and method for immobilizing nuclear waste usingthe same. (Unknown Journal!) , 1988. 
1026. Cadoff, L.H., Pope, J.M., and Barnes, S.M. 'properties of the west valley waste form'. In: Proc Ist Annu Int Top Meet High Level Radioact Waste Manage Part 2.X Publ by ASCE,Boston Society of Civil Engineers Sect,Boston, MA, USA.X $p$ 1086-1094, Anonymous Boston society of Civil Engineers Sect, Boston, MA, USA:ASCE, $1990, \mathrm{p} .1086-1094$.

1027. Cains, P., W., ; Hay, D., A., and $x$ volatilization of ruthenium in ***vitrification*** . isothermalx calcination studies of magnox and thermal oxide simulatesX. Report, Doe/Rw-82.085, Aere-M-3255; Order No.De83703913, 46 pp, 1984 .

1028. Cains, P., W., ; Yewer, K., C., and $\mathrm{x}$ fission product volatilization in the calcination and vitrificationX of high-level wastesX. Comm.Eur.Communities, Eur, Eur 10580, Gaseous Efflu-76X, 1994.

1029. Cains, P., W., and $X$ monitoring of ruthenium in process gases in vitrification plantsX. U.K.At.Energy Res.Establ., Aere-M, Aere $M$ 3551, 20 pp, 1994.

1030. Cains, P.W., Hills, K.M., Waring, S., and Pratchett, A.G. Off gas condenser performance modelling. The performance of ruthenium tetroxide and nitrogen oxides in off-gas condensers. (Unknown Journal!) , 1989.

1031. Callahan Analyses of backfilled transuranic wastes disposal rooms. (Unknown Journal!) : (127 p), 1991.

1032. Callahan, G.D. and DeVries, K.L. Analyses of backfilled transuranic wastes disposal rooms. (Unknown Journal!) , 1991.

1033. Callan, J.E. Remote handling of canisters containing nuclear waste in glass at thex savannah river plant. In: <CI> Held in Conjunction with American Nuclear Society Winter Meeting Proceedings of the Conference on Remote Systems Technology 34th. Publx by ANS, La Grange Park, IL, USA $p$ 3-7, Anonymous La Grange Park, II, USA: 1987,p. 3-7.

1034. Calle Utilization of enea's eurex pilot reprocessing plant for treatment and conditioning of hllws. (Unknown Journall) : (8 p), 1992.

1035. Calmus and Mezga [travel to mol, belgium and karlsruhe, germany to discuss decommissioning technology and noble metals testing] [information exchange on current and planned low-level and transuranic waste management practices]. (Unknown Journal!) :(15 p), 1918.

1036. Calmus, R.B. Travel to Mol, Belgium and Rarlsruhe, Germany to discuss decommissioning technology and noble metals testing. Foreign trip report, June 29--July 17, 1992. (Unknown Journal!) , 1992.

1037. Camara, B., ; Lutze, W., ; Lux, J., and $X$ an investigation on the valency state of molybdenum in glasses withx and without fission productsx. Sci.Basis Nucl.Waste Manage., 2, 93-102X-102X; 1994.

1038. Cameron, W.A. and Merlin, S. Evaluation of the avm process and its applicability to west valley. In: <CI> selected Papers presented at the American Nuclear Society TopicalX Meeting Publ by Battelle Press, Columbus, OH 
and Richland,WA, USA andX Springer-Verlag, New York, NY, USA and Heidelberg, West Ger P 542-546, Anonymous Columbus, OH and Richland, WA, USA:Battelle Press, 1983, -Verlag, New York, NY.

1039. Cameron, W.A. and; Merlin, S. an evaluation of the avm process and its applicability to westx valleyx. Treat.Handl.Radioact.Wastes, , Meeting Date 1982, 542-6:ress: Columbus, Ohio, 1994.

1040. Campbell, J.H., ; Hoenig, C.I., ; Bazan, F.R.,X Frederick J., and ; Rozsa, R. immobilization of savannah river high-level wastes in synroc: $\mathrm{X}$ results from product performance testsx. Mater.Res.Soc.Symp.Proc., $6, \mathrm{X}$ 49-57X-57X, 1994 .

1041. Caneiro, A., Ondracek, G., and Toscano, E.H. Powder technological vitrification of high level nuclear waste byx in-can hot pressing including a sol-gel route. In: <CI> Held as part of the Fall Meeting of the Materials ResearchX Society Materials Research Society Symposia Proceedings $v 44$. Publ by MaterialsX Research Soc, Pittsburgh, PA, USA p 817-822,Anonymous Pittsburgh, PA, USA:MaterialsX Research SOC, 1985,p. 817-822.

1042. Canonico, A., ; Mataloni, P., ; Scoditti, E., and $\mathrm{X}$ canister qualification for process and storage of vitrified hlwX. Proc.Symp.Waste Manage., (Waste Manage.'89, Vol. 1), 633-8X-8X, 1994.

1043. Cantale Laboratory tests on the italian bel 15 reference glass. (Unknown Journal!) : (62 p), 1990.

1044. Cantale Characterization of the italian glasses and their interaction with clay task 3 characterization of radioactive waste forms a series of final reports (1985-89) no 23. (Unknown Journal!) : (86 p), 1991.

1045. Cantale, C., ; Castelli, S., ; Donato, A., ; Traverso, D., M., ; Colombo, P., ; $X$ Scarinci, G., and $X$ a borosilicate glass for the italian high level waste.X characterization and behaviorX. Radioact. Waste Manage.Nucl.Fuel Cycle, $16,25-47 X-47 X, 1994$.

1046. Cantale, C., Donato, A., and Guidi, G. Borosilicate Glasses for the High Activity Waste Vitrification. High Activity Waste from Reprocessing of Nuclear Power Plant Fuel. (Unknown Journal!), 1984.

1047. Cantale, C., Donato, A., Ricci, G., Basili, N., and Biancifiori, M.A. Leaching of Borosilicate Glasses Incorporating H.L. Radioactive Wastes. Italian Participation in the EEC International Round Robin Test. (Unknown Journal!), 1984.

1048. Cantale, C., ; Donato, A., ; Guidi, G., and X borosilicate glasses for the high activity waste vitrificationX. Report, Enea-Rt-Comb-84-1, 69 pp, 1985.

1049. Cantale, C., ; Glatz, J., P., ; Toscano, E., H., ; Donato, A., ; Coquerelle, X.M., ; Fuger, J., and $X$ characterization of highly active waste glasses produced in a hotx vitrification pilot plantX. Mater.Res.Soc.Symp.Proc., 176, 403-10X-10X, 1994. 
1050. Cà, S., ; Candelieri, T., ; Mataloni, P., ; Risoluti, P., and $\mathrm{x}$ preliminary experience with $\star \star \star$ vitrification*** inactive pilotx plant in italyx. Ber.Kernforschungsanlage Juelich, Juel-Conf-42 (Vol. 1), X Proc:roc-Level Liquid Wastex, 1994.

1051. Caplinger Hanford waste vitrification plant quality assurance program description: overview and applications. (Unknown Journal!) : (10 p), 1990.

1052. Caplinger An update on the quality assurance for the waste vitrification plants. (Unknown Journal!) : (10 p), 1990.

1053. Caplinger, W.H. Quality assurance for the Hanford Waste Vitrification Plant project. (Unknows Journal!), 1989.

1054. Caplinger, พ.H. Hanford waste Vitrification Plant quality assurance program description: Overview and applications. Part 1. (Unknown Journal!), 1990.

1055. Caplinger, w.F., Shugars, D.L., and Carlson, M.K. Update on the quality assurance for the waste vitrification plants. (Unknown Journal!) , 1990.

1056. Caporuscio, F.A. and Vaniman, D.T. Iron and Manganese in Oxide Minerals and in Glasses: Preliminary Consideration of Eh Buffering Potential at Yucca Mountain, Nevada. (Unknown Journal!), 1985.

1057. Caprara, G. Impianto PROTEO: Prove sperimentali per la qualificazione di componenti e sistemi di remotizzazione destinati al trattamento di vetrificazione e condizionamento dei rifiuti radioattivi. (PROTEO, HLW vitrification plant test facility: Remotely controlled processing and conditioning). (Unknown Journal!) , 1989.

1058. Cargo, J. and Hughes, M. Simultaneous analysis of boron and phosphorus in deposited glasses by inductively coupled plasma atomic emission spectroscopy with internal standardization. Joumal.of.the.Electrochemical,Society. $v 136$ n 4 Apr 1989:1239-1241, 1989.

1059. Carl, D., E., ; Rykken, L., ; stimnel, J., R., ; Marlow, J., H., ; Bray, L., X A., ; Wise, B., M., and X zeolite variability in the wrdp hlw glass feed streamsX. Adv. Ceram., 20, 383-9X-9X, 1994.

1060. Carl, D.E., Pope, J.M., Rykken, L.E., Bray, L., Holton, I., Witte, and Klein, W. Design of the reference west valley alkaline waste treatment process. In: v 1. Publ by ANS, La Grange Park, IL, USA $p$ 357-370,Anonymous La Grange Park, IL, USA:ANS, 1984,p. 357-370.

1061. Carl, D.E., Rykken, L.E., and Stimmel, J.R. Zeolite variability in the WVDP [West Valley Demonstration Project] HLW glass feed streams. Adv.Ceram. $20: 383-389,1986$.

1062. Carleson, T.E., Drown, D.C., Hart, R.E., and Peterson, M.E. Evaluation of the Transport and Resuspension of a Simulated Nuclear Waste Slurry: Nuclear Waste Treatment Program. (Unknown Journal!) , 1987. 
1063. Carlos, B.A. Minerals in Fractures of the Unsaturated Zone from Drill Core USW G-4, Yucca Mountain, Nye County, Nevada. (Unknown Journal!), 1985.

1064. Carlson, M.K. Vitrification at the Savannah River site. (Unknown Journal!) , 1989.

1065. Carman, D. The thermal properties of a sodium borosilicate glass, Alfred, NY:New York State College of Ceramics at Alfred University, 1978.

1066. Carmahan, C.I. Numerical simulations of heterogeneous chemical reactions coupled to fluid flow in varying thermal fields. (Unknown Journal!), 1991.

1067. Carniglia, S. Adsorption of certain radioactive colloids on glass, [Berkeley, 1945 .

1068. Carol M.Jantzen and Dennis F.Bickford BT - Leaching Mechanisms CT Leaching of Devitrified Glass Containing Simulated SRP Nuclear Waste.ED - Carol M.Jantzen ED - John A.Stone ED - Rodney C.Ewing Anonymous 1985,p. 135-146.

1069. Carpenter Hanford waste vitrification plant technical background document for best available radionuclide control technology demonstration. (Unknown Journal!) : (135 p), 1990.

1070. Carpenter, A., B., ; Skone, S., S., ; Rodenhizer, D., G., ; Marusich, M., $V$. , and $X$ hanford waste vitrification plant technical background document forX best available radionuclide control technology demonstration: finalx reportx. Report, Whe-Mr-0222; Order No.De91007170, 135 pp, 1991.

1071. Carpenter, A.B., Skone, S.S., Rodenhizer; D.G., and Marusich, M.V. Hanford Waste Vitrification Plant technical background document for best available radionuclide control technology demonstration. Final report. Progress rept. (Unknown Journal!), 1990.

1072. Carpenter, B.H. and Wilson, D.I. Technical/Economic Assessment of Selected PCB (Polychlorinated Biphenyl) Decontamination Processes. Journal article. (Unknown Journal!) , 1988.

1073. Carter, J., Brown, K., and Bickford, D. DWPF tDefense Waste Processing Facility] glass composition control based on glass properties. Adv. Fusion.Glass. :20.1-20.8, 1988.

1074. Carter, J.T. Research Melter Feed Additives Study. (Unknown Journal!), 1987.

1075. Carter, J.T. 774-A Research Melter Operation. (Unknown Journal!) , 1987.

1076. Carter, J.T., Brown, K.G., and Bickford, D.F. DWPF (Defense Waste Processing Facility) Glass Composition Control Based on Glass Properties. (Unknown Journal!), 1988 :

1077. Cartier Management of waste contaminated with alpha emitters. (Unknown Journal!) :(6 p), 1993. 
1078. Cassibba, R.O. Repositorio subterraneo de desechos radiactivos. Evaluacion de las barreras fisico-quimicas $y$ estudio de las velocidades. (Underground repository for radioactive wastes. Evaluation of the physicochemical barriers and the study of velocities). (Unknown Journal!) , 1989.

1079. Catchings, R. Magnetization and electrical conductivity studies of some $X$ transition metal oxide glasses, 1970.

10B0. Cates, M., R., ; Noel, B., W., ; Caldwell, J., T., ; Kunz, W., E., ; Close, D., X A., ; Franks, L., A., ; Pigg, J., L., and X application of linear accelerator technology to the detection ofX trace amounts of transuranics in waste barrelsx. Manage.Alpha-Contam.Wastes, Proc.Int.Symp., Meeting Date 1980,X $531-47-47,1994$.

1081. Caurant, D., Lejus, A.M., Thery, J., and Vivien, D. Investigation of Al203-La2O3 Glasses Using $\mathrm{Eu}-3+$ and $\mathrm{Cr}-3+$ as structural Probes. EUR.J.SOLID.STATE. INORG. CHEM. 30:307-324, 1993 .

1082. Caurel, J., ; Beaufort, D., ; Vernaz, E., Y., and $X$ mineral phase identification along two profiles from the lwr frenchx reference glass: use of an $x$-ray position sensitive detectorx. Mater.Res.Soc.Symp.Proc., 112, $663-72 X-72 X, 1994$.

1083. Caurel, J., ; Vernaz, E., ; Beaufort, D., and $x$ hydrothermal leaching of r7-t7 borosilicate glassX. Mater.Res.Soc.Symp.Proc., 176, 309-18X-18X, 1994.

1084. Cavanagh, M. Part I: The fatigue resistance of a lithium aluminosilicate glass- $X$ ceramic part II: The effects of storing abraded and acid polished soda-lime $X$ glass in distilled water and $6 \mathrm{~N} \mathrm{HCl}, 1978$.

1085. Cecal, A. storage of low- and medium-level radioactive wastes in easilyx fusible glassesX. Rev.Roum.Chim., 36, 1275-8X-8X, 1994.

1086. Cecal, A., Cretu, V, and Vrabie, D. Inclusion of low- and intermediate-level radioactive wastes inlow-fusible glasses. Rev.Roum.Chim. , 1991.

1087. Cerries, A., Brun Yaba, C., and Lewi, J. Performance evaluation of repositories in deep geological formations for the medium level and alpha waste. The Pacoma project, granite option. (Unknown Journal!), 1990.

1088. Chacey, K., Pope, J.M., Plodinec, M.J., Schaus, P.S., and Maestas, E. Doe-em/producers strategy for wasteform and process startup acceptance.X. In: Proc Ist Annu Int Top Meet High Level Radioact Waste Manage Part $2 . X$ Publ by ASCE,Boston Society of Civil Engineers Sect,Boston, MA, USA.X $p$ 785-789, Anonymous Boston Society of Civil Engineers Sect, Boston, MA, USA:ASCE, 1990, p. $785-789$.

1089. Chakrabarti, A.Y. Importance of orientational rearrangement during The. Journal. of. Physical. Chemistry. v. 96 (Aug. 6 192):6762-6766, 1992. 
1090. Chambre, P., L., ; Kang, C., H., ; Lee, W., W., ; Pigford, T., and $X$ the role of chemical reaction in waste-form performancex. Mater.Res.Soc.Symp.Proc., $112,285-91 X-91 X, 1994$.

1091. Chambre, P.I., Pigford, T.H., and Zavoshy, S. Solubility-limited dissolution rate in groundwater. In: Transactions of the American Nuclear Society $v 41$ 1982. Publ by ANS, LaX Grange Park, III, USA P 153-154, Anonymous LaX Grange Park, IIl, USA:ANS, 1982,p. 153-154.

1092. Chan, H., Howitt, D., and Harkex, A. Microstructures of simulated nuclear waste. J.Am.Ceram.Soc. , 1989.

1093. Chan, H., W., ; Howitt, D., G., ; Harker, A., B., and X crystalline phases of the simulated icpp nuclear wastesX. Microbeam Anal., 22nd, 230-2X-2X, 1994.

1094. Chan, H.W., Howitt, D.G., and Harker, A.B. Microstructures of simulated nuclear waste. Journal of the American Ceramic Society 72:1040-1043, 1989.

1095. Chandappa, N. An investigation of the possibilities of glasses in the system Bb2sOb3s-Alb2sOb3s-Nab2so their structure and physical properties, Alfred, NY:New York State College of Ceramics at Alfred University, 1948.

1096. Chandler, G., Wicks, G., and Wallace, R. Effects of SA/V [surface area to leachant vol] and saturation on the chemical durability of SRP waste glass. Adv. Ceram. 20:455-463, 1986.

1097. Chandler, G.T., ; Wicks, G.G., ; Wallace, R.M., and $X$ effects of $s a / v$ and saturation on the chemical durability of $\operatorname{sxpX}$ waste glassX. Adv.Ceram., 20, $455-63 x-63 x, 1994$.

1098. Chang, $Y$. and Hoenig, C.L. Thermal and stress analysis of hot isostatically pressed, alumina ceramic, nuclear waste containers. (Unknown Journal!) , 1990.

1099. Chao, Y. and Clark, D.E. Hydrothermal corrosion of lithium disilicate glass and glass ceramics. Glass.Technology. v. 25 (June '84):152-156, 1984.

1100. Chapman Experience with a joule heated ceramic melter while convertingx simulated high-level waste to glassX. Report. , 1977.

1101. Chapman Design preferences for a slurry-fed ceramic melter suitable for vitrifyingwest valley [ny nuclear] wastes. Adv.Ceram., 1985.

1102. Chapman, Blair, and Bonner Experience with waste vitrification systems at battelle-northwestX. Report. , 1976.

1103. Chapman, Blair, and Bonner Experience with waste vitrification systems at battelle-northwestx. Aiche.Symp.Ser. :Ser, 72 (154, Radioac-Ser, 72 (154, Radi60X, 1994.

1104. Chapman and Mendel Fixation of radioactive waste in glass X. Report. , 1977. 
1105. Chapman, A.T.A. The in-can melting of a simulated HLW-frit mixture in prototype canisters containing a varying diameter central sheet billet $/$, Atlanta :School of Ceramic Engineering and School of Electrical Engineering, Georgia Institute of Technology, 1979.

1106. Chapman, C. Nuclear waste glassmelter design. Glass Ind. , 1982.

1107. Chapman, C., Pope, J., and Barnes, S. Electric melting of nuclear waste glassesulstate of the art. J.Non-Cryst.Solids, 1986.

1108. Chapman, c. Evaluation of vitrifying municipal incinerator ash. Ceram. Trans. $23: 223-231,1991$.

1109. Chapman, C., C., ; Buelt, J., J., and X nuclear waste $\star \star \star v i t r i f i c a t i o n * \star *$ $\mathrm{x}$. Back End Lwr Fuel Cycle, , Issue Conf-780304, Ix/13-Ix/14.X Ntis: Springfield, Va.X-780304, IX/13-IX/14, 1994.

1110. Chapman, C., C., ; Buelt, J., I., ; Slate, S., ; Katayama, Y., B., ;X Bunnell, $L_{.,}$., and $X * * * v i t r i f i c a t i o n * * *$ of hanford wastes in a joule-heated ceramicx melter and evaluation of resultant canisterized productx. Report, Pnl-2904, 74 pp, 1980.

1111. Chapman, C.C. Comparison of the Rotary Calciner-Metallic Melter and the Slurry-Fed Ceramic Melter Technologies for Vitrifying West Valley High-Level Wastes. (Unknown Journal!), 1983.

1112. Chapman, C.C. and Drosjack, W.P. Vitrification process equipment design for the West Valley Demonstration Project. (Unknown Journal!) , 1988.

1113. Chapman, C.C. and McElroy, J.I. Slurry-Fed Ceramic Melter-A Broadly Accepted System to Vitrify High-Level Waste. (Unknown Journal!) , 1989.

1114. Chapman, C.C., ; Buelt, J.I., and $X * \star * v i t r i f i c a t i o n * \star *$ of high-level waste in a joule-heatedx ceramic melterx. Aiche symp.Ser., 75, 56-60x-60x, 1994.

1115. Chapman, N.A., Mckinley, I.G., Savage, D., and West, J.M. Mechanisms of dissolution of radioactive waste storage glasses andx caesium migration from a granite repository. In: Materials Research society symposia proceedings $v$ 6.Publ byX North-Holland, New York, NY, USA and Amsterdam, Neth $p$ 347-354,Anonymous New York, NY, USA: 1982,p. 347-354.

1116. Chapman, N.A. and ; Savage, D. dissolution of borosilicate glasses under repository conditions ofx pressure and temperaturex. Sci.Basis Nucl.Waste Manage., 2, 183-90X-90X, 1994 .

1117. Charlesworth, D.L. Waste Immobilization Process Development at the Savannah River Plant. (Unknown Journal!) , 1986.

1118. Chen Glass melter assembly for the hanford waste vitrification plant. (Unknown Journal!) : (8 p), 1993.

1119. Chen, A.E., Russell, A., Shah, K.R., and Kalia, J. Glass melter assembly for the Hanford Waste Vitrification Plant. (Unknown Journal!), 1993. 
1120. Chen, G. Vitrification of simulated medium and high level Canadian nuclear waste in a continuous transferred arc plasma melter, Ottawa :National Library of Canada = Bibliotheque nationale du Canada, 1992.

1121. Chen, J., D., and $X$ analysis of two radioactive nepheline syenite ***glass***X hemispheres retrieved from the chalk river nuclear laboratories' $X$ waste management sitex. Radioelem.Anal.: Prog.Probl., Proc.Conf.Anal.Chem. EnergyX Technol., 23rd, Meeting Date 1-20, 1994.

1122. Chen, L.S. and Fu, S.L. Densification and Dielectric-properties of Çordierite-Lead Borosilicate Glasses. JPN.J.APPL.PHYS.PT.1. 31:3917-3921, 1992.

1123. Chen, M., James, P.F., Jones, F.R., Dalton, D.A., Howard, B.H., and Bedford, S. Strengthening of Soda Lime Silica Glass by Gel-Derived zinc Borosilicate and Sodium Alumino-Borosilicate Glass Coatings. J.NON-CRYST.SOLIDS. 139:185-197, 1992.

1124. Chen, N. and Haun, M. Control of the intergranular glass phase in alumina ceramics, Colorado school of Mines, Dept. of Metallurgical and Materials Engineering, 1992 .

1125. Chen, X.H., Ren, H.S., Hua, T.C., zhang, H., Xu, W., and Wang, Q.F. Vitrification of multicomponent solutions by cooling to cryogenic temperatures. Cryogenics. 30:539-541, 1994.

1126. Cheng, K.Y. and Bishop, P.I. Leaching Boundary Movement in Solidified Stabilized Waste Forms. J.AIR.WASTE.MANAGE.ASSOC. 42:164-168, 1992.

1127. Chia, W.T., Chowdari, B.V.R., and Tan, K.I. Structural and Physical Characterization of the Li20p205Crol.5 Ion-Conducting Glasses. J.MATER.SCI. $28: 3594-3600$, 1993 .

1128. Chick, L., Bunnell, and Strachan, D. Evaluation of lead-iron-phosphate glass as a high-level waste form. Adv.Ceram. , 1986.

1129. Chick, L., Lokken, R., and Strachan, D. Development of a west valley [ny] nuclear waste glass by empiricalmodeling. J.Am.Ceram.Soc. , 1986.

1130. Chick, L., Lokken, R., and Thomas, L. Basalt glass-ceramics for the immobilization of transuranic nuclear waste. Am.Ceram.Soc.Bul1. , 1983.

1131. Chick, L. and Piepel Statistically designed optimization of a glass composition. J.Am.Ceram.Soc. , 1984.

1132. Chick, L., A., ; Buckwalter, C., Q., and $x$ low leach rate glasses for immobilization of nuclear wastesx. Report, Pnl-3522, 27. pp, 1981.

1133. Chick, L., A., ; Bunnell, L., R., ; Strachan, D., M., ; Kissinger, H., E., ;X Hodges, F., N., and $X$ evaluation of lead-iron-phosphate glass as a high-level waste formX. Report, Pal-5878; Order No.De87001849, 23 pp, 1987. 
1134. Chick, I., A., ; Pederson; I., R., and $X$ the relationship between reaction layer thickness and leach rate forX nuclear waste glassesX. Mater.Res.Soc.Symp.Proc., 26,X 635-42X-42X, 1994.

1135. Chick, I.., A., ; Piepel, G., F., ; Gray, W., J., ; Mellinger, G., B., ; Barnes, X.B., $O .$, and $X$ statistically designed study of a nuclear waste $\star \star \star g l a s s * \star \star X$ systemX. Sci.Basis Nucl. Waste Manage., 2, 175-81X-81X, 1994.

1136. Chick, I., A., ; Piepel, G., F., ; Mellinger, G., B., ; May, R., P., ; Gray, W., X J., ; Buckwalter, C., Q., and X effects of composition on properties in an 11 -component nuclearX waste $\star \star \star$ glass $* \star \star$ systemX. Report, PnI-3188; Order No.De81030781, 120 pp, 1981.

1137. Chick, L., A., ; Swanson, J., L., ; Goldman, D., S., and X nuclear waste glass composition limitationsx. Fuel Reprocess.Waste Manage., Proc.Am.Nucl.Soc.Int.Top.X Meet., Volume 1, 386-402:ark, I11, 1994.

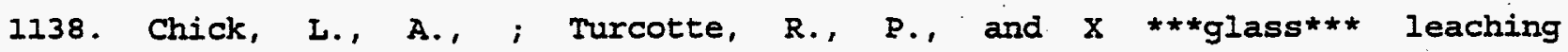
performanceX. Report, Pnl-4576; Order No.De83012465,. 59 pp, 1983.

1139. Chick, L.A., Lokken, R.O., Strachan, D.M., and Bowen, W.M. Development of a west valley nuclear waste glass by empirical modeling.X. Joumal of the - American Ceramic Society 69:114-118, 1986.

1140. Chick, L.A. and Pederson, L.R. Relationship between reaction layer thickness and leach rate forx nuclear waste glasses. In: <CI> Symposium held as part of the Annual Meeting of the MaterialsX Research Society Materials Research Society Symposia Proceedings v 26.Publ byX North-Holland, New York, NY, USA and Amsterdam, Neth $p$ 635-642, Anonymous New York, NY, USA: 1984,p. 635-642.

1141. Chick, L.A., Swanson, J.L., and Goldman, D.S. Nuclear waste glass composition limitations. In: $v 1$. Publ by ANS, La Grange Park, IL, USA $p$ 386-402, Anonymous La Grange Park, IL, USA:ANS, 1984,p. 386-402.

1142. Chick, L.A., ; Lokken, R.O., ; Thomas, L.E., and X basalt ***glass*** ceramics for the immobilization ofX transuranic nuclear wastex. Am. Ceram.Soc.Bull., 62, 505-9, 516X-9, 516X, 1994.

1143. Chickering, R., Yoldas, B., and Neuman, B. Nuclear waste encapsulation in borosilicate glass by chemicalpolymerization. (Unknown Journal!) , 1983.

1144. Chiou, S. and Hahn, H.T. Ultrasonic sol/gel processing of aluminoborosilicate glass and its composite with carbon fiber reinforcement. Journal. of.the.American.Ceramic.Society. v. 77 (Jan. '94):155-160, 1994.

1145. Chipman; N.A., Engelgau, G.O., and Berreth, J.R. Evaluation of Neutralization for Processing Sodium-Bearing Liquid Waste. (Unknown Journal!) , 1989.

1146. Chismar Experimental joule-heated ceramic melter for convertingx radioactive waste to glass $\mathrm{X}$. Report. , 1979. 
1147. Chismar, P. Experimental joule-heated ceramic melter for convertingx radioactive waste to glass X. Proc.Conf.Remote.Syst.Technol. -12X, 1978.

1148. Chiu, K.C., Pabanz, N.E., and Asuncion, O.T. Dynamic Simulation Aids DWPF off-Gas and Ventilation Design. (Unknown Journal!) , 1986.

1149. Choi Mathematical modeling of radioactive waste glass melter. (Unknown Journal!) : (11 p), 1990.

1150. Choi High level nuclear waste treatment in the defense waste processing facility: overview and integrated flowsheet model. (Unknown Journal!) : 7 p), 1991.

1151. Choi Numerical simulation of high-level radioactive nuclear waste glass production. (Unknown Journal!) : (10 p), 1991.

1152. Choi, A.S. and Fowler, J.R. Material balance tables for the DWPF basic data report (DPSP-80-1033). Revision 138: Appendix G, Table 19-1. (Unknown Journal!) , 1990.

1153. Choi, A.S., Fowler, J.R., Edwards, R.E., and Randall, C.T. High level nuclear waste treatment in the Defense Waste Processing Facility: Overview and integrated flowsheet model. (Unknown Journal!) , 1991.

1154. Choi, I. Mathematical modeling of radioactive waste-glass melter. Ceram.Trans. , 1991.

1155. Choi, I., G., ; Eyler, L., L., ; Allen, C., R., and X simulation of freeze/restart process for defense waste processingX melterX. Radioact.Waste Manage.Nucl.Fuel Cycle, 16, 119-35X-35X, 1994.

1156. Choi, $I$. and $X$ mathematical modeling of $\star \star \star$ radioactive $* \star \star \star \star \star$ waste $* \star \star X$ ***glass*** melterX. Ceram.Trans., 23, 385-94X-94X, 1994.

1157. Choi, I.G. Analysis of natural convection in a waste glass melter. (Unknown Journal!) , 1989.

1158. Choi, I.G. Mathematical modeling of radioactive waste glass melter. (Unknown Journal!) , 1990.

1159. Choi, I.G., Bickford, D.F., and Carter, J.T. Thermal effects of electrically conductive deposits in melter. (Unknown Journal!), 1992.

1160. Choi, I.G. and Ungan, A. Numerical simulation of high-level radioactive nuclear waste glass production. (Unknown Journal!), 1991.

1161. Chotin, M., M., ; Hugony, P., ; Pieraggi, A., and X industrial operating experience at the marcoulex $\star \star \star v i t r i f i c a t i o n * \star \star$ facilityx. Treat.Handl.Radioact.Wastes, , Meeting Date 1982, 72-5:ress: Columbus, Ohio, 1994.

1162. Chowdari, B.V.R., Mok, K.F., Xie, J.M., and Gopalakrishnan, R. Spectroscopic and Electrical studies of Silver sulfophosphate Glasses. J.NON-CRYST.SOLIDS. 160:73-81, 1993. 
1163. Chowning, J. The durability of soda-lime glasses /, 1936.

1164. Christensen, A., B., ; Del Debbio, J., A., ; Knecht, D., ; Tanner, J., $E .$, and $X$ immobilization and leakage of krypton encapsulated in zeolite or $X$ ***glass*** X. Mater.Res.Soc.Symp.Proc., 6,X 525-32X-32X, 1994.

1165. Christensen, A.B., DelDebbio, J.A., Knecht, D.A., and Tanner, J.E. Encapsulation of krypton-85 in zeolite molecular sieve with a hotx isostatic press. In: <CI> Volume 1: General Interest Publ by Arizona Board of Regents, $A Z$, USA $p$ 469-473, Anonymous AZ, USA:Arizona Board of Regents, 1986,p. 469-473.

1166. Christensen, H., Hermansson, H., and Bjorner, I. Leaching of simulated nuclear waste glass under dynamic conditions. Adv.Ceram. , 1986.

1167. Christensen, H., Hermansson, H., and Clark, D. Surface reactions occurring on simulated nuclear waste glass immersed inaqueous solutions containing bentonite, granite, and stainless steelcorrosion products.

Adv.Ceram. , 1985.

1168. Christensen, H., Hermansson, H., Clark, D.E., and Werme, L. Surface reactions occurring on simulated nuclear waste glass immersedx in aqueous solutions containing bentonite, granite, and stainless-steelx corrosion products. In: <CI> Held during the 85th Annual Meeting of the American CeramicX Society Advances in Ceramics $v 8$. Publ by American Ceramic SOC Inc, Columbus, $X$ OH, USA $P$ 346-357, Anonymous Columbus, $X$ OH, USA:American Ceramic SOC Inc, 1984,p. 346-357.

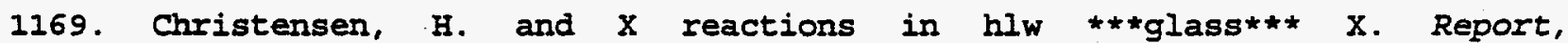
Studsvik/E2-79-136, $41 \mathrm{pp}, 1980$.

1170. Christensen, H.H.,Hans Peter; Bjoerner leaching of simulated nuclear waste glass under dynamic conditionsX. Adv.Ceram., 20, 475-85X-85X, 1994 .

1171. Christie, W., H., ; Eby, R., E., ; Warmack, R., J., ; Landau, L., and X secondary ion mass spectrometry: some applications in the analysisX of nuclear materialsX. Anal.Chem.Nucl.Technol., Proc.Conf.Anal.Chem. Energy Technol., $X$ 25th, Meeting Date 1-8, 1994.

1172. Christie, W.H., Eby, R.E., and Warmack, R.J. Determination of boron and lithium in nuclear materials by secondary ion mass spectrometry. Anal.Chem. 53 (1) : 13-17, 1981 .

1173. Chryssikos, G.D., Kapoutsis, J.A., Kamitsos, E.I., Patsis, A.P., and Pappin, A.J. Lithium-sodium metaborate glasses: structural aspects and vitrification chemistry. Joumal.of.Non-Crystalline.Solids. 167, Number $1-2: 89-92,1994$.

1174. Chun studies on the thermal decomposition of nitrates found in highlyx active waste and of chemicals used to convert the waste to glassX. U.K.At.Energy.Res.Establ. -R, 1994.

1175. Chun and Morris The thermal decomposition of harvest feed slurries and thex characterization of the productsX. U.K.At.EnergY.Res.Establ. -R, 1994. 
1176. Chun, K., S., ; Morris, J., B., and $X * * *$ vitrification*** of highly active liquid waste.ii.thermalx decomposition of harvest feed slurries and the characterization ofX the productX. J.Korean Nucl.Soc., 11, 203-12X-12X, 1994.

1177. Chun, K.S., Park, H.S., Ahn, J.S., Hwang, J.H., and Choi, J.W. Study on the safety of spent fuel management. A scenario study on spent fuel management. (Unknown Journal!), 1992.

1178. Chun, K.S.,Sang HoonX ***vitrification*** of highly active liquid waste.i.thermalx decomposition of nitrates and additives for $\star * *$ glass $\star \star *$ -makingx. J.Korean Nucl.Soc., 9, 211-22X-22X, 1994.

1179. Chun, K.S. solidification of high-level radioactive liquid wastesX. J.Korean Nucl.Soc., 11, 231-9X-9X, 1994.

1180. Cicero Heme and hepa filter element dissolution process. (Unknown Journal!) : $(26 \mathrm{p}), 1923$.

1181. Clare, A., Parker, J., and Furniss, D. Spectroscopy of $U$ sup 3 sup + in fluoride glasses. J.Phys.:.Condens.Matter. 1[44]:8753-8758, 1989.

1182. Clark, D., Gac, F., and Sutton, W. Ceramic transactions, volume 21: microwave: theory and applications inmaterials processing Y. (Unknown Jounnal!) . 1992 .

1183. Clark, D., Lodding, A., and Odelius Elemental analysis of swedish nuclear waste glassesùleachability vscomposition. Mater.Sci. Eng. , 1987.

1184. Clark; D., Zhu, and Hench, L. Evaluation of six-month burial data [on nuclear waste glasses] from stripa[sweden]. Riv.stn.Sper.Vetro, 1984.

1185. Clark, D. and zoitos, B. Corrosion of glass, ceramics, and ceramic superconductorsùprinciples, testing, characterization, and applications. (Unknown Journal!) , 1991.

1186. Clark, D., Zhu, B.F., and Robinson, R.S. Preliminary report on a glass burial experiment in granite. Adv. Ceram. 8:324-336, 1985.

1187. Clark, D., E., ; Hench, L., I., and X. an overview of the physical characterization of leached surfacesX. Nucl.Chem.Waste Manage., 2 , 93-101X-101X, 1994.

1188. Clark, D., E., ; Lodding, A., ; Odelius, H., ; Werme, L., O., and X elemental analysis of swedish nuclear waste glasses: leachabilityx vs.compositionx. Mater.sci.Eng., 91, 241-56X-56X, 1994.

1189. Clark, D., E., ; Maurer, C., A., ; Jurgensen, A., R., ; Urwongse, I., and $x$ effects of waste composition and loading on the chemical durabilityx of $a$ borosilicate ***glass*** X. Mater.Res.Soc.Symp.Proc., 11,X 1-13X-13X, 1994.

1190. Clark, D., E., ; Urwongse, I., ; Maurer, C., and X application of $\star \star \star g l a s s * \star \star$ corrosion concepts to nuclear wastex immobilizationX.

Nucl. Technol., 56, 212-25X-25X, 1994. 
1191. Clark, D.E., Christensen, H., Hermansson, H., Sundvall, S., and Werme, L. Effects of flow on corrosion and surface film formation on an alkali borosilicate glass. In: <CI> Held during the 85 th Annual Meeting of the American Ceramic Society Advances in Ceramics $v 8$. Publ by American Ceramic Soc Inc, Columbus, OH, USA P 19-29, Anonymous Columbus, OH, USA:American Ceramic SOC Inc, 1984,p. 19-29.

1792. Clark, D.E. and Hench, L.L. Theory of corrosion of alkali-borosilicate glass. In: Materials Research Society Symposia Proceedings $v 15$. Publ by ElsevierX Science Publ Co,New York,NY,USA and Amsterdam,Neth $p$ 113-124,Anonymous New York, NY, USA:ElsevierX Science Publ Co, 1983,p. 113-124.

1193. Clark, D.E., Lodding, A., Odelius, H., and Werme, L.O. Elemental analysis of swedish nuclear waste glasses: leachability vs.X composition. Materials Science and Engineering 91:241-256, 1987.

1194. Clark, D.E., Maurer, C.A., Jurgensen, A.R., and Urwongse, L. Effects of waste composition and loading on the chemical durability ofX a borosilicate glass. In: Materials Research Society Symposia Proceedings $v 11$.Publ byX North-Holland, New York, NY, USA and Amsterdam, Neth p 1-13,Anonymous New York, NY, USA: $1982, p . i-13$.

1195. Clark, S.B. and Wilhite, E.L. Low-level liquid waste disposal at the Savannah River site: A large scale demonstration of saltstone. (Unknown Journal!) , 1990.

1196. Clark, w. and Fitzgerald, C. Laboratory developemnt of processes for fixation of high-levelx radioactive wastes in glassy solids.v.continuous fixation ofX aqueous waste:the con-potglass processX. U.S.A.E.C. :Avail Dep mn; CFSTIX, 1967.

1197. Clark, W., Hess, D., Neumann, Rice, L., and English, J. Laboratory development of processes for fixation of high-levelx radioactive wastes in glassy solids.iv.corrosion studies onX candidate materials of constructionX. U.S.A.E.C., 1967.

1198. Clark, W., Suddath, J., Hancher, C., X, B.R., Godbee, H., Holmes, J., and $X, F . C$. Development of processes for solidification of high-levelx radioactive waste: summary for pot calcination and rising levelX potglass processesX. Aec.Access.Nos. , 1967.

1199. Clarke, D. Preferential dissolution of an intergranular amorphous phase in a nuclearwaste ceramic. J.Am.Ceram.Soc. , 1981.

1200. Clelland, D., Corbet, and Coles Design of a plant for the incorporation of highly active wastes intoX glassX. CHEM.ENG.PROGR. :Ser, 65(94), 89-Ser, $65(94) 101 X, \cdot 1994$.

1201. Clelland, D.W. and Corbet, A.D.W. Selection and application of a processing system for the treatment ofx high level liquid waste in the uk. In: <CI> Selected Papers presented at the American Nuclear Society TopicalX Meeting Publ by Battelle Press, Columbus, OH and Richland,WA, USA andX Springer-Verlag, New York, NY, USA and Heidelberg, West Ger $p$ 59-63, Anonymous Columbus, OH and Richland, WA, USA:Battelle Press, 1983,p. 59-63. 
1202. Clinard, F.W.J., Livak, R.J., Hobbs, L.W., Rohr, D.L., and White, T.J. Structural changes in $* * 2 * * 3 * * 8$ pu-substituted zirconolite on recovery from the metamict state Extended defect as a mechanism for the immobilization of $\mathrm{hlw}$ species inX zirconolite,perovskite and hollandite. In: Materials Research Society Symposia Proceedings $v$ 50. Publ by MaterialsX Research SOC, Pittsburgh, PA, USA p 371-378 Materials Research Society Symposia Proceedings $v$ 50. Publ by MaterialsX Research Soc,Pittsburgh, PA, USA $p$ 283-290, Anonymous Pittsburgh, PA, USA:MaterialsX Research SOC, 1986,p. 283-290.

1203. Cobb, W.T. and Hrma, P. Behavior of Ruo sub 2 in a glass melt. Ceram.Trans. 23:233-237, 1991 .

1204. Cochet and Cariou Very high performance microconcretes for the confinement of industrialwaste. CEM.CONCR.RES. , 1992.

1205. Coghlan, W.A. and Clinard, F.W. Modeling of Irradiation-Induced Amorphization in a Titanate Ceramic. (Unknown Journal!) , 1987.

1206. Cohen, Lewis, and Braun Disposal of radioactive waste in deepX silicate rOCkX. IEEE TRANS.NUCL.SCI. -6X, 1994.

1207. Cohen, J., Lewis, A., and Braun Disposal of radioactive waste in deepX silicate rockx. Report. , 1972.

1208. Colburn, R.P. Hanford Waste Vitrification Plant preliminary waste form and canister description: Fiscal year 1990 update. (Unknown Journal!), 1990.

1209. Cole, H., S., ; Brotzman, J., R., ; Simpson, G., G., and $X$ characterization of ***vitrified*** icpp alumina waste calcinex. Report, Enico-1048, 24 pp, 1980.

1210. Cole, H., S., ; Gombert, D., , R., and X properties of ***vitrified*** icpp zirconia calcinex. Report, Enico-2038, 40 pp, 1980.

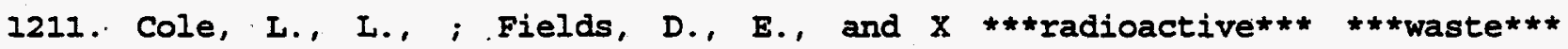
***vitrification*** : aX reviewX. Report, Ornl/Tm-11292; Order No.De90003378, $31 \mathrm{pp}, 1990$.

1212. Cole, L.L. and Fields, D.E. Radioactive Waste Vitrification: A Review. (Unknown Journal!) , 1989.

1213. Coleman Determination of noble metals in savannah river site high-level radioactive sludge. (Unknown Journal!) : (10 p), 1990.

1214. Coleman Analyses of high-level radioactive glasses and sludges at the savannah river site. (Unknown Journal!) :(22 p), 1990.

1215. Coleman Colorimetric determination of fe sup $2+/$ fe sup $3+$ ratio in radioactive glasses. (Unknown Journal!) :(5 p), 1992.

1216. Coleman, C., J., ; Bibler, N., E., ; Dewberry, R., A., and X analyses of high level radioactive glasses and sludges at theX savannah river sitex. Proc.Symp.Waste Manage., (Waste Manage. 90, Vol. 2), 651-7X-7X, 1994. 
1217. Coleman, C.J., Baumann, E.W., Bibler, N.E., Dewberry, R.A., and Sturcken, E.F. Analysis of Radioactive Waste and Glass for a Defense waste Solidification Plant. (Unknown Journal!), 1987.

1218. Coleman, C.J., Dewberry, R.A., Lethco, A.J., and Denard, C.D. Analytical Methods and Laboratory Facility for the Defense waste Processing Facility. (Unknown Journal!) , 1985.

12i9. Coles, D., Weed, H., Jackson, D., and Schweiger, X Single-pass leaching of nuclear melt glass by groundwaterX. Acs.Symp.Ser. :Ser, 100(Radioact Wa-Ser, 100 (Radioac114X, 1994.

1220. Coles, D., G., ; Weed, H.; C., ; Jackson, D., D., ; Schweiger, J., S., and $X$ single-pass leaching of nuclear melt $* *$ glass $* *$ by groundwater. $X$ part iX. Report, Ucrl-81617, Conf-790139-1, 34 pp, 1979.

1221. Compere, E.,Jr. and Godbee, H.W. Interrelation of short-term leach tests and long-term leaching. Trans.Am. Nucl.SOC. 33:207-208, 1979.

1222. Compiled by the Australian Ceramic Society| Proceedingsùninth australian ceramic conference Illus. (Unknown Journal!), 1980.

1223. Congdon, J.W. Inhibition of Nuclear Waste Solutions Containing Multiple Aggressive Anions. (Unknown Journal!), 1987.

1224. Conradt, R. and Roggendorf, H. Determination of the Corrosion Mechanisms of High Level Waste Containing Glass. Reported Period: January 1, 1983 February 28, 1985. Final Report. (Unknown Journal!), 1985.

1225. Conradt, R. and Roggendorf, H. Determination of the Corrosion Mechanisms of High Level Waste Containing Glass. Final Report (January 1981 - February 1985). (Unknown Journal!) , 1985..

1226. Conradt, R. and Roggendorf, H. Ermittlung der Rorrosionsmechanismen an HLW-haltigem Glas. Schlussbericht ueber die vom 01.01 .85 bis zum 28.02 .85 durchgefuehrten Arbeiten. (Determination of the corrosion mechanisms of high level waste containing glass. Reported period: January 1, 1983 - February 28, 1985. Final report). (Unknown Journal!), 1985.

1227. Conradt, R., Roggendorf, H., and Ostertag, R. Basic Corrosion Mechanisms of HLW Glasses. (Unknown Journal!) , 1986.

1228. Conradt, R., Roggendorf, H., and Scholze, H. Contribution to the modelling of the corrosion process for hlw glasses.x. In: <CI> Held as part of the Fall Meeting of the Materials Researchx Society Materials Research Society Symposia Proceedings $v 44$. Publ by MaterialsX Research Soc, Pittsburgh, PA, USA $p$ 155-162, Anonymous Pittsburgh, PA, USA:MaterialsX Research SOC, 1985,p. 155-162.

1229. Conradt, R., Roggendorf, H., and Scholze, H. Investigations on the role of surface layers in hlw glass leaching. In: Materials Research society Symposia proceedings $v$ 50. Publ by MaterialsX Research SOc, Pittsburgh, PA, USA $p$ 203-210, Anonymous Pittsburgh, PA, USA:MaterialsX Research SOC, 1986,p. 203-210. 
1230. Conradt, R., ; Roggendorf, H., ; Scholze, H., and X investigations on the role of surface layers in hlw glass leachingx. Mater.Res.Soc.Symp.Proc., 50, $\mathrm{X}$ 203-10X-10X, 1994.

1231. Conradt, R., ; Roggendorf, H., ; Scholze, H., and X chemical durability of a multicomponent $\star * \star g l a s s * \star$ in ax simulated carnallite/rock salt environmentX. Mater.Res.Soc.Symp.Proc., 26,X .9-15X-15X, 1994.

1232. Conradt, R., ; Roggendorf, H., ; Scholze, H., and X a contribution to the modeling of the corrosion process for hlwX glassesX. Mater.Res.Soc.Symp.Proc., $44, X \quad 155-62 X-62 X, 1994$.

1233. Constable, M., Fenton, A., Lee, D.J., Jones, D.V.C., and Wilding, C.R. Elevated temperature grouts and radioactive waste inventory. (Unknown Journal!) , 1990 .

1234. Cook, R., F., ; Lawn, B., R., ; Dabbs, T., P., ; Reeve, K., D., ; Ramm, E., J., ; X woolfrey, J., L., and $X$ a comparative study of the fatigue properties of synroc andx borosilicate ***glass*** X. J.Am.Ceram.Soc., 65, C172-C173X-C173X, 1994.

1235. Cooley Spent fuel and high-level waste management in selected countries: trends and issues. (Unknown Journal!) : (11 p), 1990.

1236. Cooley, C.R. and Schneider, K.J. Spent fuel and high-level waste management in selected countries: Trends and issues. (Unknown Journal!), 1990.

1237. Cooper, M.J. and Tasker, P.W. Nirex Safety Assessment Research Programme for 1987/1988. (Unknowri Journal!) , 1987.

1238. Corbet, Hall, and Spiller Problems in the design and specification of containers for vitrifiedx high-level liquid wastex. Manage.Radioact. Wastes.Nucl. Fuel.Cycle -30, 1994.

1239. Corbett, R.A. and Bickford, D.F. Corrosion Testing of High Chromium Alloys in Simulated Waste Environments. (Unknown Journal!) , 1989.

1240. Corbett, R.A., Bickford, D.F., and Morrison, w.S. Corrosion evaluation of alloys for nuclear waste processing. In: Publ by NACE, Houston, TX, USA Pap 254, 16p, Anonymous Houston, TX, USA:NACE, 1986,

1241. Corbett, R.A., Bickford, D.F., and Morrison, W.S. Corrosion Evaluation of Alloys for Nuclear Waste Processing. (Unknown Journal!) , 1986.

1242. Corcoran B plant secondary containment description and analysis. (Unknown Journal!) : (29 p), 1991.

1243. Corke, C.C. and Archer, M.D. The electrochemical corrosion of an Fe74Cr6P13C7 metallic glass produced by Vacuumschmelze GmbH. Corrosion.Science v.28.no4. ('88).p.353-69.bibl.il.diags. 10-938X, 1988.

1244. Cormier, G., Capobianco, J.A., Morrison, C.A., and Monteil, A. Molecular-Dynamics Simulation of the Trivalent Europium Ion Doped in Sodium 
Disilicate Glass - Electronic Absorption and Emission-Spectra. PHYS.REV.B-CONDENSED.MATTER. 48:16290-16303, 1993.

1245. Cousens, D., R., ; Lewis, R., A., ; Myhra, S., ; Segall, R., L., ; Smart, R., S., X C., ; Turner, P., and X the chemical durability of some hlw glasses: effects ofx hydrothermal conditions and ionizing radiationx. Mater.Res.Soc.Symp.Proc., 11, X 163-71X-71X, 1994.

1246. Cousens, D., R., ; Myhra, S., and $x$ the effects of ionizing radiation on hlw glassesX. J.Non-Cryst.Solids, 54, 345-65X-65X, 1994.

1247. Cousens, D., R., and $X$ the dissolution of $\star * *$ glass $\star \star *$ during irradiation by cobalt-60X .gamma.-raysX. Proc. - Aust.Ceram.Conf., 9, 135-41X-41X, 1994.

1248. Cousens, D.R., Lewis, R.A., Myhra, S., Segall, R.I., Smart, R.S.C., and Turner, P.S. Chemical durability of some hlw glasses: effects of hydrothermalx conditions and ionising radiation. In: Materials Research society symposia Proceedings $\vee$ 11.Publ byX North-Holland, New York, NY, USA and Amsterdam, Neth p 163-171, Anonymous New York, NY, USA: 1982,p. 163-171.

1249. Covington, Wicks, G., and Molecke; M. Wipp [waste isolation pilot plant]/srl in situ tests: miit [materialsinterface interactions tests] programùthe effects of metal packagecomponents. Ceram.Trans. , 1991.

1250. Covino, J., Klemm, K., and Dykema, J. Coatings for hypersonic applications. Materials. Performance. Mater Perform v 30 n, 1991.

1251. Cowan, R.E.,Rodney C. and $X$ freshwater alteration of basaltic glass, hanauma bay, oahu, hawaii:X a natural analogue for the alteration of borosilicate glass in freshX waterX. Mater.Res.Soc.Symp.Proc., 127, 49-56X-56X, 1994.

1252. Cowan, S., P., ; Fulmer, D., C., and $X$ the defense waste processing facility - a status reportX. Proc.Symp.Waste Manage., (Waste Manage.'87, Vol. 2), 75-7X-7X, 1994 .

1253. Cowan, S., P., and $x$ the defense waste processing facility. an innovative process forx high-level waste immobilizationx. Nucl.Mater.Manage., 14, 538X, 1994.

1254. Cowan, S.P. Defense Waste Processing Facility: An Innovative Process for High-Level Waste Immobilization. (Unknown Journal!) , 1985.

1255. Cowgill, M.G. Comparison of solidification media for the stabilization of low-level radioactive wastes. (Unknown Journal!) , 1991.

1256. Cowley, T. and Robertson, M.A. Effect of $\mathrm{pH}$ and temperature on fiberglass-reinforced composites in sodium hypochlorite solutions. Materials.Performance.v.30. (July. '91).p.46-9. 94-1492, 1991.

1257. Cox, G.A. and Khooli, A.-R. The natural corrosion of glass: the formation and structure of plugs. Glass.Technology. v. 33 (Apr. '92):60-62, 1992. 
1258. Cozar, O., Ardelean, I., Bratu, I., Ilonca, G., and Simon, S. EPR, Ir and Magnetic-Susceptibility Studies of Xcr2O3(1-X)(2B203.Li2O) Glasses. SOLID.STATE. COMMUN. $86: 569-572,1993$.

1259. Craievich, A.F., Alves, O.L., and Barbosa, L.C. Saxs Study of Nucleation and Growth of Cdtel-xSx Semiconductor Nanocrystals in Borosilicate Glass. J.PHYS.IV. $3: 373-376,1993$.

1260. Crandall, w. The Effect of the addition of certain oxides on the surface tension of a glass, an enamel frit, and a glaze measured by the drop weight method /, Alfred, N.Y. :New York State College of Ceramics at Alfred University, 1944.

1261. Crawford, C.I. and Bibler, N.E. Effects of temperature and radiation on the nuclear waste glass product consistency leach test. (Unknown Journal!), 1993.

1262. Creach, M. and Magonthier, M.C. Retention of radionuclides in poorly organized phases in the near fieldx of a hlw nuclear disposal facility. Applied Clay Science 7:59-69, 1992 .

1263. Criscenti, L.J. and serne, R.J. Thermodynamic modeling of cement/groundwater interaction as a tool for long-term performance assessment. (Unknown Journal!) , 1989.

1264. Crivat, D. Dependence of porosity of aluminosilicate coatings on firing conditions. Rev.Roum.Phys. 20[4]:67-68, 1975.

1265. Crivat, D. and Goran, M. Permeability of aluminosilicate coatings on vitroceramic nuclear fuel elements. J.NUCL.MATER. 95 [N 1-2]:224-227, 1980 .

1266. Crovisier, J., L., ; Atassi, H., ; Daux, V., ; Honnorez, J., ; Petit, J., C., ; $X$ Eberhart, J., $P .$, and $X$ a new insight into the nature of the leached layers formed on $x$ basaltic glasses in relation to the choice of constraints for longX term modelingX. Mater.Res.Soc.Symp.Proc., 127, 41-8X-8X, 1994.

1267. Crovisier, J., L., ; Fritz, B., ; Grambow, B., ; Bberhart, J., P., and X dissolution of basaltic glass in seawater: experiments andx thermodynamic modellingX. Mater.Res.Soc.Symp.Proc., 50,X 273-80X-80X, 1994.

1268. Crovisier, J.I., Fritz, B., Grambow, B., and Eberhart, J.P. Dissolution of basaltic glass in seawater: experiments andx thermodynamic modelling. In: Materials Research Society Symposia Proceedings $v$ 50. Publ by MaterialsX Research SOC, Pittsburgh, PA, USA P 273-280,Anonymous Pittsburgh, PA, USA:MaterialsX Research SOc, 1986,p. 273-280.

1269. Crow, K.R. Off-Gas Chemistry Study of Melter Feed by Springborn Laboratories. (Unknown Journal!) , 1985.

1270. Crow, K.R., Weisman, A.F., Guidotti, P.D., Wehner, A.M., and Griffin, G.A. Summary of Campaigns SGM-4 and SGM-5 of the DWPF Scale Glass Melter. (Unknown Journal!), 1988 . 
1271. Crubellati, R.O., ; Di Santo, R.R., and $X$ determination of microquantities of cesium in leaching tests byx atomic absorptions spectrometry with electrothermal atomizationX. An.Asoc.Quim.Argent., 76, 19-24X-24X, 1994.

1272. Csencsits, R. Vitrification of $Y$ zeolite and its effects on HREM images I. 1986 .

1273. Cuddihy, E., Lawton, R., and Gavin, T. Healing of voids in the aluminum metallization of integrated circuit chips. IEEE Transactions.on.Reliabilit. 39 n 5:564-570, 1990 .

1274. Cummins, C.I., Martin, D.K., and Todd, J.I. Savannah River. Site environmental report for 1989. Volume 2, Figures and data tables. (Unknown Journal!) , 1989.

1275. Cunnane The role of laboratory analog experiments in assessing the performance of waste package materials. (Unknown Journal!) :(8 p), 1990 .

1276. Cunnane, J. and Bates Identification of colloids in nuclear waste glass reactions. Ceram.Trans., 1991.

1277. Cunnane, J., C., ; Allison, J., M., and $X$ high-level waste glass compendium; what it tells us concerning thex durability of borosilicate waste glassX. Mater.Res.Soc.Symp.Proc., 333, 3-14X-14X, 1994.

1278. Cunnane, J., C., ; Bates, J., K., ; Ebert, W., I., ; Feng, X., ; Mazer, J., J., ;X Wronkiewicz, D., ; Sproull, J., ; Bourcier, W., ; McGrail, B., P., and $x$ high-level nuclear-waste borosilicate glass: a compendium of $x$ characteristicsX. Mater.Res.Soc.Symp.Proc., 294, 225-32X-32X, 1994.

1279. Cunnane, J., C., ; Bates, J., K., and X identification of colloids in nuclear waste glass reactionsX. Ceram.Trans., 23, 65-73X-73X, 1994.

1280. Curti, E. modeling the dissolution of borosilicate glasses for radioactivex waste disposal with the phreeqe/glassol code: theory and practicex. Psi-Ber., 86, 62 pp, 1994.

1281. Curti, E., ; Vernaz, E., Y., and X enhancement of the glass corrosion in the presence of clay minerals: $X$ testing experimental results with an integrated glass dissolutionX modelX. Mater.Res.Soc.Symp.Proc., 294, 163-70X-70X, 1994.

1282. Curti, E. and Smith, P.A. Enhancement of borosilicate glass dissolution by silica sorption and diffusion in compacted bentonite--a model study. Mater.Res.Soc.Symp.Proc. 212:31-39, 1991.

1283. Curti, E. Modelling the dissolution of borosilicate glasses for radioactive waste disposal with the PHREEQE/GLASSOL cONM: theory and practice. (Unknown Journal!) , 1991.

1284. Curti, E. Modelling the dissolution of borosilicate glasses for radioactive waste disposal with the PHREEQE/QLASSOL Code : theory and practice /, Wettingen, Switzerland :Nagra, 1991. 
1285. Curti, E. and $X$ modeling the dissolution of borosilicate glasses for radioactivex waste disposal with the phreege/glassol code: theory and practiceX. Tech.Ber. - Nagra, 91-08, 65 pp-8, 65 pp, 1994.

1286. Curtis, H.W., Salmon, A.J., Hunter, I.J., James, L.G., Knowles, D.R., Milne, W.G., Old, M., and Willis, A. Transportation of high level wastes. In: International Atomic Energy Agency, Proceedings Series $718 \mathrm{v} 2$. Publ byx IAEA, Vienna, Austria p 309-316, Anonymous Proceedings Series $718 \mathrm{~V} 2: 1987, \mathrm{p}$. 309-316.

1287. Cuzmax, R. The effect of electrodes in the thermally stimulated currents in sodium silicate glass, 1985.

1288. Czuczwa, J. Babcock \& Wilcox cyclone vitrification technology /, Cincinnati; OH :U.S. Environmental Protection Agency, 1993.

1289. D'Entremont, P., D., ; Wolf, H., C., and X development of a slurry-fed in-can melter for nuclear defense wastex. Report, Dp-1662; Order No.De84010670, $32 \mathrm{pp}, 1984$.

1290. d'Entremont, P.D. and Hobbs, D.T. Savannah River Site high-level waste safety issues: The need for final disposal of the wastes. (Unknown Journal!) . 1991.

1291. d'Entremont, P.D. and Walker, D.D. Tank Farm Processing of High-Level Waste for the Defense Waste Processing Facility. (Unknown Journal!), 1987.

1292. D.D.Walker and E.I.Wilhite BT - Vitrified Waste Forms CT - Soluble High-Level Waste Decontamination and Disposal at the Savannah River Site.ED Dillard B.Shipler ED - C.R.Allen PB - American Nuclear Society, I. Anonymous 1994.

1293. D.D.Walker and E.L.Wilhite BT - Vitrified Waste Forms CT - Soluble High-Level Waste Decontamination and Disposal at the Savannah River Site.ED Dillard B.Shipler ED - C.R.Allen PB - American Nuclear Society, I. Anonymous 1994, p. 1110-1114.

1294. D.F.Bickford $I$ and R.B Diemer Jr.2 Redox Control of electric Melters.with Complex Feed Compositions, Part 1: Analytical methods and models. Journal.of.Non-Crystalline.Solids. 84:276-284, 1986.

1295. D.F.Bickford 1, R.B.Diemer, J., and D.C.Iverson 1 Redox Control of Electric Melters with Complex Feed Compositions; Part II: Preliminary limits for radioactive waste melters. Journal.of.Non-Crystalline.Solids. 84-291, '1986.

1296. D.I Moirl and A.Chatt Studies on Leaching Behaviour of Sodium Borosilicate Glasses by Neutron Activation: Effects of groundwater composition, $\mathrm{pH}$, surface area to volume ... ratio and temperature. Journal. of.Radioanalytical.and.Nuclear.Chemistry,.Articles.PY.-.1992. 161, no. $2: 503-526,1994$.

1297. D.R.Uhlmann Crystallization and Glass formation. Journal. of.Non-Crystalline.Solids. 73:585-592, 1985. 
1298. Daev, K., ; Simeonov, V., and $X$ mathematical description of the decontamination of liquidX $* * *$ radioactive $* * * * * *$ waste $* * *$ using natural sorbents of thex tectosilicate,phyllosilicate and mixed typesx. God.Sofii.Univ., Khim.Fak., Volume Date 1975-1976, 70, Pt:t-94X, 1994.

1299. Dai, Y.S., Yamaguchi, I., Takahashi, K., and Iwaki, M. Effect of Ion Implantations and Posttreatments on Optical-Transmission of Fluorozirconate Glass. JPN.J.APPL.PHYS.PT.1. 32:4026-4032, 1993.

1300. Dai, Y.Z, and Chiang, F.P. Damage monitoring of composite material by image processing. Experimental. Technique. 14 n 4:39-41, 1990.

1301. Dalakas, M.C. High-Dose Intravenous Immunoglobulin and Serum Viscosity Risk of Precipitating Thromboembolic Events: NEUROLOGY 44:223-226, 1994.

1302. Dalton, D.A. The future of crystal. Glass.Technology. v. 34 (June 193):88-90, 1993 .

1303. Dalton, J., C., ; Eccles, E., W., ; Innes, A., J., ; Marples, J., A., and $X$ small-scale, fully-active vitrification of 'magnox' and thorpx high-level wastex. Report, Aere-R-12868, IIwrp-86/P21, Doe-Rw-86.053, 21 Pp, 1989.

1304. Dalton, J., T., ; Boult, K., A., ; Chamberlain, H., E., ; Marples, J., $C .$, and $x$ the influence of metal oxides on the leach rate and crystallization $x$ behavior of waste glassesx. Ber.Kernforschungsanlage Juelich, Juel-Conf-42 (Vol. 1) , $\mathrm{X}$ Proc:roc-Level Liquid Wastex, 1994.

1305. Damle, A.S. Modeling a Furnace Sorbent. Slurry Injection Process. J.AIR. WASTE. MANAGE.ASSOC. $44: 21-30,1994$.

1306. Daniel Microstructure and composition of silicate melts containingx simulated hanford wastex. Report. , 1975.

1307. Daniel, J., I., and $X$ zeolite $* \star * v i t r i f i c a t i o n * \star \star$ demonstration program:X characterization of nonradioactive demonstration productx. Report, Gend-025; Order No.De82022513, 43 pp, 1982.

1308. Daniel, J.I., Mellinger, G.B., and Barner, J.O. Reference and testing materials available from the materialsX characterization center. In: 〈CI> Held as part of the Fall Meeting of the Materials Researchx Society Materials Research Society Symposia Proceedings $v 44$. Publ by Materialsx Research Soc, Pittsburgh, PA, USA P 723-728, Anonymous Pittsburgh, PA, USA:MaterialsX Research SOC, 1985,p. 723-728.

1309. Daniel, J.L., Mellinger, G.B., and Barner, J.O. Reference Materials for Nuclear Waste Investigation. (Unknown Journal!), 1985.

1310. Daniels,.E., A., ; Srinivasan, S., M., R., and $X$ study of uptake of

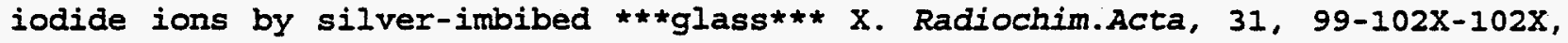
1994.

1311. Dascomb, S. Oxygen bubble formation in glass, Davis, Calif.1992. 
1312. Dasilva, D.A. Remote Crane Control: Techniques and Closed Circuit Television for the US Deparment of Energy, Defense Waste Processing Facility. (Unknown Journal!) , 1988.

1313. Daugherty, H.F., Golden, M.P., Jacoby, w.R., and Krauss, J.E. Decontamination and decommissioning at the west valley site progressx and plans. In: <CI> Volume 2: Low-Level Waste, Volume Reduction Methodologies andx Economics Publ by Arizona Board of Regents, AZ, USA $p$ 375-381, Anonymous AZ, USA:Arizona Board of Regents, 1984,p. 375-381.

1314. Daux, V., Crovisier, J.I., and Petit, J.C. Rare-earth elements [REE's] behavior during alteration of basaltic glasses--case of the weathering of Icelandic hyaloclastites. Mater.Res.Soc.Symp.Proc.,. 212:107-114, 1991.

1315. David, G. Experimenting with vitreous enamels using aluminum as a base, Eastern New Mexico University, 1964.

1316. Davidovits, J. Waste solidification and disposal method. (Unknown Journal!) , 1989.

1317. Davies, J., Lay, K., and Marlowe, M.C.P. Nuclear fuel. (Unknown Journal!) , 1989.

1318. Davies, J., Marlowe, M., and Patterson, C.C.P. Nuclear fuel element. (Unknown Journall) , 1990.

1319. Davis, B. Dynamic modelling of a slurry fed ceramic melter used in the nuclear waste vitrification process /, 1989.

1320. Davis, D. Gas bubbles in boric oxide melts, Alfred, N.Y.New York state College of Ceramics at Alfred University, 1972.

1321. Davis, I. Glass Vitrification of Nuclear Wastes. (Unknown Journal!), 1985 .

1322. Davis, I.L. and Smith, D. Ni-Rich Olivine in Minettes from 2 Buttes, Colorado - A Connection Between Potassic Melts from the Mantle and Low Ni Partition-Coefficients. GEOCHIM. COSMOCHIM.ACTA 57:123-129, 1993.

1323. Davydov, Dobrygin, Dolgov, and Sergeev Ks-kt-100 plant for two-stage vitrification ofX radioactive waste and results of tests withX. Manage.Radioact. Wastes.Nucl. Fuel.Cycle -84, 1994.

1324. Day, F. Oxidation-reduction equilibria in glass between iron and selenium in various furnace atmospheres, Pittsburgh, Pa.University of Pittsburgh, 1941.

1325. De Angelis, B. barrier against the release of radionuclides from

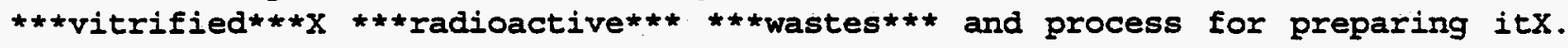
Eur.Pat.Appl., 3 pp, 1994.

1326. De Batist, R., Van Iseghem, P., De Grave, E., and Stalios, A.D. Structure and thermal stability of iron-silicate nuclear waste glasses.x. Journal of Nuclear Materials 169:342-349, 1989. 
1327. De Batist, R., ; De Grave, E., ; Timmermans, W., ; Vangeel, J., ; Vanx Iseghem, P., and $X$ structure and stability of incinerated .alpha.-waste productsX. Sci.Basis Nucl. Waste Manage., 2, 351-9X-9X, 1994.

1328. De Batist, R., ; Jacquet Francilion, N., ; Lanza, F., ; Malow, G., ;X Marples, J., A., C., and $X$ behavior of $* \star \star v i t r i f i e d * \star * ~ * \star \star$ radioactive $* \star *$ ***waste $* * * X$ under simulated repository conditionsX. Comm. Eur.Communities, Eur, Eur 10163, Radioact-31X, 1994.

1329. De Batist, R., ; Van de Voorde, N., ; Van Iseghem, P., and $\mathrm{X}$ high-temperature incineration of .alpha.-wastex. Radioact.Waste Manage., 1 , 171-80X-80X, 1994 .

1330. De Batist, R., ; Van Iseghem, P., ; De Grave, E., ; Stalios, A., D., and $X$ structure and thermal stability of iron-silicate nuclear wastex glassesX. J.Nucl.Mater., 169, 342-9X-9X, 1994.

1331. De Biasi, R.S. and Fernandes, A.A.R. Crystallization of the amorphous alloy $\mathrm{Fe} / / 4 / / \mathrm{ONi} / / 4 / / \mathrm{OB} / / 2 / / 0$ : A ferromagnetic resonance study. Journal. of.Materials.Science J Mater Sci $v 24$ n 1, 1989.

1332. De Coninck, A., ; Demonie, M., ; Claes, J., and $\mathrm{x}$ design and preliminary experience of interim storage facility forx vitrified wastex. Nucl.Eur., 6 , $27-9 x-9 x, 1994$.

1333. De Guire, M., O'Handley, R.C., and Kalonji, G. Gas atomization of cobalt ferrite-phosphate melts. Journal.of.Materials.Science $J$ Mater Sci $v 24$ n 2 , 1989.

1334. de Kever, E. and Frischat, G. Influence of batch moisture and atmosphere on melting behavior of lead oxide-containing glass. Journal.of.the.American.Ceramic.Society. J Am Ceram Soc v 73, 1990.

1335. de Marsily, G., Behrendt, V., Ensminger, D.A., Flebus, C., and Hutchinson, B.L. Radiological Assessment of the Consequences of the Disposal of High Level Radioactive Waste in sub-Seabed Sediments. (Unknown Journal!), 1987 .

1336. De Natale, J. and Howitt, D. Radiation damage in a nuclear waste glass. Am.Ceram.Soc.Bull. , 1982 .

1337. De Natale, J., McElfresh, and Howitt, D. Preliminary observations on the microstructure of nuclear waste glasses. Ceram.Int. , 1982.

1338. De Natale, J. Radiation damage in silicate glass, Davis, Calif.:University of California, Davis, University Microfilms International, 1985.

1339. De Regge, P., Loida, A., Schmidt Hansberg, T., and Sombret, C. Methods for Conditioning Wastes from Spent Fuel Cans and Dissolver Residues. (Unknown Journal!) , 1985 . 
1340. De Villiers, D.R. and Schmid, H.K. Piezoelectricity and microstructures of modified lead titanate ceramics. Journal.of.Materials.Science J Mater Sci $v$ 25 I 7, 1990.

1341. de Villiers, D., Kingon, A., and Res, M. Polymorphic mixes of zirconia from a borate glass melt. Joumal.of.the.American.Ceramic.Society. v. 71 (May ' 88) : C244-C246, 1988 .

1342. De Wet, D.J. and Van Wyk, G.N. Comparative study of the surface oxidation behaviour of amorphous and crystallized $\mathrm{Fe} / / 6 / / 7 \mathrm{Co} / / 2 / / 8 \mathrm{~B} / / 1 / / 4 \mathrm{Si} / / 1$ metallic glass. Journal. of.Materials.Science J Mater Sci v 24 n 6, 1989.

1343. De and Luckscheiter Fixation of radioactive decay products in crystal phases of glassX ceramic productsX. Fortschr.Mineral , 1994.

1344. De, Luckscheiter, Lutze, Malow, and Schiewer Fixation of fission products in glass ceramicsX. Atomwirtsch. -8), 1994.

1345. De, Luckscheiter, Lutze, Malow, Schiewer, and $X, T$. Fixation of fission products, in .glass ceramicsX. Manage.Radioact. Wastes.Nucl.Fuel.Cycle -73, 1994.

1346. De, Luckscheiter, Malow, and Schiewer Fission products in glasses.part ii: development of glassx ceramicsX. Hahn-Meitner-Inst.Kernforsch.Berlin. -Meitner-Inst, 1994.

1347. De, A., Luckscheiter, B., Lutze, w., Malow, G., and X, S. Development of glass ceramics for the incorporation of fissionx productsx. Am.Ceram.Soc. -3X, 1994.

1348. De, A., Luckscheiter, B., Lutze, W., and Malow, G. Development of glass-ceramics for the incorporation of fission products. Am.Ceram.Soc.Bull. $55[5]: 500-503,1976$.

1349. Deacon, D. the long-term dry storage of irradiated oxide fuel andx ***vitrified*** wasteX. Nucl.Eng.Int., 26, 32-6X-6X, 1994.

1350. Dedaldechamp on-line analysis and process control at the service atelier-pilotex in marcoulex. Report. , 1975.

1351. Dejneka, M., Riman, R., and Snitzer, E. Sol-gel synthesis of high-quality heavy-metal fluoride glasses. Journal.of.the.American.Ceramic.Society. Journal of the Ameri, 1993.

1352. Dekever, E. and Frischat, G.H. Melting Behavior of Glass Batches with Addition of Cadmium-Containing Compounds. GLASTECH.BER. 65:325-328, 1992.

1353. Del Cul, G.D. and Gilliam, T.M. Development of an in-line grout meter for improved quality control: January 1990 progress report. (Unknown Journal!) , 1991.

1354. Delage, F. and Dussossoy, J.L. R7T7 glass initial dissolution rate measurements using a high-temperature Soxhlet device. Mater.Res.Soc.Symp.Proc. $212: 41-47,1991$. 
1355. Delage, F., L., and X $57 t 7$ glass initial dissolution rate measurements using ax high-temperature soxhlet devicex. Mater.Res.Soc.Symp.Proc., 212, $41-7 X-7 X, 1994$.

1356. Delage, F., ; Ghaleb, D., ; Dussossoy, J., L., ; Chevallier, O., ; Vernaz, E., and $X$ a mechanistic model for understanding nuclear waste glassX dissolutionX. J.Nucl.Mater., 190, 191-7X-7X, 1994.

1357. Delage, F., ; Larche, F., ; Vernaz, E., and $X$ dissolution of r7t7 glass in static and flowing conditions: $X$ influence of silicon diffusion mechanism in the leached layerX. Mater.Res.Soc.Symp.Proc., 294, 171-6X-6X, 1994.

1358. Delage, F., Ghaleb, D., Dussossoy, J.L., Chevallier, O., and Vernaz, E. A Mechanistic Model for Understanding Nuclear Waste Glass Dissolution. J.NUCL.MATER. 190:191-197, 1992.

1359. Delage, F., Ghaleb, D., Dussossoy, J.I., Chevallier, O., and Vernaz, E. Mechanistic model for understanding nuclear waste glass dissolution. Journal of Nuclear Materials 190:191-197, 1992.

1360. Dell'orco, P.C., Foy, B.R., Robinson, J.M., and Buelow, S.J. Hydrothermal treatment of Hanford waste constituents. (Unknown Journal!), 1992.

1361. Dell, $W$. Nuclear magnetic resonance studies of the structure of sodium $X$ borosilicate, magnesium borate, lithium borate, and sodium $x$ fluoroberyllate glasses, Providence, R.I.[s.n.], 1983.

1362. Della Mea Utilization of glass in high-level waste storage. Riv.Str.Sper.Vetro (Murano, 1988.

1363. Della Mea, G., ; Dran, J., C., ; Petit, J., ; Bezzon, G., ; Rossi Alvarez, X.C., and $X$ new data on ion-induced modifications of aqueous dissolution ofX $* \star \star s i l i c a t e s * \star$ X. Mater.Res.Soc.Symp.Proc., 26,X $747-54 X-54 X, 1994$.

1364. Della Mea, G., ; Dran, J., C., ; Petit, J., ; Bezzon,. G., ; Rossi Alvarez, X.C., and $x$ use of ion beam techniques for studying the leaching properties ofx lead-implanted $\star \star \star s i l i c a t e s * *$ X. Nucl.Instrum.Methods Phys.Res., 218, 493-9X-9X, 1994.

1365. Della Mea, $G$. and $X$ use of $* *$ glass*** for immobilization of

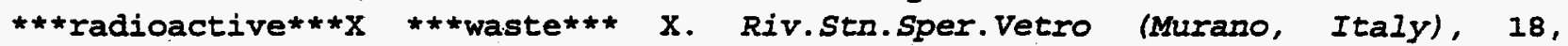
$193-6 \mathrm{X}-6 \mathrm{X}, 1994$.

1366. Delia Valle, R.G., Gazzillo, . D., and Pastore, G. Non-additive Lennard-Jones model for the structure of $\mathrm{Ni} / / 3 / / 3 \mathrm{Y} / / 6 / / 7$ metallic glass: integral equation and molecular dynamics calculations. Materials.science \&. Engineering.A: . Structural.Materials: . Properties, . Microstructure.and. Processin g. Materials Science \&, 1993.

1367. Demaroe, J.D., Was, G.S., and Sorensen, N.R. Chemical and structural effects of phosphorus on the corrosion behavior of ion beam mixed Fe-Cr-P 
alloys. Journal. of.the.Electrochemical.Society. $\mathrm{v} 140 \mathrm{n} 2$ Feb 1993:331-343, 1993.

1368. Demczyk, B.G., Artman, J.O., Virtanen, S., and Boehni, H. Magnetic properties of magnetron sputtered Co-Cr thin films Passivity, breakdown and repassivation of glassy Fe-Cr-P alloys. Journal.of.Physics.D:.Applied.Physics.Corrosion.science Passivation of Metal, 1990.

1369. Demkina, L.I. The Refractive Index, Mean Dispersion, and Density of Boron xOxide in Borosilicate Glasses Containing Sodium-Oxide and XPotassium- Oxide. The.Soviet.journal.of.glass.physics.and.chemistry. 19, Number 1:56-63, 1993.

1370. DeNatale, J. Radiation damage in nuclear waste [silicate] glass. Glasses and Glass-Ceram.for Nuclear Waste Managem , 1987.

1371. DeNatale, J. and Howitt, D. Importance of ionization damage to nuclear waste storage in glass. Am.Ceram.Soc.Bull., 1987.

1372. DeNatale, J., F., ; Howitt, D., G., and $X$ the gamma-irradiation of nuclear waste glassesX. Radiat.Eff., 91, 89-96X-96X, 1994.

1373. DeNatale, J., F., ; McElfresh, D., K., ; Howitt, D., G., and X radiation effects in nuclear waste glassesx. Mater.Res.Soc.Symp.Proc., $6, \mathrm{x}$ 697-702X-702X, 1994 .

1374. DeNatale, J., F., ; McElfresh, D., K., ; Howitt, D., G., and X preliminary observations on the microstructure of nuclear wastex glassesX. Ceram.Int., 8, 128-30X-30X, 1994.

1375. DeNatale, J.F. and Howitt, D.G. Importance of ionization damage to nuclear waste storage in glass. American Ceramic society Bulletin 66:1393-1396, 1987.

1376. DeNatale, J.F., McElfresh, D.K., Howitt, D.G., Bibler, N.E., Northrup, C.J.M.J., Arnold, G.W., and Headley,. T.J. Radiation effects in nuclear waste glasses Effects of alpha, gamma, and alpha-recoil radiation on borosilicatex glass containing savannah river plant defense high-level nuclear waste.X Ion implantation studies of nuclear waste forms. In: Materials Research Society Symposia Proceedings $v 6$. .Publ byX North-Holland, New York, NY, USA and Amsterdam, Neth $p$ 697-702 Materials Research Society Symposia Proceedings $v$ 6.Publ byX North-Holland, New York, NY, USA and Amsterdam, Neth $p$ 681-687 Materials Research Society Symposia Proceedings v 6.Publ byX North-Holland, New York, NY, USA and Amsterdam, Neth $p$ 667-679,Anonymous New York, NY, USA: 1982 ,p. 667-679.

1377. DeNatale, J.F., ; Howitt, D.G., and $X$ importance of ionization damage to nuclear waste storage in glassX. Am.Ceram.Soc.Bul1., 66, 1393-6X-6X, 1994 .

1378. DeNatale, J.F., ; Howitt, D.G., and $X$ radiation damage in a nuclear waste $\star \star *$ glass $* \star$ X. Am. Ceram.Soc.Bul1., 61, 582-4X-4X, 1994.

1379. Derby, J.U., Pye, L.D., and Plodinec, M.J. Measurement of thermal diffusivity of simulated glass forming nuclearx waste melts. In: Materials 
Science Research $v$ 15. Publ by Plenum Press, New York, NY,X USA and London, Engl p 615-625, Anonymous New York, NY, X USA:Plenum Press, 1983,p. 615-625.

1380. Derrington, J.A. Toxic and radioactive waste management. <CTS Joint ICE/ASCE/CSCE Conference <CL> London, Engl <CD> 1987 Sep 6-11 Journal of Professional Issues in Engineering 114-467, 1988.

1381. Deschaud Decontamination and dismantling of the piver prototype vitrification facility at marcoule (france). (Unknown Journal!):([11] p), 1992.

1382. Detilleux, Eschrich, and Geel The minerva processx. Report. , 1979.

1383. Detilleux, Eschrich, and Van Geel The minerva process - a versatile process for the solidification ofx liquid radioactive wastes from nuclear fuel reprocessingX. Eur.Co.Chem.Process.Irradiat.Fuels. -294, 1994.

1384. Detilleux, E., Hild, : W., and van Geel, J. Reprocessing, decontamination and decommissioning waste management atX eurochemic - current and planned activities. In: <CI> Selected Papers presented at the American Nuclear Society TopicalX Meeting Publ by Battelle Press, Columbus, OH and Richland,WA, USA andX Springer-Verlag, New York, NY, USA and Heidelberg, West Ger p 76-83,Anonymous Columbus, OH and Richland, WA, USA:Battelle Press, 1983,p. 76-83.

1385. Detilleux,. E., VanGeel, J., and Eschrich, H. Article containing highly radioactive wasteX. Ger.Offen. :Addn to Ger Offen 2, 1994.

1386. Detillewx, E., VanGeel, J., and Eschrich, H. glass body containing highly radioactiveX waste X. Ger. Offen. , 1994.

1387. Dewberry, R.A. Estimation of $\mathrm{Sm-151}$ from Measured Pm-147. (Unknown Journal!) , 1988.

1388. Di Pace, $L$. and Guerrieri, M. Analisi tecnico-economica della possibilita' di cementazione dei residui liquidi di alta attivita' IAW/MTR-CANDU di EUREX. (Technical-economical analysis of the possibility of cementation of high-level (IAW/MTR-CANDU) EUREX residues). Progress rept. (Unknown Journal!), 1989.

1389. Diamond, H.F.,Arnold $M$. and $X$ alpha spectrum profiling of plutonium in

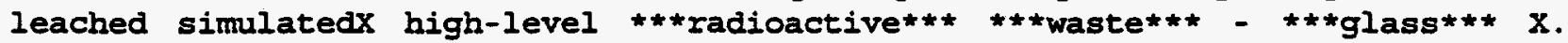
Nucl.Chem. Waste Manage., 2, 207-12X-12X, 1994.

1390. Diaz, C., Torres-Martinez, L.M., and Garza, I. Turning geothermal waste into glasses and glass ceramics. American.Ceramic.Society.Bulletin. v. 72 loct. '93) : 81-82, 1993 .

1391. DiBello, P.M. Controlling the oxidation state of a glass as a means of optimising sulphate usage in melting and refining. Glass.Technology. Glass Technology v 3, 1989.

1392. Dickey, B., R., ; Hogg, G., W., and $x$ heat transfer in high-level waste managementX. Nucl. Eng.Des., 67, 473-87X-87X, 1994. 
1393. Dickin, A., P., and $x$ hydrothermal leaching of rhyolite $\star * *$ glass $\star \star *$ in the environmentx has implications for nuclear waste disposalx. Nature (London), $294,342-7 X-7 X, 1994$.

1394. Diebold and Bates Adv.Ceram., 1986.

1395. Dierks, R. and Bonner, W. The performance of a wiped-film evaporator with simulated high levelx waste slurriesx. Aiche.Symp.Ser. :Ser, 72 (154, Radioac-Ser, 72 (154, Radio7X, 1994.

1396. Dierks; R., D., and $X$ the design and operation of $100-\mathrm{kg} / \mathrm{h}$ electric

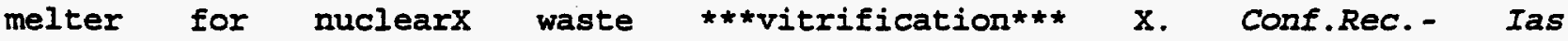
Annu.Meet. (Ieee), (I), 25-30X-30X, 1994.

1397. Dietrich, H. The formation and physical properties of a cellular glass foamed by zinc chloride, Alfied, N.Y. :New York State College of Ceramics at Alfred University, 1969.

1398. Dietz, M.I. and Horwitz, E.P. Novel Chromatographic Materials Based on Nuclear Waste Processing Chemistry. LC.GC-MAG.SEPARATION.SCI. 11:424-42\&, 1993.

1399. Dietz, T. and Kreider, K.G. Review of Materials for pH Sensing for Nuclear Waste Containment. (Unknown Journal!) , 1985.

1400. Diggs Integrating innovative technology into remedial action at a us department of energy facility. (Unknown Journal!) : $(23 \mathrm{p}), 1911$.

1401. Diggs Maws: a development program and demonstration to reduce vitrification remediation treatment costs. (Unknown Journal!) : (8 p), 1992.

1402. DiGiovanni, D.J., Morse, T.F., and Cipolla, J.W.J. Theoretical model of phosphorus incorporation in silica in modified chemical vapor deposition. Journal. of. the.American.Ceramic.Society. v 71 n 11 Nov 1988:914-923, 1988.

1403. Diliberto Defense waste tank storage at the hanford site. (Unknown Journal!) : (20 p), 1990.

1404. Dillman Technical and project highlights of the defense waste processing facility. (Unknown Journal!) : (29 p), 1990.

1405. Dillman, E.C., Elder, H.H., and Nichols, D.C. Technical and project highlights of the Defenge Waste Processing Facility. (Unknown Journal!) , 1990.

1406. Dilmore, M. Chemical durability of multicomponent silicate glasses $/$, 1977.

1407. Dippel, T. and Loida, A. Method for solidifying radioactive wastes. (Unknown Journal!) , 1985.

1408. Dippel, T., ; Guber, w., ; Hussain, M., ; Kahl, I., ; Saidl, J., and X preparation and characterization of an improved borosilicatex ***glass*** for 
the solidification of highly radioactive fissionx product solutions (haw) $X$. Kfk-Nachr., 11, 43-7X-7X, 1994.

1409. Dippel, T., ; Kahl, L., ; Saidl, J., and X further developments of borosilicate ***glass*** for theX ***vitrification*** of high-level fission product solutionsX. Atw, Atomwirtsch., Atomtech., 25, 81-2X-2X, 1994.

1410. Dippel, T., ; Kartes, H., ; Riege, U., and X solidification in ceramics

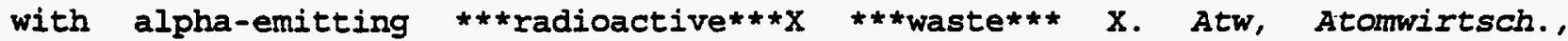
Atomtech., 26, 247-8X-8X, 1994 .

1411. Ditont, M.E. and Souffriau, J.D. Treatment of radioactive liquid wastesX. Belg. : $X, 1994$.

1412. Dix, S., ; Halaszovich, S., ; Mirschinka, V., and X fission product solidification: fipsx. Ber.Kernforschungsanlage Juelich, Juel-Conf-42 (Vol. 1) , $X$ Proc:roc-Level Liquid Wastex, 1994.

1413. Dmitriev, S., Knyazev, I., Stefanovskij, S., and Lifanov, F. Radionuclides volatilization during plasmochemical reprocessing ofX radioactive wastes. Fizika i Khimiya Obrabotki Materialov 4:74-82, 1993.

1414. Dobson, A. Vitrification. a 'high glass' business. Nuclear Engineer: Journal of the Institution of Nuclear Engineers 31X:151-153, 1990.

1415. Dobson, A. and $X$ vitrification - a "high glass" businessx. Nucl. Eng. (Inst.Nucl. Eng.), 31, 151-3X-3X, . 1994 .

1416. Doesburg, J.M. Role of innovative remediation technologies. (Unknown Journal!) , 1992.

1417. Doherty, J.P. Process Innovations to Minimize Waste Volumes at Savannah River. (Unknown Journal!) , 1986.

1418. Doherty, J.P., Eibling, R.E., and Marek, J.C. Defense Waste Processing Facility Precipitate Hydrolysis Process. (Unknown Journal!) , 1986.

1419. Doherty, J.P., Eibling, R.E., and Marek, J.C. Defense waste processing facility precipitate hydrolysis process. In: <CI> Volume 2 : High-Level Waste $v$ 2. Publ by Arizona Board of Regents, $A Z$, USA $P$ 475-478, Anonymous $A Z$, USA:Arizona Board of Regents, 1986,p. 475-478.

1420. Doherty, J.P. and Marek, J.C. Precipitate Hydrolysis Process for the Removal of Organic Compounds from Nuclear Waste Slurries. Patent Application. (Unknown Journal!) , 1987.

1421. Dolgov, Kolychev, Konstantinovich, Kulichenko, $x$, Nikipelov, Nikiforov, Martynov, $Y ., X, 0 . S . .$, Sedov, and shatsillo Development of methods for solidification and burial of fuel-cyclex radioactive wastesx. At.Energ. -60x, 1994.

1422. Donaldson Melter development needs assessment for rwmc buried wastes. (Unknown Journal!) : (140 p), 1992. 
1423. Donaldson, A.D., Carpenedo, R.J., and Anderson, G.I. Melter development needs assessment for RWMC buried wastes. (Unknown Journal!) , 1992.

1424. Donath, P. Sinterung abfallbeladener keramischer Massen mittels Mikrowelle. (Microwave sintering of waste loaded ceramic masses). (Unknown Journal!), 1990.

1425. Donato and Bocola The ester program-high-level radioactive wastex solidification. borosilicate glass experimentalx evaluation and bench-scale vitrification with simulatedX. Energ.Nucl. (Milan). -69X, 1994.

1426. Donato, A., Arcuri, L., Dotti, M., Pace, A., and Pietrelli, I. Rendering Inert Toxic and Noxious Wastes. Part Two. Process Based on Methods for Solidification of Radioactive Wastes in Cement Matrices. (Unknown Journal!) , 1989. .

1427. Donato, A., J, Z., Gottardi, A., and Soraru, A. Borosilicate Glass for the Eurex High Level Wastes. Characterization and Behaviour. (Unknown Journal!) , 1985.

1428. Donato, A., Pace, A., and Ricci, G. Optimization and characterization of cement products incorporating ashes from radwaste incineration. Third report. (Unknown Journal!) , 1989.

1429. Donato, A., Ricci, G., Grossi, G., Ward, C.R., and Rankin, W.N. Radwaste solidification modifications by means of nitrogen oxidesx catalytic abatement Decontamination of dwpf canisters by glass frit blasting. In: <CI> Volume 2 : Low-Level Waste, Volume Reduction Methodologies andx Economics publ by Arizona Board of Regents, AZ, USA P 177-182 <CI> Volume 1: Waste Policies and Programs, High-Level Waste Publ by Arizona Board of Regents, AZ, USA p 285-290,Anonymous $A Z$, USA:Arizona Board of Regents, 1984,p. 285-290.

1430. Donato, A., ; Gottardi, V., ; Soraru, A., and ; Ji Fu, Z. a borosilicate glass for the eurex high level wastes.X characterization and behaviorX. Ber.Kernforschungsanlage Juelich , Juel-Conf-54, Proc.Int.X Semin.Radioact. Waste Prod., 327-42X-42X, 1994.

1431. Donato; A., ; Grossi, G., ; Cantale, C., and X laboratory activity in italy in the field of $\star * \star v i t r i f i c a t i o n * \star * X$ of high-level wastesX. Ber.Kernforschungsanlage Juelich, Juel-Conf-42 (Vol. 1), X Proc:roc-Level Iiquid WasteX, 1994.

1432. Donato, A., ; Ricci, G., ; Grossi, G., and X radwaste solidification modifications by means of nitrogen oxidesX catalytic abatementx. Proc.Symp. Waste Manage., (2), 177-82X-82X, 1994.

1433. Dorea, A., Penzhorn, R.D., and Ache, H.J. Sequestration in Hydrothermally Modified zeolite 5A of $\mathrm{Kr}-85$ from Reprocessing: Mechanism of Fixation and Characterization of the Product. (Unknown Journal!) , 1988.

1434. Doremus, R., H., and X time dependence of the reaction of water with

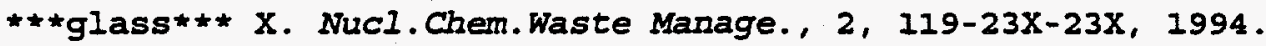


1435. Doremus, R. Glass makes its mark as a high tech material. Glass. Industry. v. 72 (Nov. 10 '91):26, 1991 .

1436. Dos Santos, D. and Aegertner, M. High-silica porous glasses for the storage of nuclear waste. Proc.Lat.Am.Tech.Symp.Glass Mfg. , 1985.

1437. Dos Santos, D., Ventura, P., and Aegertner, M. Porous glasses of high silica content for storage of nuclear wastes: ii,solidification, characterization, and leaching. Ceramica (Sao Paulo), 1984.

1438. Dos Santos, D.I.,Paulo Cezar Santos; Aegerter high silica porous glasses for storage of nuclear wastes. part ii.X solidification, characterization and leachingx. Ceramica (Sao Paulo), 30, 207-16X-16X, 1994.

1439. Dosch, R., G., ; Northrup, C., J., ; Headley, T., and X crystalline titanate ceramic nuclear waste forms: leaching andx radiation damagex. J.Am.Ceram.SOC., 68, 330-7X-7X, 1994.

1440. Dosch, $R ., G .$, and $X$ processing effects on the behavior of titanate waste forms inX aqueous solutionX. Report, Sand-81-1423C; Order No.De82001907, 8 pp, 1982 .

1441. Doud, J. and Veeder, R. The effect of phosphate additions on the physical properties of $X$ various glasses, Alfred, N.Y.New York State College of Ceramics at Alfred University, 1961.

1442. Dougherty, D., Colombo, 'P., Doty, R., and Fuhrmann, M. Leaching Mechanisms Program. Annual Report. (Unknown Journal!) , 1984.

1443. Dougherty, D.R., Pietrzak, R.F., Fuhrmann, M., and Colombo, P. Experimental Survey of the Factors that Affect Leaching from Low-Level Radioactive Waste Forms. (Unknown Journal!) ; 1988.

1444. Doweidar, H. Consideration of the boron oxide anomaly. Journal.of.Materials.Science J Mater Sci v 25 n 1, 1990.

1445. Doweidar, H., El-Shahawi, M.S., and Reicha, F.M. Phase separation and physical properties of sodium borosilicate glasses with intermediate silica content.

Journal of. Physics.D, .Applied. Physics.v.23. (Nov.14. '90) .p.1441-6.bibl.il.

22-3727, 1990 .

1446. Doweidar, H., El-Shahawi, M.S., Reicha, F.M., Lawson, M., Kim, H., and Pettit, F. Phase separation and physical properties of sodium borosilicate glasses. with intermediate silica content Hot corrosion of silica. Journal of. Physics.D, . Applied. Physics.Journal of. the American. Ceramic. Society. v. 73 (Apr. '90):989-995, 1990.

1447. Doweidar, H., El-Shahawi, M.S., Reicha, F.M., Silim, H.A., and El-Egaly, $\mathrm{K}$. Phase separation and physical properties of sodium borosilicate glasses with intermediate silica content. Journal.of.Physics.D:.Applied.Physics. J Phys D v $23 \mathrm{n} 11 \mathrm{~N}, 1990$. 
1448. Doweidar, H., Zeid, M.A.A., and Eldamrawy, G.M. Effect of Gamma-Radiation and Thermal-Treatment on Some Physical-Properties of ZnO-PbO-B2O3 Glasses. J.PHYS-D-APPL. PHYS. 24:2222-2228, 1991.

1449. Doyle, $C$. The solution of ferrous oxide in aluminosilicate melts and its effect on the solubility of sulphur, storrs:University of Connecticut, University Microfilms International, 1983.

1450. Doyle, E.F. and Donaldson, L.W. Batch preheating via a fluidized bed offers improved melter operation. Glass.Industry. v. 66 (July 10 '85):18, 1985.

1451. Drager, Emma, Fedelem, Hatch, X, S., Tuthill, and Weth Development of the phosphate glass process for ultimatex disposal of high-level radioactive wastes X. U.S.At. Energy.Comm. , 1969.

1452. Drake, R. Environmental agencies target chromium emissions for action. Glass.Industry.v.66. (Mar.10.'85).p.28-30.i1. 17-1026, 1985.

1453. Dran, J., C., and $X$ radiation effects in radioactive waste storage materialsX. Diffus.Defect Data, Pt.B, 30-31,X 367-78X-31,X 367-78X, 1994.

1454. Dran, J., C., ; Langevin, Y., ; Maurette, M., ; Petit, J., ; Vassent, B., and $\mathrm{X}$ ion implantation effects in insulators and the long-term stabilityx of

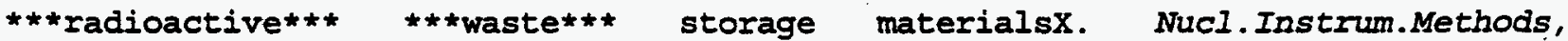
$182-183,741-6 \mathrm{X}-183,741-6 \mathrm{X}, 1994$.

1455. Dran, J., C., ; Langevin, Y., ; Maurette, M., ; Petit, J., ; Vassent, B., and $X$ leaching behavior of ion-implanted simulated hlw glasses andx tentative prediction of their alpha-recoil agingx. Mater.Res.Soc.Symp.Proc,, 6, X $651-9 \mathrm{X}-9 \mathrm{X}, 1994$.

1456. Dran, J., C., ; Langevin, Y., ; Maurette, M., ; Petit, J., and X radiation effects in radwaste glasses: a reappraisal ofX alpha-recoil aging as simulated by ion implantationX. Mater.Res.Soc.Symp.Proc., 6,X 717-25X-25X, 1994.

1457. Dran, J., C., ; Langevin, Y., ; Maurette, M., ; Petit, J., and X a

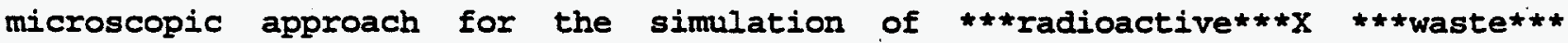
storage in $* * \star g l a s s * \star *$ X. Sci.Basis Nucl.Waste Manage., 2, 135-40X-40X, 1994.

1458. Dran, J., C., ; Maurette, M., ; Petit, J., ; Vassent, B., and X radiation damage effects on the leach resistance of glasses andx minerals: implications for $\star \star \star$ radioactive $\star \star \star \star \star \star \star$ waste $* \star \star X$ storageX. Sci.Basis Nucl.Waste Manage., 3 , $449-56 \mathrm{X}-56 \mathrm{X}, 1994$.

1459. Dran, J., C., ; Petit, J., ; Trotignon, I., ; Paccagnella, A., ; Dellax Mea, G., and $x$ hydration mechanisms of silicate glasses: discussion of thex respective role of ion exchange and water permeationx. Mater.Res.SOC.Symp.Proc., 127, 25-32X-32X, 1994.

1460. Dran, J.-C., Lombardi, J., Magonthier, M.C., Moulin, V., Petit, J.C., and Trotignon, L. Leaching of Borosilicate Glasses by Solutions Containing Humic 
XAcids: Behaviour of Metallic Elements.Jo - Radiochimica acta. (Unknown Journal!) 58-59, Part $1: 17-20,1992$.

1461. Drankhan, V., C., ; Chapman, N., E., ; Pope, J., M., and X control and data acquisition for a slurry-fed ceramic melter systemx for high-level nuclear wastex. Adv.Ceram., 20, 407-12X-12X, 1994.

1462. Drent, w. Activity Report of the European Company for the Chemical Processing of Irradiated Fuels (1984). (Unknown Journal!), 1985.

1463. Drobnik, S., Koschorke, H., Kaufmann, F., and et al| Method for avoiding malfunctions in the solidification of aqueous, radioactive wastes in a glass, glass-ceramic, or glass-ceramic-likematrix. (Unknown Journal!) , 1978.

1464. Drobnik, S., Hild, W., Kauffman, F., and Koschorke, H. Apparatus and method for pretreatment of aqueous radioactive wastesX for environmentally favorable and safe handling, transport, andX disposalx. Ger.offen. , 1994.

1465. Dubrovo, S.K.s. Stekloobraznye silikaty litila, ikh svoistva i oblast primeneniia, Moskva:Nauka, 1964.

1466. Dubrovo, S.K.S. Vitreous lithium silicates, properties and applications, New York:Consultants Bureau, 1964.

1467. Ducel, J.F., Videau, J.J., and Couzi, M. structural Study of Borophosphate Glasses by Raman and Infrared-Spectroscopy. PHYS.CHEM.GLASSES. $34: 212-218$, 1993 .

1468. Dufournet, F. Adaptation des ciments magnesiens au stockage souterrain des dechets nucleaires. (Adaptation of magnesian cements to underground storage of nuclear wastes). Thesis. (Unknown Journal!) , 1987.

1469. Dukes, M., D., and X ***vitrification*** of transuranic and beta-gamma contaminatedX solid wastesX. Report, Dp-1553, 19 pp, 1980.

1470. Dunn, T. Oranium(VI) diffusion in a supercooled borosilicate melt. J.NON-CRYST.SOLIDS. $92[1]: 1-10,1987$.

1471. Dunn, T. Uranium (vi) diffusion in a supercooled borosilicate melt. Journal of Non-Crystalline Solids $92: 1-10,1987$.

1472. Durst, F., Jakob, G., Mantel, R., Hecht, R., and Pereira, J.C.F. Investigating isothermal three-dimensional flow in a glass-melting furnace. Journal. of. the. Institute. of. Energy. J Inst Energy $v 65 \mathrm{n}, 1992$.

1473. Dussossoy, J.I., Vernaz, E., Charpentier, H., and Juliet, P. R.S.S.T. in granite: additional tests at Cen-Valrho. (Unknown Journal!), 1988.

1474. Dussossoy, J.L., Vernaz, E., Dubois, C., and Chambaudet, A. Effect of surface finish on nuclear glass dissolution rate. (Unknown Journal!) , 1991.

1475. Duvierre, G., Sertain, E., and Reber, A. Advantages of using high zirconia refractories in lead crystal glass electric furnaces. Glass. Technology. Glass Technology v 3, 1993. 
1476. Duvierre, G., Sertain, E., Reber, A., Jean, J., and Gupta, T. Advantages of using high zirconia refractories in lead crystal glass electric furnaces Alumina as a devitrification inhibitor during sintering of borosilicate glass powders. Glass.Technology.Joumal.of.the.American.Ceramic.Society. Journal of the Ameri, 1993.

1477. Dvorak, Z.T.,Martin; Jedinakova application of statistical approach to the analysis of leachingX resistivity of $* \star \star$ vitrified $* \star * \star * \star$ radioactive $* \star x$ ***wastes*** X. Jad.Energ., 33, 175-9X-9X, 1994.

1478. Dworschak, H., Giradi, F., and Grossi, G. Construction and commissioning of the petra pilot plant facility forX waste management studies. In: High Level Radioactive Waste and Spent Fuel Management Proc 1989 JointX Int Waste Manage Conf $v 2$. (of 2). Publ by American Soc of Mechanicalx Engineers (ASME), New York, NY, USA.p 559-564,Anonymous New York, NY, USA:American SOC of MechanicalX Engineers (ASME), 1989, p. 559-564.

1479. Dworschak, H.G.F.G. Construction and Commissioning of the PETRA Pilot Plant Facility for Waste Management Studies. (Unknown Journal!), 1989.

1480. Dyar Ferrous/ferric moessbauer analysis of simulated nuclear waste glass withand without computer fittingùcomment. J.Am.Ceram.Soc. ; 1986.

1481. Dyar, M. and Darbyx "ferrous/ferric moessbauer analysis of simulated nuclear waste glassX with and without computer fitting." commentsX. J.Am.Ceram.Soc., 69, C/160-C/162X-C/162X, 1994.

1482. Dyer, A., Malik, S.A., Araya, A., and McConville, T.J. New anion exchangers of zeolitic type. In: Publ by Elsevier Applied Science, London, Engl \& New York, NY, USA pX 257-263,Anonymous London, Engl \& New York, NY, USA:Elsevier Applied Science, 1987,-263.

1483. Dyment, F., Matzke, H., and Toscano, E. Diffusion of sup 8 sup 3 Rb and sup 8 sup $4 \mathrm{Rb}$ tracers in waste glasses. J.NON-CRYST.SOLIDS. 93[1]:22-34, 1987.

1484. Dyment, F., Matzke, H., and Toscano, E. Diffusion of $\star \star 8 * \star 3 r b$ and $\star \star 8 * * 4 \mathrm{rb}$ tracers in waste glasses. Journal of Non-Crystalline Solids 93:22-34, 1994.

1485. Dyment, F., ; Matzke, H., ; Toscano, E., and $\mathrm{X}$ diffusion of rubidium-83 and rubidium-84 tracers in waste glassesX. J.Non-Cryst.Solids, 93, 22-34X-34X, 1994.

1486. Dymshits, O.S., Zhilin, A.A., Chuvaeva, T.I., and Shepilov, M.P. Optical spectra and structural states of $\mathrm{Ni}$ (II) in Glass XCeramic- Forming Glasses of the Lithium Aluminosilicate xsystem. The.Soviet.journal.of.glass.physics.and.chemistry. 17, Number 1:70-77, 1991.

1487. E.I.Kamitsos, G.D.Chryssikos, and M.A.Karakassides New insights into the structure of alkali borate glasses jo -Journal of Non-Crystalline Solids. (Unknown Journal!) 123:283-285, 1990. 
1488. Eargle, J.C. Remotely maintained waste transfer pump. (Unknown Joumal!) , 1990 .

1489. Eargle, J.C. Remotely maintained waste transfer pump. In: Proceedings of the Conference on Remote systems Technology $v 2$. Publ byX ANS, La Grange Park, IL, USA.P 15-16, Anonymous La Grange Park, IL, USA: 1990,p. 15-16.

1490. Eaton, R.R., Bixler, N.E., and Glass, R.J. Predicting Flow through Low-Permeability, Partially Saturated, Fractured Rock: A Review of Modeling and Experimental Efforts at Yucca Mountain. (Unknown Journal!) , 1989.

1491. Eaton, W., Joseph, I, and Pye High-temperature properties of simulated west valley nuclear waste glass. Ceram.Trans. , 1991.

1492. Eaton, W., C., ; Joseph, I., ; Pye, I., D., and X some high temperature properties of simulated west valley nuclearX waste glassX. Ceram.Trans., 23, $509-18 \mathrm{X}-18 \mathrm{X}, 1994$.

1493. Eberhard Freude1, Bernd Grambowl, Werner Lutzel, Harald Rabel, and Rodney c. Ewing2 BT - Leaching Mechanisms CT - Long-term Release from High Level Waste Glass--Part IV: The effect of Leaching Mechanism ED - Carol M.Jantzen ED - John A.Stone ED - Rodney C.Ewing Anonymous 1985,p. 99-106.

1494. Ebert The importance of secondary phases in glass corrosion <augmentations yucca mountain project. (Unknown Journal!) : (8 p), 1990.

1495. Ebert The reaction of glass during gamma irradiation in a saturated tuff environment. (Unknown Journal!) :(185 p), 1990.

1496. Ebert, $W$. and Bates, $J$. Importance of secondary phases in glass corrosion. Mater.Res.Soc.Symp.Proc. 212:89-97, 1991.

1497. Ebert, w., L., ; Bates, J., K., ; Abrajano, T., A., , ; Gerding, T., J., and $x$ the influence of penetrating gamma radiation of the reaction of $x$ simulated nuclear waste glass in tuff groundwaterx. Ceram.Trans., 9, $155-64 X-64 X, 1994$.

1498. Ebert, W., L., ; Bates, J., K., ; Bourcier, w., and $X$ the hydration of borosilicate waste glass in Iiquid water and steamX at 200.degree.cX. Waste Manage. (N.Y.), 11, 205-21X-21X, 1994.

1499. Ebert, W., L., ; Bates, J., K., ; Buck, E., C., ; Bradley, C., R., and X accelerated glass reaction under pct conditionsx. Mater.Res.Soc.Symp.Proc., 294, 569-76X-76X, 1994.

1500. Ebert, W., I., ; Bates, J., K., ; Gerding, T., J., and $x$ the reaction of glass during gamma irradiation in a saturated tuffx environment: part 4,srl 165, atm-1C, and atm-8 glasses at $1 \mathrm{e} 3 \mathrm{r} / \mathrm{hX}$ and $O \mathrm{r} / \mathrm{hX}$. Report, Anl-90/13; Order No.Deg0013462, 185 Pp, 1990.

1501. Ebert, W., L., ; Bates, J., K., and $X$ the reaction of synthetic nuclear waste glass in steam andx hydrothermal solutionx. Mater.Res.Soc.Symp.Proc., $176,339-46 \mathrm{X}-46 \mathrm{X}, 1994$. 
1502. Ebert, W.L. and Bates, J.K. Comparison of glass reaction at high and low $\mathrm{SA} / \mathrm{V}$ : PCT vs MCC-1. (Unknown Journal!), 1992.

1503. Ebert, W.I., Bates, J.K., Abrajano, T.A., and Gerding, T.J. Influence of Penetrating gamma Radiation on the Reaction of simulated Nuclear Waste Glass in Tuff Groundwater. (Unknown Journal!) , 1989.

1504. Ebert, W.L., Bates, J.K., and Bourcier, w.L. The hydration of borosilicate waste glass in liquid water and steam at 200 (degree)C. Waste.Management. v. 11 no4 ('91):205-221, 1991.

1505. Ebert, W.I., Bates, J.K., and Buck, E.C. Reaction of SRL 202 glass in J-13 and DIW. (Unknown Journal!), 1992.

1506. Ebert, W. The reaction of glass during gamma irradiation in a saturated tuff environment, Argonne, Ill. : Springfield, Va. :Argonne National Laboratory, Chemical Technology Division; available from N.T.I.S., 1990.

1507. Ebert, W. and Bates, J. A comparison of glass reaction at high and low glass $X$ surface/solution volume. Nuclear. Technology. $v$. 104 (Dec. '93):372-384, 1993.

1508. Eddy Thermal processing systems for tru mixed waste. (Unknown Journal!) : (10 p), 1992 .

1509. Eddy and Dell'orco Thermal processing system concepts and considerations for rwmc buried waste Hydrothermal treatment of hanford waste constituents <augmentation> wet oxidation processes. (Unknown Journal!) :(15 p), 1992 .

1510. Edgar C.Pitzer Method for the disposal of waste solutions by using rigid gelsX. Us. , 1994 .

1511. Edited by Chikalla, T. and Mendel, J. Ceramics in nuclear waste management. (proceedings of an internationalsymposium held in cincinnati, ohio, april 30-may 2, 1979) Illus. (Unknown Journal!) , 1979.

1512. Edited by McCarthy, G. Scientific basis for nuclear waste management, vol. I Illus. (Unknown Journal!), 1979.

1513. Edwards Control of dwpf (defense waste processing facility) melter feed composition. (Unknown Journal!) : (9 p), 1990.

1514. Edwards, R. Application of artificial intelligence [ai] to melter controlureal-timeprocess advisor for the scale melter facility. Adv. Fusion Glass , 1988.

1515. Edwards, R. and Glascock, J. Design and Testing of the Defense Waste Processing Facility Melter Drain Valve. (Unknown Journal!), 1986.

1516. Edwards, R.E. SGM (Scale Glass Melter) Run 8: Canister and Glass Temperatures During Filling and Cooldown. (Unknown Journal!) , 1987. 
1517. Edwards, R.E. Application of Artificial Intelligence to Melter Control: Realtime Process Advisor for the Scale Melter Facility. (Unknown Journal!), 1988 .

1518. Edwards, R.E., Brown, K.G., and Postles, R.I. Control of DWPF melter feed composition. (Unknown Journal!), 1990.

1519. Edwards, R.E., Goudelock, S.I., Smith, M.E., Baron, M.R., and Guidotti, P.D. Summary of Campaign SGM-8 of the DWPF Scale Glass Melter. (Unknown Journal!) , 1987.

1520. Eggett Statistical methods to monitor the west valley off-gas system. (Unknown Journal!) : (6 p), 1990.

1521. Egnell, J., ; Larsen, J., G., ; Moeller, L., ; Roed, G., and $X$ investigation of metastable immiscibility in nuclear-waste glasses.X $\mathrm{i}$-iiix. Report, Skbf/Kbs-Tr-8I-14, 48 pp, 1982.

1522. Egorov, N., Kudryavtsev, E., Nikipelov, B., Polyakov, Zakharkin, B., and Mamaev, L. Reclamation and localization of nuclear fuel cycle waste. Atomaya Energiya $74: 307-312,1993$.

1523. Eibling Processing of tetraphenylborate precipitates in the savannab river site defense waste processing facility. (Unknown Journal!) : (9 p), 1990.

1524. Eibling, R.E. and Fowler, J.R. Mercury reduction and removal during high-level radioactive wastex processing and vitrification. In: Materials Research Society Symposia Proceedings V 6.Publ byX North-Holland, New York, NY, USA and Amsterdam, Neth p 617-622, Anonymous New York, NY, USA: 1982,p. 617-622.

1525. Eidem, G.G. and Fages, R. Shielded Canister Transporter. (Unknown Journal!) , 1993.

1526. Eikenberg, J. Problem of silica solubility at high pH. (Unknown Journal!) , 1990.

1527. Eisenstatt, I. and Chapman, C. West Valley vitrification process model--a method for providing glass composition. Adv.Ceram. 20:391-397, 1986.

1528. Eisenstatt, I.,. R., ; Chapman, C., C., and X the west valley vitrification process model: a method for providingx glass compositionx. Adv. Ceram., 20, 391-7X-7X, 1994.

1529. Eisenstatt, I., R., ; Routt, K., and $X$ west valley strategy for production of a qualified waste formx. Proc.Symp.Waste Manage., (Waste Manage.'88, Vol. 2), 791-6X-6X, 1994.

1530. Eisenstatt, L., R., and $\mathrm{X}$ description of the west valley demonstration project referencex high-level waste form and canisterX. Report, Doe/Ne/44139-16; Order No.De87008691, 57 pp, 1987.

1531. Eisenstatt, I.R. Description of the West Valley Demonstration Project Reference High-Level Waste Form and Canister. (Unknown Journal!) , 1986. 
1532. Eisenstatt, I.R., Chapman, C.C., and Bogart, R.I. Method for showing compliance with high-level waste acceptancex specifications. In: <CI> Volume 2 : High-Level Waste $v 2$. Publ by Arizona Board of Regents, AZ, USA $p$ 513-519, Anonymous AZ, USA:Arizona Board of Regents, 1986,p. 513-519.

1533. Ekimov, S.P., Titov, A.G., and Faddeev, I.S. Thermal transformations in strontium-containing borosilicate glass inX accordance with the moessbauer spectroscopy of iron. Soviet Journal of Glass Physics and Chemistry 16:499-502, 1991.

1534. Ekimov; S.P.ST. and Faddeev; I.S. Thermal Transformations in Strontium-Containing Borosilicate XGlass in Accordance with the Mossbauer Xspectroscopy of Iron. The.Soviet.journal.of.glass.physics.and.chemistry. 16, Number $6: 1-499,1991$.

1535. Elder, H.H., McIntosh, D.L., and Papouchado, L.M. Technical and Process Highlights for the Defense Waste Processing Facility. (Unknown Journal!), 1988 .

1536. Elliot Results of a pilot-scale melter test to attain higher production rates. (Unknown JournaI!) : (12 p), 1991.

1537. Elliot and Auty Durability of glass for the disposal of highlyx radioactive waste .discussion of method and effectX. GLASS.TECENOL. -13X, 1994.

1538. Elmer, T. Role of acid concentration in leaching of cordierite and alkali borosilicate glass. Joumal.of.the.American.Ceramic.Society. v. 68 (Oct. (85) : C273-C274, 1985.

1539. Elmore Materials selection for process equipment in the hanford waste vitrification plant. (Unknown Journal!) :(81 p), 1991.

1540. Elmore, M., R., ; Jensen, G., A., and $X$ materials selection for process equipment in the hanford wastex vitrification plantx. Report, Pnl-7729; Order No.De91016932, 81 pp, 1991.

1541. Elmore, M.R. and Jensen, G.A. Materials selection for process equipment in the Hanford waste vitrification plant. (Unknown Journal!), 1991.

1542. Elsden, A., D., ; Woodall, A., and $X$ high level waste vitrification at sellafieldX. Proc.Symp.Waste Manage., (Waste Manage. 188, Vol. 2), 189-93X-93X, 1994 .

1543. Endo, N., Igarashi, H., and Inada, K. Electric melting furnace for glassifying high-radioactive waste. (Unknown Journal!) , 1988.

1544. Engel, D.W., McGrail, B.P., Eslinger, P.W., and Altenhofen, M.K. AREST: The next generation. (Unknown Journal!) , 1993. •

1545. Engell, J.E., Roed, G., Woolsey, G.B., and Plodinec, M.J. Metastable liquid immiscibility in nuclear-waste-glasses vitrification of high-level radioactive waste in a small-scalex joule-heated ceramic melter. In: Materials 
Research Society Symposia Proceedings $v 6$. Publ byx North-Holland, New York, NY, USA and Amsterdam, Neth $p$ 609-616 Materials Research Society Symposia Proceedings $v 6$. Publ byX North-Holland, New York, NY, USA and Amsterdam, Neth $p$ 603-608, Anonymous New York, NY, USA: 1982,p. 603-608.

1546. Engelmann, C. Testing and Evaluation of Solidified High-Level Waste Forms. Joint Annual Progress Report 1982. Final rept. (Unknown Journal!), 1984.

1547. Erickson, C.J. and Haideri, A.Q. Electrical service and controls for joule heating of a nuclear wastex experimental glass melter. In: Conference Record - IAS Annual Meeting (IEEE Industry ApplicationsX Society) 1984.Publ by IEEE, New York, NY, USA. 'Available from IEEEX service Cent (Cat $n$ 84CH2060-2), Piscataway, NJ, USA $p$ 1-6, Anonymous New York, NY, USA:IEEE, 1984,p. $1-6$.

1548. Ericson, J.E. Durability of rhyolitic obsidian glass inferred from hydration datingx research. In: <CI> Proceedings of the 3 rd International. Symposium, held as part ofX the Annual Meeting of the Materials Research Society Scientific Basis for Nuclear Waste Management $v$ 3. Publ by PlenunX Press, New York, NY, USA and London, Engl p 283-290,Anonymous New York, NY, USA:PlenumX Press, 1981,p. 283-290.

1549. Erlstroem, M. and Pusch, R. Survey of Swedish Buffer Material Candidates and Methods for Characterization. (Unknown Journal!) , 1987.

1550. Ermold [benchmarking european spent fuel and waste management technology]. (Unknown Journal!) : (72 p), 1924.

1551. Ermold Foreign travel report: visits to uk, belgium, germany, and france to benchmark european spent fuel and waste management technology. (Unknown Journal!) : (73 p), 1993.

1552. Ermold, L.F. and Knecht, D.A. Benchmarking European spent fuel and waste management technology. Foreign trip report, October 26--November 7, 1992. (Unknown Journal!), 1992.

1553. Eskandarany, M.S., Aoki, K., and Suzuki, K. Morphological and calorimetric studies on the amorphization process of rod-milled $\mathrm{Al} / / 5 / / \mathrm{Zr} / / 5 / / 0$ alloy powders.

Metallurgical.Transactions.A. (Physical.Metallurgy.and.Materials.Science). $v$ 23A in 8 Aug 1992:2131-2140, 1992.

1554. Eslinger Preliminary total-system analysis of a potential high-level nuclear waste repository at yucca mountain. (Unknown Journal!) : (203 p), 1993.

1555. Eslinger, P.W., Doremus, L.A., Engel, D.W., Miley, T.B., and Murphy, M.T. Preliminary total-system analysis of a potential high-level nuclear waste repository at Yucca Mountain. (Unknown Journal!) , 1993.

1556. Ewart, F., T., ; Lewis, J., B., ; Morris, J., and $\mathrm{X}$ program of research into the management and storage ofX $* * \star$ radioactive $* * * \star * *$ waste $* * *$.backfilling 
and sealing.X final report 1982X. Report, Doe-Rw-83.020, Aere-G-2667; Order No.De84701164, 10. pp, 1984.

1557. Ewart, F.T., Morris, J.B., Severn, J., Sharpe, B.M., and Thomason, H.P. Source term for the release of nuclides from a radioactive wastex repository 1.vitrified waste in granite. In: <CI> Symposium held as part of the Annual Meeting of the MaterialsX Research Society Materials Research Society Symposia Proceedings $v$ 26. Publ byX North-Holland, New York, NY, USA and Amsterdam, Neth P 171-178, Anonymous New York, NY, USA: 1984,p. 171-178.

1558. Ewest and Levi Evaluation of products for the solidification of high-levelx radioactive waste from commercial reprocessing in the federalx republic of germanyx. Manage.Radioact. Wastes.Nucl. Fuel.Cycle -25, 1994.

1559. Ewest, E., Gelfort, E., and Heimerl, W. Transfer of molten radioactive waste glass into a preevacuated canisterby suction in order to produce waste packages for final disposal. GLASTECH.BER. , 1986.

1560. Ewest, E., Mertens, G., and Straschewski, H. Arrangement for vitrifying radioactive liquid waste. (Unknown Journal!) , 1987.

1561. Ewest, E., Gelfort, E., Heimerl, w., and Kunz, w. Filling of melted radioactive waste glass by suction into aX pre-evacuated canister in order to produce waste packages for finalx disposal. Glastechnische Berichte 59:360-367, 1986.

1562. Ewest, $E$. and $X$ calculations of radioactivity release due to leaching ofX

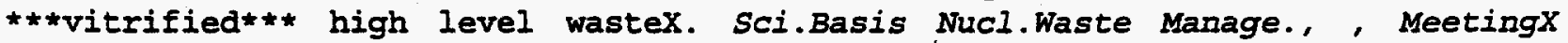
Date 1978, 161-8:lenum: NewX York, 1994.

1563. Ewest, E.G.,Eike; Heimerl filling of a pre-evacuated canister with melted

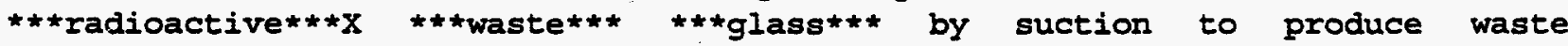
packagesX for final disposalX. Glastech.Ber., 59, 360-7X-7X, 1994.

1564. Ewest, $E$. method and apparatus for charging a metal vessel with a moltenX vitreous mass containing highly radioactive fission productsX. Belg., 31 pp. 1994.

1565. Ewing and Lutze Radiation damage effects: comparison of borosilicate glass to synrocphases. Ceram.Trans. , 1990.

1566. Ewing, R. Metamict mineral alteration: an implication for radioactive wasteX disposalX. SCIENCE -7X, 1994.

1567. Ewing, R., C., ; Haaker, R., $F_{.,}$and $X$ naturally occurring glasses: analogs for $* * *$ radioactive $* \star * X$ ***waste $* \star *$ formsX. Report, Pnl-2776, 82 pp, 1980.

1568. Ewing, R., C., ; Lutze, W., and X radiation damage effects: comparison of borosilicate glass toX synroc phasesX. Ceram.Trans., 9, 33-44X-44X, 1994.

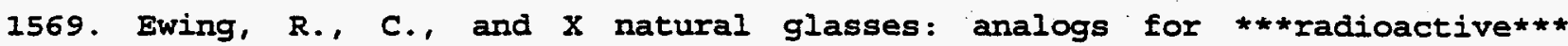

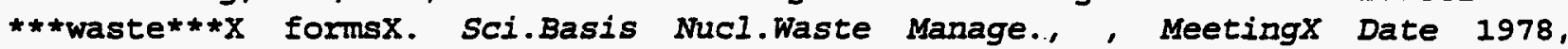
57-68:lenum: NewX York, 1994. 
1570. Ewing, R.C. and Lutze, W. High-level nuclear waste immobilization with ceramics. Ceramics International 17:287-293, 1991.

1571. Ewing, R.C., ; Headley, T.J., and $X$ alpha-recoil damage in natural zirconolite (cazrti207)X. J.NucI.Mater., 119, 102-9X-9X, 1994.

1572. Ewing, R.C., ; Jercinovic, M.J., and X natural analogs: their application to the prediction of theX long-term behavior of nuclear waste formsX. Mater.Res.Soc.Symp.Proc., 84,X 67-83X-83X, 1994.

1573. Eyal, Y., Lumpkin, G.R., and Ewing, R.C. Alpha-recoil effect on the dissolution of betafite: rapid naturald annealing of radiation damage within a metamict phase. In: Materials Research Society Symposia Proceedings $v$ 50. Publ by MaterialsX Research SOC, Pittsburgh, PA, USA p 379-386, Anonymous Pittsburgh, PA, USA:MaterialsX Research SOC, 1986,p. 379-386.

1574. Eyler Waste glass melter numerical and physical modeling. (Unknown Journal!) : (9 p), 1991.

1575. Facchini, A., ; Nannicini, R., ; Serrini, G., ; Zamorani, E., and $X$ foaming phenomenon during the $* * *$ vitrification*** of high-levelx mtr

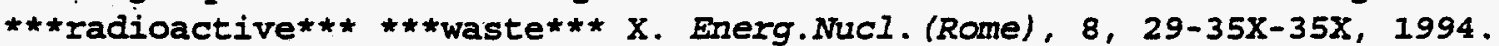

1576. Failor, R., A., ; Coles, D., G., ; Rego, J., H., and $X$ leaching study of nuclear melt $\star \star \star g l a s s * \star$.part ix. Report, Ucid-19729; Order No.De83008312, 76 pp, 1983.

1577. Falci, F.P., Allen, G.C., Zimmer, A., Golliher, K.G., and Madsen, M.M. Innovative cask for transporting defense high-level waste. In: Proc Ist Int Top Meet High Level Radioact Waste Manage Part 1. Publ byX ASCE,Boston Society of Civil Engineers Sect,Boston,MA, USA.pX 486-491,Anonymous Boston Society of Civil Engineers Sect; Boston, MA, USA: 1990, -491 .

1578. Faletti, D.W., Erb; T.A., Harty, H., and LoPresti, C.A. User's Guide for West Valley Feed Preparation Code (RECIPE). (Unknown Journal!) , 1988.

1579. Faletti, D.W. and Ethridge, I.J. Method for Predicting Cracking in Waste Glass Canisters. (Unknown Journal!) , 1986.

1580. Fanning, J.C., ; Hunter, R., and ToddX nuclear waste,glass, and the iron-2+/iron-3+ ratioX. J.Chem.Educ., 65, 888-9X-9X, 1994.

1581. Farnsworth, R.K., Chan, M.R.W., and Slate, S.C. Effect of radial temperature gradients on glass fracture in simulatedx high-level waste canisters. In: <CI> Held as part of the Fall Meeting of the Materials ResearchX Society Materials Research Society Symposia Proceedings $v$ 44. Publ by MaterialsX Research Soc,Pittsburgh,PA, USA p 831-838, Anonymous Pittsburgh, PA, USA:MaterialsX Research Soc, 1985,p. 831-838.

1582. Farnsworth, R.K. and Mishima, J. DWPF (Defense Waste Processing Facility) Canister Impact Testing and Analyses for the Transportation Technology Center. (Unknown Journal!) , 1988. 
1583. Farnsworth, R.K., Ruecker, C.M., Perez, J.M., Blair, H.T., and Thornton, G.T. Hanford Waste Vitrification Plant: Feed Process Variability Testing for Fiscal Year 1986. (Unknown Journal!), 1986.

1584. Feil, D. The density of sodium borosilicate glasses related to atomic arrangements, 1989 .

1585. Feizollahi waste management facilities cost information report. (Unknown Journal!) : (184 p), 1992 .

1586. Feizollahi Alpha low-level stored waste systems design study. (Unknown Journal!) : (257 p), 1992.

1587. Feld, R., H., ; Stammler, M., and $X$ quantitative determination of crystalline phases in nuclear wasteX glassesX. Mater.Res.Soc.Symp.Proc., 11, X

$261-71 X-71 x, 1994$.

1588. Feld, R.H. and Stammler, M. Quantitative determination of crystalline phases in nuclear wastex glasses. In: Materials Research Society Symposia Proceedings VII.Publ byX North-Holland, New York, NY, USA and Amsterdam, Neth $p$ 261-271, Anonymous New York, NY, USA: 1982,p. 261-271.

1589. Feldman, R.F., Beaudoin, J.J., and Philipose, K.E. Use of blast-furnace slag in making durable concrete for waste management repositories. (Unknown Journal!) , 1991.

1590. Feng Characteristics of colloids generated during the corrosion of nuclear waste glasses in groundwater. (Unknown Journal!) :(21 p), 1993.

1591. Feng, Muller, and Pegg, I Effect of redox state on the chemical durability of west valley glasses. Ceram.Trans., 1991.

1592. Feng, Pegg, and Saad Redox effects on the durability and viscosity of nuclear waste glasses. Ceram.Trans. , 1990.

1593. Feng, Pegg, I, and Yan Effects of $\mathrm{ph}$ on the leaching mechanism of nuclear waste glasses. Ceram. Trans. , 1991.

1594. Feng, X, ; Buck, E., ; Bradley, C., and ; Gong, M. long-term comparison of dissolution behavior between fullyX radioactive and simulated nuclear waste glassesX. Nucl.Technol., 104, 193-206X-206X, 1994.

1595. Feng, X, Pegg, I., Barkatt, A., Macedo, P., Cucinell, S., and Lai, S. Correlation between composition effects on glass durability and the structural role of the constituent oxides. Nuclear.Technology. Nucl Technol v 85 $\mathrm{n}, 1989$.

1596. Feng, $X$. Surface layer effects on waste glass corrosion. (Unknown Journal!) , 1993.

1597. Feng, X., ; Bates, J., K., ; Bradley, C., R., ; Buck, E., C., and X does fully radioactive glass behave differently than similated wastex glass?X. Mater.Res.SOC.Symp.Proc., 294, 207-14X-14X, 1994. 
1598. Feng, X., ; Fu, L., ; Choudhury, T., K., ; Pegg, I., L., ; Macedo, P., $B .$, and $X$ mechanistic effects of deuteration on the aqueous corrosion of $X$ nuclear waste glassesX. Mater.Res.Soc.Symp.Proc., 212, 49-56X-56X, 1994.

1599. Feng, X., ; Pegg, I., L., ; Saad, E., ; Cucinell, S., ; Barkatt, A., and $X$ redox effects on the duability and viscosity of nuclear wastex glassesx. Ceram.Trans., 9, 165-74X-74X, 1994.

1600. Feng, X., ; Pegg, I., L., ; Yan, Q., ; Mao, X., ; Macedo, P., B., and X effects of $\mathrm{ph}$ on the leaching mechanism of nuclear waste glassesX. Ceram.Trans., 23, 95-104X-104X, 1994.

1601. Feng, $X$. and Bates, J.K. Initial comparison of leach behavior between fully radioactive and simulated nuclear waste glasses through long-term testing. Part 1, Solution analysis. (Unknown Journal!), 1992.

1602. Feng, $X$. and Bates, J.K. Factors influencing chemical durability of nuclear waste glasses. (Unknown Journal!) , 1993.

1603. Feng, X., Bates, J.K., Buck, E.C., Bradley, C.R., and Gong Long-term comparison of dissolution behavior between fully radioactivex and simulated nuclear waste glasses. Nuclear Technology 104:193-206, 1993.

1604. Feng, X., Buck, E.C., Mertz, C., Bates, J.K., and Cunnane, J.C. Characteristics of colloids generated during the corrosion of nuclear waste glasses in groundwater. (Unknown Journal!), 1993.

1605. Feng, X., Saad, E., and Pegg, I.L. Model for the viscosity of multicomponent [silicate] glass melts. Ceram.Trans. 9:457-468, 1990.

1606. Feng, X., ; Saad, E., E., ; Freeborn, W., P., ; Macedo, P., B., ; Pegg, I., L., ;X Sassoon, R., ; Barkatt, A., ; Finger, S., M., and X composition models for the viscosity and chemical durability of westx valley related nuclear waste glassesX. Proc.Symp.Waste Manage., (Waste Manage.'88, Vol. 2), 805-10X-10X, 1994 .

1607. Feng, $x$. Initial comparison of leach behavior between fully radioactive and simulated nuclear waste glasses through long-term testing. (Unknown Journal!) : (10 p), 1992.

1608. Feng, X.B.,AaronX a modified thermodynamic model of glass dissolution under strongX interactive conditionsX. Proc.Symp.Waste Manage., (Waste Manage.'87, Vol. 1), 584-90X-90X, 1994.

1609. Feng, X.B.,Aaron; Jiang systematic composition studies on the durability of waste glassX wv205X. Mater.Res.Soc.Symp.Proc., 112, 673-83X-83X, 1994.

1610. Feng, X.B.,AaronX structural thermodynamic model for the durability and viscosity ofx nuclear waste glassesX. Mater.Res.Soc.Symp.Proc., 112, $543-54 \mathrm{X}-54 \mathrm{X}, 1994$.

1611. Feng, X.B.,AaronX effects of aqueous phase composition on the leach behavior ofX nuclear waste glassesX. Mater.Res.Soc.Symp.Proc., $84, \mathrm{X}$ $519-31 X-31 X, 1994$. 
1612. Feng, X.P.,Ian L., ; Barkatt, A.M.,Pedro B., ;X Cucinell, S.J., and ; Lai, S. correlation between composition effects on glass durability and theX structural role of the constituent oxidesx. Nucl.Technol., 85, 334-45X-45X, 1994.

1613. Feng, X. composition effects on chemical durability and viscosity of nuclearX waste glasses - systematic studies and structural thermodynamicx modelsX. (Unknown Journal!) 378 pp, 1989.

1614. Ferguson, G., Gallagher, J.F., Murphy, D., Sheehan, J.P., and spalding, $T . R$. Borosilicate Compounds of the Type H2N(CH2) $30 \mathrm{Ob}(\mathrm{R})(\mathrm{Osir3}$ ') - The Structure of 2-(Dimethylphenylsiloxy)-2-Phenyl-1,3,2-Oxazaborinane.. POLYHEDRON. $12: 859-864,1993$.

1615. Ferguson, R.B., Woolsey, G.B., Eibling, R.E., Galloway, R.M., and Baumgarten, P.K. Small-scale integrated demonstration of high-level radioactive wastex processing and vitrification using actual sIp waste. In: <CI> Proceedings of the 3rd International Symposium, held as part ofx the Annual Meeting of the Materials Research Society Scientific Basis for Nuclear Waste Management $v 3$. Publ by PlenumX Press,New York,NY, USA and London, Engl $p$ 83-92, Anonymous New York, NY, USA:PlenumX Press, 1981,p. 83-92.

1616. Ferrell Savannah river technology center monthly report, november 1993. (Unknown Journal!) : (20 p), 1993.

1617. Fetsko, T. The effects of residual carbon on the physical properties of silicon carbide-borosilicate glass matrix composites, 1990.

1618. Fett, T., Munz, D., Keller, K., and Kubler, J. Subcritical surface crack growth in borosilicate glass under xthermal fatigue. Theoretical.and.applied.fracture.mechanics. 16, Number 1:1-27, 1991.

1619. Feuerstein, J. The production of the so-called carbon amber glasses, Alfred, NY:New York State College of Ceramics at Alfred University, 1939.

1620. Fillet, S., Nogues, J.I., Vernaz, E., and Jacquet-Francillon, N. Leaching of actinides from the french lwr reference glass. In: Materials Research Society Symposia Proceedings $v$ 50. Publ by MaterialsX Research Soc, Pittsburgh, PA, USA P 211-218,Anonymous Pittsburgh, PA, USA:MaterialsX Research SOC, 1986,p. 211-218.

1621. Fillet, S., Phalippou, J., zarzycki, J., and Nogues, J.I. Texture of gels produced by corrosion of radioactive waste disposalx glass. Journal of Non-Crystalline Solids 82:232-238, 1986.

1622. Fillet, S., Vernaz, E., Nogues, J.L., and Jacquet Francilion, $N$. Corrosion Rate of Nuclear Glass in Saturated Media. (Unknown Journal!) , 1986.

1623. Fillet, S., ; Nogues, J., ; Vernaz, E., ; Jacquet Francillon, N., and $x$ leaching of actinides from the french lwr reference glassX. Mater.Res.Soc.Symp.Proc., 50,X 211-18X-18X, 1994. 
1624. Fillet, S., ; Vernaz, E., ; Nogues, J., L., ; Jacquet Francilion, N., and $X$ corrosion rate of nuclear glass in saturated mediax. Adv.Ceram., 20, $443-53 X-53 X, 1994$.

1625. Finger, S.M., Freeborn, w.P., Hojaji, H., Macedo, P.B., Mohr, R., Montrose, C.J., and Pruss, F. High level nuclear waste form development: mini-melter design andx operation. In: <CI> Volume 1: General Interest publ by Arizona Board of Regents, AZ, USA p 291-295, Anonymous AZ, USA:Arizona Board of Regents, 1986,p. 291-295.

1626. Finlayson-Dutton, G. Tinkering with glass and ceramic structures. SCIENCE v. 249 (Aug. 10 '90)::627-628, 1990.

1627. First, M.W. Proceedings of the DOE/NRC Nuclear Air Cleaning Conference (21st) Sessions 9-16. Held in San Diego, California on August 13-16, 1990. (Unknown Journal!) , 1991.

1628. Flemish, J.R. and Tressler, R.E. P//xO//Y evaporation from $S i P / / 20 / / 7$ and its relationship to phosphosilicate glass films. Journal. of. the.Electrochemical.Society. v 138 n 12 Dec 1991:3743-3746, 1991.

1629. Flemish, J.R. and Tressler, R.E. Phosphorus diffusion in silicon from enclosed solid planar sources. Journal.of.the.Electrochemical.Society. v 138 n 1 Jan 1991:205-207, 1991 .

1630. Flintoff, J.F., ; Harker, A.B., and $X$ detailed processes of surface layer formation in borosilicate wastex glass dissolutionx. Mater.Res.Soc.Symp.Proc., $44, X \quad 147-54 X-54 X, 1994$.

1631. Flynn, K., F., ; Barletta, R., E., ; Jardine, L., J., ; Steindler, M., and $X$ leach rate characterization of solid $\star * \star$ radioactive $* \star \star X \quad \star \star \star$ waste $* \star \star$ formsX. Sci.Basis Nucl.Waste Manage., , MeetingX Date 1978, 149-55:lenum: NewX

York, 1994.

1632. Foelber, S.C. and Sabbe, M.A. Structural Design Considerations for a Radwaste Processing Facility. (Unknown Journal!) , 1985.

1633. Fortsch The hanford waste vitrification plant shielding design: a historical perspective. (Unknown Journal!) : (6 p), 1993.

1634. Fow, C., L., ; Kurath, D., E., ; Pulsipher, B., A., and $x$ evaluation of the mixing system for the west valley melter feed holdx tankx. Report, PnI-6724; Order No.De89007555, 106 pp, 1989.

1635. Fow, C.I., Kurath, D.E., and Pulsipher, B.A. Evaluation of the Mixing System for the West Valley Melter Feed Hold Tank. (Unknown Journal!), 1989.

1636. Fow, C.I., Kurath, D.E., Pulsipher, B.A., and Bauer, B.P. Slurry Feed Variability in West Valley's Melter Feed Tank and Sampling system. (Unknown Journal!), 1989.

1637. Fowler, J.R. Projected Plant) Waste Glass for the (Unknown Journal!) , 1988.
Chemical Compositions of SRP Waste Acceptance Preliminary
(Savannah River Specifications. 
1638. Fowler, J.R., Edwards, R.E., and Sarma, P.V.L.N. Large Scale Process Simulation: A Case Study Integrated waste Processing Flowsheet for SRP (Savannah River Plant). (Unknown Journal!) , 1989.

1639. Franklin, B. Evaluation of a container glass compostion with small lithium $X$ carbonate additions, 1982.

1640. Freeborn, W., Phelps; Zolensky, M.S.,Barry E., ;X Komarneni, S.M.,Gregory J., ; White, W.B., and $X$. shale rocks as nuclear waste repositories: hydrothermal reactionsX with $* * *$ glass $* * *$, ceramic and spent fuel waste formsx. Sci.Basis Nucl.Waste Manage., 2, 499-506X-506X, 1994.

1641. Freeborn, W.P. and White, W.B. Role of eh in nuclear waste form dissolution. In: <CI> symposium held as part of the Annual Meeting of the MaterialsX Research Society Materials Research Society Symposia Proceedings $v$ 26.Publ byX North-Holland, New York, NY, USA and Amsterdam, Neth p 719-726; Anonymous New York, NY, USA: 1984,p. 719-726.

1642. Freeman, H.M. Innovative Thermal Treatment Processes. (Unknown Journal!) , 1986 .

1643. Freeman, H.M. and Oppelt, E.T. Innovative Thermal Processes for Hazardous Waste Treatment and Destruction. (Unknown Journal!), 1985.

1644. Freude, E.G.,Bernd; Lutze and X long-term release from high level waste glass - part iv: the effectx of leaching mechanismx. Mater.Res.Soc.Symp.Proc., $44, \mathrm{X}$ 99-106X-106X, 1994.

1645. Frischat, G., H., and $X$ self-diffusion processes in oxide glassesX. Nucl. Technol., 51, 130-5X-5X, 1994.

1646. Frischat, G. and Sebastian, $k$. Leach resistance of nitrogen-containing Na2O-CaO-SiO2 X glasses. Journal.of.the.American.Ceramic.Society. v. 68 (Nov. '85): C305-C307, 1985.

1647. Frischat, G., Sebastian, K., Strachan, D., Krupka, K., and Grambow, B. Solubility interpretations of leach tests on nuclear waste glass. Journal of. the. American. Ceramic. Society. Nuclear. and. Chemical. Waste. Management. v. 5 nol (.' 84):87-99, 1984 .

1648. Froeschen, W. and Wolf, G.K. Auslaugung von verglastem hochradioaktivem Abfall in einem realitaetsnah simulierten Endlagersystem. Schlussbericht. (Leaching of vitrified high-level-active-waste in a near reality simulated repository system. Final report). (Unknown Journal!) , 1987.

1649. Frueholz, R.P. and Wun-Fogle, M. Finite difference numerical analysis of phase-boundary reaction models for cesium penetration into glass. J.Am.Ceram.Soc. $66[9]: 605-610,1983$.

1650. Fu, J., Osaka, A., Nanba, T., and Miura, Y. CdTe Microcrystallites Doped in Melt-Quenched Borosilicate Glass. J.MATER.RES. 9:493-497, 1994. 
1651. Fu, S. and Chen, $I$. Low temperature sintering of $P / / 20 / / 5$-added cordierite glass with borosilicate glass. Japanese.Journal.of.Applied.Physics,.Part.2:.Letters. $\quad \mathrm{v} \quad 32$ n $3 \mathrm{~A}$ Mar 1 $1993: L 326-L 328,1993$.

1652. Fujiu, T., Messing, G., and Huebner, W. Processing and properties of cellular silica synthesized by foaming sol-gels. Journal.of.the.American.Ceramic.Society. J Am Ceram Soc v 73, 1990.

1653. Fujiyoshi, I. Effects of the support and sintering on hydrogen uptake of nickel supported on porous vycor glass. Journal. of. Catalysis.v.129. (June. '91).p.544-5. 21-9517, 1991.

1654. Fullam, H., T., and $X$ solubility effects in waste $* \star \star g l a s s * \star *$ /demineralized waterx systemsx. Report, pnl-3614, 66 pp, 1981.

1655. Furuya, H., ; Inagaki, Y., ; Idemitsu, K., ; Tamai, T., and X radiation effects of simulated waste glass irradiated usingx $10 b(n$, alpha.) $71 i$ reactionX. Kyoto Daigaku Genshiro Jikkensho, , Kurri-Tr-353, 3X, 1994.

1656. Furuya, H., ; Sato, S., ; Inagaki, Y., ; Obata, M., ; Tamai, T., and X radiation effects on simulated waste glass irradiated by using thex lob(n,.alpha.)7li reactionx. Kyoto Daigaku Genshiro Jikkensho, , Kurri-Tr-321, 27X, 1994.

1657. Furuya, H.S., Seichix radiation effects in solidified high level waste glassesX. Genshiryoku Kogyo, 27, 65-71X-71X, 1994.

1658. Furuya, H. research and development of high level radioactive waste formx. Nihon Genshiryoku Gakkaishi, 29, 400-5X-5X, 1994.

1659. Furuya, T.S.,Muneaki; Banba effects of various waste contents on properties of borosilicatex glasses for high-level waste solidification in several countriesX. Report, Jaeri-M-9378, 29 pp, 1982.

1660. Gahlert, S. powder technological vitrification of simulated high-level wasteX. Kernforschungszent. Karlsruhe, Kfk, Kfk 4361, 205 pp, 1994.

166I. Galloway, R., M., ; Plodinec, M., J., ; Wilhite, E., L., ; Chismar, P., $H .$, and $X$ remote experimental facility to solidify sip high-level wastex. Report, Dp-Ms-79-53, Conf-791103-33, 21 pp, 1980.

1662. Galloway, R., M., ; Plodinec, M., J., ; Wilhite, E., L., ; Chismar, P., $H .$, and $X$ remote experimental facility to solidify savannah river plantX high-level wastex. Proc.Conf.Remote syst.Technol., Volume Date 1979, 27, $391-5 X-5 X, 1994$.

1663. Galoisy, I. and Calas, G. Structural Environment of Nickel in Silicate Glass Melt Systems .1. Spectroscopic Determination of Coordination states. GEOCHIM. COSMOCHIM. ACTA $57: 3613-3626$, 1993.

1664. Garland, J.A. and White, W.B. Determination of early stages of glass dissolution by ph titration. In: <CI> Held as part of the Fall Meeting of the Materials Researchx Society Materials Research Society Symposia Proceedings $v$ 
44. PubI by MaterialsX Research Soc,Pittsburgh,PA, USA p 81-88,Anonymous Pittsburgh, PA, USA:MaterialsX Research SOC, 1985,p. 81-88.

1665. Gautier-Luneau, I., Mosset, A., Galy, J., and Schmidt, H. Sol-gel processing and structural study of a vitreous polysiloxane doped with titanium. Journal.of.Materials.Science J Mater Sci v 25 n 8, 1990.

1666. Gavaghan, H. Taking the heat out of.glass making. New Scientist. v. 106 (Apr. 11 '85):25, 1985.

1667. Gee, J.T., Iverson, D.C., and Bickford, D.F. Materials evaluation programs at the Defense Waste Processing Facility. (Unknown Journal!), 1992.

1668. Geeting Preliminary assessment of blending hanford tank wastes. (Unknown Journal!) : (138 p), 1993.

1669. Geeting, J., G., H., ; Kurath, D., E., and X preliminary assessment of blending hanford tank wastesx. Report, Pnl-8589; Order No.De93010607, 138 pp, 1993.

1670. Geipel, H. German nuclear high-level waste program - key research areas. In: Materials Research Society Symposia Proceedings $v$ 50. Publ by MaterialsX Research SOC, Pittsburgh, PA, USA $p$ 45-48, Anonymous Pittsburgh, PA, USA:MaterialsX Research SOC, 1986,p. 45-48.

1671. George G.Wicks, W.C.Mosley, Peter G.Whitkop, and Kathy A.Saturday Durability of Simulated Waste Glass--Effects of Pressure and Formation of Surface Layers. Journal. of.Non-Crystalline.Solids. 49:413-428, 1982 .

1672. Ghanbari-Ahari, K. and Cameron, A. Phase diagram of $\mathrm{Na} / / 20-\mathrm{B} / / 20 / / 3-\mathrm{SiO} / / 2$ system. Journal: of. the.American.Ceramic.Society. Journal of the Ameri, 1993.

1673. Ghandakly, A. and Curran, R. Accurate modeling of interelectrode resistance and power dissipation in electric glass melters. IEEE Transactions.on.Industry.Applications. IEEE Trans Ind Appl, 1988.

1674. Ghandakly, A. and Curran, R. A model to predict current distributions in bundled cables for electric glass melters. IEEE Transactions.on.Industry.Applications. IEEE Trans Ind Appl, 1990.

1675. Ghattas, N., Hild, W., and Guber, พ. Some studies on nuclides losses.ii.cold fingerX. J.Appl.Chem.Biotechnol. -53X, 1994.

1676. Ghattas, N., Hild, $\mathfrak{W}$, , and Guber, w. Some studies on nuclides losses. $i$. vitrification of high activityX wastex. J.Appl.Chem.Biotechnol. $-30 \mathrm{X}, 1994$.

1677. Ghattas, N. and Gompper, K. Vitrification of medium level liquid waste precipitates in VG $98 / 12$ borosilicate glass. Nuclear.and.Chemical.Waste.Management. v. 6 no2 ('86):169-174, 1986.

1678. Ghattas, N., ; Gompper, K., and X vitrification of medium level liquid waste precipitates in vg $98 / 12 X$ borosilicate glassX. Nucl.Chem. Waste Manage,, $6,169-74 \mathrm{X}-74 \mathrm{X}, 1994$. 
1679. Ghattas, N., K., ; Eskander, S., B., and $X$ some studies on nuclide losses during $\star * *$ vitrification** ofX highly active wastes.iil.effect of $* *$ glass $* * *$ compositionX. Isot.Radiat.Res., 15, 17-22X-22X, 1994.

1680. Ghezal, A. Elaboration et etude du verre borosilicate GP $98 / 12$ pour la vitrification des dechets radioactifs du Centre, de KfRarlsruhe (R.F.A.). (Elaboration and experimental study of the Borosilicate glass GP 98/12 for the vitrification of the radioactive wastes of KfKarlsruhe Centre (R.F.A.)). Thesis. (Unknown Journal!), 1987.

1681. Gibson, J. and $X$ high-temperature oxide and hydroxide vapor species of technetiumX. Radiochim.Acta, 60, 121-6x-6X, 1994.

1682. Gignac, L., M., ; Altstetter, C., J., ; Brown, S., D., and X a nuclear reaction analysis technique to determine the penetrationx of hydrogenic species into glasses exposed to leaching solutionsX. Mater.Res.Soc.Symp.Proc., 44,X 107-12X-12X, 1994.

1683. Gignac, I.M., Altstetter, C.J., and Brown, S.D. Nuclear reaction analysis technique to determine the penetration ofX hydrogenic species into glasses exposed to leaching solutions. In: <CI> Held as part of the Fall Meeting of the Materials Researchx Society Materials Research Society Symposia Proceedings $v$ 44. Publ by MaterialsX Research. SOC,Pittsburgh, PA, USA $p$ 107-112, Anonymous Pittsburgh, PA, USA:MaterialsX Research SOc, 1985,p. 107-112.

1684. Gignac,. I. The effect of processing on the water content and properties of an alkali-borosilicate glass frit /, 1985.

1685. Gilbert, A. Some electrical properties of molybdenum - phosphate glass, Alfred, N.Y.New York State College of Ceramics at Alfred University, 1978 .

1686. Gimpel Vitrification and solidification remedial treatment and disposal costs. (Unknown Journal!) : (17 p), 1912 .

1687. Gimpel Proposed plan for vitrification demonstration of low-level radioactive wastes at the fermald environmental management project. (Unknown Journal!) : (12 p), 1991.

1688. Gimpel, R.F. Proposed plan for vitrification demonstration of low-level radioactive wastes at the Fernald Environmental Management Project. (Unknown Journal!) , 1991.

1689. Gimpel, R. Proposed plan for vitrification demonstration of low-level radioactive wastes at the Fernald Environmental Management Project $/$, Cincinnati, Oh. : Springfield, Va. :Westinghouse Environmental Management Company of Ohio, Fernald Environmental Management Project; reproduced by NTIS, 1991.

1690. Giraud and Le Blaye Design of an industrial facility for the incorporation into glass ofx fission products and the storage of highly radioactive glassX. Symp.Manage.Radioactive.Wastes. Fuel.Reprocess. -46, 1972 . 
1691. Giraud and Le Blaye Design of an industrial facility for the incorporation into glass ofX fission products and the storage of highly radioactive glassX. Energ.Nucl. -50X, 1994.

1692. Giraud, J.P., Conord, J.P., and Saverot, P.M. Conceptual design for vitrification of $\mathrm{hlw}$ at west valley using ax rotary calciner/metallic melter. In: <CI> Held during the 85th Annual Meeting of the American Ceramicx Society Advances in Ceramics $v 8$. Publ by American Ceramic SOC Inc, Columbus, $X$ OH, USA $P$ 132-142, Anonymous Columbus, $X$ OH, USA:American Ceramic SOC Inc; 1984,p. 132-142.

1693. Giraud, J.P., Conord, J.P., and Saverot, P.M. Conceptual design for vitrification of HLW [high-level waste] at West Valley [NY] using a rotary calciner/metallic melter. Adv.Ceram. 8:132-14.2, 1985.

1694. Glascock, J. Drain Valve Test Stand: Runs 4 and 5 Low-Viscosity Glass Tests and Spinel Tests. (Unknown Journal!), 1987.

1695. Glascock, J. Prototype DWPF Drain Valve Temperature Profiles. (Unknown Journal!) , 1987.

1696. Glascock, J. Operability Testing of a Prototype DWPF (Defense Waste Processing Facility) Melter Drain Valve. (Unknown Journal!) , 1988.

1697. Glasser, F. Role of ceramics, cement, and glass in the immobilization ofradioactive wastes. Br.Ceram.Trans.\& J. , 1985.

1698: Glasser, F., P., and $X$ ceramic and concrete forms of radwaste immobilizationx. Radioact.Waste Manage.Perspect., Conf.Transcript, 103-16-16, 1994.

1699. Glismann, H. Apparatus for producing electrical energy from radioactive wastesX. Ger. Offen. , 1994.

1700. Gobbo, K. Model of a glass melting furnace by $\mathrm{Li} / / 20$ tracing. IEEE Transactions.on.Industry.Applications. IEEE Trans Ind Appl, 1989.

1701. Godbee, Clark, and Fitzgerald Physical properties of solids incorporating simulated radioactiveX wastesX. U.S.At. Energy.Comm. , 1967.

1702. Godbee and Kibbey Source terms for radioactive gaseous effluents from a modelx high-level waste solidification facilityx. Report. , 1978.

1703. Godon, N., ; Vernaz, E., and X r7t7 nuclear waste glass behavior in moist clay: role of the clayx mass/glass surface area ratiox: Mater.Res.Soc.Symp.Proc., 176, 319-26X-26X, 1994.

1704. Godon, N.T., Jean Hugues; Touray interaction of r7t7 model-glass, designed for nuclear waste storage, $X$ with synthetic seawater and deionized water. experimental dataX. C.R.Acad.Sci., Ser. 2, 305, 1193-7X-7X, 1994.

1705. Goebbels, J., Illerhaus, B., Kettschau, A., and Reimers, P. Nondestructive testing of tomography by computerized vitrifiedx radioactive waste. CFI, Ceramic Forum International/Berichte der DKG 66:288-291, 1989. 
1706. Gohar, I.A., Doweidar, H., Elshazly, R.M., Megahed, A.A., and Meikhail, M.S. Formation of $B O / / 4 * *$ minus tetrahedra and nonbridging oxygen ions in borosilicate glasses with low silica content. Journal.of.Materials.Science $\mathrm{J}$ Mater Sci v 25 I 2, 1990.

1707. Goldman, D. and Bewley, D. Ferrous/ferric moessbauer analysis of simulated nuclear waste glass withand without computer fitting. J.Am.Ceram.Soc. . 1985.

1708. Goldman, D. and Brite Redox characterization of simulated nuclear waste glass. J.Am.Ceram.Soc. , 1986.

1709. Goldman, D.S. Investigation of Potential Analytical Methods for Redox Control of the Vitrification Process. (Unknown Journal!) , 1985.

1710. Goldman, D.S. Melt Foaming, Foam Stability and Redox in Nuclear Waste Vitrification. (Unknown Journal!), 1985.

1711. Goldman, D.S. Melt foaming, foam stability and redox in nuclear waste vitrification. Journal of Non-Crystalline Solids 84:292-298, 1986.

1712. Goldman, D.S. and Bewley, D.E. Ferrous/ferric moessbauer analysis of simulated nuclear waste glassx with and without computer fitting. Journal of the American Ceramic Society 68:691-695, 1985.

1713. Goldman, D.S. and Brite, D.W. Redox characterization of simulated nuclear waste glass. Journal of the American Ceramic Society 69:411-413, 1986.

1714. Goldman, D.S., Brite, D.W., and Richey, W.C. Investigation of foaming in liquid-fed melting of simulated nuclearx waste glass. Journal of the American Ceramic Society 69:413-417, 1986 .

1715. Goldston The dwpf strategy for producing an acceptable product. (Unknown Journal!) : (10 p), 1991.

1716. Goles LfCm (liquid-fed ceramic melter) processing characteristics of mercury. (Unknown Journall) :(25 p), 1990.

1717. Goles Hanford waste vitrification program pilot-scale ceramic melter test 23. (Unknown Journal!) : (220 p), 1990.

1718. Goles, R., W., ; Nakaoka, R., K., and $X$ hanford waste vitrification program pilot-scale ceramic melter testx 23X. Report, Pnl-7142; Order No.De90007915, $220 \mathrm{pp}, 1990$.

1719. Goles, R., W., ; Sevigny, G., J., ; Andersen, C., M., and X $1 f c m$ processing characteristics of mercuryx. U.S.Nucl.Regul.Comm., Nureg/CP, Nureg/CP-0116, Proc.X Doe/NrC Nucl.Air.Clean.Conf., 21st, 1990, Vol-66X, 1994.

1720. Goles, R., W., ; Brauer, F., P., ; Hamilton, D., C., ; Fager, J., E., and

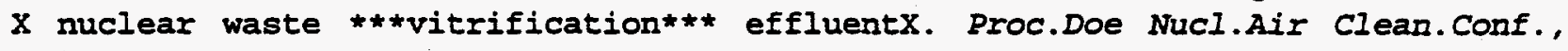
Volume Date 1980, 16, 891-910X-910X, 1994. 
1721. Goles, R., W., ; Brauer, F., P., and $X$ an automated krypton-85 .gamma.-ray stack monitorX. Ieee Trans.Nucl.Sci., Ns28(1), 740-4X-4X, 1994.

1722. Goles, R., W., ; Hamilton, D., C., ; Brauer, F., P., ; Rieck, H., G., , iX Robertson, D., M., ; Gordon, R., L., ; Kaye, J., H., and X characterization of gaseous and particulate effluents from thex nuclear ***vitrification*** projectx. Report, PnI-3181, 39 pp, 1980.

1723. Goles, R., W., ; Sevigny, G., J., and X off-gas characteristics of defense waste $* \star *$ vitrification***X using liquid-fed joule-heated ceramic meltersX. Report, PnI-4819; Order No.De84001019, 237 pp, 1983.

1724. Goles, R.W., Brauer, F.P., Hamilton, D.C., and Fager, J.E. Nuclear waste vitrification effluent. In: Proceedings of the DOE Nuclear Air Cleaning Conference 16th $v 2$. PublX by DOE (CONF-801038), Washington,DC, USA $p$ 891-910, Anonymous Washington, DC, USA: 1981,p. 891-910.

1725. Goles, R.W., Hof, P.J., Dierks, R.D., and Holton, L.K. Remote canister level/turntable positioning system. In: 〈CI> Held in Conjunction with American Nuclear Society Winter Meeting Proceedings of the Conference on Remote Systems Technology 34th. PubIX by ANS, La Grange Park, IL, USA $p$ 20-32, Anonymous La Grange Park, IL, USA: 1987,p. 20-32.

1726. Goles, R.W., Hof, P.J., Dierks, R.D., and Holton, L.K.J. Remote canister-positioning and glass level detection system. Nuclear Technology $89: 203-216,1990$.

1727. Goles, R.W., Holton, L.K.J., and Sevigny, G.J. Behavior of mercury in high-temperature vitrification processes. Nuclear Technology 100:310-321, 1992.

1728. Goles, R., Holton, L.J., and Sevigny, G. Behavior of mercury in high-temperature vitrification processes. Nuclear. Technology. CODEN: . NUTYBB. ISSN: . 0029-5450. PUB. TYPE: . JA. (Journal.Article) $X$. LANGUAGE: . English. Nucl Technol v $100 \mathrm{n}, 1992$.

1729. Golubsov, I., V., ; Korobkov, V., I., ; Karlina, O., K., ; Kachalov, M., B., ;X Ovchinnikov, A., ; Ozhovan, M., and $X$ interphase distribution of cesium-137 in sulfate-containingX glass-compositesX. Vestn.Mosk. Univ., Ser. 2: Khim-4X, 1994 .

1730. Golubtsov, I., V., ; Kachalov, M., B., ; Ozhovan, M., I., ; Popov, M., and $X$ fractal structure of $* *$ glass $* *$-composite materials for $X$ $\star \star \star$ radioactive $* \star \star \star \star *$ wastes $\star \star *$ X. Vestn.Mosk.Univ., Ser. 2: Khim-2X, 1994 .

1731. Golubtsov, I.V., Kachalov, M.B., Ozhovan, M.I., and Popov, M.V. Fractal Structure of Glass-Composite Materials for Radioactive-Waste Products. VESTN.MOSK. UNIV.KHIM. 34:161-162, 1993.

1732. Gomberg, S.E. and Vocke, W.T. Characterization of spent nuclear fuel and high-level radioactive wastex glass for hazardous components. In: High Level Radioactive Waste Management. Publ by ASCE, New York, NY,X USA.P 320-325, Anonymous New York, NY,X USA:ASCE, 1991,p. 320-325. 
1733. Gombert, Cole, and Berreth Vitrification of high-level icpp calcined wastesX. Report. , 1979.

1734. Gombert, D., , B., ; Colton, E., I., and $X$ design and installation of a pilot plant to ***vitrify***X icpp-simulated calcined high-level wastex. Report, Enico-1087, 59 pp, 1981.

1735. Gombert, D. and laboratory scale $\star \star \star$ glass $\star \star \star$ melter for testing defense wasteX ***glass*** X. Report, Conf-790420-3, 13 pp, 1979.

1736. Gombert, D., ; Pong, M., Y., and $X$ operation of a laboratory-scale ***glass*** melter toX ***vitrify*** icpp zirconia calcineX. Report, Enico-1058, $28 \mathrm{pp}, 1981$.

1737. Gombert, D., ; Priebe, S.J., ; Berreth, J., R., and X microwave energy for post-calcination treatment of high-levelx nuclear wastesx. Ieee Trans.Ind.Appl., Ia-18(6), 755-9X-9X, 1994.

1738. Gompper, K. and Krause, H. Fortgeschrittenes Behandlungskonzept fuer Abfaelle aus den Brennstoffkreislaeufen von Leichtwasserreaktoren und Schnellen Bruetern. (Advanced treatment concept for wastes from the light water reactor and fast breeder nuclear fuel cycles). (Unknown Journal!) , 1991.

1739. Goodlett, C.B., McDonnell, W.R., Thomas, S.D., and Geiger, J.W. Optimum DWPF (Defense Waste Processing Plant) Processing Rate. (Unknown Journal!) , 1988 .

1740. Gorecki, C.z., Gorecki, T., and Michno, z. Thermal stability of the $\mathrm{Fe} / / 8 / / 0 / /$ minus $/ / \mathrm{xV} / / \mathrm{xB} / / 2 / / 0$ metallic glasses as studied by the EEE and DTA methods. Journal. of.Materials.Science J Mater Sci v 25 n 3, 1990.

1741. Gould, T.H.J. Alternative waste from evaluation for savannah river plant high-levelx waste. In: Transactions of the American Nuclear Society $v 411982$. Publ by ANS, LaX Grange Park, IIl, USA P 276-277, Anonymous LaX Grange Park, IIl, USA:ANS, $1982, \mathrm{p}$. 276-277.

1742. Gowing, R. and Cory, A. Developing a flask for vitrified waste. Nuclear Engineering International 34:38-40, 1989.

1743. Grambow, B., Hermansson, H., and Bjormer, I. Reaction of nuclear waste glass with slowly flowing solutions. Adv.Ceram. , 1986.

1744. Grambow, B. Role of metal ion solubility in leaching of nuclear waste glasses. In: Materials Research Society symposia Proceedings $v 11$. Publ by $x$ North-Holland, New York, NY, USA and Amsterdam, Neth $p$ 93-102,Anonymous New York, NY, USA: 1982,p. 93-102.

1745: Grambow, B. Geochemical modeling of the reaction between glass and aqueousX solution. In: <CI> Held during the 85 th Annual Meeting of the American Ceramicx Society Advances in Ceramics $v 8$. Publ by American Ceramic Soc Inc, Columbus, $X$ OH, USA $p$ 474-481, Anonymous Columbus, $X$ OH, USA:American Ceramic SOC Inc, 1984,p. 474-481. 
1746. Grambow, B. Physical-Chemical Model for the Mechanism of Glass Corrosion with Particular Consideration of Simulated Radioactive Waste Glasses. (Unknown Journal!) , 1985.

1747. Grambow, B., ; Mueller, R., and $x$ chemistry of glass corrosion in high saline brinesX. Mater.Res.Soc.Symp.Proc., 176, 229-40X-40X, 1994.

1748. Grambow, B., Jercinovic, M.J., Ewing, R.C., and Byers, C.D. Weathered basalt glass: a natural analogue for the effects of reactionx progress on nuclear waste glass alteration. In: Materials Research Society symposia Proceedings $v$ 50. PubI by MaterialsX Research SOC,Pittsburgh, PA, USA $p$ 263-272,Anonymous Pittsburgh, PA, USA:MaterialsX Research Soc, 1986,p. 263-272.

1749. Grambow, B., Muller, R., Rother, A., and Lutze, w. Release of Rare Earth Elements and Uranium from Glass in Low pH High Saline Brines. Radiochimica.acta. 52/53, Part II:499-501, 1991.

1750. Grambow, B. and Strachan, D.M. Comparison of the Performance of Nuclear Waste Glasses by Modeling. (Unknown Journal!) , 1988.

1751. Grambow, B. and $X$ remaining uncertainties in predicting long-term performance ofX nuclear waste glass from experimentsX. Mater.Res.Soc.Symp.Proc., 333, 167-80X-80X, 1994.

1752. Grambow, B., ; Hermansson, H., P., ; Bjoerner, I., K., ; Christensen, H., ; $X$ Werme, $L .$, and $X$ reaction of nuclear waste glass with slowly flowing solutionsX. Adv. Ceram., 20, 465-74X-74X, 1994.

1753. Grambow, B., ; Lutze, W., and $X$ performance assessment of glass as a long-term barrier to thex release of radionuclides into the environmentx. Mater.Res.Soc.Symp.Proc., 112, 531-41X-41X, 1994.

1754. Grambow, B., ; Strachan, D., M., and X a comparison of the performance of nuclear waste glasses by modelingx. Report, Pnl-6698; Order No.De89004739, 59 PP, 1989.

1755. Grambow, B., ; Strachan, D., M., and X leach testing of waste glasses under near-saturation conditionsx. Mater.Res.Soc.Symp.Proc., $26, \mathrm{X}$ $623-34 \mathrm{X}-34 \mathrm{X}, 1994$.

1756. Grambow, B., ; Strachan, D., M., and X a comparison of the performance of nuclear waste glasses by modelingX. Mater.Res.Soc.Symp.Proc., 112, 713-24X-24X, 1994.

1757. Grambow, B., ; Zwicky, H., U., ; Bart, G., ; Bjoerner, I., K., ; Werme, L., $O .$, and $x$ modeling of the effect of iron corrosion products on nuclear wasteX glass performanceX. Mater.Res.Soc.Symp.Proc., 84,X 471-81X-81X, 1994.

1758. Grambow, $B$. and $X$ solubility limits of metal ions and mechanism of leaching nuclearX waste glassesX. Report, PnI-Sa-10303; Order No.De82014851, 19 Pp, 1982 . 
1759. Grambow, $B$. and $X$ physical-chemical model for the mechanism of $\star * *$ glass $* * X$ corrosion with particular consideration of simulatedX

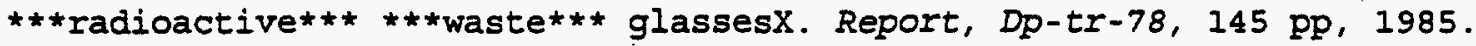

1760. Grambow, B. and $X$ a general rate equation for nuclear waste glass corrosionX. Mater.Res.Soc.Symp.Proc., 44,X 15-27X-27X, 1994.

1761. Grambow, $B$. and $x$ the role of metal ion solubility in leaching of nuclear wasteX glassesX. Mater.Res.SOC.Symp.Proc., 11,X 93-102X-102X, 1994.

1762. Grambow, B. influence of saturation on the leaching of borosilicate nuclearX waste glassesX. Glastech.Ber., 56, 566-71X-71X, 1994.

1763. Grambow, B. nuclear waste glass dissolution: mechanism, model and applicationX. Tech.Rep. - Jss Proj., 87-02, 120 pp-2, 120 pp, 1994.

1764. Grandy Tsa waste stream and final waste form composition. (Unknown Journal!) : (33 p), 1993.

1765. Grandy, J.D., Eddy, T.I., and Anderson, G.I. Property and process correlations for iron-enriched basalt waste forms. (Unknown Journal!) , 1993.

1766. Grant Interaction analysis method for the hanford waste vitrification plant. (Unknown Journal!) : (12 p), 1993.

1767. Grant, R.R., Deshotels, R.I., and Van Katwijk, C. Interaction analysis method for the Hanford Waste Vitrification Plant. (Unknown Journal!), 1993.

1768. Grant, P.R., Gruber, R.S., and Van Katwijk, C. Elevated temperature effects on concrete properties. (Unknown Journal!) , 1993.

1769. Grantham, L., F., ; McKisson, R., L., ; Guon, J., ; Flintoff, J., ;X McKenzie, D., E., and $X$ process description and plant design for preparing CeramicX high-level waste formsX. Report, Doe/Et/41900-16, Esg-Doe-13397; Order No.De83007885, 72 Pp, 1983.

1770. Grantham, L.F. and Flintoff, J.J. High nuclear waste loadings in tailored ceramics. In: Proceedings - The Electrochemical society $v$ 82-1. Publ by ElectrochemX Soc, Pennington, NJ, USA p 162-175, Anonymous Pennington, NJ, USA: ElectrochemX SOC, $1982, \mathrm{p}$. 162-175.

1771. Grantham, I.F., McKisson, R.L., De Wames, R.E., Guon, J., Flintoff, J.F., and McKenzie, D.E. Ceramic process and plant design for high-level nuclear wastex immobilization. In: <CI> Volume 2: Waste Regulations and Programs: High-Level Waste Proceedings of the Symposium on Waste Management Publ by Univ ofX Arizona, Tucson, AZ, USA p. 213-219, Anonymous Tucson, AZ, USA:Univ ofX Arizona, 1983, p. 213-219.

1772. Grauer, R. Container Material for the Disposal of Highly Radioactive Wastes: Corrosion Chemistry Aspects. (Unknown Journal!) , 1984.

1773. Grauer, R. Synthesis of Recent Investigations on Corrosion Behaviour of Radioactive Waste Glasses. (Unknown Journal!) , 1985. 
1774. Grauer, $R$. and $X$ glasses for the solidification of high-level $\star * *$ radioactive $* * x, * * *$ waste $* * *$ : their behavior in the presence of waterX. Report, Ornl-tr-4980; Order No.De83013402, 141 pp, 1983.

1775. Grauer, $R$. and $X$ glasses for solidification of high-level $\star * *$ radioactive $\star * * \mathrm{X} * \star *$ wastes $* * *$ : their behavior in contact with waterX. Report, Eir-477, 164 pp, 1984.

1776. Grauer, $R$. and $X$ synthesis of recent investigations on corrosion behavior ofX radioactive waste glassesX, Report, Eir-538, 93 pp, 1985.

1777. Grauer, $R$. and $X$ bentonite as a backfill material in the permanent storage site forX high-level radioactive waste: chemical aspectsX. Tech.Ber.Nagra, 86-12, 179 pp-12, 179 pp, 1994.

1778. Grauer, $R$, and $X$ glasses for solidification of highly $\star \star \star$ radioactive $* \star \star X$ ***waste*** : their behavior with respect to watersX. Eir-Ber., 477, 157 pp, 1994.

1779. Grauer, $R$. and $X$ review of recent investigations on corrosion behavior of radioactiveX waste glassesX. Eir-Ber., 538, 93 pp, 1994.

1780. Gray Volatility of a zine borosilicate glass containingx simulated high-level radioactive waste X. Report. , 1977.

1781. Gray, P.E. and Klein, L.C. The chemical durability of sodium ultraphosphate glasses. Jo -Glass Technology. (Unknown Journal!) v. 24 (Aug.

' 83) :202-206, 1983 .

1782. Greaves, G.N. Exafs for studying corrosion of glass surfaces. <CT> Proceedings of the Tenth University Conference on Glass Science <CL> University Park, PA, USA <CD> 1989 Jun 7-9 Journal of Non-Crystalline Solids 120:108-116, 1990.

1783. Greaves, G.N., Barrett, N.T., Antonini, G.M., Thornley, F.R., and Willis, B.T.M. Glancing Angle X-ray Absorption Spectroscopy of Corroded Borosilicate Glass Surfaces Containing Uranium. (Unknown Journal!) , 1988.

1784. Green, C.W., Brener, D., Browne, E.N.C., Holbein, B.E., DeVoe, I.W., and Ek, R. Vitrokele compositions: novel, high affinity, metal selective andx regenerable media for the removal of radioactive metals from aqueousX nuclear waste streams. In: <CI> Volume 2. Waste Policies and Programs, Low-Level Waste $\checkmark$ 2. Publ by Univ of Arizona, Tucson, AZ, USA p 251-255, Anonymous Tucson, AZ, USA:Univ of Arizona, 1985,p. 251-255.

1785. Green, J.L. and Angell, C.A. Phase relations and vitrification in saccharide-water solutions and the trehalose anomaly. The.Journal.of.Physical.Chemistry. v. 93 (Apr. 20 '89):2880-2882, 1989.

1786. Greene, H.L. and ; Subbanna, P. catalytic oxidation of chlorinated hazardous wastesX. Manage.Hazard.Toxic Wastes Process Ind., , 513-41-41, 1994. 
1787. Grindrod, P. streng: a source term model for vitrified high level wastex. Tech.Ber. - Nagra, 90-48, 46 pp-48, 46 pp, 1994.

1788. Groeber, P. Technology evaluation report. Babcock and Wilcox cyclone furnace vitrification technology /. Cincinnati, OH :Risk Reduction Engineering Laboratory, U.S.Environmental Protection Agency, 1992.

1789. Grover Glasses for the fixation of high level radioactive wastesX. Symp.Manage.Radioactive. Wastes.Fuel.Reprocess. -612, 1972.

1790. Grover, Elliot, and Jones Long term examination of glasses for the fingal processX. U.S.At.Energy. Comm. -660208, 1994.

1791. Grover, Johnson, and Morris The fixation of radioactive waste for posterityx. Nucl. Energy.Maturity. $-6,1975$.

1792. Grover, J., R., and $X$ high-level waste solidification - why we chose

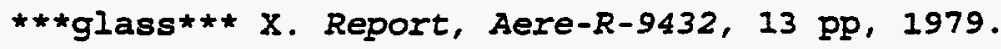

1793. Grover, J.R. and Jones, A.D. Composition of noncorrosive glassX. Brit. : Addn to Brit 1019373, 1994.

1794. Grover, J.R. and McKenzie, M. Production of radioactive fused glass bodiesX. US., 1994 .

1795. Gruenewald, W., ; Koschorke, H., ; Weisenburger, S., ; Zeh, H., and X high-level liquid waste solidification and waste glass canisterX handling at the institut fur nukleare entsorgungstechnikx. Radioact.Waste Manage., Proc.Int.Conf., Meeting Date 1983, Volumex 2, 3-82, 1994.

1796. Grygiel and Jouan Tank waste disposal program redefinition Dismantling and decontamination of piver prototype vitrification plant Demantelement et decontamination de l'installation prototype de vitrification piver. (Unknown Journal!) : (54 p), 1991.

1797. Grzeszczyk, S. and Szuba, J. Hydration reactivity of crystalline and vitrified diopside under hydrothermal conditions. Journal.of. the.American.Ceramic.Society. v. 73 (July '90):2006-2008, 1990.

1798. Gu, G. analysis of simulated waste, vitrification glass specimens by icp/aesX. Yuanzineng Kexue Jishu, 25, 15-21X-21X, 1994.

1799. Gu, G. decomposition of simulated waste vitrification glass specimens byX lithium metaborate fusion methodX. Yuanzineng Kexue Jishu, 25, 71-5X-5X, 1994.

1800. Guber, Diefenbacher, Hild, Krause, Schneider, and $x, S$. Pilot plant experience on high-level waste solidification and designx of the engineering prototype verax. Symp.Manage.Radioactive.Wastes.Fuel.Reprocess. -514, 1972.

1801. Guber, Hild, Kaufmann, Koschorke, Krause, X, R., Saidl, and Scheffler Lab-scale and pilot-plant experiments on the solidification ofX high-level wastes at the karlsruhe nuclear research centerx. Manage.Radioact. Wastes. Nucl. Fuel. Cycle -81, 1994. 
1802. Guber, Kahl, and Saidl Recent experiments on fixation of high activity wastes in karlsruhex. Report. , 1976.

1803. Guber, W., Saidl, J., Daruschy, P., and Hild, w. Thermodynamically stable glass ceramic product for theX final disposition of highly radioactive wastes X. Ger.offen., 1994.

1804. Guber, W., ; Hussain, M., ; Kahl, L., ; Ondracek, G., ; Saidl, J., ; Dippel, X.T., and $X$ fabrication and characterization of an improved borosilicatex $\star * \star g l a s s * \star$ for solidification of high-level. fission productX solutions (hlw).part 1 .studies of 25 borosilicate $* * *$ glass $* * * X$ products for

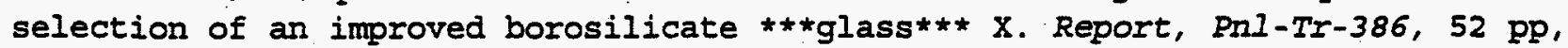
1980 .

1805. Guber, W., ; Hussain, M., ; Kahl, L., ; Ondracek, G., ; Saidl, J., ; Dippel, X.T., and $X$ production and characterization of an improved borosilicatex ***glass*** for containment of highly radioactive fission productX solutions (haw).part 1.studies of 25 borosilicate $\star * \star g l a s s * \star \star X$ products for the selection of an improved borosilicate $* \star * g l a s s * * x$. Kernforschungszent. Karlsruhe, Kfk, Kfk 2721, 17 pp, 1994.

1806. Guber, W., ; Hussain, M., ; Kahl, L., ; Ondracek, G., ; Saidl, J., and X preparation and characterization of an improved. high levelx ***radioactive***

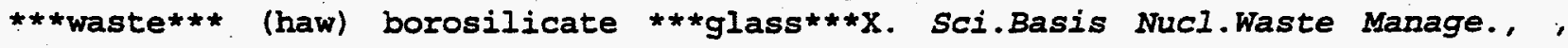
MeetingX Date 1978, 37-42:lenum: NewX York, 1994.

1807. Guber, W., ; Kahl, L., ; Kment, H., ; Mueller, W., ; Riege, U., ; Saidl,

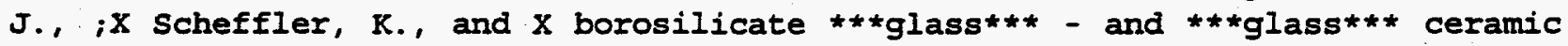
productsX with solidified high-level $* * *$ radioactive*t* $\star * *$ waste $* \star * X$ solutions of irradiated nuclear fuelsX. Kernforschungszent.Karlsruhe, Kfk, Kfk 2940 , Samml: roj-77X, 1994 .

1808. Guidotti, P.D., Crow, K.R., Weisman, A.F., Baron, M.R., and Wehner, A.M. Sumnary of Campaigns SGM- 6 and SGM-7 of the DWPF Scale Glass Melter. (Unknown Journal!) , 1987.

1809. Guo, Y. Sol-gel synthesis and characteristics of the rare earth phosphate $X$ glasses, 1993.

1810. Gupta, P., Lui, M., and Bray, P. Boron coordination in rapidly cooled and in annealed aluminum borosilicate glass fibers. Journal. of the.American.Ceramic.Society. v. 68 (Mar. '85):C82, 1985.

1811. Gurley, R., N., ; Minor, J., E., and $X$ hanford waste vitrification.an overviewX. Proc.Symp. Waste Manage., (1), 179-84X-84X, 1994.

1812. Gurley, R.N., LaRue, K.M., Thompson, R.J., Shah, K.R., Minor, J.E., and Siemens, D.H. Design aspects of the hanford waste vitrification plant. In: <CI> Volume 2: High-Level Waste $v 2$. Publ by Arizona Board of Regents, AZ, USA $p$ 455-460, Anonymous AZ, USA:Arizona Board of Regents, 1986,p. 455-460.

1813: Gurley, R.N. and Minor, J.E. Hanford waste vitrification - an overview. In: <CI> Volume 1. Waste Policies and Programs, High-Level Waste $v 1$. Publ by 
Univ of Arizona, Tucson, AZ, USA p 179-184,Anonymous Tucson, AZ, USA:Univ of Arizona, 1985,p. 179-184.

1814. Gurwell, W., E., and $X$ survey of matrix materials for solidified radioactive high-levelX wasteX. Report, PnI-3512; Order No.De82000708, 58 pp, 1981.

1815. Gutmann Travel to tokai vitrification facility to discuss the melter and process operational experiences with noble metals. (Unknown Journal!) :(238 p), 1914 .

1816. Guy, C. modeling of soret diffusion in $* * \star$ radioactive $* \star * * * *$ waste $* \star * X$ ***glass*** X. Appl.Geochem., Suppl., 1, 33-40X-40X, 1994.

1817. Guy, C. and schot, J. Modelling of soret diffusion in radioactive waste glass. Applied Geochemistry Suppl:33-40, 1992.

1818. H Lavac, J., Michajlovic, J., and Skrovankova-Rohanova, D. Vitrification of simulated intermediate-level waste from nuclear powerx plants.11.chemical stability of vitrified products in acidicx solutions. Ceramics - silikaty $37: 137-143,1993$.

1819. Hà, B.C. Rheology of Savannah River Site Tank $51 \mathrm{HLW}$ radioactive sludge. Revision 1. (Unknown Journal!) , 1993.

1820. Ha, B.C., Ferrara, D.M., and Bibler, N.E. Hydrogen production during processing of radioactive sludge containing noble metals. (Unknown Journal!). , 1992.

1821. Haaker, R., Malow, G., and Offermann, P. Effect of phase formation on glass leaching. In: <CI> Held as part of the Fall Meeting of the Materials ResearchX Society Materials Research Society Symposia Proceedings $v 44$. Publ by MaterialsX Research SoC,Pittsburgh, PA, USA p 121-128,Anonymous Pittsburgh, PA, USA:MaterialsX Research Soc, 1985,p. 121-128.

1822. Haaker, R.F. Phase Formation During Corrosion Experiments with Two Simulated Borosilicate Nuclear Waste Glasses. (Unknown Journal!) , 1985 .

1823. Habazaki, H., Kawashima, A., Asami, K., and Hashimoto, $\mathrm{K}$. Effect of tungsten on the corrosion behavior of amorphous $\mathrm{Fe}-\mathrm{Cr}-\mathrm{W}-\mathrm{P}-\mathrm{C}$ alloys in $1 \mathrm{M} \mathrm{HCl}$. Journal.of. the.Electrochemical.Society. J Electrochem Soc $v, 1991$.

1824. Hafez, M., B., ; Abo, E.K.,B., M., ; Abdel Rehiem, A., G., and X treatment of low-level radioactive liquid waste using tremoliteX ***silicate*** polymerX. Radioact.Waste Manage.Nucl.Fuel Cycle, 4, 33-9X-9X, 1994.

1825. Hagen, D., A., ; Altstetter, C., J., ; Brown, S., D., and X durability of two simulated nuclear waste glasses, a frit glass, andx tektite in aqueous solutions: final report, volume ix. Report, Dpst-88-967; Order No.De89010475, 209 pp, 1989.

1826. Haideri, A.Q. Electrical power supply and controls for a remotely operated. glassx melter for nuclear waste. In: Conference Record - IAS Annual Meeting (IEEE Industry ApplicationsX Society) 1985.PubI by IEEE, New 
York, NY, USA. Available from IEEEX Service Cent (Cat n 85CH2207-9), Piscataway, NJ, USA p 86-92, Anonymous New York, NY, USA:IEEE, 1985,p. 86-92.

1827. Halaszovich, Dix, and Odoj Fips process for fission product vitrificationx. Ber.Kernforschungsanlage.Juelich.[Conf]. -Conf-30, 1978.

1828. Halaszovich, S., Dix, S., Harms, R., Merz, E., and Rosin, D. Alternative treatment of medium level liquid waste by chemicalx precipitation and sludge vitrification. In: <CI> Volume 2: Waste Regulations and Programs: High Level Waste Proceedings of the Symposium on Waste Management Publ by Univ ofX Arizona, Tucson, AZ, USA p 173-176, Anonymous Tucson, Az, USA:Univ ofX Arizona, 1983, p. $173-176$.

1829. Hall, Dalton, Hudson, and Marples Development and radiation stability of glasses for highlyX radioactive wastesx. Manage.Radioact. Wastes.Nucl. Fuel.Cycle $-14,1994$.

1830. Hall, A., R., ; Boult, K., A., ; Marples, J., C., and $X$ evaluation of solidified highly-active waste: leaching of $\mathrm{mw}$ glassX containing plutonium and americiumx. U.K.At.Energy Auth., Harwell Lab., Aere-R, Aere $R$ 12580,X 20 pp, 1994.

1831. Hall, A., R., ; Hough, A., ; Marples, J., A., C., and $X$ leaching of

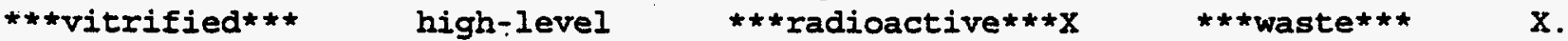
Mater.Res.Soc.Symp. Proc., 11,X 83-92X-92X, 1994.

1832. Hall, A.R., Hough, A., and Marples, J.A.C. Leaching of vitrified high-level radioactive waste. In: Materials Research Society Symposia Proceedings $v 11$.Publ byX North-Holland, New York, NY, USA and Amsterdam, Neth p 83-92, Anonymous New York, NY, USA: 1982,p. 83-92,

1833. Hamada, H. and Tamura, H. Development of system for handling vitrified packages of high-levelX radioactive waste. R\&D, Research and Development 39-15, 1989.

1834. Hamada, H.T.,Hiroshix development of a system for handling packages of

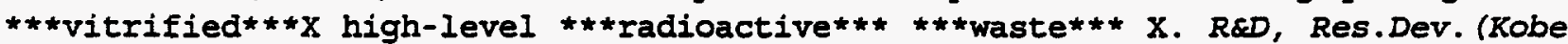
Steel Ltd.), 39, 12-15X-15X, 1994.

1835. Hamm, B.A., Eibling, R.E., Ebra, M.A., Motyka, T., and Martin, H.D. High-level radioactive insoluble waste preparation for vitrification. In: 〈CI> Held as part of the Fall Meeting of the Materials Researchx Society Materials Research Society symposia Proceedings $v 44$. Publ by MaterialsX Research Soc, Pittsburgh, DA, USA p 793-799,Anonymous Pittsburgh, PA, USA:MaterialsX Research Soc, 1985,p. 793-799.

1836. Hamza, A. and Gallup, J.D. Management of industrial solid wastes in alexandria, egypt. In: ASTM Special Technical publication 851. Publ by ASTM, Philadelphia, PA, $X$ USA $P$ 305-319, Anonymous Philadelphia, PA,X USA:ASTM, 1984,p. 305-319.

1837. Hand Hanford waste vitrification plant quality assurance program description for defense high-level waste form development and qualification. (Unknown Journal!) : (105 p), 1990. 
1838. Hand, R.L. Hanford Waste Vitrification Plant quality assurance program description for defense high-level waste form development and qualification. Part 2. (Unknown. Journal!), 1990.

1839. Hand; R.L. Hanford Waste Vitrification Plant Quality Assurance Program description for defense high-level waste form development and qualification. Revision 1, Part 2. (Unknown Journal!) , 1992.

1840. Haneda, K. phosphate glass formation from radioactive boric acid wastex solutionsX. Jpn.Kokai Tokkyo Koho, 4 pp, 1994.

1841. Hannum, W., H., ; Coolidge, S., A., ; Ploetz, D., K., and X strategy for vitrifying different waste compositions at west valleyx. Radioact.Waste Manage., Proc.Int.Conf., Meeting Date 1983, VolumeX 2, 3-34, 1994.

1842. Hanson, M., S., ; Bjorklund, W., J., and $X$ ***vitrification*** of radioactive high-level waste by sprayx calcination and in-can meltingx. Report, Pnl-3145, $87 \mathrm{pp}, 1980$.

1843. Hanson, M., S., ; Carter, J., G., and X deposition of volatile fission products during commercial high-levelX waste $* * *$ vitrification*** $\mathrm{X}$. Report, PnI-4299; Order No.De83000661, 82 pp, 1982.

1844. Hanson, M., S., ; Goles, R., W., ; Hamilton, D., C., and $\mathrm{X}$ behavior of selected contaminants in spray calciner/in-can melterX waste ***vitrification*** off-gasX. Manage.Gaseous Wastes Nucl.Facil., Proc.Int. Symp., 371-91-91, 1994.

1845. Hara, S.T.,RyoheiX chemical durability of glasses containing simulated high-levelx nuclear wastes.iii.determination of cesium and strontium inx leachatesX. Osaka Kogyo Gijutsu Shikensho Kiho, 34, 92-5X-5X, 1994.

1846. Hara, S.T.,Ryohei; Yamanaka chemical durability of glasses containing simulated high-levelX nuclear wastes.ii.continuous leaching test by various phx solutionsX. Osaka Kogyo Gijutsu Shikensho Kiho, 34, 85-91X-91X, 1994.

1847. Hara, S.T.,Ryohei; Yamanaka chemical durability of borosilicate glasses containing simulatedX high-level nuclear wastes.i.measurement of leachability byx soxhlet-type leaching apparatusX. Osaka Kogyo Gijutsu Shikensho Kiho, 34, $1-8 \mathrm{X}-8 \mathrm{X}, 1994$.

1848. Harbour An opportunity for demonstrating compliance with the waste acceptance preliminary specifications on foreign materials within dwpf (defense waste processing facility) canistered waste forms. (Unknown Journal!) : (12 p), 1990 .

1849. Harbour, J., ; Plodinec, M., J., and $X$ exclusion of foreign materials from dwpf canistered waste forms. $X$ compliance activities for the wapsX. Waste Manage. (Tucson, Ariz.), (Vol. 1), 795-8X-8X, 1994.

1850. Harbour, J., R., ; Miller, T., J., ; Whitaker, M., and $X$ the physical properties and chemical composition of the gas withinx the free volume of 
canistered waste formsx. Report, WsrC-Tr-90-521; Order No.De91005746, 15 pp, 1991.

1851. Harbour, $J$. and $X$ volatility of simulated high-level nuclear waste glass byx thermogravimetric analysisX. J.Am.Ceram.Soc., 75, 507-13X-13X, 1994.

1852. Harbour, J.R. Volatility of Simulated High-Level Nuclear Waste Glass by Thermogravimetric Analysis. J.AMER. CERAM.SOC. 75:507-513, 1992.

1853. Harbour, J.R., Marra, J.C., and Bibler, N.E. Effect of gamma irradiation of the volatility and redox state of simulated. (Unknown Jounnal!), 1993.

1854. Hardwick, w. and Gayler, R. Treatment of [radioactive] substances [in ceramic or glass container]. (Unknown Journal!), 1984.

1855. Hardwick, W.H. and Gayler, R. Method and apparatus for treating radioactive substancesX. Ger.Offen. , 1994.

1856. Hargrove, J. The determination of the glass formation area of the ternary system arsenic - sulfur - iodine and the properties thereof, Alfred, NY:New York State College of Ceramics at Alfred University, 1964.

1857. Harker, A. and Flintoff, J. Crystalline-phase formation in hot isostatic pressing of nuclear wasteceramics with high zirconia content. J.Am.Ceram.SoC. , 1985 .

1858. Harker, A. and Flintoff, J. Polyphase ceramic for consolidating nuclear waste compositions with highzr-cd-na content. J.Am.Ceram.Soc. , 1990.

1859. Harker, A. and Flintoff, J. Tailored ceramic consolidation forms for icpp waste compositions. Ceram. Trans. , 1990.

1860. Harker, A., Morgan, P., and Flintoff, J. Hot isostatic pressing [hip] of nuclear waste glasses. J.Am.Ceram.Soc. , 1984.

1861. Harker, A. ard Flintoff, J. Hot isostatically pressed ceramic and glass forms for immobilizing Hanford high-level wastes. Adv.Ceram. 8:222-233, 1985.

1862. Harker, A., B., ; Jantzen, C., M., ; Morgan, P., E., D., ; Clarke, D., $R$., and $X$ tailored ceramic nuclear waste forms: preparation andX characterizationX. Sci.Basis Nucl.Waste Manage., 3, 139-46X-46X, 1994.

1863. Harker, A.B. and Flintoff, J.F. Hot isostatically pressed ceramic and glass forms for immobilizingx hanford high-level wastes. In: <CI> Held during the 85th Annual Meeting of the American Ceramicx Society Advances in Ceramics $v$ 8. Publ by American Ceramic SOC Inc, Columbus, $X$ OH, USA $p$ 222-233, Arionymous Columbus, $X$ OF, USA:American Ceramic SOC Inc, 1984,p. 222-233.

1864. Harker, A.B. and Flintoff, J.F. Polyphase ceramic and glass-ceramic forms for immobilizing icppx high-level nuclear waste. In: <CI> symposium held as part of the Annual Meeting of the Materialsx Research Society Materials Research Society Symposia Proceedings $v$ 26.Publ byX North-Holland, New York, NY, USA and Amsterdam, Neth p 513-520, Anonymous New York, NY, USA: 1984,p: 513-520. 
1865. Harker, A.B. and Flintoff, J.F. Formation of surface layers and reaction products in the leaching ofX defense borosilicate nuclear waste glass. Nuclear Technology 76:263-275, 1987 .

1866. Harker, A.B., Flintoff, J.F., De Grave; E., Stalios, A.D., and Van Alboom, A. Polyphase ceramic for consolidating nuclear waste compositions withx high zr-cd-na content Influence of the heat treatment on the mossbauer spectrum of ax simulated nuclear-waste glass. Journal of the American Ceramic Society Journal of Nuclear Materials 171:189-197, 1990.

1867. Harker, A. and Flintoff, J. Polyphase ceramic for consolidating nuclear waste $\mathrm{X}$ compositions with high $\mathrm{Zr}-\mathrm{Cd}-\mathrm{Na}$ content.X. Journal. of.the.American.Ceramic.SocietyX. J Am Ceram Soc v 73, 1990.

1868. Harker, A.B., ; Clarke, D.R., ; Jantzen, C.M., ; Morgan, P.E., D.; and $X$ the effect of interfacial material on tailored ceramic nuclear wastex form dissolutionX. Mater.Sci.Res., 14,X 207-16X-16X, 1994.

1869. Harker, A.B., ; Flintoff, J.F., and X the formation of surface layers and reaction products in thex leaching of defense borosilicate nuclear waste glassX. Nucl.Technol., 76, 263-75X-75x, 1994.

1870. Harker, A.B., ; Morgan, P.E., D., ; Flintoff, J.F., and X hot isostatic pressing of nuclear waste glassesX. J.Am.Ceram.SoC., 67, C26-C28X-C28X, 1994 .

1871. Harmon, J.E. Nuclear technology programs. Semiannual progress report, October 1989--March 1990. (Unknown Journal!) , 1992.

1872. Harris, A.H. Post Test Inspection of the Experimental Canister Frit Blaster. (Unknown Journal!) , 1986.

1873. Harris, A.H. and Ward, C.R. Development and Demonstration of the DWPF (Defense Waste Processing Facility) Canister Decontamination Process Using Frit Slurry Blasting. (Unknown Journal!) , 1986.

1874. Harris, H., Kelley, J.E., and Kelly, H. Devitrification of a lithium disilicate glass, Washington, D.C.U.S. Dept. of the Interior, Bureau of Mines, 1965.

1875. Harrison, D.E., Pope, J.M., and Wood, S. immobilizing nuclear waste in

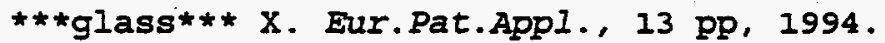

1876. Harvey, K., Larocque, C.A.B., and Watson, S. Dissolution of a single specimen of a simple [borosilicate] glass. Ceram.Trans. 23:123-133, 1991.

1877. Harvey, K., B., ; Jensen, C., D., and $X$ an intercomparison of leach-testing methods and the effects ofX waste-form composition on test type and durationX. Nucl. Chem.Waste Manage., 3, 43-50X-50X, 1994.

1878. Harvey, K., B., ; Litke, C., D., ; Boase, C., A., and X diffusion-based leaching models for glassy waste formsX. Adv.Ceram., 8, 496-507X-507X, 1994 . 
1879. Harvey, K., B., and X a semiunified approach to leach testing of nuclear waste formsX. Nucl.Chem. Waste Manage., 4, 201-5X-5X, 1994.

1880. Harvey, K.B. and Litke, C.D. Model for leaching behavior of aluminosilicate glasses developed as matrices for immobilizing high-level wastes. Journal.of.the.American.Ceramic.Society. v. 67 (Aug. 184):553-556, 1984 .

1881. Harvey, K.B., Litke, C.D., and Boase, C.A. Diffusion-based leaching models for glassy waste forms. In: <CI> Held during the 85th Annual Meeting of the American Ceramicx Society Advances in Ceramics $v 8$. Publ by American Ceramic SOC Inc, Columbus, $X$ OH, USA $p$ 496-507, Anonymous Columbus, $X$ OH, USA:American Ceramic Soc Inc, 1984,p. 496-507.

1882. Hayashi, M.K.,HidechiyoX present status of technological development for the vitrification ofX high-level liquid waste from reprocessing plantsX. Kagaku Kogaku, 49, 518-22X-22X, 1994.

1883. Hayward, P. Glass-ceramics for immobilizing high-level wastes from nuclear fuelrecycling. Glass Technol. , 1988.

1884. Hayward, P., J., ; Doern, D., C., ; George, I., M., and X dissolution of sphene glass-ceramics in calcium-sodium-chlorinex brinesx. Ceram.Trans., 9, 199-210X-210X, 1994.

1885. Hayward, P., Vance, E., and Doern, D. DTA/SEM study of crystallization in sphene glass-ceramics. Am.Ceram.Soc.Bul1. 66[11]:1620-1626, 1987.

1886. Hayward, P., J., ; Doern, F., E., ; Cecchetto, E., V., ; Mitchell, S., $I .$, and $X$ leaching studies of natural and synthetic titanite, a potential hostX for wastes from the reprocessing of canadian nuclear fuelX. Can.Mineral., 21, $611-23 X-23 X, 1994$.

1887. Hayward, P., J., ; George, I., M., ; Woods, M., P., ; Busby, T., S., and $X$ an evaluation of electric melter refractories for contact with glassX used for the immobilization of nuclear wastex. Glass Technol., 28, 43-9X-9X, 1994.

1888. Hayward, P., J., ; Hocking, W., H., ; Mitchell, S., L., ; Stanchell, M., $A .$, and $X$ leaching studies of sphene-based $\star \star \star$ glass $\star \star \star$-ceramicsX. Nucl.Chem. Waste Manage., 5, 27-37X--37X, 1994.

1889. Hayward, P., J., ; Johnson, L., H., ; Tait, J., C., and X canadian studies on the corrosion behavior of nuclear fuel wasteX formsX. Can.Metall.Q., 22, 73-9X-9X, 1994.

1890. Hayward, P., J., ; Vance, E., R., ; Cann, C., D., ; George, I., M., and X influence of heat treatment and redox conditions on crystallizationx of titanosilicate glass-ceramicsx. Adv.Ceram., 20, 215-22X-22X, 1994.

1891. Hayward, P., J., ; Vance, E., R., ; Cann, C., D., ; George, I., M., and X influence of higher waste loading on crystallization ofx titanosilicate glass-ceramicsX. Mater.Res.Soc.Symp.Proc., 50,X 347-54X-54X, 1994. 
1892. Hayward, P., J., ; Watson, D., G., ; McIlwain, A., K., ; George, I., M., ;X Mitchell, S., L., and $X$ leaching studies of sphene ceramics containing substitutedX radionuclidesX. Nucl.Chem. Waste Manage:, 6, 71-80X-80X, 1994 .

1893. Hayward, P.J. Review of Glass-Ceramics for the Immobilization of Nuclear Fuel Recycle Wastes. (Unknown Journal!) , 1987.

1894. Hayward, P.J., Hocking, W.H., and Mitchell, S.I. Leaching studies of sphene-based glass-ceramics. Nuclear.and.Chemical.Waste.Management. $v .5$ nol ('84):27-37, 1984 .

1895. Hayward, P.J̣., Vance, E.R., Cann, C.D., and Mitchell, S.L. Crystallization of sphene-based glass-ceramics for immobilization ofx high-level nuclear fuel reprocessing wastes. In: <CI> Held during the 85th Annual Meeting of the American CeramicX Society Advances in Ceramics $v 8$. Publ by American Ceramic SOC Inc, Columbus, $X$ OH, USA ip 291-301, Anonymous Columbus, $X$ OH, USA:American Ceramic SOC Inc, 1984,p. 291-301.

1896. Hayward, P., Vance, E., Cann, C.D., and Doern, D. Crystallization of titanosilicate glasses for nuclear waste immobilization. Journal. of. the.American. Ceramic.Society. J Am Ceram Soc v 72, 1989.

1897. He, Y. Development of a low temperature sealing phosphate glass, 1990.

1898. Headley, T.J., ; Healey, J.T., ; Hlava, P.F., ; Kupfer, M.J., ; Strachan, D.M., and $X$ microstructural characterization of $\star \star * g l a s s * \star *$ and ceramicX simulated waste formsX. Sci.Basis Nucl. Waste Manage., 2, 249-54X-54X, 1994.

1899. Heafield, W. and Elsden, A.D. High level waste management in the united kingdom. In: High Level Radioactive Waste and Spent Fuel Management Proc 1989 JointX Int Waste Manage Conf $v 2$ (of 2). Publ by American Soc of MechanicalX Engineers (ASME), New York, NY, USA.p 147-152, Anonymous New York, NY, USA:American Soc of MechanicalX Engineers (ASME), 1989,p. 147-152.

1900. Healey, J.T., ; Headley, T.J., ; Hlava, P.F., ; Strachan, D.M., ; Kupfer, M.J., and $X$ microstructural characterization of solidified simulated reactorX wasteformsX. Sci.Basis Nucl.Waste Manage., , MeetingX Date 1978, 83-96:lenum: NewX York, 1994.

1901. Hebbar, K. Viscosity modeling and glass formation studies in oxy-flouride melts, University of Nevada, Reno, 1991.

1902. Heckendorn, F.M. Flow Measurement and Control in the Defense Waste Process. (Unknown Journal!) , 1985.

1903. Heimainn, R., B., and $X$ evaluating the durability of a simulated nuclear waste glass: ax statistical approachx. At.Energy Can.Ltd., Aecl, Aecl-9058, 57 pp, 1994 .

1904. Heimann, R.B. Evaluating the durability of a simulated nuclear waste glass. A statistical approach. (Unknown Journal!) , 1988.

1905. Heimann, R.B., Wood, D.D., and Hamon, R.F. Multicomponent leach tests in standard canadian shield saline solutionx on glasses containing simulated 
nuclear waste. In: <CI> Symposium held as part of the Annual Meeting of the MaterialsX Research Society Materials Research Society Symposia Proceedings $v$ 26.Publ byX North-Holland, New York, NY, USA and Amsterdam, Neth $p$ 191-200, Anonymous New York, NY, USA; 1984,p. 191-200.

1906. Heimerl, Heine, Kahl, Levi, Lutze, Malow, X, S., and Schubert Behavior of radioactive waste glassesX. Symp.Manage.Radioactive. Wastes.Fuel.Reprocess. -53 , 1972 .

1907. Heimerl, Heine, Kahl, Levi, Lutze, Malow, X, S., and Schubert Research on glasses for fission product fixationx. Hahn-Meitner-Inst.Kernforsch.Berlin. -Meitner-Inst, 1994.

1908. Heimerl and schiewer New possibilities for the manufacture of fission product-containingX glasses and glass ceramicsX. Atomwirtsch. $-4 \mathrm{X}, 1994$.

1909. Heimerl, $w$. Apparatus for enclosing highly radioactive waste material in aglassmelt. (Unknown Journal!) , 1982.

1910. Heimerl, w. Device for the production of glass drops from a glassmelt containingradioactive waste. (Unknown Journal!), 1985.

1911. Heimerl, W., Grziwa, P., Van Geel, J., and Eschrich, X Chemical and technological aspects of the vitrification of $X$ high level radioactive wastes $X$. KERRTECHNIK. - 7X, 1994.

1912. Heimerl, พ., Schiewer, E., and DeKumar, A. Fixing radioactive materials in a glass ceramic-metal compositex materialx. Ger.offen. , 1994.

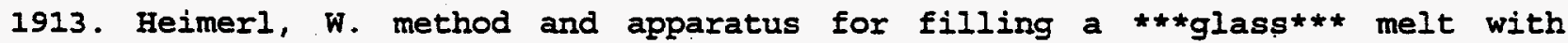

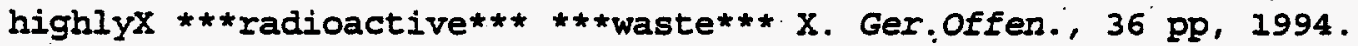

1914. Hench, A.A., ; Hench, L.L., and $X$ computer analysis of nuclear waste

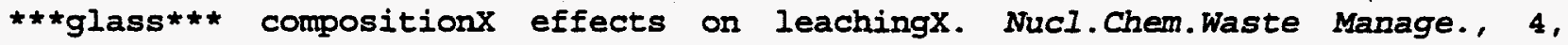
231-8X-8X, 1994 .

1915. Hench, I. Leaching of glassX. Ceram.Glass.Radioact. Waste.Forms. -770102, 1994.

1916. Hench, L., Clark, D., and Harker Nuclear waste solidsua review. J.MATER.SCI. , 1986.

1917. Hench, L., Zhu, B., and Lodding, A. Stripa burial--time dependence of leaching. Adv. Ceram. 20:583-590, 1986.

1918. Hench, L., L., ; Urwongse, L., and $X$ evaluation of five glasses and a ***glass*** ceramic forX solidification of swedish nuclear wastex. Report, $S k b f / K b s-T r-80-22,54 \mathrm{pp}, 1981$.

1919. Hench, I., L., and X leaching of nuclear waste glassesX. Nato Asi Ser., Ser.E, 92, 631-7X-7X, 1994 .

1920. Hench, I.I. International collaboration in nuclear waste solidification. Nuclear Technology 73:188-198, 1986. 
1921. Hench, L.L., Clark, D.E., and Harker, A.B. Nuclear waste solids. Journal of Materials Science 21:1457-1478, 1986.

1922. Hench, L.L., LaTorre, G., Clark, D.E., Storz, L., and Yamanaka, H. Use of fourier transform ir reflection spectroscopy in nondestructivex quality assurance of glasses and ceramics. In: <CI> Held during the 85 th Annual Meeting of the American Ceramicx Society Advances in Ceramics $v 11$. Publ by American Ceramic SOC Inc, COlumbus, $X$ OH, USA $p$ 97-107,Anonymous Columbus, $X$ OH, USA:American Ceramic SOC Inc, 1984,p. 97-107.

1923. Hench, L.I. and WILSON, M.J.R. Nuclear waste glass interfaces after one year burial in stripa, part $4: \mathrm{X}$ comparative surface profiles. $J$ NUCL MATER $V$ 136 N 2-3 NOV 1985 P 218-228 -228, 1985.

1924. Hench, L.L., ; Clark, D.E., ; Yen Bower, E., and LueX surface leaching of glasses and $\star \star \star$ glass $* \star$-ceramicsX. U.S.Nucl.Regul.Comm., Nureg/Cp, Nureg/Cp-0005, Proc.X Conf.High-Level Radioact.Solid Waste Forms, 1978; PB294865,X 1:B294865,X 299-B294865,X 238X, 1994.

1925. Hench, L.I., ; Clark, D.E., ; Yen Bower, E., and LueX corrosion of glasses and $* * \star$ glass*** -ceramicsX. Nucl.Chem.Waste Manage., 1, 59-75X-75X, 1994.

1926. Hench, L.L. and; Lodding, A.W.,LarsX nuclear waste glass interfaces after one year burial in stripa.X part 1: glass/glassX. Skb Tech.Rep., 85-08, $19 \mathrm{pp}-8,19 \mathrm{pp}, 1919$.

1927. Hench, L.L., ; Spilman, D.B., ; Buonaquisti, A., D., and X rutherford back scattering surface analysis of nuclear waste glassesx after one year burial in stripax. Nucl. Chem. Waste Manage., 5, 75-85X-85X, 1994.

1928. Hench, L.L. and; Urwongse, I. evaluation of five glasses and a ***glass*** -ceramic forX solidification of swedish nuclear wastex. Kbs Tek.Rapp., 80-22, 53 pp-22, 53 pp, 1994.

1929. Hench, L.I. and; Werme, L.I.,AlexanderX nuclear waste glass interfaces after one year burial in stripa.X part 3: glass/graniteX. Skb Tech.Rep., 85-08, 21 pp-8, 21 pp, 1994.

1930. Hench, I.I. and; Werme, L.I.,AlexanderX burial effects on nuclear waste

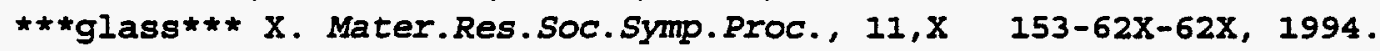

1931. Henderson, G.S., Powell, B.M., Sunder, S., Vance, E.R., and Heckendorn, F.M. Neutron and raman scattering from na//20-al//20//3-cao-tio//2-sio//2x glasses Remote viewing of melter interior defense waste processing facility. Physics and Chemistry of Glasses <CT> Proceedings of the 34 th Conference on Remote Systems Technology:<CI> Held in Conjunction with American Nuclear Society Winter Meeting.<CL> Washington, DC, USA <CD> 1986 Nov 17-20 Proceedings of the Conference on Rem 28:80-85, 1987.

1932. Hennelly Effect of nuclear waste policy act of 1982--three years later. Adv. Ceram. , 1986 . 
1933. Hennelly, E.J. Processing of nuclear waste. In: Transactions of the American Nuclear Society $v 36$ 1981. Publ by ANS, LaX Grange Park, III, USA $p$ 66-68, Anonymous LaX Grange Park, Ill, USA:ANS, 1981,p. 66-68.

1934. Hentschel, D., ; Weisenburger, S., ; Dippel, T., ; Luckscheiter, B., and $X$ process control and product quality assurance in an inactivex high-level waste $* *$ vitrification*** plant by using instrumentalX analysisX. Kfk-Nachr., 15, $16-23 X-23 X, 1994$.

1935. Herborn Documentation of hanford site independent review of the hanford waste vitrification, plant preliminary safety analysis report. (Unknown Journal!) : (45 p), 1991 .

1936. Herborn Documentation of hanford site independent review of the hanford waste vitrification plant preliminary safety analysis report. (Unknown Journal!) : (82 p), 1991.

1937. Herborn, D.I. and Smith, D.A. Hanford waste vitrification Plant Preliminary Safety Analysis Report: Volume 3. Draft. (Unknown Journal!), 1989.

1938. Hermansson, H., Bjorner, I., Christensen, H., Ohe, and Werme, I. Static leaching of fully radioactive waste glass at 90 degree $c$ in thex presence of bentonite,granite, and stainless steel corrosion products.X. In: Materials Research Society Symposia Proceedings $v$ 50. Publ by MaterialsX Research SOC, Pittsburgh, PA, USA P 179-186,Anonymous Pittsburgh, PA, USA:MaterialsX Research SOC, 1986,p. 179-186.

1939. Hermansson, H., Christensen, H., Bjorner, I., WERME, and Clark, D.E. Variables affecting leaching of swedish nuclear waste glass. NUCL CHEM WASTE MANAGE V 5 N 4 1985 P 315-332 -332, 1985.

1940. Hermansson, H., Christensen, H., Clark, D.E., and Werme, L. Effects of solution chemistry and atmosphere on leaching of alkalix borosilicate glass. In: Materials Research Society Symposia Proceedings $v$ 15. Publ by ElsevierX Science Publ Co,New York, NY, USA and Amsterdam, Neth p 143-150, Anonymous . New York, NY, USA:ElsevierX Science Publ Co, 1983,p. 143-150.

1941. Hermansson, H.P.,Hilbert; Werme the leaching behavior of the swedish kbs-glasses abs 39 and abs 41X. Mater.Res.Soc.Symp.Proc., 6,X 107-14X-14X, 1994.

1942. Herrera, E., Tittlebaum, M., Cartledge, F., and Eaton, H. Evaluation of the Leaching Properties of Solidified Heavy-Metal Wastes. J.ENVIRON.SCI.HEALTH A-SCI.E. A27:983-998, 1992 .

1943. Hervig, R. and Navrotsky, A. Thermochemistry of sodium borosilicate glasses. Journal.of.the.American.Ceramic.Society. v. 68 (June '85):314-319, 1985.

1944. Heuer, J., P., ; Howitt, D., G., and X oxygen bubble formation in nuclear waste glasses by gammax irradiationx. Microbeam Anal., 22nd, 225-6X-6X, 1994 . 
1945. Hidalgo, M., ; Rincon, J., and Mariax nuclear waste immobilization in glasses and glass-ceramic matrixesX. Bol.Soc.Esp.Ceram.Vidrio, 26, 227-34X-34X, 1994.

1946. Higashi, K. Proceedings of the specialists' meeting on radioactive wastes management. (Unknown Journal!) : (87 p), 1993.

1947. Higazy, A.A., Hussein, A., and Ewaida, M.A. Possible use of semiconducting cobalt phosphate glasses for the detection of gamma radiation. Glass. Technology. Glass Technol v n A, 19.89.

1948. Hill, $O ., F .$, and $X$ preconceptual design study for solidiying high-level waste: westx valley demonstration projectx. Report, Doe/TiC-11433 (App.), Pn1-3608-2, 162 pp, 1981.

1949. Hill, R. and Gilbert, P. High-Temperature Dynamic Mechanical Thermal-Analysis of a Lithium zinc silicate Glass-Ceramic. J.AMER.CERAM.SOC. $76: 417-425,1993$.

1950. Hiroshi Kamizono BT - Vitrified Waste Forms CT - Volatilization of Cesium and Ruthenium from High-level Waste Glass.ED - Dillard B.Shipler ED - C.R.Allen Anonymous 1990, p. 1115-1118.

1951. Hirsch, E., H., and $X$ a new irradiation effect and its implications for

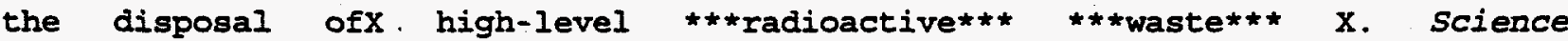
(Washington, D.C.), 209, 1520-2X-2X, 1994.

1952. Hlava and Chambers Electron microprobe analyses of selected samples from deep rockX disposal, experiment no.1X. Report. , 1976.

1953. Hlava and Chambers Interaction of a glass-based nuclear waste simulant and natural rockx. Proc. , 1994.

1954. Havac, J. vitrification of simulated intermediate-level waste from nuclearX power plants.ii.chemical stability of vitrified products in acidicX solutionsX. Ceram.-Silik., 37, 137-43X-43X, 1994.

1955. Hlavac, J., Michajlovic, J., and Skrovankovarohanova, D. Vitrification of Simulated Intermediate-Level waste from Nuclear-Power-Plants .2. Chemical-stability of Vitrified products in Acidic Solutions. CERAMICS-SILIKATY. 37:137-143, 1993.

1956. Hnat, J. Apparatus for heat processing glass batch materials. (Unknown Journal!) , 1992 .

1957. Hobbs, L.W. Radiation-disorder and aperiodicity in irradiated ceramics. Final technical report, 22 June 1989--21 June 1992. Progress rept. (Unknown Journal!) , 1992.

1958. Hodges, S.M. Emergency Avoidance Solidification Campaign at the Oak Ridge National Laboratory: Final Report. (Unknown Journal!) , 1989.

1959. Hoehlein, G., Tittmann, E., Weisenburger, S., and Wiese, H. Vitrification of high level radioactive waste - operating experiencex with the pamela plant. 
In: <CI> Volume 2: High-Level Waste $v$ 2. Publ by Arizona Board of Regents, AZ, USA p 413-420, Anonymous AZ, USA:Arizona Board of Regents, 1986,p. 413-420.

1960. Hoehlein, G., ; Weisenburger, S., ; Tittmann, E., ; Wiese, H., and X vitrification of high-level fission-product solutions in the pamelax plant using a ceramic-lined glass melter with direct ohmic heatingX. Kfk-Nachr., 18, $72-6 \mathrm{X}-6 \mathrm{X}, 1994$.

1961. Hollmann, A. and Brennecke, P. Inventory and Future Arisings of Radioactive-Waste. ATOMWIRT. ATOMTECH. 38:832-836, 1993.

1962. Holton, L., K., ; Larson, D., E., ; Mellinger, G.B., ; Nelson, T., A., and $X$ alternatives for ***vitrification*** of existing commercialx high-level waste by spray calcination/in-can meltingx. Proc.Symp.Waste Manage., (2, Waste Manage.'80: State WasteX Disposal Technol., Mill Tailings, Risk Anal.Models), 365-80X-80X, 1994 .

1963. Holton, L., K., and $X$ behavior of mercury and iodine during **tvitrification*** ofX simulated alkaline purex wasteX. Report, Pnl-3964; Order No.De82004325, 68 pp, 1982.

1964. Holton, L.K., Burkholder, H.C., McElroy, J.L., Kahl, L., and Kroebel, R. Fabrication of Vitrified Isotopic Heat and Radiation Sources for Testing in the Asse Mine. (Unknown Journal!), 1989.

1965. Holton, L.K., Dierks, R.D., Goles, R.W., Katayama, Y.B., and Surma, J.E. Operating Experience in a Radioactive Liquid-Fed Ceramic Melter Vitrification Facility. (Unknown Journal!) , 1988.

1966. Holton, L.K. and Larson, D.E. Evaluation of process alternatives for solidification of the westX valley high-level liquid wastes. In: <CI> Selected Papers presented at the American Nuclear society Topicalx Meeting Publ by Battelle Press, Columbus, $O H$ and Richland, WA, USA andX Springer-Verlag, New York, NY, USA and Heidelberg, West Ger P 537-541, Anonymous Columbus, OH and Richland, WA, USA:Battelle Press, 1983,-Verlag, New York, NY.

1967. Hong, K., Speyer, R., and Lee, S. Thermal analysis of reactions in soda-lime silicate glass batches containing melting accelerants. Journal.of.the.American.Ceramic.Society. v. 76 (Mar. '93):598-608, 1993.

1968. Horiuchi, T. Durability of glasses in aqueous alkaline solution /. 1982.

1969. Hornyak, E. and Weinberg, M. Velocity of a freely rising gas bubble in a soda-lime silicate glass melt. Journal.of.the.American.Ceramic.society. v. 67 (Nov. . 84) : C244-C246, 1984 .

1970. Horton, W.S. Improvement to Low-Level Radioactive Waste Vitrification Processes. Master's thesis. (Unknown Journal!), 1986.

1971. Horton, w. An improvement to low-level radioactive waste vitrification processes /, 1986 .

1972. Hoshino, C. and Tsuzuki, S. Management of high level radioactive wastes byX vitrifying $\mathrm{X}$. Genshiryoku.Kogyo. $-44 \mathrm{X}, 1994$. 
1973. Hosono, H. Structural Defects and the State of Implanted Ions in Silica Glasses Implanted with Silicon and or Nitrogen-Ions. NUCL. INSTRUM.METH. PHYS.RES.B. 65:375-379, 1992 .

1974. Hosono, H., Fukushima, H., Abe, Y., Weeks, R.A., and Zuhr, R.A. Cross-Sectional TEM Observation of Copper-Implanted SiO2 Glass. J.NON-CRYST.SOLIDS. 143:157-161, 1992 .

1975. Houde-Walter, S.N., Inman, J.M., and Dent, A.J. Sodium and silver environments and ion-exchange processes in silicate and aluminosilicate glasses. The.Journal.of.Physical.Chemistry. v. 97 (Sept. 16 '93):9330-9336, 1993.

1976. Hough, A., Marples, J.A.C., and Eandyside, I. 'source term' for safety assessments of the disposal of vitrifiedx high-level radioactive waste. In: Materials Research Society symposia Proceedings $v$ 50. Publ by MaterialsX Research SOC,Pittsburgh, PA, USA p 493-500, Anonymous Pittsburgh, PA, USA:MaterialsX Research SOc, 1986,p. 493-500.

1977. Houser, C.A. and Pantano, C.G. Early stages of film formation during the leaching of radioactive wasteX glasses. In: <CI> Held as part of the Fall Meeting of the Materials Researchx Society Materials Research Society Symposia Proceedings $v$ 44. Publ by MaterialsX Research SOC,Pittsburgh, PA, USA $p$ 205-212,Anonymous Pittsburgh, DA, USA:MaterialsX Research SOC, 1985,P. 205-212.

1978. Houser, C.T.,I., S., T., ; White, W.B., and X characterization of leached surface layers on simulated high-levelx waste glasses by sputter-induced optical emissionX. Sci.Basis Nucl.Waste Manage., , MeetingX Date 1978, 131-9:lenum: NewX York, 1994.

1979. Howitt, D., G., ; DeNatale, J.,.F., ; McElfresh, D., K., ; Geiss, R., H., and $\mathrm{X}$ a preliminary examination of material segregation in a nuclear wastex

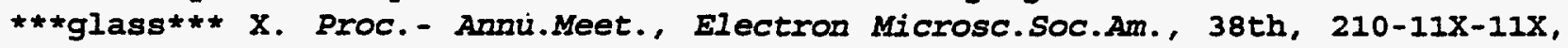
1994.

1980. Howitt, $D_{.}, G_{.}$, and $X$ radiation damage and durability in nuclear waste materials. finalX report, I may 1983-31 march 1984X. Report, Doe/Er/10437-TI; Order No.De84015485, 16 pp, 1984 .

1981. Howitt, D.G.' Electron microscopy of nuclear waste glasses. In: Proceedings - Electron Microscopy Society. of America 40 th Annualx Meeting. Publ by Claitor's Publ Div, Baton Rouge, La, USA p 610,-613, Anonymous Baton Rouge, La, USA:Claitor's Publ Div, 1982,p. 610,-6613.

1982. Hrma Processing constraints on high-level nuclear waste glasses for hanford waste vitrification plant. (Unknown Journal!) : (7 p), 1993.

1983. Hrma Effect of composition and temperature on viscosity and electrical conductivity of borosilicate glasses for hanford nuclear waste immobilization. (Unknown Journal!) : (9 p), 1993.

1984. Hrma, P. Periodic motion of bubbles in molten glass. Glass.Technology. Glass Technol $v 30 \mathrm{n}, 1989$. 
1985. Hrma, P., Piepel, G.F., Schweiger, M.J., and Smith, D.E. First-order model for durability of Hanford waste glasses as a function of composition. (Unknown Journal!), 1992.

1986. Hrma, P., Piepel, G.F., Smith, D.E., Redgate, P.E., and Schweiger, M.J. Effect of composition and temperature on viscosity and electrical conductivity of borosilicate glasses for Hanford nuclear waste immobilization. (Unknown Journal!) , 1993.

1987. Hrma, P.R. Processing constraints on high-level nuclear waste glasses for Hanford Waste Vitrification Plant. (Unknown Journal!) , 1993.

1988. Hsiu, F.J., Ng, C.K., and Almuti, A.M. Incorporating Functional Requirements into the structural Design of the Defense Waste Processing Facility. (Unknown Journal!) , 1986.

1989. Hsu Formic acid requirement for the savannah river site defense waste processing facility melter feed preparation. (Unknown Journal!) : (12 p), 1991.

1990. Hsu, C.W. Formic acid requirement for savannah river site defense wastex processing facility melter feed preparation (u). In: High Level Radioactive Waste Management. Publ by ASCE, New York, NY,X USA.p 402-405, Anonymous New York, NY,X USA:ASCE, 1991,P. 402-405.

1991. Huang Weigang, B.I.N.E. A steel used for solidification pot of vitrifying high level liquid radioactive waste. (Unknown Journal!) :([8] p), 1992.

1992. Huang Weigang, B.I.N.E. A glass formulation for vitrifying of high level liquid radioactive waste and its performance. (Unknown Journal!) :([14] p), 1992 .

1993. Huang, J., C., ; Wright, W., V., and X comparative risk assessments for the production and interim storagex of $* * \star$ glass $* *$ and ceramic waste forms: defense wastex processing facilityx. Report, Dpst-82-327, 145 pp, 1983.

1994. Huang, P.N. and Johari, G.P. Dielectric and ionic processes in sodium trisilicate glass. Journal. of.molecular.liquids. 56:220-225, 1993.

1995. Huang, w. Glass formulation for vitrifying of high level liquid radioactive waste and its performance. (Unknown Journal!) , 1992.

1996. Huang, W.C., Jain, E., Kamitsos, E.I., and Patsis, A.P. Anomalous expansion of sodium triborate melt and its effect on glass properties. Journal. of.Non-Crystalline.Solids. 162, Number 1-2:100-107, 1993.

1997. Huck, P.M. and Anderson, W.B. Deposition of $226 \mathrm{Ra}$ on surfaces during precipitation and leaching of (Ba, Water.Research.v.17.no10.('83),p.1403-6.bibl.diags. 43-1354, 1983.

1998. Huddleston Evaluation of non-destructive methods for quality checking of vitrified high level waste. (Unknown Journal!) : (35 p), 1990. 
1999. Hudgens, J. and Martin, S. Glass Transition and Infrared Spectra of Low-Alkali, Anhydrous Lithium Phosphate Glasses. Journal. of. the.American.Ceramic.Society. 76, Number 7:1689-1691, 1993.

2000. Hughes, A.E., ; Angwin, J., ; Marples, C... ; Stoneham, A., and Marshallx the significance of leach rates in determining the release ofx radioactivity from ***vitrified*** nuclear wasteX. Nucl.Technol., 61, 496-502X-502X, 1994 .

2001. Hughs, G.M., Knabenschuh, J.I., Hess, E.G., and Ploetz, D.K. Conceptual design of high-level waste vitrification process at westx valley using a slurry-fed ceramic melter. In: <CI> Held during the 85 th Annual Meeting of the American CeramicX Society Advances in Ceramics $v$. Publ by American Ceramic SOC Inc, Columbus, $X$ OH, USA $p$ 143-148, Anonymous Columbus, $X$ OH, USA:American Ceramic Soc Inc, 1984, p. 143-148.

2002. Hunt, B. The effects of SrO and TiOb2s on BaO-SrO-TiOb2s-SiOb2s glasses, Alfred, N.Y.New York State College of Ceramics at Alfred University, 1975.

2003. Hunter, R.T., Edge, M., Kalivretenos, A., Brewer, K., Brock, N., Hawkes, $A .$, and Fanning, J. Determination of the $\mathrm{Fe}^{* * 2 * *}$ plus $/ \mathrm{Fe} * 3 * *$ plus ratio in nuclear waste glasses. Journal.of.the.American.Ceramic.Society. J Am Ceram Soc $\mathrm{v} 72,1989$.

2004. Hunter, R.T. Data Acquisition System for Monitoring Nuclear Waste Vitrification. (Unknown Journal!), 1989.

2005, Huray, P.G., ; Spaar, M., T., ; Nave, S., E., ; Legan, J., M., ; Boatner, L., X A., ; Abraham, M., and X the application of iron-57 moessbauer spectroscopy to thex characterization of nuclear waste forms $x$. Mater.Res.SOC.Symp.Proc., 6, X 59-66X-66X, 1994.

2006. Hutcherson, M.N., Henry, R.E., and Pellarin, D.J. Chemical explosion potential and bounding consequences in the dwpfx melter. In: Transactions of the American Nuclear Society $v 46$ 1984. Publ by ANS, LaX Grange Park, IL, USA $p$ 156-158, Anonymous LaX Grange Park, IL, USA:ANS, 1984,p. 156-158.

2007. Eutson A pilot scale demonstration of the dwpf process control and product verification strategy. (Unknown Journal!) : (9 p), 1992.

2008. Hutson, N.D., Jantzen, C.M., and Beam, D.C. Pilot scale demonstration of the DWPF process control and product verification strategy. (Unknown Journal!) , 1992 .

2009. Hyun, S., Cheon, K., and Song, w. Effects of [oxide] additives on the phase separation and the chemicaldurability of sodium borosilicate glasses. Yoop Hakhoechi , 1988.

2010. Hyun, S.H.,Kwang SoO; Song effects of additives on the phase separation and the chemicalX durability of sodium borosilicate glassesX. Yoop Hakhoechi, $25,173-83 X-83 X, 1994$.

2011. Hyun, S.H.,Won SeonX chemical durability of simulated waste glassesX. Yoop Hakhoechi, 26, 521-31X-31X, 1994. 
2012. Igarashi, H. Electric melting furnace with partitioned melting cavity forsolidifying highly radioactive waste in glass. (Unknown Journal!), 1990.

2013. Igarashi, H. effects of noble metal elements on viscosity and electricalX resistivity of stimulated vitrified products for high-level liquidx wastex. Mater.Res.SOC.Symp.Proc., 257, 169-76X-76X, 1994.

2014. Igarashi, H. vitrification technology of high-level liquid wastesx. Kyoto Daigaku Genshiro Jikkensho, , Kurri-Tr-375, 58-65X-65X, 1994.

2015. Igarashi, H., Kato, K., and Takahashi, T. Effect of Temperature on the Entrainment of Ruthenium, Technetium and Selenium in Continuous Calcination of Simulated High-Level Liquid Waste. J.NUCL.SCI.TECHNOL. 29:576-581, 1992.

2016. Igarashi, H. and Takahashi, T. Draining of noble metals in vitrified nuclear waste by a melter with a sloping floor. Glass.Technology. Glass Technol v $32 \mathrm{n}, 1991$.

2017. Igarashi, $H$. and Takahashi, T. Three-dimensional mathematical model for an electric glass melter usedx to vitrify nuclear high level liquid waste. Glass Technology 32:206-216, 1991.

2018. Igarashi, H. Volatilization behavior of semivolatile elements in vitrification of high-level liquid waste. (Unknown Journal!) :(23 p), 1991.

2019. Ikari, H. Time-dependent specific heat in vitreous silica using diffusivity measurement. Japanese.Journal of . Applied. Physics, . Part. 1 : .Regular. Papers.\&.Short. Notes.\&.Rev iew.Papers. Japanese Journal of, 1993.

2020. Ikeda, Y. a study on the conversion of metal chlorides into oxides for theX vitrification of radioactive salt wastesX. Proc.Int.Conf.Technol.Expo.Future Nucl.syst.: Emerging FuelX Cycles Waste Disposal Options, Volume 1, 184-9:ark, IIl, 1994.

2021. Inagaki, $Y$. electron spin resonance studies of gamma-irradiation damage inX simulated nuclear waste glassX. J.Nucl.Sci.Technol., 28, 314-20X-20X, 1994.

2022. Inagaki, $Y$. leaching behavior of simulated high-level nuclear waste glassX. Kogaku Shuho - Kyushu Daigaku, 64, 517-23X-23X, 1994.

2023. Inagaki, Y., ; Furuya, H., ; Idemitsu, K., ; Banba, T., ; Matsumoto, S., ;X Muraoka, S., and $\mathrm{X}$ microstructure of simulated high-level waste glass doped withX short-lived actinides,plutonium-238 and curium-244X.

Mater.Res.Soc.Symp.Proc., .257, 199-206X-206X, 1994.

2024. Inagaki, Y., ; Furuya, H., ; Idemitsu, K., ; Yonezawa, S., and X corrosion behavior of a powdered simulated nuclear waste glass: ax corrosion model including diffusion processX. J.Nucl.Mater., 208, 27-34X-34X, 1994 .

2025. Inagaki, Y., ; Furuya, H., ; Ono, Y., ; Idemitsu, K., ; Banba, T., ;X Matsumoto, S., ; Muraoka, S., and $X$ effects of .alpha.-decay on mechanical 
properties of simulatedx nuclear waste glassX. Mater.Res.Soc.Symp.Proc., 294, $191-8 \mathrm{X}-8 \mathrm{X}, 1994$.

2026. Inagaki, Y., Furuya, H., Idemitsu, K., and Yonezawa, S. Corrosion behavior of a powdered simulated nuclear waste glass: ax corrosion model including diffusion process. Journal of Nuclear Materials 208:27-34, 1994 .

2027. Inagaki, Y. Density phenomena of an actinide-doped borosilicate waste glass. (Unknown Journal!) : (19 p), 1990.

2028. Inoue, T.Y.,Hayaichi; Onchi surface layer crystallization of simulated waste $* *$ glass $* *$ atX elevated temperaturesX. Mater.Res.Soc.Symp.Proc., 26,X $535-42 \mathrm{X}-42 \mathrm{X}, 1994$.

2029. Inoue, T.T.,Masaki; Fukushima diffusion of neptunium in simulated high level waste glassX. J.Nucl.Sci.Technol., 23, $992-1000 X-1000 X, 1994$.

2030. International Commission on Glass.Sub-Committee AII. The ChemicaI durability of glass. A bibliographic review of literature, [Charleroi,I.C.G., (Bd. Defontaine, 10], 1972 .

2031. International Congress on Glass (15th : 1989 : Leningrad, R.S.F.S.R. Glass '89 : XVth International Congress on Glass, Leningrad, 3-7 JuIy 1989, Leningrad: "Nauka" Leningrad Branch, 1988.

2032. International Symposium on Ceramics in Nuclear Waste Management (2nd : 1983 : Chicago, I. Nuclear waste management /, Columbus, Ohio :American Ceramic Society, 1984.

2033. Interrante, C., Escalante, E., Fraker, A., Kaufman, M., and Liggett, W. Evaluation and Compilation of DOE (Department of Energy) Waste Package Test Data. Rept. for Dec 85-Jul 86. (Unknown-Journal!) , 1986.

2034. Interrante, C., Escalante, E., Fraker, A., Kaufman, M., and Liggett, w. Evaluation and Compilation of DOE (Department of Energy) Waste Package Test Data. Biannual Report: December 1985-July 1986 (RE-ANNOUNCEMENT of. (Unknown Journal!) , 1987.

2035. Interrante, C., Escalante, E., Fraker, A., and Plante, E. Evaluation and Compilation of DOE (Department of Energy) Waste Package Test Data. Biannual Report: February 1988-July 1988. Technical rept. (Unknown Journal!), 1989.

2036. Interrante, C.G., Escalante, E., and Fraker, A. Evaluation and Compilation of DOE Waste Package Test Data. Biannual Report: August 1988-January 1989. Technical rept. (Unknown Journal!) , 1990.

2037. Interrante, C.G., Fraker, A.C., and Escalante, E. Evaluation and Compilation of DOE Waste Package Test Data. Biannual Report: February 1989-July 1989. Technical rept. (Unknown Journal!), 1991.

2038. Interrante, C.G., Fraker, A.C., and Escalante, E. Evaluation and Compilation of DOE Waste Package Test Data. Biannual Report, August 1989-January 1990. Technical rept. (Unknown Journal!) , 1993. 
2039. Ishida, M., Kikuchi, K., Yanagi, T., and Terai, R. Leaching behavior of crystalline phosphate waste forms. Nuclear and Chemical Waste Management $6: 127-131,1986$.

2040. Ishida, M., Yanagi, T., and Terai, R. Leach rates of composite waste forms of monazite- and zirconiumx phosphate-type. Journal of Nuclear Science and Technology 24:404-408, 1987.

2041. Ishiguro, K., Kawanishi, N., Sasaki, N., Nagaki, H., and Yamamoto, M. Growth of surface layer during the leaching of the simulated wastex glass and its barrier effects on the leaching. In: Materials Research Society Symposia Proceedings $v$ 15. Publ by ElsevierX Science Publ Co,New York,NY, USA and Amsterdam, Neth p 135-142, Anonymous New York, NY, USA:ElsevierX Science Publ Co, 1983, p. 135-142.

2042. Ishiguro, K., Sasaki, N., Kashihara, H., and Yamamoto, M. Effects of rocks and backfill materials on waste glass leaching. In: Materials Research society. Symposia proceedings $v$ 50. Pubi by MaterialsX Research Soc, Pittsburgh, PA, USA p 247-254,Anonymous Pittsburgh, PA, USA:MaterialsX Research SOC, 1986,p. 247-254.

2043. Ishikawa, T., Nomura, I., and Hashimoto, Y. ***vitrification*t* of

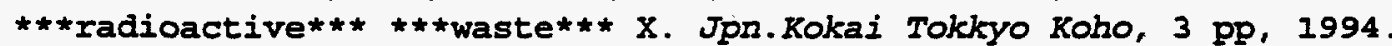

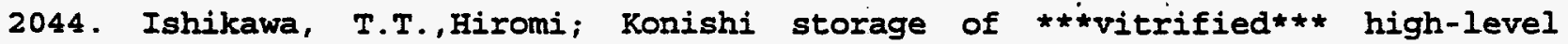
radioactive liquid wasteX. RED, Res.Dev. (Kobe Steel Ltd.), 33, 29-34X-34X, 1994.

2045. Ito, K.I.,Yasuhiro; Kanno coprecipitation of ruthenium in chloride solution withX aluminosilicate and zirconia-silica gelsX. Tohoku Daigaku Senko Seiren Kenkyusho Iho, 35, 93-8X-8X, 1994.

2046. Ivanov, I., A., ; Gulin, A., N., ; Stefanovskii, S., V., and X diffusion of sodium cations and water stability of glasses forx immobilization of medium-level wastesX. Radiokhimiya, 33, 122-7X-7X, 1994.

2047. Ivanov, I., A., ; Sedov, V., M., ; Gulin, A., N., ; Shatkov, V., and X diffusion of actinides in glasses containing simulated radioactiveX wastesX. Radiokhimiya, 32, 139-42X-42X, 1994.

2048. Ivanov, I., A., ; Sedov, V., M., ; Gulin, A., N., ; Stefanovskii, S., V., $; X$ Shatkov, $V .$, and $X$ diffusion of radionuclides in glasses simulating

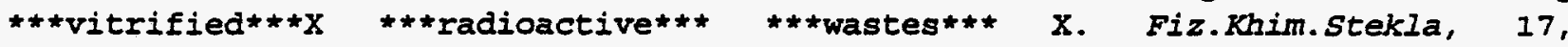
$351-4 X-4 X, 1994$.

2049. Ivanov, I., A., ; Gulin, A., N., ; Shatkov, V., M., ; Shashukov, E., and $X$ migration of neptunium-237 in glasses and ceramicsx. Radiokhimiya, 30 , 817-20X-20X, I994.

2050. Ivanov, I., A., ; Sedov, V., M., ; Shatkov, V., ; Shashukov, E., and X the diffusion of radionuclides in glasses and ceramicsX. J.Radioanal.Chem., 80 , 89-96X-96X, 1994 . 
2051. Ivanov, I.A., Sedov, V.M., Gulin, A.N., Stefanovskij, S.V., and shatkov, V.M. Diffusion of radionuclides in glasses simulating vitrified radioactivex wastes. Fizika i Khimiya Stekla 17:351-354, 1991.

2052. Ivanov, I.A., Stefanovskii, S.V., and Gulin, A.N. Water Resistance and Ion Diffusion in Glass Materials Simulating vitrified Radioactive Waste. The.Soviet.journal.of.glass.physics.and.chemistry. 19, Number 5-397, 1993.

2053. Iverson Defense waste processing facility startup progress report. (Unknown Journal!) : (8 p), 1992.

2054. Iverson, D.C. and Bickford, D.F. Evaluation of materials performance in a large-scale glass melter afterX two years of vitrifying simulated srp defense waste. In: <CI> Held as part of the Fall Meeting of the Materials ResearchX Society Materials Research Society Symposia Proceedings $v$ 44. Publ by MaterialsX Research Soc, Pittsburgh, PA, USA p 839-845,Anonymous Pittsburgh, PA, USA:MaterialsX Research Soc, 1985,p. 839-845.

2055. Iverson, D.C. and Elder, H.H. Defense waste processing facility startup progress report. (Unknown Journal!), 1992.

2056. Iwase, M., ; Watanabe, H., ; Nakayama, N., ; Hori, H., ; Ohuchi, J., ;X Kawamura, K., and $\mathrm{X}$ solubilities of $\mathrm{co} 2$ in candidate glasses for nuclear wasteX imnobilization. part 1 . systems, $\operatorname{cs} 20+\operatorname{sio2,} \operatorname{cs} 20+\mathrm{b} 203$, rb20 $+\mathrm{x}$ sio2 and na2o + b203X. Glass Technol., 35, 41-7X-7X, 1994.

2057. Izahara, S., ; Peters, I., ; Van Iseghem, P., and X preparation and microstructural characterization of $* \star \star$ silicate $* \star \star X$ and borosilicate glasses containing cerium or plutoniumX. Cent.Etude Energ.Nucl., Blg 546, 51 pp, 1994.

2058. Izumida, T., Baba, T., and Nemoto, T. solidification of radioactive wastesX. Jpn.Kokai Tokkyo Koho, 4 pp, 1994.

2059. J.K.Bates, W.I.Ebert, and T.J.Gerding BT - Vitrified Waste Forms CT Vapor Hydration and Subsequent Leaching of Transuraniccontaining SRI and $W V$ glasses.ED - Dillard B.Shipler ED - C.R.Allen Anonymous 1990,p. 1095-1102.

2060. J.I.Nogues, E.Y.Vernaz, and N.Jacquet-Francillon BT - Leaching Mechanisms CT - Nuclear Glass Corrosion Mechanisms Applied to the French LWR Reference Glass.ED - Carol M.Jantzen ED - JOhn A.Stone ED - Rodney C.Ewing Anonymous 1985,p. 89-98.

2061. J.O.Isard The mixed alkali effect in glass. Journal. of.Non-Crystalline.Solids. 1:235-261, 1969.

2062. Jacquet Francillon, N.P.,Francois; Queille an attempt to assess the long-term crystallization rate of nuclearX waste glassesX. Mater.Res.Soc.Symp.ProC., 11,X 249-59X-59X, 1994.

2063. Jacquet Francillon, N., ; Laude, F., ; Magnier, A., ; Vernaz, E., and X study of high-level $* * \star$ radioactive $* * * \star * *$ waste $* \star *$ glasses inX vulcain and piver cells.leaching of some glasses in the vulcainx cell at three temperaturesX. Comm.Eur.Communities, Eur, Eur 7371, 58 pp, 1994 . 
2064. Jacquet Francillon, N., Leroy, P., and Runge, S. HLW immobilization in glass: industrial operation and product quality. (Unknown Journal!) , 1992.

2065. Jacquet Francillon, $N$. and $X$ glasses for immobilization of nuclear wastesX. Verre (Paris), 5, 9-21X-21X, 1994.

2066. Jacquet-Francilion Glasses for the confinement of nuclear wastes. Verre (Paris) , 1991.

2067. Jacquet-Francillon Hlw imnobilization in glass: industrial operation and product quality. (Unknown Journal!) : (4 p), 1992.

2068. Jacquet-Francillon, Bonniaud, and Sombret Glass as a material for the final disposal of fission productsX. RADIOCHIM.ACTA -4), 1994.

2069. Jaganathan, J., Ewing, K.J., and Aggarwal, I. Determination of Iron, Cobalt, Nickel and Copper in a zirconium-Based Glass by Electrothermal Atomic-Absorption Spectrometry. J.ANAL.ATOM.SPECTROM. 7:1287-1290, 1992.

2070. Jagdfeld, H.J. Development and Optimization of a High Temperature Coupling System Thermoanalyzer/Mass Spectrometer. Diss. (Unknown Journal!) , 1983.

2071. Jain, $v$ redox forecasting in the west valley vitrification systemx. Ceram.Trans., 29, X 523-33X-33X, 1994.

2072. Jain, V, ; Joseph, I, David; X Pegg, I., ; Macedo, P., and $X$ impact of heat-treatment on the chemical stability of nuclear wastex glasses produced at the west valley demonstration project (wvdp)X. Ceram.Trans., 30, 367-70X-70X, 1994.

2073. Jain, V, Barnes, S., and Vethanayagam, T. Noble metal and spinel deposition on the floor of the joule-heated ceramicmelter. J.Am.Ceram.Soc.., 1991.

2074. Jain, $V$ and Varshneya, $A$. Ionic resistivity in fused silica. $I$. Conduction-history effects. Journal.of.the.American.Ceramic.Society. J Am Ceram SOC v 72, 1989.

2075. Jain, $V$ and $X$ radioactive waste solidification at the west valley. demonstrationX project (wvdp) X. Ceram.Trans., 29,X 545-52X-52X, 1994.

2076. Jain, V., ; Palmer, R., A., ; Barnes, S., M., and X glass composition development and nuclear waste vitrification systemx testing: the west valley experiencex. Phys.Non-Cryst.Solids, 246-50:ye, L, 1994.

2077. Jain, V. and Barnes, S.M. Waste Description and Previtrification Treatment Activities at WVDP, HWVP, and DWPF. (Unknown Journal!), 1989.

2078. Janakirma Rao, B. The effect of substitution of (i) Alb2sob3s and (ii) Zno for CaO on the chemical durability of soda-lime-silica glasses /, Alfred, N.Y. :New York State College of Ceramics at Alfred University, 1953. 
2079. Janik-Czachor, M. Stability of the passive state of Ni-zr glassy alloys. Corrosion. (Houston). Corrosion (Houston), 1993.

2080. Janik-Czachor, M. and Viefhaus, H. Passivity of $\mathrm{Fe}-\mathrm{Ni}$ base metal-metalloid glasses. Journal.of.the.Electrochemical.Society. v 136 in 9 sep $1989: 2481-2485$, 1989.

2081. Janke Results of vitrifying fernald k-65 residue. (Unknown Journal!) : (10 p), 1991 .

2082. Janke Characteristics of fernald's k-65 residue before, during and after vitrification. (Unknown Journal!) : (73 p), 1991.

2083. Janke, D., Chapman, C., and Vogel, R.A. Results of vitrifying Fernald [, OH] K-65 residue. Ceram.Trans. 23:53-61, 1991.

2084. Janke, D., S., ; Chapman, C., C., ; Vogel, R., A., and X results of vitrifying fernald k-65 residuex. Ceram.Trans., 23, 53-61X-61X, 1994.

2085. Jantzen Durability of glasses from pacific northwest laboratory composition variability study-ii (cvs-ii). (Unknown Journal!) :(40 p), 1910.

2086. Jantzen Characterization of radioactive-waste melter feed vitrified by microwave energy. (Unknown Journal!) : (9 p), 1927.

2087. Jantzen Characterization of the defense waste processing facility (dwpf) environmental assessment (ea) glass standard reference material <augmentation> site characterization. (Unknown Journal!) :(46 p), 1930.

2088. Jantzen Durability of glasses from the hg-doped integrated dwpf melter system (idms) campaign. (Unknown Journal!) : (46 p), 1930.

2089. Jantzen The product consistency test for the dwpf wasteform. (Unknown Journal!) : (16 p), 1990.

2090. Jantzen Nuclear waste glass product consistency test (pct), version 3.0. (Unknown Journal!) : (30 p), 1990.

2091. Jantzen The relationship between glass viscosity and composition: a first principles model for vitrification of nuclear waste. (Unknown Journal!) :(48 p), 1990 .

2092. Jantzen Use of dwpf redox measurement technique on glasses from west valley nuclear fuel services demonstration project. (Unknown Journal!) : (10 p), 1990.

2093. Jantzen The determination of the fe sup $2+/$ fe sup $3+$ ratio in simulated nuclear waste glass by ion chromatography. (Unknown Journal!) :(77 p), 1990.

2094. Jantzen Evaluation of experimental factors that influence the application and discrimination capability of the product consistency test. (Unknown Journal!) : (52 p), 1990. 
2095. Jantzen First principles process-product models for vitrification of nuclear waste: relationship of glass composition to glass viscosity, resistivity, liquidus temperature, and durability. (Unknown Journal!).:(20 p), 1991.

2096. Jantzen Remediation on off-gas system deposits in a radioactive waste glass melter. (Unknown Journal!) : (9 p), 1991.

2097. Jantzen Characterization of radioactive waste melter feed vitrified by microwave energy. (Unknown Journal!) : (12 p), 1991.

2098. Jantzen Glass melter off-gas system pluggages: cause, significance, and remediation. (Unknown Journal!) : (16 p), 1991.

2099. Jantzen Nuclear waste glass product consistency test (pct), version 5.0. (Unknown Journal!) : (50 p), 1992.

2100. Jantzen Defense waste processing facility (dwpf) startup test program: glass characterization. (Unknown Journal!) :(39 p), 1992.

2101. Jantzen Characterization of the defense waste processing facility (dwpf) environmental assessment (ea) glass standard reference material. (Unknown Journal!) : (93 p), 1994 .

2102. Jantzen Characterization of melter slurries vitrified by microwave. (Unknown Journal!) : (14 p), 1994.

2103. Jantzen, C. First principles process-product models for vitrification of nuclear waste:relationship of glass composition to glass viscosity, resistivity, liquidus temperature, and durability. Ceram.trans. , 1991.

2104. Jantzen, C. and Cadieux, J. Characterization of radioactive waste melter feed vitrified bymicrowave energy. Ceram.Trans. , 1991.

2105. Jantzen, C., Clarke, D., and Morgan, P. Leaching of polyphase nuclear waste ceramicsựicrostructural and phasecharacterization. J.Am.Ceram.Soc. , 1982 .

2106. Jantzen, C. Glass melter off-gas system pluggages: cause, significance, and remediation. Ceram.Trans. $23: 621-630,1991$.

2107. Jantzen, C., ; Brown, K., and X statistical process control of glass manufactured for nuclear wastex disposalx. Am.Ceram.Soc.Bul1., 72, 55-9X-9X, 1994.

2108. Jantzen, C., ; Cadieux, J., and X characterization of $* \star \star$ radioactive***

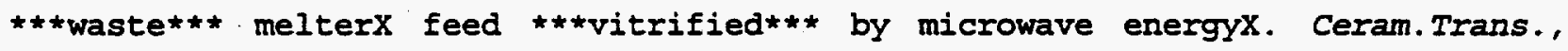
$21,441-9 x-9 X, 1994$.

2109. Jantzen, C., ; Hutson, N., ; Beam, D., and ChrisX demonstration of the defense waste processing facility (dwpf)x process control strategyx. Ceram.Trans., 29, X 503-14X-14X, 1994. 
2110. Jaritzen, C., M., ; Bibler, N., E., ; Beam, D., C., and X characterization of the defense waste processing facility (dwpf) $X$ environmental assessment (ea) glass standard reference materialx. Report, Wsrc-Tr-92-346; Order No.De93002808, 46 pp, 1993.

2111. Jantzen, C., M., ; Bibler, N., E., and X nuclear waste glass product consistency test (pct), version 3.0: $X$ revision $1 X$. Report, Wsrc-Tr-90-539-Rev.1; Order No.De91009294, 30 pp, 1991.

2112. Jantzen, C., $M .$, and $X$ glass melter off-gas system pluggages: cause, significance, andx remediationx. Report, Wsrc-Tr-90-205; Order No.De91010918, $64 \mathrm{pp}, 1991$.

2113. Jantzen, C., M., and X characterization of melter slurries vitrified by microwave: revisionX 1X. Report, WsrC-Tr-90-204-Rev.1; Order No.De92008806, 14 pp, 1992.

2114. Jantzen, C., M., and X durability of glasses from pacific northwest laboratory compositionx variability study-ii (cvs-ii)x. Report, WsrC-Rp-91-1227; Order No.De92018536, 40 pp, 1992.

2115. Jantzen, C., M., and X durability of glasses from the hg-doped integrated dwpf melterx system (idms) campaignX. Report, Wsrc-Rp-91-371; Order No.De93002154, 46 pp, 1993.

2116. Jantzen, $C$. and $x$ first principles process-product models for vitrification of nuclearX waste: relation of glass composition to glass viscosity, $\mathrm{X}$ resistivity, liquidus temperature, and durabilityx. Ceram.Trans., $23,37-51 X-51 X, 1994$.

2117. Jantzen, C., M., and X dwpf glass redox determination: summary of results from clemsonX subcontractX. Report, Dpst-86-745; Order No.De89001419, 32 pp. 1988 .

2118. Jantzen, C., M., and X glass compositions and frit formulations developed for dwpf [defensex waste processing. facility]x. Report, Dpst-88-952; Order No.De89007956, $60 \mathrm{pp}, 1989$.

2119. Jantzen, C., M., and X phosphate additions to borosilicate waste glass cause phaseX separationx. Report, Dpst-86-389; Order No.De89002451, 9 pp, 1989.

2120. Jantzen, C., M., and $X$ prediction of nuclear waste glass durability from natural analogsX. Adv.Ceram., 20,703-12X-12X, 1994.

2121. Jantzen, C., M., and $X$ prediction of glass durability as a function of environmentalx conditionsX. Mater.Res.Soc.Symp.Proc., 125,X 143-59X-59X, 1994.

2122. Jantzen, C., M., and X prediction of glass durability as a function of glass compositionX and test conditions: thermodymamics and kineticsX. Adv.Fusion Glass, Proc.Int.Conf., 1st, 24-24, 1994. 
2123. Jantzen, C.M. Effects of eh (oxidation potential) on borosilicate waste glassx durability. In: <CI> Held during the 85th Annual Meeting of the American CeramicX Society Advances in Ceramics $v 8$. Publ by American Ceramic Soc Inc, Columbus, $X$ OH, USA P 385-393, Anonymous Columbus, $x$ OH, USA:American Ceramic SOC Inc, 1984, p. 385-393.

2124. Jantzen, C.M. Measurement of Oxygen Content of DWPF Glass: A Response to Questions from the NRC (Nuclear Regulatory Commission). (Unknown Journal!) , 1986.

2125. Jantzen, C.M. DWPF (Defense Waste Processing Facility) Glass Redox Determination: Summary of Results from Clemson Subcontract. (Unknown Journal!) , 1986.

2126. Jantzen, C.M. Systems approach to nuclear waste glass development. Journal of Non-Crystalline Solids 84:215-225, 1986.

2127. Jantzen, C.M. Investigation of Lead-Iron-Phosphate Glass for SRP Waste. (Unknown Journal!) , 1986.

2128. Jantzen, C.M. Comparison of West Valley and Savannah River Waste Glass: Part I, Durability of Non-Radioactive Waste Glass. (Unknown Journal!) , 1986.

2129. Jantzen, C.M. Alternative waste Form Characterization Data. (Unknown Journal!) , 1987.

2130. Jantzen, C.M. Nuclear Waste Glass Corrosion Mechanisms. (Unknown Journal!) , 1987.

2131. Jantzen, C.M. Devitrification of Scale Melter Glass in Drain Valve Test Stand. (Unknown Journal!) , 1987.

2132. Jantzen, C.M. Pourbaix Diagram for the Prediction of Waste Glass Durability in Geologic Environnents. (Unknown Journal!) , 1987.

2133. Jantzen, C.M. Prediction of Glass Durability as a Function of Environmental Conditions. (Unknown Journal!) , 1988.

2134. Jantzen, C.M. Prediction of Glass Durability as a Function of Glass Composition and Test Conditions: Thermodynamics and Kinetics. (Unknown Journal!) , 1988.

2135. Jantzen, C.M. Verification and Standardization of Redox Measurement for DWPF (Defense Waste Processing Facility): Summary. (Unknown Journal!), 1989.

2136. Jantzen, C.M. Method for making glass. (Unknown Journal!) , 1991.

2137. Jantzen, C.M. Inorganic analyses of volatilized and condensed species within prototypic Defense Waste Processing Facility (DWPF) canistered waste. (Unknown Journal!) , 1992 .

2138. Jantzen, C.M. Nuclear Waste Glass Durability .1. Predicting Environmental Response from Thermodynamic (Pourbaix) Diagrams. J.AMER.CERAM.SOC. $75: 2435-2448$, 1992 . 
2139. Jantzen, C.M. Durability of glasses from Pacific Northwest Laboratory Composition Variability Study-II (CVS-II). (Unknown Journal!), 1992.

2140. Jantzen, C.M. and Bibler, N.E. Role of Groundwater Oxidation Potential and Radiolysis on Waste Glass Performance in Crystalline Repository Environments. (Unknown Journal!), 1985.

2141. Jantzen, C.M. and Bibler, N.E. Product Consistency Test (PCT) For DWPF Glass: Part 1, Test Deyelopment and Protocol. (Unknown Journal!) , 1987.

2142. Jantzen, C.M. and Bickford, D.F. Leaching of divitrified glass containing simulated srp nuclear waste. In: <CI> Held as part of the Fall Meeting of the Materials ResearchX Society Materials Research Society Symposia Proceedings $v$ 44. Publ by MaterialsX Research Soc, Pittsburgh, PA, USA $P$ 135-146, Anonymous Pittsburgh, PA, USA:MaterialsX Research SOC, 1985,p. i35-146.

2143. Jantzen, C.M. and Cadieux, J.R. Characterization of radioactive waste melter feed vitrified by microwave energy. (Unknown Journal!) , 1991.

2144. Jantzen, C.M. and Cadiewx, J.R. Characterization of Radioactive Waste Melter Feed Vitrified By Microwave Energy. (Unknown Journal!) , 1992.

2145. Jantzen, C.M., Pickett, J.B., and Ramsey, w.G. Reactive Additive Stabilization Process (RASP) for hazardous and mixed waste vitrification. (Unknown Journal!) , 1993.

2146. Jantzen, C.M. and Plodinec, M.J. Thermodynamic model of natural, medieval and nuclear waste glassX durability. Journal of Non-Crystalline solids $67: 207-223,1984$.

2147. Jantzen, C.M. and Plodinec, M.J. Composition and redox control of waste glasses: Recommendation for process control limit. (Unknown Journal!), 1986.

2148. Jantzen, C.M. and Ramsey, W.G. Prediction of radioactive waste glass durability by the hydration thermodynamic model: Application to saturated repository environments. (Unknown Journal!) , 1989.

2149. Jantzen, C.M., ; Bickford, D.F., ; Karraker, D.G., and X time-temperature-transformation kinetics in srl waste $\star \star \star g l a s s \star \star \star X . A d v . C e r a m .$, $8,30-8 X-8 X, 1994$.

2150. Jantzen, C.M. and $x$ effects of eh (oxidation potential) on borosilicate wasteX ***glass*** durabilityX. Adv.Ceram., 8, 385-93X-93X, 1994.

2151. Jantzen, C.M. and $X$ investigation of lead-iron-phosphate glass for srp wastex. Adv. Ceram., 20, 157-65X-65X, 1994.

2152. Jantzen, C. Defense waste processing facility (DWPF) startup test program : glass characterization (U) /, [Aiken, SC :Westinghouse Savannah River Co., Savannah River Laboratory, 1992.

2153. Jardine, L., J., ; Carlton, R., E., ; Steindler, M., and X comparison of costs for solidification of high-levelX $\star \star \star$ radioactive*** $\star \star \star$ waste*** 
solutions: ***glass***X monoliths vs metal matrixesX. Report, AnI-80-121, 155 pp, 1981 .

2154. Jean, J. and Gupta, T. Crystallization kinetics of binary borosilicate glass Xcomposite. Journal. of materials.research. 7, Number 11:3103-3111, 1992.

2155. Jean, J.H. and Gupta, T.K. Crystal-Growth Inhibitor in Binary Borosilicate Glass Composite Gallium Oxide. J.AMER.CERAM.SOC. 76:751-753, 1993.

2156. Jean, J.H. and Gupta, T.K. Alumina as a Devitrification Inhibitor During sintering of Borosilicate Glass Powders. J.AMER.CERAM.SOC. 76:2010-2016, 1993.

2157. Jeddeloh, G. The effect of glass composition on the coordination and chemical bonding af aluminum and the redox behavior of arsenic, cerium, europium and iron, University of Oregon, 1984.

2158. Jedinakova Krizova, $V$. and $X$ chemical resistance of vitrified wastesX. J.Radioanal.Nucl.Chem., 177, 271-7X-7X, 1994.

2159. Jegle, 0 . Modelluntersuchungen zur Spurenanalyse von Iod, Uran und Technetium in natriumchlorid gesaettigten Auslaugloesungen von endgelagertem radioaktivem Abfall. (Model investigations for trace analysis of iodine, uranium, and technetium in saturated sodium chloride leaching solutions of stored radioactive waste). Diss. (Unknown Journal!) , 1989.

2160. Jennings Plan for solidification of savannah river plant high-level wastex. Report. , 1978.

2161. Jennings, $A ., S_{.}$, and $X$ plan for solidification of savannah river plant high-level wastex. Aiche Symp.Ser., 75, 105-11X-11X, 1994.

2162. Jensen, G.A., ; Platt, A., M., ; Mellinger, G.B., ; Bjorklund, X.w., and $x$ recovery of noble metals from fission productsx. Nucl.Technol., 65, $305-24 X-24 X, 1994$.

2163. Jercinovic, M.J., Ewing, R.C., and A Criepi, N.S. Basaltic Glasses from Iceland and the Deep Sea: Natural Analogues to Borosilicate Nuclear Waste-Form Glass. (Unknown Journal!), 1987.

2164. Jercinovic, M.J., ; Kaser, S.A., ; Ewing, R.C., and ; Lutze, X.W. comparison of surface layers formed on synthetic basaltic glass, $X$ french $r 7 t 7$ and $\mathrm{hmi}$ borosilicate nuclear waste form glasses $-X$ materials interface interactions tests, waste isolation pilot plantx. Mater.Res.Soc.Symp.Proc., $176,355-62 X-62 X, 1994$.

2165. Jervis, M., C., and $X$ operational experience of the denitration of simulated highly activex liquid wastes during vitrificationx. Comn.Eur.Communities, Eur, Eur 10650, Denitration R-51X, 1994. 
2166. Jewell, J. and Shelby, J. Effects of water content on the properties of sodium aluminosilicate glasses. Joumal.of.the.American.Ceramic.Society. v. 75 (Apr. ' 92):878-883, 1992 .

2167. Jewell, J., Spess, M., Ortolano, R., and Shelby, J. Effect of Heat-Treatment Temperature on the Properties of a XIithium Aluminosilicate Glass. Journal. of.the.American.Ceramic.Society. 74, Number 1:92-97, 1991.

2168. Jianhui zhong and P.J.Bray Change in Boron coordination in Alkali borate glasses, and mixed alkali effects, as elucidated by NMR. Journal. of.Non-Crystalline.Solids. 111:67-76, 1989.

2169. Jing, W.P.,Shigung; Yan development of lithium borosilicate glass and perilite glass andx their process testingx. Fushe Fanghu, 3, 135-41X-41X, 1994.

2170. Jodra, L., G., ; Palancar, M., C., ; Aragon, J., M., ; Luis, P., I., and $X$ characterization of phosphate glasses used in the solidification ofX low-level $* * *$ radioactive*** $* * *$ wastes $* \star \star \quad X$. Energ.Nucl. (Madrid), 28, $129-34 \mathrm{X}-34 \mathrm{X}, 1994$.

2171. John F.Flintoff and Alan B.Harker BT - Leaching Mechanisms CT - Detailed Processes of Surface Layer Formation in Borosilicate Waste Glass Dissolution. ED - Carol M.Jantzen ED - John A.Stone ED - Rodney C.Ewing Anonymous 1985,p. 147-154.

2172. Johnson Tank waste decision analysis report. (Unknown Journal!) : (188 p), 1931.

2173. Johnson, A. A study of the determination of the volume expansion of glass at high temperature, Alfred, N.Y.New York state College of Ceramics at Alfred University, 1948.

2174. Johnson, E.R.A. Alternative waste management options, nuclear fuel services, inc. $\mathrm{X}$ high-level wastex. Report. , 1979.

2175. Johnson, K.D.B. Glasses and ceramics for immobilisation of radioactive wastes for disposal /. Harwell : [London] :United Kingdom Atomic Energy Authority ; [Distributed by H.M.S.0.], 1979.

2176. Joseph, I., ; Mathur, A., ; Capozzi, C., ; Sehgal, J., ; Butts, D.,. ;X McPherson, D., ; Pye, L., D., ; Eisenstatt, L., and $\mathrm{X}$ crystallization behavior of a fully simulated west valleyX borosilicate glassX. Proc.Symp. Waste Manage., (Waste Manage. '88, Vol. 2), 487-91X-91X, 1994.

2177. Joshi, B.C. and Joshi, M.C. Sensitizing Pr3t Ions by $\operatorname{Tm} 3+$ Ions in Phosphate-Glass. J.NON-CRYST.SOLIDS. 142:171-174, 1992.

2178. Jouan Economic and technical advantages of high temperature processes in high level radioctive waste management. (Unknown Journal!) :(8 p), 1991.

2179. Jouan Decontamination and dismantling of the piver prototype vitrification facility at marcoule: final results and conclusions. (Unknown Journal!) : ([22] p), 1991. 
2180. Jouan Decontamination and dismantling of the piver prototype vitrification facility at marcoule, france. (Unknown Journal!) :([12] p), 1992.

2181. Jouan Experimental study of glass sampling devices <augmentation> for vitrified radioactive wastes Etude experimentale de dispositifs d'echantillonnage de verre. (Unknown Journal!) :([104] p), 1992.

2182. Jouan Decommissioning of the vitrification cell of the piver plant Assainissement de la cellule de vitrification de l'installation piver. (Unknown Journal!) $:([100]$ p), 1993.

2183. Jouan Final cleansing of the piver prototype vitrification facility -decontamination of the hot-cell Assainissement final de l'installation prototype de vitrification piver. decontamination de la cellule chaude.

(Unknown Journal!) : (23 p), 1993.

2184. Jouan, Cartier, Bonniaud, and sombret Current developments in continuous vitrification of fission productx solutionsx. Manage.Radioact. Wastes.Nucl. Fuel.Cycle -70, 1994.

2185. Jouan and Sombret Continuous vitrification of concentrated fission product solutionsX. Nucl.Energy.Maturity. -301, 1975.

2186. Jouan, A. and Sombret, C. Continuous vitrification of concentrated fission-product solutionsX. Ann.Nucl.Energy. -6), 1994.

2187. Jouan; A. Demantelement de decontamination de l'installation pilote de vitrification. (Unknown Journal!) , 1989.

2188. Jouan, A., ; Roudil, S., ; Thomas, F., and $X$ dismantling and decontamination of the piver prototype vitrificationx installationx. Comm. Eur.Cormunities, Eur, Eur 13495, 60 pp, 1994.

2189. Jouan, A., Deschaud, C., Roudil, S., and Chauvet, F. Decontamination and dismantling of the PIVER prototype vitrification facility at Marcoule: Final results and conclusions. (Unknown Journal!), 1991.

2190. Jouan, A., Deschaud, C., Roudil, S., and Scelo, G. Decontamination and dismantling of the Piver prototype vitrification facility at Marcoule, France. (Unknown Journal!), 1992.

2191. Jouan, A., Deschaud, C., and scelo, G. Assainissement de la cellule de vitrification de l'installation Piver. (Decommissioning of the vitrification cell of the Piver plant). (Unknown Journal!), 1993.

2192. Jouan, A., Jacquet Francillon, N., and Cler, M. Economic and technical advantages of high temperature processes in high level radioctive waste management. (Unknown Journal!) , 1991.

2193. Jouan, A., Ladirat, C., and Moncouyoux, J.P. Performance and Development of the French Continuous Process of Vitrification. (Unknown Journal!), 1987. 
2194. Jouan, A., Moncouyoux, J.P., and Halaszovich, S. Reduction of Ru and TC Volatility During Vitrification of HLLW by Denitration. (Unknown Journal!) , 1985.

2195. Jouan, A., Ouvrier, N., and Teulon, F. Conditioning processes for incinerator ashes. (Unknown Journal!) , 1990.

2196. Jouan, A., ; Ladirat, C., ; Moncouyoux, J., P., and X present status of the french continuous fission productx vitrification processx. Adv.Ceram., 20, 105-16X-16X, 1994 .

2197. Jouan, A., ; Moncouyoux, J., P., ; Halaszovich, S., and $X$ reduction of ruthenium and technetium volatility duringx vitrification of hllw by denitrationx. Comm.Eur.Communities, Eur, Eur 10650, Denitration R-61X, 1994.

2198. Jucha, R.B. Bubble rise in molten glasses : a thesis, 1980.

2199. Judith A.Garland and William B.White BT - Leaching Mechanisms CT Determination of Early Stages of Glass Dissolution of $\mathrm{pH}$ Titration ED - Carol M.Jantzen ED - John A.Stone ED - Rodney C.Ewing Anonymous 1985,p. 81-88.

2200. Kachalov, M.B., Ozhovan, M.I., and Poluektov, P.P. Role of inhomogeneities in the fracturing of matrices with radioactiveX waste. Soviet Atomic Energy $63: 782-784,1988$.

2201. Kadokura, K. Electrolytic bubble formation in glass, 1978.

2202. Kadono, R., Tanaka, H., and Tarumi, T. Effect of Glass Composition on Precipitation of Crystallites in CuCl Doped Glasses. PHYS.CHEM.GLASSES. $35: 41-43,1994$.

2203. Raermbraenslesaekerhet Handling of spent nuclear fuel and final storage of vitrified highx level reprocessing wastex. Report. , 1978.

2204. Kahl and Kelm Fixation of maw in inorganic matrixesX. Kernforschungszentrum. Karlsruhe. -29X,. 1994.

2205. Kahl, L., ; Kroebel, R., ; Storch, W., ; Holton, L., K., ; Dierks, R., $D .$, and $X$ investigation of the thermal behavior of high level waste glass inX steel canisters during cooling and at equilibriumx. Nucl.Eng.Des., 130, $77-88 \mathrm{X}-88 \mathrm{X}, 1994$.

2206. Kahl, L., ; Mainka, E., ; Saidl, J., and $x$ uranium dioxide fixation in vg 98/12 borosilicate $\star \star \star$ glass $\star \star *$ X. Atw, Atomwirtsch., Atomtech., 27, $629-31 x-31 x, 1994$.

2207. Kahl, L., ; Ruiz Lopez, M., C., ; Saidl, J., ; Dippel, T., ; Pentinghaus, $\mathrm{H} .$, and $X$ borosilicate $* * \star g l a s s * \star *$ vg $98 / 12$ for solidifying highlyX radioactive fission product solutions (high-level waste): $\mathrm{X}$ characterization of laboratory-scale samples.X. Kfk-Nachr., 15, 11-15X-15X, 1994.

2208. Kahl, I., ; Ruiz Lopez, M., C., ; Saidl, J., ; Dippel, T., and X preparation and characterization of an improved borosilicatex ***glass*** for the solidification of high-level radioactivex fission product solutions 


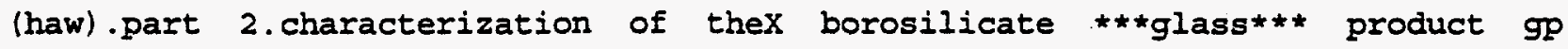
98/12X. Kernforschungszent.Karlsruhe, Kfk, Kfk 3251, 61 pp, 1994.

2209. Kahl, L. and $x$ the hydrolytic durability of two high-level waste oxide borosilicateX glasses (gp $98 / 12$ and $g p$ 98/26)X. Nucl.Chem. Waste Manage., 2, $143-6 \mathrm{X}-6 \mathrm{X}, 1994$.

2210. Kahl, $L$. and $X$ hydrolytic durability of lead-iron-phosphate glassesX. Adv.Ceram., 20, 141-8X-8X, 1994.

2211. Rahnt, H., Reau, J.M., Elyamani, A., and Poulain, M. Influence of Chlorine Fluorine substitution on the Electrical-properties of some Fluoride Glasses. J.NON-CRYST.SOLIDS. 160:255-260, 1993.

2212. Kajiwara, M. Formation and crystallisation of $A] / / 20 / / 3-T i O / / 2-S i O / / 2$ glasses. Glass. Technology. Glass Technol v 29 n, 1988.

2213. Kalan, M. and Corbman, P. Methods of calculating the thermal expansion of Nab2sO-SiOb2s and Nab2sO-Bb2sOb3s glasses, Alfred, NY:New York State College of Ceramics at Alfred University, 1938.

2214. Ramitsos, E.I. Infrared Reflectance Studies of Ionic Conductive Glasses -Network Structure and Cation Dynamics. J.PHYS.IV. 2:87-96, 1992.

2215. Kamitsos, E.I., Patsis, A.P., and Chryssikos, G.D. Infrared Reflectance Investigation of Alkali Diborate Glasses. J.NON-CRYST.SOLIDS. 152:246-257, 1993.

2216. Kamizono Effects of carbonate and sulfate ions in synthetic ground water onhigh-level waste glass leaching. J.MATER.SCI.LETT. , 1990.

2217. Kamizono, Hayakawa, and Muraoka Effects of some glass additives on nuclear waste glass durability in water. J.MATER.SCI.LETT. , 1991.

2218. Kamizono, H. time-dependence of volatilization of cesium-137 and ruthenium-106X over high-level waste glass in a canisterX. Mater.Res.SOC.Symp.Proc., 257, 191-7X-7X, 1994.

2219. Kamizono, H. durability of high-level waste glass in groundwaterX. J.Am.Ceram.Soc., 74, 2234-41X-41X, 1994.

2220. Kamizono; H., Kikkawa, S., and Togashi, Y. Volatilization of sup 1 sup 3 sup 7 cs and sup 1 sup 0 sup 6 ru fromborosilicate glass containing actual high-level waste. J.Am.Ceram.SoC. , 1989.

2221. Kamizono, H., Sagawa, T., and Tashiro, S. Continuous-flow leach tests of simulated high-level waste $x$ glass in synthetic basalt groundwater. $x$. Waste.ManagementX. Waste Manage $v 9$ n 3, 1989.

2222. Kamizono, H. Thermal shock resistance of high-level waste glass: an overview. Radioactive Waste Management and the Nuclear Fuel Cycle 8:53-63, 1987. 
2223. Kamizono, H. Volatilization of cesium and ruthenium from high-level waste glass. In: Proc 1st Annu Int Top Meet High Level Radioact Waste Manage Part 2.X Publ by ASCE,Boston Society of Civil Engineers Sect,Boston, MA,USA.X $p$ 1115-1118, Anonymous Boston Society of Civil Engineers Sect, Boston, MA, USA:ASCE, 1990,p. 1115-1118.

2224. Kamizono, H. Durability of high-level waste glass in groundwater. Journal.of. the.American.Ceramic.Society. v. 74 (Sept. '91):2234-2241, 1991.

2225. Ramizono, H. and Banba, $T$ : Relationship Between Leach Rate of Nuclear Waste Glass and Residual Amount of Sodium on the Glass Surface. (Unknown Journal!) , 1984.

2226. Kamizono, H. and Banba, T. Comparison of nuclear waste glass leached in natural groundwater at $14 \mathrm{X}$ degree $c$ with that in synthesized groundwater at 70 degree. Journal of Nuclear Science and Technology 23:755-758, 1986.

2227. Kamizono, H., Kikawa, S., Tashiro, S., Nakamura, H., Szajman, J., Smart, R.S.C., and Myhra, S. Air contamination by cesium in a canister containing nuclear wastex glass $\mathrm{X}$-ray photoelectron spectroscopy studies of valence states of ceriumx and uranium in synroc c. Journal of Nuclear Materials surf Coat Technol 30:333-342, 1987.

2228. Kamizono, H., Kikkawa, S., Tashiro, S., and Nakamura, H. Volatilization of cesium from nuclear waste glass in a canister. Nuclear Technology 72:84-88, 1986.

2229. Kamizono, H., Kikkawa, S., Togashi, Y., and Tashiro, S. Volatilization of $\star \star 1 * * 3 * * 7 \mathrm{cs}$ and $* * 1 * * 0 * * 6 \mathrm{ru}$ from borosilicate glassX containing actual high-level waste. Joumal of the American Ceramic Society 72-1440, 1989.

2230. Kamizono, H., Shimizu, I., and Banba, T. Continuous-flow leach tests of simulated high-level waste glass inx synthesized groundwater and deionized water. Journal of Nuclear Science and Technology 24:308-314, 1987.

2231. Kamizono, H.B.,Tsunetaka; Senoo leachability of a simulated high-level waste $* \star$ glass $* *$ productX at high temperaturesX. Report, Jaeri-M-9387, 16 pp, 1982 .

2232. Kamizono, H.K.,Shizuo; Togashi volatilization of cesium-137 and ruthenium-106 from borosilicatex glass containing actual high-level wastex. J.Am.Ceram.SoC., 72, 1438-41X-41X, 1994 .

2233. Kamizono, H.S.,Tamio; Tashiro factor of dilution with freshly pumped leachant in continuous-flowX leach tests on high-level waste glassX. J.Nucl.Sci.Technol., 26, 811-13X-13X, 1994 .

2234. Kamizono, H.B.,TsunetakaX a relationship between leach rate of nuclear waste glass andx residual amount of sodium on the glass surfacex. Nippon Genshiryoku Kenkyusho, Jaeri-M, Jaeri-M-84-220, 26 pp, 1994.

2235. Kamizono, H.N., KazukuniX an estimation of the thermal shock resistance of simulated nuclearX waste $\star \star \star g l a s s \star \star \star$ under water quenching conditionsX. J.Mater.Sci.Lett. , 3, 588-90X-90X, 1994 . 
2236. Kamizono, $\mathrm{H}$. tensile strength of simulated high-level waste glassX. J.Nucl.Sci.Technol., 22, 412-14X-14X, 1994.

2237. Kamizono, H.C.,David E., ; Lodding, A.R., and X accelerated leach tests of srl-165 high-level waste glass inx deionized water, solution analyses and supplemental sims analysesX. J.Nucl.Sci.Technol., 26, 441-8X-8X, 1994.

2238. Kamizono, H.C.,David $E$. and $X$ on iron enrichment on nuclear waste glass during leachingx. Nippon Seramikkusu Kyokai Gakujutsu Ronbunshi, 97, 494-7X-7X, 1994.

2239. Kang, M.J., Kim, M.S., Oh, S.K., Chung, S.J., Hong, K.S., and Sim, M.S. Li-7 MMR-Studies in Mixed-Alkali Silicate-Glasses. J.KOREAN.PHYS.SOC. $26: 361-368,1993$.

2240. Kanno, H. Double glass transitions in aqueous lithium chloride solutions vitrified at high pressures: evidence for a liquid-liquid immiscibility. The.Journal. of.Physical. Chemistry. v. 91. (Mar. 26 '87):1967-1971, 1987.

2241. Kanno, H., Shimada, K., and Katoh, T. A glass formation study of aqueous tetraalkylamnonium halide solutions. The.Journal.of.Physical.Chemistry. v. 93 (June 15 '89):4981-4985, 1989.

2242. Karaseva, I., G., ; Minaev, A., A., ; Chepovoi, V., I., and X radiation resistance of strontium-borosilicate glassesX. Radiokhimiya, 32, 158-61X-61X, 1994.

2243. Karim, D., P., ; Lam, D., J., ; Diamond, H., ; Friedman, A., M., ; Coles, D., X G., ; Bazan, F., ; McVay, G., L., and X xps valence state determination of neptunium and plutonium inX multicomponent borosilicate ** glass** and

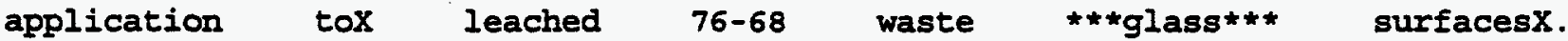
Mater.Res.SOC.Symp.Proc., 6,X 67-73X-73X, 1994.

2244. Karim, D., P., ; Lam, D., J., ; Friedman, A., M., ; Susak, N., ; Rickert, P., ; $X$ Sullivan, $J ., C .$, and $x$ the effect of radiolysis on leachability of plutonium and americiumx from 76-101 ***glass*** X. Mater.Res.Soc.Symp.Proc., $6, \mathrm{x} \quad 661-6 \mathrm{X}-6 \mathrm{X}, 1994$.

2245. Karim, D.P., Pronko, P.P., Marcuso, T.L.M., Lam, D.J., and Paulikas, A.P. Xps and ion beam scattering studies of leaching in simulated wasteX glass containing uranium. In: $\langle C I\rangle$ Proceedings of the 3 rd International symposium, held as part ofX the Annual Meeting of the Materials Research Society Scientific Basis for Nuclear Waste Management $v 3$. Publ by PlenumX Press, New York, NY, USA and London, Engl. p 397-404,Anonymous New York, NY, USA:PlenumX Press, 1981, p. 397-404.

2246. Karkhanavala and Shukla Thermal expansion behavior of some sulfate-containing lead glassesX. Cent.Glass.Ceram.Res.Inst.Bul1. -7X, 1994.

2247. Rarkhanis, S.N., ; Melling, P.J., ; Fyfe, w.S., ; Bancroft, X.G., and MichaelX stable-product low-leach glassesX. Sci.Basis Nucl.Waste Manage., 3, $115-22 X-22 X, 1994$. 
2248. Karki, A. The density of potassium and sodium borate glasses related to atomic arrangements, 1987.

2249. Karlina, O., K., ; Ozhovan, M., I., ; Popov, M., V., and X comparative analysis of water resistance of $* *$ glass $* * X$ composites and homogeneous

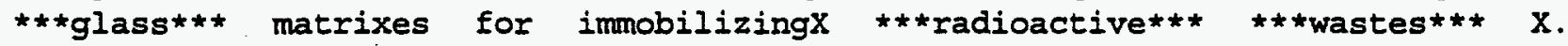
Radiokhimiya, 35, 120-4X-4X, 1994.

2250. Karlina, O., K., ; Ozhovan, M., I., ; Sobolev, I., A., ; Ovchinnikov, A., V., ;X Varlakova, G., ; Polyakov, $A_{,}, S_{.}$, and $X$ consolidation of sulfate-containing wastes in the form ofX glass-composite materialsx. At. Energ., 72, 162-5X-5X, 1994.

2251. Karlina, O.K., Ozhovan, M.I., Sobolev, I.A., Ovchinnikov, A.V., Varlakova, G.A., and Polyakov, A.S. Solidifying Sulfate-Bearing Wastes to Make Glass Composite-Materials. SOV.AT. ENERGY-ENGL.TR. 72:159-162, 1992.

2252. Karlina, O.K., Ozhovan, M.I., Sobolev, I.A., Ovchinnikov, A.V., Varlakova, G.A., and Polyakov, A.S. Vitrification of sulphates-containing wastes in form of glass-compositex materials. Atomnaya Energiya 72:162-165, 1992.

2253. Kamesky Annual report of tank waste treatability. (Unknown Journal!). : (151 p), 1990.

2254. Karraker, D., G., and $X$ ferrous/ferric ratio in dwpf glass: chemical and iron-57 moessbauerX determinationsX. Adv.Ceram.Mater., 3, 337-40X-40X, 1994 .

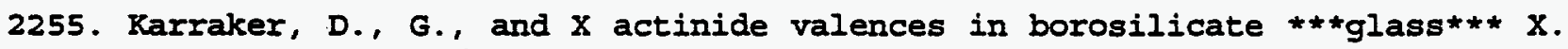
J.Am.Ceram.Soc., 65, 53-5X-5X, 1994.

2256. Rarraker, D.G., Postles, R.L., Winn, D.E., and Bickford, D.F. Moessbauer Determination of the Ferrous-Ferric Ratio in Defense Waste Glass. (Unknown Journal!), 1984.

2257. Kaser, J. and Moore, J. The development of a spray calciner-melterx. U.S.At. Energy. Corm. -660208, 1994.

2258. Kashcheev, V., A., ; Ozhovan, M., I., ; Polucktov, P., P., and X leaching of radionuclides from glass-composite materialsx. At.Energ., 73, 241-3X-3X, 1994.

2259. Kashcheev, V., Ozhovan, M., and Poluektov, P. Radionuclei leaching from glass-composite materials. Atomnaya Energiya 73:241-243, 1992.

2260. Kashcheev, V., A., ; Poluektov, P., P., ; Polyakov, A., S., and X thermodiffusion aging of solidified radioactive wastesx. At.Energ., 60 , $139-41 X-41 X, 1994$.

2261. Kashcheev, V.A., Ozhovan, M.I., and Poluektov, P.P. Radionuclide Leaching from Composite-Glass Materials. AT. ENERGY-BNGL.TR. 73:759-761, 1992. 
2262. Kashcheev, V.A., Poluektov, P.P., and Polyakov, A.S. Thermal-diffusion aging in solidified radioactive wastes. Soviet Atomic Energy 60:173-176, 1986.

2263. Kashif, I. Magnetic susceptibility of lithium borosilicate glasses containing metal oxide. Journal.of.materials.science.Materials.in electronics. ONE, Number ONE:1-49, 1990.

2264. Kashif, I., Farouk, H., Aly, S.A., Abdel-Rahman, A.A., Sanad, A.M., and Assem, E.E. Crystallization process and electrical conductivity in Xvanadium borophosphate glass containing iron. Materials.science \&.engineering.B,.Solid-state.materials.for.advanced.technology. 10, Number 1:1, 1991.

2265. Kasper, J., Feller, S., and sumcad, G. New sodium borate glasses. Journal.of. the.American.Ceramic.Society.v.67. (Apr. '84).p.C71-2.bibl. 2-7820, 1984.

2266. Kasuga, T. and Abe, Y. Phase separation and crystallization of BisrCaCu//2Al $/ / 0 / / . / / 50 / / x$ glass. Journal.of.the.American.Ceramic.Society. Journal of the Ameri, 1993.

2267. Katsunuma, Y., Murakoshi, S., Yamamoto, T., and Mitsushima, N. Research and development to handle vitrified waste to be returned from overseas reprocessing plants. In: High Level Radioactive Waste and Spent Fuel Management Proc 1989 Jointx Int Waste Manage Conf $v 2$ (of 2). Publ by American Soc of MechanicalX Engineers (ASME), New York, NY, USA.p 159-163, Anonymous New York, NY, USA:American Soc of MechanicalX Engineers (ASME), 1989,p. 159-163.

2268. Kauffman, F., Saidl, J., Koschorke, H., and Drobnik, S. Avoiding operation interruptions in the solidification of aqueousx radioactive wastes in a glass, X. Ger.Offen. , 1994 .

2269. Kaufmann, Koschorke, Guber, Hild, and Krause Recent experience with a steam-heated spray calcining unit for highx level waste solidificationx. Aiche.Symp.Ser. :Ser, 72(154, Radioac-Ser, 72(154, Radio9x, 1994.

2270. Kaufmann, Koschorke, and Weisenburger Ceramic fusion system for the solidification of haw solutions inx borosilicate glassx. Atomwirtsch. -8), 1994 .

2271. Kaufmann, F. Method for vitrifying radioactive waste solutions. (Unknown Journal!) , 1986.

2272. Kaufmann, F. Apparatus for vitrifying radioactive waste solutions. (Unknown Journal!) , 1986.

2273. Kaufmann, F., Weisenburger, S., Koschorke, H., and Seiffert, H. Apparatus and methods for filtering radioactive exhaust gases andx regeneration of the filterx. Ger.offen. , 1994.

2274. Kaufmann, F. method and apparatus for $\star \star \star v i t r i f i c a t i o n * \star *$ of

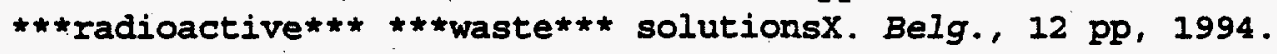


2275. Kawamoto, T., Terai, R., and Hara, S. Effects of crystallization on thermal properties and chemicalx durability of the glasses containing simulated high levelx radioactive wastesx. Osaka.Kogyo.Gijutsu.Shikensho.Kiho. -73x, 1994.

2276. Kawamoto, T., Terai, R., Hara, S., Hiroha, K., and X, T. Chemical durability of glasses suitable for the storage ofx high-level radioactive wastes.ii.continuous leaching method forx the low temperature glasses of borosilicate systemsX. Osaka.Kogyo.Gijutsu.Shikensho.Kiho. -84X, 1994 .

2277. Kawamoto, $Y$. and Koumyoji, D. Vitreous state electrolysis of $F \star \star M \star \star I * * N$ ion conducting $\mathrm{ZrF} / / 4 \quad \mathrm{BaF} / / 2-\mathrm{CsF}$ and $\mathrm{FeF} / / 3-\mathrm{MnF} / / 2-\mathrm{PbF} / / 2$ glasses. Journal.of. the.Electrochemical.Society. J Electrochem Soc v, 1989.

2278. Kawamura, K., ; Takahashi, I., ; Horie, M., ; Tsunoda, N., and X characterization of high-level waste glassx. Ceram.Trans., 9, 469-81X-81X, 1994.

2279. Kawamura, K., Takahashi, T., and Horie, M. Characterization of high-level waste glass. Ceram. Trans. 9:469-481, 1990.

2280. Kawanishi, N.I.,Hiroshi; Nagaki leaching test on chemical durability of glasses containing simulatedx high level wastesx. Tokai Works Annu.Prog.Rep.., Pnct831-80-01, 140-50X-50X, 1994.

2281. Kawasaki, N. design and construction of pnc's tokai vitrification facility (tvf)X. Ihi Eng.Rev., 26, 93-7X-7X, 1994.

2282. Keeley, Bonner, and Larson Technology status of spray calcination-vitrification of high-levelx liquid waste for full-scale applicationx. Report. , 1978.

2283. Keely, R., B., ; Bonner, W., F., ; Larson, D., E., and $\mathrm{X}$ technology status of spray calcination/ ***vitrification*** ofX high-level liquid waste for full-scale applicationX. Aiche symp.Ser., 75, 50-5X-5X, 1994.

2284. Keene, w. Development and demonstration of a system for vitrifying high level radioactive waste in high silica glass /, 1987.

2285. Kelker, J.W. Development of the DWPF Canister Temporary Shrink-Fit Seal. (Unknown Journal!) , 1986.

2286. Kelley Incorporation of savannah river plant radioactivex waste into glass X. Report. :Avail NTISX From:XNu, 1975.

2287. Kelley and Rankin Correlation of radionuclide leachabilities with microstructures ofx glasses containing savannah river plant wastex. Report. , 1976 .

2288. Kelley, Wiley, Plodinec, and Bibler vitrification studies for savannah river plantX radioactive wastes $\mathrm{X}$. Report. , 1977.

2289. Kelley, J.A. and Papouchado, L.M. Borosilicate glass for immobilization of high-level srp waste. In: Transactions of the American Nuclear Society $v 41$ 
1982. Publ by ANS, LaX Grange Park, III, USA p 277-278, Anonymous LaX Grange Park, IIl, USA:ANS, 1982,p. 277-278.

2290. Kelley, J.A. and $x$ processing and solidification of savannah river plant high-levelX wasteX. Ber.Kernforschungsanlage Juelich, Juel-Conf-42 (Vol. 1), X Proc:roc-Level Liquid Wastex, 1994.

2291. Kelly, J. Sodium diffusion in low alkali glasses, Troy, NY:Rensselaer Polytechnic Institute, University Microfilms International, 1980.

2292. Kelm, M. the platinum metals in hllw - glass productsX. Mater.Res.Soc.Symp.Proc., 257, 177-82X-82X, 1994.

2293. Kelm, M., Oser, B., Luckscheiter, B., Bernotat, W., and Pentinghaus, H. Vitrification of hllw. process and product quality studies by means ofX a lab scale liquid fed ceramic melter. In: High Level Radioactive Waste and Spent Fuel Management Proc 1989 Jointx Int Waste Manage Conf $v 2$ (of 2).Publ by American Soc of MechanicalX Engineers (ASME), New York,NY, USA.P. 171-176, Anonymous New York, NY, USA:American Soc of MechanicalX Engineers (ASME), 1989,p. 171-176.

2294. Kerm, J.B. Translating DWPF Design Criteria into an Engineered Facility Design. (Unknown Journal!) , 1986.

2295. Kempe, T.F. and Maytin, A. Pre-Disposal Storage, Transport and Handling of Vitrified High-Level Waste. (Unknown Journal!), 1981.

2296. Kenna, Murphy, and Levine Long-term elevated temperature leaching of solid waste formsX. Report. , 1979.

2297. Kenna, B., T., ; Murphy, K., D., ; Levine, H., S., and $x$ long-term elevated temperature leaching of solid waste formsx. Sci.Basis Nucl. Waste Manage., , MeetingX Date 1978, 157-60:lenum: NewX York, 1994.

2298. Kenna, B., T., ; Murphy, K., D., and $X$ mechanism for elevated temperature leachingX. Sci.Basis Nucl. Waste Manage., 2, 191-8X-8X, 1994.

2299. Kennan, $R$. and Schultes, E. Analytical facility design to support qualification of vitrified highx level waste for repository acceptance. In: High Level Radioactive Waste and Spent Fuel Management ProC 1989 Jointx Int Waste Manage Conf $v 2$ (of 2). Publ by American Soc of Mechanicalx Engineers (ASME), New York, NY, USA.p 165-170, Anonymous New York, NY, USA:American Soc of MechanicalX Engineers (ASME), 1989,p. 165-170.

2300. Kennedy, C., R., ; Flynn, K., F., ; Arons, R., M., ; Dusek, J., T., and X comparative leaching behavior of synroc $b$ and $a$ borosilicatex $\star * * g l a s s * \star * x$. Nucl.Technol., 56, 278-88X-88X, 1994.

2301. Kepak, F. the off-gas cleaning system for gases formed during thex vitrification of high-activity wastes from the nuclear power plantx alx. Jad.Energ., 38, 143-8X-8X, 1994 . 
2302. Kepak, F. atmospheric release of radionuclides during calcination andx $\star \star *$ vitrification*** of $* * *$ radioactive $* * * * * *$ wastes $* * *$ X. Jad.Energ., 37 , $290-6 \mathrm{X}-6 \mathrm{X}, 1994$.

2303. Kepak, F., ; Urbanec, Z., ; Haklova, H., ; Koutova, S., and X determination of the amount and retention efficiency of aerosols $X$ arising during the vitrification of medium-level activity wastesx from nuclear power plantsX. J.Radioanal. Nucl. Chem., 177, 335-44X-44X, 1994.

2304. Kepak, F., ; Pecak, V., ; Uher, E., ; Kanka, J., ; Koutova, S., ; Matous, $V .$, and $X$ removal of nitrogen oxides, volatile radionuclides and aerosols $X$ formed in laboratory-scale denitration, calcination andx solidification of simulated high-level wastesX. Manage.Gaseous Wastes Nucl.Facil., Proc.Int.Symp., 101-11-11, 1994.

2305. Kepak, $F$. and $X$ apparatus and method for purifying gas from the a-1 power plantX waste vitrificationx. Nukleon, (3), 3-5X-5X, 1994.

2306. Kepak, F.R., Urbanec, Z.R., Haklova, H.R., and Koutova, S.R. Determination of the amount and retention efficiency of aerosols arising during the vitrification of medium-level activity wastes from nuclear power plants. Journal.of.radioanalytical.and.nuclear.chemistry. 177, Number 2:335-344, 1994.

2307. Kerr, R. Nuclear waste disposalùalternatives to solidification in glass proposed. SCIENCE, 1979.

2308. Kessler, J.I. and Randal1, C.T. Performance of a large-scale melter and off-gas system utilizingx simulated sxp dwpf waste. In: <CI> Volume 1: Waste Policies and Programs, High-Level Waste Publ by Arizona Board of Regents, AZ; USA P 279-284, Anonymous AZ, USA:Arizona Board of Regents, 1984,p. 279-284.

2309. Kessler, J. Recrystallization and bonding change effects in a sodium borosilicate glass containing molybdenum trioxide; 1981.

2310. Khalil, M.Y. and White, W.B. Dissolution of technetium from nuclear waste forms. In: <CI> Symposium held as part of the Annual Meeting of the MaterialsX Research Society Materials Research Society Symposia Proceedings $v 26$. Publ byx North-Holland, New York, NY, USA and Amsterdam, Neth $p$ 655-662, Anonymous New York, NY, USA: 1984,p. 655-662.

2311. Khan, A. The effect of the addition of $\mathrm{zno}$ on the properties of various glasses and methods of introducing it into a glass, Alfred, NY:New York state College of Ceramics at Alfred University, 1948.

2312. Khawaja, E.E., Hallak, A.B., and Salim, M.A. Observation of surface segregation in sodium germanate glass containing cobalt. Journal. of.Non-Crystalline.Solids. 152, Number 2-3:270-273, 1993.

2313. Khodakovskaia, R. Khimiia titansoderzhashchikh stekol i sitallov, Moskva:Khimiya, 1978. 
2314. Kienzler, B. cooling and cracking of technical hlw (high level waste) glassX products: experimental and numerical studiesX. Mater.Res.Soc.Symp.Proc., 127, 191-8X-8X, 1994 .

2315. Kim Regulatory research on materials used for nuclear waste managementùupdate. Adv. Ceram. , 1986.

2316. Kim Borosilicate glass and nuclear waste. (Unknown Journal!) : (11 p), 1990.

2317. $\mathrm{Kim}$, C.H., Hsu, J.J., Oconnor, M.K., Weaver, A.L., Brown, M.L., and zinsmeister, A.R. Effect of Viscosity on Oropharyngeal and Esophageal Emptying in Man. DIGEST.DIS.SCI. 3.9:189-192, 1994 .

2318. Kim, D. and Hrma, P. Foaming in glass melts produced by sodium sulfate decomposition under isothermal conditions. Journal.of.the.American.Ceramic.Society. v. 74 (Mar. '91):551-555, 1991.

2319. Kim, D. Crystallization in simulated glasses from hanford high-level nuclear waste composition range. (Unknown Journal!) : (12 p), 1993.

2320. Kim, D.S. and Hrma, P. Foaming in Glass Melts Produced by Sodium-Sulfate Decomposition Under Ramp Heating Conditions. J.AMER.CERAM.SOC. 75:2959-2963, 1992.

2321. Kim, N.D. and Hill, S.J. Sorption of Lead and Thallium on Borosilicate Glass and Polypropylene - Implications for Analytical-Chemistry and soil Science. ENVIRON.TECHNOL. 14:1015-1026, 1993.

2322. Kim, S., Birnie, D.I., and Uhlmann, D. Early-stage microstructure development in Bi-Sr-Ca-Cu-O glasses. Journal of. the.American.Ceramic.Society.v.76.n.12.Dec.1993.p.3087-3092. , 1993.

2323. Kim, S., Lee, N., and Ra, Y. Formation mechanism of FesosisB12 metallic glass. Journal. of.Materials.Science v. 26 (Nov. 15 191):6011-6015, 1991.

2324. Kingston, H., M., ; Lutz, G., J., and X adsorption and stability prior to analysis of simulated nuclearX waste leachatex. Nucl.Chem.Waste Manage., 3, 245-9X-9X, 1994.

2325. Kinner, J., Tittmann, E., and Holl, F. Interaction of feedrate, waste composition, and power input inX electrically heated hlw glass furnaces. In: High Level Radioactive waste and Spent Fuel Management Proc 1989 JointX 'Int Waste Manage Conf $v 2$ (of 2). Publ by American Soc of MechanicalX Engineers (ASME), New York, NY, USA.p 279-283, Anonymous New York, NY, USA:American Soc of MechanicalX Engineers (ASME), 1989,p. 279-283.

2326. Kinoshita, K., ; Kakuya, E., and X stabilizing solidification.i: a method of immobilization ofx radioactive waste involving volume reductionx. Proc.Symp. Waste Manage., (2), 171-6X-6X, 1994. 
2327. Kinoshita, M., Nagata, I, and Terai, R. Preparation of glass containing high-level radioactive wastes (simulated)--copper composite compacts formed by a continuouspressure-sintering method. Funtai Oyobi Funmatsuyakin, 1981.

2328. Kinoshita, M., Toyota, C., and Terai, R. Pressure sintering of copper-glass mixtures. Funtai Oyobi Funmatsuyakin , 1978.

2329. Kinoshita, M., Harada, M., and Sato, Y. Percolation phenomenon for dissolution of sodium borosilicate glasses in aqueous solutions. Journal of. the American. Ceramic. Society.v. 74. (Apr. '91) .p.783-7.bibl.diag.

2-7820, 1991 .

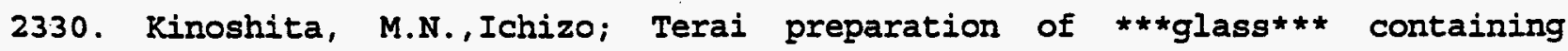
highlevelX ***radioactive*t* $* * *$ wastes*** (simulated)-copper compositeX compacts by a continuous pressure sintering methodx. Funtai oyobi Funmatsuyakin, 28, 231-6X-6X, 1994.

2331. Kiriyama, Y.F.,Takashi; Kato characteristics of potential borosilicate **glass***X compositions for high-level waste solidification in severalX countriesX. Report, Jaeri-M-8915, 57 pp, 1981.

2332. Kirkbride, R.A. Evaluation of Minimum-Fluidizing Velocity Correlations for Bed Particles Used in Fluidized-Bed Calcination Processes. (Unknown Journal!) , 1988.

2333. Klein, M., ; Weyers, C., ; Goossens, W., R., A., and X off-gas cleaning of a liquid waste vitrifierx. Corm. Eur.Communities, Eur, Eur 10580, Gaseous Efflu-89X, 1994.

2334. Klein, M., ; Weyers, C., ; Goossens, W., R., A., and X volatilization and trapping of ruthenium in high temperaturex processesx. Proc.Doe Nucl.Air Clean.Conf., Volume Date 1982, 17th, X 371-8-80x, 1994.

2335. Klein, M., ; Weyers, C., ; Goossens, W., R., A., and $\mathrm{X}$ behavior of ruthenium, cesium, and antimony in high temperaturex processes for waste conditioningx. Radioact.Waste Manage.Nucl.Fuel Cycle, 6, 255-76x-76x, 1994.

2336. Klein, M., ; Weyers, C., ; Goossens, W., R., A., and X the behavior of ruthenium, cesium and antimony during simulated hllwX vitrificationX. Proc.Doe Nucl.Airborne Waste Manage.Air Clean.Conf., Volume DateX 1984, 18th, $702-31 X-31 X, 1994$.

2337. Klein, R.F., Siemens, D.H., and Kuruzar, D.L. Waste Canister Closure Welding Using the Inertia Friction Welding Process. (Unknown Journal!), 1986.

2338. Kleykamp, H. Materialforschung im Kernforschungszentrum Karlsruhe. Bericht zum 25jaehrigen Bestehen des Instituts fuer Material- und Festkoerperforschung. (Materials research in the Nuclear Research Centre Karlsruhe. Report on 25 years' existence of the Institute for Material and Solids Research). (Unknown Journal!), 1990.

2339. Kline, R. Magnetic studies of the manganese oxide aluminosilicate glass system, Wayne State University, 1974. 
2340. Klinger, L.M. and Abellera, P.L. Joule-Heated Glass Furnace Processing of a Highly Aqueous Hazardous Waste Stream. (Unknown Journal!), 1989.

2341. Klingler, I., M., ; Abellera, P., I., and X glass furnace processing of rocky flats plant wastes: an evaluationx. Report, MIm-3493; Order No.De88010333, 58 pp, 1988.

2342. Klingler, L.M. and Abellera, P.L. Glass Furnace Processing of Rocky Flats Plant Wastes: An Evaluation. (Unknown Journal!), 1988.

2343. Klingler, L.M. and Armstrong, K.M. Evaluation of Operating Experience for Low-Level Nuclear Waste Processing. Glass Furnace Project Final Report. (Unknown Journal!) , 1985.

2344. Klingler, L.M. and Armstrong, K.M. Application of a Glass Furnace System to Low-Level Radioactive and Mixed Waste Disposal. (Unknown Journal!) , 1986.

2345. Klingler, I. Joule-heated glass furnace processing of a highly aqueous hazardous waste stream /, [Miamisburg, Ohio] : springfield, Va. :Mound ; available from National Technical Information Service, 1989.

2346. Knabenschuh, J., L., ; Hannum, W., H., ; Carrell, J., R., and X waste conversion approach for the west valley demonstration projectx. Fuel Reprocess.Waste Manage., Proc.- Am.Nucl.Soc.Int.Top.X. Meet., Volume 1, 161-75:ark, Ill, 1994 .

2347. Knabenschuh, J.L., Englert, A.E., and Hannum, พ.H. West valley demonstration project - three years of progress. In: <CI> Volume 1. Waste Policies and Programs, High-Level Waste. $e v 1$. Publ by Univ of Arizona, Tucson, $A Z$, USA $p$ 4I-45,Anonymous Tucson, AZ, USA:Univ of Arizona, 1985,p. 41-45.

2348. Knabenschuh, J.L., Kannum, W.H., and Carrell, J.R. Waste conversion approach for the west valley demonstration project. In: $v$ 1. Publ by ANS, La Grange Park, IL, USA p 161-175,Anonymous La Grange Park, IL, USA:ANS, 1984,p. 161-175.

2349. Knapp, G., S., ; Veal, B., w., ; Paulikas, A., P., ; Mitchell, A., ; Lam, D., X J., ; Klippert, T., E., and X exafs studies of sodium silicate glasses containing dissolvedX actinidesX. Springer Proc.phys., 2, 305-7X-7X, 1994.

2350. Knapp, G.S., Veal, B.W., Lam, D.J., Paulikas, A.P., and Pan, H.K. Exafs studies of silicate glasses containing uranium. Materials Letters 2:253-256, 1984.

2351. Knauss, K.G., ; Bourcier, W.L., ; McKeegan, K.D., ;X Merzbacher, C.I., ; Nguyen, S.N., ; Ryerson, F.J., ; Smith, X.D., ; Weed, H.C., and ; Newton, I. dissolution kinetics of a simple analog nuclear waste glass as ax function of ph,time and temperatureX. Mater.Res.Soc.Symp.Proc., 176, 371-81X-81X, 1994.

2352. Knecht The idaho hlw technology program, progress in hlw disposal strategy and glass-ceramic waste form development. (Unknown Journal!) : (6 p), 1994. 
2353. Knecht, D., A., ; Berreth, J., R., and $x$ icpp high-level radioactive waste immobilization and wastex acceptanceX. Proc.Symp.Waste Manage., (Waste Manage.'89, Vol. 1), 751-9X-9X, 1994.

2354. Knecht, D.A. and Berreth, J.R. Management of defense high-level radioactive waste at the Idaho Chemical Processing Plant. (Unknown Journal!), 1989.

2355. Knecht, D.A., Berreth, J.R., Chipman, N.A., Cole, H.S., and Geczi, L.S. Scoping Studies to Reduce ICPP High-Level Radioactive Waste volumes for Final Disposal. (Unknown Journal!) , 1985.

2356. Knecht, D.A., Berreth, J.R., Chipman, N.A., Cole, H.S., Staples, B.A., and Kerr, W.B. Scoping studies to reduce icpp high-level radioactive waste volumes forX final disposal. In: <CI> Volume 2: High-Level Waste $v 2$. Publ'by Arizona Board of Regents, AZ, USA $p$ 463-469, Anonymous AZ, USA:Arizona Board of Regents, 1986, p. 463-469.

2357. Knecht, D.A., ; Berreth, J.R., and $X$ immobilization of idaho chemical processing plant high-level wastesx. Ber.Kernforschungsanlage Juelich, Juel-Conf-42 (Vol. I) , $X$ Proc:roc-Level Liquid WasteX, 1994.

2358. Knieper, J., Printz, H., and May, K. Solidification of aqueous solutions containing radioactive or toxicx wastesx. Ger.offen. :Division of Ger offe, 1994 .

2359. Knieper, J., Printz, H., and May, K. Solidification of an aqueous solution containing radioactive orX toxic waste materialsX. Ger. :Division of Ger 2,53, 1994 .

2360. Knight, J.R., Boersma, M.D., and Mahoney, J.L. Overview of the DKPF (Defense Waste Processing Facility) and a Discussion of Its Unique Technology. (Unknown Journal!) , 1987.

2361. Knowlton, D.E. and Bonner, W.F. Status, direction, and critical issues of waste treatment technology. In: <CI> Volume 5: Energy Conservation, Late Papers, Index Proceedings of the Intersociety Energy Conversion nngineeringx Conference 18th. Publ by AIChE, New York, NY, USA $p$ 2254-2259, Anonymous New York, NY, USA:AIChE, 1983,p. 2254-2259.

2362. Kobayashi, K. Structural interpretation of the low temperature reflow of borophosphosilicate glasses doped with arsenic. Glass.Technology. Glass Technol $\checkmark$ I J, 1989.

2363. Kobayashi, K.F., Tachibana, N., and Shingu, P.H. Amorphous Al-Cr alloys by mechanical grinding of rapidly solidified crystalline powders. Journal.of.Materials.Science J Mater Sci v 25 n 2, 1990.

2364. Koch, D. and Grupe, M. Heavy-Metal Sorption of a New Developed Porous Borosilicate Glass Suction Cup. Z.PFLANZ.BODENK. 156:95-96, 1993.

2365. Kochen, R.L., ; Navratil, J.D., and $X$ americium and plutonium removal from contaminated soilx. Radioact. Waste Manage., 6, 95-110X-110X, 1994. 
2366. Kocher, D.C. and Croff, A.G. Proposed Classification system for High-Level and Other Radioactive Wastes. (Unknown Journal!) , 1987.

2367. Koegler, S.S. Pilot-Scale Ceramic Melter 1985-1986 Rebuild: Nuclear Waste Treatment Program. (Unknown Journal!), 1987.

2368. Koegler, S.S. Vitrification technologies for Weldon Spring raffinate sludges and contaminated soils : Phase I report : development of alternatives /, Richland, Wash. :Pacific Northwest Laboratory, 1988.

2369. Koegler, S.S. and Mitchell, S.J. Evaluation of Liquid-Fed Ceramic Melter Scale-Up Correlations. (Unknown Journal!), 1988.

2370. Koennecke, R. and Kirsch, J. EC (European Communities) Static High-Temperature Leach Test. Summary Report of an European Community Interlaboratory Round Robin. (Unknown Journal!) , 1985.

2371. Kohler, M. and Leckie, J.O. Neptunium(V) sorption on quartz and albite in aqueous suspension. Annual progress report. (Unknown Journal!) , 1991.

2372. Kohli, J.T., Condrate, R.A., and Shelby, J.E. Raman and Infrared-Spectra of Rare-Earth Aluminosilicate Glasses. PHYS.CHEM.GLASSES. 34:81-87, 1993.

2373. Kohn, S.C., Dupree, R., and Mortuza, M.G. NMR evidence for five-and six-coordinated aluminum fluoride. cormlexes in F-bearing aluminosilicate glasses. The.American.Mineralogist. v. 76 (Jan./Feb. 191:309-312, 1991.

2374. Kojima, T., Ohtani, T., Shimizu, T., and Furusawa, T. Effect of Coal Ash Properties and Burning Temperature on Behavior of Minerals with Vitrification and Sintering of Ash. FUEL.PROCESS. TECHNOL. $36: 129-135,1993$.

2375. Kokubu, $T$. and Yamane, M. Incorporation of transition metal in porous glass-ceramics of TiO//2-SiO//2 system. Journal.of.Materials.Science J Mater Sci v 25 n $6,1990$.

2376. Kokubu, T., Matsuyama, T., and Yamane, M. Uranium adsorption capacity of tio//2-sio//2 porous glass-ceramics. Nippon Seramikkusu Kyokai Gakujutsu Ronbunshi/Journal of the CeramicX Society of Japan 99:763-767, 1991.

2377. Kolitsch, A., ; Richter, E., and $X$ corrosion behavior of alkali ***silicate*** ***glass*** inX mineral acid modified by alkaline earth elementsx. Met.Corros., Proc.: Int.Congr.Met.Corros./, 8th, volume 2,x $16: 1646-9$, 1994 .

2378. Kolitsch, A.R.,EdgarX properties of highly-radioactive glassesX. Silikattechnik, 34, 146-50X-50X, 1994.

2379. Kolodziejski, W., Fornes, V., and Corma, A. Solid-state MMR-Study of Ultrastable Zeolite-Y Modified with Orthophosphoric Acid. SOLID.STATE.NUCL.MAGN.RESON. 2:121-129, 1993.

2380. Komarneni, S. and Roy, R. Alternative radwaste solidification route for Three Mile Island wastes. J.Am.Ceram.Soc. 65[N 12]:C198, 1982. 
2381. Komarneni, S. and Roy, R. Hydrothermal reaction and dissolution studies of csalsi sub $5 \circ$ sub 1 sub. 2 in water and brines. J.Am.Ceram.Soc. , 1983.

2382. Romameni, S. Phillipsite in cs decontamination and immobilization. Clays and Clay Minerals 33:145-151, 1985.

2383. Komarneni, S., ; Freeborn, W., P., ; Scheetz, B., E., ; White, W., B., ;X McCarthy, G., J., and $X$ reaction and devitrification of a prototype nuclear-waste-storageX ***glass*** with hot magnesium-rich brineX. Report, Onwi-305; Order No.De83002639, 67 pp, 1983.

2384. Komarneni, S.R.,RustumX hydrothermal reaction and dissolution studies of cesium aluminumx $* * *$ silicate*** (csalsi5012) in water and brinesX. J.Am.Ceram.SoC., 66, 471-4X-4X, 1994 .

2385. Komarneni, S. strontium-basalt reactions under nuclear waste repositoryx conditions.X. Mater.Res.SOC.Symp.Proc., 6,X 389-95X-95X, 1994.

2386. Komarneni, S.W.,William B. and $X$ alteration of cesium aluminum ***silicate*** (csalsio4) inX hydrothermal fluidsX. Nucl.Chem.Waste Manage., 3 , $169-72 X-72 X, 1994$.

2387. Komatsu, F., Takusagawa, A., Wada, R., and Asahina, K. Application of microwave treatment technology for radioactive wastes. Waste Management $10: 211-215,1990$.

2388. Komatsu, T., Kuken, Y., Matsusita, K., Kasuga, T., and Abe, Y. Kinetics of nonisothermal crystallization of $\mathrm{Bi} / / 2 \mathrm{Sr} / / 2 \mathrm{CaCu} / / 20 / / \mathrm{x}$ glasses with different copper valence states phase separation and crystallization of BisrCaCu $/ / 2 \mathrm{Al} / / 0 / / . / / 50 / / \mathrm{x}$ glass. Journal. of the. American. Ceramic. Society.v.76.n.11.Nov.1993.p.2795-2800.Journal. of.the.American.Ceramic.Society.v.76.n.7.Jul.1993.p.1885-1887. , 1993.

2389. Komatsu, T., Shioya, K., and Matusita, K. Fabrication of transparent tellurite glasses containing potassium niobate crystals by an incorporation method. Journal.of.the.American.Ceramic.Society. Journal of the Ameri, 1993.

2390. Konaicheva, N.V., Buler, P.I., and Myakin, V.K. Reaction of Lead Borate glass with Aluminum and IronNickel XAlloys. Journal.of.applied.chemistry. of.the.USSR. 63, Number 3- Part 2:640-643, 1990.

2391: Kondos, P. Kinetics of volatilization of sodium borate melts : a thesis, 1983 .

2392. Kondos, P. The dissolution of rising helium bubbles in a soda-lime-silica glass melt : a dissertation /, Potsdam, NY :Department of Chemical Engineering, Clarkson University, 1993.

2393. Konopkova, B.H.,Lenka; Rybarikova methods for determining the hydrolytic durability of glasses forX radioactive-waste immobilizationx. Sb.Vys.Sk. Chem.-Technol.Praze, Chem.Technol.Silik., L14,X 121-40X-40X, 1994. 
2394. Konovalov, E.V., Lastov, A.I., Malumyan, I.V., Davydov, V.V., Plyukhov, and Samarin, E.N. Ecologically safe localization of radioactive alkali metal wastes. Atomnaya Energiya 70:307-310, 1991.

2395. Konstantinovich, Kulichenko, Bel'tyukov, X, N.A.., Nikipelov, Stepanov, Baskov, and $x$, K.S.. Features of a process for vitrifying radioactivex waste without precalcination and radionuclide behavior inx. Manage.Radioact.Wastes.Nucl.Fuel.Cycle -95, 1994.

2396. Koo, B., No, K., and $\mathrm{Kim}, \mathrm{H} . \mathrm{AC}$ complex impedance investigation for RuO//2-glass composites IEEE

Trans. Compon.Hybrids. Manuf. Technol.v.14.n.3.Sep. 1991. Publ.by. IEEE, . IEEE

Service.Center,. Piscataway,..NJ, .USA,.1991.p.580-584. , 1991.

2397. Koploy, M., Schlafer, W., Urias, P., Zimmer, A., and warrant, M.M. Analysis of the dhlw cask under normal and hypotheticalx accident-condition loads with initial pressure. In: International Atomic Energy Agency, Proceedings Series $718 \vee 2$. Publ byX IAEA, Vienna, Austria p 525-527, Anonymous Proceedings Series $718 \vee 2: 1987, p$. 525-527.

2398. Koppenaal The impact of safety analyses on the design of the hanford waste vitrification plant. (Unknown Joumal!) : (9 p), 1993.

2399. Korenkov, A.P. Classification of Solidified Radioactive-Waste: AT. ENERGY-ENGL.TR. 73:649-651, 1992 .

2400. Korenkov, A.P. Basic Concepts of Reliability Assessment of Solid Radioactive-Waste Disposal. AT. ENERGY-ENGL.TR. 73:603-606, 1992.

2401. Kou, T. and Asano, M. Mass spectrometric study of vaporization in the sro-b//2 o//3 system. High Temperature Science 24:1-19, 1987.

2402. Kowada, Y., Adachi, H., Tatsumisago, M., and Minami, T. Application of the Dv-X-Alpha Cluster Method to Calculations of the Electronic-structure of Silicate and Phosphate-Glasses. J.NON-CRYST.SOLIDS. 150:318-321, 1992.

2403. Kozhina, E.L. and Shakhmatkin, B.A. Thermodymamic Properties and the Chemical structure of Lithium XBorosilicate Melts. The.Soviet.journal. of.glass.physics.and.chemistry. 16, Number $3: 1-197,1991$.

2404. Kozhukharov, V., Stoyanova, G., Danova, D., and Atanasov, S. Quantitative Chemical-Analysis of Borosilicate Glasses by the Inductively Coupled Plasma Atomic Emission-Spectroscopy Method. J.MATER.SCI.LETT. 11:1702-1704, 1992.

2405. Krause Solidification of high-level radioactive wastes in glass and ceramics. Enviceram '88, 1989.

2406. Krause, C. and Luckscheiter, B. Properties and behavior of the platinum group metals in the glass resulting from the vitrification of simulated nuclear fuel reprocessing waste. Journal. of.materials.research. 6, Number 12:2530-2535, 1991.

2407. Krause, H. Consolidation of highly radioactive wastesX. CHEM-ING-TECH. -Ing-Tech, 1994. 
2408. Krause, H. Final Conditioning of High-Level Liquid Radioactive Waste. (Unknown Journal!) , 1981.

2409. Krause, $H$. and $X$ final conditioning of high level fission product solutionsX. Atw, Atomwirtsch., Atomtech., 27, 618-21X-21X, 1994.

2410. Krech, R.H., Gauthier, M.J., and Caledonia, G.E. High velocity atomic oxygen/surface accommodation studies. Journal.of.Spacecraft.and.Rockets. Journal of Spacecraf, 1993.

2411. Krikorian, O.H., Condit, R.H., Fontes, A.F., Morris, W.F., and Magana, J.W. Study of plutonium volatility under microwave melting conditions used for glass encapsulation of plutonium sludge wastes: An interim report. (Unknown Journal!) , 2992.

2412. Krikorian, O.H., Condit, R.H., Fontes, A.S., Morris, W.F., and Magana, J.W. Study of plutonium volatility under microwave melting conditions used for glass encapsulation of plutonium sludge wastes: Final report. Progress rept. (Unknown Journal!) , 1993.

2413. Krischer, A., ; Simon, R., A., and $X$ results of a round robin leaching test for $\star * *$ vitrified $* * * X * * *$ radioactive $* * * * *$ waste $* * * X$. Riv.stn.Sper.Vetro (Murano, Italy), 14, 179-84X-84X, 1994.

2414. Kriven, w. Possible alternative transformation tougheners to zirconia: crystallographic aspects. Journal.of.the.American.Ceramic.Society. J Am Ceram Soc $v 71,1988$.

2415. Krol, D.M. and Rommers, P.J. Oxidation-reduction behaviour of antimony in silicate glasses prepared from raw materials and cullet. Glass.Technology. $v$. 25 (Apr. '84): $115-118,1984$.

2416. Kroth, K., ; Schaedlich, W., and X .gamma.-scanning as a new method for controlling the quality ofx borosilicate. $\star * *$ glass*** blocks from the solidification ofx highly-active wastex. Report, Juel-1641, 34 pp, 1980.

2417. Kroth, K., ; Schaedlich, W., and X .gamma.-scanning as a new method for controlling the quality ofx borosilicate ***glass** blocks from the solidification of highx active wastex. Ber.Kernforschungsanlage Juelich, JuI-1641, $38 \mathrm{pp}, 1994$.

2418. Krug, G., Lahr, H., and Vornhusen, H. Disposal of radioactive wastes by conversionX into phosphate glass X. Ger.Offen. , 1994.

2419. Krug, G., Lahr, H., and Vornhusen, H. Isolation of radioactive wastes by phosphateX glass X. Ger.Offen. , 1994 .

2420. Kruger Hanford waste vitrification plant applied technology plan. (Unknown Journal!) : (36 p), 1992.

2421. Kruger, O.I. Hanford Waste Vitrification Plant Applied Technology Plan. (Unknown Journal!) , 1992. 
2422. Kruger, O.L. and Peterson, M.E. Control of the Reduction/Oxidation Potential of Hanford Waste Vitrification Plant Feeds. (Unknown Journal!) , 1988.

2423. Krumhansl, J., L., ; Sundberg, W., D., and X conasauga near surface heater experiment.implications for ax repository sited in a water-saturated argillaceous formationx. Report, Sand-79-1474C, Conf-790938-3, 10 pp, 1980.

2424. Krumbansl, J., I., ; Sundberg, พ., D., and $x$ the conasauga near surface heater experiment -'implications for ax repository sited in a water-saturated argillaceous formationx. Proc.Workshop Use Argillaceous Mater.Isol.Radioact. Waste, $X$ Meeting Date 1979, 129-38:aris, Fr, 1994.

2425. Krusinelbaum, L., Civale, L., Blatter, G., Marwick, A.D., Holtzberg, F., and Feild, C. Bose-Glass Melting in YBaCuo Crystals with Correlated Disorder. PHYS.REV.LETT. 72:1914-1917, 1994 .

2426. Krylova, N., V., ; Kulichenko, V., ; Salamatina, R., N., and $x$ thermal history influence on the properties of $* * *$ vitrified $* * \star X$ high-level

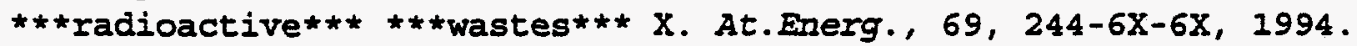

2427. Krylova, N., V., ; Salamathina, R., N., ; Shavruk, V., ; Yuzvikova, M., $A$. , and $X$ possible leaching of long-lived radionuclides from phosphate glassesX used for radioactive waste fixation into stratal water of graniticx formationsx. At. Energ., 69, 303-6X-6X, 1994.

2428. Kubarewicz Performance of a feasibility study for remediation of wag 6 at oak ridge national laboratory. (Unknown Journal!) : (7 p), 1992.

2429. Kuchinski, F.A. the effect of lead species on the durability of simulated nuclearX waste glassX. Diss. Abstr. Int. B. 1988282 pp-70X, 1994.

2430. Kuhn, K.D., Kunz, w., and Gruenewald, w. Vitrification of high level waste in the frg. development and operationx of the pamela process. In: High Level Radioactive Waste and Spent Fuel Management Proc 1989 JointX Int Waste Manage Conf $v 2$ (of 2). Publ by American Soc of MechanicalX Engineers (ASME), New York, NY, USA.P 111-117,Anonymous New York, NY, USA:American Soc of Mechanicalx Engineers (ASME), 1989,p. 111-117.

2431. Kuhn, W., L., ; Toland, M., R., ; Pulsipher, B., A., and X process simulation and statistical approaches for validating wastex form qualification modelsX. Report, Anl-6699; Order No.De89013342, 198 pp, 1989.

2432. Kuhn, W.I. and Peters, R.D. Leach models for a commercial nuclear waste glass. In: Materials Research Society Symposia Proceedings $v$ 15 . Publ by ElsevierX Science PubI Co,New York,NY, USA and Amsterdam,Neth $p$ 167-174,Anonymous New York, NY, USA:ElsevierX Science Publ Co, 1983,p. 167-174.

2433. Kuhn, W.L., Reimus, P.W., Peters, R.D., and Pulsipher, B.A. Method for Qualifying Canisters of Vitrified High-Level Waste for Disposal. (Unknown Journal!) , 1986.

2434. Kuhn, W.I. and Slate, S.C. Using process instrumentation to obviate destructive examination ofX canisters of hlw glass. In: <CI> Volume 1: Waste 
Regulations and Programs: High-Level Waste Proceedings of the Symposium on Waste Management PubI by Univ ofX Arizona, Tucson, AZ, USA $p$ 121-126, Anonymous Tucson, AZ, USA:Univ ofX Arizona, 1983,p. 121-126.

2435. Kuhn, W.I., Toland, M.R., and Pulsipher, B.A. Process Simulation and Statistical Approaches for Validating Waste Form Qualification Models. (Unknown Journal!) , 1989.

2436. Kuhn, W.L., Westsik, J.H.J., and Plodinec, M.J. Application of stochastic dynamic simulation to waste formx qualification for the hwvp vitrification process Establishing the acceptability of savannah river site waste glass. In: High Level Radioactive Waste and Spent Fuel Management Proc 1989 Jointx Int Waste Manage Conf $\checkmark 2$ (of 2). Publ by American Soc of Mechanicalx Engineers (ASME), New York, NY, USA.p 187-192 High Level Radioactive Waste and Spent Fuel Management Proc 1989 Jointx Int Waste Manage Conf $v 2$ (of 2). Publ by American Soc of MechanicalX Engineers (ASME), New York, NY, USA.p 181-186, Anonymous New York, NY, USA:American Soc of MechanicalX Engineers (ASME), 1989,p. 181-186.

2437. Kuhn, W.I., ; Peters, R.D., ; Simonson, S.A., and $X$ development of a leach model for a commercial nuclear wasteX $* \star \star$ glass $* \star * X$. Nucl.Technol., 63 , $82-9 X-9 X, 1994$.

2438. Kuhn, w., Peters, R., and Simonson, S. Development of a leach model for a commercial nuclear waste glass. Nuclear. Technology. :863-867, 1983.

2439. Kuhn, w., Peters, R., and Simonson, S. Development of a leach model for a commercial nuclear waste glass. Nuclear. Technology. v. 63 (Oct. '83):82-89XPY - 1983, 1994.

2440. Kulichenko, Krylova, and Musatov Thermal, chemical, and radiation stability of vitrifiedx radioactive waste X. Manage.Radioact. Wastes.Nucl.Fuel.Cycle -84, 1994 .

2441. Kulichenko, V.V., Savel'ev, V.F., Prokhodtsev, V.A., and Ryabova, A.A. Calculation of model high-level wastes in a horizontal apparatus. Soviet Atomic Energy $56: 314-318,1984$.

2442. Kulp, D.T., Ackland, G.J., Sob, M., Vitek, V., and Egami, T. Many-Body Potentials for Cu-Ti Intermetallic Alloys and a Molecular-Dynamics Study of Vitrification and Amorphization. MODEL.SIMUL.MATER.SCI.ENG. 1:315-333, 1993.

2443. Kumar Improved treatment/disposal of reactive metals. (Unknown Journal!) : (19 p), 1991 .

2444. Kumar, A. Palladium-catalyzed sintering of molybdenum paste applied to multilayer substrate Proceedings.-.Electronic. Components.and.Technology.Conference. Proceedings Electr, 1993.

2445. Kumar, B. Redox state of iron and its related effects in the CaO-P2O5-Fe2O3 glasses. Journal of the. American. Ceramic. Society.v.74. (Jan. '91) .p.226-8.bibl. diags.

2-7820, 1991. 
2446. Kumar, R., ; Helt, J., E., and X improved treatment/disposal of reactive metals: phase 2, technicalX research and developmentX. Report, Doe/Hwp-92, AnI-91/21; Order No.De91015097, 19 pp, 1991.

2447. Kumata, M., Murakami, T., and Muraoka, S. Hydrothermal Interactions Between Simulated High-Level waste Glass and Rocks at $300 \mathrm{deg}$ C, 30 MPa. (Unknown Journal!) , 1985.

2448. Kummerlen, J., Merwin, I., and Sebald, A. Structural role of H2O in sodium silicate glasses: results from $29 \mathrm{Si}$ and $2 \mathrm{H}$ MMR spectroscopy. The. Journal. of. Physical. Chemistry. v. 96 (July 23 '92):6405-6410, 1992.

2449. Kumta, P.N. and Sriram, M.A. Novel low-temperature synthesis of glasses and glass-ceramics in the B2O3-SiO2-P2O5 system. Journal.of.Materials.Science v. 28 (Feb. 15 '93):1097-1106, 1993.

2450. Kung-Cheh Li Use of fly ash in solidification of metal-bearing sludges. In: $v$ 3, 10p, Anonymous 10p: 1987 ,

2451. Kuno, Y., Sato, S., and Masui, J. Online Determination of Iodine in Nuclear-Fuel Reprocessing off-Gas Streams by a Combination of Laser-Induced Fluorometry and Laser Photoacoustic-Spectroscopy. ANAL.CHIM.ACTA 270:181-186, 1992.

2452. Kupfer Fixation of hanford alkaline radioactive wastex liquors by conversion to glass X. Report. , 1979.

2453. Kupfer Vitrification of hanford bismuth phosphate and uranium recoveryx process sludgesX. Report. , 1979.

2454. Kupfer and Schulz Endothermic process.application to immobilization of hanfordx in-tank solidified wastex. Report. , 1974.

2455. Kupfer and Schulz Fixation of hanford sludge by conversion to glassx. Report. , 1977.

2456. Kupfer and Schulz, W. High-temperature processes for immobilization of hanford in-tankx solidified wastex. Report. , 1973.

2457. Kupfer, M., Schulz, พ., Hobbick, C., and Mendel, X Glass. forms for alpha waste managementX. Aiche.Symp.Ser. :Ser, 72(154, Radioac-Ser, 72 (154, Radio $7 X$, 1994.

2458. Kupfer, M., J., and $X * \star \star v i t r i f i c a t i o n * \star *$ of hanford radioactive defense wastesX. Report, Rho-Sa-89, Conf-790420-17, 18 pp, 1979.

2459. Rupfer, M.J. Costs and Impacts of Retrieval and Processing of Wastes from Selected Single-Shell Tanks. (Unknown Journal!) , 1987.

2460. Kupfer, M.J. Disposal of Eanford site tank wastes. (Unknown Journal!) , 1993 .

2461. Kurath Cesium removal from hanford tank waste. (Unknown Journal!) : (29 p), 1993 . 
2462. Kurath, D.E., Richmond, W.G., Jones, E.O., Bray, I.A., and Bunker, B.C. Cesium removal from Hanford tank waste. (Unknown Journal!), 1993.

2463. Kurihara, Y., Takahashi, S., Yamada, K., Endoh, T., and Kanai, K. Thick film resistors for AIN ceramics. IEEE Transactions.on. Components, .Hybrids.and.Manufacturing.Technology. $14 \quad \mathrm{n}$ $1: 199-203,1991$.

2464. Kurkumeli, A., Molokhov, M., Sadkovskaya, O., Kononov, V., Borisov, Savel'ev, V., and Kachurin, A. The use of micro-wave energy on the retreatment high-level wastes. Atomnaya Energiya 73:210-215, 1992.

2465. Kushnikov, V., V., ; Matyunin, Y., I., ; Krylova, N., and X alpha-emitting radionuclide behavior during high-level radioactivex waste solidificationx. At.Energ., 70, 239-43X-43X, 1994.

2466. Kutub, A.A. and Elmanharawy, M.S. Gamma irradiation-induced effects in sodium diborate glasses doped with some transition metals. Journal.of.Materials.Science v, 26 (July 15 '91):3964-3968, 1991.

2467. Kwon, C. Spin glass with two replicas, statics and dynamics, 1989.

2468. Kyrs Annual report 1990. (Unknown Journal!) : (108 p), 1991.

2469. Kyrs, M. Annual report 1990 (Ustav Jaderneho Vyzkumuj). Progress rept. (Unknown Journal!), 1991.

2470. Kyrs, M.S.,MarieX effects of matrix on the leachability of nuclear waste. formsX. Jad.Energ., 33, 93-8X-8X, 1994.

2471. L.A.zellmer and W.B.White BT - Leaching Mechanisms CT - Characterization of Hydrated Surface Layers on Nuclear Waste Glasses by Infrared Reflectance Microscopy.ED - Carol M.Jantzen ED - John A.Stone ED - Rodney C.Ewing Anonymous 1985, p. 73-80.

2472. L.H.Cadoff, J.M.Pope, and S.M.Barnes BT - Vitrified Waste Forms CT Properties of the West Valley Waste Form ED - Dillard B.Shipler ED - C.R.Allen Anonymous 1990,p. 1086-1094.

2473. L.I.Hench Characterization of Glass Corrosion and Durability. Journal.of.Non-Crystalline.Solids. 19:27-39, 1975.

2474. L.I.Hench and D.E.Clark Physical Chemistry of Glass Surfaces. Journal.of.Non-Crystalline.Solids. 28:83-105, 1978.

2475. I.M.Gignacl, C.J.Altstetter2, and S.D.Brown1 BT - Leaching Mechanisms CT - A Nuclear Reaction Analysis Technique To Determine The Penestration of Hydrogenic Species into Glasses Exposed to Leaching Solutions.ED - Carol M.Jantzen ED - John A.Stone ED - Rodney C.Ewing Anonymous 1985,p. 107-112.

2476. I.O.WermeI, I.L.Hench2, and A.Lodding3 BT - Leaching Mechanisms CT Nuclear Waste Glass Interfaces After 1 year Burial in Stripa ED - Carol M.Jantzen ED - John A.Stone ED - Rodney C.Ewing Anonymous 1985,p. 37-44. 
2477. La Barge Ust-id critical path, number 2, may--september 1992. (Unknown Journal!) : (24 p), 1993.

2478. Lackey, พ., J., ; Angelini, P., ; Layton, F., L., ; Stinton, D., P., ;X

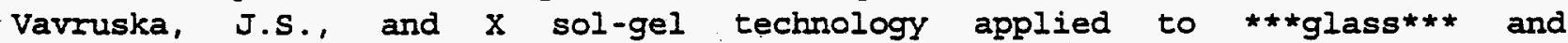
crystallineX ceramicsX. Proc.Symp. Waste Manage., (2, Waste Manage.'80: State WasteX Disposal Technol., Mill Tailings, Risk Anal.Models), 391-417X-417X, 1994.

2479. Lackey, W., J., ; Blanco, R., E., ; Lotts, A., L., and X application of sol-gel technology to fixation of nuclear reactorx wastex. Nucl.Technol., 49, $321-4 \mathrm{X}-4 \mathrm{X}, 1994$.

2480. Lacy, A. Kinetics of the dissolution and diffusion of divalent cobalt oxide in sodium disilicate glass, 1966.

2481. LaFage, B. and Taxil, P. Titration of molten soda lime silicate glasses by square wave voltammetry. Journal.of.the.Electrochemical.Society. Journal of the Elect, 1993.

2482. Lahoda, E.J. solid siloxane formation with radioactive wastex. Eur.Pat.Appl., 5 pp, 1994.

2483. Lai, S.K. and Chen, H.C. The Structural and Dynamical Liquid-Glass Transition for Metallic Sodium. J.PHYS-CONDENS.MATTER. 5:4325-4342, 1993.

2484. Lakatos Vitrified waste from nuclear power reactorsX. Glastek.Tidskr. $-31 x, 1994$.

2485. Lakatos, T., Johansson, L.G., and Simmingskoeld, B. Effects of Li2O and B203 in soda-lime-silicated (crown) glass on viscosity, 1975.

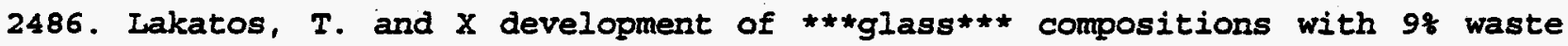
contentx for the $* \star \star v i t r i f i c a t i o n * \star *$ of high-level waste from 1 wr nuclearX reactorsX. Report, Skbf/Kbs-Tr-79-24, 20 pp, 1980.

2487. Laktos Resistance of borosilicate glassX. Report. , 1978.

2488. Lam, D., J., ; Veal, B., พ., ; Chen, H., ; Knapp, G., S., and X bonding

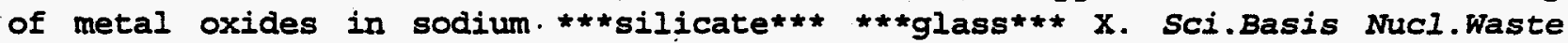
Manage., , MeetingX Date 1978, 97-107:lenum: NewX York, 1994.

2489. Lamar [the 5th department of energy/power reactor and nuclear fuel development corporation vitrification workshop]. (Unknown Journal!) :(216 p), 1915.

2490. Lamastro, R. Compositional and structural factors affecting the chemical durability of some cadmium-containing glasses under acetic acid attack /, 1982 .

2491. Lambert, D.P., Shah, H.B., Young, S.R., Edwards, R.E., and Carter, J.T. steam stripping of polycyclic aromatics from simulated high-level radioactive waste. (Unknown Journal!), 1992. 
2492. Lammertz, H., Merz, E., and Halaszovich, S. Technetium volatilization during hllw vitrification. In: <CI> Held as part of the Fall Meeting of the Materials ResearchX Society Materials Research Society Symposia Proceedings $v$ 44. Publ by MaterialsX Research Soc,Pittsburgh, PA, USA $p$ 823-829, Anonymous Pittsburgh, PA, USA:MaterialsX Research SOC, 1985,p: 823-829.

2493. Lampe, R.F. Radioactive Waste Disposal Package. Patent Application. (Unknown Journal!) , 1985.

2494. Landa, E.R. and Bush, C.A. Geochemical hosts of solubilized radionuclides in uranium millx tailings. Hydrometallurgy 24:361-372, 1990.

2495. Landau, B., Russillo, A., Frank, D., and Garland, D. Design, construction, and operation of the Integrated Radwaste Treatment System (IRTS) Drum Cell. (Unknown Journal!) , 1989.

2496. Landron, C. Transport processes in glasses on electron irradiation. Journal. of.Applied.Physics. v. 63 (Jan. 15 '88):586-587, 1988.

2497. Lane Annual report of tank waste treatability. (Unknown Journal!) :(178 p), 1993.

2498. Ianford Characterization of the reaction between water and soda-lime andx reactor waste glassesX. IEEE TRANS.NUCL.SCI. -9X, 1994.

24.99. Lange, P., Schnakenberg, U., and Ullerich, S. Disorder in vitreous SiO2: the effect of thermal annealing on structural properties. Journal.of.Applied.Physics. v. 68 (Oct. I '90):3532-3537, 1990.

2500. Lange, R.A. and Navrotsky, A. Heat-Capacities of Tio2-Bearing Silicate Liquids - Evidence for Anomalous Changes in Configurational Entropy with Temperature. GEOCHIM. COSMOCHIM.ACTA 57:3001-3011, 1993.

2501. Langlet, M., Saltzberg, M., and Shannon, R.D. Aluminum Metaphosphate Glass-Ceramics. J.MATER.SCI. 27:972-982, 1992 .

2502. Langton, C.A. Challenging Applications for Hydrated and Chemically Reacted Ceramics. (Unknown Journal!) , 1988.

2503. Langton, C.A. and Wilhite, E.I. Savannah River Plant Saltstone: Formulation Variability and Operating Limits. (Unknown Journal!) , 1988.

2504. Lanza and Parnisari Evaluation of long term leaching of borosilicate glassesX. Comm. Eur. Communities. , 1994.

2505. Lanza, F. Feasibility of Disposal of High-Level Radioactive Waste into the Seabed. Volume 8 . Review of Processes Near a Buried Waste Canister. (Unknown Journal!) , 1988.

2506. Lanza, F., Cambini, M., Della Rossa, M., and Pamisari, E. Investigation of the Form in Which Technetium is Retained in a XBorosilicate Glass Containing Simulated High Level Nuclear XWaste. Journal.of.trace and.microprobe. techniques. :257-266, 1992. 
2507. Lanza, $F$. and Ronsecco $C$ Influence of $a$ backfilling material on borosilicate glass leaching. In: Materials Research society Symposia Proceedings $v$ 11.Publ byX North-Holland, New York, NY, USA and Amsterdam, Neth p 125-133, Anonymous New York, NY, USA: 1982,p. 125-133.

2508. Lanza, F., ; Demicheli, J., ; Parnisari, E., and X development of a test method for leaching glasses immersed in porousX mediax. Eur.Appl.Res.Rep., Nucl.Sci.Technol.Sect., 5, 719-40X-40X, 1994.

2509. Lanza, F., ; Jacquet Francillon, N., ; Marples, J., A., C., and X methodology of leach testing of borosilicate glasses in waterx. Corm.Eur.Communities, Eur, Eur 6871, Radioact-40X, 1994.

2510. Lanza, F., ; Manaktala, H., ; Parnisari, E., and $X$ leaching of borosilicate $* \star \star$ glass $* \star *$ in confined systemsX. Eur.Appl.Res.Rep., Nucl.Sci.Technol.Sect., 5, 363-97X-97X, 1994.

2511. Lanza, F., ; Manara, A., ; Antonini, M., ; Van Rutten, F., and $\dot{X}$ a critical review of radiation effects on borosilicate glassesx. Ber.Kernforschungsanlage Juelich, Juel-Conf-42 (Vol. 2), $\mathrm{x}$ Proc:roc-Level Liquid Wastex, 1994.

2512. Lanza, F., ; Manara, A., ; Mammarella, L., ; Blasi, P., ; Ceccone, G., and $\mathrm{X}$ borosilicate $\mathrm{hlw}$ glass leaching in silica saturated solutionx. Mater.Res.Soc.Symp.Proc., 112, 685-91X-91X, 1994.

2513. Lanza, F., ; Parnisari, E., and $X$ influence of film formation and its composition on the leaching ofx borosilicate glassesx. Nucl.Chem. Waste Manage., $2,131-7 X-7 X, 1994$.

2514. Lanza, F., ; Parnisari, E., and $X$ the leaching of a plutonium-Ioaded

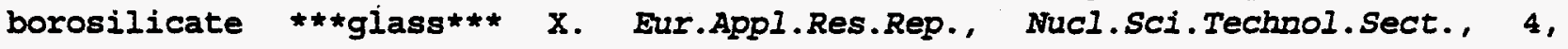
1151-69X-69X, 1994 .

2515. Lanza, F., ; Parnisari, E., and X evaluation of long-term leaching of borosilicate $* * *$ glass*** inx pure waterx. Ceram.Nucl.Waste Manage., Proc.Int. Symp., Issue Conf-790420, X 238-42-42, 1994.

2516. Lanza, F., ; Ronsecco, C., and $X$ influence of a backfilling material on borosilicate $* *$ glass $* \star x$ leachingx. Mater.Res.Soc.Symp.Proc., 11, X $125-33 X-33 X, 1994$.

2517. Lanza, F...; Saltelli, A., and $X$ an experimental and modeling approach of the near field release andx transport processesx. Mater.Res.Soc.symp.Proc., $26, \mathrm{X} 605-12 \mathrm{X}-12 \mathrm{X}, 1994$.

2518. Lanza, F.P.,EzioX release and diffusion in clay of elements leached from aX borosilicate glassX. Radiochim.Acta, 44-45, 225-9X-45, 225-9X, 1994 .

2519. Lapp, J. Alkali bismuth gallate glasses. American. Ceramic. Society.Bulletin.v.71. (Oct. '92) .p.1543-9.bibl.diags. $2-7812: 1543-9,1992$. 
2520. Lapp, J. and Shelby, J. Effect of small concentrations of gallium oxide on the structure of sodium silicate glasses. Journal. of. the.American.Ceramic.Society.VL.-.v.69. (July.'86). :C146-Cl47, 1986.

2521. Lapp, J. and Shelby, J. Acid durability of sodium and potassium galliosilicate glasses. Journal.of.the.American.Ceramic.Society. v. 70 (Apr. (87) :270?-2274, 1987 .

2522. Larker, H. Binding radioactive materials into a body resistant to leaching byx waterx. Ger. Offen. , 1994.

2523. Larker, H.T. Ceramic Encapsulation of Nuclear Wastes. (Unknown Journal!) , 1988 .

2524. Larkin, M.J. Development of highly active waste conditioning at sellafield. Nuclear Energy 25:343-354, 1986.

2525. Larson Hanford waste vitrification plant. (Unknown Journal!) :(24 p), 1991.

2526. Larson and Bonner High-level waste vitrification by spray calcination/in-can melterx. Proc.Symp. Waste.Manage. -761020XXX, 1976.

2527. Larson, Bonner, and et al.X High-level waste vitrification by spray calcination/in-can meltingx. Report. , 1977.

2528. Larson, D., E., ; Buelt, J., I., ; Heath, w., O., ; Partain, W., and X assessment of power reactor waste immobilization byX **tvitrification** $X$. Report, Epri-Np-3225; Order No.De84001893, 159 pp, 1984.

2529. Larson, D., F., ; Blair, H., T., ; Bonner, W., ; Garrett, A., A., ; Hanson, X.M., S., ; Romero, L., ; Siemens, D., H., and X conceptual design of a nuclear waste ***vitrification***X facilityX. Report, Pnl-2690, 69 pp, 1979.

2530. Larson, D.E., Allen, C.R., Kruger, O.I., and Weber, E.T. Hanford Waste Vitrification Plant. Technology overview. (Unknown Journal!) , 1991.

2531. Larson, D.E., Berger, D.N., Allen, R.P., Bryan, G.H., and Place, B.G. Electropolishing Decontamination system for High-Level Waste Canisters. (Unknown Journal!) , 1988.

2532. Larson, E.M., Lytle, F.W., Eller, P.G., Greegor, R.B., and Eastman, M.P. Xas study of lanthanide ion speciation in borosilicate glass. Joumal of Non-Crystalline Solids 116:57-62, 1990.

2533. Larson, R. Preparation and characterization of lithium phosphorus oxynitride $X$ glass, 1985.

2534. LaRue Permitting of the hanford waste vitrification plant. (Unknown Journal!) : (9 p), 1991.

2535. LaRue, J.H. and Cross, S.L. Permitting of the Hanford Waste Vitrification Plant. (Unknown Journal!), 1991. 
2536. Lasday, S. Potential of mechanically alloyed materials for components in thermal processing. Industrial.Heating. Industrial Heating v, 1993.

2537. Laser, Halaszovich, Merz, and Thiele Fips - a process for solidifying highly radioactive fission-productx solutionsx. Reaktortag. -81, 1994.

2538. Laude, Bonniaud, Sombret, and Rabot Confinement of radioactivity in glassX. Manage. Radioact. Wastes. Nucl. Fuel. Cycle $-48,1994$.

2539. Laude, F. Pot vitrification of concentrated fission product solutionsX. Aec.Access.Nos. , 1966.

2540. Laude, F., I., and $X$ french experience in $* * *$ vitrification** of

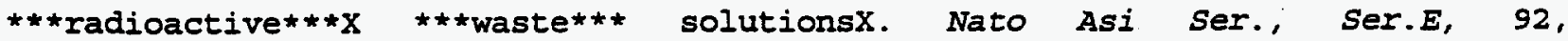
$638-55 X-55 X, 1994$.

2541. Laude, F.V.,Etienne; Saint Gaudens fracture appraisal of large scale ** glass*** blocks underX realistic thermal conditionsX. Mater.Res.Soc.Symp.Proc., 11,X 239-47X-47X, 1994.

2542. Laughlin, W. Dielectric relaxation of sodium metaphosphate glass, 1966.

2543. Lautensleger, A.W. Determination of Fission Product Noble Metals by Inductively Coupled Plasma Atomic Emission Spectrometry. (Unknown Journal!). 1983 .

2544. Lautensleger, A., W., ; Hara, F., T., and $X$ techniques for the quantitative analysis of fission-product noblex metalsx. Report, Pnl-3986; Order No.De82022212, 37 pp, 1982.

2545. Lavalette, D., Tetreau, C., Gavish, B., and Yedgar, S. Viscosity Dependence of Oxygen Escape from Respiratory Proteins as a Function of Cosolvent Molecular-Weight. BIOPHYS.J. 66:AlO, 1994.

2546. Lawson, M., Kim, B., Pettit, F., and Blachere, J. Hot corrosion of silica. Journal of.the.American.Ceramic.Society. J Am Ceram Soc v 73, 1990.

2547. Lazarev, L., N., ; Kuznetsov, Y., V., ; Shashukov, E., A., ; Aloi, A., S., ;X Kuznetsov, B., and X use of $* * *$ glass $* * *$-metal compounds and ceramic

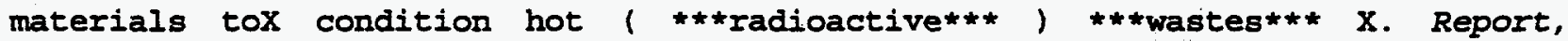
Rfp-Trans-405, 11 pp, 1983.

2548. Lazarev, L., N., ; Kuznetsov, Y., V., ; Shashukov, E., A., ; Aloi, A., S., ;X. Kuznetsov, B., and $X$ use of glass-metal composites and ceramic materials for fixation ofx high-level wastesX. Radioact.Waste Manage., Proc.Int.Conf., Meeting Date 1983, VolumeX 2, 2-305, 1994.

2549. Lazarev, L., N., ; Kuznetsov, Y., V., ; Shashukov, E., A., ; Krylov, L., I., ;X Tutov, A., G., ; Dolgov, V., ; Aloi, A., S., ; Dobrygin; P., ;X Romanovskii, V., ; et al., and $X$ development of processes for incorporation of

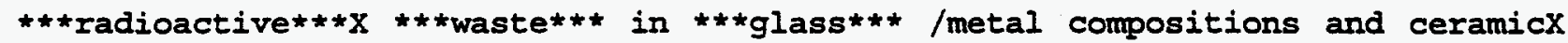
materialsX. Cond.Radioact. Wastes Storage Disposal, Proc.Int.Symp., MeetingX Date 1982, 253-63-63, 1994; 
2550. Lazarev, L., N., ; Lyubtsev, R., I., ; Galkin, B., Ya., ; Romanovskii, V., ;X Pryanishnikov, A., A., ; Kulichenko, V., V., ; Ageenkov, A., T., ; Kamenskii, X.A., M., ; Shashukov, E., and X ***vitrification** of liquid

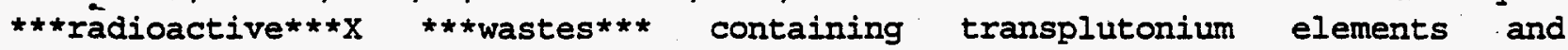
investigationx of the properties of solidified productsx. Radiokhimiya, 27, $488-90 X-90 X, 1994$.

2551. Lazarev, L.N., Kuznetsov, Y.V., Shashukov, E.A., Krylov, I.I., and Tutov, A.G. Development of Processes for the Inclusion of Radioactive Waste in Glass-Metal Compounds and Ceramic Materials. (Unknown Journal!) , 1984.

2552. Le Toullec, M., Simmons, C., and Simmons, J. Infrared spectroscopic studies of the hydrolysis reaction $x$ during leaching of heavy-metal fluoride glasses. Journal:of.the.American.Ceramic.Society. v. 71 (Apr. '88):219-224, 1988 .

2553. Lebeau, M. and Girod, M. Incorporation of simulated nuclear ashes in basalt: an experimentalx investigation. American Ceramic Society Bulletin $66: 1640-1646$, 1987 .

2554. Lebeau, M.J. Elaboration de materiaux vitreux et vitrocristallins basaltiques contenant des dechets de cendres radioactives simulees. Etude de quelques proprietes physiques et du comportement a la lixiviation. (Elaboration of vitreous and vitrocrystalline basalt materials containing simulated radioactive ash wastes. Study of some physical properties and leaching behaviour). Thesis. (Unknown Journal!), 1988.

2555. LeBlanc, J. How Brockway's lower checker sulfate test works. Glass. Industry.v.65. (Aug.10.'84).p.22-5.il. 17-1026, 1984.

2556. Ledermann, P., ; Pradel, P., ; Masson, H., and $x$ the quality of residues produced at la haguex. Proc.Int.Conf.Technol.Expo.Future Nucl.Syst.: Emerging FuelX Cycles Waste Disposal Options, Volume 1, 679-85:ark, Ill, 1994.

2557. Ledford, J., A., ; Williams, P., M., and X utilization of borosilicate ***glass*** for transuranic wastex immobilizationX. Report, Rfp-2915, Conf-790597-1, $10 \mathrm{pp}, 1979$.

2558. Ledford, J., A., ; Williams, P., M., and X utilization of borosilicate ***glass*** for transuranic wasteX immobilizationx. Ceram.Nucl.Waste Manage., Proc.Int.Symp., .Issue Conf-790420,X 338-41-41, 1994.

2559. Lee Formation rate of ammonium nitrate in the off-gas line of srat and sme in dwpf. (Unknown Journal!) : $(27 \mathrm{p}), 1925$.

2560. Lee, B. brighter future for nuclear wastes?X. New Sci., 90, 227-9x-9x, 1994 .

2561. Lee, C. Surface and solution chemistry of glass/water interactions, 1986.

2562. Lee, C. and Clark, D. Effects of solution cations on waste glass leaching. Adv. Ceram. 20:541-550, 1986. 
2563. Lee, C. and Clark, D. Role of colloid formation on waste glass leaching and surface layer formation. Adv. Ceram. 20:505-514, 1986.

2564. Lee, C., T., ; Clark, D., E., and X the role of colloid formation on waste glass leaching and surfacex layer formationx. Adv.Ceram., 20, 505-14X-14X, 1994 .

2565. Lee, C., T., ; Clark, D., E., and X effects of solution cations on waste glass leachingx. Adv.Ceram., 20, 541-50X-50X, 1994.

2566. Lee, C.-K. and Speyer, R.F. Glass formation and crystallization of barium ferrite in the Na2O-BaO-Fe2O3-SiO2 system. Journal.of.Materials.Science v. 29 (Mar. 1 '94):1348-1351, 1994.

2567. Lee, C.T. and Clark, D.E. Electrokinetics, adsorption and colloid study of simulated nuclearX waste glasses leached in aqueous solutions. In: <CI> HeId as part of the Fall Meeting of the Materials Researchx society Materials Research Society Symposia Proceedings $v$ 44. Publ by MaterialsX Research Soc, Pittsburgh, PA, USA $p$ 221-228,Anonymous Pittsburgh, PA, USA:MaterialsX Research Soc, 1985,p. 221-228.

2568. Lee, C.T., ; Clark, D., E., and X electrokinetics, adsorption and colloid study of simulated nuclearX waste glasses leached in aqueous solutionsX. Mater.Res.Soc.Symp.Proc., 44,X 221-8X-8X, 1994.

2569. Lee, L. Thermal Analysis of DWPF Canister during Pouring and Cooldown. (Unknown Journal!), 1989.

2570. Lee, L. Cesium Volatilization from a Filled DWPF Canister. (Unknown Journal!) , 1989.

2571. Lee, L. Spray nozzle pattern test for the DWPF HENE task technical plan. (Unknown Journal!) , 1991.

2572. Lee, L.M. prediction of waste glass melt ratesX. Proc.Symp.Waste Manage., (Waste Manage.' 87, Vol. 1), 591-3X-3X, 1994.

2573. Lee, S.W., Hong, K.S., Condrate, R.A., Hapanowicz, R.P., and Speyer, R.F. Characterization of Gas Components and Deposits in Bubbles in Silicate-Glasses Prepared with Sodium-Sulfate. J.MATER.SCI. 27:4961-4966, 1992.

2574. Lee, S.Y., Tamura, T., and Essington, E.H. Characteristics of radioactivity contamination of soil at the nevadax test site. Nuclear and Chemical Waste Management 7:179-190, 1987.

2575. Lee, S. and Condrate, R.A. Raman microprobe investigation of oxygen and carbon dioxide dissolution from bubbles in silicate glasses containing arsenic oxide. Journal. of.the.American.Ceramic.Society. J Am Ceram Soc v 73, 1990.

2576. Lee, S., Hong, K., and Condrate, R.A. Raman microprobe investigation of oxygen and carbon dioxide dissolution from bubbles in silicate glasses containing antimony oxide. Journal.of.Materials.science v. 26 (Aug. 1

'91.):4250-4254, 1991 . 
2577. Lee, W., Kondo, H., Hosono, H., and Abe, Y. Superconducting $\mathrm{Bi} / / 2 \mathrm{Sr} / / 2 \mathrm{Ca} / / 1 \mathrm{Cu} / / 20 / / 8 / /$ plus $/ / \mathrm{y}$ glass-ceramics with different melting histories.

Japanese. Journal of . Applied. Physics, . Part. 1 : . Regular. Papers.\&.Short. Notes.\&.ReV iew. Papers. Japanese Journal of, 1993.

2578. Lee, W.H.,Kang; Risen, , and $X$ actinide silicate binary glasses: low-temperature sol-gelX preparation of uranium and thorium silicate glassesx. J.Non-Cryst.Solids, 104, 123-8X-8X, 1994.

2579. Leedecke, C. Infrared and raman studies of a phase separated sodium silicate glass, Alfred, NY:New York state College of Ceramics at Alfred University, 1972 .

2580. Lefort, H., Selby, C., and Price, J.R. Soluble, vitreous ceramic coatings for decontaminating stainless steel canisters filled with radioactive glass. Ceram. Trans. 23:551-556, 1991.

2581. Legein, C., Buzare, J.Y., and Jacoboni, C. EPR Structural Investigations of Transition-Metal Fluoride Glasses (Tmfg). J.NON-CRYST.SOLIDS. 161:112-117, 1993.

2582. Lehman, R., L., ; Kuchinski, F., A., and $X$ the effect of various lead species on the leaching behavior ofX borosilicate waste glassX. Lead: Its Role Nucl.Waste Manage., Semin.Rep., Meeting Date 1984,X 47-53, 64-53, 64, 1994.

2583. Lehman, R.L. and Kuchinski, F.A. Effect of various lead species on the leaching behavior of borosilicatex waste glass. In: <CI> Held as part of the Fall Meeting of the Materials Researchx Society Materials Research Society Symposia Proceedings $v$ 44. Publ by MaterialsX Research Soc, Pittsburgh, PA, USA $p$ 179-186, Anonymous Pittsburgh, PA, USA:MaterialsX Research Soc, 1985,p. 179-186.

2584. Lehman, R. A method for improving glass batch formulation. Glass. Industry. v. 64 (Dec. 10 '83):24-28+, 1983.

2585. Lehman, R. Microcomputers can be used to optimize batch formulation. Glass.Industry. v. 66 (July 10 ,85):14-17, 1985.

2586. Lehman, R. Lead-ion stability in soda-lime lead silicate glasses. Journal. of. the.American.Ceramic.Society. v. 75 (Aug. '92):2194-2199, 1992.

2587. Lei, $X$ and Day, D. Preparation and properties of oxynitride glasses made from potassium metaphosphate. Journal.of.the. American.Ceramic.Society. v 72 n 9 Sep 1989:1601-1603, 1989 .

2588. Lei, X. and Day, D. Preparation and properties of oxynitride glasses made from potassium metaphosphate. Journal.of.the.American.Ceramic.Society. v. 72 (Sept. ' 89 ) : 1601-1603, 1989 .

2589. Leider, H.R., Nguyen, S:N., Weed, H.C., and Steward, S.A. Dissolution rate of $\mathrm{UO}(\mathrm{sub} 2)$ in the alkaline regime under oxidizing conditions using a simplified ground water analog. (Unknown Journal!), 1992. 
2590. Leimkuehler, J. and Kearney, P. Integrated utilisation of the waste heat from flue gases for. glass furnaces. Glass.Technology. Glass technol v $32 \mathrm{n}$, 1991.

2591. Lembke, R. Themal decay kinetics in gamma irradiated systems: sodium hydroxide aqueous glass, Di-p-tolyl carbonate and $N$-Hydroxyurea, 1973 .

2592. Lemmens, K., ; Van Iseghem, P., ; Wang, L., and $X$ the leaching of plutonium, americium, neptunium and technetium fromx high-level waste glasses in clay mediax. Mater.Res.Soc.Symp.Proc., 294, 147-54X-54X, 1994.

2593. Lemmens, $K ., ;$ Van Iseghem, P., and $X$ the long-term dissolution behavior of the pamela borosilicate glassX sm527 - application of sa/v as accelerating parameterX. Mater.Res.Soc.Symp.Proc., 257, 49-56X-56X, 1994.

2594. Leng, Y. and Courtney, T.H. Some tensile properties of metal-metallic glass laminates. Journal.of.Materials.Science J Mater Sci v 24 n 6, 1989.

2595. Lepez, O., Choplin, I., and Tanguy, P. Thermorheological analysis of glass beads-filled polymer melts. Polymer.Engineering.and.science Polym Eng sci $\checkmark 30 \mathrm{n}, 1990$.

2596. Lepnev, G.P., Artem'ev, Y.M., and Artem'eva, M.A. Changes in the Character of the Electrode Function upon the Application of Al, $\mathrm{Si}$, and $\mathrm{Ti}$ Oxides to the Surface of a Glass Electrode. The.Soviet.journal.of.glass.physics.and.chemistry. 19, Number 5:426-428, 1993.

2597. Lerch, R.E. Hanford Defense Waste Management Program. (Unknown Journall) , 1988 .

2598. Lerch, R.E. Hanford Waste Management. (Unknown Journal!) , 1988.

2599. Leriche, A. Vitrification kinetics of ternary SiO2-AI203-CaO glass powders, 1983.

2600. Lethco, A.J. and Beasley, K.M. Master slave manipulator maintenance at the defense waste processingx facility. In: Proceedings of the Conference on Remote Systems Technology. PubI byX ANS, La Grange Park, IL, USA.p 70-73, Anonymous La Grange Park, IL, USA: 1991, P. 70-73.

2601. Lethco, A.J. and Beasley, K.M. Master slave manipulator maintenance at the Defense Waste Processing Facility. (Unknown Journal!) , 1991.

2602. Levi Leaching of radioactivity from glassesX. Report. , 1973.

2603. Levi, Lutze, and Malow Parametric study of borosilicate glasses for radioactive wastex solidificationx. Atomwirt. $-60 \mathrm{X}, 1994$.

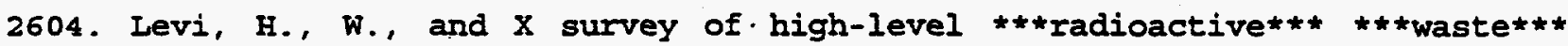
forms andx their role in waste managementx. Sci.Basis Nucl.Waste Manage., 2, 21-30X-30X, 1994. 
2605. Levins, D.M., ; Smart, R.S., and $X$ effects of acidification and complexation from radiolytic reactions $x$ on leach rates of synroc $c$ and nuclear waste $\star * \star$ glass $* \star x$. Nature (Londion), 309, 776-8X-8X, 1994.

2606. Levy, S.S., ; O'Neil, J.R., and $X$ moderate-temperature zeolitic alteration in a cooling pyroclasticX depositX. Chem.Geol., 76, 321-6X-6X, 1994.

2607. Lewiner, C.G.,A. and $X$ nuclear fuel cycle.the french reprocessing programx. Atw, Atomwirtsch., Atomtech., 33, 227-9x-9x, 1994.

2608. Lewis, G., Skaar, E., and Jackson, M. Student glass batching program on CERABULI. American.Ceramic.Society.Bulletin. v. 69 (Dec. '90):1925-1926, 1990.

2609. Lewis, R., A., ; Myhra, S., ; Segall, R., L., ; Smart, R., S., C., ; Turner, $P_{.}, X$ S., and $X$ the surface layer formed on zinc-containing $* * *$ glass $* * *$ duringX aqueous attackX. J.Non-Cryst.Solids, 53, 299-313X-313X, 1994.

2610. Lewis, R., A., ; Segall, R., L., and X pressure dependence of $\star * \star$ glass $* \star *$ dissolution and nuclear wasteX disposalX. Nature (London), 299, 140-1X-1X, 1994.

2611. Lezama, I., Rojo, J.M., Pizarro, J.L., Arriortua, M.I., and Rojo, T. Reduced Molybdenum Phosphates - Synthesis, Characterization and Magnetic-Properties. SOLID.STATE. IONICS. 63-5:657-665, 1993.

2612. Li, Sengers, and Janssen Morphologies of camoo sub 4 crystals in simulated nuclear waste disposalglass. J.MATER.SCI.LETT. , 1992.

2613. Li, D., Sengers, G.F., Janssen, F.J.J.G., and Dewaal, H. Morphologies of Camoo4 Crystals in simulated Nuclear Waste-Disposal Glass. J.MATER.SCI.LETT. $11: 928-929,1992$.

2614. Li, K. Remote determination of radioactive molten glass properties /, 1991.

2615. Li; $K$. and $X$ remote determination of radioactive molten glass propertiesx. (Unknown Journal!) 273 pp, 1992.

2616. Li, K.K., Schneider, A., and schumacher, R.F. Remote system for the monitoring of molten waste glass. In: Proceedings of the Conference on Remote Systems Technology. Publ byX ANS, La Grange Park, IL, USA.P 161-166, Anonymous La Grange Park, IL, USA: 1991,p. 161-166.

2617. Li, K.K., Schneider, A., and Schumacher, R.F. Remote system for the monitoring of molten waste glass. (Unknown Journal!) , 1991.

2618. Li, P. The viscosity of molten glass, 1955.

2619. Libby, I.M.,M., G., ; Whipple, C.G., and $X$ evaluation of an international, perpetual, and retrievable facilityx for storage of

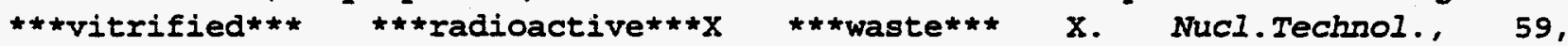
$85-98 X-98 X, 1994$. 
2620. Libera, M. and Chen, M. Time-Resolved Reflection and Transmission Studies of Amorphous Ge-Te Thin-Film Crystallization. J.APPL.PHYS. 73:2272-2282, 1993.

262I. Liem, M.Y., ; Pye, L., D., ; Bickford, D., and X the thermal diffusivity of simulated nuclear waste glass below theX glass transition temperaturex. Mater.Sci.Res., 19, 371-87X-87X, 1994.

2622. Liepmann, M. Durability of fluorozirconate glass in water /, 1981.

2623. Lifanov, F., A., ; Stefanovskii, S., V., ; Kobelev, A., P., ; Tsveshko, $0 ., N .$, and $x$ crucible induction furnace for glass meltingx. Steklo Keram., (7); 10-11X-11X, 1994

2624. Lifanov, F., A., ; Stefanovskii, S., V., ; Lashchenova; T., N., ; Kobelev, A., $X$ P., and $X$ use of local loam for $\star * * v i t r i f i c a t i o n * *$ of

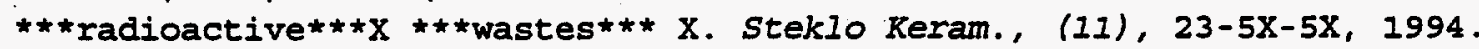

2625. Lifanov, F., A., ; Stefanovskii, S., V., ; Tsveshko, O., N., ; Lashchenova, $X .$, and $X$ immobilization of radioactive ash in glassx. Fiz.Khim.Stekla, 17, 810-15X-15x, 1994.

2626. Lifanov, F., A., ; Stefanovskii, S., V., ; Zakharenko, V., N., ; Kobelev,

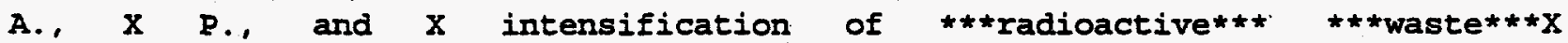
$\star \star \star v i t r i f i c a t i o n * \star *$ in continuous electric meltersx. At.Energ., 69, 300-3X-3X, 1994.

2627. Lifanov, F:A., Stefanovskii, S.V., Zakharenko, V.N., and Kobelev, A.P. Accelerating radioactive-waste vitrification in continuously-runningX electric furnaces. Soviet Atomic Energy 69:942-945, 1991.

2628. Lifanov, F.A., Stefanovskij, S.V., Lashchenova, T.N., and Kobelev, A.P. Use of local loam in vitrification of radioactive wastes. Steklo $i$ Keramika $11: 23-25,1991$.

2629. Lifshitz, E., Yassen, M., Bykov, L., Dag, I., and Chaim, R. Nanometer-Sized Particles of Pbi2 Embedded in sio2-Films. J.PHYS.CHIMY. $98: 1459-1463,1994$.

2630. Ligero, R.A., Casasruiz, M., Vazquez, J., and Jimenezgaray, R. Crystallization Processes and Glass-Forming Ability of a set of Glassy Alloys in the as-Se-Te System. PHYS.CHEM.GLASSES. 34:12-17, 1993.

2631. Ligero, R.A., Vazquez, J., Casasruiz, M., and Jimenezgaray, R. Crystallization Kinetics in the Cu-Ge-Te Glassy system. J.THERM.ANAL. 39:695-706, 1993.

2632. Lin, I. Viscosity and glass transition temperature of oligomer solutions, 1983.

2633. Lin, K., H., ; Clark, W., E., ; Howerton, W., B., and X processes for immobilization of high-level solid wastes by $\mathrm{X} * \star \star g l a s s * \star$ and ceramic matrixesX. Report, Conf-790420-9, 16 pp, 1979. 
2634. Lin, T., Angell, C.A., and Dingwell, D.B. Electronic spectra and coordination of $\mathrm{Ni2}+$ in potassium borate glass and melt to 1000 (degree) C Redox viscometry of some Fe-bearing silicate melts. Journal of. the. American. Ceramic. Society.v.67. (Feb. '84) p. C. 33-4.bibl. The. Americ an.Mineralogist.v.76. (Sept./Oct.'91).p.1560-2.bib1. 3-004X, 1991.

2635. Iin, พ.Y., Hsu, J.Y., Berta, Y., and Speyer, R.F. Combustion Gas Corrosion-Resistance of Heat-Exchange Materials and Refractories for Glass Furnaces at High-Temperatures. .1. Silicon-Carbide and Molybdenum Silicide. AMER. CERAM. SOC.BULL. $73: 72-78,1994$.

2636. Linden, R., Gebauer, M., and Pfitzner, R.P. Experimental-Determination of Pressure-Dependence and Temperature-Dependence of the Viscosity of Lubricating Oils. CHEM-ING-TECH. 65:1495-1497, 1993.

2637. Lingineni, S. and Dhir, V.K. Theoretical and experimental investigation of vapor extraction systemsx for remediation of hazardous waste sites. In: National Conference on Environmental Engineering. Publ by ASCE, NewX York, NY, USA.p 487-494, Anonymous NewX York, NY, USA:ASCE, 1990,p. 487-494.

2638. Lisina, T.A., Nikitina, I.Y., Zaitseva, N.A., and Nikitin, Y.P. Temperature of the Dependence of Borosilicate Solutions Viscosities. ZH.FIZ.KHIM. 67:623-624, 1993.

2639. Litt, R.D. and Tewksbury, T.L. Trace metal retention in a fluidized bed combustor., In: 1989 Int Conf Fluid Bed Combust: FBC - Technol Today Vol 1. Publ byX American Soc of Mechanical Engineers (ASME), New York,NY, USA.pX 127-130, Anonymous New York, NY, USA: 1989,-130.

2640. Litvan, G.G. Durability of cement and.glass impregnated with sulfur and polymethyl methacrylate /, Ottawa :National Research Council Canada, Division of Building Research, 1982.

2641. Liu, D., Piercy, and Purdy Nucleation of sphene in glass-ceramics for the imnobilization of nuclearwaste. Phys.Chem.Glasses , 1985.

2642. Liu, D.P.,G., R., ; Purdy, G., ; Hayward, P., J., and $X$ nucleation of sphene in glass ceramics for the immobilization ofx nuclear wastex. Phys.Chem.Glasses, 26, 197-207X-207X, 1994.

2643. Liu, F., Garofalini, S.H., Kingsmith, R.D., and Vanderbilt, D. Structural and Electronic-Properties of Sodium Metasilicate. CHEM.PHYS. LETT. 215:401-404, 1993.

2644. Liu, H., Knutson, R., Jia, W., and Yen, W.M. Effect of the energy level separation on the luminescence decay of Cr**3** plus doped mullite gláss-ceramics. Jourmal.of.the.Electrochemical.society. J Electrochem Soc $v$, 1991.

2645. Liu, I. The effect of divalent cations on low-temperature viscosity and some other properties of glass, Alfred, N.Y.New York State College of Ceramics at Alfred University, 1947. 
2646. Livens, F.R. and Baxter, M.S. Chemical associations of artificial radionuclides in cumbrian soils. Journal of Environmental Radioactivity $7: 75-86,1988$.

2647. Livingston Behan, E. Travel to French nuclear facilities to identify innovative technologies and operating practices for waste management. Foreign trip report, June 28--July 5, 1991. (Unknown Journal!), 1991.

2648. Llosa, J.M.T., Ruf, H., Schorb, K., and Ache, H.J. Stripping voltamnetric assay of trace technetium with a topo coatedx glassy carbon electrode. <CT> Accuracy in Trace Analysis: Accomplishments, Goals, Challenges <CL> Gaithersburg, $M D$, USA $\angle C D\rangle$, 1988 Sep 28-OCt 1 Journal of Research of the National Bureau of Standards X 93:493-495, 1988.

2649. Lodding, A., Engstrom, and Clark, D. Sims analysis of leached layers formed on srl glasses during burial. Adv. Ceram. , 1986.

2650. Lodding, A., Engstrom, and Clark, D. Quantitative concentration profiling and element balance in srl [savannahriver lab] glass after two years in wipp [waste isolation pilot plant]. Ceram.Trans. , 1990.

2651. Lodding, A., Engstrom, and zoitos, B. Elemental depth profiling of nuclear waste glasses after two-years' burialin a salt geology. J.Am.Ceram.Soc. , 1992 .

2652. Lodding, A. and Odelius, H. Applications of sims in interdisciplinary materials characterization. In: Mikrochimica Acta, Supplementum 10 . Publ by Springer-Verlag, Vienna, $X$ Austria and New York,NY, USA $p$ 21-49,Anonymous Vienna, X Austria and New York, NY, USA:Springer-Verlag, 1983,p. 21-49.

2653. Lodding, A., R., ; Engstroem, E., U., ; Clark, D., E., ; Werme, L., O., ; Wicks, X.G., G., and $X$ sims analysis of leached layers formed on srl glasses during burialx. Adv.Ceram., 20, 567-81X-81X, 1994.

2654. Lodding, A.H.,Larry L. and; Werme, L. nuclear waste glass interfaces after one year burial in stripa.X part 2: glass/bentonitex. Skb Tech.Rep., $85-08,20 \mathrm{pp}-8,20 \mathrm{pp}, 1994$.

2655. Lodding, A.H., Larry L. and ; Werme, L. nuclear waste ***glass** interfaces after one year burial inx stripa.part 2: ***glass***/bentonitex. J.Nucl.Mater., 125, 280-6X-6X, 1994.

2656. Lodge, E.A. Crystalline to amorphous transition of dehydrated ca a zeolite. In: Proceedings - Electron Microscopy Society of America 40 th AnnualX Meeting. Publ by Claitor's Publ Div, Baton Rouge, La, USA p 652-653, Anonymous Baton Rouge; La, USA:Claitor's Publ Div, 1982,p. 652-653.

2657. Loida and Kahl Solidification of tru-wastes by embedding into an aluminum-silicate-basedceramic matrix. Ceram.Trans. , 1990.

2658. Loida, A. and Krause, H. Produktentwicklungen zur Verfestigung radioaktiver Abfaelle aus der Wiederaufarbeitung und Fertigung von Kernbrennstoffen in einer aluminiumsilikatischen keramischen Matrix. (Evaluation of aluminium-silicate ceramics as a matrix for the solidification 
of radioactive wastes from the reprocessing and fabrication of nuclear fuels). (Unknown Journal!), 1991.

2659. Lokken, R., O., ; Chick, L., A., ; Thomas, L., E., and X development and characterization of basalt- $* *$ glass $* * *$ ceramicsX for the immobilization of transuranic wastesX. Report, PnI-4136; Order No.De83001225, 81 pp. 1983.

2660. Lokken, $R ., O .$, and $X$ multibarrier waste forms.part iii: process considerationsX. Report, PnI-2668-3, 32 Pp, 1980.

2661. Lokken, R., $O .$, and $X$ thermal conductivity of multibarrier waste form componentsX. Report, Pnl-3090, 52 pp, 1981.

2662. Lokken, $R_{.}, O_{.}$, and $X$ leaching behavior of $* * * g l a s s * * *$-ceramic nuclear waste formsX. Report, Pal-4022; Order No.De82005595, 72 pp, 1982.

2663. Lokken, R.O. and Strachan, D.M. Long-term leaching of two simulated waste glasses. In: 〈CI> Held during the 85th Annual Meeting of the American CeramicX Society Advances in Ceramics $v 8$. Publ by American Ceramic Soc Inc, Columbus, $X$ OH, USA P 39-48, Anonymous Columbus, $X$ OH, USA:American Ceramic SOC Inc, 1984,p. 39-48.

2664. Lomovskoi, V.A. and Bartenev, G.M. Effects of Sodium Borate Glass Composition on Relaxation Parameters. Inorganic.materials. 28, Number $4: 528-531,1992$.

2665. Lopez Perez High-level nuclear wastes. Glasses and Glass-Ceram.for Nuclear Waste Managem , 1987.

2666. Lord, A.E., ; Weist, F.C., ; Roerner, R.M., ; Arland, X.F., and X the hydraulic conductivity of $\star \star \star s i l i c a t e * \star$ grouted sands withx various chemicalsX. Natl.Conf.Manage. Uncontrolled Hazard. Waste Sites, 175-8-8, 1994.

2667. Loretz, T. Electrical and optical properties of a ZnO-Bb2sOb3s-SiOb2s glass containing cerium, lead, antimony and bismuth oxide additions, Alfred, NY:New York State College of Ceramics at Alfred University, 1978.

2668. Lottici, P.P., Bersani, D., and Braghini, M. Raman scattering characterization of gel-derived titania glass. Journal.of.Materials.science $v$. 28 (Jan. 1 ' 93):177-183, 1993.

2669. Lou, S.J.,Yaozhong; Qu experimental study of sulfur whereabouts in hlw vitrificationX processX. He Huaxue Yu Fangshe Huaxue, 9, 22-8X-8X, 1994.

2670. Lou_er, D. Formation of zno hemispheres from a mixed-nitrate glass melt. Journal.of the.American.Ceramic.Society. v. 68 (Dec. '85):C315-c316, 1985.

2671. Lovinger, L. and Lucek, J. Analysis of a titanium-phosphate glass, Alfred, N.Y.New York State College of Ceramics at Alfred University, 1974.

2672. Lowder, R. Gas turbine operates on catalytic reformer offgas. $0 i l$ and.Gas.Journal. Oil Gas $J \vee 87$ n 41, 1989. 
2673. Lowenstern, J.B., Mahood, G.A., Hervig, R.L., and Sparks, J. The occurrence and Distribution of $M o$ and Molybdenite in Unaltered Peralkaline Rhyolites from Pantelleria, Italy. CONTRIB.MINERAL PETROL. 114:119-129, 1993.

2674. Loytty, E. The determination of the chemical durability of glass /, Alfred, N.Y. :New York State College of Ceramics at Alfred University, 1936.

2675. Lu, K. and Wang, J.T. Crystallization kinetics of Ni-P glass - activation energies for nucleation and growth of nuclei. Journal.of.Materials.Science $v 23$ I 8 Aug 1988:3001-3005, 1988 .

2676. Lucas, J. Fluoride glasses. Journal.of.Materials.Science J Mater Sci v 24 n 1, 1989.

2677. Luce, A., Troiani, F., Momo, S., Di Pace, L., and Risoluti, P. Treatment and conditioning of HLLW stored at ENEA's reprocessing pilot plants. (Unknown Journal!), 1992.

2678. Lucek, J. Devitrification of the glassy phase fused-cast alumina-zirconia-silica refractories, Alfred, N.Y. :New York State College of Ceramics at Alfred University, 1976.

2679. Luckenbach, T. Dynamic mechanical rheological testing. A versatile tool for the elastomer lab. Elastomerics. Elastomerics v $123 \mathrm{n}, 1991$.

2680. Lucktong, C. and Hrma, P. Oxygen evolution during Mno-Mn sub 3 o sub 4 dissolution in a borosilicate melt. J.Am.Ceram.Soc. 71[5]:323-328, 1988.

2681. Lukac, M. and Marincek, M. Energy storage and heat deposition in flashlamp-pumped sensitized erbium glass lasers. IEEE Journal.of.Quantum.Electronics. IEEE J Quantum Elect, 1990.

2682. Lukacs, J., M., ; Bates, J.,. L., ; Devine, J., R., ; Gray, W., J., ; Weber, W., $X$ J., and $X$ compatibility of two idaho chemical processing plant glasses withX electric melting processesx. Report, Pnl-2751, 49 pp, 1979.

2683. Lukacs, J., M., ; Petkus, L., L., ; Mellinger, G., B., and X evaluation of defense-waste ***glass*** produced by full-scaleX ***vitrification*** equipmentx. Report, Pal-3550, 102 pp, 1981.

2684. Lumetta Process chemistry for the pretreatment of hanford tank wastes. (Unknown Journal!) : (21 p), 1992.

2685. Lumetta Underground storage tank integrated demonstration: evaluation of pretreatment options for hanford tank wastes. (Unknown Journal!) :(34 p), 1993.

2686. Lumetta Evaluation of solid-based separation materials for the pretreatment of radioactive wastes. (Unknown Journal!) :(29 p), 1993.

2687. Lumetta Pretreatment of neutralized cladding removal waste (ncrw) sludge - results of fy 1991 studies. (Unknown Journal!) : $(53 \mathrm{p}), 1993$. 
2688. Iumetta, G.J. and Swanson, J.I. Pretreatment of neutralized cladding removal waste sludge. Status report. Progress rept. (Unknown Journal!), 1993.

2689. Lumetta, G.J. and Swanson, J.I. Evaluation of 1-hydroxyethane-1,1-diphosphonic acid and sodiumx carbonate as stripping agents for the removal of am(iii) and pu(iv)x from truex process solvent. <CT> 7 th Symposium on Separation Science and Technology for EnergyX Applications <CL> Knoxville, TN, USA <CD 1991 OCt 20-24 Separation Science and Technology $28: 43-58$, 1993 .

2690. Iumetta, G.J. and Swanson, J.L. Pretreatment of Plutonium Finishing Plant (PFP) sludge: -Report for the period October 1990--March 1992. (Unknown Journal!) , 1993.

2691. Lumetta, G.J., Wagner, M.J., Colton, N.G., and Jones, E.O. Underground storage tank integrated demonstration: Evaluation of pretreatment options for Hanford tank wastes. (Unknown Journal!) , 1993.

2692. Lung, M., Doucet, F.Y., Creissels, M., and Beroud, Y. Special equipment for nuclear applications in the back end of the fuelx cycle. In: High Level Radioactive Waste and Spent Fuel Management Proc 1989 JointX Int Waste Manage Conf $v 2$ (of 2). Publ by American Soc of Mechanicalx Engineers (ASME), New York, NY, USA.P 31-37, Anonymous New York, NY, USA:American Soc of MechanicalX Engineers (ASME), 1989, p. 31-37.

2693. Luo, S... Jiang, Y., and Liu, D. Devitrification behaviour of GC-12/9B HIW-glass. Waste.Management. Waste Manage v $10 \mathrm{n:23-27,1990.}$

2694. Luo, S.X.,Qinghua; Yan study on the leachability of simulated hlw glass formx. He Huaxue Yu Fangshe Huaxue, 10, 30-5X-5X, 1994.

2695. Luo, S. glass solidification for treatment of high-level radioactive liquidX wastesX. Guisuanyan Tongbao, 5, 35-9X-9X, 1994.

2696. Lutze, W., ; Grambow, B., ; Ewing, R., C., and $X$ performance of borosilicate glass, synroc and spent fuel as nuclearX waste formsX. Proc.Symp. Waste Manage., (Waste Manage. '90, Vol. 2), 847-51X-51X, 1994.

2697. Lutze, w., ; Marples, J., A., C., ; Van Iseghem, P., and $X$ results and evaluation of the ec-repository systems simulationx. Radioact.Waste Manage.Disposal, , 3rd, X Meeting Date-27, 1994.

2698. Lutze, W., Malow, G., Rabe, H., and Headley, T.J. Surface layer formation on a nuclear waste glass. In: Materials Research Society Symposia Proceedings $v$ 15. PubI by ElsevierX Science PubI Co,New York,NY, USA and Amsterdam, Neth $p$ 37-45, Anonymous New York, NY, USA:ElsevierX Science Publ Co, 1983,p. 37-45.

2699. Lutze, w., Manara, A., Marples, J.A.C., Offermann, P., and Van Iseghem, P. Radiation, thermal and mechanical effects in hlw glass. In: Commission of the European Commities, (Report) EUR 10163. PubI byX Cambridge Univ Press, Cambridge, Engl p 232-251, Anonymous (Report) EUR 10163: 1986,p. 232-251. 
2700. Lutze, W., ; Borchardt, J., ; De, A., K., and $\mathrm{X}$ characterization of **tglass*** and ***glass*** ceramicX nuclear waste formsX. Sci.Basis Nucl. Waste Manage., MeetingX Date 1978, 69-81:lenum: NewX York, 1994.

2701. Lutze, W., ; Ewing, R., C., and $X$ comparison of glass and crystalline nuclear waste formsX. Mater.Res.Soc.Symp.Proc., 127, 13-24X-24X, 1994.

2702. Lutze, W., ; Malow, G., ; Ewing, R., C., ; Jercinovic, M., J., ; Keil, K., and $X$ alteration of basalt glasses: implications for modelling thex long-term stability of nuclear waste glassesx. Nature (London), 314, 252-5X-5X, 1994.

2703. Lutze, พ., ; Muller, R., ; Montserrat, w., and $x$ chemical corrosion of cogema glass $r 7 t 7$ in high saline brines. partx iix. Mater.Res.Soc.Symp.Proc., 127, 81-8X-8X, 1994.

2704. Lutze, w., ; schiewer, E., ; De, A., K., and $X$ development of borosilicate ***glass*** for the pamelax ***vitrification*t* plantx. Ber.Kernforschungsanlage Juelich, Juel-Conf-42 (Vol. 2)X Proc:roc-Level Liquid WasteX, 1994.

2705. Lutze, W.M.,R., ; Montserrat, W., and $x$ chemical corrosion of cogema glass r7t7 in high saline brinesX. Mater.Res.Soc.Symp.Proc., 112, 575-84X-84X, 1994.

2706. Lutze, W.M.,Guenter; Rabe and $X$ surface layer formation on a nuclear waste $\star * *$ glass $* \star$ X. Mater.Res.Soc.Symp.Proc., 15,X 37-45X-45X, 1994.

2707. Lutze, W.S.,P. and $X$ chemical corrosion of lead-iron phosphate glassX. Mater.Res.Soc.Symp.Proc., 112, 641-9X-9X, 1994.

2708. LXaczka, M. Effect of aluminum and neodymium admixtures on devitrification of silica glasses. Journal. of. the. American.Ceramic.Society.v.74. (Aug. '91).p.1916-21.bibl. 2-7820, 1991.

2709. Lyon, K.E. and Patterson, R.J. Evidence for non-equilibrium adsorption of **9**0sr from ground water. Water Pollution Research Journal of Canada $19: 23-34,1984$.

2710. Macaulay Newcombe, R., G., ; Thompson, D., A., ; Puls, M., P., and X radiation damage effects in solid wastesX. Can.Metall.Q., 22, 81-6X-6X, 1994 .

2711. Macdonald Effectiveness of processes applied to the remediation of mixed transuranic wastes. (Unknown Journal!) :(13 p), 1918.

2712. MacDowell, J. Aluminoborate glass-ceramics with low thermal expansivity. Journal.of. the.American.Ceramic.Society. J Am Ceram Soc v 73:2287-2292, 1990.

2713. Macedo, P., B., ; Barkatt, A., and X evaluation of bulk properties of radwaste $* * *$ glass $* *$ andx ceramic container materials to determine long-term stabilityx. Report, Order No.Nureg/Cr-2737, 117 pp, 1982. 
2714. Macedo, P., B., ; Barkatt, A., and X evaluation of bulk properties of radwaste $\star * *$ glass $* \star$ andx ceramic container materials to determine long-term stabilityx. Report, Nureg/Cr-2737, 113 pp, 1983.

2715. Macedo, P., B., ; Barkatt, A.S.,J., H., and $x$ a flow model for the kinetics of dissolution of nuclear wastex glassesx. Nucl.Chem. Waste Manage., 3 , $13-21 X-21 X ; 1994$.

2716. Macedo, P., B., ; Simmons, J., H., ; Barkatt, A., ; Litovitz, T., A., and

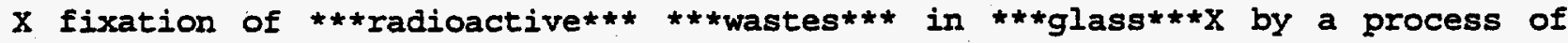
molecular stuffingx. Back End LWr Fuel Cycle, , Issue Conf-780304, $X i / 15-X i / 16 . X$ Ntis: Springfield, Va.X -780304, XI/15-XI/16, 1994.

2717. Macedo, P., B., ; Tran, D., C., ; Simmons, J., H., ; Saleh, M., ; Barkatt, A., ;X Simmons, C., J., ; Lagakos, N., ; DeWitt, E., and X porous $\star \star \star g l a s s \star * \star$ matrix method for encapsulating high-levelX nuclear wastesX. Ceram.Nucl. Waste Manage., Proc.Int.Symp., Issue Conf-790420, X 321-6-6, 1994.

2718. Macedo, P.B., Barkatt, A., and Simmons, J.H. Flow model for the kinetics of dissolution of nuclear waste forms; ax comparison of borosilicate glass,synroc and high-silica glass. In: Materials Research Society Symposia Proceedings $v$ 11.Publ byX North-Holland, New York, NY, USA and Amsterdam, Neth p 57-69, Anonymous New York, NY, USA: 1982,p. 57-69.

2719. Macedo, P., Barkatt, A., and Gibson, B. Long-term release rates of borosilicate glass waste forms. Nuclear.Technology. v. 73 (May '86):199-209, 1986 .

2720. Macedo, P.B., Barkatt, A., and Sutter, H.G. method of separating and purifying cations by ion exchange withX regenerable porous glassX. U.S., 13 pp, 1994.

2721. Macedo, P.B., Simnons, J.H., and Litovitz, T.A. fixation of radioactive materials in a ***glass*** matrixx. U.S., 11 pp-in-part of $U, 1994$.

2722. Macfarlane, D.R. and Angell, C.A. Emulsion techniques for the study of glass formation. Low melting point salt hydrates. The.Journal.of. Physical. Chemistry. v. 88 (Sept. 27 i84):4779-4781, 1984 .

2723. MacFarlane, D. Attempted glass formation in pure KRSO4. Journal.of.the.American. Ceramic.Society. v. 67 (Feb. '84):C28, 1984.

2724. Machida, N., Katano, Y., Kamiya, Y., Jardine, L.J., and Hoekwater, J. Conceptual design of a high-level vitrified waste storage facility. In: High Level Radioactive Waste and Spent Fuel Management Proc 1989 JointX Int Waste Manage Conf $v 2$ (of 2). Publ by American Soc of MechanicalX Engineers (ASME), New York, NY, USA.P 291-296, Anonymous New York, NY, USA:American Soc of MechanicalX Engineers (ASME), 1989,p. 291-296.

2725. Machida, N., Tanaka, H., Shigematsu, T., Nakanishi, N., and Minami, T. Mixed Anion Effect on Conductivity of the Glasses in the system AgI-Ag2MOO4-AgpO3. CHEM. LETT. : 1755-1758, 1993. 
2726. Machiels, A.J. and Pescatore, C. Functional dependence of leaching on the surface area-to-solutionx volume ratio. In: Materials Research Society Symposia Proceedings $v$ 15. Publ by ElsevierX Science Publ Co,New York, NY, USA and Amsterdam, Neth p 209-216, Anonymous New York, NY, USA:ElsevierX Science Publ CO, 1983, p. $209-216$.

2727. Machin, J. and Hanna, D. Viscosity studies of system CaO-MgO-Alb2sOb3s-SiOb2s: 1, 40\% SiOb2s, Urbana, IIl. : State Geological Survey, 1945.

2728. Machin, J. and Yee, T. Viscosity studies of system CaO-MgO-Alb2sOb3s-SiOb2s, Urbana, Ill. : State Geological Survey, 1948.

2729. Machin, J., Yee, T., and Hanna, D. Viscosity studies of system CaO-MgO-AIb2sOb3s-SiOb2s, Urbana, Ill. : State Geological Survey, 1953.

2730. Mackenzie, J: Final report to NASA-Ames University Consortium, NASA Ames Research Center ... on low expansion copper aluminosilicate glasses and glass-ceramics, Los Angeles, Calif.School of Engineering and Applied Science, University of California, 1982.

2731. Maerk, T., D., ; Walder, G., and $\mathrm{X}$ annealing and leaching studies with natural and artificial obsidianx glassx. Mater.Res.soc.Symp.Proc., 112, 693-701X-701X, 1994.

2732. Maestas, E. and Walter, H. Waste management strategy at the west valley [ny] demonstrationproject. Ceram.Trans. , 1990.

2733. Magini, M., ; Sedda, A., F., ; Licheri, G., ; Paschina, G., ; Piccaluga, G., ; X Pinna, G., ; Cocco, G., and $x$ on the coordination of iron ions in sodium borosilicate glasses. $i . x$ a wide angle $x$-ray diffraction investigation $x$. J.Non-Cryst.Solids, 65, 145-59X-59X, 1994.

2734. Magonthier, M., C., ; Petit, J., ; Dran, J., and X rhyolitic glasses as natural analogs of nuclear waste glasses: $X$ behavior of an icelandic glass upon natural aqueous corrosionX. Appl.Geochem., Suppl., 1, 83-93X-93X, 1994.

2735. Magonthier, M., C., ; Brousse, C., ; Petit, J., ; Dran, J., ; Dellax Mea, G., ; Paccagnella, A., and $X$ hydration rates of natural and nuclear glasses investigated by ax resonant nuclear reactionx. Int.Conf.Nat.Glasses, 2nd, Meeting Date 19:rague, Czech, 1994.

2736. Magrabi, C., ; Smith, w., ; Larkin, M., J., and X development of the glass formulation for the windscale vitrificationx plantx. Radioact.Waste Manage.Nucl. Fuel Cycle, 9, 85-106x-106x, 1994.

2737. Magruder, R., Kinser, D., and Weeks, R. Dependence of sodium ion mobility upon melt atmosphere in GeO2 glasses. Journal.of.the.American.Ceramic.Society. v. 69 (Jan. ' 86 ): C10-C11, 1986.

2738. Maher, R., Shafranek, L.F., Kelley, J.A., Zeyfang, R.W., and Lethco, A.J. Defense waste processing facility: a remote process for solidificationx of savannah river plant high level waste. In: <CI> Selected papers presented at the American Nuclear society Topicalx Meeting Publ by Battelle 
Press, Columbus, $O H$ and Richland,WA, USA andX Springer-Verlag, New York, NY, USA and Heidelberg, West Ger $p$ 421-430,Anonymous Columbus, $O H$ and Richland, WA, USA:Battelle Press, 1983,p. 421-430.

2739. Mailhot, A.M., Elyamani, A., and Riman, R.E. Reactive Atmosphere Synthesis of Sol-Gel Heavy-Metal Fluoride Glasses. J.MATER.RES. 7:1534-1540, 1992.

2740. Maillet, J.S.,Claudex high-level waste vitrification: the state of the art in francex. Proc.Symp.Waste Manage., (Waste Manage. '88, Vol. 2), $165-72 X-72 X, 1994$.

2741. Majewski, S., Kross, B., Wojcik, R., Weisenberger, A., and. Zorn, C. Studies of Position-Sensitive Photomultipliers in Readout of Scintillating and Waveshifting Fibers. NUCL.INSTRUM.METH.PHYS.RES.A. 323:489-504, 1992.

2742. Makishima, A., Kubo, H., and Shimohira, T. Formation and crystallization of yttrium aluminosilicate glasses containing calcium oxide. Journal.of. the.American.Ceramic.Society. v. 69 (June '86):C130-C131, 1986.

2743. Malone, 'P., G., and $X$ cementing reactions in the $* *$ hazardous***

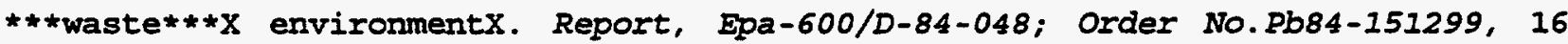
pp, 1984 .

2744. Malone, P.G. and $X$ cementing reactions in the hazardous waste environmentX. Hazard.Wastes Environ. Emerg.: Manage., Prev., Cleanup, Control, $X$ , 299-301-301, 1994 .

2745. Malow Characterization of hlw glass samples task 3 characterization of radioactive waste forms a series of final reports (1985-89) no 20. (Unknown Journal!) : (22 p), 1991.

2746. Malow, Beran, Lutze, Marples, Dalton, X, H.A.., Hough, and Boult Testing and evaluation of the properties of various potentialx materials for immobilizing high activity wastex. Comm. Eur.Communities. , 1978.

2747. Malow and Schiewer Fission products in glasses.part i: borosilicate glassesX containing fission productsx. Hahn-Meitner-Inst.Kernforsch.Berlin. -Meitner-Inst, 1994.

2748. Malow, G. Mechanisms for hydrothermal leaching of nuclear waste glasses: $\mathrm{X}$ properties and evaluation of surface layers. In: Materials Research Society Symposia Proceedings $v$ 11.Publ byX North-Holland, New York, NY, USA and Ansterdam, Neth p 25-36, Anonymous New York, NY, USA: 1982,p. 25-36.

2749. Malow, G. Testing and Evaluation of Solidified High-Level Waste Forms. Joint Annual Progress Report 1983. (Unknown Journal!) , 1985.

2750. Malow, G. Testing and Evaluation of Solidified High-Level Waste Forms. Joint Annual Progress Report 1983. Final rept. (Unknown Journal!), 1986.

2751. Malow, G., Lutze, w., and Ewing, R.C. Alteration effects and leach rates of basaltic glasses: implicationsx for the long-term stability of nuclear waste 
form borosilicate glasses.x. Journal of Non-Crystalline Solids 67:305-321, 1984.

2752. Malow, G., ; Andresen, H., and $X$ helium formation from .alpha.-decay and its significance forX. $\star \star \star$ radioactive**. $\star \star \star$ waste $* \star \star$ glassesX. Sci.Basis Nucl.Waste Manage., , MeetingX Date 1978, 109-15:lenum: NewX York, 1994.

2753. Malow, G., ; Beran, V., ; Lutze, w., ; Borchardt, J., ; Marples, J., A., C., ;X Dalton, J., T., ; Hall, A., R., ; Hough, A., ; Boult, K., ; et al., and $X$ testing and evaluation of the properties of various potentialx materials for immobilizing high activity wastex. Eur.Appl.Res.Rep., Nucl.Sci.Technol.Sect., 2, $62 \mathrm{pp}, 1994$.

2754. Malow, G., ; Marples, J., A., C., ; sombret, C., and $\mathrm{X}$ thermal and radiation effects on properties of high level wastex productsx. Comm. Eur.Communities, Eur, Eur 6871, Radioact-64X, 1994.

2755. Malow, $G$. and $X$ an investigation of crystallization in glasses containing fissionX productsX: Ceram.Nucl.Waste Manage., Proc.Int.Symp., Issue Conf-790420, X 203-9-9, 1994 .

2756. Malow, $G$. and $X$ thermal and radiation effects in the range of the glass transitionX temperature tgX. Mater.Res.Soc.Symp.Proc., 127, 153-62X-62X, 1994.

2757. Malow, G.E., Rodney $C$. and $X$ nuclear waste glasses and volcanic glasses: $a$ comparison of theirX stabilitiesX. Sci.Basis Nucl.Waste Manage., 3, $315-22 \mathrm{X}-22 \mathrm{X}, 1994$.

2758. Manaktala, H.K. and Interrante, C.G. Technical Considerations for Evaluating Substantially Complete Containment of High-Level Waste within the Waste Package. Technical rept. (Unknown Journal!), 1990.

2759. Manara, A., Sacchi, M., and Ceccone, G. Alkali effects on the resistance to radiation and leaching of borosilicate glasses. Riv.Stn.Sper.Vetro. $16[6]: 47-51,1986$.

2760. Manara, A., ; Gibson, P., N., ; Antonini, M., and X structural effects of radiation damage in silica-based glassesX. Mater.Res.Soc.Symp.Proc., 11, $\mathrm{X}$ $349-56 \mathrm{X}-56 \mathrm{X}, 1994$.

2761. Manara, A., ; Lanza, F., ; Ceccone, G., ; Della Mea, G., ; Salvagno, G., and $X$ application of xps and nuclear technique to the study of the gelx layers formed under different redox conditions on leached glassesX. Mater.Res.Soc.Symp.Proc., 44,X 63-71X-71X, 1994.

2762. Manara, A., ; Lanza, F., ; Ceccone, G., ; Visani, T., and X influence of bicarbonate ions and redox conditions on the surfacex composition of a leached borosilicate glassX. Comm. Eur.Communities, Eur, Eur 12022, 25 pp, 1994.

2763. Manara, A., ; Lanza, F., ; Della Mea, G., ; Rossi, C., ; Salvagno, G., and $x$ influence of redox condition in iron, silicon and hydrogen contentsx of leached ***glass $\star \star *$ surfaceX. Mater.Res.Soc.Symp.Proc., 26,X 735-9X-9X, 1994. 
2764. Mandal, S. and Ghosh, A. Structure and Physical-Properties of Glassy Lead Vanadates. PHYS.REV.B-CONDENSED.MATTER. 48:9388-9393, 1993.

2765. Mangin, J., P., and ; Nguyen Ngoc HoanX condiment - a convection calculation method for ion diffusion in thex case of precipitate formationx. DOC.B.R.G.M., 160, 507-18X-18X, 1994.

2766. Manickam, $O$. and Homsy, G.M. Simulation of Viscous Fingering in Miscible Displacements with Nonmonotonic Viscosity Profiles. PHYS.FLUIDS. 6:95-107, 1994 .

2767. Mao, Y. and Liu, S. Electronic properties of the interface between DLC films and silicon. Vacuum. 42 n $16: 1084,1991$.

2768. Marboe, E. and Weyl, W.A. Atomistic interpretation of the effect of the composition on the viscosity of glass, State College, Pa.Pennsylvania state University, College of Mineral Industries, 1954.

2769. Marchand, R., Laurent, Y., Parent, C., and Leflem, G. Structural Investigation of Phosphorus Oxynitride Glasses Using Nd-3+, $\mathrm{Pb}-2+$ and Eu-3+ as Local Probes. J.PHYS.IV. 2:235-238, 1992.

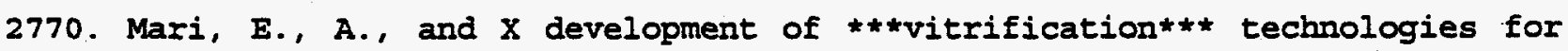
immobilizingX $* * *$ radioactive $* * * *$ waste $* * * x$. Bol.Soc.Esp.Ceram.Vidrio, 25 , $307-14 X-14 X, 1994$.

2771. Mark, T., D., ; Ritter, W., and $\mathrm{X}$ radiation damage and its annealing in sodium silica glassX. Mater.Res.Soc.Symp.Proc., 84,X 659-69X-69X, 1994.

2772. Markworth, A.J. Kinetics of the crystal size distribution during glass crystallization.x. Journal of Materials Science Letters 5:161-162, 1986.

2773. Marples Preparation, properties, and disposal of vitrified high level waste fromnuclear fuel reprocessing. Glass Technol. , 1988.

2774. Marples, J., A., C., ; Godon, N., ; Lanza, F., ; Van Iseghem, P., and X radionuclide release from high level waste forms under repositoryx conditions in clay or granitex. Radioact.Waste Manage.Disposal, , 3rd, $\mathrm{X}$ Meeting Date-301, 1994.

2775. Marples, J., A., C., ; Dalton, J., T., ; Hall, A., R., ; Hough, A., ; Boult, K., X A., ; Malow, G., ; Beran, V., ; Borchardt, J., ; Lutze, W., and X testing and evaluation of the properties of various potentialx materials for immobilizing high activity wastex. Eur.Appl.Res.Rep., Nucl.Sci.Technol.Sect., 3, 395-484X-484X, 1994 .

2776. Marples, J., A., C., ; Lutze, w., ; Kawanishi, M., ; Van Iseghem, P., and $\mathrm{X}$ a comparison of the behavior of vitrified hlw in repositories inx salt, clay and granite: part ii: resultsX. Mater.Res.Soc.Symp.Proc., 176, 275-82X-82X, 1994. 
2777. Marples, J., A., C., ; Lutze, W., ; Sombret, C., and $x$ the leaching of solidified high level waste under various conditionsx. Comm.Eur.Communities, Eur, Eur 6871, Radioact-23X, 1994.

2778. Marples, J., A., C., and $X$ the preparation, properties, and disposal of vitrified high levelx waste from nuclear fuel reprocessingx. Glass Technol., $29,230-47 X-47 X, 1994$.

2779. Marples, J., A., C., and $X$ the european commissions round robin of their repository systemX simulation test. a compilation and evaluation of the results for thex granite optionX. U.K.At.Energy Auth., Harwell Lab., Aere-R, Aere $R$ $13660, \mathrm{X} 109 \mathrm{pp}, 1994$.

2780. Marples, J., A., C., and $X$ dose rate effects in radiation damage to

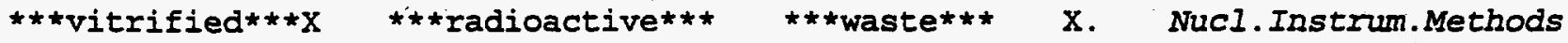
Phys.Res., Sect.B, B32(I-4), 480-6X-6X, 1994.

278I. Marples, J.A.C. Preparation,properties, and disposal of vitrified high $X$ level waste from nuclear fuel reprocessing.X. Glass.TechnologyX. Glass Technol v $29 \mathrm{n}, 1988$.

2782. Marra Dwpf glass transition temperatures: what they are and why they are important. (Unknown Journal!) : (14 p), 1991.

2783. Marra Thermal history and crystallization characteristics of the dwpf glass waste form. (Unknown Journal!) : (10 p), 1992.

2784. Marra Characterization of projected dwpf glasses heat treated to simulate canister centerline cooling. (Unknown Journal!):(38 p), 1993.

2785. Marra, S., Jantzen, C., and Ramsey, A. Dwpf [defense waste processing facility] glass transitiontemperaturesưhat they are and why they are important. Ceram.Trans. , 1991.

2786. Marra, S., L., ; Jantzen, C., M., and X characterization of projected dwpf glasses heat treated to simulatex canister centerline coolingx. Report, WsrC-Tr-92-142; Order No.De93003325, 38 pp, 1993.

2787. Marra, S.I., Andrews, M.K., and Cicero, C.A. Time-temperature-transformation-diagrams for DWPF projected glass compositions. (Unknown Journal!), 1993 :

2788. Marsh, D.L. Commissioning of high level liquid waste facilities. In: High Level Radioactive Waste Management. Publ by ASCE, New York, NY,X USA.P 396-401, Anonymous New York, NY,X USA:ASCE, 1991,p. 396-401.

2789. Marter, W., L., and $X$ relative hazard of dwpf reference ***glass*** canister icrp 2 vsX icrp 30X. Report, Dpst-82-475; Order No.De83012457, 20 pp, 1983.

2790. Martin, A., ; Rempe, T., F., ; Browning, R., and $X$ management of

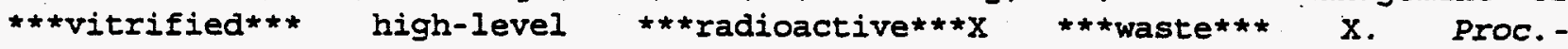
Soc.Radiol.Prot., Int.Symp.: Radiol.Prot.--Adv.Theoryx Pract., 3rd, volume 2, 570-5: rot, 1994 . 
2791. Martin, D. The corrosive effects on refractories of ions driven by $a$ potential in a glass melt /, Alfred, N.Y. :New York state College of Ceramics at Alfred University, 1962.

2792. Martin, S. and Bloyer, D. Preparation of high-purity vitreous B2S3. Journal.of.the.American.Ceramic.Society, v. 73 (Nov. '90):3481-3485, 1990.

2793. Martinsen, w. Selected properties of sodium silicate glasses and their structural significance, 1969.

2794. Masnik, J., Kieffer, J., and Bass, J. Structural relaxations in alkali silicate systems by Brillouin light scattering. Journal.of.the.American.Ceramic.Society. Journal of the Ameri, 1993.

2795. Massard, P. Irreversible thermodynamics of silicate mineral dissolution. $x$ experimental study of an albite. Applied Geochemistry Suppl:167-177, 1992 .

2796. Massieon, C., Cutler, A., and Shadman, F. Hydrogen reduction of iron-bearing silicates. Industrial.\&. Engineering. Chemistry.Research. Industrial \& Enginee, 1993.

2797. Matecki, M., Javel, J.F., Charron, C., Fonteneau, G., and Lucas, J. Devitrification Studies of Heavy-Metal Fluoride Glasses Containing. Alkali Fluoride. MATER.RES.BULL. 28:997-1004, 1993.

2798. Matecki, M. and Lucas, J. Devitrification study of a Cadmium Fluorochloride Glass. J.NON-CRYST.SOLIDS. 162:51-57, 1993.

2799. Matej, J. and Bernard, V. Optimum Loading of Molybdenum Electrodes in Corrosive Glass Melts: GLASTECH.BER. 66:307-311, 1993.

2800. Mateva, R. and Dencheva, N. Flammability and thermal behavior of phosphorus-containing polyamide-6. Journal.of.Applied.Polymer.Science v 47 n 7 Feb $151993: 1185-1192,1993$.

2801. Mathers, W., G., ; Harvey, K., B., and $x$ the dissolution of a glass in an infinite volume of waterX. Nucl.Chem. Waste Manage., 7, 163-6X-6X, 1994.

2802. Matsuda, Y., Ong, N.P., Yan, Y.F., Harris, J.M., and Peterson, J.B. Vortex Viscosity in YBazCu307-Delta at Low-Temperatures. PHYS.REV.B-CONDENSED.MATTER. 49:4380-4383, 1994 .

2803. Matsui, S. Note on an Example of a zero Viscosity Limit for Navier-Stokes Flows with the Initial-Boundary Layer in the Disk. IETT.MATH.PHYS. 29:281-286, 1993.

2804. Matsumoto, S., Aoyama, S., Tashiro, S., and Nagai, S. Gamma-Ray Shielding Design and Performance Test of WASTEF: (Unknown Journal!), 1984.

2805. Matsuo, M., Nakazawa, T., and Oshima, H. Low-temperature activation of impurities implanted by ion doping technique for poly-si thin-films transistors. 
Japanese.Journal of.Applied.Physics, .Part.1:.Regular.Papers.\&.Short.Notes. v 31 n 12B Dec 1992.4567-4569, 1992.

2806. Matsushita, K.S., Sumiox crystallized $\star \star \star g l a s s * \star \star$ for treatment of

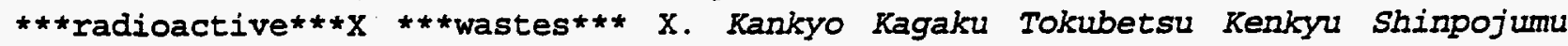
Yoshishu, Volume 2, 5-8-8, 1994.

2807. Matsuyama, I., Susa, K., and Satoh, S. Syntheses of high-purity silica glass by the sol-gel method. American.Ceramic.Society.Bulletin. v. 63 (Nov. (84) : 1408-1411, 1984 .

2808. Matsuzuru, H., Kurosawa, N.; and Suzuki, A. Development of Partial Models of Comprehensive Safety Assessment Model for Shallow Land Disposal of Low Level Radioactive Wastes, 2. Simulation Model for the Release of Radionuclides from an Engineered Barrier (ENBAR). (Unknown Journal!), 1987.

2809. Mattus, A.J. and Lee, D.D. Nitrate to ammonia and ceramic (NAC) process. (Unknown Journal!), 1993.

2810. Mattus, A.J. and Lee, D.D. Nitrate to ammonia and ceramic (NAC) process -- a newly developed low-temperature technology. (Unknown Journal!) , 1993.

2811. Matusita, K., Satou, M., and Komațsu, T. Interface reaction between oxide glasses and Fe-Al-Si magnetic alfoy. Journal.of.Materials.Science $v$. 28 (Dec. 1 193):6333-6339, 1993 .

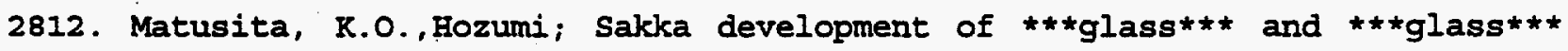
-ceramics ofX lithium oxide-aluminum oxide-silicon(iv) oxide system forX solidification of high-level nuclear wasteX. Res.Rep.Fac.Eng., Mie Univ., 4, $59-69 x-69 x, 1994$.

2813. Matyushin, Y., I., ; Astakhov, M., N., ; Savin, M., F., and X immobilization of .alpha.-emitting radionuclides in phosphatex glass-like compositionsX. Radiokhimiya, 32, 154-8X-8X, 1994.

2814. Matzke Diffusion of uranium in phosphate waste glassesx. Reaktortag. $-60 \mathrm{X}, 1994$.

2815. Matzke, H., Kahl, and Saidl Effect of composition and radiation on the hertzian indentation behavior ofnuclear waste glasses. Adv.Ceram. , 1985.

2816. Matzke, H., Toscano, E., and Routbort, J. Temperature dependence and fracture toughness and elastic moduli of a wasteglass. J.Am.Ceram.Soc. , 1986.

2817. Matzke, H. Application of ion beam techniques to solid state physics andx technology of nuclear materials. J NUCL MATER $V 136 \mathrm{~N}$ 2-3 NOV 1985 P 143-153 $-153,1985$.

2818. Matzke, H., ; Vernaz, E., and X thermal and physicochemical properties important for the long termX behavior of nuclear waste glassesX. J.Nucl.Mater., 201, 295-309X-309x, 1994. 
2819. Matzke, H., Kahl, L., Saidl, J., and Routbort, J.L. Effect of composition and radiation on the hertzian indentationx behavior of nuclear waste glasses. In: <CI> Held during the 85th Annual Meeting of the American Ceramicx Society Advances in Ceramics $v 8$. Publ by American Ceramic SOC Inc, Columbus, $X$ OH, USA $p$ 697-709, Anonymous Columbus, $X$ OH, USA:American Ceramic SOC Inc, 1984,p. 697-709.

2820. Matzke, H., Mea, G.D., Dran, J.C., Linker, G., and Tiveron, B. Radiation damage in nuclear waste glasses following ion implantation atX different temperatures. <CT> Proceedings of the Fifth International Conference on RadiationX Effects in Insulators <CL> Hamilton, Ont, Can <CD> 1989 Jun 19-23 Nuclear Instruments \& Methods in Physics Research, Section B: BeamX Interactions with Materials and Atoms B46:256-260, 1990.

2821. Matzke, H., Sacchi, M., Antonini, M., and Prudenziati, M.'Radiation damage effects in nuclear materials Ru-metal segregation in borosilicate glasses. <CT> Radiation Effects in Insulators: Proceedings of the FourthX International Conference on Radiation Effects in Insulators; includingX the Workshop on Radiation Damage in Nuclear Waste Materials <CL> Lyon, Fr <CD> 1987 Jul 6-10 Nuclear Instruments \& Met 109:K23-K26X, 1988.

2822. Matzke, H., Toscano, E., and Linker, G. Alkali diffusion and radiation effects in the waste glass vg $98 / 12$. <CT Radiation Effects in. Insulators: Proceedings of the FourthX International Conference on Radiation Effects in Insulators, includingX the Workshop on Radiation Damage in Nuclear Waste Materials <CL> Lyon, Fr <CD> 1987 Jul 6-10 Nuclear Instruments \& Met $B 32$ :508-511X, 1988 .

2823. Matzke, H., Toscano, E., Routbort, J., and Reimann, K. Temperature dependence and fracture toughness and elastic moduli of ax waste glass. Joumal of the American Ceramic Society 69:C, 1986.

2824. Matzke, H. and Vernaz, E. Thermal and physicochemical properties important for the long termx behavior of nuclear waste glasses. <CT> Simultaneous Convening of the 8th International Symposium onx Thermodynamics of Nuclear Materials and the 12th IUPACX Conference on Chemical Thermodymamics and the 47th CalorimetryX Conference.<CL> Snowbird, UT, USA Journal of Nuclear Materials 201:295-309, 1993.

2825. Matzke, H., ; Kahl, L., ; Saidl, J., ; Routbort, J., I., and X effect of composition and radiation on the hertzian indentationx behavior of nuclear waste glassesX. Adv.Ceram., 8, 697-709X-709X, 1994.

2826. Matzke, H., ; Linker, G., and X fracture toughness and leaching behavior of ion bombarded wastex glassesx. Nucl.Instrum.Methods Phys.Res., Sect.B, 229, 569-80X-80X, 1994.

2827. Matzke, H., ; Scheibel, H., G., ; Friehmelt, V., and X characterization of waste glasses using vickers indentation, shortx rod fractometry and drop testsX. Mater.Res.SOC.Symp.Proc., 127, 173-80X-80X, 1994.

2828. Matzke, $\mathrm{H}$. and $\mathrm{X}$ radiation damage and defects in ceramics and glasses for safex long-time storage of radioactive wastex. Cryst.Lattice Defects Amorphous Mater., 17, 21-8X-8X, 1994. 
2829. Matzke, H. and $\mathrm{X}$ rutherford backscattering for measuring corrosion layers on glassesx for long-term storage of radioactive wastex. Fresenius' Z.Anal.Chem., 319, 801-8X-8X, 1994.

2830. Matzke, $H$. and $X$ actinide diffusion in waste glassesX. Thermodyn.Nucl.Mater., Proc.Int.Symp., Meeting Date 1979, VolumeX 1, 3-29, 1994.

2831. Matzke, H.,Jr. and $\mathrm{X}$ nuclear waste materialsX. Beam Modif.Mater., 2, 501-30X-30X, 1994 .

2832. Maul, P.R. and Passant, F.H. Radioactive Waste Storage and Disposal in the U.K. Advances.in nuclear.science and.technology. 21:250-255, 1990.

2833. Maupin, G.D., Bowen, W.M., and Daniel, J.L. Fabrication and Characterization of MCC Approved Testing Material: (Unknown Journal!), 1988.

2834. Maupin, G.D., Bowen, W.M., and Daniel, J.L. Fabrication and Characterization of MCC (Materials Characterization Center) Approved Testing Material: ATM-10 Glass: (Unknown Journal!) , 1988.

2835. Maurex, C., Clark, D.E., Hench, L.I., and Grambow, B. Solubility effects of the corrosion of nuclear defense waste glasses. Nuclear and Chemical Waste Management 5:193-201, 1985.

2836. Maxted, A. Remote systems for sampling of highly active slurry in windscalex vitrification plant. In: Proceedings of the Conference on Remote Systems Technology. Publ byX ANS, La Grange Park, IL, USA.p 74-80, Anonymous Ia Grange Park, IL, USA: 1991,P. 74-80.

2837. Maxwell, R. and Eckert, H. Chemical-Equilibria in Glass-Forming Melts High-Temperature $\mathrm{P}-31$ and Se-77 MMR of the Phosphorus Selenium system. J. AMER. CHEM. SOC. $116: 682-689,1994$.

2838. Mayberry Technical area status report for low-level mixed waste final waste forms. (Unknown Journal!) : (123 p), 1993.

2839. Mayberry, J.L., DeWitt, L.M., and Darnell, R. Technical area status report for low-level mixed waste final waste forms. volume-1. Progress rept. (Unknown Journal!), 1993.

2840. Mayberry, J.L., Feizollahi, F., and Del Signore, J.C. Preliminary systems design study assessment report. Volume 4, Leach resistant/high integrity structure concepts. (Unknown Journal!) , 1991.

2841. Mayer, E. New method for vitrifying water and other liquids by rapid cooling of the aerosols. Journal.of.Applied.Physics. v. 58 (July 15 '85): 663-667, 1985 .

2842. Mayer, E. Vitrified dilute aqueous solutions. Infrared spectra of alkali metal nitrates and perchlorates as solutes. The.Journal.of.Physical.Chemistry. v. 90 (Aug. 28,86 ) :4455-4461, 1986 . 
2843. Mayer, E. and Bruggeller, P. Devitrification of glassy water. Evidence for a discontinuity of state? The.Journal. Of.Physical.Chemistry. v. 87 (Nov. 10 '83) :4744-4749, 1983 .

2844. Mayer-Schwinning, G., Merlet, H., Pieper, H., and Zschocher, H. Verglasungsverfahren zur inertisierung von rueckstands-produkten ausX der schadgasbeseitigung bei thermischen abfallbeseitigungsanlagen. VGB Kraftwerkstechnik 70:332-336, 1990.

2845. Mayuzumi, M. Effect of Test Temperature and sensitization on stress Corrosion Cracking of Canister Materials in Air. (Unknown Journal!) , 1988.

2846. Mazer, J., ; Bates, J., ; Biwer, B., ; Bradley, C., R., and X aem analyses of srl 131 glass altered as a function of $\mathrm{sa} / \mathrm{vX}$. Mater.Res.SoC.Symp.Proc., 257, 73-81X-81X, 1994.

2847. Mazer, J. and No, H. Prospects for vitrification of mixed wastes at ANL-E. (Unknown Journal!), 1993.

2848. Mazer, J.J. Temperature effects on waste glass performance /, Argonne, Il1. : Springfield, Va. :Argonne National Laboratory, Chemical Technology Division ; available from N.T.I.S., 1991.

2849. Mazer, J.J., Bates; J.K., Bradley, C.R., and Stevenson, C.M. Obsidians and tektites: Natural analogues for water diffusion in nuclear waste glasses. (Unknown Journal!), 1991.

2850. Mazer, J.J., Bates, J.K., Bradley, C.R., and stevenson, C.M. Water diffusion in tektites: an example of the use of natural analoguesx in evaluating the long-term reaction of glass with water. Journal of Nuclear Materials 190:277-284, 1992 .

2851. Mazoyer, R. and Vernaz, E. Conditioning of Waste Cladding Hulls by Eutectic Melting and Embedding in Glass. (Unknown Journal!) , 1986.

2852. Mazurin, O.V. and Antropova, T.V. The rate at which sodium borosilicate glass undergoes selective dissolution in acid as a function of the level to which the solution is saturated by dissolution products, 1988.

2853. Mazzoldi, P. atomic processes in charged particle irradiation of glassesX. Nato Asi Ser., Ser.E, 92, 597-614X-614X, 1994.

2854. Mcadams, C.I. Technologies for soil remediation. Waste Age 24:37-44, 1993 .

2855. MeCarthy, D., Chan, M.K.C., and Lokken, R.O. Rheological Evaluation of Pretreated Cladding Removal Waste. (Unknown Journal!), 1986.

2856. McCarthy, G. Ceramics and glass ceramics as high level waste formsX. Ceram.Glass.Radioact. Waste.Forms. -770102, 1994.

2857. McCarthy, G. and Davidson, M. Ceramic nuclear waste forms: ii, ceramic-waste composite prepared byhot-pressing. Am.Ceram.Soc.BuIl. , 1976. 
2858. MCCarthy, G. and Davidson, M. Ceramic nuclear waste forms.i.crystal chemistry and phaseX formationX. Am. Ceram.Soc. $-6 \mathrm{X}, 1994$.

2859. MCCarthy, G.J., ; Pepin, J.G., ; Pfoertsch, D.E., ; Clarke, X.D., and X crystal chemistry of the synthetic minerals in currentx supercalcine-ceramicsx. Ceram.Nucl.Waste Manage., Proc.Int.Symp., Issue Conf-790420,X 315-20-20, 1994.

2860. MCCarthy, G.J., ; Scheetz, B.E., ; Komarneni, S.S.,X Deane K., ; White,

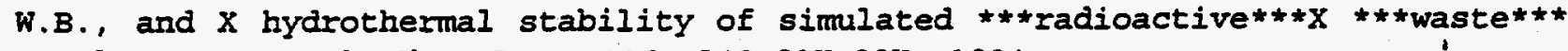
***glass*** X. Adv. Chem.Ser., 186, 349-89X-89X, 1994.

2861. McClellan, A. The aspects of the devitrification behavior of a sodium borosilicate glass. containing ten percent molybdenum trioxide, 1983.

2862. McCombie, C., Issler, H., and Mckinley, I.G. High-level wastè disposal in switzerland. In: High Level Radioactive Waste and Spent Fuel Management Proc 1989 Jointx Int Waste Manage Conf $v 2$ (of 2).Publ by American Soc of MechanicalX Engineers (ASME), New York, NY, USA.p 399-401, Anonymous New York, NY, USA:American SoC of MechanicalX Engineers (ASME), 1989,p. 399-401.

2863. MCCoy and Markworth, A. Water chemistry and dissolution kinetics of waste-form glasses. J.Non-Cryst.Solids , 1987.

2864. McCOY, H., E., and X studies of waste-canister compatibilityX. Report, Ornl/Tm-8491; Order No.De83005917, 92 pp, 1983.

2865. McCoy, J.K. and Markworth, A.J. Water chemistry and dissolution kinetics of waste-form glasses. Journal of Non-Crystalline Solids 89:47-59, 1987.

2866. MCCright, R.D., Van Konynenburg, R.A., and Ballou, L.B. Corrósion test plan to guide canister material selection and design forX a tuff repository. In: <CI> Symposium held as part of the Annual Meeting of the Materialsx Research Society Materials Research Society Symposia Proceedings $v$ 26. Publ byX North-Holland, New York, NY, USA and Amsterdam, Neth $p$ 309-318, Anonymous New York, NY, USA: 1984,p. 309-318.

2867. McCright, R.D., Weiss, H., Juhas, M.C., and Logan, R.W. Selection of candidate canister materials for high-level nuclear wastex containment in a tuff repository. In: Publ by NACE, Houston, Tex, USA Pap 198, 24p, Anonymous Houston, Tex, USA:NACE, 1984,

2868. MaDonald, F.N. Equation for predicting elutriation rates above the transportx disengaging height in a gas fluidized-bed calciner. In: Annual Meeting - American Institute of Chemical Engineers 1982. Publ byX AIChE,New York, NY, USA Pap a 80f, 23p, Anonymous New York, NY, USA: 1982,

2869. McDonell, W., R., and $x$ comparison of srp high-level waste disposal costs for borosilicatex ***glass*** and crystalline ceramic waste formsx. Report, Dpst-82-346; Order No.De82015011, 38 pp, 1982.

2870. MCDonell, W.R. Economic Analysis of Projected High-Level Waste Immobilization Operations at the Savannah River Plant. (Unknown Journal!), 1986 . 
2871. MCDonelI, W.R. and Jantzen, C.M. Effects of Waste Content of Glass Waste Forms on Savannah River High-Level Waste Disposal Costs. (Unknown Journal!), 1985.

2872. McDonell, W.R., Thomas, S.D., and Goodlett, C.B. Costs of Nuclear Waste Glassmaking at Savannah River. (Unknown Journal!) , 1988.

2873. MCDonell, W.R., ; Goodlett, C.B., and X systems costs for disposal of savannah river high-level waste sludgex and saltx. Fuel Reprocess.Waste Manage., Proc.- Am.Nucl.Soc.Int.Top.X Meet., Volume 1, 414-28:ark, Ill, 1994.

2874. MCDonnell, Thomas, and Goodlett Costs of nuclear waste glassmaking at savannah river. Adv. Fusion Glass, 1988.

2875. McElfresh, D., K., ; DeNatale, J., F., ; Howitt, D., G., ; Butler, E., P., and $X$ direct observations of the leaching of a simulated nuclear wastex ** glass*** in a radiation environmentx. Radiat.Eff., 79, 285-90X-90X, 1994.

2876. McElfresh, D.K., Howitt, D.G., and Geiss, R.H.E.. Electron microscopy of leached glasses Microbeam analysis 1981, proceedings of the 16th annual conference ofX the microbeam analysis society. In: Proceedings, Annual Conference - Microbeam Analysis Society 16th.PubIX by San Francisco Press, Inc, Calif, USA $p$ 276-278 Proceedings, Annual Conference - Microbeam Analysis Society 16 th.PublX by San Francisco Press,Inc,Calif, USA 378 p,Anonymous Annual Conference - Microbeam Analysis Society 16th: 1981,p. 276-Microbeam Analysis S.

2877. MCElroy and Bonner United states developments in the solidification of high-levelX radioactive wasteX. Int.Fachmesse.Fachtag.Kerntech.Ind. :Schweiz Mustermesse, 1994.

2878. MCElroy and Siemens Remote operations in nuclear waste conversion facilitiesX. Report. , 1975.

2879. McElroy, J.I: Processing of High-Level Radioactive Waste. (Unknown Journal!) , 1985.

2880. McElroy, J.I., Bjorklund, W.J., and Bonner, W.F. Waste vitrification: a historical perspective. In: <CI> Selected Papers presented at the American Nuclear Society TopicalX Meeting Publ by Battelle Press,Columbus, $O H$ and Richland,WA, USA andX Springer-Verlag, New York, NY, USA and Heidelberg, West Ger $p$ 171-177,Anonymous Columbus, $O F$ and Richland, WA, USA:Battelle Press, 1983, p. $171-177$.

2881. MCElroy, J.L. and Powell, J.A. Nuclear Waste Management. Semiannual Progress Report, April 1984-September 1984. (Unknown Journal!) , 1984.

2882. McGinnis, P. The effect of hydroxyl content on phase separation in sodium silicate and alkali borosilicate glasses, 1991.

2883. McGrail Evaluating long-term performance of in situ vitrified waste forms: methodology and results. (Unknown Journal!) :(74 p), 1992. 
2884. McGrail, Kumar, and Day, D. Sodium diffusion and leaching of simulated nuclear waste glass. J.Am.Ceram.Soc. , 1984.

2885. McGrail, B., P., ; Engel, D., W., and X coupled process modeling and waste-package performanceX. Mater.Res.Soc.Symp.Proc., 294, 215-23X-23X, 1994.

2886. McGrail, B., P., ; Eliason, V., L., and $X$ data report on static leach tests with savannah river laboratoryx defense waste glass in pbbl brine at 90.degree.c: salt repositoryx projectx. Report, PnI/Srp-6253; Order No.De87011272, 18 pp, 1987.

2887. McGrail, B., P., ; Eliason, V., L., and $X$ data report on static leach tests with savannah river laboratoryx defense waste glass in pbb3 brine at 90.degree.c: salt repositoryx projectx. Report, Pnl/Sxp-6694; Order No.De89000282, 19 pp, 1988.

2888. McGrail, B., P., and $X$ preliminary analysis of dhlw [defense high-level waste] glassx performance as related to the nre 10 cfr6o slow release limitx. criterionx. Report, PnI/STP-6660; Order No.De89000264, 13 pp, 1988.

2889. McGrail, B., P., and $X$ radiocolloid formation in waste package leach tests with savannahx river defense waste glass in salt brineX. Adv.Ceram., 20, $601-8 \mathrm{X}-8 \mathrm{X}, 1994$.

2890. MCGrail, B., P., and X modeling the dissolution behavior of defense waste glass in a saltx repository environmentx. Mater.Res.Soc.Symp.Proc., 112, 595-606X-606x; 1994.

2891. McGrail, B.P. Radiocolloid formation in waste package leach tests with Savannah River defense waste glass in salt brine. Adv.Ceram. 20:601-608, 1986.

2892. McGrail, B.P. Waste package component interactions with savannah river defense wastex glass in a low-magnesium salt brine. Nuclear Technology $75: 168-186,1986$.

2893. McGrail, B.P. Preliminary Analysis of DHLW (Defense High-Level Waste) Glass Performance as Related to the NRC (Nuclear Regulatory Commission) 10CFR60 Slow Release Limit Criterion. (Unknown Journal!) , 1988.

2894. McGrail, B.P. and Eliason, V.I. Data Report on Static Leach Tests with Savannah River Laboratory Defense Waste Glass in PBBI Brine at 90 sup $0 \mathrm{C}$ : Salt Repository Project. (Unknown Journal!) , 1987.

2895. McGrail, B.P. and Eliason, V.L. Data Report on Static Leach Tests with Savannah River Laboratory Defense Waste Glass in PBB3 Brine at 90 Degree C: Salt Repository Project. (Unknown Journal!) , 1988.

2896. McGrail, B.P., Kumar, A., and Day, D.E. Sodium diffusion and leaching of simulated nuclear waste glass. Journal. of the. American. Ceramic. Society.v. 67. (July. '84) .p.463-7.bibl.diag. $2-7820, \cdot 1984$. 
2897. MCGrail, B.P. and Reimus, M.A. Defense Waste Glass Studies Program, FY 1986 Annual Report: Salt Repository Project. (Unknown Journal!), 1987.

2898. McGrail, B.P. and Strachan, D.M. General Model for the Dissolution of Nuclear Waste Glasses in Salt Brine. (Unknown Journal!) , 1988.

2899. McGrail, B. Sodium diffusion and the leaching of simulated nuclear waste glass, 1982 .

2900. McGrain, B.P. Modeling the Dissolution Behavior of Defense Waste Glass in a Salt Repository Environment. (Unknown Journal!) , 1988.

2901. McIntosh, T., W., ; Bixby, W.W., ; Krauss, J.E., ; Leap, D.R., and X an overview of waste management systems at the west valleyx demonstration projectX. Proc.Symp.Waste Manage., (Waste Manage.'88, Vol. 2), 785-90X-90X, 1994.

2902. McIntyre, N., S., ; Strathdee, G., G., ; Phillips, B., F., and X secondary ion mass spectrometric studies of the aqueous leaching ofx a borosilicate waste $* \star \star g l a s s * \star * X$. Surf.Sci., 100, 71-84X-84X, 1994.

2903. MCKee, R.W., Daling, P.M., and Wiles, L.E. Economic comparison of crystalline ceramic and glass waste forms forX hlw disposal. In: <CI> Held during the $85 \mathrm{th}$ Annual Meeting of the American Ceramicx Society Advances in Ceramics $v 8$. Publ by American Ceramic SOC Inc, Columbus, $X$ OH, USA $p$ 666-676, Anonymous Columbus, $X$ OH, USA:American Ceramic SOC Inc, 1984,p. 666-676.

2904. McKenney Defense waste treatment and disposal activities at the hanford site. (Unknown Journal!) : (19 p), 1990.

2905. McKenzie, W.F. Natural glass analogues to alteration of nuclear waste glass: A review and recommendations for further study. (Unknown Journal!) , 1990.

2906. McKenzie, W.F. Secondary phases formed during nuclear waste glass-water interactions: Thermodynamic and derived properties. (Unknown Journal!), 1992.

2907. MCKibben, J.M., Benjamin, R.พ., Bickford, D.F., Fernandez, L.P., and Jackson, W.N. Vitrification of excess plutonium. (Unknown Journal!), 1993.

2908. MCKibben, J.M., Pair, C.R., and Bethmann, H.K. Design and construction innovations of the Defense Waste Processing Facility. (Unknown Journal!) , 1990.

2909. Mokinley, I.G. Geochemistry of the Near-Field. (Unknown Journal!) , 1985.

2910. MaKisson, R., L., ; Grantham, L., F., ; Guon, J., ;. Recht, H., and X commercial high-level-waste management: options and economics. ax comparative analysis of the ceramic and $\star \star \star$ glass $\star \star *$ waste formsx. Report, Doe/Et/41900-17, Esg-Doe-13391; Order No.De83006235, $133 \mathrm{X}$ pp, 1983. 
2911. MCPherson, D.M., Bowan, B.W., and Pye, I.D. Dissolution of zeolitic compounds in borosilicate glass melts. In: $v .3$. Publ by Indian Ceramic Soc, Calcutta, India p 35-41, Anonymous Calcutta, India p 35-41:Indian Ceramic Soc, 1986, p. $35-411$.

2912. McVay and Pederson Effect of gamma radiation on glass leaching. J.Am.Ceram.SOC. , 1981.

2913. McVay, C.w., Stimmel, J.R., and Marchetti, S. Cement Waste Form Qualification Report: WVDP (West Valley Demonstration Project) PUREX Decontaminated Supernatant: Report of Work Performed for the Period of 1983 through 1988. (Unknown Journal!) , 1988.

2914. McVay, G., I., ; Bradley, D., J., ; Kircher, J., F., and X elemental release from $* * *$ glass*** and spent fuelx. Report, Onwi-275; Order No.De82015754, 63 pp, 1982.

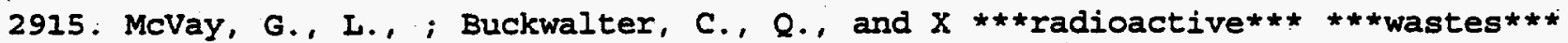
.the nature of $* * *$ glass $* * x$ leachingX. Nucl.Technol., 51, 123-9X-9X, 1994 .

2916. McVay, G., L., ; Pederson, L., R., and $X$ effect of .gamma.radiation on **tglass*** leachingX. J.Am.Ceram.Soc., 64, 154-8X-8X, 1994 .

2917. MCVay, G., L., ; Weber, w., J., ; Pederson, L., R., and $\mathrm{X}$ effects of radiation on the leaching behavior of nuclear waste formsx. Nucl. Chem. Waste Manage., 2, 103-8X-8X, 1994.

2918. McVay, G.L., ; Buckwalter, C.Q., and $X$ effect of iron on waste**tglass*** leachingX. J.Am.Ceram.Soc., 66, 170-4X-4X, 1994 .

2919. Means, J. and spinosa, E. simulated nuclear waste glass leachingualteration layer artifacts producedby reprecipitation of solutes during cooling. Am.Ceram.Soc.BuIl. , 1986.

2920. Means, J.L. and Spinosa, E.D. Simulated nuclear waste glass leaching: alteration layer artifactsx produced by reprecipitation of solutes during cooling. American Ceramic Society Bulletin 65:780-782, 1986.

2921. Means, J. and Spinosa, E. Simulated nuclear waste glass leaching: alteration layer $\mathrm{x}$ artifacts produced by reprecipitation of solutes during $\mathrm{x}$ cooling Performance of borosilicate glass high-level waste forms in $x$ disposal systems. American.Ceramic.Society.Bulletin.Nuclear.Technology. v. 65 (May '86) :139-209 XPY - 1986, 1986.

2922. Mecham, W., J., ; Jardine, L., ; Pelto, R., H., ; Steindler, M., and X characterization of impact fracture of brittle solid waste formsX. Sci.Basis Nucl. Waste Manage., 2, 307-14X-14X, 1994.

2923. Mecham, W.J., ; Jardine, L.J., ; Steindler, M.J., and $\mathrm{X}$ a methodology for characterizing brittle fracture of solid wastex forms in accidental impactsx. Mater.Res.Soc.Symp.Proc., 6,X 125-31X-31X, 1994. 
2924. Medda, M.P., Musinu, A., and Piccaluga, G. X-ray structural investigation on sodium borate samples prepared by the sol-gel method. Journal. of.Materials. Science v.29. (Mar.1.'94).p.1330-5.bibl. 22-2461, 1994 .

2925. Medda, M.P., Musinu, A., Piccaluga, G., and Pinna, G. Na+ Coordiriation in Sodium Diborate and Triborate Glasses by X-Ray-Diffraction. J.NON-CRYST.SOLIDS. $162: 128-135,1993$.

2926. Meier, M., Braetsch, V, and Frischat, G. Self-diffusion in $\mathrm{Na} / / 20-\mathrm{Rb} / / 20-\mathrm{SiO} / / 2$ glass melts as obtained by microgravity experiments. Journal. of the.American.Ceramic.Society. J Am Ceram Soc v 73, 1990.

2927. Meitz, H. Use of spodumene ore as a flux for glass melting. Glass. Technology. Glass Technol $v 30 \mathrm{n}, 1989$.

2928. Mellen, J.B., Burke, T.H., and Kitchen, B.G. Technical and Project Highlights for the Defense Waste Processing Facility. (Unknown Journal!) , 1989 .

2929. Melling, P., J., ; Allnatt, A., R., and $X$ modeling of leaching and corrosion of $* * *$ glass $* * *$. J.Non-Cryst.Solids, 42, 553-9, 1980.

2930. Melling, P.J., Karkhanis, S.N., and Fyfe, w.S. The hydrothermal leaching behaviour and properties of sodium- $X$ calcium aluminophosphosilicate glasses. Glass. Technology. v. 24 (Aug. '83):192-197, 1983.

2931. Mellinger, G.B. Standardized Test Methods for Use in Waste Compliance Testing in the Department of Energy's Waste Acceptance Process. (Unknown JournaI!) , 1986 .

2932. Mellinger, G.B., Perez, J.M.J., Pope, J.M., and Harrison, D.E. Small-scale glass melter tests using alkoxide/hydroxide slurry feeds containing simulated west valley waste. In: <CI> Held during the 85th Annual Meeting of the American Ceramicx Society Advances in Ceramics $v 8$. Publ by American Ceramic SOC Inc, Columbus, $X$ OH, USA $P$ 171-178, Anonymous Columbus, $X$ OH, USA:American Ceramic Soc Inc, 1984,p. 171-178.

2933. Melnyk, T.พ.; Walton, F.B., and Johnson, H.L. High-Level Waste Glass Field Burial Tests at CRNL. The Effect of Geochemical Rinetics on the Release and Migration of Fission Products in a Sandy Aquifer. (Unknown Journal!), 1983.

2934. Melnyk, T.W., Walton, F.B., and Johnson, L.H. High-level waste glass field burial test: leaching and $X$ migration of fission products. Nuclear.and. Chemical. Waste.Management. v. 5 nol ('84):49-62, 1984.

2935. Memmert, G. evaluation of the barriers in a permanent storage area for $\star \star *$ radioactive $* * * \star \star *$ waste ${ }^{* \star}$. Ber.Kernforschungsanlage Juelich, Juel-Conf-42 (Vol. 2) Proc:roc-Level Liquid Waste, 1982.

2936. Mendel High-level waste glassX. Report. , 1977.

2937. Mendel Glass as a waste form: overview and processing considerationsX. Ceram.Glass. Radioact. Waste. Forms. -770102, 1994. 
2938. Mendel and McElroy Waste solidification program. 10. evaluation of solidified wastex productsx. Report. , 1972.

2939. Mendel and McElroy Incorporation of high level radioactive waste inX glass .reviewX. Report. , 1975.

2940. Mendel and Ross Chemical durability of glasses containing radioactive fissionX product wasteX. Report. , 1976.

2941. Mendel, Ross, Roberts, Turcotte, X, K.Y.., and Westsik Thermal and radiation effects on borosilicate waste glassesX. Report. , 1976.

2942. Mendel, Ross, Roberts, Turcotte, X, K.Y.., and Westsik Thermal and radiation effects. on borosilicate waste glassesX.

Manage.Radioact. Wastes.Nucl. Fuel.Cycle -61, 1994.

2943. Mendel, J. Glassùan available material for the immobilization of nuclear waste. Trans.Am.Nucl.Soc. , 1979.

2944. Mendel, J. High-level waste glassX. NUCL.TECHNOL. -87X, 1994.

2945. Mendel, J., McElroy, J., and Platt, A. High-level radioactive waste management research and developmentx program at battelle pacificx. Adv. Chem.Ser. -107X, 1974.

2946. Mendel, J.E. waste glasses - requirements and characteristics. Treat.Handl.Radioact.Wastes, , Meeting Date 1982:178-183, 1983.

2947. Mendel, J.E. the fixation of high-level wastes in glasses. Philos.Trans.R.SOc.London, A, 319:49-62, 1986.

2948. Mendel, J.E., Ross, W.A., Turcotte, R.P., and McElroy, J.I. physical properties of waste ***glass***. U.S.Nucl.Regul.Comm., Nureg/Cp, Nureg/Cp-0005, Proc.X Conf.High-Level Radioact.Solid Waste Forms, 1978; PB294865, 37-7:B294865, 37-B294865, 79X, 1979 .

2949. Mendel, J.E., Ross, W.A., Turcotte, R.P., and McElroy, J.L. physical properties of $\star * \star$ glass $* \star$ for imnobilization of high level $\star \star \star$ radioactive*** ***waste***. Nucl. Chem. Waste Manage., 1:17-28, 1980.

2950. Merk, N., Morris, D.G., and Morris, M.A. Ductilization and embrittlement during the crystallization of $\mathrm{Ni}-\mathrm{Ti}-\mathrm{B}$ glasses. Journal.of.Materials.Science $\mathrm{J}$ Mater Sci v $23 \mathrm{n} 1$; 1988.

2951. Merlin, S. La hague vitrification facilities. In: <CI> Volume 2: High-Level Waste $v 2$. Publ by Arizona Board of Regents, $A Z$, USA $P$ 421-425, Anonymous Az, USA:Arizona Board of Regents, 1986,p. 421-425.

2952. Merriam, S. Conductivities and densities of sodium vanadium phosphate glasses, 1983. 
2953. Merrill, B. Effects of additions of Ceb2sob4s, Ndb2sOb3s, Lab2sOb3s and Yb2sob3s on the acid resistance of crystallized lithium silicate glass, Alfred, N.Y.New York State College of Ceramics at Alfred University, 1971.

2954. Merrill, R.A. and Chapman, C.C. Preliminary estimates of cost savings for defense high level waste vitrification options. (Unknown Journal!) , 1993.

2955. Merrill, R.A. and Janke, D.S. Results of vitrifying Fernald OU-4 wastes. (Unknown Journal!), 1993.

2956. Merritt High-level waste glass: field leach testx. NUCL.TECFNOL. -91X, 1994.

2957. Merritt Fixation of radioactive waste in glass X. At.Energy.Can.Ltd. $-5800,1994$.

2958. Merritt The leaching of radioactivity from highly radioactive glass blocksX buried below the water table: fifteen years of resultsX. Manage.Radioact. Wastes.Nucl. Fuel.Cycle -35, 1994.

2959. Merritt The leaching of radioactivity from highly radioactive glass blocksx buried below the water table: fifteen years of resultsx. At. Energy.Can.Ltd. $-5317,1994$.

2960. Merritt Permanent disposal by burial of highly radioactivex wastes incorporated into glass X. Disposal.Radioact.Wastes.Ground. -8X, 1994.

2961. Merritt, W.F. The leaching of radioactivity from highly radioactive glass blocks buried below the water table : fifteen years of results /, Chalk River, Ont. :Chalk River Nuclear Laboratories, 1976.

2962. Mertens, L.A., Lutze, W., Marples, J.C., Van Iseghem, P., and Vernaz, E. a comparison of the behavior of vitrified $\mathrm{hlw}$ in repositories inX salt, clay and granite.i: experimentalx. Mater.Res.Soc.Symp.Proc., 176, 267-74, 1990.

2963. Merz, E. Final storage forms for high-level radioactive fission product wastes. Atw, Atomwirtsch., Atomtech., 24, 409-13, 1979.

2964. Merz, E. Treatment of Radioactive Waste in the Nuclear Fuel Cycle. (Unknown Journal!) , 1987.

2965. Merz, E., Kuehn, K., Bloser, M., and Matting, A. Implementation of the federal republic of germany's strategy of radioactive waste disposal. In: Publ by IAEA, Vienna, Austria p 77-86, Anonymous Vienna, Austria p 77-86:IAEA, 1986, P. $77-866$.

2966. Merz, E. and Nowak, R. Radioactive Waste Management. Waste Forms of High-Level Radioactive Wastes from Reprocessing. (Unknown Journal!) , 1987.

2967. Messaddeq, Y. and Poulain, M. Stabilizing Effect of Aluminum, Yttrium and zirconium in Divalent Fluoride Glasses. J.NON-CRYST.SOLIDS. 140:41-46, 1992.

2968. Messsaddeq, Y. and Poulain, M. Influence of Sulfate Impurities on the Ir Transmission of InF3-Based Glasses. J.NON-CRYST.SOLIDS. 140:77-81, 1992. 
2969. Messier, D. and Gleisner, R. Preparation and characterization of Li-Si-Al-O-N glasses. JO -Journal of the American Ceramic Society. (Unknown Journal!) v. 71 (June '88):422-425, 1988 .

2970. Messier, D., Gleisner, R., and Rich, R. Yttrium-silicon-aluminum oxynitride glass fibers. Joumal.of.the.American.Ceramic.Society. J Am Ceram SOC $\mathrm{v} 72,1989$.

2971. Metson, J.B., Bancroft, G.M., Kanetkar, S., Nesbitt, H.w., Fyfe, W.S., and Hayward, P.J. leaching of natural and synthetic sphene and perovskite. Mater.Res.Soc.Symp.Proc., 11, 329-38, 1982.

2972. Meyer, R.E.R. Thermodynamics of technetium related to nuclear waste disposal solubilities of TC(IV) oxides and the electrode potential of the $T C$ (VII)/TC(IV)-oxide couple, Washington, DC:Division of Engineering, office of Nuclear Regulatory Research, U.S. Nuclear Regulatory Commission, 1989.

2973. Mezga, L.J. and Radcliffe, L.I. Information exchange on current and planned low-level and transuranic waste management practices. Foreign trip report, November 1--12, 1992. (Unknown Journal!) , 1993.

2974. Michalske, T. and Bunker, B. Chemical kinetics model for glass fracture. Journal.of.the.American.Ceramic.Society. Journal of the Ameri, 1993.

2975. Mierzwa, J. and Dobrowolski, R. Silica-Gel Analysis by Slurry-Sampling Graphite-Furnace Atomic-Absorption Spectrometry. FRESENIUS.J.ANAL.CHEM. $348: 422-425,1994$.

2976. Migge, H. thermochemical comparison of the rhenium-oxygen and technetiumoxygen systems. Mater.Res.Soc.Symp.Proc., 127, 205-13, 1989.

2977. Migge, H. simultaneous evaporation of cesium and technetium during vitrification - a thermochemical approach. Mater.Res.Soc.Symp.Proc., 176, 411-17, 1990.

2978: Miles, J. Future trends in nuclear fuel reprocessing. Nuclear Engineer $34: 27-30,1993$.

2979. Miles, J.H. and Butterworth, G.J. Management options for used lithium ceramic breeder materials. <CT> Proceedings of the 5th International Conference on Fusion ReactorX Materials - ICFRM-5 <CL> Clearwater, FL, USA <CD> 1991 NoV 17-22 Journal of Nuclear Materials 191-94:199-203, 1992.

2980. Millano, E.F., Jones, H.V., and Ball, R.O. Hazardous-Waste - Storage, Disposal, Remediation, and Closure. WATER.ENVIRON.RES. 64:492-501, 1992.

2981. Millex Thermodynamics of gas-metal-slag equilibria for applications in in situ and ex situ vitrification melts. (Unknown Journal!) : (51 p), 1993.

2982. Miller, A. The viscosity of molten glass, 1954. 
2983. Miller, D.D., Hoekwater, J.L., Machida, N., Katano, Y., and Jardine, L.J. New concept for passively-cooled dry storage of vitrified high level waste in japan. Nuclear Engineering International 36:58-59, 1991.

2984. Miller, F.A. design and performance of a full-scale spray calciner for

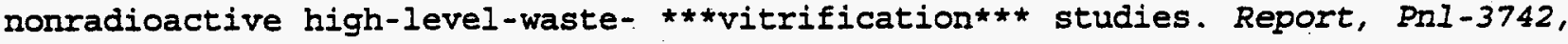
$243 \mathrm{pp}, 1981$.

2985. Miller, M.C., Close, D.A., Sigg, R.A., and Moore, F.S. Computer simulation of a germanium detector response to highly radioactive waste. (Unknown Journal!), 1992.

2986. Miller, P.L.H. State-of-the-ART Review of Quality Assurance Techniques for Vitrified High Level Waste. (Unknown Journal!), 1984.

2987. Miller, w., C., ; Hamilton, D., พ., ; Holton, L., K., ; Bailey, J., and X hanford waste vitrification systems risk assessment: final reportx. Report, Whe-Ep-0421; Order No.De92002976, 341 pp, 1992.

2988. Miller, w.C. Hanford Waste Vitrification Systems Risk Assessment action plan. (Unknown Journal!), 1990.

2989. Miller, W.C., Appel, J., Barton, W.B., Orme, R.M., and Holton, I.K. Tank waste pretreatment issues, alternatives and strategies for resolution. (Unknown Journal!) , 1993.

2990: Miller, w.C., Hamilton, D.w., Holton, L.K., and Bailey, J.w. Hanford waste vitrification systems risk assessment. Final report. Progress rept. (Unknown Journal!) , 1991.

2991. Mimura, H.S.,Masahiro; Akiba Hydrothermal stability of pollucite and leachability of cesium. Tohoku Daigaku Senko Seiren Kenkyusho Iho, 44, 182-90, 1989.

2992. Minaev, Prokhorova, Kozlov, Gavrish, and X, S.G.. X-ray diffraction study of the behavior of iron in thex vitrification of radioactive wastes $x$. Radiokhimiya. -33X, 1994.

2993. Minaev, A.A., Oziraner, S.N., and Prokhorova, N.P. the use of $* * \star g l a s s * \star \star$ -ceramic materials for the fixation of $\star * \star$ radioactive $* \star *$ ***wastes $* *$. Ceram.Nucl.Waste Manage., Proc.Int.Symp., Issue Conf-790420, :229-32, 1980.

2994. Miniscalco, w. Erbium-doped glasses for fiber amplifiers at $1500 \mathrm{~nm}$. Journal. of. Lightwave. Technology. 9 n 2:234-250, 1991.

2995. Mirschinka, V. Properties of container and filling materials for the final storage of highly radioactive fission products. Spez.Ber.Kernforschungsanlage Juelich, Juel-Spez-226, 104 pp, 1984.

2996. Mirschinka, V., Ealaszovich, S., Odoj, R., Forch, U., and Forch, $\mathrm{K}$. Investigations of suitable metallic container materials for haw solidification. Mater.Res.SOC.Symp.PrOC., 15:695-702, 1983. 
2997. Mitamura, H., Banba, T., and Murakami, T. Effects of crystalline phases on leaching of a devitrified simulated high-level waste glass. Nuclear and Chemical Waste Management 6:223-231, 1986 .

2998. Mitamura, H., ; Senoo, M., ; Ishizaki, K., ; Tashiro, S., ; Kato, O., and $X$ Safety evaluation of simulated high-level waste $\star \star \star g l a s s * \star$ products.3.drop impact test of products. Report, Jaeri-M-9191; order No.De81700108, 22 pp, 1982 .

2999. Mitamura, H.S.,Muneaki; Tashiro Safety evaluation of encapsulated ***vitrified*** products. (1). thermal conductivity of borosilicate $* *$ glass*** - encapsulated simulated high-level waste. Report, Jaeri-M-8573, , 1980.

3000. Mitamura, H.M.,Takashi; Banba Crystalline phases in a devitrified simulated high-level waste glass containing the elements of the platinum group. J.Nucl.Mater., 136:104-116, 1985.

3001. Mitamura, H.B.,Tsunetaka; Murakami Effects of crystalline phases on leaching of a devitrified simulated high-level waste glass. Nucl. Chem. Waste Manage., 6:223-31, 1986.

3002. Mitamura, H., Murakami, T., Banba, T., Kiriyama, Y., Kamizono, H., Kumata, M., and Tashiro, S. Segregation of the elements of the platinum group

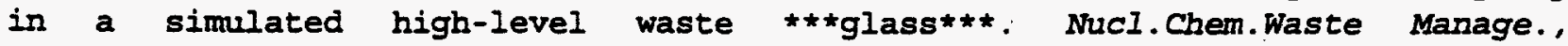
$4: 245-251$, 1984 .

3003. Mitcheil, D.E. Hanford Waste Vitrification Plant: Preliminary Description of Waste. Form and Canister. (Unknown Journal!) , 1986.

3004. Mitchell, D.E. Hanford Waste Vitrification Plant Preliminary Description of Waste Form and Canister. (Unknown Journal!), 1987.

3005. Mitchell, D.E. and Nelson, J.I. Hanford Waste Vitrification Plant Preliminary Description of Waste Form and Canister: FY 1988 Update. (Unknown Journal!) , 1988 .

3006. Mitsuru Asano, Tomoyuki Kou, and Yoshihiko Yasuel Mass Spectrometric study of vaporization of Cesium-Containing Borosilicate Glasses. Journal. of.Non-Crystalline.Solids. 92:245-260, 1987.

3007. Mitsushima, N. Kobe steel's present involvement in transportation and storage of radioactive materials. R\&D, Research and Development 39:2-3, 1989.

3008. Miyahara, K., Ashida, T., Kohara, Y., Yusa, Y., and Sasaki, N. Evaluation of plutonium migration in artificial barrier (compacted bentonite) using leaching data of fully radioactive waste glass. Comparison with leaching model and limited solubility model. (Unknown Journal!), 1990.

3009. Miyahara, K., Ashida, T., Yusa, Y., Sasaki, N., and Tsunoda, N. Static Leaching of Actinides and Fission Products from Fully Radioactive Waste Glass of HILW Generated in Tokai Reprocessing Plant. (Unknown Journal!) , 1989.

3010. Miyahara, K., ; Ashida, T., ; Yusa, Y., ; Sasaki, N., ; Tsunoda, N., and $X$ Static leaching of actinides and fission products from fully 


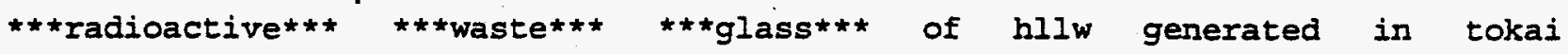
reprocessing plant. Mater.Res.Soc.Symp.Proc., $127: 121-128,1989$.

3011. Miyaji, F., Hasegawa, S., Yoko, T., and Sakka, S. Mixed-Alkali Effect in Nonconventional Alkali Gallotitanate Glasses. J.AMER.CERAM.SOC. 76:545-546, 1993.

3012. Miyaji, F., Yoko, T., and Sakka, s. Structure of Sodium Gallotitanate Glass in Relation to Glass Formation. Nippon.Seramikkusu.Kyokai.gakujutsu.ronbunshi. 102, Number 3,243-247, 1994.

3013. Miyake, M., Baret, G., Madar, R., Bernard, C., Nauka, K., and Iiu, C. Diffusion of boron into silicon from borosilicate glass using rapid thermal processing silica-based oxide systems $I$. Experimental and calculated phase equilibria in silicon, boron, phosphorus, germanium, and arsenic oxide mixtures Suppression of water absorption in borophosphosilicate glass thin layers with high boron concentration. Journal. of . the. Electrochemical. Society. Journal of. the. Electrochemical. Society. J ournal. of. the.Electrochemical.Society. J Electrochem Soc v, 1991.

3014. Miyake, M., Komameni, S., and Roy, R. Kinetics, equilibria and thermodynamics of ion exchange in substitutedx tobermorites. Materials Research Bulletin 24:311-320, 1989.

3015. Miyake, M., ; Atsumi, H., ; Nakamura, Y., ; Yamanaka, S., ; Yamamoto, Y., and ; Kitagawa, K. Thermal release of tritium from neutron irradiated **tglass***. Comm. Eur. Communities, 7983, Fusion Technol-60, 1982.

3016. Miyao, H., ; Tanimoto, K., ; Miyazaki, M., ; Wakui, H., ; Oasada, K., ;X Ishikawa, $F .$, and $X$ demonstration plant and test of an incinerating melter system forx radioactive wastesx. Therm.Treat.Radioact., Hazard.Chem., Mixed Med.Wastes, Proc.X Incineration Conf., 11th, 323-6-6, 1994 .

3017. Mizutani, $U$. and Lee, $c$. Effect of mechanical alloying beyond the completion of glass formation for $\mathrm{Ni}-\mathrm{Zr}$ alloy powders. Journal.of.Materials.Science J Mater Sci v 25 n 1, 1990.

3018. Moegling, S.D. Using borosilicate glass as a hlw storage medium. In: Environ Eng Proc 1989 Spec Conf. Publ by ASCE, New York, NY, USA.Anonymous New York, NY, USA:ASCE, 1989,p. 154-159.

3019. Moffat, T.P., Flanagan, W.F., and Lichter, B.D. Active dissolution of iron-metalloid metallic glasses. Journal.of. the.Electrochemical.Society. $v 135$ n 11 Nov $1988: 2712-2719,1988$.

3020. Moffat, T.P., Latanision, R.M., and Ruf, R.R. Production and characterization of extremely corrosion resistant chromium-metalloid alloys. Journal. of. the.Electrochemical.Society. v $138 \mathrm{n}$ Il Nov 1991:3280-3288, 1991 .

3021. Moir, D., L., ; Chatt, A., and X studies on leaching behavior of sodium borosilicate glasses byx neutron activation: effects of groundwater composition, $\mathrm{ph}$, surfacex area to volume ratio, and temperaturex. J.Radioanal.Nucl.Chem., 161, 503-26X-26X, 1994. 
3022. Moir, D.L. and Chatt, A. Studies on Leaching Behavior of Sodium Borosilicate Glasses by Neutron-Activation - Effects of Groundwater Composition, $\mathrm{pH}$, Surface-Area to Volume Ratio, and Temperature. J.RADIOANAL. NUCL. CEEM.ART. 161:503-526, 1992.

3023. Moir, D.I. and Chatt, A. Characterization of simulated vitrified highly active waste and its leachates by neutron activation. J.Radioanal.Nucl.Chem., $116: 389-400,1987$.

3024. Molecke, M.A. Wipp waste package testing on simulated dhlw: emplacement. Mater.Res.Soc.Symp.Proc., 44:265-271, 1985.

3025. Molecke, M.A., Bradley, D.J., and Shade, J.W. PNL-Sandia hlw package interactions test: phase one. Mater.Res.Soc.Symp.Proc., 6:337-345, 1982.

3026. Molitor, K., Jagdfeld, H.J., and Odoj, R. Development of $a$ high-temperature furnace for coupling a thermal analyzer with $a$ mass spectrometer. Spez.Ber. Kernforschungsanlage Juelich, Juel-Spez-148, , 1983.

3027. Moncouyoux Investigation of full-scale high-level waste containment glass blocks. task 3 characterization of radioactive waste forms a series of final reports (1985-89) - no 24. (Unknown Journal!) : (108 p), 1991.

3028. Moncouyoux, J., ; Aure, A., ; Ladirat, C., and X investigation of full-scale high-level waste containmentx $\star \star \star g l a s s * \star *$ blocks.task 3. characterization ofX **tradioactive*****waste** forms.a series of finalX reports (1985-89) - no.24X. Comm. Eur.Communities, Eur, Eur 13612, 113 pp, 1994.

3029. Moncouyoux, J., P., ; Hugony, P., ; Pieraggi, A., and X the marcoule ***vitrification*** plant.thirty months of operation. Ber.Kernforschungsanlage Juelich, Juel-Conf-42 (Vol. 1), Proc:roc-Level Liquid Waste, 1982.

3030. Moncouyoux, J., P., ; Ladirat, C., ; Jouan, A., and X quality control procedures for glass produced by the french continuous vitrification process. Ber.Kernforschungsanlage Juelich , Juel-Conf-54, Proc.Int.X Semin.Radioact. Waste Prod., 86-96X-96X, 1994.

3031. Moncouyoux, J.P., Boen, R., Pouyou, M., and Jouan, A. New vitrification techniques. (Unknown Journal!), 1991.

3032. Moncouyoux, J.P. and Sombret, C. French High-level waste management research and development program. (Unknown Journal!) , 1992.

3033. Montagne, L., Palavit, G., and Draoui, M. Mechanism of Polyphosphate Gel Formation in the Na20-A1203-P205 System. J.NON-CRYST.SOLIDS. 155:115-121, 1993.

3034. Montenero, A., Ugozzoli, F., Schiroli, D., Gnappi, G., Giori, D.C., and Pye, L.D. Further studies on thermal evolution of glass-forming gels. Journal.of. the.American.Ceramic.Society. J Am Ceram Soc v 72, 1989.

3035. Montrose, C., J., ; Barkatt, A.M.,P., and B. time dependent leaching in two-phase composite glasses. Mater.Res.Soc.Symp.Proc., 26:741-746, 1984. 
3036. Moore, H.H. Selenium, tellurium, cobalt and nickel in glass making, London:Mond Nickel Co., Ltd. 1956.

3037. Morgan, S. Infrared and Raman Investigation of Rare-Earth Phosphate Glasses for Potential Use as Radioactive Waste Forms: Final Technical Report. (Unknown Journal!), 1986.

3038. Morgan, S. infrared and raman investigation of rare-earth phosphate glasses for potential use as radioactive waste forms: final technical report. Report, Doe/Or/00033-T277; Order No.De87005964, , 1987.

3039. Morgan, S.H. Infrared and Raman investigation of rare-earth phosphate glasses for potential use as radioactive waste forms. Final Report. (Unknown Journal!) , 1989.

3040. Morgan, S.H. and Magruder, R.H.I. Raman spectra of molybdenum phosphate glasses and some crystallinex analogues. Journal of the American Ceramic Society $73: 753-756,1990$.

3041. Morgenstein, M.E. Physics and Chemistry of the Transition of Glass to Authigenic Minerals: State of Nevada, Agency for Nuclear Projects/Nuclear Waste Project Office. (Unknown Journal!) , 1984.

3042. Morlevat, J.P. Microanalysis of glasses for the disposal of high-activity wastes. In: Journal de Physique (Paris), Colloque C2 Suppl. to $v 45$ a 2 Feb 1984 pX 815-818, Anonymous Collogue C2 Suppl to $v 45$ n 2 Feb 1984 pX 815-818: $1984,-8188$.

3043. Morlevat, J.P. microanalysis of glasses for the storage of high-activity [nuclear] wastes. J.phys., Collog., (C2), :815-818, 1983.

3044. Morlevat, M., ; Uny, M., G., and ; Jacquet Francillon, M. compared quantitative determination of nuclear waste $\star \star \star$ glass $\star \star \star$ crystallization rate by light microscopy and $x$-ray diffraction. Ber.Kernforschungsanlage Juelich, Juel-Conf-42 (Vol. 2), Proc:roc-Level Liquid Waste, 1982.

3045. Moroni, V., Nannicini, R., Bertelli, S., and Dell'Igna, R. Forno a bacino per la vetrificazione di rifiuti radioattivi ad alta attivita'. (Tank furnace for continuous vitrification of high radioactive liquid wastes). (Unknown Journal!) , 1991.

3046. Morozova, E.V. Effect of Antimony oxide on Phase Separation in Sodium Borosilicate The.Soviet.journal.of.glass.physics.and.chemistry.PY.-.1991. 17, Number $5: 390-397,1991$.

3047. Morozova, E.V. Phase Separation in Sodium Borosilicate Glass with zrosub 2 and CaO ' Additives. The.Soviet.journal.of.glass.physics.and.chemistry.PY.-.1992. 17, Number $5: 398-408$, 1992 . 
3048. Morrell, M., S., ; Hardwick, W., H., ; Murphy, V., ; Wace, P.. and F. a pilot plant demonstration of the vitrification of radioactive solutions using microwave power. Nucl.Chem. Waste Manage., 6:193-195, 1986.

3049. Morrell, M., S., and; Smith, M. microwave vitrification - the development of a full-scale inactive plant. U.K.At.Energy Res.Establ., Aere-M, Aere $M 3373,13 \mathrm{pp}, 1986$.

3050. Morrell, M.S. Microwave vitrification--the development of the evaportion stage of a full scale inactive plant $/$ [Oxfordshire, Eng. :Chemical Engineering Division, Harwell Laboratory, 1986.

3051. Morrell, M.S., Hardwick, W.H., and Murphy, V. A pilot plant demonstration of the vitrification of radioactive solutions using microwave power. Nuclear.and. Chemical. Waste. Management. v. 6 no3-4 ('86):193-195, 1986.

3052. Morrell, M.S., Hardwick, W.H., Murphy, V., and Wace, P.F. Pilot plant demonstration of the vitrification of radioactive solutionsx using microwave power. Nuclear and Chemical Waste Management 6:193-195, 1986.

3053. Morrey Laboratory-scale vitrification and leaching of hanford high-level waste for the purpose of simulant and glass property models validation. (Unknown Journal!) : (12 p), 1993.

3054. Morrey, E.V., Elliott, M.I., and Tingey, J.M. Laboratory-scale vitrification and leaching of Hanford high-level waste for the purpose of simulant and glass property models validation. (Unknown Journal!) , 1993.

3055. Morris, Boult, Dalton, Delve, Gayler, $X$, Herring, Hough, and Marples Durability of vitrified highly active waste from nuclearX reprocessingx. Nature (London). $-16 \mathrm{X}, 1994$.

3056. Morris and Chidley Preliminary experience with the new harwell inactive vitrificationX pilot plantX. Manage.Radioact. Wastes.Nucl. Fuel.Cycle -58, 1994.

3057. Morris, B. and Marples, A. See-through solution to nuclear wastex. New Sci. $-8 \mathrm{X}, 1994$.

3058. Morris, D.G., Merk, N., and Morris, M.A. Crystallization embrittlement of Ni-Ti-B glasses. Journal.of.Materials.Science J Mater Sci v 23 n 1, 1988.

3059. Morris, J., B., ; Chidley, B., E., ; Walmsley, D., and $X$ a comparison of wet slurry and dry frit (crizzle) feeding ofx $* *$ glass*** -formers in pot ***vitrification*** $\mathrm{X}$. Ber.Kernforschungsanlage Juelich, Juel-Conf-42 (Vol. 1), Proc:roc-Level Liquid Waste, 1982.

3060. Morris, J., B., ; Chidley, B., E., ; Walmsley, D., and X off-gas behavior in the harvest pot $\star * *$ vitrification*** processx. Radioact.Waste Manage.Nucl. Fuel Cycle, 3:347-370, 1983.

3061. Morris, J., B., ; Hollinrake, A., ; Wall, G., P., ; Dalton, J., T., ; Paige, E., X L., ; Sutcliffe, P., W., ; Finch, J., E., ; Watson, B., and X program on radioactive waste management for the uk department of thex 
environment - joule ceramic melterX. U.K.At.Energy Auth., Harwell Lab., Aere-R, Aere $R$ 12871, X $35 \mathrm{pp}, 1988$.

3062. Morris, J., B., ; Hollinrake, A., ; Wall, G., P., ; Dalton, J., T., ; Paige, E., X L., ; Sutcliffe, P., W., and $X$ joule ceramic melter research report for $1987 / 88$ and $1988 / 89 X$. U.K.At. Energy Auth., Harwell Lab., Aere-R, Aere $R 13377, \mathrm{X} \quad 151 \mathrm{pp}, 1989$.

3063. Morris, J.B. Solidification of Highly Active Wastes. Final Reports for Contracts Carried out in the Period 1ST April 1983 to March 31ST 1984. (Unknown Journal!) , 1984.

3064. Morris, J.B. Solidification of Highly Active Liquid Waste. Progress Report 1 April 1982 to 31 March 1983. (Unknown Journal!) , 1985.

3065. Morris, J.B. Solidification of Highly Active Wastes. Final Reports for Contracts Carried out in the Period 1 April 1984 to 30 June 1985 . (Unknown Journal!) , 1986.

3066. Morsi, M.M., ; Tawansi, A., and $x$ electrical conductivity of borate glasses containing uranium. Egypt.J.Phys., . 15:341-346, 1984.

3067. Moser, R., Schaeffer, H.A., and Tomandl, G. Thermodiffusion in Glasschmelzen. Abschlussbericht (Thermal Diffusion in Glass Melts. Final Report). (Unknown Journal!), 1983.

3068. Moser, R.S.,Eelmut A. and Tomandl, G. thermal diffusion in $\star \star * g l a s s * * *$ melts. Glastech.Ber., $56: 492-497,1983$.

3069. Moser, R.S.,Helmut A. and Tomandl, G. thermal diffusion in $\star \star \star g l a s s * \star *$ melts. Forschungsber.- Bundesminist.Forsch.Technol., Weltraumforsch./Weltraumtechnol., Bmft-Fb-W 83-033, 63 pp-33, 63 pp, 1983 .

3070. Moskovits, P. Viscosity of molten glass, Rochester, N.Y.,Dept. of Chemical Engineering, The University of Rochester, 1954.

3071. Mosslehi, M., ; Lambrosa, A., ; Marinsky, J., A., and $X$ the interaction of bentonite and $* *$ glass $* *$ with aqueous media. Report, Skbf-Kbs-Tr-83-33, 37 pp, 1984 .

3072. Mouche, E., ; Vernaz, E., and X aqueous corrosion of the french lwr solution reference glass: first generation model. Mater.Res.Soc.Symp.Proc., $112: 703-712,1988$.

3073. Moulin, J., Reboux, J., Bonniaud, R., and Sombret, C. New Developments in the Electrical Melting of Refractory Glasses. (Unknown Journal!) , 1972.

3074. Moyer, R.A. comparative transportation risk assessment for borosilicate ***glass*** and ceramic forms for immobilization of srp defense waste. Report, Dpst-82-294; Order No.De82014168, 26 pp, 1982.

3075. Mueller, J. and DiToro, D. Multicomponent adsorption of volatile organic chemicals from air stripper offgas. Water.Environment Research. Water Environment Re, 1993. 
3076. Mukerji Fixation of high level nuclear waste in glass for ultimate disposal: $i$,general aspects. J.Sci.Ind.Res., 1974.

3077. Mukerji Work done at cgcri on fixation of high-level radioactivex wastes in glass for ultimate disposalx. Cent:Glass.Ceram.Res.Inst.Bull. -9X, 1994.

3078. Mukerji and Kayal Fixation of high level nuclear waste in glass for ultimate disposal: iii,thermal decomposition of fission product nitrates and their reactionwith some glass batch additives. J.Sci.Ind.Res. , 1975.

3079. Mukerji and Sanyal Ultimate disposal of high-level atomic waste by incorporation in glass. Cent.Glass Ceram.Res.Inst.Bul1. , 1981.

3080. Mukerji and Sanyal Vitreous matrixes for the containment of high-level purex wastex. Ann.Nucl. Energy. -6), 1994.

3081. Mukerji, J. Work done at Central Glass Ceramic Research Institute on fixation of high-level atomic wastes in glass for ultimate disposal. Bull. Cent.Glass. Ceram.Res. Inst., . Calcutta. 22 [4]:152-172, 1975.

3082. Mukerji, J., ; Sanyal, A., and s. ultimate disposal of high-level nuclear waste by incorporation in ***glass***. Cent.Glass Ceram.Res.Inst.Bull., $28: 1-72,1981$.

3083. Muller, E., Feide, K., and zanotto, E.D. Molecular-structure and Nucleation in Silicate-Glasses. J.NON-CRYST.SOLIDS. 155:56-66, 1993.

3084. Muller, I., S.; ; Buechele, A., C., ; Pegg, I., I., ; Macedo, P., B., and $X$ nonlinear effects of glass composition on chemical durability: $X$ physical stability of surface layersX. Mater.Res.Soc.Symp.Proc., 257, 91-8X-8X, 1994.

3085. Muller, P., ; Schvoerer, M., and X effects of high .alpha.-irradiation and recrystallization on thex thermoluminescence of borosilicate glassX. Phys.Status Solidi A, 123, 369-77X-77X, 1994.

3086. Muller, P. and Schvoerer, M. Effet d'une forte irradiation alpha et d'une recristallisation sur la thermoluminescence d'un verre borosilicate. Physica Status Solidi Applied Research 123:369-377, 1991.

3087. Mundy, J.N. and Gin, G.I. Ionic Transport in Mixed Sodium Rubidium Aluminogermanate Glass. SOLID.STATE. IONICS. 66:69-83, 1993.

3088. Mungall, J.E. and Martin, R.F. Severe Leaching of Trachytic Glass Without Devitrification, Terceira, Azores. GEOCHIM. COSMOCHIM.ACTA 58:75-83, 1994.

3089. Munz, R., J., ; Chen, G., Q., and $X$ design and commissioning of a continuous transferred arc plasma melter for the vitrification of nuclear waste. Mater.Res.Soc.Symp.Proc., 98:417-423, 1987.

3090. Munz, R.J. and Chen, G.Q. Vitrification of nuclear waste in a transferred arc plasma melter. Journal of Nuclear Materials 161:140-147, 1989. 
3091. Murai, T., Nakashiki, T., and Harada, Y. apparatus for transportation of **glass*** elements at plant for $* * * g l a s s * *$-solidification of

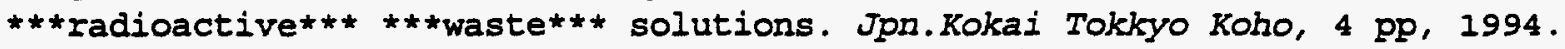

3092. Murakami, T. and Banba, T. The leaching behavior of a glass waste form, part I: the characteristics of surface layers. Nuclear. Technology. v. 67 (Dec. (84) : 419-428, 1984 .

3093. Murakami, T., ; Banba, T., ; Jercinovic, M., J., ; Ewing, R., and C. formation and evolution of alteration layers on borosilicate and basalt glasses: initial stage. Mater.Res.Soc.Symp.Proc., 127:65-72, 1989.

3094. Murakami, T., ; Ewing, R., C., and ; Bunker, B. analytical electron microscopy of leached. layers on synthetic basalt glass. Mater.Res.Soc.Symp. Proc., 112:737-748, 1988.

3095. Murakami, T.B.,Tsunetaka crystalline phase in surface layers of ***glass*** waste form. J.Nucl.Sci.Technol., 20:614-617, 1983.

3096. Muraoka, S. progress of research and development of waste forms for high-levelX wastesX. Seramikkusu, 27, 1056-60X-60X, 1994.

3097. Muraoka, S., Senoo, M., and Kobayashi, Y. Progress report on safety research on high-level waste management for the period April 1989 to March 1990. (Unknown Journal!), 1991.

3098. Muraoka, S., Senoo, M., and Kobayashi, Y. Progress report on safety research on high-level waste management for the period April 1990 to March 1991. (Unknown Journal!) , 1992.

3099. Muraoka, S. Progress report on safety research on high-level waste management for the period april 1991 to march 1992. (Unknown Journal!) : (78 p), 1993.

3100. Murata, M., Yamauchi, K., Kojima, H., Yokoyama, A., Inoue, T., and Iwamori, T. Parasitic channel induced by spin-on-glass in double-level metallization complementary metal oxide semiconductor process. Its formation and method of suppression.

Journal of the. Electrochemical.Society.v.140.n.8.Aug.1993.p.2346-2356. , 1993.

3101. Murawski, T., F., ; Barnes, S., M., ; Petkus, I., L., ; Chapman, C., and C. results from functional checkout of the vitrification process at the west valley demonstration project. Adv. Ceram., 20:413-420, 1987.

3102. Murawski, T.F., Barnes, S., and Petkus, L.I. Results from functional checkout of the vitrification process at the West Valley demonstration project [WVDP] . Adv. Ceram. 20:413-420, 1986.

3103. Murray, R. Comparison of the electronic structures of sodium metasilicate and the gas and gbs phases of sodium disilicate, 1981.

3104. Murray, R. Electronic and vibrational structure calculations on models of the sodium silicate glass system, 1988. 
3105. Murthy, A.K., Komvopoulos, K., and Brown, S.D. Processing and characterization of multi-layered wear- resistant ceramic coatings. Journal of. Engineering.Materials.and.Technology, .Transactions.of. the.ASME. J Eng Mater Technol, 1990.

3106. Murthy, M., K., ; Baranyi, A., and D. an assessment of methods for

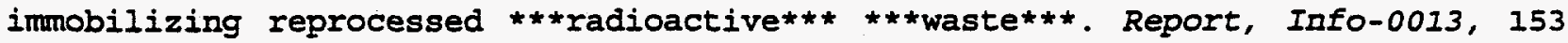
pp, 1981.

3107. Music, $S . * \star 5 * \star 7 f e$ moessbauer effect in borosilicate glasses. Journal of Materials Science Letters 8:537-539, 1989.

3108. Music, S., Bajs, Z., Furic, K., and Mohacek, V. Mossbauer and vibrational spectra of sodium borosilicate glasses containing europium or tin ions. Journal.of.materials.science letters. 10, Number 15:889-892, 1991.

3109. Music, S., Furic, K., Bajs, Z., and Mohacek, v. Spectroscopic Characterization of Alkali Borosilicate Glasses Containing Iron Ions. J.MATER.SCI. 27:5269-5275, 1992 .

3110. Music, S., Gotic, M., and Popovic, S. Corrosion of stainless steel in contact with a melt of phosphateX glasses. Joumal of Materials Science Letters $8: 1389-1390,1989$.

3111. Music, S. iron-57 moessbauer effect in borosilicate glasses. J.Mater.Sci.Lett., 8:537-539, 1989.

3112. Music, S., ; Gotic, M., and ; Popovic, S. corrosion of stainless steel in contact with a melt of phosphate glasses. J.Mater.Sci.Lett., 8:1389-1390, 1989.

3113. Music, S., ; Gotic, M., ; Popovic, S., and ; Grzeta, B. influence of iron ions on the structural properties of some inorganic glasses. J.Radioanal.Nucl.Chem., 116:141-157, 1987.

3114. Music, S., ; Ristic, M., ; Gotic, M., and ; Foric, J. corrosion of simulated nuclear waste glass. J.Radioanal.Nucl.Chem., 122:91-102, 1988.

3115. Mustarelli, P., Tomasi, C., Magistris, A., and Scotti, S. Water-Content and Thermal-Properties of Glassy Silver Metaphosphate - Role of the Preparation. J.NON-CRYST.SOLIDS. 163:97-103, 1993.

3116. Nabatian, D. Mossbauer [sic] study of an iron-containing sodium disilicate glass as a prelude to a glass-metal bonding investigation, 1977.

3117. Nagaki, H.O.,Naohiko; Tsunoda development of ***vitrification*** technique of hllw in engineering scale at pnc. Report, Pnct-841-79-54, 18 pp, 1981.

3118. Nagaya, K., Fujimoto, Y., Hashimoto, Y., and Nomura, I. Solidification of radioactive waste. the durability of a vitrified products and test plant operation. Hitachi Zosen Technical Review 46:61-67, 1985. 
3119. Nagaya, K., Fujimoto, Y., Hashimoto, Y., Takahashi, and Noumura, I. Solidification of concentrated liquid waste from bwr through the decomposition and vitrification of $\mathrm{na} / / 2 \mathrm{so} / / 4$ with silica. Hitachi zosen Technical Review $45: 8-12$, 1984 .

3120. Naito, K., Matsui, T., and Tanaka, Y. recovery of noble metals from insoluble residue of spent fuel. J.Nucl.Sci.Technol., 23:540-549, 1986.

3121. Nakamura, H., Kikkawa, S., Kamizono, H., Senoo, M., and Tashiro, S. Volatilization of sup $137 \mathrm{Cs}$ and sup $90 \mathrm{Sr}$ from Simulated High-Level waste Glass. (Unknown Journal!) , 1984.

3122. Nakamura, H., Kikkawa, S., Sato, M., Kamizono, H., and Senoo, M. volatility of (137) Cs and (90) Sr from High-Level Waste Glass. (Unknown Journal!) , 1988.

3123. Nakamura, H. and Tashiro, S. Progress Report on Safety Research of High-Level Waste Management for the Period April 1983 to March 1984. (Unknown Journal!) , 1984.

3124. Nakamura, F. and Tashiro, S. Progress Report on Safety Research of High-Level Waste Management for the Period April 1986 to March 1987. (Unknown Journal!) , 1987.

3125. Nakamura, H. and Tashiro, S. Progress Report on Safety Research of High-Level Waste Management for the Period April 1987 to March 1988. (Unknown Journal!) , 1988.

3126. Nakamura, H.M., Seiichiro; Senoo neutron irradiation test of simulated waste glass form. Report, Jaeri-M-84-146, 16 pp, 1985.

3127. Nakamura, H.K.,Shizuo; Kamizono volatilization of cesium-137 and strontium-90 from simulated high-level waste glass. Report, Jaeri-M-84-141, 20 pP, 1985.

3128. Nakamura, H. and Champ, D.R. field studies on radionuclide migration at chalk river nuclear laboratories, canada. Nihon Genshiryoku Gakkaishi, $31: 350-356,1989$.

3129. Nakanishi, K.S.,NaohiroX solidification of polluting substances into glass. Kagaku Kogyo, 40:632-636, 1989.

3130. Nakaoka, R.K., Perez, J.M., Buchmiller, W.C., Goles, R.w., and Bates, S.o. Hanford Waste Vitrification Plant: Nonradioactive Liquid-Fed Ceramic Melter Testing for Fiscal Year 1986. (Unknown Journal!) , 1986.

3131. Nakayama, $S$. and Banba, T. Release of neptunium from neptunium-doped borosilicate waste glass. Journal of Nuclear Science and Technology 26:607-615. 1989.

3132. Nakayama, S, and Sadaoka, Y. Ionic-Conductivity of Ceramics Prepared by Sintering of M2O-In2O3-2SiO2 Mixtures $\mathrm{M}=\mathrm{Ii}, \mathrm{Na}, \mathrm{K}, \mathrm{Rb}, \mathrm{Cs}$ In $=\mathrm{La}$, Nd, Sm, Gd, DY, Y, HO, EY, Yb). J.MATER. CHEM. 3:1251-1257, 1993. 
3133. Nakayama, S.B., Tsunetakax release of neptunium from neptunium-doped borosilicate waste glass. J.Nucl.Sci.Technol., 26:607-615, 1989.

3134. Nakayamar, K., Suzuki, N., and Hashimoto, H. Triboemission of charged particles and photons from solid surfaces during frictional damage. Journal.of. Physics.D: .Applied.Physics. 25:303-308, 1992.

3135. Namboodri srl in-situ tests in the united kingdom: part 2, surface analyses of srs waste glass buried for one and two years in limestone at ballidon, uk. (Unknown Journal!) :(32 p), 1926.

3136. Namboodri, C.G.,Jx., Namboodri, S.I., and Wicks, G. Surface analyses of SRS [Savannah River Site] waste glass buried for up to two years in limestone in the United Kingdom. Ceram.Trans. 23:653-662, 1991.

3137. Nan, Y., Lee, W., and James, P. Crystallization behavior of CaO-P205 glass with TiO2, SiO2, Al203 and additions. Journal of the.American. Ceramic.Society.v.75. (June. '92) .p.1641-7.bibl.il. $2-7820,1992$.

3138. Nannicini, R., Dworschak, H., and Daniele, F. R and D Activities Carried out in Ispra, According to a Cooperation Between ENEA COMB and JRC-Ispra in the Field of Radioactive Waste Management. (Unknown Journal!) , 1987.

3139. Nannicini, R., Strazzer, A., Cantale, C., Donato; A., and Grossi, G. Hot Bench Scale Plant Ester for the Vitrification of High Level Wastes. The First Vitrification Campaign. (Unknown Journal!) , 1985.

3140. Napolitano, A. and Hawkins, E. Viscosity of a standard lead-silica glass, Washington:For sale by the Superintendent of Documents, U.S. Govt. Print. Off. 1966 .

3141. Napolitano, A. and Hawkins, E. Viscosity of a standard borosilicate glass, Washington:For sale by the Superintendent of Documents, U.S. Govt. Print. Off. 1970.

3142. Nash, C.A. Summary of Heat Transfer Models for the DWPF (Defense Waste Processing Facility), Scale and IDMS Melters. (Unknown Journal!), 1986.

3143. Nash, C.A. IDMS melter emergency power needs. (Unknown Journal!), 1987.

3144. Nash, C.A. 3-D Heat Transfer Model of the IDMS Melter. (Unknown Journal!) , 1987.

3145. Nash, C.A. Results from the PATRAN Lidheater Model. (Unknown Journal!), 1987 .

3146. Nash, K., L., Fried, S., Friedman, A., M., Susak, N., Rickert, P., Sullivan, $J .$, and $C$. radiation effects in solution and on the solid/liquid interface. Nucl.Technol., 60:257-266, 1982 . 
3147. National Research Council (J.S.).Highway Research Board. Nuclear applications, pipe corrosion, and aggregate and glass bead testing; Washington, 1972 .

3148. Navrotsky, A., Hervig, R.I., Roy, B.N., and Huffman Thermochemical studies of silicate, aluminosilicate, and borosilicate. glasses. High Temperature science 19:133-150, 1985.

3149. Nechaev, A., F., ; Aloy, A., S., ; Suvorov, O., A., ; Fadeev, I., and X esr study of .gamma.-irradiated borosilicate glass containing cesiumx and strontium oxidesX. At.Energ., 75, 295-9X-9X, 1994.

3150. Nechaev, A.F., Aloi, A.S., Suvarov, O.A., and Fadeev, I.S. An ESR Study of Gamma-Irradiated Borosilicate Glass Containing Cesium and strontium. Atomic.energy.=. Atomnaia.energiia. 75, Number 4:796-800, 1993 .

3151. Neck, V., Kim, J.L., and Kanellakopulos, B. Solubility and Hydrolysis Behavior of Neptunium(V) . RADIOCHIM.ACTA 56:25-30, 1992.

3152. Nelson Bdat vitrification of icpp hlw. (Unknown Journal!) :(55 p), 1991.

3153. Nelson, C. Transition elements in alkali-aluminosilicate melts : spectroscopy and thermodynamics of glass analogues, University Park:The Pennsylvania State University, University Microfilms International, 1981.

3154. Nelson, C. and White, W.B. Transition-Metal Ions in Silicate Melts .3. Nickel in Quenched Oxide Glasses. PHYS.CHDM.GLASSES. 34:219-225, 1993.

3155. Nelson, J.L. Preliminary Hanford Waste Vitrification Plant Waste Form Qualification Plan. (Unknown Journal!) , 1986.

3156. Nelson, J.I. Preliminary Hanford waste Vitrification Plan Waste Form Qualification Plan. (Unknown Journal!) , 1987.

3157. Nelson, J.L. Hanford Waste Vitrification Plant Preliminary Waste Form Qualification Plan - FY 1988 Opdate. (Unknown Journal!) , 1988.

3158. Nelsoin, J.T., ; Martineit, R.A., ; Helms, R., and E. characterization and treatment of wastes comprised of hazardous, radioactive mixed, and transuranic fractions. U.S.Environ.Prot.Agency, Res.Dev., Epa,X Epa/600/9-87/018F, Proc. Int.Conf.New Front.Hazard.Wastex Manage., 2nd, 1987:323-330, 1987.

3159. Nelson, $L ., \quad O .$, and $x$ bdat vitrification of icpp hlwX. Report, Winco-1091; Order No.De92011336, 55 pp, 1992.

3160. Nelson, L.O. BDAT vitrification of ICPP HLW. (Unknown Journal!), 1991.

3161. Nelson, R., G., ; Nesbitt, J., F., ; Slate, S., and C. nuclear waste encapsulation by metal-matrix casting. Report, Pnl-3750, 60 pp, 1981.

3162. Nemec, $I$. and Lubas, J. A simple-Model of Refining in Glass Melting Furnace with Vertical Flow and Covered Level. CBRAMICS-SILIKATY. 37:35-42, 1993. 
3163. Nemec, I. and Luxova,. I. Selecting the Character of Glass Melt Flow in Tank Melting Zones. CERAMICS-SILIKATY. 37:29-34, 1993.

3164. Nese, M. and Hanneborg, A. Anodic bonding of silicon to silicon wafers coated with aluminum, silicon oxide, polysilicon or silicon nitride. Sensors.and.Actuators, A:.Physical. v 37-38 n 2 Jun-Aug:61-67, 1993.

3165. Neumann, L. Minimalizace tvorby, zpracovani a trvale ulozeni radioaktivnich odpadu. Sbornik $z$ konference. (Minimization of formation, processing and disposal of radioactive wastes. Conference proceedings). (Unknown Journal!) , 1989.

3166. Neumann, w. high-level $\star * *$ radioactive $* \star \star * * *$ waste $* * *$ granules coated and embedded in a metal matrix -an alternative to disposal in $* * *$ glass***. Atomkernenerg./Kerntech., 35:297-299, 1980.

3167. Newsom, P.C., Roberts, C.J., and Yuchien Yuan, M.S. Technical and Administrative Approach for the west Valley Demonstration Project safety Program. (Unknown Journal!) , 1987.

3168. Newton Ballidon glass burial experiment. Glass Technol. , 1985.

3169. NEWTON, R.G. Durability of glass - a review. GLASS TECHNOL $V 26 N I$ FEB 1985 P 21-38-38, 1985.

3170. NEWTON, R.G. The future of the Ballidon glass burial experiment. Glass. Technology. v. 33 (Oct. '92):179-180, 1992.

3171. NEWTON, R.G. and Seddon, A.B. The durability of silicate glass in the presence of a X saturated leachant. Corrosion.Science v. 33 (Apr. '92):617-626, 1992.

3172. Newton, R.G.R. More results from the Ballidon glass burial experiment. Glass. Technology. v. 29 (June '88):106-107, 1988.

3173. Newton, w. Resistivity of partially crystallized lithium disilicate glass with tin-antimony, Alfred, N.Y.New York State College of Ceramics at Alfred University, 1970.

3174. Ng, C.K., Hsiu, F.J., and Almuti, A.A. Incorporating Functional Requirements into the Structural Design of the. (Unknown Journal!) , 1986.

3175. Nguyen Apollo: a computer program for the calculation of chemical equilibrium and reaction kinetics of chemical systems. (Unknown Journal!) : (44 p) , 1991.

3176. Nicaise, E., Gandini, A., and Cheradame, H. Behaviour of composites used in the confinement of nuclear wastes.3.X diffusion of ions through epoxide networks. British Polymer Journal 19:535-542, 1987.

3177. Nicholl, M.J., Glass, R.J., and Nguyen, E.A. Wetting front instability in an initially wet unsaturated fracture. (Unknown Journal!)， 1992. 
3178. Nickels, J.M. Hanford Site high-level waste management: Grout and vitrification processes. (Unknown Journal!), 1992.

3179. Nicole, I., De Laat, J., Dore, M., Duguet, J.P., and Bonnel, $C$. Utilisation du rayonnement ultraviolet dans le traitement des eaux. Mesure du flux photonique par actinometrie chimique au peroxyde d'hydrogene. Water.Research. Water Res V 24 I 2 F, 1990.

3180. Niederstetter Haw end-product casks [for waste disposal] using the pamelax solidification processX. Reaktortag. $-6 \mathrm{X}, 1994$.

3181. Nielsen, M.G. Design of Agitation Systems in Bingham Slurries by Pilot Simulation. (Unknown Journal!) , 1987.

3182. Nielsen, M.G. design of dwpf agitation systems in bingham slurries by pilot simulation. Proc.Symp. Waste Manage., (Waste Manage. 87, Vol. 1), 595-8, 1988.

3183. Nijhawan, S. Glass transition temperature of the sodium borosilicate system and an analysis of the structure of rubidium borate glasses using MMR spectroscopy and transition temperatures, 1993.

3184. Nikiforov, A., S., ; Aloi, A., ; Dolgov, V., v., ; Kuznetsov, Y., ;X Kulichenko, V., ; Nikipelov, B., ; Osnovin, V., I., ; Polyakov, A., X S., ; Sedov, V., M., ; et al., and $X$ treatment of high-level radioactive wastes produced in nuclear fuel reprocessing. At. Energ., 63:319-323, 1988.

3185. Nikiforov, A., S., ; Kulichenko, V., V., ; Krylova, N., ; Musatov, N., D., ; $X$ Polyakov, $A$., and $X$ thermal,chemical and radiation stability of vitreous $\star \star \star$ radioactive*** ***wastes***. Sci.Basis Nucl.Waste Manage., , MeetingX Date 1978, 117-21: lenum: NewX' York, 1980.

3186. Nikiforov, A.S., Nesterenko, R.Y., and Polyakov, A.S. Radiation-stimulated drift and escape of radionuclides from glassyX matrices. Soviet Atomic Energy 66:59-61, 1989.

3187. Nikiforov, A.S., Polyakov, A.S., Krylova, N.V., Salamatina, R.N., Vlasov, V.I., and Bochvar, A.A. Properties of solidified hlw and their changes under storage andx disposal conditions. In: High Level Radioactive Waste Nanagement. Publ by ASCE, New York, NY,X USA.P 435-44I, Anonymous New York, NY, X USA:ASCE, 1991, p. 435-441.

3188. Nikiforov, A.S., Vlasov, V.I., Davydov, V.I., Dobrygin, P.G., Kachurin, Krivyakov, O.A., Savel'ev, V.F., and Filippov, S.N. Dewatering of liquid radioactive wastes in thin-film rotaryx evaporators. Soviet Atomic Energy $67: 501-506,1990$.

3189. Ninomiya, M., ; Yamanaka, T., ; Sakane, T., ; Hora, M., ; Nakamura, S., iX Kawamura, $S .$, and $X$ diopside $\star \star \star g l a s s * \star *$-ceramic material for the immobilization of $\star * *$ radioactive*** $* * *$ wastes $* * *$. Ber. Kernforschungsanlage Juelich, Juel-Conf-42 (Vol.2), $\mathrm{X}$ Proc:roc, 1994. 
3190. Nishi, T., Matsuda, M., Chino, K., and Kikuchi, M. Reduction of Cesium Leaching Ratio from Cementitious Resin Forms Using Natural Active Silica. J.NUCL.SCI.TECHNOL. 29:779-785, 1992.

3191. Nishi, T., Matsuda, M., Chino, K., and Kikuchi, M. Reduction of Cesium Leachability from Cementitous Resin Forms Using Natural Acid Clay and Zeolite. CEM. CONCR.RES. 22:387-392, 1992 .

3192. Nishi, Y., Ninomiya, N., and Kanai, F. Brittleness of high TC Bi0.7Pbo.3SrCaCul.80x crystal and glass. Journal.of.Applied.Physics. v. 66 (Sept. 1 '89):2069-2073, 1989.

3193. Nishida, T., Inoue, S., and Takashima, Y. Comparison of IR-Transmission Method with the Conventional DTA Method (Kissinger Plot) in the Crystallization Study of Iron Tellurite Glass. Bulletin.of.the.Chemical.Society.of.Japan.PY.-.1992. 65, Number 7:1-1927, 1994.

3194. Nishioka, M., Hirai, S., Yanagisawa, K., and Yamasaki, N. Solidification of Glass. Powder with Simulated HighLevel Radioactive Waste During $H$ Hydrothermal HotPressing. Journal.of.the.American.Ceramic.Society. 73, Number $2: 317-322,1990$.

3195. Nitta, A., Miura, T., Komatsu, T., and Matusita, K. Glass formation in the system Sio//2-pbo containing transition-metal oxides. Journal.of.the.American.Ceramic.Society. J Am Ceram Soc v 72, 1989.

3196. Nitta, A., Nakamura, H., Komatsu, T., and Matusita, K. Interface reactions between silicon dioxide-lead oxide glass and manganese zinc ferrite. Journal.of.the.American.Ceramic.Society. J Am Ceram Soc v 72, 1989.

3197. Noell, J., Wilkes, G., Mohanty, D., and McGrath, J. Preparation and characterization of new polyether ketone-tetraethylorthosilicate hybrid glasses by the sol-gel method. Journal.of.Applied.Polymer.Science J Appl Polym Sci v 4, 1990.

3198. Nogues, Thomassin, and Touray Characterization of nuclear glass corrosion by the ultramicrotomesectioning technique. Riv.stn.Sper.Vetro, 1984.

3199. Nogues, J., L., ; Hench, L., ; Zarzycki, J., and X comparative study of seven. glasses for solidification of nuclearX wastesX. Mater.Res.Soc.Symp.Proc., 11 211-18, 1983.

3200. Nogues, J., I., ; Hench, I., and $X$ effect of ferric oxide/zinc oxide on two $\star * \star$ glass $* * x$ compositions for solidification on swedish nuclear wastesX. Report, Skbf/Kbs-Tr-81-15, $30 \mathrm{pp}, 1982$.

3201. Nogues, J., L., ; Terki, A., and $X$ effect of leaching method on the alterability of glass for fixationX of fission product.X. Riv.Stn.Sper.Vetro (Murano, Italy), 14, 171-8, 1984.

3202. Nogues, J., L., ; Thomassin, J., H., ; Touray, J., C., and X application of the ultramicrotome sectioning technique to thex characterization of the 
alterability of nuclear glassesX. Riv.Stn.Sper.Vetro (Murano, Italy), 14, $155-62$, 1984 .

3203. Nogues, J., L., ; Vernaz, E., Y.; ; Jacquet Francillon, N., and X nuclear glass corrosion mechanisms aplied to the french lwrX reference glassX. Mater.Res.SOC.Symp.Proc., 44, X 89-98, 1985.

3204. Nogues, J.-I., Majewski, S., and walker, J.K. Fast, radiation-hard scintillating detector: a potential application for sol-gel glass. Journal.of. the.American. Ceramic.Society. v. 71 (Dec. '88):1159-1163, 1988.

3205. Nogues, J.L. and Terki, A. Influence of the Leaching Mode on the Durability of a Glass for Fission Product Containment. (Unknown Journal!) , 1984 .

3206. Nogues, J.L., Thomassin, J.H., and Touray, J.C. Application of Ultramicrotome Section Technique to the Characterization of Nuclear Glass Durability. (Unknown Journal!), 1984.

3207. Nogues, J.L., Vernaz, E., Jacquet Francillon, N., and Pasquini, $S$. Interaction Between a Nuclear Glass and Nearfield Materials in Various Rigs Simulating a Geological Repository. (Unknown Journal!) , 1984.

3208. Nogues, J.L., Vernaz, E.Y., Jacquet Francillon, N., and Pasquini, $S$. Alterability of the French LWR Solution Reference Glass in Repository Conditions. (Unknown Journal!), 1984.

3209. Nogues, J.L., Vernaz, E.Y., and Jacquet-Francillon, N. Nuclear glass corrosion mecharisms applied to the french lwr referenceX glass. In: <CI> Held as part of the Fall Meeting of the Materials ResearchX Society Materials Research Society Symposia Proceedings $v 44$. Publ by MaterialsX Research SOC, Pittsburgh, PA, USA p 89-98,Anonymous Pittsburgh, PA, USA:MaterialsX Research Soc, 1985, p. $89-98$.

3210. Nomura, I., Hashimoto, Y., Takahashi, S., and Nagaya, $K$.

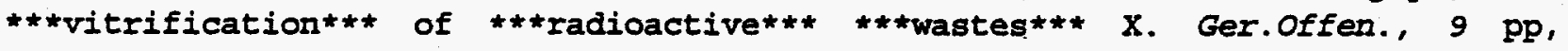
1994.

3211. Nomura, I., Ishikawa, T., Nagaya, K., and Fujimotot, Y. vitrification of medium- and low-level radioactive wastewaters from fuel reprocessingx. Jpn.Kokai Tokkyo Koho, 3 pp, 1994.

3212. Noorishad, J., Carnahan, C.L., and Benson, L.V. Development of the Non-Equilibrium Reactive Chemical Transport Code. (Unknown Journal!) , 1987.

3213. Northrup, C.J., M., , ; Amnold, G.W., ; Headley, T.J., and $x$ ion implantation studies of nuclear waste formsX. Mater.Res.Soc.Symp.Proc., 6, $667-79,1983$.

3214. Nyholm, R. and Werme, L.O. Esca investigation of molybdenum containing silicate and phosphateX glasses. In: <CI> Proceedings of the 3rd International Symposium, held as part ofX the Annual Meeting of the Materials Research Society Scientific Basis for Nuclear Waste Management $v 3$. Publ by Plenumx 
Press, New York, NY, USA and London, Engl p 101-108,Anonymous New York, NY, USA:PlenumX Press, 1981,p. 101-108.

3215. Nyman, D.H. Multi-Purpose Storage Complex description. (Unknown Journal!) , 1993.

3216. Nyman, D.H., wolfe, B.A., and Hoertkorn, T.R. Description of a Multipurpose Processing and Storage Complex for the Hanford Site's radioactive material. (Unknown Journal!) , 1993.

3217. O'Keefe, J.A. and $X$ the corrosion of tektite glassx. Adv.Ceram., 20, $689-92,1988$.

3218. O.V.Mazurin Theory of glass transition: chemical equilibria approach Jo -Journal of Non-Crystalline Solids. (Unknown Journal!) 129:259-265, 1991.

3219. Oblath, S.B. and Congdon, J.W. Inhibiting Localized Corrosion During Storage of Dilute SRP (Savannah River Plant) Wastes. (Unknown Journal!) , 1986.

3220. Odoj, R. and Aheimer, D. Vitrification of highly radioactive dissolver sludges. In: $v$ 1. Publ by ANS, La Grange Park, IL, USA p 403-413, Anonymous La Grange Park, IL, USA:ANS, 1984,P. 403-413.

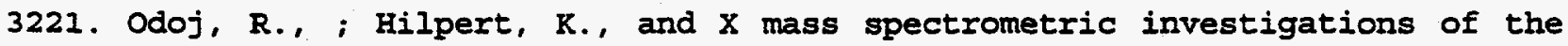
evaporation of crystallinex compounds of the system cesium oxide-alumina-silica, part ii.theX cesium aluminum $* \star \star s i l i c a t e * \star$ compounds csalsio4 and csalsi5o12X. Z.Naturforsch., A, 35A, 9-13, 1980.

3222. Odoj, R., ; Schwitz, M., and $X$ on-line measurements of the volatilization of ruthenium in aX $\star * \star$ vitrification*** processX. Mater.Res.Soc.Symp.Proc., 6 , 575-83, 1982 .

3223. Odoj, $R$. and $x$ volatility of alkali fission products during solidification processx. Report, Inka-Conf-79-003-015, Iaea-Sm-236/23, 7 pp, 1979.

3224. Odoj, R.M.,Erich icp measurements of leach rates of waste glasses. Nucl.Chem. Waste Manage., 2, 139-42, 1982.

3225. Odoj, R. $\star \star \star$ glass $\star \star \star$ as a material for the disposal of $x \star \star$ radioactive*** $\star \star \star$ wastes*** X. Sprechsaal, 113, 345-50, 1980.

3226. Odowd, A.T., Spalding, T.R., Ferguson, G., Gallagher, J.F., and Reed, D. Synthesis and Crystal-structure of the Novel Borosilicate Cage Compound (B (Osiph2Osiph20) 3B) . J. CHEM.SOC. CHEM. COMMUN. :1816-1817, 1993.

3227. Oertel, G., K., ; Crandall, J., I., ; MCElroy, J., and X treatment and conditioning of wastes from nuclear fuel reprocessingx plants in the united states of americaX. Radioact.Waste Manage., Proc.Int.Conf., Meeting Date 1983, Volume $2,2-17,1984$.

3228. Offermann, P. and Richter, H. Slow crack growth in nuclear waste glasses. Adv.Ceram. , 1985. 
3229. Offermann, P. and Richter, H. Slow crack growth in nuclear waste glasses. In: <CI> Held during the 85th Annual Meeting of the American CeramicX Society Advances in Ceramics $v 8$. Publ by American Ceramic Soc Inc, Columbus, $X$ OH, USA $p$ 677-686, Anonymous Columbus, $\mathrm{x}$ OH, USA:American Ceramic Soc Inc, 1984,p. 677-686.

3230. Offermann, P., ; Bidoglio, G., and X retention properties of pressed salt for technetium, neptunium, $X$ plutonium, and americium leached from simulated hlw glassX. Radiochim.Acta, 44-45, 271-6, 1988.

3231. Offermann, P., ; Matzke, H., and X chemical stability of hlw glasses under irradiationX. Atw, Atomwirtsch., Atomtech., 26, 350-3, 1981.

3232. Offermann, P.R., HerbertX slow crack growth in nuclear waste glassesX. Adv. Ceram. , 8, 677-86, 1984.

3233. Ogata, Y., Kobayashi, H., Takahashi, T., and Horie, M. Development of dismantling technology for spent melter. In: High Level Radioactive Waste and Spent Fuel Management Proc 1989 JointX Int Waste Manage Conf $v 2$ (of 2). Publ by American SOC of MechanicalX Engineers (ASME), New York, NY, USA.P 261-264,Anonymous New York, NY, USA:American Soc of MechanicalX Engineers (ASME), 1989,p. 261-264.

3234. Oguino, N., ; Masuda, S., ; Tsunoda, N., ; Yamanaka, T., ; Ninomiya, M., and $\mathrm{X}$ solidification of $\mathrm{hllw}$ by the $* \star \star$ glass $* \star *$-ceramic processx. Report, Pnct-841-79-55, 21 pp, 1981.

3235. Oguino, N.T.,Shinichiro; Nagaki a development of $* * *$ vitrification*** of hllw by joule heatedx ceramic melter.an experimental melting operationx. Tokai Works Semi-Annu.Prog.Rep., Volume Date 1978, PNCT831-79-02,NCT831-NCT879, 1978.

3236. Oguino, N.S.,Noriaki; Torata study for ***vitrification*** of high level radioactive liquidx wastes.(i).survey of the composition of the wastes

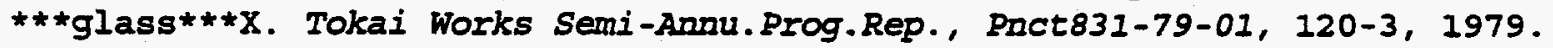

3237. Oguino, N.N.,Hiroshi; Tsunoda solidification of high level liquid waste by $* \star *$ glass $* *$-ceramicX processX. Tokai Works Semi-Annu.Prog.Rep., Volume Date 1978, PNCT831-79-02,NCT831-NCT879, 1994.

3238. Oh, M.S. and Oversby, V.M. Effect of sample preparation methods on glass performance. (Unknown Journal!), 1990.

3239. Ohashi, M. and Hampshire, S. Formation of Ce-Si-O-N 'glasses. Journal. of. the.American.Ceramic.Society. v. 74 (Aug. '91):2018-2020, 1991.

3240. Ohashi, M.J., Tateda, M.J., Tajima, K.J., and Shiraki, K.J. Fluorine concentration dependence of viscosity in Fdoped silica glass. Electronics.Letters. 28, Number 11:1008-1009, 1992.

3241. Ohe, $T$ : repository system simulation test of high level waste glass. $X$ results of ec round robin testX. Nihon Genshiryoku Gakkaishi, 33, 761-70X-70x, 1994. 
3242. Ohe, T., Tsukamoto, M., Kinoshita, M., and Inoue, T. Analysis of high-level waste glass performance by the physical andx geochemical simulation code strag4. Waste Management 11:191-203, 1991.

3243. Ohnsorg, R. Effect of high pressure on sodium borate glass, Alfred, $\mathrm{NY}$ : New York State College of Ceramics at Alfred University, 1959.

3244. Ohoka, K., Kawanishi, N., and Konishi, S. solidification of

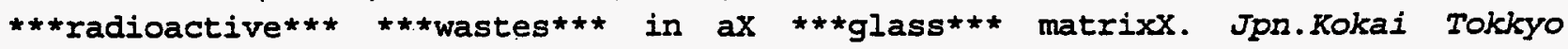
Koho, 8 pp, 1994.

3245. Okafor, I.C.I. and Martin, D. Effect of temperature on the fracture-surface energy of a waste disposal glass. J.Am.Ceram.Soc. $65[\mathrm{~N}$ 2] : 87-90, 1982 .

3246. Okamoto, F.O.,Yoshifusa; Kaya analysis relating to solidification of simulated high level liquidx wastes.1.determination of cesium by flameless atomic absorptionX spectrometryx. Tokai Works Semi-Annu.Prog.Rep., Volume Date 1978, PNCT831-79-02,NCT831-NCT879, 1978.

3247. Okamoto, H., Matsuoka, J., Nasu, H., Kamiya, K., and Tanaka, H. Effect of Cadmium to Sulfur Ratio on the Photoluminescence of CdS-Doped Glasses. J.APPL. PHYS. 75:2251-2256, 1994 .

3248. Okamoto, H., ; Yamamoto, M., ; Nagai, H., ; Ohnishi, N., and X development. of high-level liquid waste solidification in pncx. Treat.Handl.Radioact.Wastes, , Meeting Date 1982, 64-71:ress: Columbus, Ohio, 1994 .

3249. Okamoto, M.S.,Muneaki; Tashiro formation of isolated metal in a metallic melter forX $* * *$ vitrification*** of high-level wasteX. Report, Jaeri-M-8574, 28 pp, 1980 .

3250. Okine, R. Mixing of viscous liquids and glass fiber slurries using mechanical and electro-mechanical hybrid laminar mixers, 1978.

3251. Oldman, D., M., ; Marlow, J., H., ; Stimmel, J., R., and $X$ chemical determination of west valley waste form productsx. Adv.Ceram., 20, 399-405, 1986.

3252. Olds, F.C. Nuclear waste management. Power Engineering 89:30-36, 1985.

3253. Olson Fabrication, characterization, and evaluation of a fully radioactive glass using commercial nuclear waste from the west valley demonstration project. (Unknown Journal!) : (11 p), 1991.

3254. Olson, K., M., ; Elliott, M., L., ; Shade, J., W., ; Smith, H., D., and X fabrication, characterization, and evaluation of a fully radioactivex glass using commercial nuclear waste from the west valleyx demonstration projectx. Ceram.Trans., 23, 577-86X-86X, 1994.

3255. Olson, K., M., ; Alzheimer, J., and X defense waste processing facility canister impact testingX. Proc.Symp.Waste Manage., (Waste Manage.'89, V0.1. 1), $639-45,1989$. 
3256. Olsson, G., Devell, L., Johnsson, B., and Gulden, W. Quantification and Disposal of Radioactive-Waste from ITER Operation. FUSION.ENG.DES. 17:415-422, 1991.

3257. Oma, K., H., ; Nelson, T., A., and $X$ behavior of selected contaminants in liquid-fed ceramic melterx waste- $\star * \star v i t r i f i c a t i o n * \star *$ offgasx. Proc.Doe Nucl.Air Clean.Conf., Volume Date 1980, 16, 911-28, 1980.

3258. Ondracek, G., ; Toscano, E., H., and X powder technological ***vitrification*** of medium-level wastex by in-can hot pressingx. J.Nucl.Mater., 124, 75-9, 1984.

3259. Ondracek, G., ; Toscano, E., H., and $X$ in-can hot pressing of borosilicate $* *$ glass*** for theX immobilization of high- and medium-level wastesX. Mater.Res.Soc.Symp.Proc., 26, 591-6, 1984.

3260. Ondracek, G. and $X$ sinter ***gass*** - further development of $* * *$ glass $* * * X$ technology for solidification of high-level **tradioactive***X ***wastes*** X. Kernforschungszent.Karlsruhe, Kfk, Kfk 2940, Samml:roj-89, 1980 .

3261. Onyiriuka, E.C. Zinc phosphate glass surfaces studied by XPS. JO Journal of non-crystalline solids. (Unknown Journal!) 163, Number 3:265-268, 1993.

3262. Onyiriuka, E.C. Zinc Phosphate-Glass surfaces studied by XPS. J.NON-CRYST. SOLIDS. $163: 268-273,1993$.

3263. Ooka, K.O.,Kiichi; Yoshio leaching characteristics of constituent ions

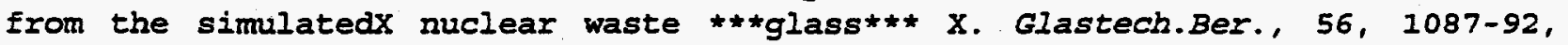
1983.

3264. Opitzova, V.H.,Jan; Vojtech glasses of the system sodium oxide (na20)-boron oxideX (b203)-aluminum oxide (a1203)-silica for fixing wastes from nuclearX power stationsx. Sb.Vys.Sk.Chem.-Technol.Praze, Chem.Technol.silik., L10, 163-80, 1983 .

3265. Orchard, S.W., Sato, Y., Schoebrechts, J.-P., and Mamantov, G. Use of sodium ion conducting glasses in $\mathrm{Na} / \mathrm{S}$ (IV) molten chloroaluminate electrochemical cells. Journal.of.the.Electrochemical.Society. J Electrochem Soc $v, 1990$.

3266. Orfield, M. An investigation into the structure of silicate glasses containing iron, 1981.

3267. Orou, J.C. and Johnson, J.A. 2nd Viscosity Enhancement in Turbulent Nonequilibrium-Flow. PHYS.FLUIDS. 6:415-417, 1994 .

3268. Ortins de Bettencourt, A. and Jouan, A. Volatility of ruthenium during vitrification of fission products.X. Commis.Energ.At. [Fr]. :Avail CEAX, 1994. 
3269. Oscarson, D., W., ; Cheung, S., C., H., and $X$ evaluation of phyllosilicates as a buffer component in the disposalx of nuclear fuel wastex. At.Energy Can.Ltd., Aecl, Aecl-7812, 41 pp, 1983.

3270. Oscarson, D., W., ; Heimann, R., B., and X the effect of an iron(ii)-silicate on selected properties of ax montmorillonitic clayx. Clay Miner., 23, 81-90, 1988.

3271. Osipenco, A., Hild, w., Marchant, Y., De Beukelaer, R., and De Coninck, A. Interim storage facility for vitrified hlw. In: $v 2$. Publ by ANS, La Grange Park, IL, USA P 425-436, Anonymous La Grange Park, IL, USA:ANS, 1984,p. 425-436.

3272. Osorio, S.P.A., Montero, I.; Perriere, J., and Martinez-Duart, J.M. Effect of annealing on the composition of PECVD borosilicate Xand boraaphosphosilicate glasses. Applied.surface. science. 70-71:1-772, 1993.

3273. Ostuka, H.T.,Yukito; Nomura development of gamma-scanning system for vitrified hlw formsX. Report, Jaeri-M-84-067, 48 pp, 1985.

3274. Ota, R. Conditions for vitrification of a sillica - magnesia - calcium oxide - alumina - titanium dioxide system synthetic slag melt, 1989.

3275. Otsuka, K., Aikawa, H., and Tamai, H. solid **kglass*** disposal method for $* \star *$ radioactive $* \star X$ X $* \star$ waste $* \star$ sodium compoundX. Jpn. Kokai Tokkyo Koho, 4 pp, 1985.

3276. Ougouag and Machiels, A. Modeling of ion-bombardment effects on nuclear waste glass leaching. Adv.Ceram. , 1985.

3277. Ougouag, A.M. and Machiels, A.J. Modeling of ion-bombardment effects on nuclear waste glass leaching. In: <CI> Held during the 85th Annual Meeting of the American CeramicX Society Advances in Ceramics $v 8$. Publ by American Ceramic SOC Inc, COlumbus, $X$ OH, USA $p$ 76-85, Anonymous Columbus, $X$ OH, USA:American Ceramic Soc Inc, 1984,p. 76-85.

3278. Ougouag, A. and Machiels, A.J. Effects of radiation-induced stress on the chemical durability ofX nuclear waste glasses. In: <CI> Held as part of the Fall Meeting of the Materials Researchx Society Materials Research Society Symposia Proceedings $v 44$. Publ by MaterialsX Research Soc, Pittsburgh, PA, USA $p$ 609-616, Anonymous Pittsburgh, PA, USA:MaterialsX Research Soc, 1985,p. 609-616.

3279. Ougouag, A. Modeling of radiation effects on the chemical durability of nuclear waste forms /, 1986.

3280. Oversby, V., M., ; Phinney, D., L., and $x$ the structure of alteration layers on cast glass surfacesX. Mater.Res.Soc.Symp.Proc., 257, 99-108X-108X, 1994.

3281. Oversby, V., M., ; Phinney, D., L., and $X$ the development of surface alteration layers on srl-165 nuclearX waste glassesX. J.Nucl.Mater., 190, 247-68X-68X, 1994 . 
3282. Oversby, V., M., ; Ringwood, A., E., and $X$ leach testing of synroc and

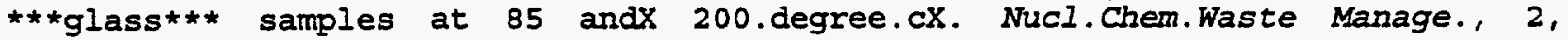
$201-6 \mathrm{X}-6 \mathrm{X}, 1981$.

3283. Oversby, V., M., and $X$ reference waste forms and packing material for the nevada nuclearX waste storage investigations projectX. Report, Ucrl-53531, 28 pp, 1985.

3284. Oversby, V.M. and Phinney, D.L. Structure of alteration layers on cast glass surfaces. (Unknown Journal!), 1991.

3285. Oversby, V.M. and Phinney, D.L. Development of surface alteration layers on srl-165 nuclear wastex glasses. Journal of Nuclear Materials 190:247-268, 1992.

3286. Owens-Illinois Physical and chemical properties of various glass compositions / General Research. Laboratory, Owens-Illinois Glass Company, Alton, IL:Owens-Illinois Glass Company General Research Laboratory, 1937.

3287. Oyoshi, K., Tagami, T., and Tanaka, S. Formation of buried oxynitride layers in silica glass by ion implantation. Journal.of.Applied.Physics. v. 68 (Oct. 1 '90):3653-3660, 1990 .

3288. Ozaki, S., Abe, H., Fukuda, S., Shiomi, S., Kobayashi, S., Saegusa, Sanui, T., Ishida, R., Hironaga, M., Ohnuma, H., and Maki, Y. Design, safety analyses and tests of packagings for $\mathrm{hlw}$ and spent fuelx transport/storage. In: International Atomic Energy Agency, Proceedings Series $718 \vee 2$. Publ by $x$ IAEA, Vienna, Austria p 151-160, Anonymous Proceedings Series 718 v 2: 1987,p. 151-160.

3289. Ozhovan, M., I., ; Batyukhnova, O., G., ; Barinov, A., S., ; Devyatkova, L., X I., ; Semenov, K., N., ; Shcherbatova, T., D., ; Manyukova, N., ; Titov,

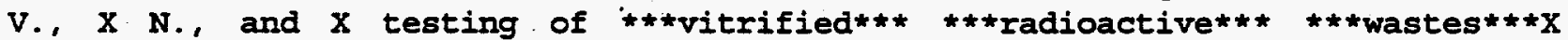
under open site conditionsX. Radiokhimiya, 34, 100-6X-6X, 1994.

3290. Ozhovan, M., I., ; Batyrukhnova, O., G.., ; Karlina, O., K., ; Devyatkova, L., X I., ; Shcherbatova, T., D., and X microstructure of $* * \star$ glass*** -composite materials duringX immobilization of $\star \star \star$ radioactive*t* $\star \star \star$ wastes $* \star *$ X. Fiz.Khim.Stekla, 17, 830-2X-2X, 1994.

3291. Ozhovan, M., I., ; Karlina, O., K., ; Batyukhnova, O., G., ; Devyatkova, L., $X$ I., and $X$ structure of $\star * \star$ glass $* \star \star$-composite materials forX

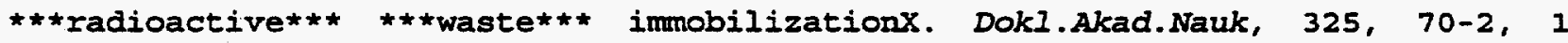
plate $X-2,1$ plate $x, 1994$.

3292. Ozhovan, M., I., ; Karlina, O., K., and X preparation and properties of the $* *$ glass $* *$ compositex materials for the solidification of

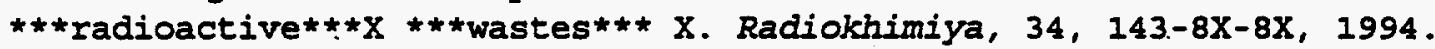

3293. Ozhovan, M., I., ; Semenov, K., N., and X determination of the leaching factors and effective diffusionx coefficients of radionuclides based upon prolonged test resultsX. At. Energ., 70, 196-7X-7X, 1994. 
3294. Ozhovan, M.I., Batyukhnova, O.G., Karlina, O.K., Devyatkova, L.I., and Shcherbatova, T.D. Microstructure of glass-composite materials during imnobilization ofX radioactive wastes. Fizika i Khimiya Stekla 17:830-832, 1991.

3295. Ozhovan, M.I., Batyukhnova, O.G., Karlina, O.K., Devyatkova, I.I., and Shcherbatova, T.D. Microstructure of Glass Composite Materials in Immobilization of Radioactive Wastes. The.Soviet.journal.of.glass.physics.and.chemistry. 17, Number 5:490-491, 1992.

3296. Ozhovan, M.I. and Karlina, O.K. Preparation and Properties of Glass Composites for Solidification of Radioactive-Wastes. SOV.RADIOCHEM-ENGL.TR. $34: 265-269$, 1992 .

3297. Ozhovan, M.I., Karlina, O.K., Batyukhnova, O.G., and Devyatkova, L.I. The Structure of Glass-Composite Materials for Radioactive-Waste Immobilization. DOKL. AKAD.NAUK. $325: 70-7 \&, 1992$.

3298. Ozhovan, M.I. and Semenov, K.N. Determination of leaching factors and effective diffusion coefficientsx of radionuclides from the results of long tests. Soviet Atomic Energy 70:257-258, 1991.

3299. Oziraner, S., N., ; Minaev, A., A., ; Kuznetsov, D., G., ; Prokhorova, N., P., and $X$ comparison of certain properties of phosphate and $* \star *$ silicate***X glasses intended for the $\star \star \star v i t r i f i c a t i o n * \star$ of $x$ aluminum-containing ***radioactive*** ***wastes*** $\mathrm{X}$. Issled. $v$ obl.Obezvrezhivaniya zhidk., Tverd.i Gazoobrazn.X Radioakt.Otkhodov $i$ Dezaktivatsii Zagryaznen.Poverkhnostei.X Materialy 4-i Nauch-i Nauch, 1976.

3300. Pacaud, F., ; Fillet, C., ; Jacquet Francillon, N., and $X$ effect of platinoids on french 1 wr reference glass propertiesX. Mater.Res.Soc.Symp.Proc., 257, 161-7X-7X, 1994.

3301. Pacaud, F., Fillet, C., and Jacquet Francillon, N. Effect of platinoids on French LWR reference glass properties. (Unkiown Journal!), 1991.

3302. Pacaud, F., ; Jacquet Francillon, N., ; Terki, A., ; Fillet, C., and $\mathrm{X}$ r7t7 light water reference glass sensitivity to variations inX chemical composition and operating parametersX. Mater.Res.Soc.Symp.Proc., 127, 105-12, 1989 .

3303. Pacific Northwest Laboratory. Conceptual design of a nuclear waste vitrification facility /, Richland, Wash. : [Springfield, Va. :Dept. of Energy, Pacific Northwest Laboratory; for sale by the National Technical Information Service], 1978.

3304. Pacific Northwest Laboratory. Technical sumary, Nuclear waste vitrification project /, Richland, Wash. : [Springfield, Va. :Dept. of Energy, Pacific Northwest Laboratory; for sale by the National Technical Information Service], 1979.

3305. Pacovsky, V Electric crucible furnaces for vitrification of radioactive wastes. SkIar Keram. , 1984. 
3306. Pacovsky, V Induction funnaces for vitrification of radioactive wastes. Sklar Keram. , 1984.

3307. Pacovsky, $V$ Double-compartment vitrification of radioactive wastes. Sklar Keram. , 1984.

3308. Pacovsky, $V$ All-electric furnaces for vitrification of radioactive wastes. Sklar Keram. , 1984.

3309. Pacovsky, $\mathrm{V}$ and Vojtech, O. Vitrification of radioactive wastes. Sklar Keram. , 1983.

3310. Pacovsky, V., Konarek, F., and Vojtech, O. sealing ***radioactive***

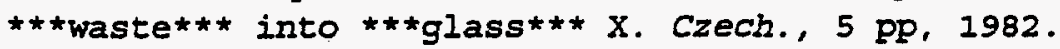

3311. Pacovsky, V.V.,otakarX ***vitrification*** of ***radioactive*** ***wastes*** X. Sklar Keram., 33, 302-4, 1983.

3312. Pacovsky, V. two-compartment $* \star \star v i t r i f i c a t i o n * * *$ of. $* * \star$ radioactive $* \star \star X$

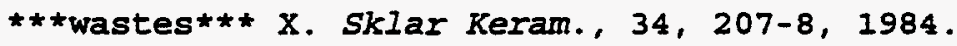

3313. Pacovsky, $v$. electric crucible furnaces for ***vitrification*t* ofX

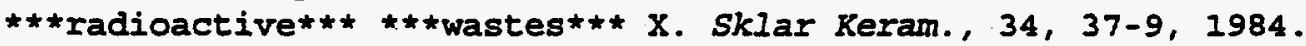

3314. Paeglis, A. Spectroscopic investigations of structure and glass transition $X$ behavior in alkali arsenate,phosphate, and arsenatophosphate $X$ glasses, Providence:s.n. 1979.

3315. Paige, J.I.J., Harris, H., and Kelly, H. Devitrification of vacuum-melted glasses of the Iithium $X$ metasilicate-silica compositional series, Washington, D.C.U.S. Dept. of the Interior, Bureau of Mines, 1965.

3316. Palancar and Luis Heat transfer in vitrified radioactive waste. Glasses and Glass-Ceram.for Nuclear Waste Managem , 1987.

3317. Palancar, M., C., ; Montero, M., A., ; Aragon, J., M., ; Luis, P., ; Jodra, L., X G., and $X$ model for simulation of temperature distribution in high-levelX radioactive waste glassesX. Energ.Nucl.(Madrid), 28, 339-48, 1984 .

3318. Palmer, B.J. Transverse-Current Autocorrelation-Function Calculations of the Shear Viscosity for Molecular Liquids. PHYS.REV.E. 49:359-366, 1994.

3319. Palmer, C., R., ; Mellinger, G., B., ; Rusin, J., M., and X investigation of vitreous and crystalline ceramic materials forx immobilization of alpha-contaminated residuesX. Manage.Alpha-Contam.Wastes, Proc.Int.Symp., Meeting Date 1980, 339-54, 1980.

3320. Palmiter, T., ; Joseph, I.,; Pye, L., and DavidX effects of heat treatment on the microstructure of a fully simulatedx nuclear waste glassx. Mater.Res.SoC.Symp.Proc., 212, 153-8X-8X, 1994. 
3321. Pariagopoulos, C., Fasoula, E., and Michaelides, A. The abrasive wear of borosilicate glass. Jo - Journal of materials science. (Unknown Journal!) 29, Number 3-773, 1994.

3322. Parkinson, G. Glass making. Chemical.Engineering. v. 97 (Oct. '90):30-31, 1990.

3323. Parotrajaona, T., Cote, B., Vaills, Y., and Gervais, F. Degree of Coherence of Vibrations in Silicate-Glasses. J.PHYS.IV. 2:227-230, 1992.

3324. Parsons, B.K. Shop Completion of Melter Vessel Assembly No. 1 for the Defense Waste Processing Facility at Savannah River Plant. (Unknown Journal!) , 1988 .

3325. Partridge, B.A. AERE (Atomic Energy Research Establishment Harwell, England) Contracts with DOE on the Treatment and Disposal of Intermediate Level Wastes. Annual Report for 1984/1985. (Unknown Journal!) , 1985.

3326. Partridge, G. and Doremus, R. A review of surface crystallisation in vitreous systems Alumina substructure and electrical conductivity in vitreous silica. Glass.Technology.Journal.of.the.American.Ceramic.Society. v. 67 (July '84) : C150-C118, 1984 .

3327. Pascova, R., Gutzow, I., and schmelzer, J. Model investigation of the process of phase formation in photochromic glasses. Part 2. Theory of phase formation and Ostwald ripening in viscoelastic media. Journal. of.Materials.Science J Mater Sci v 25 n 2, 1990.

3328. Pascova, R., Gutzow, I., and Tomov, I. Model investigation of the process of phase formation in photochronic glasses. Part 1. Solubility of AgCl in sodium borate melts and experimental results on the kinetics of phase formation. Journal.of.Materials.Science J Mater Sci v 25 n 2, 1990.

3329. Patil, A.O. and Datta, S. Multifunctional Viscosity Index Improvers. ABSTR. PAP.AMER. CHEM. SOC. 207:336-POLY, 1994 .

3330. Patyn, J., ; Van Iseghem, P., ; Timmermans, w., and $\mathrm{x}$ the long-term corrosion and modeling of two simulated belgianx reference high-level waste glasses - part iix. Mater.Res.Soc.Symp.Proc., 176, 299-307, 1990.

3331. Pavlovskii, V.K., Petrov, V.N., and sobolev, Y.V. Interaction of Refractories with a Borosilicate Glass Melt. Glass.and.ceramics. 47, Numbers 9-10:389-391, 1990 .

3332. Pavlovskii, V.K. and Sobolev, Y.S. Temperature Dependence of Corrosion of Refractories in Barium Borosilicate Glass Melts. Glass.and.ceramics.PY.-.1993. 49. Numbers 5-6:280-282, 1994 .

3333. Pecak, V., ; Matous, V., and $\mathrm{X}$ pyrolytic denitrification and stabilization of radioactive solutionsX containing nitratesX. Nukleon, (3), 16-20, 1984. 
3334. Pederson, L., R.; ; Buckwalter, C., Q., ; McVay, G., L., and $X$ the effects of surface area to solution volume on wastex $\star \star \star$ glass $* \star$ leachingx. Nuc1.Technol., 62, 151-8X-8X, 1983.

3335. Pederson, L., R., ; McVay, G., L., and $x$ influence of gamma irradiation on leaching of simulated nuclearX waste $\star * \star$ glass $* \star *$ : temperature and dose rate dependence inX deaerated waterX. J.Am.Ceram.Soc., 66, 863-7X-7X, 1983.

3336. Pederson, L., R., ; McVay, G., L., and $X$ effect of gamma radiolysis on waste $* *$ glass ${ }^{\ddagger *}$ leaching onX brinesX. Adv.Ceram., 8, 49-56X-56X, 1984 .

3337. Pederson, L., R., ; Thomas, M., T., ; McVay, G., L., and X application of esca to corrosion studies of glasses containingX simulated nuclear wastesX. J.Vac.Sci.Technol., 18, 732-6X-6X, 1981.

3338. Pederson, I.R., MCGrail, B.P., MCVay, G.I., Petersenvillalobos, D.A., and Settles, N.S. Kinetics of Alkali Silicate and Aluminosilicate Glass Reactions in Alkali Chloride Solutions - Influence of Surface-Charge. PHYS.CHEM.GLASSES. $34: 140-148$, 1993 .

3339. Pederson, L.R. and McVay, G.L. Influence of gamma irradiation on leaching of simulated $X$ nuclear waste glass: temperature and dose rate dependence in $X$ deaerated water. Journal.of.the.American.Ceramic.Society. v. 66 (Dec. '83) : 863-867, 1983 .

3340. Pederson, L.R. and McVay, G.L. Effect of gamma radiolysis on waste glass leaching on brines. In: <CI> Held during the 85th Anoual Meeting of the American CeramicX Society Advances in Ceramics $v$. Publ by American Ceramic Soc Inc, Columbus, $X$ OH, USA $p$ 49-56, Anonymous Columbus, $X$ OH, USA:American Ceramic Soc Inc, 1984,p. 49-56.

3341. Pederson, L.R., ; Buckwalter, C.Q., ; McVay, G.I., ; Riddle, X.B., and Lynnx ***glass*** surface area to solution volume ratio and itsX implications to accelerated leach testingx. Mater.Res.Soc.Symp.Proc., 15, 47-54, 1983.

3342. Pederson, L. and MeVay, G. Influence of gamma irradiation on leaching of simulated nuclear wasteglassitemperature and dose rate dependence in deaerated water. J.Am.Ceram.Soc. , 1983.

3343. Pederson, I. and McVay, G. Effect of gamma radiolysis on waste glass leaching on brines. Adv. Ceram., 1985.

3344. Pegg, I., I., ; Saad, E., E., ; Feng, X., ; Adiga, R., B., ; Freeborn, w., P., ; X Macedo, P., and $X$ product models for the vitrification of west valley high-levelX wastesX. Mater.Res.Soc.Symp.Proc., 127, 215-21, 1989.

3345. Pegg, I.I., Saad, E., Freeborn, W.P., and Macedo, P.B. Verification of product quality from process control-preliminary results. (Unknown Journal!), 1988 .

3346. Pegg, I.I., ; Freeborn, W., Phelps; Macedo, P.B., and $X$ a process model for west valley waste vitrificationx. Proc.Symp.Waste Manage., (Waste Manage. '88, Vol. 2), 797-804, 1988. 
3347. Penberthy, L. Electric furnace for nuclear waste glass. In: Ceramic Engineering and Science Proceedings v 5 n $1-2$ Jan-Feb 1984 pX 87-91, Anonymous 1984, -2 Jan-Feb 1984 pX 87.

3348. Penberthy, L. Use of electric glass melting furnaces for destruction of hazardousX wastes. In: American Institute of Chemical Engineers, National Meeting 1986. PublX by AIChE, New York,NY, USA Pap 71f,4p, Anonymous National Meeting 1986: 1986,

3349. Penberthy, L. and Hotaling, D. Use of electrically heated radiant glass furnace for destruction ofX hazardous waste. In: <CI> volume 1: General Proceedings of the Symposium on Waste Management 1982. Publ by ArizonaX Board of Regents, Ariz, USA $p$ 311-313,Anonymous Ariz; USA:ArizonaX Board of Regents, 1982 ,p. $311-313$.

3350. Penberthy, I. the structure of $* *$ glass $* *$ as a host for radwaste, or why weX need a $\star * \star$ glass $* \star *$ better than "borosilicate"X. Proc.Symp. Waste Manage., 1 , $227-36 \mathrm{X}-36 \mathrm{X}, 1981$.

3351. Penberthy, $L$. an electric furnace for nuclear waste glassX. Ceram. Eng.Sci.Proc., 5, 87-9X-9X, 1984.

3352. Peng, Y.B. and Day, D.E. High thermal expansion phosphate glasses. Part 1. Glass. Technology. 32 in 5:166-173, 1991.

3353. Peng, Y. Factors affecting nitrogen dissolution in sodium meta-phosphate glass, 1985.

3354. Pentinghaus, $H$. and $X$ on the process chemistry of hllw-vitrification in a liquid-fedX ceramic melter ( $1 \mathrm{fcm}$ ) X. NukI. Entsorgung, 4, 229-38X-38X, 1994 .

3355. Penzhorn, R., D., ; Mertin, w., and $x$ electron diffraction and $x$-ray investigation of hydrothermallyx ***vitrified*** 5 a zeolite containing trapped gasesX. J.Solid State Chem., 54, 235-44X-44X, 1984.

3356. Penzhorn, R.-D., Noppel, H.E.,. Schuster, P., Leitzig, H., Dorea, and Kroebel, $R$. Immobilization of radioactive gaseous waste liberated duringX reprocessing of spent reactor fuel. In: $v 2$. Publ by ANS, La Grange Park, IL, USA p 354-361, Anonymous La Grange Park, IL, USA:ANS, 1984,p. 354-361.

3357. Penzhorn, R.D., Noppel, H.E., Dorea, A., Guenther, K., and Leitzig, H. Long-Term Storage of sup $85 \mathrm{Kr}$ in Amorphous zeolite 5A. (Unknown Journal!), 1984.

3358. Pepin, J., G., ; Davis, D., D., ; McCarthy, G., J., ; Vance, E., R., and

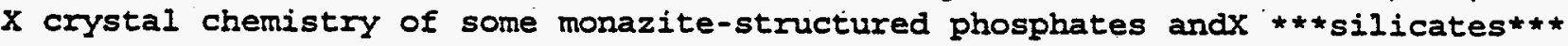
X. RepoIt, Doe/Et/41900-7, Esg-Doe-13351, 37 pp, 1981.

3359. Perera, G. and Doremus, R. Dissolution Rates of Commercial Soda-Lime and Pyrex Borosilicate Glasses: Influence of Solution pH. Journal.of. the.American.Ceramic.Society.PY.-.1991. 74, Number 7:1554-1558, 1991. 
3360. Perera, G., Doremus, R., and Lanford, W. Dissolution rates of silicate glasses in water at pH 7. Journal.of.the.American.Ceramic.Society. v. 74 (June '91) :1269-1274, 1991 .

3361. Perez, Goles, and Nakaoka Liquid-fed ceramic melter testing for the hanford waste vitrification plant [hwvp]. Ceram.Trans. , 1990.

3362. Perez, J., M., , ; Goles, R., W., ; Nakaoka, R., K., ; Sevigny, G., J., ;X Larson, D., E., ; Kruger, O., I., and X liquid-fed ceramic melter testing for the hanford wastex vitrification plantX. Ceram.Trans., 9, 549-65, 1990.

3363. Perez, J., M., , and $x$ design and performance of feed-delivery systems for simulatedX $* * \star$ radioactive $* \star \star * \star *$ waste $* \star *$ slurriesX. Report, PnI-4423; Order No.De83008721, 72 pp, 1983.

3364. Perez, J.M., Goles, R.W., Nakaoka, R.K., Sevigny, G.J., and Larson, D.E. Vitrification Process Testing for Reference HWVP (Hanford Waste Vitrification Plant) Waste. (Unknown Journal!) , 1987.

3365. Perez, J.M., Goles, R.W., Nakaoka, R.K., Sevingy, G.J., and Larson, D.E. Liquid-fed ceramic melter testing for the Hanford Waste Vitrification plant waste. (Unknown Journal!), 1989.

3366. Perez, J.M. and Nakaoka, R.R. Vitrification Testing of Simulated High-Level Radioactive Waste at Hanford. (Unknown Journal!) , 1986.

3367. Perez, J.M.J. and Nakaoka, R.K. Vitrification testing of simulated high-level radioactive waste fromx hanford. In: <CI> Volume 2: High-Level Waste $\checkmark$ 2. Publ by Arizona Board of Regents, $A Z$, USA $P$ 495-505, Anonymous AZ, USA:Arizona Board of Regents, 1986,p. 495-505.

3368. Perez, J.M., , ; Westsik, J.H., and X effects of cracks on $\star * \star$ glass $* \star \star$ leachingX. Nucl. Chem. Waste Manage., 2, 165-8X-8X, 1981.

3369. Pernice, P., Aronne, A., and Marotta, A. The non-isothermal devitrification of lithium heptagermanate glass. Thermochimica.acta.PY.-.1992. 196. Number $1: 1-6,1992$.

3370. Pernice, P.N., Aronne, A.N., and Marotta, A.N. The non-isothermal devitrification of Iithium tetragermanate glass. Materials.chemistry.and.physics.PY.-.1992. 30, Number 3:195-198, 1992.

3371. Perry, c. Preparation and magnetic properties of titanium phosphate glass, Nashville:1976.

3372. Perry, R. Photographic investigation of bubble formation in glass melts with refractory material in contact with molten glass, Alfred, N.Y.New York State College of Ceramics at Alfred University, 1956.

3373. Pescatore, C. and Machiels, A. Mechanistic approach to modeling of nuclear waste form leaching. Adv. Ceram. , 1985.

3374. Pescatore, C. and Machiels, A.J. Mechanistic approach to modeling of nuclear waste form leaching. In: <CI> Held during the 85 th Annual Meeting of 
the American CeramicX Society Advances in Ceramics $v 8$. Publ by American Ceramic SOC Inc, Columbus, $X$ OH, USA $p$ 508-578, Anonymous Columbus, $X$ OH, USA:American Ceramic SOC Inc, 1984,D. 508-578.

3375. Pescatore, C., ; Machiels, A., J., and $X$ effects of surfaces on ***glass*** waste form leachingX. J.Non-Cryst.Solids, 49, 379-88X-88X, 1982.

3376. Pestov, Y.N. and Shekhtman, I.I. Influence of the Bulk Resistivity of Glass with Electronic Conductivity on the Performance of Microstrip Gas Chamber. NUCL. INSTRUM.METH. PHYS.RES.A. 338:368-374, 1994.

3377. Peters Database for waste glass composition and properties. (Unknown Journal!) : (7 p), 1993:

3378. Peters Vitrification development plan for us department of energy mixed wastes. (Unknown Journal!) : (95 p), 1993.

3379. Peters, Elliott, and Chapman Proposed noble metals compatible melter: preliminary modeling results. Ceram.trans. , 1990.

3380. Peters, A. Analytical determination of impurities in glassmaking sands containing at least $958 \mathrm{sio} / / 2$. Glass.Technology. $v 34$ n 6 Dec 1993.23-248, 1993.

3381. Peters, A. Improved Method to Determine Fluorides in Glasses and Glass Raw-Materials - Report of the International-Commission-on-Glass Technical Committee-2 Chemical Durability and Analysis. GLASTECH.BER. 65:292-295, 1992.

3382. Peters, A. Determination of Reducing Components in Glassmaking Raw-Materials - Report of the International-Comnission-on-Glass Technical Committee-2 Chemical Durability and Analysis. GLASTECH.BER. 66:159-164, 1993.

3383. Peters, A. and Fletcher, W.พ. Chemical durability: a study of ISO 695, the standard test method for measuring the resistance of glass to a boiling solution of mixed alkali. Glass.Technology. v. 28 (Dec. '87):232-236, 1987.

3384. Peters, R., D., ; Diamond, H., and $X$ actinide leaching from waste **\#lass*** : air-equilibratedX versus deaerated conditionsX. Report, Pal-3971; Order No.De82003098, 42 PP, 1982.

3385. Peters, R., D., ; Slate, S., C., and $x$ fracturing of simulated high-level waste $* \star \star g l a s s * \star \star$ inX canistersX. Nucl.Eng.Des., 67, 425-45X-45X, 1981.

3386. Peters, R., D., ; Slate, S., C., and $\mathrm{X}$ fracturing of simulated high-level waste $\star * \star$ glass $\star \star *$ inX canistersX. Report, PnI-3948; Order No.De81030621, 58 pp, 1981 .

3387. Peters, R.D., Elliott, M.L., and Chapman, C.C. Proposed Noble Metals-Compatible Melter: Preliminary Modeling Results. (Unknown Journal!) , 1989.

3388. Peters, R.D. and Kurath, D.E. Treatment alternatives for Greater-Than-Class C low-level waste. (Unknown Journal!) , 1990. 
3389. Peters, R.D., ; Jenquin, U.P., ; Holton, L.K., , and $X$ measuring and predicting gamma radiation from radioactiveX glass-filled canistersX. Nucl. Technol., 90, 78-86X-86X, 1989.

3390. Petersen, R.D. Microwave vitrification of Rocky Flats TRU sludge. (Unknown Journal!) , 1990.

3391. Petersen, R.D. and Johnson, A.J. In-Drum Vitrification of Transuranium Waste Sludge Using Microwave Energy. (Unknown Journal!); 1989.

3392. Peterson, M.E., Berger, D.N., Blair, H.T., and Siemens, D.H. Adaptation of an air-displacement slurry pump for remote service. In: 〈CI> Held in Conjunction with the American Nuclear society winterx Meeting.Held in Conjunction with the American Nuclear Society Winterx Meeting Proceedings of the Conference on Remote Systems Technology 33rd. Publx by ANS, La Grange Park, IL, USA P 51-54, Anonymous La Grange Park, IL, USA: 1986,P. 51-54.

3393. Peterson, M.E., Berger, D.N., Blair, H.T., and Siemens, D.N. Adaptation of an Air Displacement Purmp for Remote Service. (Unknown Journal!) , 1985.

3394. Peterson, M.E., McCarthy, D., and Muhlstein, K.D. Design of a Mixing System for Simulated High-Level Nuclear Waste Melter Feed Slurries. (Unknown Journal!) , 1986.

3395. Petit Maire, D. Structure locale autour d'actinides et d'elements nucleants dans des verres borosilicates d'interet nucleaire: resultats de spectroscopie d'absorption des rayons $x$. (Local structure near actinides and nucleating elements in borosilicate glass for nuclear industry: Results of $\mathrm{X}$-ray absorption spectroscopy). Thesis. (Unknown Journal!), 1988.

3396. Petit, J., C., ; Dran, J., ; Della Mea, G., ; Brousse, C., ; Paccagnella, X.A., ; Mando, P., A., and $X$ ion-implantation effects on silicates: new insights into theirX aqueous dissolutionx. Nucl.Instrum.Methods Phys.Res., Sect. $B, B 32(1-4), 498-503 X-503 X$; 1988 .

3397. Petit, J., C., ; Dran, J., ; Maurette, M., and X ion implantation characterization of irradiation effects related toX alpha.-decay in high-activity glassesX. Sci.Rech. 44-51X-51X, 1982.

3398. Petit, J., C., ; Dran, J., ; Trotignon, L., ; Casabonne, J., M., ;X Paccagnella, A., ; Della Mea, G., and X mechanism of heavy element retention in hydrated layers formed onx leached silicate glassesx. Mater.Res.Soc.Symp.Proc., $127,33-40 x-40 x, 1989$.

3399. Petit, J., C., ; Langevin, Y., ; Lameille, J., M., ; Dran, J., and $X$ on the leaching behavior of a simple borosilicate **tglass*t* inx a confined environmentx. Mater.Res.Soc.Symp. Proc., 11,X 203-10X-10X, 1983.

3400. Petit, J.-C., Magonthier, M.-C., and Dran, J.-C. Long-term dissolution rate of nuclear glasses in confined environments: does a residual chemical affinity exist. J.MATER.SCI. 25[7]:3048-3052, 1990 .

3401. Petit-Maire, D., Petiau, J., Calas, G., and Jacquet-Francillon, N. Insertion of neptunium in borosilicate glasses. <CTs Proceedings of the Fifth 
International Conference on X-RayX Absorption Fine structure <CL> Seattle, WA, USA <CD> 1988 Aug 21-26 Physica B: Condensed Matter 158:56-57, 1989.

3402. Petrovskii, G.T. and Ter-Nersesyants, V.E. Nuclear-physics methods for analyzing the near-surface layers ofx glasses. Soviet Journal of Glass Physics and Chemistry $14: 343-366,1989$.

3403. Petru, z. Vypocet viskozity sklovin z chemickeho slozeni, Hradec Kralove :Statni vyzkumny ustav sklarsky $v$ Hradci Kralove, 1988.

3404. Petzoldt, O. Aerosole aus Hochtemperaturprozessen am Beispiel der Verglasung von hochradioaktiven Abfalloesungen in der PAMELA. Probenahme, Analytik und Bewertung. (Aerosols from high-temperature procedures illustrated by vitrification of high-level radioactive waste solutions at PAMEIA: Sampling, analysis and evaluation). Diss. (Dr.rer.nat). (Unknown Journal!), 1988.

3405. Pezzimenti, D.M., Vlad, P.M., and Landau, B. Use of the Deep Kerfer for thick, steel-reinforced concrete cutting. (Unknown Journal!) , 1989.

3406. Phifer, c.c. The Structure of Barium zinc Aluminate Glasses. J.NON-CRYST.SOLIDS. 152:157-160, 1993.

3407. Philipose, K.E., Feldman, R.F., and Beaudoin, J.J. Qualifying concrete for a low-level waste repository. (Unknown Journall), 1990.

3408. Philipose, K.E., Feldman, R.F., and Beaudoin, J.J. Durability predictions from rate of diffusion testing of normal portland cement, fly ash, and slag concrete. (Unknown Journal!) , 1991.

3409. Phinney, D., L., ; Ryerson, F., J., ; Oversby, V., M., ; Lanford, พ., A., iX Aines, R., D., ; Bates, J., K., and X integrated testing of the srl-165 glass waste formX. Mater.Res.Soc.Symp.Proc., 84, X 433-46X-46X, 1987.

3410. Phlippen, P., พ., ; Jaroni, U., ; Kugeler, K., ; Schmidtlein, P., and $X$ safe interim storage of $* * *$ vitrified*** high-levelX $\star * \star r a d i o a c t i v e * * *$ ***wastes***.X. Atomkernenerg./Keratech., 44, 132-6X-6X, 1984.

3411. Pickering Kinetics of surface-layer formation on simulated nuclear waste glass. J.Am.Ceram.SOC. , 1980.

3412. Pickering, S., Walker, C.T., and offermann, P. Leaching of actinides from simulated nuclear waste glass. In: Materials Research Society Symposia Proceedings $v$ 11.Publ byX North-Holland, New York, NY, USA and Ansterdam, Neth p 113-124, Anonymous New York, NY, USA: 1982,p. 113-124.

3413. Pickering, $S$. and $x$ kinetics of surface-layer formation on simulated

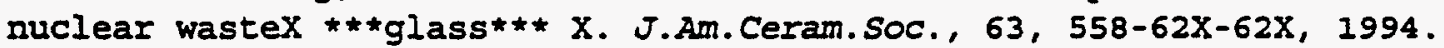

3414. Pickrell, G., ; Jackson, D., D., and $x$ user's guide to protocol, $a$ numerical simulator for the dissolutionx reactions of inorganic solids in aqueous solutionsX. Report, Ucid-20236; Order No.De85002803, 62 pp, 1985. 
3415. Piepel A statistical approach for identifying nuclear waste glass compositions that will meet quality and processability requirements. (Unknown Journal!) : (5 p), 1990.

3416. Piepel, G.F., Hrma, P.R., Bates, S.O., Schweiger, M.J., and Smith, D.E. First-order study of property/composition relationships for Hanford Waste Vitrification Plant glasses. (Unknown Journal!), 1993.

3417. Piepel, G.F., Jones, T.E., Eggett, D.I., and Melinger, G.B. Product Consistency Testt Round Robin Conducted by the Materials Characterization Center: Summary Report. (Unknown Journal!), 1989.

3418. Piepel, G.F., Mellinger, G.B., and Reimus, M.A.F. Characterizing Waste Glass Durability: A Highly-Constrained 1l-Component Mixture Case Study. (Unknown Journal!), 1988.

3419. Piepel, G.F., Mellinger, G.B., and Reimus, M.A.H. Statistical approach for characterizing chemical durability within a waste glass compositional region. Waste.Management. Waste Manage v 9 n 1, 1989.

3420. Pietrelli, L., ; Marrocchelli, A., ; Luce, A., and X chemical processing of high-level radioactive wastes of the enea: $X$ the serse pilot plantx. Energ.Nuc1. (Rome), 5, 78-87X-87X, 1988.

3421. Pigford, T.F. and Chambre, P.I. Reliable Predictions of Waste Performance in a Geologic Repository. (Unknown Journal!), 1985.

3422. Pigford, T.H. and Chambre, P.I. Closed-System Postulates for Predicting Waste-Package. Performance in a Geological. Repository. (Unknown Journal!), 1986 .

3423. Pilkington, N.J. and Stone, N.S. Solubility and sorption of nickel and niobium under high pH conditions. (Unknows Journal!) , 1990.

3424. Pine, G.I. and Jantzen, C.M. Implications of One-Year Basalt Weathering/Reactivity Study for a Basalt Repository Environment.' (Unknown Journall) , 1987.

3425. Place, B., G., and X treatment technology for transuranic waste streams: cementation, $X$ vitrification, and incineration testing for the treatment of spentx ion exchange mediax. Report, Whe-Ep-0462; Order No.De93006250, 81 pp, 1993.

3426. Place, B.G. Engineering study for the treatment of spent ion exchange resin resulting from nuclear process applications. (Unknown Journal!) , 1990.

3427. Place, B.G. Treatment technology for transuranic waste streams: Cementation, vitrification, and incineration testing for the treatment of spent ion exchange media. (Unknowis Journal!) , 1992.

3428. Platts, D. The behavior of bubbles of oxygen and sulfur dioxide in glass, Alfred, N. Y.New York State College of Ceramics at Alfred University, 1965. 
3429. Plecas, I., Peric, A., Glodic, S., and Kostadinovic, A. Comparative Interpretation of Leach Rate of $\mathrm{Cs}-137$ and Co-60 from Cement Matrix. J.RADIOANAL. NUCL. CHEM. LETT. $165: 377-384,1992$.

3430. Plecas, I., Peric, A., Kostadinovic, A., Drljaca, J., and Glodic, $S$. Leaching Behavior of Co-60 and Cs-173 from Spent Ion-Exchange Resins in Cement Matrix. CEM. CONCR.RES. 22:937-940, 1992.

3431. Plecas, I.B., Peric, A.D., Drljaca, J.D., and Kostadinovic, A.M. Mathematical-Modeling of Physicochemical Characteristics of Cement-Waste Composites in Radioactive-Waste Management. J.RADIOANAL.NUCL.CHRM.ART. $157: 95-104,1992$.

3432. Plecas, I.B., Peric, A.D., Drljaca, J.D., Kostadinovic, A.M., and Glodic, S.D. Immobilization of Radioactive-Waste Water Residues in a Cement Matrix. CEM. CONCR.RES. $22: 571-576,1992$.

3433. Plecas, I.B., Peric, A.D., Glodic, S.D., and Kostadinovic, A.M. Conditioning of Industrial-Waste in Cement Matrix. J.RADIOANAL.NUCL.CHEM.LETT. $166: 373-381$, 1992 .

3434. Plodinec Identification of items and activities important to waste form acceptance by westinghouse goco sites <augmentation> government-owned contractor-operated. (Unknown Journal!) : (22 p), 1912.

3435: Plodinec Aspects of the dwpf melter significant to waste acceptance. (Unknown Journal!) : (6 p), 1924.

3436. Plodinec Glass sampling program during dwpf integrated cold runs. (Unknown Journal!) : (34 p), 1930.

3437. Plodinec Development of glass compositions form immobilization of srp wastex. Report. , 1979.

3438. Plodinec Viscosity of glasses containing simulated savannah river plant wastex. Report. , 1979.

3439. Plodinec Development of glass compositions for immobilization of savannahx river plant wastex. Report. , 1979.

3440. Plodinec Vitrification chemistry and nuclear waste. J.Non-Cryst.Solids , 1986 .

3441. Plodinec Rheology of glasses containing crystalline material. Adv.Ceram: , 1986 .

3442. Plodinec Advances in processing nuclear waste glasses. Adv. Fusion Glass, 1988 .

3443. Plodinec Establishing the acceptability of savannah river site waste glass. (Unknown Journal!) : (5 p), 1990.

3444. Plodinec Application of hydration thermodynamics to control of the dwpf process. (Unknown Journal!) : (13 p), 1990. 
3445. Plodinec Dwpf waste form compliance plan (draft revision). (Unknown Journal!) : (231 p), 1991.

3446. Plodinec Technical bases for the dwpf testing program. Mater.Res.SOC.Symp.Proc. , 1991.

3447. Plodinec projected radionuclide inventories of dwpf glass from current waste at time of production. (Unknown Journal!) : (13 p), 1994.

3448. Plodinec Method of calculation of heat generation rates for dwpf glass. (unknown Journal!) : (5 p), 1994.

3449. Plodinec and Wiley Viscosity and electrical conductivity of glass melts as a functionX of waste compositionX. Report. , 1979.

3450. Plodinec, J. Small-scale, joule-heated melting of Savannah River Plant waste glass, Aiken, S.C. : [Springfield, Va. :Dept. of Energy, Savannah River Laboratory ; for sale by the National Technical Information Service], 1979.

3451. Plodinec, M., J., and $X$ aspects of the dwpf melter significant to waste acceptanceX. Report, Wsrc-Rp-92-323; Order No.De93002813, 6 pp, 1993.

3452. Plodinec, M., J., and $X$ controlling the durability of nuclear-waste glassX. High-Perform.Glasses, 187-209, 325-7:arker, J, 1994.

3453. Plodinec, M., J., ; Chismar, P., H., and X small-scale,joule-heated melting of savannah river plant wastex $* *$ glass*** .i.factors affecting large-scaleX ***vitrification*** testsX. Report, Dp-1535, 33 pp, 1980.

3454. Plodinec, M., J., ; Chismar, P., H., and $X$ design and operation of

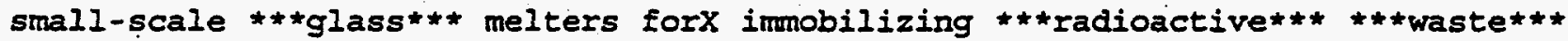
X. Conf.Rec. - Ias Annu.Meet. (Ieee), (1), 20-4X-4X, 1994.

3455. Plodinec, M., J., ; Soper, P., D., ; Bibler, N., E., ; Kessler, J., I.,

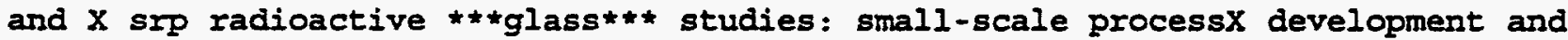
product performancex. Treat.handl.Radioact.Wastes, , Meeting Date 1982, 431-4:ress: Columbus, Ohio, 1994.

3456. Plodinec, M., J., ; Wicks, G., G., ; Bibler, N., E., and $X$ assessment of savannah river borosilicate $* * *$ glass $* * *$ in thex repository environmentx. Report, Dp-1629; Order No.De82014913, 98 pp, 1982.

3457. Plodinec, M., J., ; Wiley, J., R., and $X$ evaluation of $\star \star \star g l a s s * \star *$ as a matrix for solidifying savannahx river plant waste: properties of glasses containing lithium oxidex. Report, Dp-1498, 41 PP, 1979.

3458. Plodinec, M., J., ; Wiley, J., R., and $X$ viscosity and electrical conductivity of ***glass** melts as ax function of waste compositionX. Ceram.Nucl.Waste Manage., Proc. Int.Symp., Issue Conf-790420,X 210-12-12, 1994. 
3459. Plodinec, M., J., and X cesium $\star \star \star g l a s s * \star$ irradiation sourcesX. Report, Dpst-82-854, 11 pp, 1983.

3460. Plodinec, M., J., and $X$ characterization of savannah river plant waste glassX. Proc.Symp.Waste Manage., (1), 441-4X-4X, 1986.

3461. Plodinec, M., J., and $X$ advances in processing nuclear waste glassesX. Adv.Fusion Glass, Proc.Int.Conf., 1st, 9-9, 1988.

3462. Plodinec, M., J., and $X$ rheology of melts containing crystalline materialX. Report, Dpst-86-527; Order No.De89001409, 10 pp, 1988.

3463. Plodinec, M., J., and X development of $\star \star \star$ glass $\star \star \star$ compositions for immobilization ofx savannah river plant wastex. Sci.Basis Nucl. Waste Manage.;, MeetingX Date 1978, 31-5:lenum: New York,X, 1994.

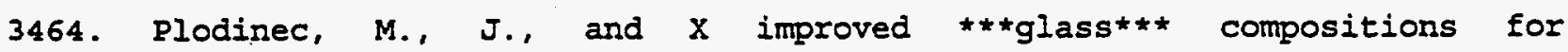
immobilization of srpX wasteX. Sci.Basis Nucl.Waste Manage., 2, 223-9X-9X, 1994.

3465. Plodinec, M. and JohnX rheology of glasses containing crystalline materialX. Adv. Ceram., 20, 117-24X-24X, 1986.

3466. Plodinec, M.J., Jantzen, C.F., and wicks, G. Thermodynamic approach to prediction of the stability of proposed radwaste glasses. Adv. Ceram. 8:491-495, 1985 .

3467. Plodinec, M.J. Evaluation of glass as a matrix for solidifying Savannah River Plant waste properties of glasses containing Lib2so /; Aiken, S.C. : [Springfield, Va. :Dept. of Energy, Savannah River Laboratory; for sale by the National Technical Information Service], 1979.

3468. Plodinec, M.J. Vitrification Chemistry and Nuclear Waste. (Unknown Journal!) , 1985.

3469. Plodinec, M.J. Development of a Glass Durability Test for the DWPF (Defense Waste Processing Facility). (Unknown Journal!) , 1986.

3470. Plodinec, M.J. Rheology of Melts Containing Crystalline Material. (Unknown Journal!) , 1986.

3471. Plodinec, M.J. Vitrification chemistry and nuclear waste. Journal of Non-Crystalline Solids 84:206-214, 1986.

3472. Plodinec, M.J. Effect of Glass Composition on Surface Tension, Viscosity, and Redox Equilibria of Initial DWPF (Defense Waste Processing Facility) Glass. (Unknown Journal!), 1986.

3473. Plodinec, M.J. DWPF Cold Testing Activities for Waste Form Compliance. (Unknown Jouraal!) , 1987.

3474. Plodinec, M.J. Requirements for WCP Initial Actions: II, Projections of Chemical Composition and Radionuclide Inventory of SRP (Savannah River Plant) Waste streams. (Unknown Journal!) , 1987. 
3475. Plodinec, M.J. Charter for Task Team: Development of DWPF Cold Feed Specifications. (Unknown Journal!), 1987.

3476. Plodinec, M.J. NNWSI (Nevada Nuclear Waste storage Investigation) Strategy for Repository Licensing. (Unknown Journal!) , 1987.

3477. Plodinec, M.J. Costs of Compliance. (Unknown Journal!) , 1987.

3478. Plodinec; M.J. Advances in Processing Nuclear Waste Glasses. (Unknown Journal!) , 1988 .

3479. Plodinec, M.J. Glass sampling program during DWPF Integrated Cold Runs. Revision 1. (Unknown Journal!) , 1990.

3480. Plodinec, M.J. Uniformity of material in the SME and MFT. (Unknown Journal!) , 1992.

3481. Plodinec, M.J. Waste acceptance and the DWPF Startup Test Program: Impacts of process changes. (Unknown Journal!), 1992.

3482. Plodinec, M.J. Method of calculation of heat generation rates for DWPF glass. Revision 2. (Unknown Journal!) , 1993.

3483. Plodinec, M.J. Projected radionuclide inventories of DWPF glass from current waste at time of production. Revision 1. (Unknown Journal!) , 1993.

3484. Plodinec, M.J. and Bibler, N.E. Workshop on Glass Development and Product Quality: Foreign Trip Report. (Unknown Journal!), 1988.

3485. Plodinec, M.J. and Kitchen, B.G. Establishing the acceptability of Savannah River site waste glass. (Unknown Jounnal!), 1990.

3486. Plodinec, M.J. and Marra, S.L. DWPF waste form compliance plan (Draft Revision). (Unknown Journal!) , 1991.

3487. Plodinec, M.J., Marra, S.I., Dempster, J., and Randklev, E.H. Identification of items and activities important to waste form acceptance by Westinghouse GoCo sites. (Unknown Journal!), 1993.

3488. Plodinec, M.J., Soper, P.D., Bibler, N.E., and. Kessler, J.I. SIP radioactive glass studies: small-scale process development andx product performance. In: <CI> Selected Papers presented at the American Nuclear Society TopicalX Meeting PUbl by Battelle Press, Columbus, OH and Richland, WA, USA andX Springer-Verlag, New York, NY, USA and Heidelberg, West Ger $p$ 431-434, Anonymous Columbus, OH and Richland, WA, USA:Battelle Press, 1983,p. 431-434.

3489. Plodinec, M.J., Stevens, W.R., Hacker, B.A., and Baxter, R.G. Toward Acceptance of DWPF (Defense Waste Processing Facility) Glass at a Federal Repository. (Unknown Journal!) , 1987.

3490. Plodinec, M.J., Wicks, G.G., and Bibler, N.E. Borosilicate glass as a matrix for the immobilization of savannah riverX plant waste. In: <CI> Papers presented at the National Waste Terminal storagex Information Meeting us 
Department of Energy, Technical Information Center, (TechnicalX Report) DOE/TIC $4621 \vee 2 . P u b l$ by US DOE, Technical Information Cent, $X$ Oak Ridge, TN, USA.Available from NTIS (DE82009593), Springfield, VA, $X$ USA $p$ 336-345, Anonymous Technical Information Cent, $X$ Oak Ridge, TN, USA:US DOE, 1984,p. 336-345.

3491. Ploetz, D.K. and Leonard, I.M. Supernatant Treatment System Design through Testing. (Unkrown Journal!), 1988.

3492. Ploetz, I. The effects of amorphous phase separation on some physical properties of Nab2sO-SiOb2s glasses, Alfred, NY:New York State 'College of Ceramics at Alfred University, 1975.

3493. Poirot, I. Investigation on Neptunium in a Borosilicate Glass. These (D. Univ.). (Unknown Journal!), 1988.

3494. Pole, G. and Taylox, N. Kinetics of solid-phase reactions of certain carbonates with mullite, silica, and alumina, Columbus, OH:Pennsylvania state College, 1935.

3495. Policke Analysis of mercury in simulated nuclear waste. (Unknown Journal!) : (6 p), 1991.

3496. Polyakov, A., S., ; Borisov, G., B., ; Khasanov, Z., ; Moiseenko, N., I., and $X$ development of electrodes for the high-level waste vitrificationX furnaceX. Proc.Symp. Waste Manage., (Waste Manage. 89, Vol. 1), 397-9X-9X, 1994.

3497. Pope, Chapman, and Harrison Improved feed compositions for slurry-fed ceramic melters. Adv. Ceram. , 1985.

3498. Pope, E.A. and Mackenzie, J. Sol-gel processing of neodymia-silica glass. Journal.of. the.American.Ceramic.Society. v. 76 (May '93):1325-1328, 1993.

3499. Pope, J., M., ; Barnes, S., and $X$ performance of the waste compliance plan at west valleyx. Proc.Symp.Waste Manage., (Waste Manage. 89, Vol. 1), $737-42 X-42 X, 1994$.

3500. Pope, J., M., ; Harrison, D., E., and $X$ nuclear waste immobilization in

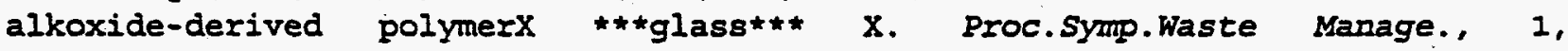
$237-48 x-48 x, 1994$.

3501. Pope, J.M., Chapman, C.C., and Harrison, D.E. Improved feed compositions for slurry-fed ceramic melters. In: <CI> Held during the 85th Annual Meeting of the American CeramicX Society Advances in Ceramics $v 8$. Publ by American Ceramic SOC Inc, Columbus, $X$ OH, USA $p$ 161-170,Anonymous Columbus, $X$ OH, USA:American Ceramic SOC Inc, 1984,p. 161-170.

3502. Pope, J.M. and Harrison, D.E. Advanced method for making vitreous waste forms. In: <CI> Proceedings of the 3rd International Symposium, held as part ofx the Annual Meeting of the Materials Research society Scientific Basis for Nuclear Waste Management $v 3$. Publ by PlenumX Press, New York,NY, USA and London, Engl p 93-100, Anonymous New York, NY. USA:PlenumX Press, 1981,p. 93-100. 
3503. Pope, J.M. and Harrison,.D.E. Alkoxide derived vitreous waste forms. In: Proceedings - The Electrochemical Society $v$ 82-1. Publ by Electrochemx SOC, Pennington, NJ, USA p 186-200, Anonymous Pennington, NJ, USA:Electrochemx SOC, 1982,p. $186-200$.

3504. Pope, J.M., Harrison, D.E., Spitsyn, V.I., Minaev, A.A., Barsova, I.I., Glazunov, P.Y., and Vetchkanov, V.N. Alkoxide derived amorphous solids as an alternate nuclear waste form study of the interaction of the components of imitator-glasses ofX glassified radioactive wastes with various surrounding rocks. In: Materials Research society Symposia Proceedings $v$.Publ byX North-Holland; New York, NY, USA and Amsterdam, Neth $p$ 133-139 Materials Research Society Symposia Proceedings $v 6$. Publ byX North-Holland, New York, NY, USA and Amsterdam, Neth p 9-14, Anonymous New York, NY, USA: 1982,p. 9-14.

3505. Pope, J.M., Leonard, I.M., and Mayer, E.J. Spectrum '86: Proceedings: Volume 1. (Unknown Journal!), 1987.

3506. Post waste management 190: working towards a cleaner environment: waste processing, transportation, storage and disposal, technical programs and public education. (Unknown Journal!) : $(813 \mathrm{p}), 1990$.

3507. Postles The dwpf product composition control system at savannah river: statistical process control algorithm, (Unknown Journal!) : (11 p), 1991.

3508. Postma, A., K., ; Chapman, C., C., ; Buelt, J., I., and X assessment of water/ ***glass*** interactions in wasteX $\star * \star g l a s s * *$ melter operationX. Report, Pnl-2622, 88 pp, 1980.

3509. Poulain, M. Magnesium in Fluoride Glasses. J.NON-CRYST.SOLIDS. 140:87-91, 1992 .

3510. Pouxviel, J.C. and Boilot, J.P. Gels from a double alkoxide: (BuO) //2-Al-O-Si-(OEt)//3. Journal.of.Materials.Science J Mater Sci $v 24 \mathrm{n} I$, 1989.

3511. Powell, J.A. Nuclear Waste Treatment Program. Annual Report for FY 1985. (Unknown Journal!), 1986.

3512. Powell, M.R. and Mahalingam, R. Continuous Solidification Stabilization Processing of Hazardous Wastes Through Polymeric Microencapsulation. IND. ENG. CHEM.RES. 31:543-549, 1992 .

3513. Powell, M.R. and Mahalingam, R. Leach Studies on Hazardous-Waste Monoliths from Continuous Solidification stabilization Processing. ENVIRON.SCI.TECHNOL. 26:507-511, 1992.

3514. Prevel, B., Jal, J.F., Dupuyphilon, J., and Soper, A.K. Collective Dynamical Aspect Related to Vitrification in Connection with Structural Characterization. PHYSICA.A. 201:312-317, 1993.

3515. Priebe, S., J., ; Piper, T., C., ; Berreth, J., R., and $X$ application of microwave energy to post-calcination treatment ofX high-level nuclear wastesX. Report, ICp-1183, 34 pp, 1979. 
3516. Primak, $w$. Notes on radiation effects in glasses pertinent to solid storage ofX radioactive wastesX. Ceram.Glass.Radioact.Waste.Forms. -770102, 1994 .

3517. Primak, $W$. and $X$ effects of ionization on $\star * \star$ silicate $* *$ glassesX. Report, AnI-82-7; Order No.De82012595, 43 pp, 1982.

3518. Primak, W.R.,F., P., and $X$ stored energy in a **tradioactive*** ***waste***X borosilicate ***glass*** : its frequency factor and kinetics andX its sourceX. Nucl.Sci.Eng., 86, 191-205X-205X, 1994.

3519. Primak, $W$. stress relaxation in unirradiated and in helium ion bombardedx **glass*** plates: dimensional stabilityX. J.Appl.Phys.; 55, 852-66X-66X, 1994.

3520. Primak, $w$. radiation-enhanced saline leaching of $\star \star \star s i l i c a t e * *$ glassesX. Nucl.Sci.Eng., 80, 689-99X-99X, 1994.

3521. Primak, $w$. radiation effects in $\star \star \star s i l i c a t e * *$ glasses pertinent to theirX application as a $\star * \star$ radioactive*** $\star * *$ waste $* \star$ - storageX - mediumX. Nucl.Technol., 60, 199-205X-205X, 1994.

3522. Prokhorov, B.N., Shalaev, V.V., Dymov, A.T., and Sokolov, M.I. Electric Melting Borosilicate Glasses in a Furnace with Plate XElectrodes. Glass.and.ceramics. 47, Numbers 1i-12:1-420, 1991.

3523. Prokin, E., S., ; Alekseev, O., A., ; Ananina, T., N., ; Ermolaev, E., $E .$, and $X$ the behavior of plutonium dioxide in phosphate glass meltx. Radiokhimiya, 31, 140-44X-44X, 1994.

3524. Prokin, E., S., ; Kuptsov, V., ; Ananina, T., N., ; Ermolaev, E., E., iX Kuznetsov, I., D., and $X$ effect of heat treatment and irradiation on the

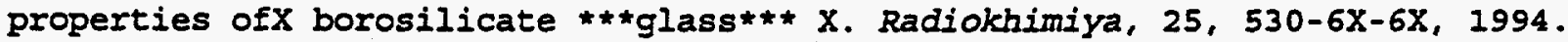

3525. Prokin, E., S., ; Kuptsov, V., ; Aranina, T., N., ; Ermolaev, E., E., and $X$ characteristics of borosilicate glass in simulation ofx .alpha.-particle radiation and thermal conditions for storage ofX high-level vitrified wastesx. Radiokhimiya, 30, 694-8X-8X, 1994.

3526. Pulsipher High-level waste qualification: managing uncertainty. (Unknown Journal!) : (8 p), 1993.

3527. Pulsipher, B., A., ; Kuhn, W., L., and X statistical process control: an approach to quality assurance inx the production of vitrified nuclear wastex. Proc.Symp.Waste Manage., (Waste Manage. '87, Vol. 2), 483-8X-8X, 1994.

3528. Pusch, R. Use of Bentonite for Isolation of Radioactive-Waste Products. CLAY.MINER. 27:353-361, 1992 .

3529. Puyou Vitrification of fission product solutions: investigation of the effects of noble metals on the fabrication and properties of r7t7 glass. (Unknowr Journal!) : (4 p), 1993. 
3530. Puyou, M., ; Jacquet Francillon, N., ; Moncouyoux, J., P., ; Sombret, C., ;X Teulon, F., and $X$ vitrification of fission product solutions: investigation of thex effects of noble metals on the fabrication and properties of $r 7 t 7 x$ glassX. Proc.Int.Conf.Technol.Expo.Future Nucl.Syst.: Emerging FuelX Cycles Waste Disposal Options, Volume 2, 965-8:ark, Ill, 1994.

3531. Pye, L., D., and $X$ physical and thermal properties of simulated nuclear waste glassesX and their meltsX. Report; Dpst-85-397; Order No.De86015863, 60 pp, 1986 .

3532. Pye, L.D. Semiconductivity of some chalcogenide glasses, Alfred, NY:New York State College of Ceramics at Alfred University, 1968.

3533. Pye, I.D. Physical and Thermal Properties of simulated Nuclear Waste Glasses and Their Melts. Final Report. (Unknown Journal!) , 1985.

3534. Pye, L.D., Locker, R., and Plodinec, M.J. Volume-temperature relationships in simulated glass forming nuclearX waste melts. In: Materials Science Research $v$ 15. Publ by Plenum Press, New York, NY,X USA and London, Eng $I$ $p$ 627-637, Anonymous New York, NY, X USA:Plenum Press, 1983,p. 627-637.

3535. Qi, G., Spear, K.E., and Pantano, C.G. Carbon-layer formation at silicon-carbide-glass interfaces. Materials.science g. Materials Science \&, 1993.

3536. Quigley, M., S., ; Kreid, D., K., and X physical modeling of joule-heated

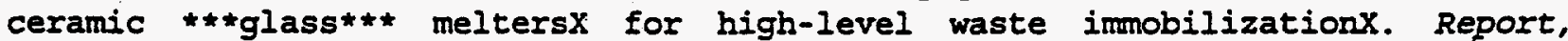
Pnl-2809, 159 pp, 1979.

3537. R.Conradt, H.Roggendorf, and H.Scholze BT - Leaching Mechanisms CT - A Contribution to the Modelling of the Corrosion Process fOr HIW Glasses ED Carol M.Jantzen ED - John A.Stone ED - Rodney C.Ewing Anonymous 1985,p. 155-162.

3538. Radu, D. Structural modelling of silicate glasses. Glass.Technology. Glass Technol $\vee 33 \mathrm{n}, 1992$.

3539. Radu, D. and Dumitrescu, O. Temperature distribution in a glass melt correlated with glass tank depth. Glass.Technology. Glass Technol v $33 \mathrm{n}, 1992$.

3540. Rahman, M:H., Dwivedi, B.P., Kumar, Y., and Khanna, B.N. Inelastic Light-Scattering in Strontium Borate Glasses in the System Xsro. $(1-X) B 2 O 3$ and (SrCl2)Y. (Xsro. (1-Y-X) B2O3) 1-Y. PRAMANA-J.PHYS. 39:597-614, 1992.

3541. Rai, D., Felmy, A.R., Fulton, R.W., and Ryan, J.I. Aqueous Chemistry of Nd in Borosilicate-Glass Water-Systems. RADIOCHIM.ACTA 58-9:9-16, 1992.

3542. Rai, D., Schramke, J.A., Moore, D.A., and McVay, G.I. Americium concentrations in solutions contacting americium-doped glass.x. Nuclear Technology $75: 350-355$, 1986 . 
3543. Rai, D.S.,Richard G., ; McVay, G.I., and $X$ neptunium concentrations in solutions contacting actinide-dopedx $\star \star \star$ glass $\star \star * X$. Nucl.Technol., 58, $69-76 \mathrm{X}-76 \mathrm{X}, 1994$.

3544. Rainisch, R. Alternative design concept for the second Glass Waste Storage Building. (Unknown Journal!), 1992.

3545. Raj, K. and Samuel, M.T. Modified pot glass process for vitrification of high level radioactivex liquid waste - process engineering aspects. In: $v 2$. Publ by Indian Ceramic Soc, Calcutta, India p 399-407, Anonymous Calcutta, India p 399-407: Indian Ceramic Soc, 1986,p. 399-4077.

3546. Rajan, J.B., Kumar, R., and vissers, D.R. Integrated Oxidation-Glass Formation Process for Waste Sodium Disposal. (Unknown Journal!), 1987.

3547. Rajan, J.B., Kumar, R., and Vissers, D.R. Process for direct conversion of reactive metals to glass. Patent Application. (Unknown Journal!) , 1988.

3548. Rajan, J.B., Kumar, R., and Vissers, D.R. direct conversion of reactive metals to glassX. U.S., 5 pp, 1994.

3549. Rajan, J.B., ; Kumar, R.V.,Donald R., and $x$ improved treatment/disposal of reactive metalsX. Nucl.Technol., 83, 205-11X-11X, 1994.

3550. Rajaokarivony-Andriambololona, Z., Thomassin, J.H., Baillif, P., Touray, J.C., Hsu, J., Speyer, R., Conde, C.F., Miranda, H., Conde, A., and Marquez, R. Experimental hydration of two synthetic glassy blast furnace slags in water and alkaline solutions (NaOH and $\mathrm{KOH} 0.1 \mathrm{~N}$ ) at 40 degree c. Structure, composition and origin of the hydrated layer comparison of the effects of titania and tantalum oxide nucleating agents on the crystallization of $\mathrm{Li} / / 20$ center dot $\mathrm{Al} / / 20 / / 3$ center dot $6 \mathrm{SiO} / / 2$ glasses Non-isothermal crystallization and isothermal transformation kinetics on the $\mathrm{Ni} / / 6 / / 8 / / . / / 5 \mathrm{Cr} / / 1 / / 4 / / .1 / 5 \mathrm{P} / / 1 / 17$. Journal. of.Materials.Science

Journal.of.the.American.Ceramic.Society.Journal.of.Materials.Science J Mater Sci v 24 n 1, 1989.

3551. Rajaram; M. and Day, D. Nitrogen dissolution in alkali-barium-metaphosphate melts. Journal.of.Materials.Science J Mater Sci $v$ 24 n 2, 1989.

3552. Ralkova, J. and Pribyl, J. Synthetic frits for the fixation of highly radioactive wastex. Silikaty. $-54 \mathrm{X}, 1994$.

3553. Ralkova, J. and Pribyl, J. Synthetic frits for the fixation of high-level radioactive wastes.X $i \mathrm{ix}$. Silikaty. $-8 \mathrm{X}, 1994$.

3554. Ralkova, J. and Saidl, J. Solidification of high-level radioactive wastes.iii.diffusionx and elution rates of radionuclides incorporated in basaltsx. Kernenergie. $-4 \mathrm{X}, 1994$.

3555. Ram, S., Ram, K., and Shukla, B.S. Optical-Absorption and EPR Studies of Borate Glasses with Pbcro4 and Pb2Cro5 Microcrystals. J.MATER.SCI. 27:511-519, 1992. 
3556. Raman Hot isostatically-pressed aluminosilicate glass-ceramic with natural crystalline analogues for immobilizing the calcined high-level nuclear waste at the idaho chemical processing plant. (Unknown Journal!) : (134 p), 1993.

3557. Ramirez-Dorantes, H. Opacity-microstructure relationships in amorphously phase separated glasses, Alfred, NY:New York state College of Ceramics at Alfred University, 1979.

3558. Ramsey production and remediation of low-sludge, simulated purex waste glasses, 1: effects of sludge oxide additions on melter operation. (Unknown Journal!) : (17 p), 1915 .

3559. Ramsey, Taylor, T., and Jantzen, C. Predictive modeling of leachate ph for simulated high-level waste glass. Ceram.Trans. , 1991.

3560. Ramsey, W., G., ; Jantzen, C., M.,; ; Bickford, D., F., and X redox analyses of srs melter feed slurry; interactions betweenX nitrate, formate and phenol based dopantsX. Ceram.Trans., 23, 259-66X-66X, 1994.

3561. Ramsey, W., G., ; Taylor, T., D., ; Jantzen, C., M., and X predictive modeling of leachate $\mathrm{ph}$ for simulated high-level wastex glassX. Ceram.Trans., $23,105-14 \mathrm{X}-14 \mathrm{X}, 1994$.

3562. Ramsey, W.. G., ; Taylor, T., D., ; Jantzen, C., M., and X durability study of sodium borosilicate glasses leached in tuff $j-13 x$ groundwaterx. Ceram. Trans., 23, 685-93X-93X, 1994.

3563. Ramsey, W.G., Taylor, T.D., and Jantzen, C.M. Durability study of sodium borosilicate glasses leached in tuff J-13 groundwater. (Unknown Journal!), 1990.

3564. Ramsey, . Durability study of simulated radioactive waste glass in a brine environment /, 1989.

3565. Ramthun, $H$. and $X$ radiant energy dissipation during final storage of high-levelX *t*radioactive*t* *t*waste*** in rock saltX. Report, Ptb-Fmrb-88, $34 \mathrm{pp}, 1982$.

3566. Randall, M., Simmons, J., and El-Bayoumi, O. Primary and secondary phase separation in $\mathrm{CdF} / / 2-L i F-A] F / / 3 \quad-\mathrm{PbF} / / 2$ glasses. Journal.of.the.American.Ceramic.Society. J Am Ceram Soc v 71, 1988.

3567. Randall, P. An investigation into the influence of suspended glass particles on bubble diameter, gas hold up, and interfacial area in an agitated tank, 1985.

3568. Raskin and Kelley Microstructures and leachability of vitrifiedx radioactive wastes X. NUCL. TECFNOL. $-80 \mathrm{X}, 1994$.

3569. Rankin, W., Duncan; Wicks, G.G., and $X$ chemical durability of savannah river plant waste $\star \star \star$ glass $\star \star \star$ asX a function of waste loadingX. J.Am.Ceram.SOC., 66, 417-20X-20X, 1994. 
3570. Rankin, W., N., ; Whitkop, P., G., and $x$ bonding of radioactive contamination.iii.auger electronx spectroscopic investigationx. Report, Dpst-83-638; Order No.De84005838, 16 pp, 1984 .

3571. Rankin, W., N., and $X$ decontamination processes for waste ***glass*** canistersX. Report, Dp-1574; Order No.De82010814, 30 pp, 1982.

3572. Rankin, $W_{.}, N_{.}$, and $X$ bonding of radioactive contamination. iv. effect of surface finishx. Report, Dpst-83-765; Order No.De84005837, 11 pp, 1984 .

3573. Rankin, W. and Nevynx decontamination processes for waste $\star \star \star g l a s s * \star *$ canistersX. Nucl.Technol., 59, 314-20X-20X, 1994.

3574. Rankin, W.D. and Wicks, G. Chemical durability of Savannah River Plant waste glass as a function of waste loading. J.Am.Ceram.SoC. $66[\mathrm{~N}$ 6]:417-420, 1983.

3575. Rankin, W.N. Corrosion of melter materials. In: Proceedings - The Electrochemical Society $v$ 82-1. Publ by Electrochemx Soc,pennington, NJ, USA $p$ 212-219, Anonymous Pennington, NJ, USA:ElectrochemX Soc, 1982,p. 212-219.

3576. Rao, A. The fracture mechanics of lithium disilicate glass and glass-ceramics, 1977.

3577. Rao, P. Thermal expansion of some glasses and crystalline-phases in the ternary system Nab2so-MgO-SiOb2s, Alfred, NY:New York state College of Ceramics at Alfred University, 1968.

3578. Rastogi, R., C., ; Jahagirdar, P., B., ; Vaswari, G., A., ; Rajan, N., S., and $X$ sunderX corrosion evaluation of high-temperature alloys in moltenX **\#glass*** using neutron activation analysis methodx. Proc.Nucl.Chem.Radiochem.Symp., Meeting Date 1980, 561-5-5, 1994.

3579. Rawal, B. Electrical properties and structure of BaO-Bb2sOb3s-SiOb2s glass containing titanium ions, Troy, N.Y..Rensselaer Polytechnic Institute, University Microfilms International, 1977.

3580. Ray, C. and Day, D. Determining the Nucleation Rate Curve for Lithium Disilicate XGlass by Differential Thermal Analysis. Journal. of.the.American.Ceramic.Society. 73, Number 2:439-442; 1990.

3581. Ready, Cooley, and EditorsX Ceramic and glass radioactive wastex forms (conf-770102)X.'(Ntis:.Springfield. , 1994 .

3582. Reeve, A. Control systems design for nuclear reprocessing. Control and. Instrumentation $19: 133-134,1987$.

3583. Reeve, K.D., Levins, D.M., Ramm, E.J., and woolfrey, J.L. Synroc for containment of high-level nuclear waste. In: Transactions of the American Nuclear Society $v 41$ 1982. Publ by ANS,LaX Grange Park,III, USA $P$ 278-279, Anonymous LaX Grange Park, Ill, USA:ANS, 1982,p. 278-279.

3584. Reeve, K.D. and Walker, D.G. Australian atomic energy commission's synroc programme. In: Uranium and Nuclear Energy, Proceedings of the International 
Symposiumx held by the Uranium Institute 8th.Publ by Uranium Inst, London, Engl pX 184-192, Aronymous London, Engl pX 184-192:Uranium Inst, 1983,-1922.

3585. Regenbrecht, A. A rapid quantitative determination of the ferric and ferrous iron in glass, Alfred, N.Y.New York State College of Ceramics at Alfred University, 1948 .

3586. Regnier, P., Serruys, Y., and Zemskoff, A. Electric field stimulated sodium depletion of glass and relatedx penetration of environmental atomic species. Physics and Chemistry of Glasses 27:185-189, 1986.

3587. Rego, J. and X radiochemical separation of neptunium and plutonium from leaching ofx reactor waste $\star * \star g l a s s * \star *$ in brine solutionsx. Radioelem.Anal.: Prog.Probl., Proc.Conf.Anal.Chem.EnergyX Technol., 23rd, Meeting Date 1-62, 2994.

3588. Regulla, D.F. Untersuchungen zur Lumineszenz von Phosphatglasern im Hinblick $X$ auf ihre Verwendung als Festkorperdosimeter, Munchen:Gesellschaft fur Strahlen- und Umweltforschung, 1977.

3589. Reimann Summary of inel research on the iron-enriched basalt waste form. (Unknown Journal!) : (59 p), 1992.

3590. Reimann, G.A., Grandy, J.D., Eddy, T.L., and Anderson, G.I. Summary of INEL research on the iron-enriched basalt waste form. (Unknown Journal!), 1992.

3591. Reimann, G.A. and Kong, P.C. Improving iron-enriched basalt with additions of Zro(sub 2) and TiO(sub 2). (Unknown Journal!), 1993.

3592. Reimus, M., A., H., ; Piepel, G., F., ; Mellinger, G., B., ; Bunnell, L., $R .$, and $X$ west valley glass product qualification durability studies,fyX 1987-1988: effects of composition,redox state,thermal history, $x$ and groundwaterX. Report, Pnl-6723; Order No.De89003724, 130 Pp, 1989.

3593. Reimus, M., A., H., ; Piepel, G., F., ; Mellinger, G., B., and X west valley glass product qualification durability studies: effectsX of composition, redox state, heat treatment, and groundwaterx. Proc.Symp.Waste Manage., (Waste Manage.'88, Vol. 2), 819-30X-30X, 1994.

3594. Reimus, M.A.H., Piepel, G.F., Mellinger, G.B., and Bunnell, I.R. West. Valley Glass Product Qualification Durability Studies, FY 1987-1988: Effects of Composition, Redox State, Thermal History, and Groundwater. (Unknown Journal!) . 1988 .

3595. Reimus, P., $\mathrm{W} .$, and $\mathrm{X}$ a computer program for predicting the composition of nuclear wastex glass produced by a slurry-fed ceramic melterX. Report, PnI-6244; Order No.De87013296, 129 pp, 1987.

3596. Rekhson, $s$. Measuring physical properties of glass in the glass-transition region. American.Ceramic.Society.Bulletin. Am Ceram Soc Bull v. 1989. 
3597. Renault, M. Investigation of the high temperature viscosities of glasses in the system PbO-Kb2sO-SiOb2s, Alfred, N.Y.New York State College of Ceramics at Alfred University, 1963.

3598. Richard Haaker, Gunter Malow, and Peter Offermann BT - Leaching Mechanisms CT - The Effect of Phase Formation on Glass Leaching ED - Carol M.Jantzen ED - John A.Stone ED - Rodney C.Ewing Anonymous 1985,p. 121-134.

3599. Richards, $R$. Rapid melting and refining system. American.Ceramic.Society.Bulletin. An Ceram Soc Bull v, 1988.

3600. Richardson, I., Brough, A., Brydson, R., Groves, G., and Dobson, C. Location of aluminium in substituted calcium silicate hydrate (C-S-H) gels as determined by $\star \star 2 \star \star 9 S i$ and $\star \star 2 \star \star 7 A I$ NMR and EELS. Journal of. the.American. Ceramic. Society. Journal of. the. American. Ceramic. Society - v 76 n 9 Sep 1993.2285-2288, 1993.

3601. Richet, P., Robie, R.A., and Hemingway, B.S. Entropy and Structure of Silicate-Glasses and Melts. GEOCHIM.COSMOCFIM.ACTA 57:2751-2766, 1993.

3602. Richter, H. and Offermann, P. Characterization of mechanical properties of nuclear waste glasses. In: Materials Research Society Symposia Proceedings VII.Publ byX North-Holland, New York, $N Y$, USA and Amsterdam, Neth $p$ 229-238, Anonymous New York, NY, USA: 1982,p. 229-238.

3603. Riebling, E., F., and $X$ instrument for determining viscosities and electrical resistivitiesX of molten ***glass** candidates for immobilizing hanfordx nuclear defense wastesx. Report, Rho-Sa-50, 40 PP, 1980.

3604. Rincon Lopaz, J.M. Glasses and Glass-Ceramics for Nuclear Waste Management. (Unknown Journal!) , 1987.

3605. Ringler, $E$. The effect of various copper compounds and stannous oxide on the $X$ absorption characteristics of a phosphate based glass, Alfred, NY:New York State College of Ceramics at Alfred University, 1969.

3606. Ringwood, Kesson, Ware, Hibberson, and Major, $X$ Immobilization of high level nuclear reactor wastes in synrocX. Nature (London). -23X, 1994.

3607. Ringwood, A., E., ; Willis, P., and $X$ stress corrosion in a borosilicate

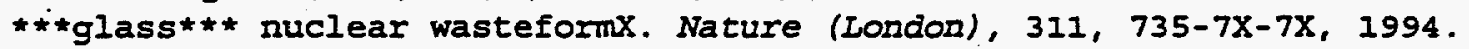

3608. Risbud, S., Kirkpatrick, R.J., and Taglialavore, A. Solid-state NMR evidence of 4-, 5-, and 6-fold aluminum site in roller-quenched SiO2-Al203 glasses. Journal.of.the.American.Ceramic.Society. v. 70 (Jan. 187):C10-C12, 1987.

3609. Risoluti, P. and Cao, S. ***vitrifying*** active ***adioactive** ***waste*t* X. Brit. Uk Pat.Appl., 6 pp, 1994.

3610. Risoluti, P., ; Canonico, A., ; Dello Vicario, B., ; Mataloni, P., and $X$ two years' experience with an inactive vitrification pilot plant inX italyx. Radioact.Waste Manage., Proc.Int.Conf., Meeting Date 1983, volumex 2, 3-403, 1994. 
3611. Ritter Immobilization of simulated high-level radioactive waste in borosilicate glass: pilot scale demonstrations. (Unknown Journal!) : (14 p), 1991.

3612. Ritter, J., Hutson, N., and Zamecnik, J. Immobilization of simulated high-level radioactive waste irborosilicate glass: pilot-scale demonstrations. Ceram.Trans. , 1991.

3613. Ritter, J., ; Hutson, N., ; zamecnik, J., ; Carter, J., and $X$

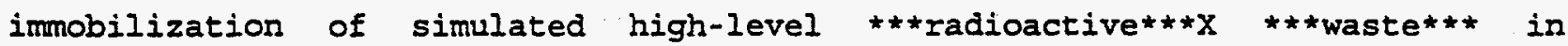
borosilicate $* *$ glass*** : pilot scalex demonstrationsx. Ceram.Trans., 23, 295-307X-307X, 1994.

3614. Ritter, J., A., ; Zamecrik, J., R., ; Hutson, N., D., ; Smith, M., E., ;

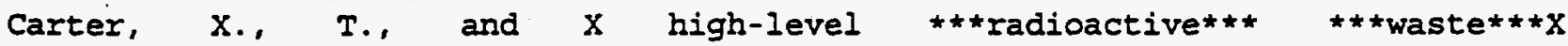
$* \star *$ vitrification*** technology and its applicability to industrialx waste sludgesX. Water Sci.Technol., 25, 269-71X-71X, 1994.

3615. Ritter, J.A., Zamecnik, J.R., and Hsu, C.I.W. Hydrogen Generation During Treatment of Simulated High-Level Radioactive-Waste with Formic-Acid. NUCL. TECFINOL. $104: 330-342,1993$.

3616. Ritter, J.A., Zamecnik, J.R., Hutson, N.D., Smith, M.E., and Carter, J.T. High-level radioactive waste vitrification technology and itsX applicability to industrial waste siudges. <CT> Proceedings of the IAWPRC 2nd International Conference on Wastex Management in Chemical and Petrochenical Industries Toxics ManagementX <CL> New Orleans, LA, USA <CD> 1991 Jun 17-20 Water Science and Technology $25: 269-271,1992$.

3617. Ritter, W., ; Maerk, T., D., ; White, W., B., and $x$ radiation damage in **tglass*** and apatite and surface analysisx of leached high-level nuclear

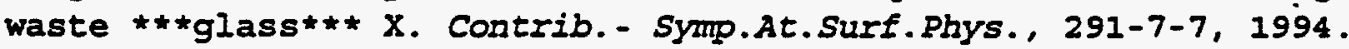

3618. Ritter, W., ; Maerk, T., D., and $X$ radiation damage and its annealing in apatiteX. Nucl. Instrum.Methods Phys.Res., Sect.B, B14(3), 314-22X-22X, 1994.

3619. Robbins, J. Repeated leaching of a simulated borosilicate waste glass /, Harwell, Eng. :Institute of Geological Sciences, 1982.

3620. Roberts, Jenks, and Bopp Radiation effects in solidified high-level waste. part $i$. storedX energyX. Report. , 1976.

3621. Robinson, C., H., ; Fry, C., J., and $X$ steam explosions caused by the contact of molten $\star \star \star g l a s s * \star *$ andx waterX. Ber.Kernforschungsanlage Juelich, Juel-conf-42 (Vol. I) , X Proc:roc-Level Liquid Wastex, 1994.

3622. Robinson, K., S., ; Fowler, G., and $X$ design of harwell joule ceramic melterX. Radioact. Waste Manage.Nucl. Fuel Cycle, 3, 29-45X-45X, 1994.

3623. Robson, $M$. and Davies, $M$. Influence of iron and chromiun on crystallization of some CaO-AI2O3-MgO-SiO2 glasses, London:BISRA, 1969. 
3624. Rocherulle, J., Guyader, J., Verdier, P., and Laurent, Y. Ii-Si-Al-O-N and Li-Si-O-N oxynitride glasses study and characterization. Journal.of.Materials.Science J Mater Sci v 24 n 1, 1989.

3625. Roggendorf, H., ; Conradt, R, , - Schmidt, H., and X characterization of the surface of the hlw glass $r 7 t 7$ reacted inX salt brinesX. Mater.Res.SOC.Symp.Proc., 127, 89-96X-96X, 1994.

3626. Rogozin,. Y.M., Smirnova, E.A., Savonenkov, V.G., Krivokhatskii, A.S., Avdeev, V.A., and Sagaidachenko, E.Y. Leaching of Radionuclides from Technogenic New Formations Extracted from the Basement of the 4 th Block of the Chernobyl Npp .2. Leaching from Pumice-Glass and Metal Granules. RADIOCHEMISTRY-ENGL.TR. 35:124-127, 1993.

3627. Rohr, U., Meckel, L., and Ortner, H.M. Ultratrace Analysis of Uranium and Thorium in Glass .1. ICP-MS, Classical Photometry and Chelate-GC. FRESENIUS.J.ANAL. CHEM. 348:356-363, 1994 .

3628. Romanov, V.P. and Ulyanov, S.V. Bulk Viscosity in Relaxing Media. PHYSICA.A. 201:527-542, 1993.

3629. Ropp, R.C. molecular glasses for nuclear waste encapsulationX. U.S., 10 pp-in-part of U, 1994.

3630. Ross Sintering of radioactive wastes into ax glass matrixx. Report. :Avail NTIS (U S Sale, 1975.

3631. Ross Properties and characteristics of high-level waste glassX. Report. , 1978.

3632. Ross Development of glass formulations containing high-level nuclearX wastesx. Report. , 1978.

3633. Ross Properties and characteristics of high-level waste glassX. Ceram.Glass.Radioact. Waste.Forms. -770102, 1994.

3634. Ross and Mendel Development of glasses for high-level waste solidificationx. Report. , 1977.

3635. Ross and Mendel glass waste forms for radioactive wastex containmentX. Report. , 1979.

3636. Ross, W., A., ; Turcotte, R., P., ; Mendel, J., E., ; Rusin, J., M., and $X$ a comparison of $\star * * g l a s s * \star *$ and crystalline waste materialsx. Ceram.Nucl. Waste Manage., Proc.Int.Symp., Issue Conf-790420,X 52-6-6, 1994.

3637. Ross, W. Development of glass formulations containing high-level nuclear wastes / by Wayne A. Ross, Richland, Wash. : [Springfield, Va. :Dept. of Energy, Pacific Northwest Laboratory ; for sale by the National Technical Information Service], 1978.

3638. Ross, W. Solidifying high-level nuclear wastex. Us. , 1994: 
3639. Ross, W., Westsik, J., and Roberts, F. Comparative leach testing of alternative transuranic waste forms. American.Ceramic.Society.Bulletin. v. 62 (Sept. '83):1026-1029, 1983 .

3640. Rosselet, $A$. and $X$ creep behavior of unalloyed steel materials for a permanent storagex container: evaluaton of the literature datax. Tech.Ber.Nagra, 84-35, $27 \mathrm{pp}-35,27 \mathrm{pp}, 1994$.

3641. Roth, G.. and X integrated off-gas treatment facilities in vitrification plantsX. Radioact. Waste Manage.Handb., 2, 491-523X-523X, 1994.

3642. Rothman, M. Properties of high temperature Ni-Cr-W-Mo alloy related to its applicability. Industrial.Heating. Ind Heat $v 55 \mathrm{n} 12 \mathrm{D}, 1988$.

3643. Routbort, J. and Matzke, H. Effect of composition and radiation on the fracture of a nuclear wasteglass. Mater.Sci.Eng. , 1983.

3644. Routbort, J., L., ; Matzke, H., and $X$ the effect of composition and radiation on the fracture of a nuclearX waste $* *$ glass** $X$. Mater.Sci.Eng., $58,229-37 X-37 X, 1994$.

3645. Routbort, J., I., ; Offermann, P., ; Matzke, H., and X mechanical stability of a curium-doped celsian $\star \star \star g l a s s * \star \star X$-ceramicX. Mater.Res.Soc.Symp.Proc., 15, X 415-22X-22X, 1994.

3646. Routt, K., R., and $X$ modeling principles applied to the simulation of a joule-heatedX ***glass*** melterX. Report, Dp-1540, 47 pp, 1980.

3647. Routt, K.R. Physical modeling of a glass melter designed for vitrification ofX defense waste. In: <CI> Held during the 85th Annual Meeting of the American CeramicX Society Advances in Ceramics $\checkmark 8$. Publ by American Ceramic SOC InC, Columbus, $X$ OH,USA $p$ 536-549,Anonymous Columbus, $X$ OH, USA:American Ceramic SOC Inc, 1984,p. 536-549.

3648. Routt, K.R. and Crow, K.R. Theoretical predictions for glass flow into an evacuated canister. In: <CI> Held during the 85th Annual Meeting of the American CeramicX Society Advances in Ceramics $v$ 8. Publ by American Ceramic SOC Inc, Columbus, $X$ OH, USA $p$ 567-579, Anonymous Columbus, $X$ OH, USA:American Ceramic Soc Inc, 1984;p. 567-579.

3649. Routt, K.R., ; Cosper, M.B., ; Iverson, D.C., and $X$ theoretical predictions of melting rates in a powder-fedX ***glass*** melterX. Glastech.Ber., 56, 48-53X-53X, 1994.

3650. Routt, K.R. and $X$ theoretical predictions for continuous slurry feeding

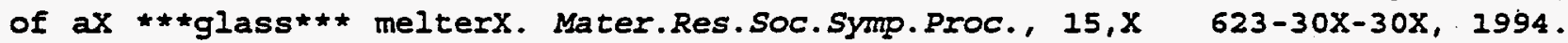

3651. Rouxel, T., Besson, J., and Goursat, P. Improvement of creep resistance of sintered silicon nitride by hot isostatic exudation of intergranular glass. Journal.of.the.American.Ceramic.Society. Journal of the Ameri, 1993.

3652. Rowan, K. Differential thermal analysis studies of soda-line-silica glass batches with sodium sulfate additions, 1982 . 
3653. Roy, A., Eaton, H.C., Cartledge, F.K., and Tittlebaum, M.E. Solidification Stabilization of Hazardous-Waste - Evidence of Physical Encapsulation. ENVIRON.SCI.TECHNOL. 26:1349-1353, 1992.

3654. Roy, B. and Navrotsky, A. Thermochemistry of charge-coupled substitutions in silicate glasses: the systems $\mathrm{MI} / \mathrm{nn}+\mathrm{AlO2}-\mathrm{SiO2}(\mathrm{M}=\mathrm{Li}, \mathrm{Na}, \mathrm{K}, \mathrm{Rb}, \mathrm{Cs}, \mathrm{Mg}$, $\mathrm{Ca}, \mathrm{Sr}, \mathrm{Ba}, \mathrm{Pb}$ ). Joumal.of.the.American.Ceramic.Society. v. 67 (Sept. 184) :606-610, 1984 .

3655. Roy, P. Extinction coefficients of nickel in soda-lime-silica and potash-lime-silica glasses, Alfred, N.Y.New York State College of Ceramics at Alfred University, 1952.

3656. Roy, R. New Low Temperature (Hydroxylated) Materials: A Progress Report, December 1986. (Unknown Journal!) , 1986.

3657. Roy, R. and Nilsson, L.B. Role of ceramics in different aspects of rad-waste disposal Condensed version of the swedish kbs concepts regarding final storagex of high level radioactive waste and spent fuel. In: Science of Ceramics $v$ 1I. Publ by Swed Ceram Soc. p 267-282 V 2. Publ by Pergamon Press, Oxford, Engl and New York, NY, USA $p X$ 955-961, Anonymous Oxford, Engl and New York, NY, USA:Pergamon Press, 1981,p. 267-961.

3658. Roy, S. and Chakravorty, D. Resistivity of Ultrafine Iron Particles in a Glass Matrix.

Japanese.journal of.applied.physics.Part.1,.Regular.papers.\&.short.notes. 32, Number $8: 1-3515,1993$.

3659. Royle, M., Sharma, M., Feller, S., Mackenzie, J., and Nijhawan, $s$. Densities and Structural Models Resulting from Extremely Modified Cesium and -Rubidium Borate Glasses. PHYS. CHEM. GLASSES. 34:149-152, 1993.

3660. Ruby, S., I., and $X$ possible applications of the moessbauer technique in wasteX management studiesX. Nucl.Technol., 51, 178-81X-81X, 1994.

3661. Rudd, G.I., Garofalini, S.H., Hensley, D.A., and Mate, C.M. Atomic-Force Microscopy and $X$-Ray Photoelectron-Spectroscopy Investigation of the Onset of Reactions on Alkali Silicate Glass Surfaces. J.AMER.CERAM.SOC. 76:2555-2560, 1993.

3662. Rudolph, Saidl, Dronik, Guber, Hild, Krause, and X, M. Lab-scale research and development work on fission productX solidification by vitrification and thermite processx. Symp.Manage.Radioactive.Wastes.Fuel.Reprocess. -81, 1972.

3663. Rudolph, T., Pannhorst, W., and Petzow, G. Determination of Activation-Energies for the Crystallization of a Cordierite-Type Glass. J.NON-CRYST. SOLIDS. $155: 273-281,1993$.

3664. Rueter, K. Control loop and unit operational realtime modeling on a Distributed Control system. (Unknown Journal!), 1990.

3665. Ruggles, J.S., Cook, R.G., and Cole, R. Microgravity bubble migration in rotating flows. Journal.of.Spacecraft.and.Rockets. J Spacecr. Rockets v, 1990. 
3666. Ruppe, H., O., ; Hayn, D., and $X$ deposition of highly active nuclear wastesX. Report, Tum-Lrt-Tb-81/3; Order No.N82-29153, 36 pp, 1982.

3667. Rusin, J., M., ; Gray, W., J., ; Wald, J., W., and X multibarrier waste forms. part $i$. characterization and evaluationx. Report, Pnl-2668-2, 66 pp, 1979.

3668. Rusin, J., M., ; Lokken, R., O., ; Wald, J., W., and X characterization and evaluation of multibarrier nuclear waste formsx. Ceram.Nucl. Waste Manage., Proc.Int.Symp., Issue Conf-790420,X 66-72-72, 1994.

3669. Rusin, J., M., ; Wald, J., W., ; Lokken, R., O., and X alternative waste forms -- a comparative studyX. Sci.Basis Nucl.Waste Manage., 2, 255-64X-64X, 1994.

3670. Rusin, J., M., and $X$ a review of $* *$ glass $* *$ ceramic waste formsX. Alternate Nucl.Waste Forms Interact.Geol.Media, Proc.WorkshopX Summ.Adv.Act.Formulating Requir.Future, Meeting Date 1980, IssueX CONF--8005107, 331-54, 1994.

3671. Rusin, J.M., Lokken, R.O., May, R.P., and Wald, J.W. Crystallization behavior of nuclear waste forms. In: Proceedings - The Electrochemical Society $\checkmark$ 82-1. Publ by ElectrochemX SOC, Pennington, NJ, USA $p$ 133-143, Anonymous Pennington, NJ, USA:ElectrochemX Soc, 1982,p. 133-143.

3672. Russell, E.W., Clarke, W., Domian, H.A., and Madson, A.A. Cost estimate of high-level radioactive waste containers for the Yucca Mountain site Characterization Project. (Unknown Journal!), 1991.

3673. Russo, D.O., Messi de Bernasconi, N., and Audero, M.A. High-Ievel Radioactive Waste Fixation in Sintered Vitreous Matrix. (Unknown Journal!), 1987.

3674. Russo, D.O., Messi de Bernasconi, N., and Audero, M.A. Immobilization of High-Level Wastes into Sintered Glass: 1. Hot Pressing Process. (Unknown Journal!) , 1987.

3675. Ryan, M. and Blevins, J.K. The viscosity of synthetic and natural silicate melts and glasses at high temperatures and 1 bar (10p5s Pascals) pressure and at higher pressures, Washington: Denver, CO:U.S. G.P.O. ; For sale by the Books and Open-File Reports Section, U.S. Geological Survey, 1987.

3676. Rykken, I.E., Wilson, J.A., and Hardt, T.L. Analytical characterization of west valley high-level waste sludge. In: <CI> Volume 2. Waste Policies and Programs, Low-Level Waste $v 2$. Publ by Univ of Arizona, Tucson, AZ, USA $p$ 603-609, Anonymous Tucson, Az, USA:Univ of Arizona, 1985,p. 603-609.

3677. Saad, E., Laberge, N.L., and Feng, X. Modeling of the viscosity of glasses used in the immobilization ofx high-level liquid nuclear waste. Nuclear Technology 86:66-69, 1989 . 
3678. Saad, E. Physical properties of multicomponent borosilicate glasses : $a$. study of viscosity, processing and durability /, 1988.

3679. Saad, M., Elfarissi, M., and Poulain, M. Influence of Sulfate Anions on the Chemical Durability of the Baty Glass. J.NON-CRYST.SOLIDS. 140:112-118, 1992 .

3680. Sabbe, M.A. and Foelber, S.C. Structural considerations for a radwaste facility. In: <CI> Proceedings of the symposium held in conjunction with the ASCEX Convention Publ by ASCE, New York, NY, USA p 222-233, Anonymous New York, NY, USA:ASCE, 1985,p. 222-233.

3681. Sacchi, M., Antonini, M., Buckley, S.N., and Manara, A. Alkali effects on bubble formation in irradiated borosilicate glasses. Materials Letters 4:10-12, 1985.

3682. Sachse, J., ; Eisenstatt, L., and $X$ design of a low-level waste resin vitrification facilityx. Ceram.Trans., 29, 561-6X-6X, 1994.

3683. Saidl, J. and Ralkova, J. Solidification of high-level radioactive wastes. $i$. selection ofX the raw materialsX. Kernenergie. $-5 X, 1994$.

3684. Saidl, J. and Ralkova, J. Solidification of high-level radioactive wastes. ii. basalt as ax favorable incorporation and fixation mediumx. Rernenergie. $-31 X, 1994$.

3685. Saidl, J. and Hild, W. Avoidance of accidents in the solidification of radioactive wastex waterX. Ger.offen. , 1994.

3686. Saidl, J., ; Kahl, L., and $X$ absorption power of the vg $98 / 12$ borosilicate $\star \star \star g l a s s \star \star *$ forX components of high-level $\star \star \star$ radioactive***

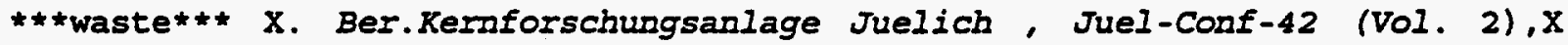
Proc:roc-Level Liquid Wastex, 1994.

3687. Sakai, A., Sugiura, N., Teranishi, N., Ohuchi, Y., and Saiga, H. Application of scaled $1 \mathrm{fcm}$ mock-up test to commercial scalex vitrification. In: High Level Radioactive Waste and Spent Fuel Management Proc 1989 JointX Int Waste Manage Conf $v 2$ (of 2). Publ by American Soc of Mechanicalx Engineers (ASME), New York, NY, USA.p 21-24,Anonymous New York, NY, USA:American SOC of MechanicalX Engineers (ASME), 1989,p. 21-24.

3688. Sakai, A.A.,Hidekazu; Murakoshi development of liquid-fed ceramic melter (lfcm) for comnercial-scaleX vitrificationX. Ihi Eng.Rev., 21, 81-7X-7X, 1994.

3689. Sakka, S. Sol-gel synthesis of glasses: present and future: American.Ceramic.Society.Bulletin. v. 64 (Nov. '85):1463-1466, 1985.

3690. Salam, A. The growth and shrinkage of bubbles of nitrogen and oxygen rising through boric oxide melts with various water contents, Alfred, N.Y.New York State College of Ceramics at Alfred University, 1970.

3691.. Sales and Boatner Lead iron phosphate glassùa stable storage medium for high-level nuclearwaste. Science (Washington, 1984. 
3692. Sales and Boatner Lead phosphate glass as a stable medium for the immobilization and disposalof high-level nuclear waste. Mater.Lett. , 1984.

3693. Sales and Boatner Physical and chemical characteristics of lead-iron phosphate nuclear wasteglasses. J.Non-Cryst.Solids, 1986.

3694. Sales, Boatner, and Naramoto Rutherford backscattering investigation of the corrosion of borosilicatenuclear waste glass. J.Non-Cryst.Solids, 1982 .

3695. Sales, White, and Begun, G. Surface layer formation on corroded nuclear waste glasses. J.Non-Cryst.Solids, 1984.

3696. Sales, White, and Boatner Application of ion implantation and backscattering techniques to theanalysis of nuclear waste glass corrosion. Mater.Lett. , 1983.

3697. Sales, B., C., ; Boatner, L., A., ; Naramoto, H., ; White, C., W., and X rutherford backscattering investigation of the corrosion ofx borosilicate ***glasș** X. Mater.Res.Soc.Symp.Proc., 6,X 83-90X-90X, 1994.

3698. Sales, B., C., ; Boatner, I., A., ; Naramoto, H., ; White, C., W., and $X$ rutherford backscattering investigation of the corrosion ofx borosilicate

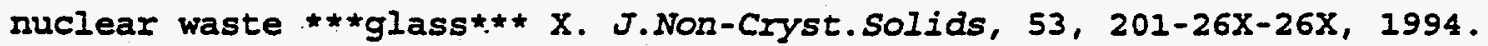

3699. Sales, B., C., ; Boatner, I., A., and $x$ physical and chemical characteristics of lead-iron phosphate nuclearX waste glassesX. Report, ornl-6168, $61 \mathrm{pp}, 1985$.

3700. Sales, B., C., ; White, C., พ., ; Boatner, L., A., and X a comparison of the corrosion characteristics of synthetic monazitex and borosilicate $\star \star \star$ glass $* \star$ containing simulated nuclearx defense wastex. Nucl.Chem.Waste Manage., 4, 281-9X-9X, 1994.

3701. Sales, B.C. and Boatner, I.A. Lead phosphate glass as a stable medium for the immobilization andx disposal of high-level nuclear waste. Materials Letters $2: 301-304,1984$.

3702. Sales, B.C. and Boatner, L.A. Lead-iron phosphate glass: a stable storage medium for high-level nuclear waste. Science v.226.(Oct.5.'84).p.45-8.bibl.. 36-8075, 1984 .

3703. Sales, B.C. and Boatner, L.A. Physical and Chemical Characteristics of Lead-Iron Phosphate Nuclear Waste Glasses. (Unknown Journal!) , 1985.

3704. Sales, B.C. and Boatner, I.A. Physical and chemical chracteristics of lead-iron phosphate nuclearX waste glasses. Journal of Non-Crystalline Solids $79: 83-116,1986$.

3705. Sales, B.C., Chakoumakos, B.C., Boatner, L.A., and Ramey, J.O. Structural-Properties of the Amorphous Phases Produced by Heating Crystalline Mghpo4.3H2O. J.NON-CRYST.SOLIDS. 159:121-139, 1993. 
3706. Sales, B.C., Petek, M., and Boatner, I.A. Electrical conductivity measurements of leachates for the rapidx assessment of waste form corrosion resistance. In: Materials Research Society Symposia Proceedings $v 15$. Publ by ElsevierX Science Publ Co,New York, NY, USA and Amsterdam,Neth $p$ 251-258, Anonymous New York, NY, USA:ElsevierX Science Publ Co, 1983,p. 251-258.

3707. Sales, B.C., White, C.W., Begun, G.M., and Boatner, L.A. Surface layer formation on corroded nuclear waste glasses. Journal of Non-Crystalline Solids $67: 245-264,1984$.

3708. Sales, B.C., White, C.W., and Boatner, L.A. Application of ion implantation and backscattering techniques to theX analysis of nuclear waste glass corrosion. Materials Letters $2: 1-5 ; 1983$ :

3709. Sales, B. and Boatner, I. Optical, structural, and chemical characteristics of lead-indium phosphate and lead-scandium phosphate glasses. Journal.of. the.American.Ceramic.Society. v. 70 (Sept. 187):615-621, 1987.

3710. Sales, B.C. and X phosphate glassesX. Mrs Bul1., 12, 32-4X-4X, 1994 .

3711. Salim, M.A. and Khawaja, E.E. X-Ray Photoelectron-Spectroscopy Study of Sodium Germanate Glass Containing Cobalt Oxide. J.NON-CRYST.SOLIDS. 151:71-80, 1992.

3712. Salmon Non-lwr and special lwr spent fuels: characteristics and criticality aspects of packaging and disposal. (Unknown Journal!) : (88 p), 1990.

3713. Salmon, P.S. and Liu, J. The Relation Between the Melt Topology and Glass-Forming Ability for Liquid Ge-Se Alloys. J.PHYS-CONDENS.MATTER. $6: 1449-1460,1994$.

3714. Salomoni, A., Toscano, E.H., Caneiro, A., Montenero, A., and Ondracek, G. Relevant properties of ceramics for immobilization of high level waste, $X$ an example: a glass-ceramic through a sol-gel route. Materials Chemistry and Physics 17:475-484, 1987.

3715. Saltelli, A., ; Avogadro, A., ; Bidoglio, G., and $X$ americium filtration in glauconitic sand columnsX. Nucl.Technol., 67, 245-54X-54X, 1994.

3716. Saltzberg, M. and Hu, $Y$. Metastable-phase formation during the crystallization of magnesium metaphosphate glass. Journal. of.the.American.Ceramic.society. J Am Ceram Soc v 73, 1990.

3717. Sanghera, J. and Aggarwal, I. Micro-Raman analysis of carbon inclusions in heavy-metal fluoride glasses. Journal.of.the.American.Ceramic.Society. Journal of the Ameri, 1993 :

3718. Sanghera, J., Eart, P., Sachon, M., Ewing, K., and Aggarwal, I New fluorination reactions of amonium bifluoride. Journal.of.the.American.Ceramic.Society. J Am Ceram Soc v 73, 1990.

3719. Sanyal and Mukerji Fixation of high-level atomic waste in glass for ultimate disposal.X ii.development of vitreous matrixes for the containment of 
cirus, $\mathrm{X}$ tarapur and ranapratapsagar nuclear fuel reprocessing wastesX. J.Sci.Ind.Res. -60X, 1994 .

3720. Sasaki, K., Grigorieva, I, Bagnall, K., Midgley, P., Mori, T., Wilson, $J .$, and steeds, J. Observation of - hexatic vortex glass in Al-doped $\mathrm{YBa} / / 2 \mathrm{Cu} / / 30 / / 7 / /$ minus $/ / \mathrm{x}$ single crystals. Japanese.Journal of. Applied.Physics, .Part.2 : Letters.v.32.n.7B.Jul.15.1993.p.L9 90-L993. , 1993.

3721. Sasaki, $j$. Chemical durability of vitrified high-level radioactive waste forms. Seramikkusu, 1983.

3722. Sasaki, N. Glass solidification system for high-level radioactive waste disposal. New Glass , 1986.

3723. Sasaki, N., Komarneni, S., and Roy, R. Alteration of glass and crystalline ceramic nuclear waste forms underhydrothermal conditions. Am.Ceram.Soc.Bull. , 1982 .

3724. Sasaki, N., Karino, M., Okamoto, H., Kashibara, H., and Yamamoto, M. Solidification of the high-level waste from the tokai reprocessingx plant. In: $v$ 1. Publ by ANS, La Grange Park, IL, USA p 147-160, Anonymous La Grange Park, IL, USA:ANS, 1984,p. 147-160.

3725. Sasaki, N.I.,Satoshi; Saro nondestructive techniques for evaluating the integrity of vitrifiedx solidsx. Ber.Kernforschungsanlage Juelich, Juel-Conf-54, Proc. Int.X Semin.Radioact. Waste Prod., 282-90X-90X, 1994.

3726. Sasaki, N.K.,Sridhar; Roy alteration of ***glass** and crystalline ceramic nuclear wastex forms under hydrothermal conditionsx. Am. Ceram.Soc.Bul1., 61, 649-55X-55X, 1994.

3727. Sasaki, N.O.,Masaaki; Sakata solidification experiments of high-level liquid wastes. (vi). $X$ characterization, and $\star \star \star v i t r i f i c a t i o n * \star$ studies ofX fluidized-bed calcination productsx. Tokai Works Semi-Annu.Prog.Rep., Pact831-79-01, 129-33X-33X, 1994.

3728. Sasaki, N.O.,Masaaki; Sakata pot ***vitrification*** of high-level $\star * \star$ radioactive $* * * X$ **waste $* * *$. denitration and concentration prior to theX

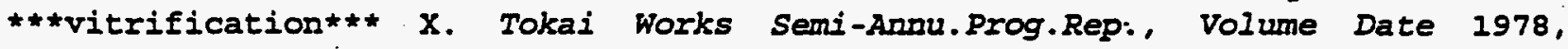
PNCT831-79-02,NCT831-NCT879, 1994.

3729. Sasaki, N.K.,Sridhar; Scheetz and; Roy, R. backfill-waste interactions in repository simulating testsX. Mater.Res.Soc.Symp.Proc., 6,X 397-404X-404X, 1994 .

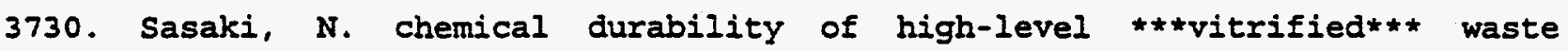
formsX. Seramikkusu, 18, 592-8X-8X, 1994 .

3731. Sassoon, $R_{.}$, ; Gong, M., and $X$ analysis of brine leachates from materials interface interactions $x$ tests.l.leaching of nuclear waste glass doped with chemicalX tracersX. Ceram.Trans., 9, 307-16X-16X, 1994. 
3732. Sato, M., ; Furuya, H., ; Tamai, T., and $X$ density change and annealing process for irradiated waste glassx. Kyoto Daigaku Genshiro Jikkensho Gakujutsu Koenkai Koen Yoshishu, X 20, 45-50X-50X, 1994.

3733. Sato, R. A high resolution solid state nuclear magnetic resonance investigation of aluminosilicate and oxynitride glasses, Arizona state University, 1990.

3734. Sato, R., Bolvin, J., and McMillan, P. Synthesis and characterization of a SiAloN glass. J.Am. Ceram.Soc.v. 73.n.8.Aug.1990.P.2494-2497. Joumal. of. the.American. Ceramic. So ciety. , 1990 .

3735. Sato, S., Furuya, H., Inagaki, Y., Kozaka, T., and Sugisaki Volumetric change of simulated radioactive waste glass irradiated byx electron accelerator. Journal of Nuclear Science and Technology 24:920-924, 1987.

3736. Sato, S., Furuya, H., Kozaka, T., Inagaki, Y., and Tamai Volumetric change of simulated radioactive waste glasses irradiated byx the $\star * 1 * * O b(n, a l p h a) * * 7 l i$ reaction as simulation of actinidex irradiation. Journal of Nuclear Materials 152:265-269, 1988.

3737. Sato, S., Furuya, H., Morikawa, K., Sugisaki, and Inagaki, Y. Behavior of helium release from simulated radioactive waste glasses. Journal of Nuclear Science and Technology 27:343-349, 1990.

3738. Sato, S., Furuya, B., Nishino, Y., and Sugisaki, M. Thermal conductivity of simulated radioactive waste glass. Nuclear Technology 70:235-242, 1985.

3739. Sato, S., Furuya, H., Ohta, K., Sugisaki, M., and Tamai Leaching behavior of simulated radioactive waste glass by neutronx activation method. In: <CI> Symposium held as part of the Annual Meeting of the Materialsx Research Society Materials Research Society Symposia Proceedings $v$ 26.Publ byX North-Holland, New York, NY, USA and Amsterdam, Neth $p$ 773-779,Anonymous New York, NY, USA: $1984, \mathrm{p} .773-779$.

3740. Sato, S., Inagaki, Y., Furuya, H., and Tamai, T. Radiation effects on volumetric change and corrosion for simulatedx radioactive waste glass. In: High Level Radioactive Waste and Spent Fuel Management Proc 1989 JointX Int Waste Manage Conf $v 2$ (of 2). Publ by American Soc of Mechanicalx Engineers (ASME), New York, NY, USA.p 323-328,Anonymous New York, NY, USA:American Soc of MechanicalX Engineers (ASME), 1989,p. 323-328.

3741. Sato, S.A.,Koichi; Furuya microstructure of high-level *t*radioactive***

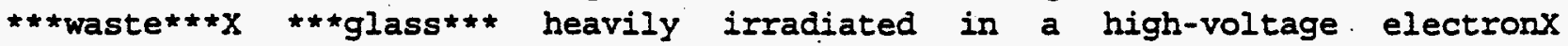
microscopex. Nucl. Chem. Waste Manage., 4, 147-51X-51X, 1994.

3742. Sato, S.F., Hirotaka; Kojima new analytical method for corrosion studies

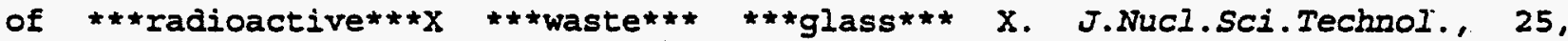
$831-4 \mathrm{X}-4 \mathrm{X}, 1994$

3743. Sato, S.F.,Hirotakax thermal properties of high-level $\star \star \star r a d i o a c t i v e * * *$ $\star \star \star$ waste $* \star X * * \star$ glass $* \star * X$. Netsu Sokutei, 9, 151-60X-60X, 1994. 
3744. Sato, S.F.,Hirotaka; Asakura radiation effect of simulated waste

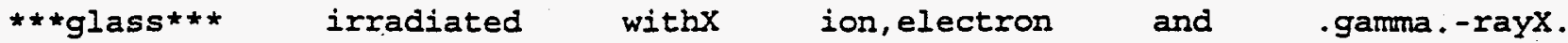
Nucl.Instrum.Methods Phys.Res., Sect.B, 229, 534-7X-7X, 1994.

3745. Sato, S.N.,Yuji; Nishikawa determination of heat capacity of simulated $\star \star *$ radioactive $* \star X$ tasses by drop calorimetryX. J.Nucl.Sci.Technol., 18, 540-4X-4X, 1994.

3746. Sauer, R.E. and Jessop, D. Radwaste incinerator slated for southeast compact region.- Power $129: 78-80,1985$.

3747. Saunders, N. and Miodownik, A.P. Evaluation of glass forming ability in binary and ternary metallic alloy systems - an application of thermodynamic phase diagram calculations. Materials.Science and.Technology. Mater Sci Technol $\mathrm{v}, 1988$.

3748. Savage, D. and Chapman, N. Geochemical factors controlling the nuclide release source-term in granite: dissolution of the waste form, Harwell, England :Environmental Protection Unit, Institute of Geological Sciences, 1980.

3749. Savage, D. Geochemical Interactions of Simulated Borosilicate Waste Glass, Granite and Water at 100-350 deg C and 50MPa. (Unknown Journal!), 1984.

3750. Savage, D. and Robbins, J.E. Interaction of borosilicate glass and granodiorite at 100 degree $c, 50 \mathrm{x}$ ma: implications for models of radionuclide release. In: Materials Research Society Symposia Proceedings $v 11$. Publ byX North-Holland, New York, $N Y$, USA and Amsterdam, Neth $p$ 145-152,Anonymous New York, NY, USA: 1982,P. 145-152.

3751. Savage, D., ; Chapman, N., A., and $x$ hydrothermal behavior of simulated

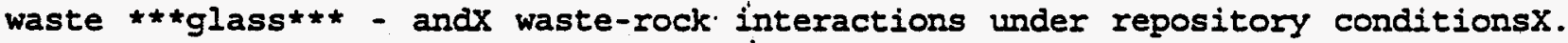
Chem.Geol., 36, 59-86X-86X, 1994.

3752. Savage, D.R.,Jane E., ; Merriman, R.J., and $X$ hydrothermal

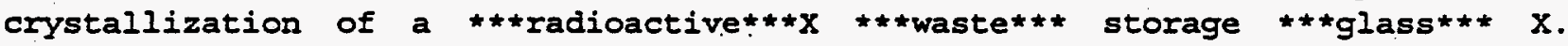
Mineral.Mag., 49, 195-201X-201X, 1994.

3753. Savage, D. The geochemical interactions of simulated borosilicate waste glass, granite and water at 100-350p0sC and 50MPa, Keyworth, England :British Geological Survey, 1984.

3754. Savard, M.E. and Speyer, R.F. The effects of particle size and additions of $\mathrm{Na} / / 2 \mathrm{SO} / / 4$ and $\mathrm{NaNO} / / 3$ on the reactions in soda-lime-silica glass batches. Glass.Technology. Glass Technology v 3, 1993.

3755. Schaake, H. Electron transport phenomena in transition metal oxide glasses, 1968 .

3756. Scheetz, B., E., ; Komarneni, S., ; Smith, D., K., ; Anderson, C.., A., F., ;X Atkinson, S., D., ; McCarthy, G., J., and X hydrothermal interaction of simulated nuclear waste $* \star \star g l a s s * \star \star X$ in the presence of basaltsX. Sci.Basis Nucl.Waste Manage., 2, 207-14X-14X, 1994. 
3757. Scheetz, B.E., Freeborn, W.P., Smith, D.K., Anderson, Zolensky, M., and White, W.B. Role of boron in monitoring the leaching of borosilicate glass wasteX forms. In: <CI> Held as part of the Fall Meeting of the Materials ResearchX Society Materials Research Society Symposia Proceedings $v 44$. Publ by MaterialsX Research Soc, Pittsburgh, PA, USA $p$ 129-134, Anonymous Pittsburgh, PA, USA:MaterialsX Research Soc, 1985,P. 129-134.

3758. Scheetz, B.E., ; Freeborn, W., Phelps; Komarneni, S.A.,Scott D., ; White, W.B., and $X$ comparative study of hydrothermal stability experiments: $X$ application to simulated nuclear waste formsx. Nucl.Chem.Waste Manage., 2, $229-36 \mathrm{X}-36 \mathrm{X}, 1994$.

3759. Scheetz, B.E., ; Freeborn, W., Phelps; Smith, D.K., ; Anderson, $x . C$. Michael; White, and $X$.the role of boron in monitoring the leaching of borosilicate glassX waste formsX. Mater.Res.Soc.Symp.Proc., 44,X 129-34X-34X, 1994 .

3760. Scheffler Solidification of highly active wastesx. Kernforschungszentrum. Karlsruhe. , 1975.

3761. Scheffler and Krause Evaluation of the borosilicate glass matrix for the immobilizationx of actinide waste concentratesX. Proc.Tech.Semin.Treat. -78, 2977.

3762. Scheffler and Riege studies on the long-term radiation stability of borosilicate glassesX against alpha-emittersX. Kernforschungszentrum.Karlsruhe. , 1994.

3763. Scheffler, Riege, and Walker Chemical compatibility of hlw borosilicate glasses with actinides: $X$ solubilities and segregation processesX. Comm. Eur. Communities. , 1994.

3764. Scheffler, K., Stritzke, D., and Tittmann, E. Pamela demonstrates the vitrification of high level waste. (Eurochemic reprocessing plant at Mol, Belgium). Nuclear. Engineering. International. v. 29 (Sept. '84):39-42, 1984 .

3765. Scherer, G. and Drexhage, M. Stress in leached phase-separated glass. Nournal. of. the.American.Ceramic.Society. v. 68 (Aug. '85):419-426, 1985.

3766. Schiewer, Heimerl, and Heine Crystallization in low-alkali metal borosilicate glasses for fixingx fission productsx. Reaktortagung. [Kurzfassungen. Fachvortr]. -8, 1994.

3767. Schiewer, E., Lutze, W., and Heimerl, W. Fixation of radioactive wastes in glassX. GLASTECH.BER. -8X, 1994.

3768. Schiewer, E., Lutze, W., Boatrer, I.A., and Sales, B.C. Characterization of lead-iron phosphate nuclear waste glasses. In: Materials Research Society Symposia Proceedings $\checkmark 50$. Publ by MaterialsX Research Soc, Pittsburgh, DA, USA $p$ 231-238, Anonymous Pittsburgh, PA, USA:MaterialsX Research SOC, 1986,p. 231-238.

3769. Schiewer, E., Rabe, H., and Weisenburger, S. Materials balance scientific fundamentals for the quality assurancex of vitrified waste. In: Materials Research Society Symosia Proceedings VII.Publ byX North-Holland, New 
York, NY, USA and Amsterdam, Neth $p$ 289-297,Anonymous New York, NY, USA: 1982, p. 289-297.

3770. Schiewer, $\mathrm{E}$. and $\mathrm{X}$ the borosilicate glass for 'pamela'X. Radioact. Waste Manage.Nucl.Fuel Cycle, $7,121-38 \mathrm{x}-38 \mathrm{x}, 1994$.

3771. Schiewer, E.R.,Harald; Weisenburger the materials balance - scientific fundamentals for the qualityx assurance of $* \star \star v i t r i f i e d * *$ wastex. Mater:Res.SOC.Symp.Proc., 11,X 289-97X-97X, 1994.

3772. Schiewer, E.I., Werner; Boatner, ; Sales, B.C., and X characterization of lead-iron phosphate nuclear waste glassesX. Mater.Res.Soc.Symp.Proc., 50,X $231-8 X-8 X, 1994$.

3773. Schiewer, E. phase boundary effects in metal matrix embedded glassesX. Ceram.Nucl.Waste Manage., Proc.Int.Symp., Issue Conf-790420,X 218-23-23, 1994.

3774. Schiffhauer, M.A., Groth, J.T., and Scott, D.W. Status of the waste removal system for the west valley demonstrationx project. In: <CI> Volume 2. Waste Policies and Programs, Low-Level Waste $v 2$. Publ by Univ of Arizona, Tucson, AZ, USA $p$ 61I-619, Anonymous Tucson, AZ, USA:Univ of Arizona, 1985,p. 611-619.

3775. Schiffhauer, M.A., Rykken, L.E., and Pope, J.M. Program for the removal of the neutralized purex high-level waste (hlw)X stored at the west valley site. In: $v$ l. Publ by ANS, La Grange Park, IL, USA $p$ 327-344,Anonymous La Grange Park, IL, USA:ANS, 1984,p. 327-344.

3776. Schmidt, S.O. Hersteliung und Charakterisierung keramischer Produkte als Abfallverwahrform unter Einsatz der sol-Gel-Technik. (Fabrication and characterization of ceramic for final disposal products by sol-gel process). Diss. (Unknown Journal!), 1990.

3777. Schneider, A., ; Schumacher, R., and $X$ remote monitoring of molten radioactive glassX. Mater.Res.Soc.Symp.Proc., 257, 207-15X-15X, 1994.

3778. Scholze, H.C.,Reinhard; Engelke determination of the corrosion mechanisms

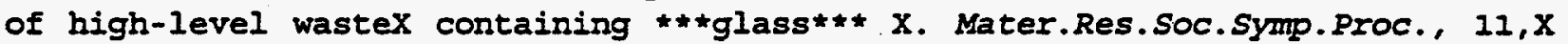
$173-80 \mathrm{X}-80 \mathrm{X}, 1994$.

3779. Schreiber, $H$. and Balazs Chemistry of uranium in borosilicate glasses: $i$, simple base compositionsrelevant to the immobilization of nuclear waste. Phys.Chem.Glasses , 1982.

3780. Schreiber, H., Balazs, and Jamison Chemistry of uranium in borosilicate glasses: $i$, base compositionscontaining titanium relevant to the immobilization of nuclear waste. Phys.Chem.Glasses, 1982 .

3781. Schreiber, H., Harville, T., and Damron, G. Redox-controlled solubility of palladium in a borosilicate glass melt. J.Am.Ceram.Soc. , 1990.

3782. Schreiber, H. and Hockman, A. Redox chemistry in candidate glasses for nuclear waste immobilization. J.Am.Ceram.Soc. , 1987. 
3783. Schreiber, H., Kozak, and Merkel Redox equilibria and kinetics of iron in a borosilicate glass-forming melt. J.Non-Cryst.Solids, 1986.

3784. Schreiber, H., Kozak, S., and Leonhard, P. Sulfur chemistry in a borosilicate melt: $i$, redox equilibria andsolubility. GLASTECH.BER. , 1987.

3785. Schreiber, H., Kozak, S., and Leonhard, P. Sulfur chemistry in a borosilicate melt: ii, kinetic properties. GLASTECH.BER. , 1988.

3786. Schreiber, H., Kozak, S., and Wetmore, D. Immobilization of high-level nuclear waste in glass: processing constraintsimposed by iron-nickel-sulfur interactions. Ceram. Trans. , 1990.

3787. Schreiber, H., Minnix, and Carpenter Chemistry of $u$ in borosilicate glasses: $i$ ii, mutual interactions ofoxidizing agents (ce sup 4 sup + , cr sup 6 sup + , fe sup 3 sup + andmn sup 3 sup + ) with $u$ in base composition for the immobilization ofnuclear waste. Phys.Chem.Glasses, 1983.

3788. Schreiber, H., Rietmiller, M., and Duggan, T. Solution chemistry of noble metals in a model nuclear waste glass. Ceram.Trans. , 1991.

3789. Schreiber, H., Sisk, and schreiber, C. Solubilities of nickel and cobalt chalcogenides in a nuclear waste glassmelt. Ceram. Trans. , 1991.

3790. Schreiber, H., ; Kozak, S., ; Wetmore, D., ;X Schreiber, C., ; Downey, J., and sloanX immobilization of high-level nuclear waste in glass: processingX constraints imposed by iron-nickel-sulfur interactionsx. Ceram.Trans., 9, 581-90X-90X, 1994 .

3791. Schreiber, H., ; Riethmiller, M., ; Duggan, T., and X solution chemistry of noble metals in a model nuclear waste glassX. Ceram.Trans., 23, 135-44X-44X, 1994.

3792. Schreiber, H., ; Sisk, E., Denton; Schreiber, C., ;X Burns, J., and $X$ solubilities of nickel and cobalt chalcogenides in a nuclear wastex glass meltx. Ceram.Trans., 23, 213-22X-22X, 1994.

3793. Schreiber, H. and Balazs, G.B. Chemistry of $U$ in borosilicate glasses: VI, The leaching of uranium from glass. PHYS.CHEM.GLASSES. 26[2]:35-45, 1985.

3794. Schreiber, H., Balazs, G.B., and Kozak, S. Chemistry of uranium in glass-forming melts--redox interactions of uranium with chromium and iron in aluminosilicates. J.Am.Ceram.Soc. $66[\mathrm{~N} \mathrm{5]}: 340-346,1983$.

3795. Schreiber, H., Carpenter, B.E., and Eckenrode, J.P. Chemistry of $U$ in borosilicate glasses: V, Ferric-ferrous couple as a redox buffer for the U redox state distribution against reducing agents in a borosilicate melt. PHYS. CHEM.GLASSES. $26[1]: 24-30,1985$.

3796. Schreiber, H., Kozak, S., and Trundel, B.D. Oxygen diffusion in SRL [Savannah River Lab] waste glassmelts. Adv.Ceram. 20:125-132, 1986. 
3797. Schreiber, H., Minnix, L.M., and Balazs, G.B. Chemistry of $U$ in borosilicate glasses: IV, Ferric-ferrous couple as a potential redox buffer for the $U$ redox state distribution against oxidizing agents in a borosilicate melt. PHYS. CHEM. GLASSES. $25[1]: 1-10,1984$.

3798. Schreiber, H., D., ; Balazs, G., B., ; Jamison, P., I., ; Shaffer, A., $P .$, and $X$ the chemistry of uranium in borosilicate glasses.part 2 .baseX compositions containing titanium relevant to the immobilization ofx nuclear wastex. Phys.Chem.Glasses, 23, 147-53X-53X, 1994.

3799. Schreiber, H., D., ; Balazs, G., B., and $X$ the chemistry of uranium in borosilicate glasses. part 1 . simplex base compositions relevant to the immobilization of nuclear wastex. Phys.Chem.Glasses, 23, 139-46X-46X, 1994 .

3800. Schreiber, H.D., Balazs, G.B., Solberg, T.N., Rees, T.F., Cleveland, J.M., and Nash, K.I. Chemistry of uranium in borosilicate glasses. part 6 . the leaching ofx uranium from glass Leaching of plutonium from a radioactive waste glass by eightx groundwaters from the western united states. Physics and Chemistry of Glasses Nuclear Technology 70:133-140, 1985.

3801. Schreiber, H.D., Balazs, G.B., Williams, B.J., and Andrews Structural and redox properties of uranium in ca-mg-al-silicatex glasses. In: <CI> Proceedings of the $3 \mathrm{rd}$ International Symposium, held as part ofX the Annual Meeting of the Materials Research Society Scientific Basis for Nuclear Waste Management v. 3. Publ by PlenumX Press, New York, NY, USA and London, Engl p 109-114, Anonymous New York, NY, USA:PlenumX Press, 1981,P. 109-114.

3802. Schreiber, H.D., Carpenter, B.E., Eckenrode, J.P., and Balazs, G.B. Chemistry of uranium in borosilicate glasses - 5 . the ferric-ferrousX couple as a redox buffer for the uranium redox state distributionx against reducing agents in a borosilicate melt. Physics and Chemistry of Glasses 26:24-30, 1985 .

3803. Schreiber, H.D., Fowler, R.W., and Ward, C.C. Sulfate as a selective Redox Buffer for Borosilicate Melts. PHYS.CHBM.GLASSES. 34:66-70, 1993.

3804. Schreiber, H.D., Hockman, A.L., Yamasaki, N., Yanagisawa, K., and Nishioka, M. Redox chemistry in candidate glasses for nuclear waste immobilization Hydrothermal immobilization of glass powder containing simulated highx level radioactive waste. Journal of the American Ceramic Society Nippon Genshiryoku Gakkaishi/Journal of the Atomic Energy Society ofX Japan $28: 266-273$, 1986 .

3805. Schreiber, H.D., Kozak, S.J., Leonhard, P.G., and McManus Sulfur chemistry in a borosilicate melt: part 1. redox equilibria andx solubility. Glastechnische Berichte 60:389-398, 1987.

3806. Schreiber, H.D., Kozak, S.J., Leonhard, P.G., McManus, and Schreiber, C.W. Sulfur chemistry in a borosilicate melt: part 2. kinetic properties. Glastechnische Berichte 61:5-11, 1988.

3807. Schreiber, H.D., Kozak, S.J., Merkel, R.C., Balazs, G.B., and Jones, P.W.J. Redox equilibria and kinetics of iron in a borosilicate glass-formingx melt. Journal of Non-Crystalline Solids 84:186-195, 1986. 
3808. Schreiber, H.D. and Schreiber, C.W. Polyselenide formation in borosilicate glasses. Jo - Journal of non-Xcrystalline solids. (Unknown Joural!) 155, Number 3:1-209, 1993.

3809. Schreiber, H., Balazs, G.B., and Carpenter, B. An electromotive force series in a borosilicate glass- forming melt. Journal.of. the.American.Ceramic.Society. v. 67 (June '84):C106-C108, 1984 .

3810. Schreibèr, H., Harville, T., and Damron, G. Redox-controlled solubility of palladium in a borosilicate glass melt. Joumal.of. the.American.Ceramic.Society. J Am Ceram Soc v 73, 1990.

3811. Schreiber, H., Harville, T., and Damron, G. Redox-Controlled Solubility of Palladium in a Borosilicate XGlass Melt. Journal. of.the.American.Ceramic.Society.PY.-.1990. 73, Number 5:1435-1437, 1994.

3812. Schreiber, H., Kozak, S., Balazs, G.B., Fritchman, A., and Schreiber, C. Equilibrium and transport properties of gases in E-glass melts. Journal.of.the.American.Ceramic.Society. I Am Ceram Soc v 72, 1989.

3813. Schreiber, H.D., ; Balazs, G., Bryan; Carpenter, B.E., ;X Kirkley, J.E., ; Minnix, L.M., ; Jamison, P., and Lynnex an electromotive force series in a borosilicate $* *$ glass $* * x$ forming meltX. J.Am.Ceram.Soc., 67, C106-C108X-C108X, 1994.

3814. Schreiber, H.D., ; Balazs, G., Bryan; Williams, B.J., ;X Andrews, S.M., and $X$ structural and redox properties of uranium in calcium-magnesium- $X$ aluminum ***silicate** glassesX. Sci.Basis Nucl.Waste Manage.; 3, 109-14X-14X, 1994 .

3815. Schreiber, H.D., ; Carpenter, B.E., ; Minnix, L.M., ;X Balazs, G., Bryan; Solberg, T.N., and $X$ precipitation of iron, cobalt, and nickel metal from $a$ borosilicateX ***glass*** meltX. Glastech.Ber., 56, 1017-22X-22X, 1994 .

3816. Schreiber, H.D., ; Hockman, A.L.; and $X$ redox chemistry in candidate glasses for nuclear wastex immobilizationX. J.Am.Ceram.Soc., 70, 591-4X-4X, 1994.

3817. Schreiber, H.D., ; Kozak, S.J., ; Trandel, B., Dawn; Schreiber, X.C., and $X$ oxygen diffusion in srl waste glass meltsx. Adv.Ceram.,.20, 125-32X-32X, 1994 .

3818. Schreiber, H.D., ; Leonhard, P.G., ; Nofsinger, R.G., ;X Henning, M.W., ; Schreiber, C.W., ; Kozak, S.J., and $X$ oxidation-reduction chemistry of nonmetals in a referencex borosilicate meltx. Adv. Fusion Glass, Proc.Int.Conf., 1st, 29-29, 1994 .

3819. Schreiber, H.D., ; Schreiber, C.W., ; Kozak, S.J., and X the interaction of water vapor with a borosilicate meltx. Diffus.Defect Data, 53-54, 145-53X-54, 145-53X, 1994. 
3820. Schreiber, H.D., ; Schreiber, C.W., ; Leonhard, P.G., ;X McManus, K.K., ; Trandel, B., and DawnX solubility and diffusion of gases in a reference borosilicate meltx. Diffus.Defect Data, 53-54, 345-50X-54, 345-50x, 1994.

3821. Schreiber, H.D., ; Schreiber, C.W., ; Riethmiller, M.W., ; Downey, J., and sloanx the effect of temperature on the redox constraints for thex processing of high-level nuclear waste into a glass waste formx. Mater.Res.SoC.Symp.Proc., 176, 419-26X-26X, 1994.

3822. Schreiber, H.D., ; Settle, F.A., , ; Jamison, P., Lynne;X Eckenrode, J.P., ; Headley, G.W., and $X$ ruthenium in glass-forming borosilicate meltsX. J.Less-Common Met., 115, 145-54X-54X, 1994.

3823. Schulz Microwave processing of simulated nuclear-waste glass. (Unknown Journal!) : (8 p), 1927.

3824. Schulz and Dressen Immobilization of spent cladding hulls by conversion to silicatex formsX. Report. , 1974.

3825. Schulz, Dressen, Hobbick, and Babad Glass forms for immobilization of hanford wastesx. Report. , 1975.

3826. Schulz, Dressen, Hobbick, and Kupfer Conversion of hanford salt cake to glass: laboratory studiesX. Report. , 1977.

3827. Schulz, Fathi, Z., and Clark, D. Microwave processing of simulated nuclear waste glass. Ceram.Trans. , 1991.

3828. Schulz, R., Fathi, z., and Clark, D. Microwave processing of simulated nuclear waste glass. Ceran.Trans. , 1991.

3829. Schulz, R., Zoitos, B., and Clark, D. In situ zeta potential measurements of simulated nuclear waste glass usingelectrokinetic sonic amplitude techniques. Ceram.Trans., 1991.

3830. Schulz, R., I., ; Clark, D., E., ; Lodding, A., R., ; Wicks, G., G., and $X$ long term field leaching studies of simulated nuclear waste glass inX granite and saltX. Mater.Res.Soc.Symp.Proc., 257, 65-72X-72X, 1994.

3831. Schulz, R., L., ; Fathi, z., ; Clark, D., E., ; Wicks, G., G., and X microwave processing of simulated nuclear waste glassx. Ceram.Irans., 21, 451-8X-8X, 1994.

3832. Schulz, $w$. and Kupfer Application of the hanford thermite process to increaseX immobilization of in-tank solidified wastex. Report. , 1973.

3833. Schulz, w., w., ; Beary, M., M., ; Gallagher, S., A., ; Higley, B., ;X Johnston, R., G., ; Jungfleisch, F., ; Kupfer, M., J., ; Palmer, R., ;X Watrous, R., ; Wolf, G., and $X$ preliminary evaluation of alternative forms for immobilization ofX hanford high-level defense wastesX. Report, Rho-St-32, 345 pp, 1981.

3834. Schulz, พ.พ. and Dressen, A.L. Conversion of radioactive ferrocyanide compounds to immobile glassesX. Us. , 1994 . 
3835. Schumacher Dwpf batch 1, waste glass investigations. (Unknown Journal!) :(12 p), 1991.

3836. Schumacher status of vitrification for doe low-level mixed waste. (Unknown Jounnal!) : (10 p), 1993.

3837. Schumacher Lot no. 1 of frit 202 for dwpf cold runs. (Unknown Journal!) :(16 p), 1994.

3838. Schumacher Lot no. 2 of frit 202 for dwpf cold runs <augmentation> waste processing facility. (Unknown Journal!) : (16 p), 1994.

3839. Schumacher, R. Dwpf [defense waste processing facility] batch: $i$, waste glassinvestigations. Ceram.Trans. , 1991.

3840. Schumacher, $R_{.}, F .$, and $X$ errors of dwpf frit analysis: final report: revision 1X. Report, WsrC-Rp-92-037-Rev.1; Order No.De93009899, 48 pp, 1993.

3841. Schumacher, R.F. Errors of DWPF Frit analysis. Final report. Progress rept. (Unknown Journal!) , 1992.

3842. Schumacher, R.F. and Ramsey, W.G. Conditions for precipitation of copper phases in DWPF waste glass. Revision 1. (Unknown Journal!) , 1993.

3843. Schumacher, R.F. and Ramsey, W.G. Conditions for precipitation of copper phases in DWPF waste glass. (Unknown Journal!), 1993.

3844. Schumacker Copper solubility in dwpf, batch 1 waste glass: update report. (Unknown Journal!) : (12 p), 1918.

3845. Schumacker, R.F. Copper solubility in DWPF, Batch 1 waste glass: Update report. (Unknown Journal!), 1992.

3846. Schuman, R., P., and X determination of nuclear waste from leach rates by activationX analysisX. Report, Conf-79.1103-5, 5 pp, 1979.

3847. Schvoerer, M., Martinaud, M., Chapoulie, R., and Muller, P. Detection by thermoluminescence of damages created by alphax desintegrations in radionuclear waste glass. Waste Management 9:57-61, 1989.

3848. Schwartz, Cohen, Lewis, and Braun High-level radioactive waste isolation byx incorporation in silicate rockX. Peaceful.Nucl.Explos. $-72 X, 1976$.

3849. Schwartz, Cohen, Lewis, and Braun High level radioactive waste isolation byx incorporation in silicate rockx. Report. , 1977.

3850. Schwartz, I., ; Mintz, M., H., ; Shamir, N., and $\mathrm{X}$ the effect of adsorbed lead on the chemical durability of nuclearX waste glassesX. J.Nucl.Mater., 172 , $314-18 X-18 X, 1994$.

3851. Schweinberg, R. Polarization and conductivity studies in molten sodium disilicate glass with Feo, 1968. 
3852. Scott, J., L., ; Wolfe, B., A., ; Allen, C., R., ; Bates, S., O., and $\mathrm{X}$ update on the hanford waste vitrification plant technicalx developmentsx. Proc.Symp.Waste Manage., (Waste Manage.'88, Vol. 2), 211-15X-15X, 1994.

3853. Sears, J.w., Eschenbach, R.C., and Hill, R.A. Plasma centrifugal furnace.a method for stabilization andx decomposition of toxic and radioactive wastes. Waste Management 10:165-175, 1990.

3854. Sedighi-Dehkordi Leaching kinetics of phosphate glasses with regard to theX solidification of radioactive wastesX. Report. , 1972.

3855. Selg; R.A. Nuclear hazardous waste cost control management. In: Transactions of the American Association of Cost Engineers. Publ byX AACE, Morgantown, WV, USA.p J.3.1-J.3.4,Anonymous Morgantown, WV, USA: 1991,p. J

3856. Selig, M. Remote maintenance demonstration tests at a pilot plant for high levelx waste vitrification. In: $v$ 2. Publ by ANS, La Grange Park, IL, USA p 418-424, Anonymoụs La Grange Park, IL, USA:ANS, 1984,p. 418-424.

3857. Selig, M. Remote maintenance techniques in a radioactive vitrification plant. In: <CI> Volume 1: Held in conjunction with American Nuclear Society SummerX Meeting Proceedings of the Conference on Remote Systems Technology 31st. PublX by ANS, La Grange Park, IL, USA $p$ 131-136, Anonymous La Grange Park, II, USA: $1984, \mathrm{P} \cdot 131-136$.

3858. Sellin, P., Apted, M., and Gago, J. Proceedings from the technical workshop on near-field performance assessment for high-level waste. (Unknown Journal!) , 1991.

3859. Sengers, E., G., F., ; Janssen, F., J., ; De Waal, H., and X diffusion of cesium in sodium borosilicate glasses for nuclear wastex immobilizationx. Mater.Res.SOC.Symp.ProC., 176, 441-6X-6X, 1994.

3860. Sengers, E.G.F., Andriesse, C.D., van der Staak, H.P.A.M., and de Waal Diffusion and crystallisation in glasses containing fission-productx elements. Kema Scientific \& Techrical Reports 7:7-10, 1989.

3861. Senoo, M. characterization test program on the vitrified hlw sample fromx cogema and bnflX. Kyoto Daigaku Genshiro Jikkensho, , Kurri-Tr-375, 66-72X-72X, 1994.

3862. Senoo, M.B.,Tsunetaka; Iashiro high pressure soxhlet type leachability testing device and leachingX test of simulated high-level waste $\star \star \star g l a s s * \star *$ at highx temperatureX. Nippon Genshiryoku Kenkyusho, Jaeri-M, Jaeri-M-8571, 13 pp, 1994.

3863. Serruys, Y., ; Limoge, Y., ; Brebec, G., and X diffusion processes in nuclear waste glassesX. Diffus.Processes Nucl.Mater., 353-89-Holland: Ansterdam, 1994 .

3864. Sestak, J. Phase diagrams, melt solidificattion and glass crystallization Xinthe Bi-Ca-Sr-Cu-(0) system. Journal.of.thermal.analysis. 36, Number $5: 1635-1639,1990$. 
3865. Sestak, J. and Malek, J. Diagnostic Limits of Phenomenological Models of Heterogeneous Reactions and Thermal-Analysis Kinetics. SOLID.STATE.IONICS. 63-5:245-254, 1993.

3866. Seveque, J.I., Decayeux, M.D., Elert, M., and Nouguier, H. Mathematical-Modeling of Radioactive-waste Leaching. CEM. CONCR.RES. 22:477-488, 1992.

3867. Seymour, W., C., ; Kelsey, P., V., and X immobilization of inel low-level $\star * \star$ radioactive $* \star \star X$. $\star *$ wastes $* \star *$ in ceramic containment materialsX. Report, Egg-Re-M-78-033, $22 \mathrm{pp}, 1980$.

3868. Shackelford, J. Nature of the glassy stateùimplications for radioactive waste storage: Glasses and Glass-Ceram.for Nuclear Waste Managem , 1987.

3869. Shade Approach to the prediction of waste-form stabilityx. Report. , 1975 .

3870. Shade, J. and Strachan, D. Effect of high-surface-area- to- solution volume $[S A / V 3]$ ratios on waste-glass leaching. Am.Ceram.Soc.BuIl. $65[12]: 1568-1573,1986$.

3871. Shade, J., Thompson, I.E., and Kindle, C.H. In situ vitrification [ISV] of buried waste sites. Ceram. Trans. 23:633-640, 1991.

3872. Shade, J., W., ; Ames, L., L., ; McGarrah, J., E., and $X$ actinide and technetium sorption on iron- $* \star \star$ silicate*t* andX dispersed clay colloidsX. Acs Symp.Ser., 246, 67-77X-77X, 1994.

3873. Shade, J.; W., ; Pederson, I., R., ; MCVay, G., I., and $x$ waste

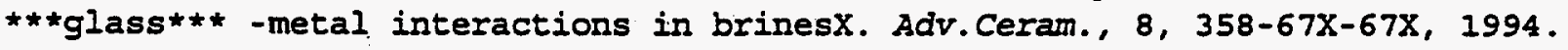

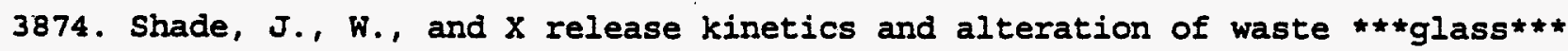
inX crystalline rocks systemsX. Chem.Geol., 36, 103-21X-21X, 1994.

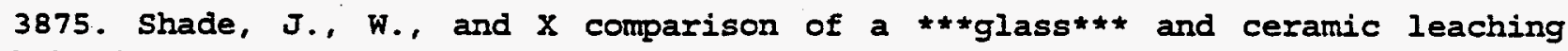
behavior byX natural analogsX. Nucl.Chem. Waste Manage., 2, 219-28X-28X, 1994 .

3876. Shade, J.W. Evaluation of Synroc-C as a Second Generation Waste Form. (Unknown Journal!) , 1986.

3877. Shade, J.W., Pederson, $\dot{L}$., and McVay, G. Waste glass-metal interactions in brines. Adv. Ceram. 8:358-367, 1985.

3878. Shade, J.W., Pederson, I.R., and McVay, G.L. Waste glass-metal interactions in brines. In: <CI> Held during the 85th Annual Meeting of the American CeramicX Society Advances in Ceramics $v 8$. Publ by American Ceramic SOC InC, Columbus, $X$ OH, USA $p$ 358-367,Anonymous Columbus, $X$ OH, USA:American Ceramic Soc Inc, $1984, p$. 358-367.

3879. Shade, J.W. and Piepel, G.F. Evaluation of experimental factors that influence the application and discrimination capability of the product consistency test. (Unknown Journal!) , 1991. 
3880. Shade, J. and Strachan, D. Effect of high surface area to solution volume ratios on waste $X$ glass leaching. American.Ceramic.Society.Bulletin. v. 65 (Dec. ' 86) : $1568-1573,1986$.

3881. Shafer, M.W., Awschalom, D.D., and Warnock, J. The chemistry of and physics with porous sol-gel glasses. Journal.of.Applied.Physics. v. 61 (June 15 (87) : 5438-5446, 1987.

3882. Shah, K., R., ; Stegen, G., E., and $X$ hanford waste vitrification plant process description,processX advancements, and hanford site interfacesX. Proc.Symp.Waste Manage., (Waste Manage.'90, Vol. 2), 759-64X-64X, 1994.

3883. Shah, K.R. and Stegen, G.E. Hanford Waste Vitrification Plant process description, process advancements, and Hanford Site interfaces. (Unknown Journal!) , 1990.

3884. Shah, R., ; Behrman, E., C., ; Oksoy, D., and X calculation of the viscosity of nuclear waste glass systemsX. Mater.Res.Soc.Symp.Proc., 176, 427-32X-32X, 1994 .

3885. Shao, $F$. sulfate distribution in the pot-type facility for vitrification ofX simulated sulfate-containing high level wastesX. Yuanzineng Kexue Jishu, 24, 58-65X-65X, 1994 .

3886. Shao, F.z.,Baoshan; Sun designing and testing a pilot plant for vitrification of simulatedx high-level liquid wastex. Fushe Fanghu, 3 , $26-32 X-32 X, 1994$.

3887. Sharp, S.D., Nankani, F.D., Bray, I.A., Eakin, D.E., and Larson, D.E. Removal of dissolved and suspended radionuclides from Hanford waste Vitrification Plant liquid wastes. (Unknown Journal!), 1990.

3888. Shaw, M.T. and Tuminello, W.H. A Closer Iook at the MWD-Viscosity Transform. POLYM. ENGG.SCI. 34:159-165, 1994 .

3889. Shaw, T.M., Thomas, G., and Loehman, R.E. Formation and microstructure of Mg-Si-O-N glasses. Journal.of.the.American.Ceramic.Society. v. 67 loct. '84) :643-647, 1984 .

3890. Sheckler, C. and Dinger, D. Effect of particle size distribution on the melting of soda-lime-silica glass. Journal.of.the.American.Ceramic.Society. J Am Ceram Soc $v 73,1990$.

3891. Shelby; J.E. Property/morphology relations in alkali silicate glasses. Journal.of. the.American.Ceramic.Society. v. 66 (Nov. '83):754-757, 1983.

3892. Shelby, J.E. Formation and properties of calcium aluminosilicate glasses. Journal.of.the.American.Ceramic.Society. v. 68 (Mar. 185):155-158, 1985.

3893. Shelby, J. and Kohli, J. Rare-earth aluminosilicate glasses. J.Am. Ceram. SoC. v. 7.3.n.1.Jan.1990.p.39-42. Journal. of. the.American.Ceramic. Societ $y$. , 1990. 
3894. Shelby, J. and Lord, C. Formation and properties of calcia-calcium fluoride-alumina glasses. Journal.of.the.American.Ceramic.Societ. J Am Ceram Soc $v 73,1990$.

3895. Shelley, S. Turning up the heat on hazardous waste. Chemical. Engineering. v. 97 (Oct. '90):47+, 1990 .

3896. Shenkler, E., Graham, and Greenhut, V Secondary lead smelter slags: minimizing lead release levels. Ceram.Trans. , 1991.

3897. Sherhod, C. and Stowell, M.J. Dual phase vitreous enamels. Part 2. Adhesion of vitreous enamels on steel. Materials.Science and.Technology. Mater Sci Technol v, 1989.

3898. Shi, X.Y., Nasev, K.S., Brungs, M.P., and Young, D.J. Determination of total and sulphide sulphur in float glass by ion chromatography. Glass.Technology. Glass Technol v $33 \mathrm{n}, 1992$.

3899. Shimbo, M., Tai, S., and Tanzawa, K. Glass formation range, acid resistivity, and surface charge density of zno-B203-SiO2 passivation glass containing Al203. Journal.of.the.American.Ceramic.Society. v. $69^{\circ}$ (Jan. '86) : 23-26, 1986 .

3900. Shimizu, I. and Kamizono, H. Leaching Behavior of Simulated High-Level Waste Glass in Flowing Water. (Unknown Journal!) , 1986.

3901. Shiraki, K., Ohashi, M., Tajima, K., Tateda, M., and Tsujikawa, K. Viscosity of $F$ and $G e O / / 2$ codoped silica glass. Electronics.Letters. Electronics Letters, 1993.

3902. Shrivastava, O.P., Komanneni, S., and Malla, P. Hydrothermal synthesis, cesium selectivity and water sorption propertyx of $\mathrm{v} / / 20 / / 5$ center dot $\mathrm{nh} / / 20$ gel. Materials Research Bulletin 26:357-366, 1991.

3903. Shukla, Vaswani, and Rajan studies on the immobilization of sulfate-bearing waste in leadx monoxide-boron oxide-silicon dioxide systemx. India. -951, 1994.

3904. Shukla, B.S. and Dignam, M.J. Approximation method for diffusion based leaching models. Physics and Chemistry of Glasses 28:85-94, 1994.

3905. Shulz, W.W. and ressen, A.I.C. Conversion of radioactive ferrocyanide compounds to immobile glasses. (Unknown Journal!) , 1981.

3906. Siddiqui, M. Caustic soda as a batch material and its effects on the melting, homogeneity and refining of a soda-lime-silica glass, Sheffield:The University of Sheffield, 1974.

3907. Siegriest, R. Melting reactions in the system BaS-Nab2sSob4s, Alfred, NY:New York State College of Ceramics at Alfred University, 1968.

3908. Siemens and Bonner Design. features of a full-scale high-level waste vitrificationx systemX. Report. , 1977. 
3909. Siemens and Bonner Design features of a full-scale high-level waste vitrificationX systemX. Proc.Conf.Remote.Syst.Technol. $-42 \mathrm{X}, 1994$.

3910. Siemens, D., H., ; Knowlton, D., E., ; Shupe, M., W., and X three mile island zeolite **tvitrification*** demonstrationx programx. Aiche Symp.Ser., $78,41-4 X-4 X, 1994$.

3911. Siemens, D.H., Beary, M.M., Berger, D.N., Heath, W.O., and Larson, D.E. Development of hwrp melter/turntable components for canyon-remotex maintenance and replacement. In: <CI> Volume 1. Waste Policies and Programs, High Level Waste $v$ 1. Publ by Univ of Arizona, Tucson, AZ, USA $p$ 207-217, Anonymous Tucson, Az, USA:Univ of Arizona, 1985,p. 207-217.

3912. Siemens, D.H. and Chapman, C.C. Remote design features for the west valley slurry-fed ceramic melterx system. In: <CI> Held during the 85th Annual Meeting of the American CeramicX Society Advances in Ceramics $v$ 8. Publ by American Ceramic SOC Inc, Columbus, $X$ OH, USA $p$ 179-182, Anonymous Columbus, $X$ OH, USA:American Ceramic SOC Inc, 1984,p. 179-182.

3913. Siemens, D.H. and Chapman, C.C. Remote design features for the West Valley [NY] slurry-fed ceramic melter system. Adv.Ceram. 8:179-182, 1985.

3914. Sikorski, c. Cadmium and sodium release behavior of certain soda-cadmia-silica glasses under acetic acid attack, 1979.

3915. Silverman, L. The formation and characterization of nickel sulfide stones in thermally tempered glass, 1981.

3916. Simmons, C., Simmons, J., and Macedo, P.P. Fixation by ion exchange of toxic materials in a glass matrix. (Unknown Journal!), 1984.

3917. Simmons, C. Chemical durability of fluoride glasses: the effect of solution pH. Journal.of.the.American.Ceramic.Society. v. 70 (Sept. '87) : 654-661, 1987 .

3918. Simmons, c. Chemical durability of fluoride glasses: reaction of barium-thorium-based glasses with water: Journal. Of. the.American.Ceramic.Society. V. 70 (Apr. '87):295-300, 1987.

3919. Simmons, C. and simnons, J. Chemical durability of fluoride glasses: reaction of fluorozirconate glasses with water. Journal.of. the.American.Ceramic.Society. v. 69 (Sept. '86):661-669, 1986.

3920. Simmons, J., Macedo, P., Barkatt, A., and Litovitz, X Fixation of radioactive waste in high silica glassesX. Nature (London). -31X, 1994.

3921. Simmons, J. and Simmons, C. Nonlinear viscous flow in glass forming. American.Ceramic.Society.Bulletin. An Ceram Soc Bull v, 1989.

3922. Simmons, J.H., ; Barkatt, A.M.,Pedro B., ; Pehrsson, P.E., ; Simmons, C.J., ; Barkatt, A.T.,Danh, and ; Sutter, X.H.,MervetX chemical durability of nuclear waste glassesX. Ceram.Nucl.Waste Manage., Proc.Int.Symp., Issue Conf-790420, X 263-8-8, 1994. 
3923. Simmons, J.H., ; Barkatt, A.M.,Pedro B., and X mechanisms that control aqueous leaching of nuclear wasteX $\star * \star$ glass $* \star \star x$. Nucl.Technol., 56, 265-70X-70X, 1994.

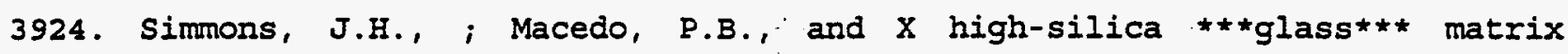
process for high-level wastex solidificationx. Alternate Nucl.Waste Forms Interact.Geol.Media, Proc.WorkshopX Sum.Adv.Act.Formulating Requir.Future, Meeting Date 1980, IssueX CONF--8005107, 317-30, 1994.

3925. Simon, $\dot{R}$. Qualification of waste forms and engineered barriers. In: Proc Eur Conmun Conf Radioact Waste Manage Disposal. Publ by ElsevierX Science Publishers B.V.,Amsterdam, Neth.p 159-182,Anonymous Amsterdam, Neth:ElsevierX Science Publishers B.V. 1991,p. 159-182.

3926. Simonson, S.A. Glass leach model I /, Richland, Wash. :Waste Package Program, Pacific Northwest Laboratory, 1983.

3927. Simonson, S.A. and Machiels, A.J. Analysis of leaching data using asymptotic expansion techniques. In: <CI> Held during the 85th Annual Meeting of the American Ceramicx Society Advances in Ceramics $v 8$. Publ by American Ceramic SOC Inc, Columbus, $X$ OH, USA $p$ 528-535, Anonymous Columbus, $X$ OH, USA:American Ceramic SOC Inc, 1984,p. 528-535.

3928. Simpson, Y. and Carter, C.B. Faceting behavior of alumina in the presence of a glass. Journal.of.the.American.Ceramic.Society. J Am Ceram Soc v 73, 1990.

3929. Sinclair, R., Desa, and Wright, A. Neutron scattering studies of vitrified radioactive waste. J.Am.Ceram.Soc. , 1983.

3930. Sinclair, R.N., ; Desa, J., A., Erwin; wright, A.C., and $x$ neutron

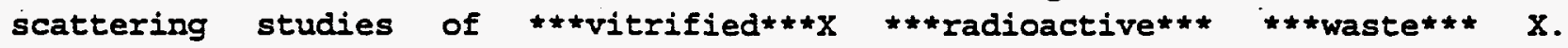
J.Am.Ceram.SoC., 66, 72-7X-7X, 1994.

3931. Singh, R. and Zacharias, E. Systematic studies on Bi-Sr-Ca-Cu-O glasses and glass ceramics. J.Phys.D.v.23.n.2. Feb.14.1990.p.199-204. , 1990.

3932. Sirato, K. development of hlw vitrification offgas treatment processx. Ishikawajima-Harima Giho, 29, 316-21X-21X, 1994.

3933. Sircar, A. How composition affects workability. Glass.Industry. v. 72 (July 10 '91):13-14t, 1991.

3934. Skancke, A. and Kierkegaard, P. X-ray studies of some wolfram oxide phosphate glasses, stockholm:Almqvist \& wiksell, 1967.

3935. Skelcher, B. Uranium in Glass. HEALTH PHYS. $65: 441,1993$.

3936. Skokan, A. and schauer, V. Microstructures and crystallization in simulated waste glasses. In: <CI> Selected Papers presented at the American Nuclear society TopicalX Meeting Publ by Battelle Press,Columbus, $O H$ and Richland, WA, USA andX Springer-Verlag, New York, NY, USA and Heidelberg, West Ger $p$ 212-217,Anonymous Columbus, $O H$ and Richland, WA, USA:Battelle Press, 1983,p. 212-217. 
3937. Skokan, A., ; schauer, $V_{.}$, and $X$ microstructures and crystallization in simulated waste glassesX. Treat.Handl.Radioact.Wastes, , Meeting Date 1982, 212-17:ress: Columbus, Ohio, 1994.

3938. Skrovankova, D. vitrification of simulated intermediate-level waste from nuclearX power plants.i.melting behavior and properties of selected glassesX. Ceram.-Silik., 37, 49-55, ix-55, ix, 1994.

3939. Skrovankova, D., Bennerova, L., and Hlavac, J. Vitrification of Simulated Intermediate-Level Waste from Nuclear-Power-Plants .1. Melting Behavior and Properties of Selected Glasses. CERAMICS-SILIKATY. 37:49-4\&, 1993.

3940. Slate and Maness Corrosion experience in nuclear waste processing atx battelle-northwestx. Mater. Perform. -21X, 1994.

3941. Slate, S., C., ; Bunnell, L., R., ; Ross, W., A., ; Simonen, F., ; Westsik, X.J., H., , and $X$ stesses and cracking in high-level waste $* \star \star g l a s s * \star \star$ $X$. U.S.Nucl.Regul.Conm., Nureg/Cp, Nureg/Cp-0005, Proc.X Conf.High-Level Radioact.Solid Waste Forms, 1978; PB294865,X 3:B294865,X 393-B294865,X 455X, 1994 .

3942. Slate, S., C., ; Ross, W., A., ; Partain, W., L., and X reference commercial high-level waste $\star \star \star$ glass $\star \star \star$ and canisterX definitionX. Report, Pal-3838; Order No.De82001503, 103 pp, 1982.

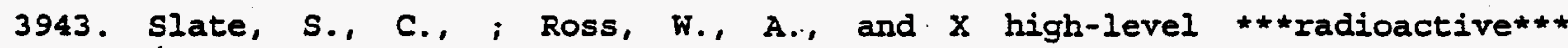

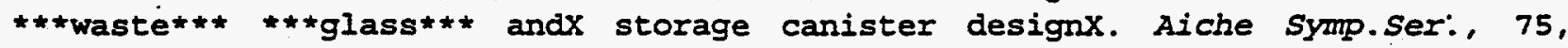
$61-8 \mathrm{X}-8 \mathrm{X}, 1994$.

3944. Slate, S.C. Full-scale impact tests of simulated high-level waste canisters. In: Transactions of the American Nuclear Society $v 41$ 1982. Publ by ANS, LaX Grange Park, I11, USA $p$ 160-161, Anonymous LaX Grange Park, I11, USA:ANS, 1982, p. 160-161.

3945. Slater Summary of in situ vitrification modeling and analysis accomplishments for fiscal year 1991. (Unknown Journal!) : (32 p), 1991.

3946. Slates X-ray spectrometric determination of glass content ofx melts incorporating radioactive waste : ax. Report. $-1474,1994$.

3947. Smailos, E., ; Schwarzkopf, W., ; Koester, R., ; Fiehn, B., ; Halm, G., and $X$ corrosion testing of selected packaging materials for disposal of $x$ high-level waste $\star * \star$ glass $* *$ in rock-salt formations.task $3 . x$ characterization

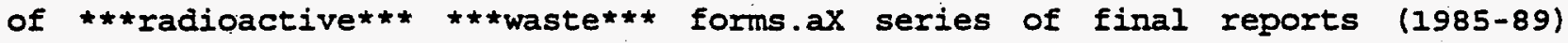
no.27X. Comm. Eur. Communities, Eur, Eur 13672, 57 pp, 1994.

3948. Smailos, E., Schwarzkopf, W., Koester, R., and Storch, w. Investigations on the Suitability of Ceramic Containers for Corrosion Protection of High-Level Waste Forms During Disposal in Rock Salt Formations. (Unknown Journal!), 1987.

3949. Smailos, E., ; mechanical tests of
Stichel, W., ; Koester, R., and X corrosion studies and metallic materials for thex design of containers for 


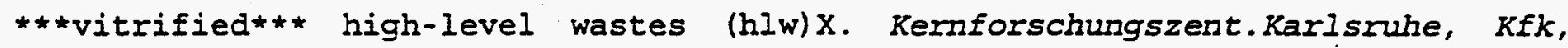
Kfk 3230, $71 \mathrm{pp}, 1994$.

3950. Smets, B.J. and Tholen, M.W. Leaching of glasses with molar composition $20 \mathrm{Na2O}$. 10RO - XAl2O3 . (70-x)SiO2. Joumal.of. the American.Ceramic.Society. v. 67 (Apr. '84):281-284, 1984 .

3951. Smets, B.J. Tholen, M.W.TL.R. Journal. of. the.American.Ceramic.Society. V. 67 (Apr. '84):281-284, 1984.

3952. Smith Reaction sequences in simulated neutralized current acid waste slurry during processing with formic acid. (Unknown Journal!) : (9 p), 1993.

3953. Smith, Hart, and Lumpkin Description of the kinetics and mechanisms which control the release ofhlw [high-level radioactive waste] elements from synroc. Mater.Res.Soc.Symp.Proc. , 1991.

3954. Smith, C.,Jr. The vibrational spectra of high-purity and chemically-substituted vitreous silicas, Alfred, NY:New York state College of Ceramics at Alfred University! 1973.

3955. Smith, D. Mineralogical, textural, and compositional data on the alteration of basaltic glass from Kilauea, Hawaii to 300 degrees C--insights to the corrosion of a borosilicate glass waste form. Mater.Res.Soc.Symp.Proc. $212: 115-121,1991$.

3956. Smith, D.J. Uk finds a solution for nuclear waste. Power Engineering $92: 44-47$, 1988 .

3957. Smith, D. A brief investigation of phosphate solubility in glasses, Alfred, N.Y.New York State College of Ceramics at Alfred University, 1936.

3958. Smith, H.D., Wiemers, K.D., Langowski, M.H., Powell, M.R,. and Larson, D.E. Reaction sequences in simulated neutralized current acid waste slurry during processing with formic acid. (Unknown Journal!), 1993.

3959. Smith, J.G. and $X$ ion chromatographic determination of boron in borosilicate glassesx. Anal.Chem.Nucl.Technol., Proc.Conf.Anal.Chem. Energy Technol.,X 25th, Meeting Date 1-7, 1994.

3960. Smith, P., K., ; Baxter, C., A., and $X$ fracture during cooling of cast borosilicate $* \star$ glass $* \star \star X$ containing nuclear wastesX. Report, $D p-1602$; order No.De82002602, 51 pp, 1982.

3961. Smith, R.A., Nyman, D.H., and Anderson, B.N. Westinghouse Hanford plans facility to vitrify defense nuclear waste by 1999. JOM. v. 41 (Dec. '89):56-57, 1989.

3962. Snyder, D.E. and Gunnels, D.I. Remote operation of defense waste processing facility samplingx stations. In: 〈CI> Held in Conjunction with the American Nuclear Society WinterX Meeting.Held in Conjunction with the American Nuclear Society WinterX Meeting Proceedings of the Conference on Remote systems Technology 33rd. PublX by ANS, La Grange Park, IL, USA $p$ 90-93, Anonymous La Grange Park, IL, USA : 1986, p. 90-93. 
3963. Soares, M.I.L. and Gomes, H. Development of Work on the Treatment of Radioactive wastes at IPR (Instituto de Pesquisas Radioativas, Minas Gerais, Brazil). (Unknown Journal!), 1974.

3964. Sobolev I., A., ; Barinov, A., S., ; Ozhovan, M., I., and X full-scale tests under natural conditions of radioactive wasteX solidification productsX. At. Energ., 69, 306-9X-9X, 1994.

3965. Sobolev, Lifanov, and stefanovskii Vitrification of sulfate- and chloride-containing radioactive waste inan electric furnace. Glass Ceram. (Engl.Transl.), 1990.

3966. Sobolev, Makarchenko, and Stefanovskii High-temperature immobilization of harmful industrial waste in glass. Glass Ceram.(Engl.Transl.), 1991.

3967. Sobolev, I., A., ; Lifanov, F.: ; stefanovskii, s., V., ; Dmitriev, S., X A., ; Musatov, N., D., ; Kobelev, A., P., ; zakharenko, V., N., and $X$ experimental nuclear power plant $\star \star \star$ radioactive*t* $\star \star \star$ waste $\star \star \star X$ processing at $a$ ***itrification*** pilot plant with aX continuous electric melterX. At.Energ., $69,233-6 X-6 X, 1994$.

3968. Sobolev, I., A., ; Lifanov, F., ; Stefanovskii, S., V., ; Kobelev, A., P., iX Zakharenko, V., N., ; Misatov, N., D., ; Krylova, N., and X **vitrification*** of sulfate- and chloride-containingx ***radioactive*** ***wastes** in an electric furnaceX. Steklo Keram., (7), 5-6X-6X, 1994.

3969. Sobolev, I., A., ; Makarchenko, G., V., ; Stepanovskii, S., ; Lifanov, $F ., X$ A., and $X$ high-temperature immobilization of harmful industrial wastes inX glassX. Steklo Keram., (3), 8-11X-11X, 1994..

3970. Sobolev, I., A., ; Lifanov, F., ; Stefanovskii, S., V., ; Dmitriev, S., X A., ; Zahkarenko, N., D., ; Musatov, N., and $X$ some characteristics of stable liquation in $\star \star *$ vitrification $* \star \star x$ of sulfate- and chloride-containing

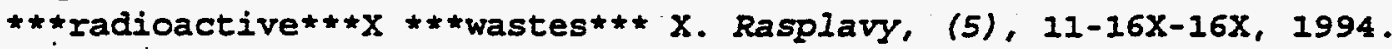

3971. Sobolev, I.A., Lifanov, F.A., Stefanovskii, s.V., Dmitriev, S.A., Zakharesko, V.N., and Musatov, N.D. Some systematic features of the stability against phase separationX during vitrification of radioactive wastes containing sulfates andX chlorides. Melts 3:297-302, 1991.

3972. Sobolev, I.A., Lifanov, F.A., Stefanovskii, S.V., Kobelev, A.P., zakharenkov, V.N., Musatov, N.D., and Krylova, N.V. Vitrification of Sulfateand Chloride-Containing Radioactive waste in an Electric Furnace. Glass.and.ceramics. 47, Numbers 7-8:235-240, 1991.

3973. Sobolev, I.A., Makarchenko, G.V., stefanovskii, S.V., and Lifanov, F.A. High-temperature immobilization of harmful industrial waste in glass. Glass and Ceramics 48:97-102, 1991 .

3974. Sobolev, I.A., Makarchenko, G.V., Stefanovskij, S.V., and Lifanov, F.A. High-temperature immobilization of hazardous industrial wastes inX glass. steklo i Keramika 3:8-11, 1991. 
3975. Soga, N., Tanaka, K., and ota, R. Construction of phosphate glasses containing chromium oxide and observations on their chemical durability, 1986.

3976. Solomah, A.G. and Odoj, R. Investigations of the volatilization of molybdenum and ruthenium duringx subsolidus sintering of modified synroc-b crystalline waste forms. Nuclear Technology 67:92-101, 1984.

3977. Sombret Amorphous glasses used for radioactive waste packagingX. J.NUCL.MATER. - 71X, 1994.

3978. Sombret, c. Status of french high-level radioactive wastes solidification. In: <CI> Selected Papers presented at the American Nuclear Society TopicalX Meeting Publ by Battelle Press, Columbus, OH and Richland, WA, USA andX Springer-Verlag, New York, $N Y$, USA and Heidelberg, West Ger $p$ 50-53, Anonymous Columbus, $O H$ and Richland, WA, USA:Battelle Press, 1983,p. 50-53.

3979. Sombret, C. Vitrification of High Level Wastes in France. (Unknown Journal!) , 1984.

3980. Sombret, C. Glasses used for high level radioactive waste storage. In: Colloque de Metallurgie 26th. Publ by Masson, Paris, Fr and New York, $X$ NY, USA $p$ 447-460, Anonymous Paris, Fr and New York, $X$ NY, USA:Masson, 1984, P. 447-460.

3981. Sombret, C. French Industrial Plants for Nuclear Waste Vitrification. (Unknown Journal!) , 1987.

3982. Sombret, C., Jouan, A., Fournier, W., Alexandre, D., and Leroy, L. Start-up of commercial high level waste vitrification facilities at La Hague. (Unknown Journal!), 1991.

3983. Sombret, C. and Maillet, J. Eigh-Level Waste Vitrification: The State-of-the-Art in France. (Unknown Jourpal!), 1988.

3984. Sombret, C., G., and $X$ the **tvitrification** of high level

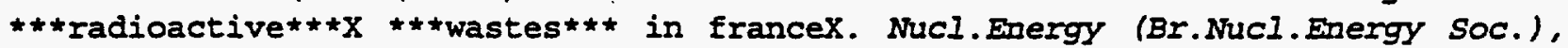
$24,85-98 X-98 X, 1994$.

3985. Sombret, C., G., and X vitrification experience and projects in francex. Fuel Reprocess.Waste Manage., Proc.- Am.Nucl.Soc.Int.Top.X Meet., Volume 1 , 92-100:ark, IIl, 1994 .

3986. Sombret, $C$. and $X * \star \star g l a s s * * *$ as a medium for the ultimate disposal of

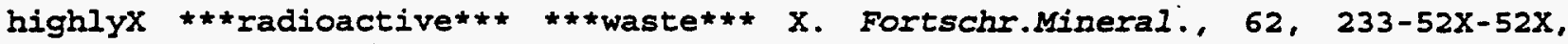
1994.

3987. Sombret, $C$. and $X$ glasses considered as an amorphous structure utilized forX containment of $\star \star \star$ radioactive $* \star * *$ wastes $* \star x$. Collog.Metall., 21st, 179-203X-203X, 1994 .

3988. Sombret, $C$. and $X$ glasses used for the storage of high-level

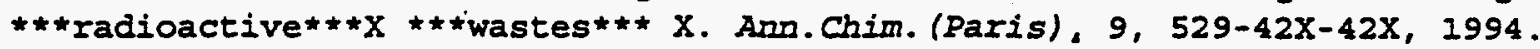


3989. Sombret, C.G. Vitrification experience and projects in france. In: $v 1$. Publ by ANS, La Grange Park, IL, USA $p$ 92-100, Anonymous La Grange Park, II, USA:ANS, 1984, p. 92-100.

3990. Sombret, C.G. Vitrification Experience and Projects in France. (Unknown Joumal!) , 1984 .

3991. Sombret, C.G. Vitrification of high level radioactive wastes in france. Nuclear Energy 24:85-98, 1985.

3992. Sombret, C.G. French high level nuclear waste program - key research areas. In: Materials Research Society Symposia Proceedings $v$ 50. Publ by MaterialsX Research Soc, Pittsburgh, PA,USA $p$ 37-44,Anonymous Pittsburgh, PA, USA:MaterialsX Research Soc, 1986,p. 37-44.

3993. Sombret, C.G. and $X$ vitrification of fission product solutions in franceX. Nucl.Eur., 8, 11X, 1994.

3994. Sombret, C.C.,MichelX vitrification of fission product solutionsX. Clefs Cea, 10, 14-21X-21X, 1994.

3995. Sombret, G. French High-Level Nuclear Waste Program: Key Research Areas. (Unknown Journal!) , 1985.

3996. Soo, P. and Milian, L.W. Impact of LWR Decontaminations on Solidification, Waste Disposal and Associated Occupational Exposure: Effects of Composition on the strength, Swelling, and water-Immersion properties of Cement-Solidified Ion-Exchange Resin Wastes. Technical rept. (Unknown Journal!) , 1991.

3997. Soper, P., Walker, D., and Plodinec, J. Optimization of glass composition for the vitrification of nuclear waste atthe savannah river plant. Am.Ceram.SOC.BuIl. , 1983.

3998. Soper, P.D., ; Walker, D.D., ; Plodinec, M., John; Roberts, X.G., ; Lightner, L.F., and $X$ optimization of $\star *$ glass $* \star$ composition for theX ***itrification*** of nuclear waste at the savannah river plantx. Am.Ceram.Soc.Bul1., 62, 1013-18X-18X, 1994.

3999. Soper, P., Walker, D., and Plodinec, M.J. Optimization of glass composition for the vitrification of nuclear waste at the Savannah River plant. American.Ceramic.society.Bulletin. v. 62 (Sept. '83):1013-1018, 1983.

4000. Soundararajan, R. Overview of present day immobilization technologies. Journal.of.Hazardous.Materials. Journal of Hazardous, 1990.

4001. Soundararajan, R. Overview of present day immobilization technologies. <CT Proceedings of the Gulf Coast Hazardous Substance Research CenterX Second Annual Symposium: Mechanisms and Applications ofx Solidification/stabilization <CL> Beaumont, IX, USA <CD> 1990 Feb $15-16$ Journal of Hazardous Materials $24: 199-212$, 1990 .

4002. Soundararajan, R. Overview of present day imnobilization technologies.x. Joumal.of.Hazardous.MaterialsX. Journal of Hazardous, 1990. 
4003. Sousselier and Pradel Management of radioactive wastes and their long-term storagex. Report. -8X, 1971.

4004. Sousselier, $Y$. and $X * \star \star v i t r i f i c a t i o n * * *$ of high-level wastes in franceX. Waste Disposal Other Radiat.Probl.Nucl.Ind., Proc.Int.SummerX Sch.Radiat.Prot., 4 th, 171-80-80, 1994 .

4005. Spencer Evaluations of glass vitrification techniques on iron ratio determinations.' (Unknown Journal!) : (8 p), 1991.

4006. Speranzini, R., A., ; Hayward, P., J., and $x$ development of sphene-based ***glass*** -ceramics for disposal ofX some canadian wastesX. Adv.Ceram., 8 , $273-81 X-81 X, 1994$.

4007. Speranzini, R.A. and Buckley, I.P. Sumiary of Methods for Conditioning and Immobilizing Ion-Exchange Resins. (Unknown Journal!) , 1983.

4008. Speranzini, R.A. and Hayward, P.J. Development of sphene-based glass-ceramics for disposal of somex canadian wastes. In: <CI> Held during the 85 th Annual Meeting of the American CeramicX Society Advances in Ceramics $v 8$. Publ by American Ceramic SOC Inc, Columbus, $X$ OH, USA $p$ 273-281, Anonymous Columbus, $X$ OH, USA:American Ceramic SOC Inc, 1984,p. 273-281.

4009. Spilker, H. Naturzugkuehlung waermeerzeugender radioaktiver abfaelle in transport-X und lagerbehaeltern. Kerntechnik 54:270-278, 1989.

4010. Spilker, H. and Huggenberg, R. Status of the thermal evaluation and development of transport andX storage casks for vitrified high level wastes. In: American Society of Mechanical Engineers (Paper). PubI by ASME, NewX York, NY, USA.p 1-16, Anonymous NewX York, NY, USA:ASME, 1991, P. 1-16.

4011. Spilman, D., B., ; Hench, L., L., ; Clark, D., E., and X devitrification and subsequent effects on the leach behavior of ax simulated borosilicate nuclear waste glassX. Nucl.Chem. Waste Manage., 6, 107-19X-19X, 1994.

4012. Spilman, D.B., Hench, L.I., and Clark, D.E. Devitrification and subsequent effects on the leach behavior $X$ of a simulated borosilicate nuclear waste glass. Nuclear.and.Chemical. Waste.Management. v. 6 no2 (186):119, 1986.

4013. Spilman, D.B., Hench, L.L., and Clark, D.E. Devitrification and subsequent. effects on the leach behavior of ax simulated borosilicate nuclear waste glass. Nuclear and Chemical Waste Management 6:107-119, 1986.

4014. Spilman, D.B.AH. and Clark, D.E. Devitrification and subsequent effects on the leach behavior $x$ of a simulated borosilicate nuclear waste glass.XJo Nuclear and Chemical Waste Management. (Unknown Journal!) v. 6 no2 ('86):107-119, 1986 .

4015. Spinosa, E. and Means, J. Progress report on experimental evaluation of a nuclear waste glasscorrosion model. Adv.Ceram. , 1986.

4016. Spitsyn, V., I., ; Minaev, A., A., ; Barsova, L., ; Glazunov, P., Ya., ;X Vechkanov, V., N., and $X$ the study of the interaction of the components of 


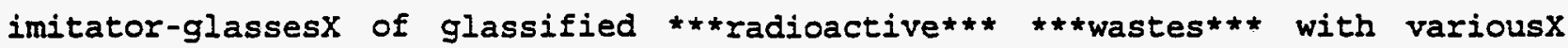
surrounding rocksX. Mater.Res.Soc.symp.Proc., 6,X 9-14X-14X, 1994.

4017. Sproull, J.F., Marra, S.L., and Jantzèn, C.M. High level radioactive waste glass production and product description. (Unknown Journal!), 1993.

4018. St Pierre, J., ; Tran, H., H., ; Zikovsky, L., and $\mathrm{X}$ immobilization of

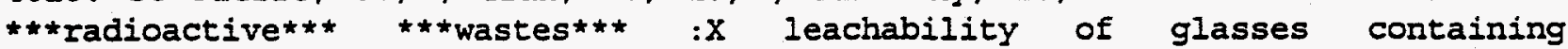
zirconiumx. J.Nucl.Mater., 107, 286-9X-9X, 1994.

4019. St., Pierre, J.Z.,L., and $X$ long-term leaching behavior of glasses containing zirconiumX. J.Nucl.Mater., 125, 320-5X-5X, 1994.

4020. Stahl, D. and Cloninger, M. Waste acceptance for vitrified high-level waste forms. Ceram.Trans. , 1991.

4021. Stahl, D. and $X$ waste acceptance for vitrified high-level waste formsX. Ceram.Trans., 23, 433-41X-41X, 1994.

4022. Stahl, D. and Miller, N.E. Long-Term Performance of Materials Used for High-Level Waste Packaging, First Quarterly Report, Year Four April - June 1985. (Unknown Journal!) , 1985.

4023. Stahl, D. and Miller, N.E. Long-Term Performance of Materials Used for High-Level Waste Packaging, Third Quarterly Report, Year Three, October December 1984. (Unknown Journal!) , 1985.

4024. Stahl, D. and Miller, N.E. Long-Term Performance of Materials Used for High-Level Waste Packaging. Annual Report, Year Three, April 1984-April 1985. (Unknowns Journal!) , 1985.

4025. Stahl, D. and Miller, N.E. Long-Term Performance of Materials Used for High-Level Waste Packaging, Second Quarterly Report, Year Four July-September 1985. (Unknown Journal!) , 1986.

4026. Stahl, D. and Miller, N.E. Long-Term Performance of Materials Used for High-Ievel Waste Packaging, Annual Report, Year Four, April 1985-March 1986. (Unknown Journal!) , 1986.

4027. Staley, L.TS. Journal.of.the.Air.\&.Waste.Management.Association. $v .42$ (Oct. '92): 1372-1376, 1992 .

4028. Stalios, A., D., ; De Batist, R., ; Van Iseghem, P., and $X$ long term crystallization behavior of glasses at temperatures $t<t g x$. Mater.Res.SOC.Symp.Proc., 127, 163-71X-71X, 1994.

4029. Stalios, A., D., ; De Batist, R., and $X$ crystallization behavior of a ferrisilicate .alpha.-waste glassx. Mater.Res.Soc.Symp.Proc., 50,X $255-62 X-62 X, 1994$.

4030. Stalios; A., D., ; Delavignette, P., ; De Batist, R., and $x$ tem observation of the crystallization behavior of a complexx ferrisilicate .alpha. -waste glassX. Adv.Ceram., 20, 133-40X-40X, 1994. 
4031. Stalios, A.D. and De Batist, R. Crystallization behavior of a ferri-silicate alpha -waste glass. In: Materials Research Society Symposia Proceedings $v$ 50. Publ by MaterialsX Research SOC,Pittsburgh, PA, USA $p$ 255-262,Anonymous Pittsburgh, PA, USA:MaterialsX Research Soc, 1986,p. 255-262.

4032. Stalios, A.D., Delavignette, P., and De Batist, R. TEM observation of the crystallization behavior of a complex ferrisilicate alpha -waste glass. Adv. Ceram. 20:133-140, 1986.

4033. Stammler, M.E.,RolfX a method of $* *$ vitrifying*** dissolver sludge (product andX process development)X. Proc.Symp.Waste Manage., 1, 293-307X-307X, 1994.

4034. Staples Effects of hiping time, temperature and pressure on experimental icpp waste form properties. (Unknown Journal!) : (32 p), 1914.

4035. Staples, Cole, and Geczi Development of candidate high-level waste glasses. Adv. Fusion Glass , 1988.

4036. Staples, B. and Miley, D.V. Effects of HIPing time, temperature, and pressure on experimental ICPP [Idaho Chemical Processing Plant] waste form properties. Ceram.Trans. 23:27-35, 1991.

4037. Staples, B., A., ; Cole, H., S., ; Geczi, L., and X development of candidate high-level waste glassesX. Adv.Fusion Glass, Proc.Int.Conf., 1st, 52-52, 1994 .

4038. Staples, B., A., ; Pálica, D., ; Cole, H., S., and X properties of formula $127 * \star \star g l a s s * \star$ prepared with radioactiveX zirconia calcineX. Report, Enico-1120; Order No.De83000790, 52 pp, 1983.

4039. Staples, B.A., Rnecht, D.A., and Berreth, J.R. Technology for the Long-Term Management of Defense HIW (High-Level Waste) at the ICPP (Idaho Chemical Processing Plant). (Unknown Journal!), 1986.

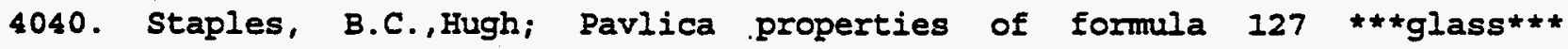
prepared with radioactivex zirconia calcineX. Mater.Res.Soc.Symp.Proc., 15, X $125-34 X-34 X, 1994$.

4041. Stefanovskii structure and some properties of glasses for the immobilization ofradioactive waste of medium activity. Sov.J.Glass Phys.Chem. (Engl.Trans1.) , 1990.

4042. Stefanovskii structure and some properties of glasses for immobilization ofradioactive wastes with an intermediate level of activity. Fiz.Khim.Stekla , 1990.

4043. Stefanovskii, Ivanov, and Gulin Ir and electron paramagnetic resonance spectra of aluminoborosilicateand aluminophosphate glasses, imitating vitrified radioactive wastes. Fiz.Khim.Stekla , 1990.

4044- Stefanovskii, S.V. Structure and some properties of glasses for the immobilization ofx radioactive waste of medium-activity. Soviet Jounal of Glass Physics and Chemistry 16:443-451, 1991. 
4045. Stefanovskii, S.V. EPR and IR spectroscopic study of the structure of Borosilicate Glasses for Immobilizing Radioactive wastes. Soviet.radiochemistry. 34, Number 3:422, 1992.

4046. Stefanovskii, S.V. EPR and Ir Spectroscopic study of the structure of Borosilicate Glasses for . Immobilizing Radioactive-Wastes. SOV.RADIOCHEM-ENGL.TR. 34:422-427, 1992.

4047. Stefanovskii, S., A., ; Lifanov, $F_{.,}$and $X$ phase separation upon immobilization of sulfate-containingX $\star \star \star$ radioactive $\star \star \star \star \star \star \star$ wastes $* \star \star$ in calcium oxide-boronX oxide-silica $* \star \star$ glass $* *$ X. Radiokhimiya, 30, 825-9X-9X, 1994 .

4048. Stefanovskii, S., B., ; Sobolev, I., A., ; Lifanov, F., ; Dmitriev, S.. and $X$ microstructure and chemical stability of glasses containing $x$ intermediate-level radioactive wastesX. Radiokhimiya, 30, 820-4X-4X, 1994 .

4049. Stefanovskii, S.V., Ivanov, I.A., and Gulin, A.N. Ir and epr spectra of aluminoborosilicate and aluminophosphate glassesX simulating vitrefied radioactive wastes. Soviet Journal of Glass Physics and Chemistry 17:83-87, 1991.

4050. Stefanovskii, S.v., Knyazev, J.A., and Dmitriev, S.A. Vitrification of radioactive waste in a plasma reactor. Physics and Chemistry of Materials Treatment $25: 386-393,1991$.

4051. Stefanovskii, s.V., Ozhovan, M.I., and Karlina, O.K. Spectroscopic Study of Glass Compositions for Immobilization of Radioactive-Wastes. SOV.RADIOCHEM-ENGL.TR. 34:505-510, 1992 .

4052. Stefanovskii, S.V., Sazonov, A.I., Kuz'min, A.Y., and Purans, Y.Y. Local Environment of Cobalt Atoms in Borosilicate Glasses. The. Soviet. journal.of.glass.physics.and.chemistry.PY.-.1992. 17, Number $5: 413-417,1994$.

4053. Stefanovskii, S.V. and Trul', O.A. Radiation-Induced Paramagnetic Centers and the structure of silicate Glasses for Immobolizing xthe Ashes of Burnt Radioactive Waste Materials. Journal.of.applied.spectroscopy. 57, Number 3-4:769-771, 1992 .

4054. Stefanovskii, S., V., ; Ivanov, I., A., ; Gulin, A., N., ; Lifanov, F., and $X$ incorporation of sodium-containing $\star \star \star$ radioactive $* \star x ~ * \star *$ wastes $\star \star \star$ into $a$ loam-based ***glass*** X. Radiokhimiya, 35, 106-13X-13X, 1994.

4055. Stefanovskil, S., V., ; Ivanov, I., A., ; Gulin, A., N., and X study of the structure of glasses, containing ash of incineratedx radioactive wastes, by the ir spectroscopy methodx. zh.Prikl.Spektrosk., 57, 67-74X-74X, 1994.

4056. Stefanovskii, S., V., ; Ivanov, I., A., ; Gulin, A.,.N., and X specific features of the structure of borosilicate glasses based onX datolite for immobilization of radioactive wastes according to thex ir spectroscopy datax. Zh.Prikl.Spektrosk., 54, 648-51X-51X, 1994. 
4057. Stefanovskii, S., V., ; Ivanov, I., A., ; Gulin, A., N., and X ir and epr spectra of aluminoborosilicate and aluminophosphatex glasses simulating

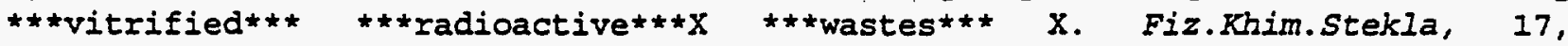
$120-5 X-5 X, 1994$.

4058. Stefanovskii, S., V., ; Knyazev, I., A., ; Dmitriev, S., and $x$

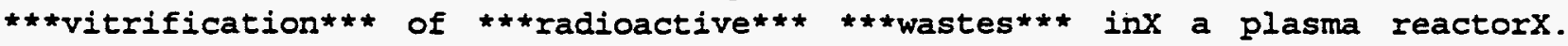
Fiz.Khim. Obrab.Mater., (4), 72-80X-80X, 1994.

4059. Stefanoviskii, S., V., ; Minaev, A., A., ; Lifanov, F., and X lead-containing glasses for immobilization of radioactive wastesx. Radiokhimiya, 32, 162-6X-6X, 1994.

4060. Stefanovskii, S., V., ; Ozhovan, M., I., ; Karlina, O., K., and X spectroscopic investigation of the $\star * \star$ glass $* \star$ compositex materials for immobilization of $\star \star \star$ radioactive $* *$ ***wastes $* \star x$. Radiokhimiya, 34 , $106-12 X-12 X, 1994$.

4061. Stefanovskii, S., V., ; Sazonov, A., I., ; Kuz'min, A., Yu., ; Purans, $Y ., X$ Ya., and X local environment of cobalt atoms in borosilicate glassesX. Fiz.Khim.Stekla, 17, 744-9X-9X, 1994.

4062. Stefanovskii, S., V., ; Trul, O., A., and $X$ radiation-induced paramagnetic centers and the $* \star \star s i l i c a t e * \star X$ to $\star *$ glass*** structure for immobilization of incineratedX $\star \star \star$ radioactive*t* $\star \star \star$ waste $* \star *$ ashX. Zh.Prikl.Spektrosk., 57, 322-6X-6X, 1994.

4063. Stefanovskii, S., $\nabla .$, and $X$ epr and ir spectroscopic study of the structure of borosilicatex glasses for immobilization of radioactive wastesX. Radiokhimiya, 34, 214-22X-22X, 1994.

4064. Stefanovskii, S., V., and $X$ structure and some properties of glasses for immobilization ofX medium-level radioactive wastesX. Fiz.Khim.stekla, 16, $818-27 X-27 X, 1994$.

4065. Stefanovskii, $S_{.}, V_{.}$, and $X$ immobilization of sulfate-containing

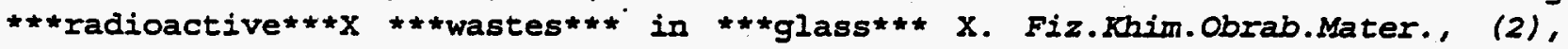
$63-77 X-77 X, 1994$.

4066. Stefanovskii, S., Knyazev, I., and Dmitriev, S. Vitrification of radioactive waste in a plasma reactor. Physics.and.Chemistry.of.materials.treatment. 25, Number 4:386-393, 1991.

4067. Stefanovskij, $S$. The immobilisation of sulfat-contained radioactive waste in the glass. Fizika i Khimiya Obrabotki Materialov 2:63-77, 1993.

4068. Stefanovskij, S.V., Ivanov, I.A., and Gulin, A.N. Ir and esr spectra of alumoborosilicate and alumophosphate glasssesX imitating vitrified radioactive wastes. Fizika $i$ Khimiya Stekla 17:120-125, 1991.

4069. Stefanovskij, S.V., Knyazev, I.A., and Dmitriev, S.A. On volatilization of unhomogenic melts microcomponents. Rasplavy 6:36-41, 1991. 
4070. Stefanovskij, S.V., Knyazev, I.A., and Dmitriev, S.A. Vitrification of radioactive wastes in plasma reactor. Fizika $i$ Khimiya Obrabotki Materialov $4: 72-80,1991$.

4071. Stefanovskij, S.V., Sazonov, A.I.; Kuz'min, A.Y., and Purans, Y.Y. Local surrounding of cobalt atoms in borosilicate glasses. Fizika i Khimiya stekla $17: 744-749,1991$.

4072. Stejskal, J., Alexa, J., Kepak, F., Suessmilch, J., and Vojtech, 0 . vitrification of radioactive liquid wastesx. Czech., 2 pp, 1994.

4073. Stejskal, J., ; Voldan, J., ; Vojtech, 0. , and $X$ the system sodium borate (na20.b203)-aluminum oxide-phosphorusx pentoxide as a medium for ***Vitrification*** fixing of wastesx from nuclear power plants.simple experiment and a test for ax technological melting apparatusx. Ustav Jad.Vyzk., , Ujv 6387-CH, $31 \mathrm{pp}-\mathrm{CH}, 31 \mathrm{pp}, 1994$.

4074. Stepanek, V., ; Urbanec, Z., and X statistical treatment of experiments in the research of theX vitrification of reactor wastex. Nucleon (Rez, Czech.), (2), 10-13X-13X, 1994 .

4075. Steude and Tonner Detection of free liquid in cement-solidified radioactive waste drumsusing computed tomography [ct]. Mater.Res.Soc.Symp.Proc. , 1991.

4076. Stevanovic, D.V., Thompson, D.A., and vance, E.R. Rutherford backscattering investigation of radiation damage effects on the leaching of sphene and sphene-based glass-ceramics. Journal of Nuclear Materials 161:169-174, 1989 .

4077. Stinton, D., Angelini, and Caputo, A. Coating of crystalline nuclear waste forms to improve inertness. J.Am.Ceram.Soc. , 1982.

4078. Stoessel, J. Self-consistent phonon theory of aperiodic solids and density functional theories of freezing and vitrification /. 1985.

4079. Stone, J., A., ; Allender, J., S., ; Gould, T., H., , and X comparison of properties of borosilicate $\star \star \star g l a s s * \star$ andX crystalline ceramic forms for immobilization of savannah river plantx wastex. Report, $D p-1627$; Order No.De82014133, 144 Pp, 1982.

4080. Stone, J. Comparison of properties of borosilicate glass and crystalline ceramic forms for immobilization of Savannah River Plant waste /, Aiken, $S$. C. :E. I. du Pont de Nemours \& Co., Savannah River Laboratory, 1982 .

4081. Stone, J.A. and $X$ an experimental comparison of alternative solid forms for savanahx river high-level wastesX. Mater.Res.Soc.Symp.Proc., 6, 1-8X-8X, 1994.

4082. Storch, W., A., ; Kroebel, R., H., ; Kahl, I., ; Friesel, M., ; Hutton, P., X H., ; Dawson, J., F., and $X$ investigations of the cooling of two high-level glass canisters byx acoustic emission analysis (aea) $x$. Proc.Symp.Waste Manage., (Waste Manage.'89, Vol. 1), 601-5X-5X, 1994. 
4083. Strachan and Schulz Glass and ceramic materials for the immobilization ofX megacurie-amounts of pure cesium-137X. Report. , 1976.

4084. Strachan and Schulz Vitrification of strontium-90 fluoridex, Report. , 1977 .

4085. Strachan, D. Effect of flow rate on the leaching of nuclear waste glass. Adv. Ceram. . 1985.

4086. Strachan, D. Effect of gamma irradiation on simulated waste glass leaching and on the leach vessel. J.Am.Ceram.Soc. $66[9]:$ C158-C160, 1983.

4087. Strachan, D., M., ; Turcotte, R., P., ; Barnes, B., O., and X mcc-1: a standard leach test for nuclear waste formsx. Nucl.Technol., 56, 306-12X-12X, 1994.

4088. Strachan, D., M., and X a general model for the dissolution of nuclear waste glasses in saltX brineX. Report, Pal/S2p-6676; Order No.De89000266, 57 Pp, 1988 .

4089. Strachan, D., M., and $X$ effect of flow rate on the leaching of nuclear

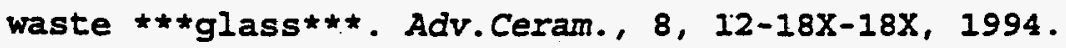

4090. Strachan, D.M. Results from a one-year leach test: long-term use of mcc-1. In: Materials Research Society Symposia Proceedings $V 11$.Publ byX North-Holland, New York, NY, USA and Amsterdam, Neth $p$ 181-191,Anonymous New York, NY, USA: 1982,p. 181-191.

4091. Strachan, D.M. Results from long-term use of the MCC-1 static leach test $X$ method. Nuclear.and.Chemical. Waste.Management. v. 4 no2 ('83):177-188, 1983.

4092. Strachan, D.M. Effect of flow rate on the leaching of nuclear waste glass. In: <CI> Held during the 85th Annual Meeting of the American CeramicX Society Advances in Ceramics $v 8$. Publ by American Ceramic Soc Inc, Columbus, $x$ OH, USA $p$ 12-18, Anonymous Columbus, $X$ OH, USA:American Ceramic SOC Inc, 1984,p. 12-18.

4093. Strachan, D.M., Pederson, L.R., and Lokken, R.O. Results from the Iong-Term Interaction and Modeling of SRL-13I Glass with Aqueous Solutions. (Unknown Journal!) , 1985.

4094.- Strachan, D.M., Pederson, L.R., and Lokken, R.O. Results from the long-term interaction and modeling of srl-131 glassX with aqueous solutions. In: Materials Research Society Symposia Proceedings $v$ 50. Publ by MaterialsX Research Soc, Pittsburgh, PA, USA P 195-202, Anonymous Pittsburgh; PA, USA:MaterialsX Research Soc, 1986,p. 195-202.

4095. Strachan, D.M., ; Krupka, K.M., and; Grambow, B. solubility interpretations of leach tests on nuclear wasteX $\star \star \star g l a s s * \star * X$. Nucl. Chem. Waste Manage., 5, 87-99X-99X, 1994. 
4096. Strachan, D.M. and $X$ effect of gamma irradiation on simulated waste $\star \star \star$ glass $* \star x \mathrm{X}$ leaching and on the leach vesselX. J.Am.Ceram.SoC., 66, C158-C160X-C160X, 1994.

4097. Strachan, D. Effect of gamma irradiation on simulated waste glass leaching $\mathrm{X}$ and on the leach vessel. Journal.of.the.American.Ceramic.Society. $v$. 66 (Sept. '83):C158-C160, 1983.

4098. Strachan, D., Krupka, K., and Grambow, B. Solubility interpretations of leach tests on nuclear waste glass. Nuclear.and.Chemical. Waste.Management. v. 5 no1 ('84):87-99, 1984 .

4099. Straschewski, H. Apparatus for [remote] withdrawing a sample from a glass-melting furnace. (Unknown Journal!), 1989.

4100. Strathdee, G., G., ; McIntyre, N., S., ; Taylor, P., and X development of aluminosilicate and borosilicate glasses as matrixesx for candu high-level wastex. Ceram.Nucl.Waste Manage., Proc.Int.Symp., Issue Conf-790420,X 243-7-7, 1994.

4101. Stritzke, D. Method and device for the removal of the suction tube of a glass-filledfinal [nuclear waste] storage container. (Unknown Journal!), 1984.

4102. Stritzke, D. Melting furnace for vitrifying highly radioactive waste. (Unknown Journal!) , 1987.

4103. Stritzke, D., Ewest, E., and Heimerl, W. Method of producing a glass block containing radioactive fission products and apparatus therefor. (Unknown Journal!) , 1986.

4104. Stritzke, D., Ewest, E., and Meimerl, W. filling a metallic receiver of a radioactive molten vitreousX composition and a device for receiving itx. Belg., $13 \mathrm{pp}, 1994$.

4105. Strizke, D. and Ewest, E. Method of preparing a suction mold for receiving vitrified radioactivewaste materials and apparatus therefor. (Unknown Joural!) , 1987.

4106. Stukenbroeker, G.I. and Suriani, E. Fixation of high-level radioactive wastesX. Us., 1994 .

4107. Sturcken Use of 'self-heating' ceramics as crucibles for microwave melting metals and nuclear-waste glass. (Unknown Journal!) : (8 p), 1927.

4108. Sturcken Use of self-heating ceramics as crucibles for microwave melting metals andnuclear waste glass. Ceram.Trans., 1991.

4109. Sturcken, E., F., and X the use of "self heating" ceramics as crucibles for microwavex melting metals and nuclear waste glassx. Ceram.Trans., 21, 433-40X-40X, 1994.

4110. Sturcken, E.F. Method of Determining Weight Percent Solids in SRAT/SME Slurries as a Function of Temperature. (Unknown Journal!) , 1986. 
4111. Su, $X$ selection of materials for the removal of volatile ruthenium from $x$

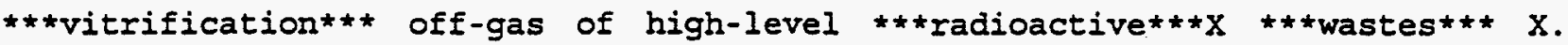
Yuanzineng Kexue Jishu, 25, 50-7X-7X, 1994.

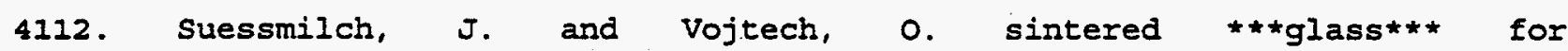

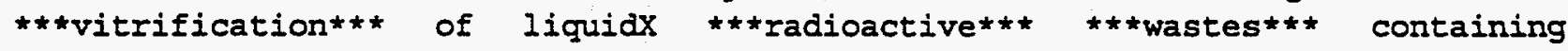
chromium inX dissolved and solid formsx. Czech., 2 pp, 1994.

4113. Sullivan, $T$. and Machiels, A. Growth of hydrated gel layers in nuclear waste glasses. Adv.Ceram. , 1985.

4114. Sullivan, T.M. and Machiels, A.J. Growth of hydrated gel layers in nuclear waste glasses. In: 〈CI> Held during the 85th Annual Meeting of the American CeramicX Society Advances in Ceramics $v$. Publ by American Ceramic SOC Inc, Columbus, $X$ OH, USA $P$ 519-527, Anonymous Columbus, $X$ OH, USA:American Ceramic Soc Inc, 1984,p. 519-527.

4115. Sullivan, T.M. and Machiels, A.J. Modeling chemical interactions in the hydrated layers of nuclear wastex glasses. In: <CI> Symposium held as part of the Annual Meeting of the MaterialsX Research Society Materials Research Society Symposia Proceedings v 26. Publ byX North-Holland, New York, NY, USA and Amsterdam, Neth p 597-604, Anonymous New York, NY, USA: 1984,P. 597-604.

4116. Sullivan, T.M.,.; Machiels, A.J., and $\mathrm{X}$ modeling chemical interactions in the hydrated layers of nuclearX waste glassesX. Mater.Res.Soc.Symp.Proc., 26,X 597-604X-604X, 1994.

4117. Sullivan, T.M., ; Machiels, A.J., and $X$ growth of hydrated gel layers in nuclear waste glassesX. Adv. Ceram., 8, 519-27X-27X, 1994.

4118. Sullivan, T.M. and $X$ predictive modeling of diffusional processes within the hydratedx layer of $\star \star \star v i t r i f i e d * \star \star$ nuclear waste formsX. (Unknown Journal!) $182 \mathrm{pp}-5 \mathrm{X}, 1994$.

4119. Sunder Rajan, Kumra, and Thomas Waste immobilization plant at tarapur. survey of process and designX featuresx. Symp.Manage.Radioactive. Wastes.Fuel.Reprocess. -704, 1972.

4120. Sundquist Preliminary corrosion studies of glass ceramic code 9617 and ax sealing frit for nuclear waste canistersx. Report. , 1979.

4121. Surma Evaluation of the graphite electrode dc arc furnace for the treatment of inel buried wastes. (Unknown Journal!) : (67 p), 1993.

4122. Susman, S., Volin, K., and Liebermann structural changes in irreversibly densified fused silica: implications forthe chemical resistance of high level nuclear waste glasses. Phys.Chem.Glasses, 1990.

4123. Susman, S., ; Volin, K., J., ; Liebermann, R., C., ; Gwanmesia, G., D., and; wang, $X$ structural changes in irreversibly densified fused silica: $X$ implications for the chemical resistance of high-level nuclear wastex glasses [erratum to document cited in cal13(14):122405h]X. Phys.Chem.Glasses, 31, 222X, 1994. 
4124. Susman, S., ; Volin, K., J., ; Liebermann, R., C., ; Gwanmesia, G., D., and $;$ Wang, $X$ structural changes in irreversibly densified fused silica:X implications for the chemical resistance of high-level nuclear wastex glassesx. Phys.Chem.Glasses, 31, 144-50X-50X, 1994.

4125. Susman, S., Volin, K.J., Liebermann, R.C., Gwanmesia, G.D., and Wang, Y. structural changes in irreversibly densified fused silica. implicationsX for the chemical resistance of high level nuclear waste glasses. Physics and Chemistry of Giasses 31:144-150, 1990.

4126. Sutcliffe, W.G. Fissile materials from nuclear arms reductions: $A$ question of disposition. (Unknown Journal!), 1991.

4127. Suzuki, A.U.,Hiroyuki; Kiyose an uncertainty analysis on leaching rate measurements of nuclearx waste glassx. Ber.Kernforschungsanlage Juelich , Juel-Conf-54, Proc.Int.X Semin.Radioact. Waste Prod., 370-88X-88X, 1994.

4128. Swanson, J., $L .$, and $X$ composition of high fission product wastes resulting from futurex reprocessing of commercial nuclear fuelsx. Report, PnI-5830; Order No.De86014820, 40 pp, 1986.

4129. Swanson, J.L. Clean option: An alternative strategy for Hanford Tank Waste Remediation. Volume 2, Detailed description of first example flowsheet. (Unknown Journal!) , 1993.

4130. T.Banba, T.Murakami, and H.Kimura BT - Leaching Mechanisms CT - Moving Boundary Model for Leaching of Nuclear Waste Glass ED - Carol M. Uantzen ED John A.Stone E - Rodney C.Ewing Anonymous 1985,p. 113-120.

4131. Tacca and Wicks Wipp/srl [waste isolation pilot plant/savannah river lab] in situ tests:miit [materials interface interactions test] program-surface studies ofsrl. waste glasses. Ceram.Trans. , 1990.

4132. Tacca, J. and Wicks, G. Radioactivity of dwpf [defense waste processing facility] waste glasscompared to natural uranium ore. Ceram.Trans. , 1991.

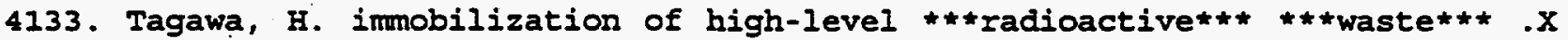
i. research objectiveX. Yokohama Kokuritsu Daigaku Karikyo Kagaku Kenkyr Senta Kiyo, 8,X 89-97X-97X, 1994.

4134. Tait, J., Hayward, P., and Rummens Crystallization and viscosity of sphene glass-ceramics containing simulatednuclear fuel recycle waste. Phys.Chem.Glasses , 1986.

4135. Tait, J., Hocking, พ.H., and Betteridge, J.S. Field burial results and SIMS analysis of the Chalk River glass blocks. Adv.Ceram. 20:559-565, 1986.

4136. Tait, J., C., ; Hocking, W., H., ; Betteridge, J., S., ; Bart, G., and X field burial results and sims analysis of the chalk river glassx blocksx. Adv. Ceram., 20, 559-65X-65X, 1994. 
4137. Tait, J., C., ; Jensen, C., D., and $X$ the effect of zinc(ii) ion adsorption on the durability of sodiumx borosilicate glassesx. J.Non-Cryst.Solids, 49, 363-77X-77X, 1994.

4138. Tait, J., C., '; Mandolesi, D., L., and $x$ the chemical durability of alkali metal aluminosilicate glassesx. At.Energy Can.Ltd., Aecl, Aecl-7803, 42 pp, 1994.

4139. Tait, J.C., Hayward, P.J., and Hocking, W.H. Aluminosilicate glass samples from the MIIT [Materials Interface Interaction Test] in situ WIPP [Waste Isolation Pilot Plant] salt burial test. Ceram.Trans. 9:363-376, 1990.

4140. Tait, J.C., Stroes-Gascoyne, S., and Hocking, W.H. Dissolution behavior of used CANDU fuel under disposal conditions. Mater.Res.SOc.Symp.Proc. $212: 189-196,1991$.

4141. Tait, J.C., ; Wilkin; D.L., ; Hamon, R.F., and X gama-radiolysis effects on leaching of nuclear fuel waste forms: $X$ influence of groundwaters and granite on gaseous radiolysis productsX. At.Energy Can.Ltd., Aecl, Aecl-8731, 25 pp, 1994.

4142. Takahashi, Y., Terai,. T., and Ohsato, T. Thermal conductivities of LiAlo sub 2 . Li sub 4 sio sub 4 , and $L_{i}$ sub 2 sno sub 3. Adv.Ceram. 27:199-218, 1990 .

4143. Takamori, T. and Tomozawa, M. Comment on 'Nonlinear viscous flow in glass forming'. American.Ceramic.Society.Bulletin. Am Ceram Soc Bull v, 1990.

4144. Takeda, T., Nakamura, H., and Niwa, K. Evaluation of Destruction Behavior of High-Level Radioactive Waste Glass. (Unknown Journal!) , 1987.

4145. Tamata, S. and Horiuchi, S. Process [alkali silicate] for solidifying radioactive waste. (Unknown Journal!) , 1986.

4146. Tammaro, D. Automated mass spectrometer for analysis of gas bubbles in glass. Americas.Ceramic.Society.Bulletin. American Ceramic Soc, 1994.

4147. Tanaka, S., Yamawaki, M., Nagasaki, S., and Moriyama, H. Geochemical Behavior of Neptunium. J.NUCL.SCI.TECFNOL. 29:706-718, 1992.

4148. Tanaka, $T$. solidification of boron-containing radioactive liquid wastes asX borosilicate glassX. Jpn.Kokai Tokkyo Koho, 4 pp, 1994.

4149. Tananaev, I.G. Preparation and Characterization of Neptunium(V) and Americium(V) Hydroxide Compounds. SOV.RADIOCHEM-ENGL.TR. 33:224-230, 1991.

4150. Tananaev, I.G. Solid-State Reaction of Certain Neptunium(V) Compounds with Bases. SOV.RADIOCHEM-ENGL.TR. 33:219-224, 1991.

4151. Tananaev, I.G. New Hydroxide Compounds of NP(V). SOV.RADIOCFEM-ENGL.TR. $34: 85-89,1992$.

4152. Tananaev, I.G. Hydroxide Compounds of Pu(V). SOV.RADIOCHEMM-ENGL.TR. 34:161-163, 1992 . 
4153. Tashiro, S., Banba, T., Mitamura, H., Kamizono, H., Kikkawa, S., Matsumoto, Muraoka, S., and Nakamura, H. Safety examination of hlw solidified products at wastef. In: High Level Radioactive Waste and Spent Fuel Management Proc 1989. JointX Int Waste Manage Conf $v 2$ (of 2).Publ by American Soc of MechanicalX Engineers (ASME), New York, NY, USA.p 153-157, Anonymous New York, NY, USA:American SOC of MechanicalX Engineers (ASME), 1989,p. 153-157.

4154. Tashiro, S., Morita, J., Tuboi, T., Kikkawa, S., and Shiota, U. Vitrification Apparatus. Design and Performance Test. (Unknown Journal!), 1984.

4155. Tashiro, S.T.,Akimasa; Mitamura mock-up tests for a hot

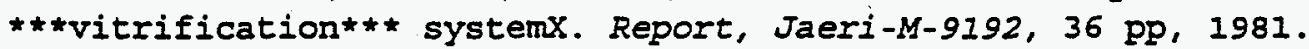

4156. Tashiro, S.M.,Junichi; Tuboi vitrification apparatus.design and performance testx. Report, Jaeri-M-84-044, 56 pp, 1985.

4157. Tawansi, A., Morsi, M., and El-Konsol, S. Electrical conductivity of gamma-irradiated Ti silicate glasses. J.Phys.Chem.Solids. 48[8]:723-728, 1987.

4158. Taylor A survey of methods for separating and immobilizing krypton-85 arising from a nuclear fuel reprocessing plant. (Unknown Journal!) :(36 p), 1990.

4159. Taylor, B., L., ; Metcalfe, B., ; Russen, L., C., and X measurement of incorporation levels of vitrified waste by $x$-rayX absorptiometryX. Report, Aere-R-12618, $30 \mathrm{pp}, 1988$.

4160. Taylor, C. The viscosity of suspensions of glass spheres, 1951.

4161. Taylor, P. a review of phase separation in borosilicate glasses, with referencex to nuclear fuel waste immobilizationx. At.Energy Can.Ltd., Aecl, Aecl-10173, 52 pp, 1994.

4162. Taylor, P. and owen, D. Iiquid immiscibility in complex borosilicate glasses. J.Non-Cryst.Solids, 1980.

4163. Taylor, P. Review of phase separation in borosilicate glasses, with reference toX nuclear fuel waste imnobilization. Atomic Energy of Canada Limited, AECL 10173, 1990.

4164. Taylor, p. Review of phase separation in borosilicate glasses, with reference to nuclear fuel waste immobilization. Bibliography. (Unknown Journal!) , 1990.

4165. Taylor, P., Ashmore, S., and Owen, D. Chemical durability of some sodium borosilicate glasses improved by phase separation. Journal. of. the. American. Ceramic. Society.VI. -.v.70. (May. '87). :333-338, 1987.

4166. Taylor, P., Ashmore, S., and owen, D. Chemical durability of some sodium borosilicate glasses improved by phase separation. Journal.of.the.American.Ceramic.Society. v. 70 (May '87):333-338, 1987. 
4167. Taylor, P., Devaal, S., and Owen, D. Effects of zirconia, scandia, and other trivalent metal oxides on liquid immiscibility in sodium borosilicate glasses. American.Ceramic.Society.Bulletin.v.65. (Nov. '86).p.1513-17.bibl. $2-7812,1986$.

4168. Taylor, P., Devaal, S., and Owen, D. Effects of zirconia, scandia, and other trivalent metal oxides on liquid immiscibility in sodium borosilicate glasses. American.Ceramic.Society.Bulletin. v. 65 (Nov. '86):1513-1517, 1986.

4169. Taylor, P.C.,Allan B., ; Owen, D.G., and X liquid immiscibility in multicomponent borosilicate glassesx. Proc.Int.Conf.Radioact.Waste Manage., $390-3-3,1994$.

4170. Taylor, P.O.,Derrek G. and X liquid immiscibility in complex borosilicate glassesX. J.Non-Cryst.Solids, 42, 143-50X-50X, 1994.

4171. Taylor, $R_{.}, F .$, and $x$ chemical engineering problems of $\star \star \star$ radioactive $* \star *$ $\star \star \star$ waste $\star \star \star X$ fixation by $* \star *$ vitrification $* \star * X$. Chem. Eng.Sci., 40, 541-69X-69X, 1994.

4172. Taylor, R.F. Chemical engineering problems of radioactive waste fixation byx vitrification: Chemical Engineering Science 40:541-569, 1985.

4173. Tehranian, F. and Olander, D.R. Laser-pulse vaporization of urarium carbide [at $3000-5000 \mathrm{~K}$ ]. High.Temp.Sci. 25 [1] 55, 1988.

4174. Tejika, Y., Komatsu, F., Masaki, T., Yoshida, N., and Fukai, I. Three-dimensional analysis of microwave heating system with square-typex furnace. IEEE Transactions on Nuclear Science NS-34:1065-1069, 1987.

4175. Tempest, P., A., and $X$ the structures and stability of media intended for thex immobilization of high level $* \star \star$ radioactive*t* $* \star \star$ waste $* \star x$. Report, Cegb-Rd-B-N-4573, 28 Pp, 1979.

4176. Tempest, P., A., and $X$ a comparison of borosilicate $\star \star \star g l a s s * \star *$ and synthetic mineralsx as media for the immobilization of high-level $\star \star \star$ radioactive $\star \star \star X ~ * \star \star$ waste $\star \star \star X$. NuCl.Technol., 52, 415-25X-25X, 1994 .

4177. Tenaglia, R., D., ; McCall, J.; L., and $X$ induction melting of simulated transuranic wastex. Report, Egg-2263; Order No.De83013837, 97 pp, 1983.

4178. Tennant, M., H., ; Murphree, B., E., and $X \star \star \star v i t r i f i c a t i o n * \hbar \star$ of nuclear waste with low heat generationX. Nucl.Eng.Des., 67, 415-23X-23X, 1994.

4179. Terai, R. Solidification of nuclear wastes into glass and ceramics. Seramikkusu , 1981.

4180. Terai, R. Leaching mechanisms and long-term stability of glass containinghigh-level radioactive waste. New Glass, 1989.

4181. Terai, R., Hara, S., Kawamoto, T., Nanbu, T., and $X, N$. The chemical durability of glasses suitable for the storage of highx level radioactive wastes.i.on the mechanism of dissolution ofx the glasses of 
borax-alumina-silica system in waterx. Osaka.Kogyo.Gijutsu.Shikensho.kiho. $-30 x, 1994$.

4182. Terai, R. and Hori, M. Measurement of thermal conductivity of borosilicate glasses by laserflash method. Yogyo Kyokai shi, 1977.

4183. Terai, R., Kinoshita, M., and Eguchi, K. Pressure sintering of simulated high level radioactivex wastes with glass powdersx. Osaka.Kogyo.Gijutsu. Shikensho.Kiho. $-47 \mathrm{X}, 1994$.

4184. Terai, R. and Kosaka, E. Volatilization of low-temperature borosilicate glasses for theX treatment of high-level radioactive wastes at elevated temperaturesX. Osaka.KogYo.Gijutsu.Shikensho.Kiho. -6X, 1994.

4185. Terai, R., ; Eguchi, K., ; Yamanaka, H., and $X$ characterization of borosilicate glasses containing simulatedx high-level ***adioactive*** ***wastes*** from pncX. Ceram.Nucl.Waste Manage., Proc.Int.Symp., Issue Conf-790420, X 62-5-5, 1994 .

4186. Terai, R.E.,Kiyohisa; Yamanaka characterization of borosilicate glasses

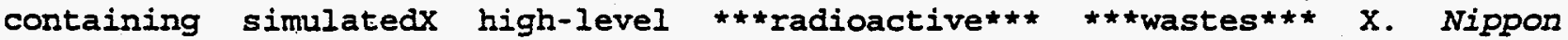
Genshiryoku Gakkaishi, 21, 424-33X-33X, 1994.

4187. Terai, R.Y.,Hiroshi; Wakabayashi change of electrical properties of the borosilicate glassesX containing molybdenum(vi) oxide by phase separationX. Osaka Kogyo Gijutsu Shikensho Kiho, 32, 152-62X-62X, 1994.

4188. Terai, R. solidification of nuclear wastes into ***glass*** and ceramicsX. Seramikkusu, 16, 916-23X-23X, 1994.

4189. Terki, A., Pacaud, F., Jacquet Francillon, N., and Morlevat, J.P. Methodology for Evaluating the Aqueous Leach Resistance of a Glass Used in a Characterization Study. (Unknown Journal!), 1985.

4190. Terki, A., ; Pacaud, F., ; Jacquet Francillon, N., ; Morlevat, J., P., and $X$ methodology for evaluating the aqueous leach resistance of a glass $X$ used in a characterization studyx. Ber.Kernforschungsanlage Juelich, Juel-Conf-54, Proc.Int.X Semin.Radioact.Waste Prod., 343-69X-69X, 1994.

4191. Thiel, R.D., McLaurin, A.W., and Kochen, R.L. Effects of size reduction techniques on TCLP analysis of solidified mixed waste. (Unknown Journal!), 1993.

4192. Thiele Use of extrusions in the vitrification of radioactive fissionx productsX. Ber.Kernforschungsanlage.Juelich. -1026-CT, 1994.

4193. Thiele, D. Process [glass encapsulation] for the stabilization of radioactivewastes. (Unknown Journal!), 1984.

4194. Thiele, D. Encasing radioactive fission productsX. Ger.Offen. , 1994.

4195. Thomas vitrification of compatible intermediate and high-levelx liquid radioactive wastes .final report, 1 . Report. , 1973. 
4196: Thomas, L.E., Chick, L.A., and Lokken, R.O. Analytical electron microscopy characterization of basalt glassx ceramics. In: Proceedings Electron Microscopy Society of America 40 th AnnualX Meeting. Publ by Claitor's Publ Div, Baton Rouge, La, USA $p$ 616, Anonymous Baton Rouge, La, USA:Claitor's Publ Div, 1982, p. 616

4197. Thomas, M. and Matzke, H. Sodium diffusion in the nuclear waste glass gP 98/12. J.Am.Ceram.Soc. , 1989.

4198. Thomas, M., Matzke, H., Taylor, P., Ashmore, S., and Owen, D. Sodium diffusion in the nuclear waste glass GP98/12 Chemical durability of some sodium borosilicate glasses improved by phase separation. Journal of the. American. Ceramic. Society.v.72. (Jan. '89) .p. 146-7.bibl. Journal of. the.American. Ceramic.Society.v.70. (May.'87).p.333-.8.bibl.il. 2-7820, 1987.

4199. Thomas, M.P., Matzke, H., Asano, M., and Kou, T. Sodium diffusion in the nuclear waste glass gp $98 / 12$ vaporisation of sodium-rubidium borosilicate glasses. Journal of the American Ceramic Society Physics and Chemistry of Glasses 30:39-45, . 1989.

4200. Thomas, M.P., ; Matzke, F., and $X$ sodium diffusion in the nuclear waste glass gP 98/12X. J.Am.Ceram.Soc., 72, 146-7X-7X, 1994.

4201. Thomas, M. and Matzke, H. Sodium diffusion in the nuclear waste glass GP98/12. Jo -Jounnal of the American Ceramic Society. (Unknown Journal!) v. 72 (Jan. '89):146-147, 1989.

4202. Thomas, M. and Matzke, H. Sodium diffusion in the nuclear waste glass GP 98/12.X. Journal.of.the:American.Ceramic.SocietyX. J Am Ceram Soc v 72, 1989.

4203. Thomas, M. and Matzke, H. Sodium diffusion in the nuclear waste glass GP 98/12. Journal.of.the.American.Ceramic.Society. J Am Ceram Soc v 72, 1989.

4204. Thompson, R., Mendel, Hampton, Irby, and Kleinpeter Waste solidification demonstration program. experimental techniquesx for characterization of high-level radioactive solidified wastex. U.S.At.Energy.Corm. , 1971.

4205. Thompson, R., Mendel, and Kleinpeter, Waste solidification demonstration program: characterization ofX nonradioactive samples of solidified high-level wasteX. U.S.At. Energy. Corm. , 1970.

4206. Thornhill, R.E. and Knox, C.A. Hot cell preparation of testing materials. In: <CI> Held as part of the Fall Meeting of the Materials ResearchX Society Materials Research Society Symposia Proceedings $v$ 44. Publ by MaterialsX Research SOc, Pittsburgh, PA, USA P 735-740,Anonymous Pittsburgh, PA, USA:MaterialsX Research SOC, 1985,p. 735-740.

4207. Thornley, F., R., ; Barrett, N., T., ; Greaves, G., N., ; Antonini, G., M., and $X$ exafs with grazing incidence: application to leached nuclear wasteX glassesX. J.Phys.C: Solid State Phys., 19, L563-L569X-L569X, 1994.

4208. Thornton, H.R. Asalysis of oxygen bubbles in glass, Alfred, N.Y.New York State College of Ceramics at Alfred University, 1954. 
4209. Tick, P!. Durability and properties in alkali aluminofluorophosphate glasses.

Journal. of. the.American. Ceramic. Society.v.66. (Oct. '83) .p. 716-19.bibl.diags.

$2-7820,1983$.

4210. Tick, P. Durability and properties in alkali aluminofluorophosphate glasses. Joumal.of.the.American.Ceramic.Society. v. 66 (Oct. '83):716-719, 1983.

4211. Tick, P. Durability and properties in alkali aluminofluorophosphate XXglasses. Journal.of.the.American.Ceramic.Society.VL. -.v.66. (Oct.'83).

:716-719, 1983 .

4212. Timmel, P. Effect of composition on the thermal and chemical properties and the effect of heat treatment on crystallization of a zno-Bb2sob3s-siob2s passivating glass, Alfred, NY:New York State College of Ceramics at Alfred University, 1975 .

4213. Timsit, R.S. and Pelow, C.V. Shear strength and tribological properties of stearic acid films. Part $I$. On glass and aluminum-coated glass. Journal.of.Tribology, .Transactions.of. the.ASME. 114 n 1:151-158, 1992.

4214. Tingey, G.L., Lytle, J.M., and Gray, W.J. Solid-state storage of radioactive krypton in a silica-based matrix. J.Am.Ceram.SOC. 65 [N 1]:5-9, 1982 .

4215. Tingey, J., Elliott, M., and Larson Laboratory characterization and vitrification of hanford radioactivehigh-level waste. Ceram.Trans. , 1991.

4216. Tingey, J., M., ; Elliott, M., L., ; Larson, D., E., ; Morrey, E., V., and $X$ laboratory characterization and vitrification of hanford radioactivex high-level wasteX. Ceram.Trans., 23, 15-25X-25X, 1994.

4217. Tingey, J.M., Elliott, M.I., Larson, D.E., and Morrey, E.V. Laboratory characterization and vitrification of Hanford radioactive high-level waste. (Unknown Journal!), 1991.

4218. Tinivella, G., ; Stoneham, A., M., and $X$ the compaction of waste-disposal glasses and its dependence onX compositionX. Report, Aere-M-3142, 16 pp, 1981.

4219. Tittmann, E.S.,DetlefX ***vitrification*** of high-level

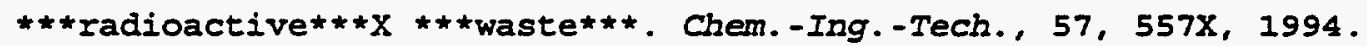

4220. Tkalcec, E., Senija, D., Dovur, V, and Petranovic, $N$. Influence of Dopants on Nucleation and Growth of High-Quartz XSolid Solution in Lithium Aluminosilicate Glass. Journal.of.the.American.Ceramic.society. 75, Number $7: 1958-1963,1992$.

4221. Tobie, W., ; Weisenburger, S., and $x$ advanced joule-heated nuclear waste glass meltersX. Proc.Symp. Waste Manage., (Waste Manage. '90, Vol. 2), 77I-8X-8X, 1994. 
4222. Toki, M., Takeuchi, T., and Miyasita, S. Fabrication of high-purity silica glass through the WSPA-sol-gel process. Journal.of.Materials.Science v. 27 (June 1 '92):2857-2862, 1992.

4223. Tomozawa, M. and Doremus, R. Treatise on materials science and technology: vol. 26, glass iv. (Unknown Journal!), 1985.

4224. Tomozawa, M., ; Singer, G., M., ; Oka, Y., ; Warden, J., T., and X phase separation in nuclear waste glassesx. Ceram.Nucl.Waste Manage., Proc.Int.Symp., Issue Conf-790420; X 193-7-7, 1994.

4225. Tomsia, A., Zhang Feipeng.,. and Pask, J. Reactions and bonding of sodium disilicate glass with chromium. Journal.of. the.American. Ceramic. Society.v.68. (Jan. '85).p.20-.4.bibl.il. 2-7820, 1985.

4226. Tomsia, A., zhang Feipeng., and Pask, J. Reactions and bonding of sodium disilicate glass with chromium. Joumal.of.the.American.Ceramic.Society. v. 68 (Jan. '85) :20-24, 1985 .

4227. Tong, H.Y., Ding, B.z., and Jiang, H.G. Formation kinetics of nanocrystalline FeBSi alloy by crystallization of the metallic glass. Journal.of.Applied.Physics. v. 75 (Jan. I 194):654-656, 1994.

4228. Torata, S.K.,Nobuo; Nagaki development of $\star * *$ vitrification** of hllw by joule-heatedx ceramic melter. process testing and components examination of theX equipmentX. Tokai Works Angu. Prog.Rep., Pnct831-80-01, 130-9X-9X, 1994.

4229. Torata, S.M.,Tadashi; Oguiho $* * *$ vitrification*** of high-level liquid waste. (ii).researchX on $\star \star \star$ glass $\star \star \star$ compositionX. Tokai Works Semi-Annu. Prog.Rep., Pnct831-79-01, 117-19X-19X, 1994.

4230. Tossell, J.A. Theoretical studies of the speciation of Al in F-bearing aluminosilicate glasses. The.American.Mineralogist. v. 78 (Jan./Feb. 193:16-22, 1993.

4231. Tossell, J.A. Theoretical studies of the speciation of AI in F-bearing aluminosilicate glasses. The.American.Mineralogist.v.78. (Jan./Feb. '93).p.16-22.bibl.diag. 3-004X, 1993.

4232. Tosten, M., H., and $X$ tem [transmission electron microscopy] examination of irradiatedX waste glassX. Report, WsrC-Rp-89-584; Order No.De90000590, 27 pp, 1989.

4233. Toyohara, N., Matsura, H., and Kawanishi, N. ***vitrification*** of

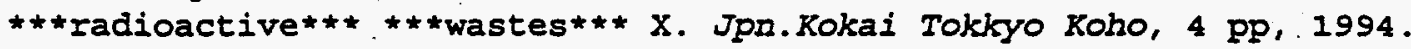

4234. Train, P. A study of the effects of iron addition on glass bead melts, Alfred, N.Y.New York State College of Ceramics at Alfred University, 1966.

4235. Tran, D., Macedo, P., and simmons, J.C. Fixation by anion exchange of toxic materials in a glass matrix. (Unknown Journal!) , 1982. 
4236. Tran, D., Macedo, P., and Simmons, J.C. Fixation by anion exchange of [radioactive] toxic materials in a glass matrix. (Unknown Journal!), 1985.

4237. Tran, D.C., Macedo, P.B., Simmons, J.H., Simmons, C.J., and Lagakos, N. fixation by anion exchange of toxic materials in a $\star \star \star g l a s s * \star \star X$ matrixX. U.S., 21 pp-in-part of $U, 1994$.

4238. Treat, R., L., ; Oma, K., H., ; Slate, S., C., and X high level waste forms: $\star * \star$ glass $* * *$ marbles and thermal sprayX coatingsX. Treat.Handl.Radioact.Wastes, , Meeting Date 1982, 331-5:ress: Columbus, Ohio, 1994.

4239. Treat, R.I. and $X$ a comparative study of alternative high-level waste solidificationX processesX. Proc.Symp.Waste Manage., (2, Waste Manage.'80: State WasteX Disposal Technol., Mill Tailings, Risk Anal.Models), 503-14X-14X, 1994.

4240. Trillas, M., Barber, R., and Munoz, J. Photoreduction of Cr(VI) over CdS supported on a glass matrix. Hazardous. Waste.\&.Hazardous.Materials.v.8. (Spring. '91).p.151-.9.bibl. 882-5696, 1991.

4241. Triplett, M.B. and Hunter, V.L. Public involvement in the Hanford Double-Shell Tank waste disposal program. (Unknown Journal!) , 1992.

4242. Trotignon, L., ; Petit; J., C., ; Della Mea, G., ; Dran, J., and $x$ the compared aqueous corrosion of four simple borosilicate glasses: $X$ influence of aluminum, calcium, and iron on the formation and naturex of secondary phasesX. J.Nucl.Mater., 190, 228-46X-46X, 1994.

4243. Trotignon, L., Petit, J.-C., and Dran, J.-C. Nature of leached layers formed on borosilicate glasses during aqueous corrosion. Ceram.Trans. $9: 229-239,1990$.

4244. Trotignon, L., Petit, J.-C., Mea, G.D., and Dran, J.-C. The compared aqueous corrosion of four simple borosilicate Xglasses: Influence of $\mathrm{Al}, \mathrm{Ca}$ and $\mathrm{Fe}$ on the formation and nature of secondary phases. Journal.of.nuclear.materials.Journal.des.materiaux.nucleaires. 190:1-228, 1992.

4245. Trotignon, L., Petit, J.C., Dellamea, G., and Dran, J.C. The Compared Aqueous Corrosion of 4 Simple Borosilicate Glasses -Influence of $\mathrm{Al}$, $\mathrm{Ca}$ and $\mathrm{Fe}$ on the Formation and Nature of Secondary Phases. J.NUCL.MATER. 190:228-246, 1992 .

4246. Tsang, K.H. and Kui, H.W. Viscosity of molten Pd82Sils and the scaling of viscosities of glass forming systems. Journal.of.Applied.Physics. v. 72 (July 1 '92) : 93-96, 1992 .

4247. Tsuboya, T. vitrification of high-level liquid wastex. Enerugi, Shigen, $13,66-73 X-73 X, 1994$.

4248. Tsuboya, T., ; Tsunoda, N., and $X$ the japanese vitrification programX. Proc.Symp.Waste Manage., (Waste Manage.'88, Vol. 2), 181-8X-8X, 1994. 
4249. Tsukamoto, M.B., Inga Kari; Christensen leaching of americium-241 from a

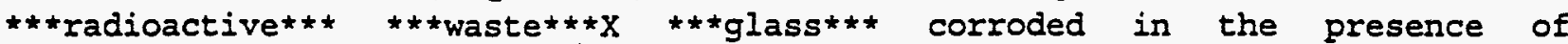
stainless ' steel corrosionX products and/or bentonitex. Mater.Res.SOC.Symp.Proc., 112, 565-74X-74X, 1994.

4250. Tsukimura, $K$. alteration of borosilicate glass under water saturated conditionX. Chishitsu Chosasho Geppo, 42, 333-6X-6X, 1994.

4251. Tsunoda, N. Solidification of high level radioactive liquid waste. Seramikkusu. 12 (11):913-920, 1977.

4252. Tsunoda, N. New Japanese vitrification plant due for 1992. Nuclear. Engineering. International. v. 34 (Feb. '89):36-37, 1989.

4253. Tsunoda, $N$. and $X$ present status of technology for the solidification of

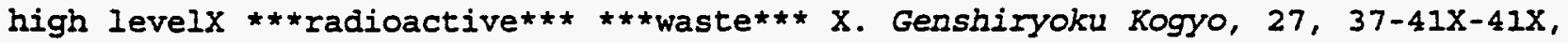
1994 .

4254. Tundo, D., Gessner, R.F., and Lawrence, R.E. Lessons Learned at West Valley. during Facility Decontamination for Re-Use (1982-1988). (Unknown Journal!) , 1988 .

4255. Tungare, A.V., Martin, G.C., and Gotro, J.T. Chemorheological characterization of thermoset cure. Polymer.Engineering.and.Science Polym Eng Sci v 28 R, 1988.

4256. Turcotte Radiation effects in solidified high level wastes. part 2. heliumx behaviorX. Report. , 1977.

4257. Turcotte and Roberts Phase behavior and radiation effects in high-level waste glassX. Report. , 1977.

4258. Turcotte and Roberts Phase behavior and radiation effects in high level waste glassX. Ceram.Glass.Radioact.Waste.Fonms. -770102, 1994.

4259. Turcotte and Wald Devitrification behavior in a zinc borosilicate nuclear waste glassX. Report. , 1978.

4260. Turcotte, Wald, and Roberts Radiation damage in nuclear waste ceramics. J.Am.Ceram.SOC. , 1982 .

4261. Turcotte, R., P., ; Wald, J., W., ; May, R., and $x$ devitrification of nuclear waste glassesX. Sci.Basis Nucl.Waste Manage., 2, 141-6X-6X, 1994.

4262. Turcotte, R., P., ; Wald, J., W., ; Roberts; F., ; Rusin, J., M., ; Lutze, $X$.W., and $X$ radiation damage in nuclear waste ceramicsX. J.Am.Ceram.SOC., 65, 589-93X-93X, 1994.

4263. Tuthill, Strickland, G., and Weth Platinum for high-temperature crucibles used in processingX radioactive wastesX. Ind. Ing.Chem. $-43 X, 1994$. 
4264. Tuthill, Weth, Emma, Strickland, G., and Hatch, $X$ Phosphate- glass process for disposal of high-levelx radioactive wastes $x$. Ind. Eng. Chem. Process.Des.Dev. -21X, 1994.

4265. Tuzzeo, J. Effects of presisure on kinetics of crystal nucleation in lithiun $X$ disilicate glass, 1976.

4266. U.Giese, H.Hessenkemper, and R.Bruckner Crystallization behavior of $\mathrm{CaBa}(\mathrm{PO}) 4$ glass depending on temperature and load. Journal. of.Non'-Crystalline.Solids. 127:75-80, 1991.

4267. Uberoi, M. and Risbud, S. Processing of amorphous calcium aluminate powders at <900(degree)C. Journal.of.the.American.Ceramic.Society. v. 73 (June '90): $1768-1770,1990$.

4268. Uchida, S., Fuke, H., Shimosaka, S., Kitamura, and Zako, M. Aseismic structure evaluation tests on storage pit. IHI Engineering Review 18:63-68, 1985.

4269. Uchino, T., Sakka, T., and Ogata, Y. Mechanism of hydration of sodium silicate glass in a stream environment: $29 \mathrm{Si}$ MMR and ab initio molecular orbital studies. The.Journal.of.Physical.Chemistry. v. 96 (Sept. 3 ' 92) : 7308-7315, 1992 .

4270. Uchino, T., Sakka, T., and Ogata, Y. Mechanism of hydration of sodium silicate glass in a stream environment: 29Si NMR and ab initio molecular orbital

studies.

The.Journal of. Physical.Chemistry.v.96. (Sept.3. '92) .p.7308-.15.bibl.diags. 22-3654, 1992 .

4271. Uchino, T.,. Sakka, T., and Ogata, Y. Local structure of sodium aluminosilicate glass: an ab initio molecular orbital study. The.Journal of. Physical.Chemistry.v.97. (Sept.23.'93) .p.9642-.9.bibl.diags. 22-3654, 1993.

4272. Uchino, T., Sakka, T., Ogata, Y., and Iwasaki, M. Mechanism of Hydration of Sodium-Silicate Glass in a Steam Environment - Si-29 NMR and Abinitio Molecular-Orbital Studies. J.PHYS. CHEM. 96:7308-7315, 1992.

4273. Uchino, T., Sakka, T., Ogata, Y., and Iwasaki, M. Changes in the Structure of Alkali-Metal Silicate-Glasses with the Type of Network Modifier Cation - An Abinitio Molecular-Orbital Study. J.PHYS.CHEM. 96:2455-2463, 1992.

4274. Uchino, T., Sakka, T., Ogata, Y., and Iwasaki, M. Local-Structure of Sodium Aluminosilicate Glass - An Ab-Initio Molecular-Orbital study. J.PHYS. CHEM. 97:9642-9649, 1993.

4275. Uedono, A. and Tanigawa, S. Positron annihilation in vitreous silica glasses.

Japanese.Journal. of. Applied. Physics, . Part. 1 : . Regular. Papers.\&.Short.Notes.\&.Rev iew.Papers. Japanese Journal of, 1993. 
4276. Uematsu, K. Remote and automation technologies: review of japan's experience in thex nuclear field. International Atomic Energy Agency Bulletin 27-42, 1985.

4277. Uematsu, K. Design of the vitrification plant for hllw generated from the tokaix reprocessing plant. In: 〈CI> Volume 2: High-Level Waste $v 2$. Publ by Arizona Board of Regents, AZ, USA $p$ 427-433, Anonymous AZ, USA:Arizona Board of Regents, 1986, p. 427-433.

4278. Uetake, N., Fukasawa, T., Kawamura, F., and Yusa, H. Alternative sealing materials for radioactive waste longterm storage orX disposal. In: 〈CI> Volume 2. Waste Policies and Programs, Low-Level Waste $v 2$. Publ by Univ of Arizona, Tucson, AZ, USA p 201-204,Anonymous Tucson, AZ, USA:Univ of Arizona, 1985,p. 201-204.

4279. Uetake, N. and Hashimoto, H. method and apparatus for solidification of trialkylphosphatex containing radioactive substancesX. Jpn.Kokai Tokkyo Koho, 6 pp, 1994 .

4280. Uetake, N., Ozawa, Y., and Kikuchi, M. High-level radioactive waste glass synthesis at low temperatures. Nuclear Technology 67:221-227, 1984.

4281. Uetake, N.O.,Yoshihiro; Kikuchi high-level $\star \star \star$ radioactive*** ***waste*** $\star * \star$ glass $* \star x$ synthesis at low temperaturesX. Nucl.Technol., 67, 221-7X-7X, 1994.

4282. Uetake, N.F.,Tetsuo; Kawamura alternative sealing materials for radioactive waste longterm storagex or disposalx. Proc.symp.Waste Manage... (2), $201-4 \mathrm{X}-4 \mathrm{X}, 1994$.

4283. Uhlmann The stability of glasses, with special reference to the disposal ofX radioactive wastesX. Ceram.Glass.Radioact. Waste.Forms. -770102, 1994.

4284. Uhlmann, D.R.D. and Kreidl, N.J. Glass--science and technology, New York:Academic Press, 1980.

4285. Uhlmann, E., Weinberg, M., Kreidl, N., and Goktas, A. Glass-forming ability in calcium aluminate-based systems. Journal.of. the.American.Ceramic.Society. Journal of the Ameri, 1993.

4286. Ulmer, G., Racandes, and Grandstaff Icelandic geothermal fields as an analog for nuclear waste disposal inbasalt. Adv.Ceram. , 1986.

4287. Umeki, H., Suzuki, A., and Kiyose, R. Leach model for safety assessment. Adv. Ceram. 20:523-529, 1986.

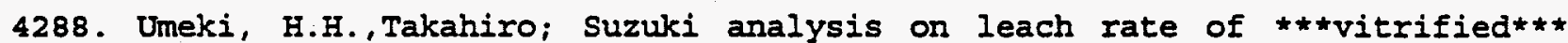
wastex. Sogo Shikensho Nenpo (Tokyo Daigaku Kogakubu), 42, 113-18X-18X, 1994 .

4289. United Kingdom Atomic Energy Authority.Research Group.Atomic $X$ Energy Research Establishment.Nuclear Physics Division. Some tests on 1ithium glass scintillators for detecting neutrons, H.M.S.O. 1961. 
4290. Upson Observed properties of some solidified high-level wastes and theirX stability under simulated storage conditionsX. U.S.At. Energy.Comm. -660208, 1994.

4291. Upson and weth Fixation of high-level radioactive wastes inX phosphate glass X. U.S.A.E.C., 1966.

4292. Upton, B.H., Wicks, G.G., and Walllace, R.M. Early Leaching Behavior of SRP (Savannah River plant) Waste Glass Effects of Surface Finish and Temperature. (Ùnknown Journal!) , 1983.

4293. Urbanec, $Z$., ; Haklova, F., and $X$ hydrolytic resistance of glass obtained by the vitrification ofx low-level waste arising in czechoslovak nuclear power plants andx other properties of the product - planned experimentx. Nucleon (Rez, Czech.), (1), 5-13X-13X, 1994.

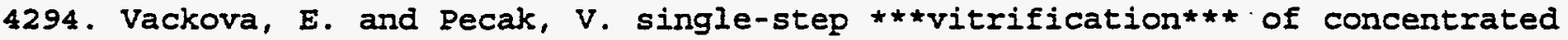

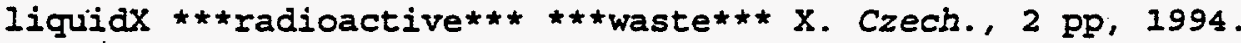

4295. Vackova, $\mathrm{E}$. and Ralkova, J. borosilicate ***glass*** fixation of

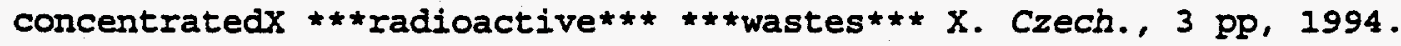

4296. Vackova, E. zinc-phosphate ** glass*** for fixation of concentratedx

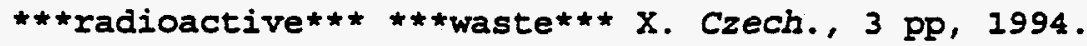

4297. Van De voorde Treatment techniques of radioactive wastes.reviewX. Disposal.Radioactive. Waste. $-48,1972$.

4298. Van De Voorde, N., ; Taeymans, A., ; Hennart, D., ; Balleux, w., ; Geenen, X.G., ; Gijbels, J., and $X$ an integrated facility for the treatment of radioactive wastesX contaminated by .alpha.and .beta.-.gamma.emittersX. Radioact.Waste Manage., Proc.Int.Conf., Meeting Date 1983, VolumeX 2, 3-66, 1994.

4299. Van den Broek, พ., M., G., T., ; Bruining, J., ; Dietz, D., N., ; Weijdema, J., and $X$ dissolution of $\star \star \star$ radioactive $* \star \star \star \star \star$ waste $* \star *$ mixed withX ** glass*** in groundwaterX. I2-Procestechnologie, (1), 29-32X-32X, 1994.

4300. Van der Plas Inclusion of radioactive waste in glassX. Klei.Keram. -10X, 1994.

4301. Van Geel, Eschrich, and Detilleux A versatile process for the solidification of liquid radioactivex wastes $X$. Int.Fachmesse.Fachtag.Kerntech.Ind. :Schweiz Mustermesse, 1994.

4302. Van Geel, Eschrich, Heimerl, and Grziwa Solidification of high-level liquid wastes to phosphate glass-metalx matrix blocksx. Manage.Radioact. Wastes.Nucl. Fuel.Cycle -59, 1994.

4303. Van Geel, J., Dobbels, F., and Theunissen, w. Device for the continuous production of glass bodies especiallycontaining radioactive waste. (Unknown Journal!) , 1984. 
4304. Var Geel, J. and $X$ inactive pamela ***vitrification*** plant in mol. 2. preparationx and properties of vitromet productsx. Ber.Kernforschungsanlage Juelich, Juel-Conf-42 (Vol. 1) X Proc:roc-Level Liquid Wastex, 1994.

4305. Van Iseghem and De Batist Corrosion mechanisms of simulated high-level nuclear waste glasses indistilled water. Riv.stn.Sper.Vetro, 1984.

4306. Van Iseghem, De Batist, and $L i, w$. Interaction between nuclear waste glasses and clay. Adv.Ceram. , 1986.

4307. Van Iseghem, P., ; Amaya, T., ; Suzuki, Y., ; Yamamoto, H., and $X$ the role of aluminum oxide (al203) in the long-term corrosionx stability of nuclear waste glassesX. J.Nucl.Mater., 190, 269-76X-76X, 1994.

4308. Van Iseghem, P., ; Berghman, K., ; Lemmens, K., ; Stalios, A., D., ; $\mathrm{X}$ Timmermans, W., ; Van Winckel, $S_{.}$, and $x$ the characterization of nuclear waste glassX. Riv.Stn.Sper.Vetro (Murano, Italy), 20, 179-83X-83X, 1994.

4309. Van Iseghem, P., ; Cantale, C., ; Coquerelle, M., ; Dussossoy, J., L., ;X Malow, G., ; Roggendorf, H., and X corrosion mechanisms of vitrified high-level wasteX. Radioact. Waste Masage.Disposal, , 3rd,X Meeting Date-86, 1994.

4310. Van Iseghem, P., Amaya, T., Suzuki, Y., and Yamamoto, H. Role of al $/ / 20 / / 3$ in the long-term corrosion stability of nuclear wastex glasses. Journal of Nuclear Materials 190:269-276, 1992.

4311. Van Iseghem, P., ; De Batist, R., and ; Li, w. the interaction between nuclear waste glasses and clayX. Adv.Ceram., 20, 627-37X-37X, 1994.

4312. Van Iseghem, P., ; De Batist, R., and $X$ corrosion mechanisms of simulated high level nuclear waste glassesx in distilled waterx. Riv.Stn.Sper.Vetro (Murano, Italy), 14, 163-70x-70x, 1994.

4313. Van Iseghem, P., ; De Grave, E., ; Peters, L., ; De Batist, R., and $x$ incorporation of ferric oxide, ferrous oxide and aluminum oxide inx **silicate** glasses and its effect on their structure andx chemical stabilityX. Report, Blg-560; Order No.Pb84-203306, 13 pp, 1984.

4314. Van Iseghem, P., ; Grambow, B., and $X$ the long-term corrosion and modelling of two simulated belgianX reference high-level waste glassesX. Mater.Res.SOC.Symp.Proc., 112, 631-9X-9X, 1994.

4315. Van Iseghem, P., ; Timmermans, W., ; De Batist, R., and X interaction of ***itrified*** high-level waste with clayx environmentX. Ber.Kernforschungsanlage Juelich, Juel-Conf-42 (Vol. 2), $\mathrm{x}$ Proc:roc-Level Liquid Wastex, 1994.

4316. Van Iseghem, P., ; Timmermans, W., ; De Batist, R., and X corrosion behavior of truw base and reference glassesx. Mater.Res.Soc.symp.Proc., 26, X 527-34X-34X, 1994 .

4317. Van Iseghem, P., ; Timmermans, W., ; De Batist, R., and $X$ the characterization of ceramic incinerator slags and theirX simulantsX. Radioact. Waste Manage., 13, 27-42X-42X, 1994. 
4318. Van Iseghem, P.P., ; Timmermans, W., ; De Batist, R., and X parametric study of the corrosion behavior in static distilled waterX of simulated european reference high level waste glassesX. Mater.Res.Soc.Symp.Proc., 44,X $55-62 \mathrm{X}-62 \mathrm{X}, 1994$.

4319. Van Kessel, O., ; Brongersma, H., H., ; Holscher, J., G., A., ; Van Welzenis, X., ; Sengers, E., F., ; Janssen, F., J., and X diffusion of cesium in sodium borosilicate glasses for nuclear wastex immobilization, studied by low-energy ion scatteringX. Nucl.Instrum.Methods Phys.Res., Sect.B, B64(1-4), $593-5 X-5 X, 1994$.

4320. Van Vechten, J., Gambino, R., and Cuomo, J. Encapsulation of radioactive noble gas waste in amorphous alloy. IBM.J.Res.Dev. 23 [N 3]:278-285, 1979.

4321. Vance, Hayward, and Cann Crystallization of uranium-bearing sphene glass-ceramics for theimmobilization of nuclear waste. Glass Technol. , 1984.

4322. Vance, E. Sol-gel production of titanosilicate glass-ceramics for nuclear wasteimmobilization. J.MATER.SCI., 1986.

4323. Vance, E., Hayward, P., and Tait, J. Alternative preparative method for sphene glass-ceramics. Am.Ceram.Soc.Bul1. , 1986.

4324. Vance, E., Urquhart, and Anderson Inmobilization of uranium-rich high-level nuclear waste: Adv.Ceram. , 1986.

4325. Vance, E. Dissolution of sphene and sphene glass-ceramics in aqueous media. Adv. Ceram. 20:231-239, 1986.

4326. Vance, E., Hayward, P., and Hamon, R.F. Volatile losses from sphene glass-ceramic and borosilicate glassmelts. J.Am.Ceram.Soc. 71[7]:C318-C320, 1988 .

4327. Vance, E., R., ; Adl, T., and $X$ leaching studies of crystalline sodium phases in nuclear waste formsX. Mater.Res.Soc.Symp.Proc., 6,X 163-71X-71X, 1994.

4328. Vance, $E ., R_{.}$, ; Agrawal, D., K., and $X$ incorporation of radionuclides in crystalline titanatesX. Nucl. Chem. Waste Manage., 3, 229-34X-34X, 1994.

4329. Vance, E., R., ; Hayward, P., J., ; Cann, C., D., ; Mitchell, S., L., ;X Stanchell, M., A., T., ; Wren, D., and X crystallization of uranium-bearing sphene ***glass** ceramicsX for the immobilization of nuclear wastex. Glass Technol., 25, 232-9X-9X, 1994.

4330. Vance, E., R., ; Hayward, P., J., ; George, I., M., and X crystallization of sodium oxide-aluminum oxide-calciumx oxide-titanium dioxide-silica glasses containing rare earth oxidesX. Phys.Chem.Glasses, 27, 107-13X-13X, 1994.

4331. Vance, E., R., ; Hayward, P.J., ; Hamon, R., F., and X volatile losses from sphene glass-ceramic and borosilicate glassX meltsX. J.Am.Ceram.Soc., 71, C318-C320X-C320X, 1994. 
4332. Vance, E., R., ; Karioris, F., G., ; Cartz, I., ; wong, M., S., and X radiation effects on sphene and sphene-based $\star \star \star g l a s s * \star \star X$-ceramicsX. Adv. Ceram., 8, 62-70x-70x, 1994.

4333. Vance, E., R., ; Urquhart, S., ; Anderson, D., ; George, I., M., and X immobilization of uranium-rich high-level nuclear wastex. Adv.Ceram., 20, $249-58 x-58 x, 1994$.

4334. Vance, $E, R_{.}$, and, $X$ dissolution of sphene and sphene glass-ceramics in aqueous mediax. Adv.Ceram., 20, 231-9X-9X, 1994.

4335. Vance, E., R.; and $X$ sol-gel production of titanosilicate glass-ceramics for nuclearX waste immobilizationX. J.Mater.Sci., 21, 1413-16X-16X, 1994.

4336. Vance, E.R. Sol-gel production of titanosilicate glass-ceramics for nuclear wasteX immobilization. Journal of Materials Science 21:1413-1416, 1986.

4337. Vance, E.R., Hayward, P.J., and George, I.M. Crystallization of $\mathrm{na} / / 20-a l / / 20 / / 3-c a o-t i o / / 2-s i o / / 2$ glassesX containing rare earth oxides. Physics and Chemistry of Glasses 27:107-113, 1986.

4338. Vance, E.R., Hayward, P.J., Tait, J.C., George, I.M., Carmichael, A.A., Bickford, D.F., and Corbett, R.A. Alternative preparative methods for sphene glass-ceramics Material selection for nuclear waste processing facility. American Ceramic Society Bulletin Jounal of Materials for Energy Systems B: $142-149,1986$.

4339. Vance, E.R., Karioris, F.G., Cartz, L., and Wong, M.S. Radiation effects on sphene and sphene-based glass-ceramics. In: <CI> Held during the 85th Annual Meeting of the American CeramicX Society Advances in Ceramics $v 8$. Publ by American Ceramic SOC InC, Columbus, $x$ OH, USA $p$ 62-70,Anonymous Columbus, $x$ OH, USA:American Ceramic Soc Inc, 1984,p. 62-70.

4340. Vance, E.R., ; Hayward, P.J., ; Tait, J.C.., ; George, I.M., ;X Carmichael, A.A., and $X$ alternative preparative methods for sphene glass-ceramicsX. Am. Ceram.Soc.Bul1., 65, 1423-6X-6X, 1994.

4341. VanGeel; J., Eschrich, H., and Detilleux, E. Method for the conditioning of high level radioactive wastes forX their safe storage and disposalx. Brit. , 1994.

4342. Vaniseghem, P., Amaya, T., Suzuki, Y., and Yamamoto, H. The Role of Al203 in the Long-Term Corrosion Stability of Nuclear waste Glasses. J.NUCL.MATER: $190: 269-276,1992$.

4343. Varani, J., L., ; Pasquali, R., C., ; Petraitis, E., ; Nollmann, C., E., and $X$ analysis of different vitreous matrixes of the borosilicate typex. Radiat., Risk, Prot., Int.Congr., 6th, Volume 3, 1373--6, 1994.

4344. Varma, R., Brown, A.P., Kumar, R., San Pedro, R., and Freeman, C.J. Identification of Glass Compositions Suitable for Disposal of Waste Reactive Metal. (Unknown Journal!) , 1988. 
4345. Varma, R., ; Brown, A., P., ; Kumar, R., ; San Pedro, R., ; Freeman, C., $\mathrm{J} ., ; X$ Helt, $J ., E:$, and $X$ identification of glass compositions suitable for disposal of wasteX reactive metalX. Report, Doe/Hwp-70, AnI-88-39; Order No.De89002804, 37 pp, 1989.

4346. Vashman, A., A., ; Pronin, I., S., ; Poljakov, A., and $X$ $\mathrm{nmr}$-spectroscopic study of compounds in sodium aluminophosphateX $\star \star \star g l a s s * \star *$

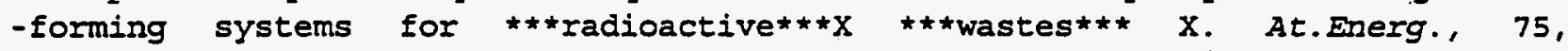
$435-42 X-42 X, 1994$.

4347. Vaswani, G., A., ; Jahagirdar, P., B., ; Rastogi, R., C., ; Rajan, N., S., and $X$ Sunder $X$ development of suitable $\star * \star v i t r i f i e d * * * * \star \star$ radioactive $* \star \star X$ ***waste*** products with low formation temperatures and improvedx leach resistance - a practical approachx. India, A.E.C., Bhabha At.Res.Cent., B.A.R.C. $-1028,34$ pp, 1994 .

4348. Vaswani, G., A., ; Jahagirdar, P., B., and $X$ formulation and characterization of borosilicate $\star * \star$ glass $* \star$ forX immobilizing highly

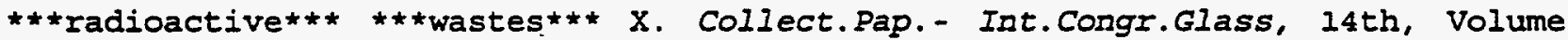
$2,451--60,1994$.

4349. Vaswani, G., A., ; Yeotikar, R., G., ; Rastogi, R., C., ; Rajan, N., S., and SunderX development of improved leaching techniques for $\star \star \star v i t r i f i e d * \star \star X$ $\star \star *$ radioactive*** ***waste*** productsx. India, A.E.C., Bhabha At.Res.Cent., B.A.R.C. $-1032,39$ pp, 1994 .

4350. Vaswani, G.A. and Jahagirdar, P.B. Formulation and characterisation of borosilicate glass for immobilisingx highly radioactive wastes. In: $v 2$. Publ by Indian Ceramic Soc, Calcutta, India $p$ 451-460, Anonymous Calcutta, India $p$ 451-460: Indian Ceramic Soc, 1986,p. 451-4600.

4351. Vatteroni, R. Sol-gel process development at fuel cycle department of ENEA, Italy. (Unknown Journal!) , 1989.

4352. Vejmelka, P., Rudolph, G., Kluger, W., and Koester, R. Ie conditionnement par cimentation des dechets liquides radioactifs. (Conditioning of radioactive waste solutions by cementation). (Unknown Journal!) , 1992.

4353. Velez Sanchez, M. Alkali metal attack of borate glasses, 1981.

4354. Venditti, P. and Grossi, G. Italian r\&d activities in the field of treatment and conditioning ofx third category (high level) liquid radioactive wastes. In: High Level Radioactive Waste and Spent Fuel Management Proc 1989 Jointx Int Waste Manage Conf $v 2$ (of 2). Publ by American Soc of MechanicalX Engineers (ASME), New York, NY, USA.P 131-139, Anonymous New York, NY, USA:American Soc of MechanicalX Engineers (ASME), 1989,p. 131-139.

4355. Ventura, P., Dos Santos, D., and Aegertner, M. Porous glasses of high silica content for storage of nuclear wastes: i,preparation and characterization of spinodal phase separation. Ceramica (Sao Paulo), 1984.

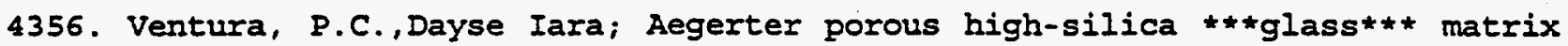
for nuclear waste storage. $X$ part 1 : preparation and characterization of spinodal phaseX separationX. Ceranica (SaO Paulo), 30, 175-82X-82X, 1994. 
4357. Venzel', B.I., Svatovskaya, L.G., and Zhdanov, S.P. Effect of Two-Stage Thermal Treatment of Two-Phase Sodium XBorosilicate Glasses on the structure of Porous Glasses xobtained from Them. The.Soviet.journal.of.glass.physics.and.chemistry.PY.-.1992. 17, Number $6: 569-573,1994$.

4358. Verachtert, $w$. and Heimerl, . apparatus for removing dust particles from the waste gas from ax nuclear installation by washingx. Belg., 12 pp, 1994 .

4359. Verkerk Glass in salt.reflection of individual facets for storage ofX nuclear fission wastes in salt formationX. Energiespectrum. -53X, 1994.

4360. Verkerk Actinide partitioning: arguments againstx. Manage.Radioact. Wastes. Nucl. Fuel. Cycle -32, 1994.

4361. Vernaz Thermal and physicochemical properties important for the long term behavior of nuclear waste glasses. (Unknown Journal!) : ([37] p), 1992.

4362. Vernaz study on behaviour in long term of vitrified materials Etude du comportement a long terme des materiaux vitrifies. (Unknown Journal!) : (33 p), 1993.

4363. Vernaz, Deymier, and Jacquet-Francilion Mechanical properties of some candidate glasses for high-levelradioactive waste management. Adv.Ceram. , 1985 .

4364. Vermaz, E. and Godon, N. Key parameters of glass dissolution in integrated systems. Mater.Res.Soc.Symp.Proc. , 1991.

4365. Vernaz, E., ; Advocat, T., ; Dussossoy, J., L., and X effects of the sa/v ratio on the long-term corrosion kinetics ofX $27-t 7$ glassX. Ceram.Trans., 9, $175-85 X-85 X, 1994$.

4366. Vernaz, E., ; Loida, A., ; Malow, G., ; Marples, J., A., C., ; Matzke, $H$. and $X$ long-term stability of high-level waste formsX. Radioact.Waste Manage.Disposal, , 3rd,X Meeting Date-15, 1994.

4367. Vernaz, E., Advocat, T., and Dussossoy, J.L. Effects of the SA/V ratio on the long-term corrosion kinetics of R7-T7 glass. (Unknown Journal!), 1989.

436B. Vernaz, E., Advocat, T., and Dussossoy, J.L. Effects of the SA/V ratio on the long-term corrosion kinetics of R7-T7 glass. Ceram.Trans. 9:175-185, 1990.

4369. Vernaz, E., Deymier, P., and Jacquet-Francillon, N. Mechanical properties of some candidate glasses for high-levelx radioactive waste management. In: <CI> Held during the 85th Annual Meeting of the American CeramicX Society Advances in Ceramics $v$. Publ by American Ceramic SOC Inc, Columbus, $X$ OH, USA $P$ 687-696, Anonymous Columbus, $X$ OH, USA:American Ceramic SOC Inc, 1984,p. 687-696.

4370. Vernaz, E., Dussossoy, J.I., Caurel, J., and Crovisier, J.I. Early phyllosilicates formed by alteration of R7T7 glass in water at 250 deg $\mathrm{C}$. (Unknown Journal!), 1991. 
4371. Vernaz, E., Fillet, S., and Jacquet-Francillon, N. Actinides in glass. Journal of the Less-Common Metals 121:637-644, 1986.

4372. Vernaz, E. and Matzke, H.J. Thermal and physicochemical properties important for the long term behavior of nuclear waste glasses. (Unknown Journal!) , 1992 .

4373. Vernaz, E., Y., ; Dussossoy, J., I., and X current state of knowledge of nuclear waste glass corrosionX mechanisms: the case of $r 7 t 7$ glassX. Appl.Geochem., Suppl., 1, 13-22X-22X, 1994.

4374. Vernaz, E., Y., ; Godon, N., and X leaching of actinides from nuclear waste glass: french experienceX. Mater.Res.Soc.Symp.Proc., 257, 37-48X-48X, 1994.

4375. Vermaz, E., ; Deymier, P., ; Jacquet Francillon, N., and X mechanical properties. of some candidate glasses for high-levelX $\star \star \star$ radioactive*** $\star \star \star$ waste $* \star \star$ managementX. Adv. Ceram., 8, 687-96X-96X, 1994.

4376. Vernaz, E., ; Fillet, S., ; Jacquet Francillon, N., and $X$ actinides in glassX. J.Less-Common Met., 121, 637-44X-44X, 1994 .

4377. Vernaz, E., ; Jacquet Francillon, N., ; Bonniaud, R., and X .alpha.-decay effects in glassesX. Sci.Rech. 38-43X-43X, 1994.

4378. Vernaz, E., Y., ; Dussossoy, J., ; Fillet, S., and $X$ temperature dependence of $\quad 27 t 7$ nuclear waste glass alterationx mechanismsX. Mater.Res:Soc.Symp.Proc., 112, 555-63X-63X, 1994.

4379. Vernaz, E.Y. and Dussossoy, J.I. Current state of knowledge of nuclear waste glass corrosion mechanisms: the case of R7T7 glass. Applied.geochemistry. : . journal. of. the. International.Association. of. Geochemistry .and.XCosmochemistry. S1:13-22, 1992.

4380. Vetrov, E., M., ; Ikhlov, E., and $X$ possible use of highly

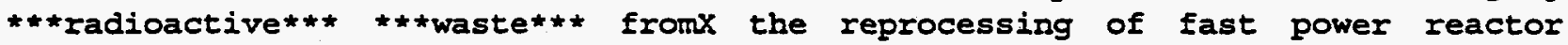
fuelX. At. Energ., 47, 187-8X-8X, 1994.

4381. Vetter, G. Investigation of the Entrainment of Fission Products During the Vitrification of High-Active waste. A Basic conception of the off-Gas Treatment. Diss. (Unknown Journal!) , 1987.

4382. Vetter, G. investigation of the entrainment of fission products during theX vitrification of high-level waste.basic concepts of the offgasX purification facilityx. Ber.Kernforschungsanlage Juelich, Juel-2170, 119 pp, 1994.

4383. Vida, J. Chemischen Verhalten des Technetiums bei der BehandIung des hochradioaktiven Abfalls. (Chemical behaviour of technetium during treatment of high-level radioactive waste). Diss. (Unknown Journal!), 1989. 
4384. Villegas, M.A., Pascual, I., and Navarro, J.M.F. Nitridation of Silicate and Borosilicate Glasses Prepared by Sol-Gel Process. GLASTECH.BER. 66:51-55, 1993.

4385. Vinjamuri Densification/creep behavior of experimental glass-ceramic waste forms for immobilization of high-level calcined waste at the idaho chemical processing plant. (Unknown Joumal!) :(4 p), 1930.

4386. Vinjamuri waste form development for immobilization of high level waste calcine at the idaho chemical processing plant. (Unknown Journal!) : (24 p), 1930.

4387. Vinjamuri, K. Effect of aluminum and silicon reactants and HIP soak time on characteristics of glass-ceramic waste forms. (Unknown Journal!), 1993.

4388. Vinjamuri, $\mathrm{K}$. Talc-silicon glass-ceramic waste forms for immobilization of high- level calcined waste. (Unknown Journal!) , 1993.

4389. Vinjamuri, $\dot{K}$. Effect of aluminum and silicon reactants and process parameters on glass-ceramic waste form characteristics for immobilization of high-level fluorinel-sodium calcined waste. (Unknown Journal!) , 1993.

4390. Vogler, S., ; Trevorrow, L., E., ; Ziegler, A., A., ; steindler, M., J., and $x$ alternatives for conversion to solid interim waste forms of thex radioactive liquid high-level wastes stored at the western new yorkx nuclear service centerX. Report, Anl-81-46; Order No.De82003008, 80 pp, 1982.

4391. Voitech, Plasil, Kourim, and Suessmilch The use of emanation thermal analysis for the investigation ofX radioactive waste fixation processesX. J.Radioanal. Chem. -92X, 1994.

4392. Vojtech, Santarova, stejskal, and Sussmilch Phosphate systems for the solidification of highly radioactivex wastesX. Ustav.Jad.Vyzk. , 1994.

4393. Vojtech, O., Santarova, M., and Voldan, J. Use of Borosilicate System for Solidification of Nuclear Power Plant. Wastes. (Unknown Journal!) , 1984.

4394. Vojtech, O., ; Santarova, M., ; Sussmilch, J., and X study of the borate-phosphate system for fixation of wastes fromx nuclear power plantsX. Ustav Jad.Vyzk., , Ujv 6216 CH, 16 pp, 1994.

4395. Vojtech, O., ; Santarova, M., ; Voldan, J., and $X$ use of a borosilicate

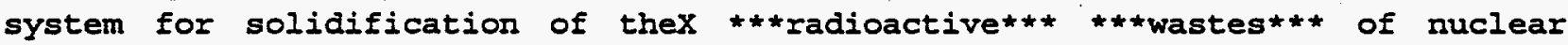
power stationsX. Ustav Jad.Vyzk., , Ujy 6818-CH, 22 pp-CH, 22 pp, 1994.

4396. Vojtech, O., ; stejskal, J., and $X$ present state of research on the ***vitrification*** of nuclearX power plant wastesX. Nukleon, (2), 5-9X-9X, 1994 .

4397. Vojtech, O., ; Voldan, J., ; Sussmilch, J., ; Santarova, M., and X phosphate system as a medium for solidification of high-level wastesx - simplex experiment.part iix. Ustav Jad.Vyzk., Ujv 5927-CH, 19 pp-CH, 19 pp, 1919. 
4398. Vojtech, $O$. and $X$ present state of research on $* \star \star v i t r i f i c a t i o n * * *$ of $\star \star \star$ radioactive $* \star * * \star *$ wastes $* \star *$ at the nrix. Nukleon, (3), 12-15X-15X, 1994 .

4399. Vojtech, O.S.,Marie; Sussmilch phosphate systems as a medium for high-level waste solidificationX. Jad.Energ., 29, 45-9X-9X, 1994.

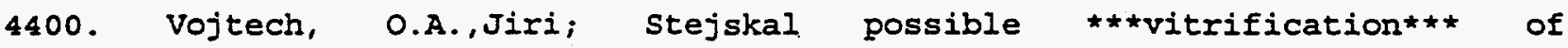

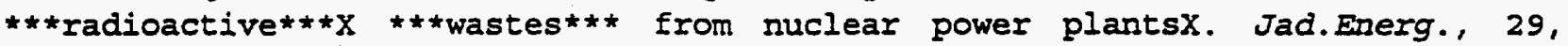
$361-5 X-5 X, 1994$ :

4401. Vollath, D. and Wedemeyer, H. Aluminum-doped lithium orthosilicate as a breeder material. Adv.Ceram. 27:3-12, 1990.

4402. Voskuil, $T$. Vitrification Technologies for Treatment of Hazardous and Radioactive Waste. (Unknown Journal!) , 1992.

4403. Voskuil, $T$. and $X * \star * v i t r i f i c a t i o n * \star *$ technologies for treatment of hazardous andX $\star * \star$ radioactive $\star \star \star * \star *$ waste $* \star \star X$. Report, Epa/625/R-92/002; Order No.Pb92-201110, $90 \mathrm{pp}, 1992$.

4404. W.Timmermans and R.De Batist 1 BT - Leaching Mechanisms CT - Parametric Study of the Corrosion Behavior in Static Distilled Water of Simulated European Reference High Level Waste Glasses ED - Carol M.Jantzen ED - John A.Stone ED Rodney C. Ewing Anonymous 1985,p. 55-62.

4405. Waal, $\mathrm{H}$. On the internal friction in ion-exchanged sodium silicate glasses and in sodium aluminoborate glasses, n.p.1967.

4406. Wada, M. and Kawamura, S. Glass-ceramics for special applications. Bull.Inst.Chem.Res. , 1981.

4407. Wada, M.R.,Susumux some $* \star \star g l a s s * \star *$-ceramics for special applicationsX. Bull.Inst.Chem.Res., Kyoto Univ., 59, 256-65X-65X, 1994.

4408. Wadachi, $Y$. and Shigaki, $Y$. Treatment of isotopic waste watersX. Japan.Kokai. , 1994.

4409. Wagh, A.S., Cunnane, J.C., Singh, D., Reed, D.T., and Armstrong, S. Chemically bonded phosphate ceramics for radioactive and mixed waste solidification and.stabilization. (Unknown Journal!) , 1993.

4410. Wakabayashi, H., Fukumoto, S., and Yamanaka, H. Effect of moo sub 3 addition on phase separation in borosilicate glasses. Yogyo Kyokaishi , 1987.

4411. Wakabayashi, H., Fukumoto, S., Yamanaka, H., and Terai, R. Effect of moo//3 addition on phase separation in borosilicate glasses. Yogyo Kyokai Shi/Journal of the Ceramic Society of Japan 95:486-493, 1987.

4412. Wald and Weber Effects of self-radiation damage on the leachability of actinide-hostphases. Adv.Ceram. , 1985.

4413. Wald, J. and Roberts, F. Comparison of short-term leaching in both radiation-damaged and annealednuclear waste glasses. J.Am.Ceram.Soc. , 1984. 
4414. Wald, J., W., ; Brite, D., ; Gurwell, W., E., ; Buckwalter, C., Q., ;X Bunnell, L., R., ; Gray, W., J., ; Blair, H., T., ; Rusin, J., M., and X development and testing of matrixes for the encapsulation ofX ***glass*** and ceramic nuclear waste formsX. Report, Pnl-4098; Order No.De82008774, 116 pp. 1982 .

4415. Wald, J., พ., ; Westsik, J., H.,., and $\mathrm{X}$ devitrification and leaching effects in $h l w * *$ glass $* * *-x$ comparison of simulated and fully

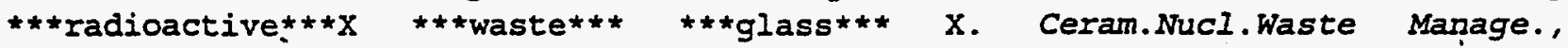
Proc.Int.Symp., Issue Conf-790420,X 277-83-83, 1994.

4416. Wald, J., W., and X fabrication and characterization of mcc approved testing material $-\mathrm{X}$ atm-8 glassX. Report, Pnl-5577-8; Order No.De86003801, 37 pp, 1986.

4417. Wald, J., พ., and $X$ fabrication and characterization of mcc approved testing material -X atm-1 glassX. Report, Pnl-5577-1; Order No.De86003795, 37 Pp, 1986 .

4418. Wald, J., W., and $X$ fabrication and characterization of mcc approved testing material.X atm-12 glassX. Report, Pal-5577-12; Order No.De86003802, 40 pp, 1986.

4419. Wald, J., W., and $X$ fabrication and characterization of mcc approved testing material:X atm-9 glassX. Report, Pal-5577-9; Order No. 86013071, 38 pp, 1986 .

4420. Wald, J.w. Fabrication and Characterization of MCC Approved Testing Material - ATM-I Glass. (Unknown Journal!), 1985.

4421. Wald, J.W. and Daniel, J.I. Fabrication and Characterization of MCC Approved Testing Material: ATM-11 Glass. (Unknown Journal!), 1986.

4422. Wald, J.W. and Weber, W.J. Effects of self-radiation damage on the leachability of actinide-hostx phases. In: <CI> Held during the 85th Annual Meeting of the American CeramicX Society Advances in Ceramics $v$. Publ by American Ceramic SOC Inc, Columbus, $x$ OH, USA $P$ 71-75, Anonymous Columbus, $x$ OH, USA:American Ceramic SOc Inc, 1984,p. 71-75.

4423. Wald, J.W., ; Roberts, F.P., and $X$ comparison of short-term leaching in both radiation-damaged andX annealed nuclear waste glassesx. J.Am.Ceram.Soc., 67. C69-c70X-c70X, 1994 .

4424. Wald, J. and Roberts, F. Comparison of short-term leaching in both radiation-damaged and amnealed nuclear waste glasses. Journal.of.the.American.Ceramic.Society. v. 67 (Apr. '84):C69-C70, 1984.

4425. Walker, C., T., ; Riege, U., and X compatibility of actinides with hlw borosilicate $\star \star \star g l a s s * \star * \mathrm{X}$ solubility and phase formationX. Ceram.Nucl. Waste Manage., Proc.Int.Symp., Issue Conf-790420,X 198-202-202, 1994.

4426. Walker, C., T., ; Scheffler, K., ; Riege, U., and $X$ chemical compatibility of hlw borosilicate glasses with actinidesx. Report, Kfk-2552, Eur-5750e, Pwa-90/78, 23 pp, 1979. 
4427. Walker, D., D., ; Wiley, J., R., ; Dukes, M., ; LeRoy, J., H., and X leach rate studies on $\star \star \star$ glass $* \star \star$ containing actualx $\star \star \star$ radioactive $\star * \star$

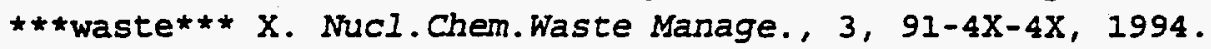

4428. Walker, N. and Whitaker, M. Analysis of frit by sodium peroxide fusion and flow injection analysis. (Unknown Jounnal!) , 1990.

4429. Wallace and Kelley Impact test for solid waste formsx. Report. , 1976.

4430. Wallace, R.M., ; Wicks, G.G., and $X$ leaching chemistry of defense borosilicate ***glass*** X. Mater.Res.Soc.Symp.Proc., 15,X 23-8X-8X, 1994 .

4431. Walters, J. Choosing the right materials for a dry vault store. (for spent nuclear fuel and/or vitrified waste). Nuclear. Engineering. International. v. 30 (Dec. ' 85 ): 43-44, 1985.

4432. Walton, $R$. Radioactive waste management development in europex. Adv. Chem.Ser. $-60 \mathrm{X}, 1974$.

4433. Wang, $I$. and $X$ plutonium leaching from a reference nuclear waste glass in syntheticX interstitial claywaterX. Mater.Res.Soc.Symp.Proc., 294, 155-62X-62X, 1994.

4434. Wang, S. Bubble formation, movement and distortion in viscous glass, 1987 .

4435. Wang, S.P. and Day, D. Bubble performs for producing glass macroshells for inertial confinement fusion targets. Fusion.Technology. Fusion Technol $v$ $17,1990$.

4436. Wang, $x$ Developing techniques for waste disposal in China. Nuclear. Engineering.International. Nuclear Engineering, 1993.

4437. Wang, Z.Q., Stroud, D., and Markworth, A.J. Thermal-Conductivity and viscosity of Liquid CdTe - A Theoretical-Study. SCR.METALL.MATER. 30:899-904, 1994.

4438. Watanabe, K., Tomobuchi, M., Yoshifuji, T., Ozawa, and Hanaoka, H. Immobilization of simulated high level nuclear wastes withx tholeiite-type basalt. Journal of the Ceramic society of Japan, International Edition $101: 479-486,1993$.

4439. Watanabe, X., Tomobuchi, M., Yoshifuji, T., Ozawa, and Hanaoka, H. Inmobilization of simulated high level nuclear wastes withx tholeiite-type basalt. Nippon Seramikkusu Kyokai Gakujutsu Ronbunshi/Journal of the Ceramicx Society of Japan 101:489-496, 1993.

4440. Watkins, D. and Watkins, R. The effect of alumina on the tensile strength of a glass, Alfred, N.Y.New York state College of Ceramics at Alfred University, 1949. 
4441. Watrous and Kruger, $O$. Recycle stream impacts on feed treatment flowsheets and glass formulationfor the hanford waste vitrification plant. Ceram.Trans. , 1991.

4442. Weber, Matzke, H., and Routbort, J. Indentation testing of nuclear waste glasses. J.MATER.SCI. , 1984.

4443. Weber, พ. Effect of radiation on nuclear waste forms. Jom, 1991.

4444. Weber, W., Wald, J., and McVay, G. Effects of alpha -radiolysis on leaching of a nuclear waste glass. J.Am.Ceram.Soc. , 1985.

4445. Weber, $w$. Radiation damage in a rare-earth silicate with the apatite structure. J.Am.Ceram.SoC. 65 [N 11]:544-548, 1982 .

4446. Weber, W. and Matzke, H. Effects of radiation on microstructure and fracture properties in $\mathrm{Ca}$ sub 2 Nd sub 8 (SiO sub 4 ) sub 60 sub 2 . Mater.Lett. 5[1-2]:9-16, 1987.

4447. Weber, W., J., ; Matzke, H.,'; Routbort, J., L., and X indentation testing of nuclear-waste glassesX. J.Mater.Sci., 19, 2533-45X-45X, 1994.

4448. Weber, W., J., ; Matzke, H., and $X$ radiation effects in actinide host phasesX. Radiat.Eff., 98, 93-9X-9X, 1994.

4449. Weber, W., J., ; Pederson, L., R., ; Gray, W., ; McVay, G., I., and X radiation effects on nuclear waste storage materialsx. Nucl.Instrum.Methods Phys.Res., Sect.B, 229, 527-33X-33X, 1994.

4450. Weber, $W ., J .$, and $X$ radiation-induced swelling and amorphization in calcium neodymiumx $\star \star \star s i l i c a t e * \star$ oxide (ca2nd8(sio4)602)x. Radiat.Eff., 77, 295-308X-308X, 1994 .

4451. Weber, W.J. Radiation effects in nuclear waster glasses. <CT Radiation Effects in Insulators: Proceedings of the Fourthx International Conference on Radiation Effects in Insulators, includingX the Workshop on Radiation Damage in Nuclear Waste Materials <CL> LyOn, Fr <CD> 1987 Jul 6-10 Nuclear Instrunents \& Met B32:471-479X, 1988 .

4452. Weber, W.J., Wald, J.W., and McVay, G.I. Effects of alpha -radiolysis on leaching of a nuclear waste glass. Journal of the American Ceramic Society $68: C, 1985$.

4453. Weber, 'W., Walds, J., and McVay, G. Effects of a-radiolysis on leaching of a nuclear waste glass. Journal.of.the.American.Ceramic.Society. v. 68 (Sept. '85) :C253-C255, 1985.

4454. Weed, Coles, Bradley, Mensing, and X, S.J.. Leaching characteristics of actinides from simulated reactor wastex glassX. Report. , 1979.

4455. Weed, H., C., ; Coles, D., G., ; Bradley, D., J., ; Mensing, R., พ., ;X Schweiger, J., S., ; Rego, J., H., and X leaching characteristics of actinides from simulated reactor wasteX $\star \star \star$ glass $* \star x$. Report, Ucid-18240, 14 pp, 1979. 
4456. Weed, H., C., ; Coles, D., G., ; Bradley, D., J., ; Mensing, R., W., ;X Schweiger, J., S., ; Rego, J., H., and X leaching characteristics of actinides from simulated reactor waste, $X$ part $2 X$. Sci.Basis Nucl.Waste Manage., 2 , $167-73 X-73 X, 1994$.

4457. Weed, H., C., ; Coles, D., G., ; Bradley, D., J., ; Mensing, R., W., ;X Schweiger, J., S., and $x$ leaching characteristics of actinides from simulated reactor wasteX $\star \star \star g l a s s * \star x$. Sci.Basis Nucl.Waste Manage., , MeetingX Date 1978, 141-7:Ienum: NewX York, 1994.

4458. Weinberg, M., Uhlmann, D., and Zanotto, E. "Nose method" of calculating critical cooling rates for glass formation. Journal. of the.American.Ceramic.Society. v. 72 (Nov. '89):2054-2058, 1289.

4459. Weisenburger, S., ; Roth, G., and X status and plans for high-level liquid waste vitrification in thex federal republic of germanyx. Fuel Reprocess.Waste Manage., Proc.- Am.Nucl.Soc.Int.Top.X Meet., volume 1 , 116-30:ark, IIl, 1994 .

4460. Weisenburger, S., ; Seiffert, H., and $X$ process engineering in the ***vitrification*** of high-levelx radioactive fission product solutions from reprocessing plantsX. Glastech.Ber., 56, 106-12X-12X, 1994.

4461. Weisenburger, S., ; Seiffert, H., and $X$ off-gas cleanup system designed for hllw ***vitrification** inX a liquid-fed ceramic waste melterX. Manage.Gaseous Wastes Nucl.Facil., Proc.Int.Symp., 531-43-43, 1994.

4462. Weisenburger, S., ; Weiss, $K$., and $X$ ruthenium volatility behavior during hllw $t * *$ vitrification*** inX a liquid-fed ceramic waste melterX. Sci.Basis Nucl.Waste Manage., 2, 901-10X-10x, 1994.

4463. Weisenburger, $S$. and Roth, G. Status and plans for high-level liquid waste vitrification in thex federal republic of germany. In: $v 1$. Publ by ANS, La Grange Park, IL, USA $p$ 116-130,Anonymous La Grange Park, IL, USA:ANS, 1984 ,p. $116-130$.

4464. Weisenburger, $S$. and $X$ high-level waste $\star \star \star v i t r i f i c a t i o n * \star *$ technique in a full-scalex pilot plantx. Treat.Handl.Radioact.Wastes, , Meeting Date 1982, 184-90:ress: Columbus, Ohio, 1994.

4465. Weisenburger, $S$. and $X$ electrodes for the direct firing of highly radioactive borosilicatex glasses in haw ceramic melting funnacesx. Ber.Kernforschungsanlage Juelich, Juel-Conf-42 (Vol. 1), X Proc:roc-Level Iiquid Wastex, 1994.

4466. Weisenburger, $S$. and $x$ nuclear waste $\star \star \star v i t r i f i c a t i o n * \star *$ in $a$ ceramic-lined electricX $\star \star \star$ glass $* \star *$ melterX. Ieee Trans.Ind.Appl., Ia-18(1), $73-82 X-82 X, 1994$.

4467. Weisenburger, $S$. and $x$ nonradioactive operation experience with a joule heated ceramicx melter for $\star \star *$ vitrification*** of high-level liquid wastex. Sci.Basis Nucl.Waste Manage., , MeetingX Date 1978, 51-6:lenum: New York,X, 1994 . 
4468. Weisenburger, $S$. and $X$ nuclear waste $* \star \star v i t r i f i c a t i o n * * *$ in $a$ ceramic-lined electricx ***glass*** melterx. Conf.Rec.- Ias Annu.Meet. (Ieee), (1), 43-54X-54X, 1994 .

4469. Weisman, A., F., ; Papouchado, L., M., ; Knight, J., R., ; McIntosh, D., $I .$, and $X$ high level waste vitrification at the srp (dwpf summary) $X$. Proc.Symp. Waste Manage., (Waste Manage. '88, Vol. 2), 203-10X-10X, 1994.

4470. Weisman,. A.F. Startup Sequence of the DWPF (Defense Waste Processing Facility) Scale Glass Melter. (Unknown Journal!), 1986.

4471. Weisman, A.F., Knight, J.R., McIntosh, D.L., and Papouchado, L.M. High Level Waste Vitrification at the SRP (Savannah River Plant) DWPF (Defense Waste Processing Facility). Summary. (Unknown Journal!) , 1988.

4472. Weitzman, I. Factors for selecting appropriate solidification/stabilization methods. Journal.of.Hazardous.Materials. Journal of Hazardous, 1990.

4473. Welch, J., M., ; Schuman, R., P., ; Flinn, J., E., and X immobilization of transuranic sludge in $\star *$ glass $* \star$-ceramicX materialsX. Report, Egg-Fm-5709; Order No.De82015621, 42 pp, 1982.

4474. Welch, J.M., ; Sill, C.W., ; Fl.inn, J.E., and X leach tests of simulated low-level transuranic waste formsx containing transuranic elementsx. Mater.Res.Soc.Symp.Proc., 15,X 603-10X-10X, 1994.

4475. Weren, B.H. and Savin, N.I. Neutron source levels in dhlw borosilicate glass. In: <CI> Volume 1: General Interest Publ by Arizona Board of Regents, AZ, USA p 287-289, Anonymous AZ, USA:Arizona Board of Regents, 1986,p. 287-289.

4476. Werme, I. Materials research society symposium proceedings, vol. 50: scientificbasis for nuclear waste management ix Y. (Unknown Journal!) , 1987.

4477. Werme, I., Bjorner, I, and Bart, G. Chemical corrosion of highly radioactive borosilicate nuclear waste glassunder simulated repository conditions. J.MATER.RES. , 1990.

4478. Werme, I., Bjorner, I., Bart, G., Zwicky, H., Grambow, B., Lutze, W., Ewing, R., and Magrabi, C. Chemical corrosion of highly radioactive borosilicate nuclear Xwaste glass under simulated repository conditions. Journal.of.materials. research. 5, Number 5:1-1130, 1990.

4479. Werme, L., O., ; Hench, I., L., ; Lodding, A., and $X$ nuclear waste glass interfaces after 1 year burial in stripax. Mater.Res.Soc.Symp.Proc., 44,X $37-44 X-44 X, 1994$.

4480. Werme, L., O., ; Hench, L., L., ; Nogues, J., ; Odelius, H., ; Lodding, A., and $X$ on the $\mathrm{ph}$ dependence of leaching of nuclear waste glassesX. J.Nucl.Mater., 116, 69-77X-77X, 1994.

4481. Werme, L.B.,Inga K., ; Bart, G.z.,Hans U., ;X Grambow, B.L.,Werner; Ewing, and; Magrabi, C. chemical corrosion of highly radioactive borosilicate 
nuclear wastex glass under simulated repository conditionsx. J.Mater.Res., 5, $1130-46 \mathrm{X}-46 \mathrm{X}, 1994$.

4482. Werner, E.A. Development of a HIP-Facility (Hot Isostatic Pressuring), for the Production of High Radioactive Bundles for Final Disposal. Diss. (Unknown Journal!) , 1987.

4483. Wescott, R., I.; ; Slate, S., C., and $X * \star *$ vitrification*** of high-level wastes: a review of thex computer thermal analyses for storage canistersX. Nucl.Eng.Des., 67, 447-58X-58X, 1994.

4484. Westsik and Mendel Chemical durability of zinc borosilicate nuclear waste glassX. Report. , 1978.

4485. Westsik, Pulsipher, B., and Eggett, D. Sampling and analysis strategies to support waste form qualification. Ceram.Trans. , 1990.

4486. Westsik, J., H., , ; Harvey, C., O., ; Kuhn, W., L., and $X$ high-temperature leaching of an actinide-bearing,simulatedx high-level waste

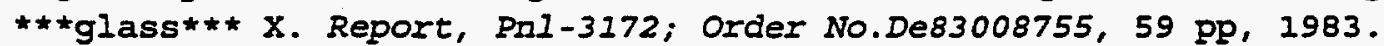

4487. Westsik, J., H., , ; Peters, R., D., and $X$ time and temperature dependence of the leaching of a simulatedx high-level waste $\star \star \star g l a s s \star \star \star ~ X$. Sci.Basis Nucl. Waste Manage., 3, 355-62X-62X, 1994.

4488. Westsik, J., H., , ; Shade, J., W., ; McVay, G., L., and X temperature dependence for hydrothermal reactions of waste glassesX and ceramicsX. Sci.Basis Nucl. Waste Manage., 2, 239.-48X-48X, 1994.

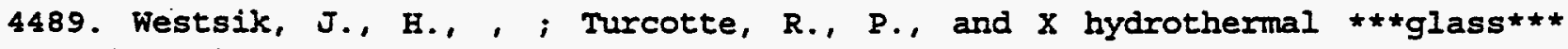
reactions in salt brinex. Sci.Basis Nucl.Waste Manage., , MeetingX Date 1978, 341-4:lenum: NewX York, 1994.

4490. Westsik, J.H. Temperature Control System for Liquid-Fed Ceramic Melters. (Unknown Journal!), 1986.

4491. Westsik, J.H., Kuhn, W.L., Pulsipher, B.A., and Nelson, J.I. Evaluation of Strategies for Controlling HWVP (Hanford Waste Vitrification Plant) Glass by Process Simulation. (Unknown Journal!), 1988.

4492. Whan, R., E., and $X$ microstructural characterization of simulated reactor waste formsX. Anal.Chem.Nucl.Technol., Proc.Conf.Anal.Chem.Energy Technol.,X 25th, Meeting Date 1-8, 1994.

4493. Wheaton, I. An investigation of the effect of temperature on the chemical durability of glass /, Alfred, N.Y. :New York state College of Ceramics at Alfred University, 1942 .

4494. Wheelwright Partitioning of long-lived nuclides from radioactive waste fy 1975X annual reportx. Proc. Conf.Manage.Radioact. Waste: .Waste.Partitioning.AlternativeXXX. -207, 1994. 
4495. Wheelwright, E., J., ; Bjorklund, W., ; Browne, L., M., ; Bryan, G., H.,

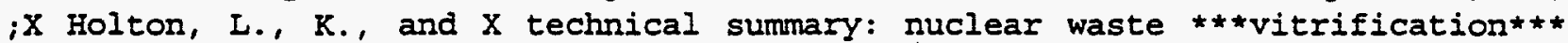
projectX. Report, Order No.Pnl-3038, 82 pp, 1980.

4496. Wheelwright, E.J., ; Bjorklund, w.J., ; Browne, L.M., ;X Bryan, G.H., ; Holton, L.K., ; Irish, E.R., ; Siemens, D.H., and $X$ generation and ***vitrification*** of high-level light waterx reactor liquid wastex. Nucl. Technol., 58, 271-93X-93X, 1994.

4497. White, $A$. Surface reactions of natural glasses--effects on radionuclide transport. Adv. Ceram. 20:713-722, 1986.

4498. White, $W$. Dissolution mechanisms of nuclear waste glassesùa critical review. Adv.Ceram. , 1986.

4499. White, W.B. and $X$ dissolution mechanisms of nuclear waste glasses: a critical reviewX. Adv.Ceram., 20, 431-42X-42X, 1994.

4500. Wick, E., A., ; Chang, K., ; Jungling, T., L., ; Johnson, T., C.,. ; Peterson, X.C., H., ; Voglewede, J., and X nrc staff perspective on performance of vitrified $\mathrm{hlw}$ and how itx relates to other componentsx. Proc.Symp. Waste Manage., (Waste Manage.'87, Vol. 2), 323-6X-6X, 1994.

4501. Wicks Immobilization of radioactive waste inX glass matrixesX. Report. , 1978 .

4502. Wicks, G. Nuclear waste vitrificationùthe geology connection. J.Non-Cryst.Solids , 1986.

4503. Wicks, G. and Ross, W. Advances in ceramics, 8: nuclear waste management. (Unknown Journal!) , 1985.

4504. Wicks, G., G., and $X$ nuclear waste glasses: corrosion behavior and field testsX. Corros.Glass, Ceram.Ceram.Supercond., 218-68:ark Ridge; N, 1994.

4505. Wicks, G., Mosley, W.C., and Whitkop, P. Durability of simulated waste glass--effects of pressure and formation of surface layers. J.NON-CRYST.SOLIDS. $49[N]-3]: 413-428,1982$.

4506. Wicks, G., G., ; Dukes, M., D., and X durability of sxp waste glasses program documentx. Report, Dpst-80-542 (Draft), 36 pp, 1981.

4507. Wicks, G., G., ; Stone, J., A., ; Chandler, G., T., ; Williams, S., and X long-term leaching behavior of simulated savannah river plant wasteX glass.part 1.mcc-1 leachability results, four-year leaching datax. Report, Dp-1728; Order No.De87004515, 107 pp, 1987.

4508. Wicks, G., G., and X compatibility tests of materials for a prototype ceramic melter forX defense **tglass** waste productsX. Report, DP-Ms-78-90, Conf-790420-18, 12 pp, 1979.

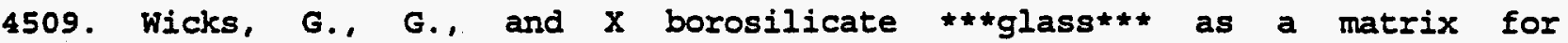
inmobilization of sxpX high-level wastex. Report, Dp-Ms-80-93, 20 pp, 1981. 
4510. Wicks, G., G., and $X$ •**vitrification*** of simulated high-level $\star \star \star$ radioactive $\star \star \star X ~ \star \star \star$ waste $\star \star \star$ by a slurry-fed ceramic melterX. Nucl.Technol., $55,601-6 \mathrm{X}-6 \mathrm{X}, 1994$.

4511. Wicks, G.G. Durability of SRP (Savannah River Plant) Waste Glass: Effect of Ground Water pH. (Unknown Journal!), 1980.

4512. Wicks, G.G., Macedo, P.B., Barkatt, A., Gibson, B.C., and Montrose, C.J. Nuclear waste. glasses Long-term release rates of borosilicate glass waste forms. Treatise on Materials science and Technology Nuclear Technology $73: 199-209,1986$.

4513. Wicks, G.G., Rankin, W.D., and Gore, S.L. International waste glass study: composition and leachabilityx correlations. In: <CI> Held as part of the Fall Meeting of the Materials ResearchX Society Materials Research Society Symposia Proceedings $v 44$. Publ by MaterialsX Research SOC,Pittsburgh, PA, USA $p$ 171-177, Anonymous Pittsburgh, PA, USA:MaterialsX Research SOC, 1985,p. 171-177.

4514. Wicks, G.G., ; Mosley, W., C., ; Whitkop, P.G., ; Saturday, K.A., and X durability of simulated waste $\star * * g l a s s * * *$ - effects of pressurex and formation of surface layersX. J.Non-Cryst.Solids, 49, 413-28X-28X, 1994 .

4515. Wicks, G.G., ; Rankin, W., Duncan; Gore, S.I., and X international waste glass study - composition and leachabilityx correlationsX. Mater.Res.SOC.Symp.Proc., 44,X 171-7X-7X, 1994.

4516. Wicks, G.G., ; Robnett, B.M., ; Rankin, W., and Duncanx chemical durability of $\star \star \star g l a s s * \star$ containing sxp waste $-X$ leachability characteristics,protective layer formation, andx repository system interactionsX. Mater.Res.Soc.Symp.Proc., 11,X 15-24X-24X, 1994.

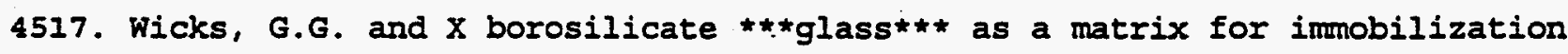
of srpX high-level wasteX. Proc.Symp. Waste Manage., 1, 321-35X-35X, 1994.

4518. Wicks, G.G. and $X$ nuclear waste glassesX. Treatise Mater.Sci.Technol., 26, 57-118X-118X, 1994.

4519. Wiederhorn Mechanical properties of glassX. Ceram.Glass.Radioact. Waste.Forms. -770102; 1994.

4520. Wiemers Preliminary assessment of candidate immobilization technologies for retrieved single-shell tank wastes. (Unknown Journal!) : (75 p), 1992.

4521. Wiemers, K.D., Mendel, J.E., Kruger, A.A., Bunnell, L.R., and Mellinger, G.B. Preliminary assessment of candidate imnobilization technologies for retrieved single-shell tank wastes. (Unknown Journal!), 1992.

4522. Wiersma Measurement of the ductile to brittle transition temperature for waste tank cooling coils. (Unknown Journal!) : (22 p), 1992.

4523. Wiese, H. operation of the pamela high-level waste vitrification facilityx. Nucl.Eng.Des., 137, 147-51X-51X, 1994. 
4524. Wiese, H. and Demonie, M. Operation of the Pamela High-Level Waste Vitrification Facility. NUCL.ENG.DES. 137:147-151, 1992.

4525. Wiese, H. and Demonie, M. Operation of the Pamela high-level waste vitrification

facility.

Nuclear.engineering.and. design. : an.international. journal devoted. to. the. therma 1, mechanical.and.structural.problems.of.nuclear.energy. 137, Number 1:140-147, 1992 .

4526. Wiese, $\dot{H} ., \mathrm{W} .$, and $\mathrm{X}$ comparison of calculated and routinely measured inventories of $X$ irradiated $\mathrm{knk} i \mathrm{i} / \mathrm{l}$ fuel elements as well as determination of $x$ ***vitrification*** -relevant fission productsX. Kernforschungszent.Karlsruhe, $K f k, K f k 3775, \mathrm{X}$ Brueterbren-21X, 1994.

4527. Wiese, H., W., and $X$ neutron source and spectra from (.alpha.,n)-reactions andx spontaneous fission in spent fuel and vitrified high active wastex. Top.Meet.React.Phys.Shielding, , Volume 2, 567-77:ark, IIl, 1994.

4528. Wiese, H.E.,Eckhart; Demonie industrial vitrification of high level liquid wastes in the pamelax plantx. Proc.Symp.Waste Manage., (Waste Manage. '88, Vol. 2), 173-9X-9X, 1994.

4529. Wikjord, A., G., ; Shoesmith, D., W., ; Goodwin, B., ; Sargent, F., P., and $X$. canadian research on high-level nuclear-waste products and processesX. Proc.Int.Conf.Radioact. Waste Manage., 383-9-9, 1994.

4530. Wilder, A.D., Boghosian, A.A., Bayne, S.C., and Heymann, H.O. Clinical-Evaluation of Wetting and Viscosity on Glass-Ionomer Bonding. J.DENT.RES. $73: 183,1994$.

4531. Wilds Volatilization from borosilicate glass melts of simulated savannahx river plant wasteX. Proc.Doe.Nucl.Air.Clean.Conf. -110X, 1978.

4532. Wilds Vaporization of semivolatile components from savannah river plantx waste glassX. Report. , 1979.

4533. Wilds volatilization from borosilicate glass melts of simulated savannahx river plant wastex. Report. , 1979.

4534. Wilds, G.W. Vaporization of semi-volatile components from Savannah River Plant waste glass /, Aiken, S.C. : [Springfield, Va. :Dept. of Energy, loffice of Energy Technology], Savannah River Laboratory : for sale by the National Technical Information Service], 1978.

4535. Wiley Decontamination of alkaline radioactive waste by ion exchange. Ind. Eng.Chem. Process Des.Dev. , 1977.

4536. Wiley Leach rates of high activity waste from borosilicate glassX. Report. :Avail NTISX From:XEn, 1978.

4537. Wiley Preparations for high-level defense waste immobilization at savannahx river plantx. Report. , 1978. 
4538. Wiley Electrical resistivities of glass melts containing simulated stpX waste sludgesX. Report. , 1979.

4539. Wiley and LeRoy Long-term leach rates of glasses containing actual wastex. Report. , 1979 .

4540. Wiley, J. Leach rates of high activity waste from borosilicate glassX. NUCL. TECHNOL. -72X, 1994.

4541, Wiley, J., R., ; Bibler, N., E., ; Dukes, M., D., ; Plodinec, M., J., and $X * * * g l a s s * *$ as a matrix for srp high-level defense wastex. Report, Dpst-79-294, 53 pp, 1980.

4542. Wiley, J., R., ; LeRoy, J., H., and X long-term leach rates of glasses containing actual wasteX. Ceram.Nucl.Waste Manage., Proc.Int.Symp., Issue Conf-790420,X 284-8-8, 1994.

4543. Wiley, J., R., and $X$ preparations for high-level defense waste immobilization at savannahx river plantX. Astm Spec.Tech.Fubl., Stp 698, Effluent Enviro-51X, 1994.

4544. Wiley, J.R.J. Electrical resistivities of glass melts containing simulated SRP waste sludges /, Aiken, S.C. : [Springfield, Va. :Dept. of Energy, Savannah River Laboratory; for sale by the National Technical Information Service], 1978.

4545. Wiley, J.R. and $x$ leach rates of high activity waste from borosilicate **tglass***. Back End Lw Fuel Cycle, , Issue Conf-780304, Xi/17-Xi/22.X Ntis: Springfield, Va.X -780304, XI/I7-XI/22, 1994.

4546. Williams, Johnson, and Ledford Vitrification of tru wastes at rocky flats plantx. Report. , 1979.

4547. Williams, J.P., Wicks, G., and Clark, D. Analyses of SRS [Savannah River Site] waste glass buried in granite in sweden and salt in the United states. Ceram.Trans. 23:663-674, 1991 .

4548. Williams, P.M., ; Johnson, A.J., ; Ledford, J.A., and $x$

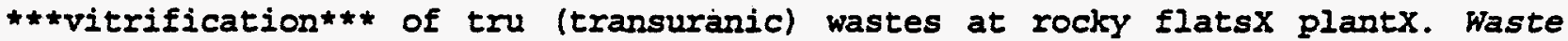
Manage.'79 : State Waste Disposal Technol.X Soc.Polit.Implic., Proc.Symp., 367-78:ost, Roy G, 1994.

4549. Winkler, U. ***glass*** wall for the sealing, of groundwater occurrences.X new perspectives for the clean-up of $\star *$ hazardous $* \star X * * *$ waste $* * *$ and former manufacturing sitesX. Wasserwirtsch.-Wassertech., 42, 43-5X-5X, 1994.

4550. Wise, B., M., ; Veltkamp, D., J., ; Ricker, N., I., ; Kowalski, B., R., ;X Barnes, S., ; Arakali, V., and X application of multivariate statistical process control (mspc) tox the west valley slurry-fed ceramic melter processx. Waste Manage. (Tucson, Ariz.), (Vol. 2), 169-76X-76X, 1994.

4551. Witte, H. Vitrification of high level wastes in borosilicate glass using thex pamela ceramic melter. In: <CI> Volume 2: Waste Regulations and Programs: High Level Waste Proceedings of the Symposium on Waste Managenent Publ by Univ 
ofX Arizona, Tucson, AZ, USA p 189-193, Anonymous Tucson, AZ, USA:Univ ofX Arizona, 1983 ,p. 189-193.

4552. Wodrich, D.D. and Bracken, E.A. Progress in Defense High-Level Waste Disposal. (Unknown Journal!) , 1988.

4553. Woodall, A. and Maillet, J. Solidifying sellafield's high level waste. Nuclear Engineering International 32:44-47, 1987.

4554. Woodley, R.E., Einziger, R.E., and Buchanan, H.C. Measurement of the Oxidation of Spent Fuel between 140 and $225 \mathrm{C}$ by Thermogravimetric Analysis. (Unknown Journal!) , 1988.

4555. Woolsey, G., B., ; Baumgarten, P., K., ; Eibling, R., E., ; Ferguson, R., and $X$ a small-scale integrated demonstration of high-levelX **tradioactive*** ***waste*** processing andx ***vitrification*** using actual srp wastex. Proc.Symp. Waste Manage., 2, 811-23X-23X, 1994.

4556. Woolsey, G.B., ; Plodinec, M., and JohnX ***vitrification*** of

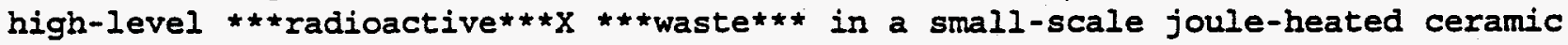
melterX. Mater.Res.Soc.Symp.Proc., 6,X 603-8X-8X, 1994.

4557. Wranglen selective storage of nuclear wastex. Nucl.Energy. (BY.Nucl.Energy.SOC). , 1994.

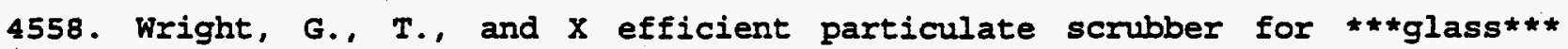
melter off-gasX. Mater.Res.Soc.Symp.Proc., 15,X 631-8X-8X, 1994.

4559. Wronkiewicz, D., ; Young, J., ; Bates, J., and X effects of alpha and gamma radiation on glass reaction in anX unsaturated environmentx. Mater.Res.Soc.Symp.Proc., 212, 99-106X-106X, 1994.

4560. Wronkiewicz, D., Young, J., and Bates, J. Effects of alpha- and gamma-radiation on glass reaction in an unsaturated environment. Mater.Res.Soc.Symp.Proc. 212:99-106, 1991.

4561. Wronkiewicz, D.J., Young, J.E., and Bates, J.K. Effects of alpha and gamma radiation on glass reaction in an unsaturated environment. (Unknown Journal!) , 1990.

4562. Wu, S.L.,Yunniangx analysis of inorganic anions in the off-gas from

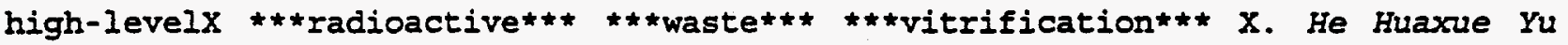
Fangshe Huaxue, 11, 177-82X-82X, 1994.

4563. Xing, $S$, and $X$ effects of container material on pct leach test results forX high-level nuclear waste glassesX. Mater.Res.Soc.Symp.Proc., 333, $557-64 X-64 X, 1994$.

4564. Xue, X.Y. and Stebbins, J.F. Na-23 NMR Chemical-Shifts and Local Na Coordination Environments in Silicate Crystals, Melts and Glasses. PHYS. CHEM.MINER. 20:297-307, 1993 . 
4565. Y.H.Yunl and P.J.Bray BII Nuclear Magnetic Resonance Studies of Li20-B203 Glasses of High Li20 content. Journal.of.Non-Crystalline.Solids. 44:227-237, 1981.

4566. Yamada, R., Nakamura, K., and Sone, K. Measurement of chemical sputtering yields of various types of carbon. J.NUCL.MATER. 95:278-284, 1980.

4567. Yamaguchi, T. and Kageyama, M. Oxidation behavior of AlN in the presence of oxide - and glass for thick film applications. IEEE Transactions.on.Components, .Hybrids.and.Manufacturing.Technology. IEEE Trans Compon Hy, 1989.

4568. Yamamoto, Y.N. YoshinoriX release behavior of tritium from neutron-irradiated borosilicateX $\star \star \star g l a s s * \star \star X . R \& D$, Res.Dev. (Kobe Steel Ltd.), $33,47-50 x-50 x, 1994$.

4569. Yamanaka, H. hydration mechanism of radioactive vitrified waste and safetyx evaluationx. Hyomen, 29, 989-95X-95X, 1994.

4570. Yamanaka, H. preparation of hydrated glass as a model of nuclear waste glassX after long-term leachingx. Osaka Kogyo Gijutsu Shikensho Kiho, 44, $53-8 X-8 X, 1994$.

4571. Yamanaka, H.T.,Ryohei; Hara deposition of vapor from borosilicate

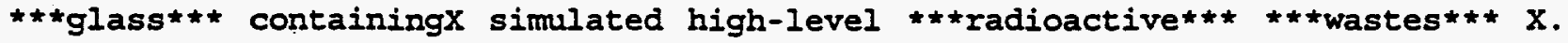
Osaka Kogyo Gijutsu Shikensho Kiho, 34, 261-6X-6X, 1994.

4572. Yamanaka, H.Y.,Masaru; Wakabayashi the effect of composition deviation on the properties of nuclearX waste glasses (ii).leach ratex. Osaka Kogyo Gijutsu Shikensho Kiho, 38, 206-11X-11X, 1994.

4573. Yamanaka, H.T.,Ryohei; Wakabayashi phase separation of molybdates in borosilicate glasses containingx the simulated high-level nuclear wastesX. Osaka Kogyo Gijutsu Shikensho Kiho, 36, 155-61X-61X, 1994.

4574. Yamanaka, H.T.,Ryohei; Hara the effect of surface roughness of **\#glass*** on theX.leachabilityx. Osaka Kogyo Gijutsu Shikensho Kiho, 33, $355-62 X-62 X, 1994$.

4575. Yamane, M. and Nakao, $Y$. Phase separation in the glass containing high levelX radioactive waste $X$. Yogyo.Kyokaishi. $-32 X, 1994$.

4576. Yamane, M. and Nakao,. Y. Phase separation in glass containing high level radioactive waste. Yogyo Kyokai Shi;87 (6): 327-32;79, 1994.

4577. Yamane, M., Nakao, Y., and Okuyama, M. Effects of the addition of various oxides on phase separation in glasscontaining high-level radioactive waste. Yogyo Kyokaishi , 1980.

4578. Yamane, M.N.,Yasumasa; Okuyama effects of the addition of various oxides on the phase separation inX the $\star \star \star$ glass $* \star *$ containing high level

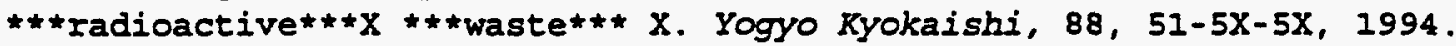


4579. Yamasaki, N., Nishioka, M., and Yanagisawa, K. Immobilization of simulated $\mathrm{hlw}$ by hydrothermal hot-pressing of glassx powder. Nippon Genshiryoku Gakkaishi/Journal of the Atomic Energy Society ofX Japan 30:815-820, 1988 .

4580. Yamasaki, N., Yanagisawa, K., Kinoshita, K., and Kashiwai Solidification of waste containing sodium borate by hydrothermalx hot-pressing. Nippon Genshiryoku Gakkaishi/Journal of the Atomic Energy Society ofx Japan $30: 714-724$, 1988 .

4581. Yamasaki, N.N.,Mamoru; Yanagisawa shrinkage process and compressive strength of high-level radioactivex waste form by hydrothermal hot-pressing methodx. Yogyo Kyokaishi, 93, 151-3X-3X, 1994.

4582. Yamasaki, N.Y.,Kazumichi; Nishioka solidification of inorganic powder compact by hydrothermalx hot-pressing methodx. Yoyuen oyobi Koon Kagaku, 32, $177-95 X-95 X, 1994$.

4583. Yamasaki, N. immobilization of high-level radioactive waste by hydrothermalx hot-pressing methodx. Chem.Aspects Down stream Thorium Fuel Cycle, 135-62-62, 1994.

4584. Yamasaki, N.Y.,Kazumichi; Nishioka hydrothermal immobilization of ***glass*** powder containingx simulated high level ***radioactive*** ***wastes*** X. Nihon Genshiryoku Gakkaishi, 28, 266-73X-73X, 1994.

4585. Yamasaki, N.N.,Mamoru; Yanagisawa immobilization of simulated hlw by hydrothermal hot-pressing ofx glass powderX. Nihon Genshiryoku Gakkaishi, 30 , 815-20X-20X, 1994.

4586. Yamasaki, N.Y.,Kazumichi; Kinoshita solidification of waste containing sodium borate by hydrothermalx hot-pressingx. Nihon Genshiryoku Gakkaishi, 30, $714-24 X-24 X, 1994$.

4587. Yamashita, Terai, R., and Wakabayashi, H. Self-diffusion of alkali ions in nuclear waste glass. J.Non-Cryst.Solids, 1986.

4588. Yamashita, M., ; Matzke, H., ; Linker, G., and $X$ tellurium and palladium diffusion in the german waste glass vg $98 / 12 X$ measured with the rbs methodx. Mater.Res.SOC.Symp.PrOC., 257, 183-90X-90X, 1994.

4589. Yamashita, M., Terai, R., and Wakabayashi, H. Self-diffusion of alkali ions in nuclear waste glasses. Journal of Non-Crystalline Solids 79:213-216, 1986 .

4590. Yamashita, M.Y.,Hiroshi; Wakabayashi the effect of composition deviation on the properties of nuclearx waste glasses (i).electrical conductivityX. Osaka Kogyo Gijutsu Shikensho Kiho, 38, 155-62X-62X, 1994.

4591. Yanagi, T., Yoshizoe, M., and Kuramoto, K. Leach rates and thermal properties of lead-iron phosphate glass wastex forms. Journal of Nuclear Science and Technology 26:948-954, 1989.

4592. Yanagi, T.Y.,Makoto; Nakatsuka leach rates of lead-iron phosphate glass waste formsX. J.Nucl.Sci.Technol., 25, 661-6X-6X, 1994. 
4593. Yanagi, T.Y.,Makoto; Kuramoto leach rates and thermal properties of lead-iron phosphate glassX waste formsX. J.Nucl.Sci.Technol., 26, 948-54X-54X, 1994.

4594. Yanagisawa, F. ***vitrification*** of high level $\star \star \star$ radioactive***X

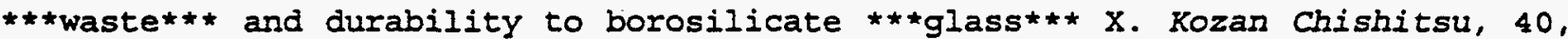
$421-8 \mathrm{X}-8 \mathrm{X}, 1994$.

4595. Yanagisawa, F.S.,Hitoshix leaching behavior of a simulated nuclear waste glass in groundwaterX of 50-240.degree.cX. Appl.Geochem., 3, 153-63X-63X, 1994.

4596. Yanagisawa, F.S.,Hitoshix effect of iron and potassium contents in simulated borosilicatex glass on its leaching behaviors at hydrothermal conditionsX. Geochem.J., 21, 209-17X-17X, 1994.

4597. Yanagisawa, H., Gohonzyo, K., and Eguchi, K. Corrosion of electrodes by borosilicate glasses containing simulatedhigh-level radioactive wastes. Chen. Express , 1989.

4598. Yanagisawa, H., Gohonzyo, K., and Eguchi, K. Corrosion of electrodes by boro-silicate glasses containing simulatedx high-level radioactive wastes. Chemistry Express $4: 421-424,1989$.

4599. Yanagisawa, H.G.,Keiji;. Eguchi corrosion of electrodes by boro-

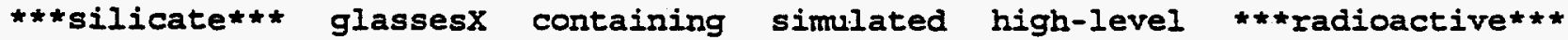
$\star \star \star$ wastes $* \star$ X. Chem.Express, 4, 421-4X-4X, 1994.

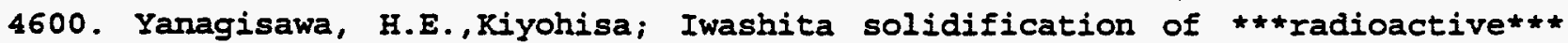

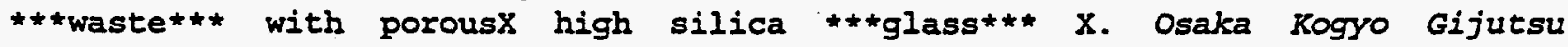
Shikensho Kiho, 39, 84-90X-90X, 1994.

4601. Yanagisawa, K., Nishioka, M., and Yamasaki, N. Immobilization of radioactive wastes by hydrothermal hot-pressing. Am.Ceram.Soc.Bul1. , 1985.

4602. Yanagisawa, K., Nishioka, M., and Yamasaki, N. Hydrothermal treatment of radioactive wasteusolidification ofhigh-level radioactive waste by hydrothermal .hot-pressing. Trans.Mater.Res.Soc.Jpn. , 1990.

4603. Yanagisawa, K., Nishioka, M., and Yamasaki, N. Immobilization of radioactive wastes by hydrothermal hot pressing. American Ceramic Society Bulletin 64:1563-1567, 1985.

4604. Yang, J., Sakka, S., and Yoko, T. Preparation of lithium aluminosilicate glass-ceramic monolith from metal alkoxide solution. Journal.of.Materials.Science v. 26 (Apr. 1 '91):1827-1833, 1991.

4605. Yang, L., Komarneni, S., and Roy, R. Leach resistance of NzP [Nazr sub 2 (PO sub 4) sub 3 ] waste form. Adv.Ceram. 8:377-384, 1985.

4606. Yang, L.J., Komaneni, S., and Roy, R. Leach resistance of nzp waste form. In: <CI> Held during the 85th Annual Meeting of the American CeramicX Society Advances in Ceramics $v 8$. Publ by American Ceramic Soc Inc, Columbus, $X$ 
OH, USA p 377-384, Anonymous Columbus, $X$ OH, USA:American Ceramic SOC Inc, 1984,p. 377-384.

4607. Yang, w. Hydrothermal reaction of crystalline albite, sodium aluminosilicate glass, and a rhyolitic-composition glass with aqueous solution : a solid-state study, 1988.

4608. Yannopoulos, L. Synthetic monazite-coated nuclear waste-containing glass. (Unknown Journal!) , 1983.

4609. Yannopoulos, L. Synthetic monazite-coated nuclear waste-containing glass. (Unknown Journal!), 1984.

4610. Yasuda, D. and Hrma, P. Effect of slurry rheology on melter cold cap formation. Ceram. Trans. , 1991.

4611. Yates, R. The durability of soda-lime glass /, 1935.

4612. Yau, W. and Durant, W.S. Response of a glass melter to steam explosion. In: Publ by Springer-Verlag, Berlin, West Ger and New York, NY, USA $p$ 8.X 3-8.10,Anonymous Berlin, West Ger and New York, NY, USA:Springer-Verlag, 1984, p. 8

4613. Yazawa, T., Tarika, H., Eguchi, K., Yokoyama, S.) and Arai, T. Novel Porous-Glass with Chemical-Resistance and Good Shaping Ability Prepared from Borosilicate Glass Containing zno. J.MATER.SCI.LETT. 12:263-264, 1993.

4614. Yen, J. Viscosity and structure of high temperature glass-ceramic melts, 1992 .

4615. Ying, J., Benziger, J., and Navrotsky, A. Structural evolution of colloidal silica gels to glass. Journal.of.the.American.Ceramic.Society. v. 76 (Oct. ' 93) :2561-2570, 1993.

4616. Yingfan Xu. and Wenkui Wang. Undercooling and formation of bulk metallic glass of $\mathrm{Pd}-\mathrm{Ni}-\mathrm{P}$ in a containerless environment. Journal.of.Materials.Science v. 26 (Mar. 15 '91):1677-1682, 1991.

4617. Yokoyama, H., ; Hermansson, H., P., ; Christensen, H., ; Bjoerner, I., $\mathrm{K} ., ; X$ Werme, $I .$, and $X$ corrosion of simulated nuclear waste glass in a gamma radiationX fieldx. Mater.Res.Soc.Symp.Proc., 44,X 601-8X-8X, 1994.

4618. Yoshioka, M., ; Torata, S., ; Igarashi, H., ; Takahashi, T., ; Horie, M., and $X$ glass melter and process development for pnc tokai vitrificationX facilityX. Waste Manage. (N.Y.), 12, 7-16X-16X, 1994.

4619. Yoshioka, M., Torata, S., Igarashi, H., Takahashi, T., and Horie, M. Glass melter and process development for PNC TOKAI vitrification facility. Waste.Management. Waste Manage $v 12 \mathrm{n}, 1992$.

4620. Yurik, T.K., Tananaev, I.G., and Mironov, V.S. Structure of Np(V) Hydroxides Studies by EPR. SOV.RADIOCHEM-ENGL.TR. 33:140-142, 1991. 
4621. Yusa, $Y$. natural analog study on long-term leaching behavior of

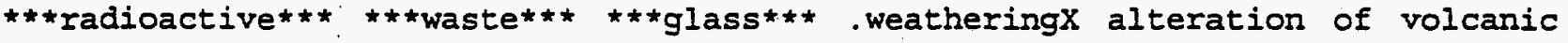
glasses from fuji and izu-ohshima volcanoes, $X$ japanx. Nihon Genshiryoku Gakkaishi, 33, 890-905X-905X, 1994.

4622. Zamecnik, J., R., and $X$ evaluation of the dwpf chemical process cell sample condenser in thex integrated dwpf melter systemx. Report, WsIC-Tr-92-255; Order No.De93002160, 6 pp, 1993.

4623. Zamecnik, J.R. Measurement of cesium and mercury emissions from the vitrification of simulated high level radioactive waste. (Unknown Journal!), 1992 .

4624. Zamecnik, J.R., Hutson, N.D., Ritter, J.A., and Carter, J.T. Processing of simulated high-level radioactive waste sludges containing nitrites and mercury. (Unknown Journal!), 1991.

4625. Zamecnik, J.R., Miller, D.H., and Carter, J.T. Measurement of cesium emissions during the vitrification of simulated high level radioactive waste. (Unknown Journal!), 1992.

4626. Zanotto, E. Immobilization of radioactive wastes in glasses and ceramics [--currentworld efforts]. Ceramica (Sao Paulo) , 1983.

4627. Zanotto, E.D. immobilization of ***radioactive*** ***wastes*** in glassesX and ceramicsX. Ceramica (Sao Paulo), 29, 347-52X-52X, 1994.

4628. Zavoshy, S., J., and $X$ high-level waste dissolution and secondary mineral(s) formation andx dissolutionx. Mater.Res.Soc.Symp.Proc., 112, 361-70X-70X, 1994.

4629. Zavoshy, S.J., Chambre, P.I., and Pigford, T.H. Mass Transfer in a Geologic Environment. (Unknown Journal!), 1984.

4630. Zavoshy, S.J. a glass dissolution model and mass transfer from a waste glassX cylinder intersected by a fissurex. (Unknown Jounal!) 239 pp, 1988.

4631. Zeitzoff, P.M., Hossain, T.z., Boisvert, D., and Downing, R.G. Measurement and Control of the Boron and Phosphorus Concentration in LPCVD XBorophosphosilicate Glass. Journal.of.the.Electrochemical.Society. 137, Number $12: 3915-3917$, 1990 .

4632. Zeller and Saunders Radioactive waste disposal.suggestion for a permanentx international polar high-level radioactive waste repositoryx. Report. , 1973.

4633. Zellmer, L.A., ; White, W.B., and $x$ characterization of hydrated surface layers on nuclear waste glassesx by infrared reflectance spectroscopyx. Mater.Res.SOC.Symp.Proc., 44,X 73-80X-80X, 1994.

4634. Zhang, $C$. impact test study of glass waste formsX. Fushe Fanghu, 13, $60-3 x-3 x, 1994$. 
4635. Zhang, H. Glass transition temperature study of lithium borosilicate glass $x$ systems related to atomic arrangements, 1991.

4636. Zhou, Z.P., Newman, P.J., and Macfarlane, D.R. Electroanalytical Methods for Transition-Metal Analysis in Heavy-Metal Fluoride Melts. J.NON-CRYST. SOLIDS. 161:36-40, 1993.

4637. Zhou, 2 . chemical durability of simulated nuclear waste glasses and theirX natural. analogs in submarine conditionsX. No pp.Given Avail.NIcX From: Diss.Abstr.Int.B 1990, 50, 4422X, 1994.

4638. Zhu, B., Clark, D., and Hench, L. Leaching behavior of nuclear waste glass heterogeneities. J.Non-Cryst.Șolids, 1986.

4639. Zhu, B., Clark, D., and Lodding, A. Two-year leaching behavior of three srl nuclear waste glasses in granite. Adv.Ceram. , 1986.

4640. Zhu, B., Clark, D.E., Hench, L.I., and Wicks, G.G. Leaching behavior of nuclear waste glass heterogeneities. Journal of Non-Crystalline Solids $80: 324-334,1986$.

4641. Zhu, B.F., Clark, D.E., Hench, L.I., and Wicks, G.G. Leaching Behavior of Nuclear Waste Glass Heterogeneities. (Unknown JournaI!) , 1985.

4642. Zhu, B. Nuclear waste glass leaching in a simulated granite repository /. 1987 .

4643. Zhu, B.F.,D., E., ; Lodding, A., R., ; Wicks, G., G., and X two-year leaching behavior of three srl nuclear waste glasses inx granitex. Adv. Ceram., 20, 591-9X-9X, 1994 .

4644. Zhu, B.C.,D., E., ; Hench, I., L., ; Wicks, G., G., and X leaching behavior of nuclear waste glass heterogeneitiesx. J.Non-Cryst.Solids, 80 , $324-34 \mathrm{X}-34 \mathrm{X}, 2994$.

4645. Ziegler and Johnson Disposal of hepa filters by fluidized bed incinerationX. Report. , 1978.

4646. Ziegler, D. and Johnson, A. Disposal of hepa filters by fluidized bed incinerationX. Proc.Doe.Nucl.Air.Clean.Conf. -16X, 1978.

4647. Ziegler, D., L., ; Johnson, A., J., ; Ledford, J., A., and $X$ waste immobilization process development at rocky flats plant [usa]X. Manage.Alpha-Contam.Wastes, Proc.Int.Symp., Meeting Date 1980, X 369-79-79, 1994.

4648. Zielinski, R. Uranium mobility during interaction of rhyolitic glass with alkaline solutions : dissolution of glass, Reston, VA:U.S. Geological Survey, 1977.

4649. Zizka, T. vitrification of low-radioactivity wastes from nuclear power plantsX. Sklar Keram., 40, 161-4X-4X, 1994. 
4650. Zizka, $T$. and Baborak, R. Vitrification of low-active wastes from the atomic power stations. Sklar Keram., 1990.

4651. Zoitos and Clark, D. Resolution-enhanced reflectance spectroscopy of nuclear waste glass. Adv.Ceram. , 1986.

4652. Zoitos, Schulz, and Clark, D. Marker study of surface layer formation and partial dissolution. Ceram. Trans. , 1990.

4653. Zoitós, B., K., ; Clark, D., E., ; Lodding, A., R., ; Wicks, G., G., and $X$ correlation of laboratory and stripa field leaching studiesX. Mater.Res.SOC.Symp.Proc., 127, 145-51X-51X, 1994.

4654. Zoitos, B., K., ; Clark, D., E., and X resolution-enhanced reflectance spectroscopy of nuclear waste glassX. Adv.Ceram., 20, 191-6X-6X, 1994.

4655. Zoitos, B., K., ; Clark, D., E., and $X$ role of surface layers in the leaching behavior of glassX. Mater.Res.Soc.Symp.Proc., 125,X 169-76X-76X, 1994.

4656. Zorpette, G. and Stix, G. Nuclear waste: The challenge is global.X. IEEE SpectrumX. IEEE Spectrum v $27 \mathrm{n}, 1990$.

4657. Zorpette, G. and Stix, G. Nuclear waste: The challenge is global. IEEE Spectrum. IEEE Spectrum v $27 \mathrm{n}, 1990$.

4658. Zorpette, G. and stix, G. Nuclear waste: the challenge is global. IEEE Spectrum 27:18-24, 48, 1990 .

4659. Zwicky, H., U., ; Graber, T., ; Grauer, R., ; Restani, R., and X cationic corrosion inhibitors for alkali [metal] borosilicate glassX. Mater.Res.Soc.Symp.Proc., 257, 83-90x-90X, 1994. 